$$
\text { UNIVERSIDADE DE SÃO PAULO }
$$

FACULDADE DE FILOSOFIA, LETRAS E CIÊNCIAS HUMANAS DEPARTAMENTO DE GEOGRAFIA

PROGRAMA DE PÓS-GRADUAÇÃO EM GEOGRAFIA FÍSICA

\title{
PADRÕES ATMOSFÉRICOS ASSOCIADOS A CONCENTRAÇÕES DE OZÔNIO TROPOSFÉRICO NA REGIÃO METROPOLITANA DE SÃO PAULO
}

Júlio Barboza Chiquetto 


$$
\text { UNIVERSIDADE DE SÃO PAULO }
$$

FACULDADE DE FILOSOFIA, LETRAS E CIÊNCIAS HUMANAS

DEPARTAMENTO DE GEOGRAFIA

PROGRAMA DE PÓS-GRADUAÇÃO EM GEOGRAFIA FÍSICA

\title{
PADRÕES ATMOSFÉRICOS ASSOCIADOS A CONCENTRAÇÕES DE OZÔNIO TROPOSFÉRICO NA REGIÃO METROPOLITANA DE SÃO PAULO
}

\author{
Júlio Barboza Chiquetto
}

\begin{abstract}
Dissertação apresentada ao Programa de Pós-Graduação em Geografia Física, do Departamento de Geografia da Faculdade de Filosofia, Letras e Ciências Humanas da Universidade de São Paulo, para obtenção do título de Mestre em Geografia.
\end{abstract}

Orientadora: Profa ${ }^{a}$ Dra. Maria Elisa Siqueira Silva

São Paulo

2008 


\section{AGRADECIMENTOS}

À Dra ${ }^{a}$ Maria Elisa Siqueira Silva, por todo o empenho, conhecimento e boa vontade fundamentais para o início, desenvolvimento e conclusão deste trabalho;

Aos professores participantes da banca de qualificação, $\operatorname{Dr}^{\mathrm{a}}$ Fátima Andrade e Dr. Tarik de Azevedo, pelas observações, sugestões e encorajamento;

Aos meus pais, Neuci Barboza Chiquetto e Antônio José Chiquetto. Sem seu apoio e motivação esta pesquisa não teria sido possível;

À Elisa Helena Polônio, pela paciência, carinho, dedicação e companheirismo nos momentos de dificuldade. Também pela ajuda com a revisão e edição do texto e figuras na fase final do trabalho;

Aos meus amigos e parentes; todos eles, não citarei nomes pois todos sabem seu valor. Tenho sorte demais para saber que essa lista é longa demais para ser escrita aqui. Pela amizade, compreensão e bons momentos;

À CETESB pela disponibilização dos dados das estações automáticas;

Ao Dr. Emerson Galvani do Departamento de Geografia, pela importância na minha vida acadêmica e observações a cerca dos cronogramas e burocracias a que estamos todos sujeitos;

Às $\operatorname{Dr}^{\text {as }}$ Adalgiza Fornaro, Rita Yiuri Ynoue e Leila Droprinchinski Martins por amigavelmente desvendarem os mistérios da química atsmoférica;

Aos colegas Jorge Sleimann, Karine Mirieli dos Santos Costa, Elaine Rosângela da Silva, Antônio Jaschke Machado, Daniela Onça, Roseane Mateus e demais colegas do LCB pela consideração e apoio e por tornarem o LCB um local agradável de estudo;

A Rogério Rozolen Alvez, técnico do LCB e colega, pela competência, boa vontade e colaboração em diversas fases do trabalho;

Aos professores do Departamento de Ciências Atmosféricas Dr. Paulo Takeshi e $\operatorname{Dr}^{a}$ Rosmeri Porfírio da Rocha pela ajuda com a interpolação e obtenção de dados meteorológicos; 
À Rafal Konrad Pawlaszek e Laura Rhian Pickard pelos contatos iniciais com a Associação Internacional dos Estudantes de Física e por me motivarem a apresentar um trabalho na conferência da associação;

Às funcionárias da secretaria de pós-graduação da USP pela disponibilidade e atenção;

À Maria Fernanda Cassávia pelas suas sugestões e por compartilhar seu conhecimento suas experiências acadêmicas;

À CAPEs pelo auxílio financeiro disponibilizado para a realização desta pesquisa. 


\section{RESUMO}

Nos últimos anos, tem-se observado que na RMSP o ozônio troposférico foi o poluente responsável pela maior parte das ultrapassagens dos padrões de qualidade do ar estabelecidos pela CETESB. Supõe-se que diferentes padrões atmosféricos possam interferir nas concentrações de ozônio, devido à influência na variabilidade da concentração de poluentes, já estudada, e devido ao fato deste poluente ser formado pela interação entre seus precursores e a radiação solar. Dados horários de ozônio, provenientes de 17 estações da rede de monitoramento de poluentes da CETESB, foram utilizados para a construção de séries de médias anuais, mensais e diárias.

O ciclo sazonal médio do ozônio, para a região de estudo, indicou um máximo em meados da primavera e mínimo no final do outono, o que é fortemente influenciado pelo ciclo médio de radiação solar e cobertura de nuvens. As estações situadas em áreas com reduzida atividade urbana e longe do centro da mancha urbana apresentaram ciclo sazonal mais bem definido e concentrações sobremaneira mais altas, sugerindo que as concentrações absolutas e o ciclo sazonal do ozônio sejam influenciados pelo uso do solo no entorno da estação.

Os meses com anomalias positivas e negativas intensas de ozônio foram selecionados, e as anomalias climáticas e os padrões atmosféricos predominantes em alguns destes meses foram analisados, em escala mensal e diária. Os resultados indicaram, na análise dos padrões atmosféricos mensais e de evolução diária, que as anomalias positivas de ozônio estiveram associadas a anomalias positivas de radiação solar e, negativas de umidade relativa, o que foi resultante da variabilidade dos sistemas atmosféricos atuantes em escala sinótica que contribuíam para o aumento da divergência em superfície, tais como os anticiclones na retaguarda de sistemas frontais, o anticiclone do Atlântico Sul, e VCANs provenientes do NE do Brasil. Para os meses com anomalias negativas, verificou-se maior frequência ou intensidade dos sistemas frontais, em 
comparação ao valor médio climatológico para a região, bem como anomalias positivas de nebulosidade e aumento da atividade convectiva, associada, algumas vezes, à ocorrência da ZCAS. Além disso, verificou-se que a maioria dos meses com anomalias negativas de ozônio foram também precedidos por meses com anomalias negativas, próximas de zero, ou períodos com tendência de queda da concentração.

Palavras-chave: variabilidade climática, ozônio troposférico, CETESB, clima urbano, poluição atmosférica. 


\begin{abstract}
In the past few years, tropospheric ozone has been noticed to exceed the state's environmental agency (CETESB) air quality standards more than any other air pollutant in the Sao Paulo Metropolitan Area (SPMA), Brazil. It's assumed that different atmospheric patterns are responsible for different impacts on ozone concentrations, due to already known phenomena concerning atmospheric variability and air pollutants, but also to the fact that this specific pollutant is formed at surface level through interactions between its precursors and incoming shortwave solar radiation.
\end{abstract}

Ozone hourly data from 17 CETESB air quality network stations were used to calculate annual, monthly and daily averages. The seasonal cycle observed for the area of study indicated a middle spring maximum and late autumn minimum, both visibly influenced by mean seasonal solar radiation and cloud covering cycles. Stations located in areas away from the urban center or with lesser urban activity showed a well characterized seasonal cycle and higher concentrations in general, thus suggesting that ozone absolute concentrations and its seasonal cycle are somewhat linked to the predominant land use in the stations' surroundings.

Months with intense positive and negative ozone anomalies were selected, and climatic anomalies and atmospheric patterns were evaluated in some of these months in the monthly and daily time scale. Results from the monthly atmospheric pattern analysis and daily variability analysis point out that positive ozone anomalies were associated with solar radiation positive anomalies and relative humidity negative anomalies, resulting from synoptic-scale variability of atmospheric systems that contributed to air divergence strengthening at surface level, such as high-latitude anticyclones that followed frontal systems, the Southern Atlantic semipermanent anticyclone and Upper Level Cyclonic Vortexes from Northeastern Brazil. For months displaying anomalous negative behaviour, a higher than average frequency or intensity of frontal systems was observed for the 
region, as well higher cloudiness and increased convective activity, sometimes associated with the ZCAS (Southern Atlantic Convergence Zone). Besides that, it was perceived that most months with ozone negative anomalies were preceded by months already showing negative anomalies, or either way, a decreasing tendency on concentrations.

Key words: climatic variability, tropospheric ozone, CETESB, urban climate, atmospheric pollution. 


\section{Sumário}

Lista de figuras

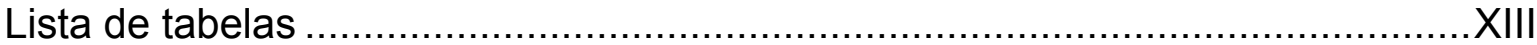

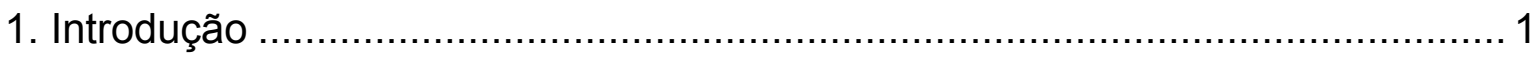

1.1 Os poluentes do ar e suas fontes........................................................................

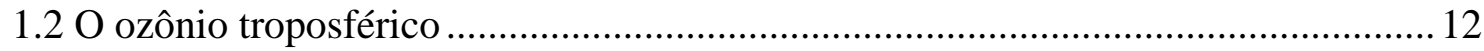

1.2.1 O ozônio troposférico nos grandes centros urbanos............................................ 16

1.3 Caracterização climática da RMSP ……………………………………………......29

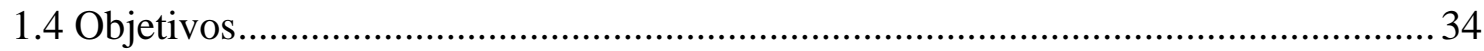

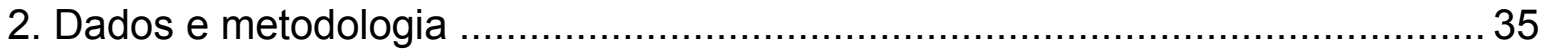

2.1 Caracterização da fonte de dados de poluição do ar: a CETESB ................................. 35

2.1.1 As redes de monitoramento de poluentes .......................................................... 38

2.1.2 Caracterização de algumas estações medidoras da CETESB.............................. 43

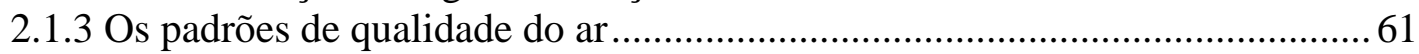

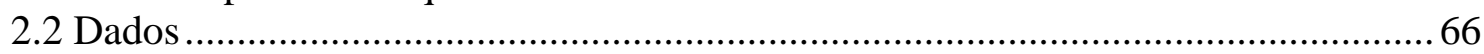

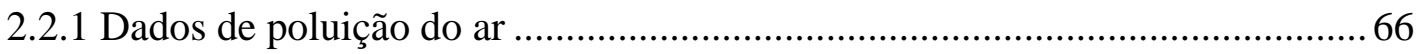

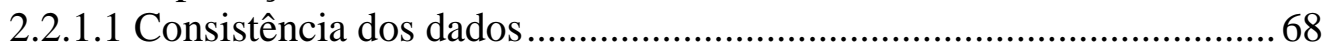

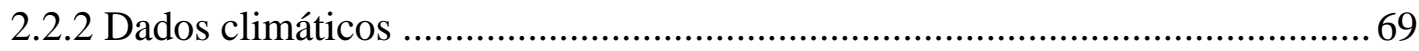

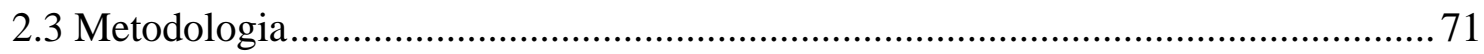

2.3.1 Comportamento do ozônio na RMSP ................................................................ 71

2.3.2 Análise da influência dos padrões atmosféricos nas concentrações de ozônio da RMSP ................................................................................................ 75

2.3.2.1 Seleção de meses com anomalias de ozônio e as anomalias atmosféricas observadas ................................................................................ 77

2.3.2.2 Associação de padrões atmosféricos às concentrações de ozônio.........79

2.3.2.3 Influência da atmosfera na variabilidade diária do ozônio

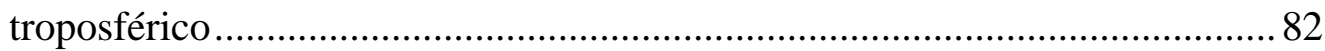

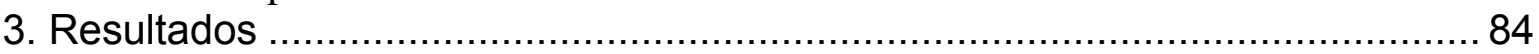

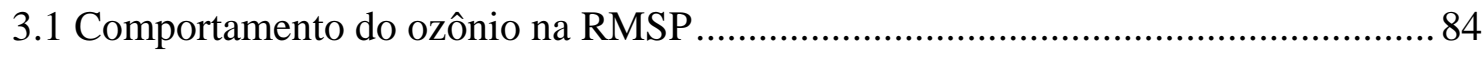

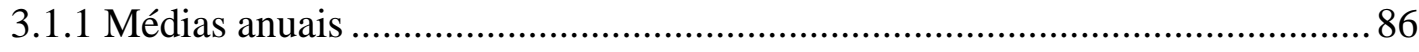

3.1.2 Médias mensais …………………………………………………………..... 95

3.1.2.1 O ciclo sazonal do ozônio troposférico na RMSP ................................ 103

3.1.3 Médias diárias.............................................................................................117

3.1.3.1 O ciclo diurno do ozônio troposférico na RMSP ................................ 131

3.1.4 Análise da distribuição espacial do ozônio troposférico na RMSP.................138

3.2 Meses de anomalias de ozônio e as anomalias atmosféricas observadas .................. 144

3.3 Associação de padrões atmosféricos às concentrações de ozônio.............................. 160

3.3.1 Meses com anomalias negativas intensas de ozônio. .......................................161

3.3.2 Meses com anomalias positivas intensas de ozônio.......................................... 189

3.4 Interferência da atmosfera na variabilidade diária do ozônio troposférico ..............237

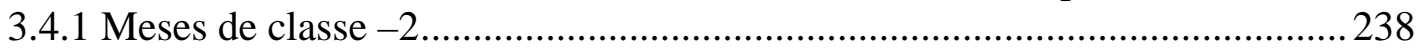

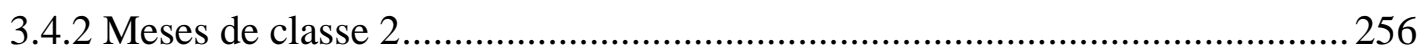

4. Conclusões e considerações finais ....................................................... 290

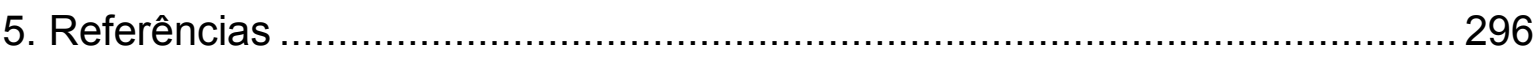

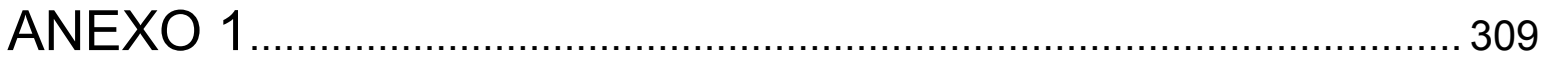




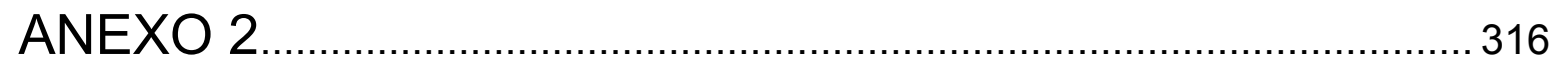

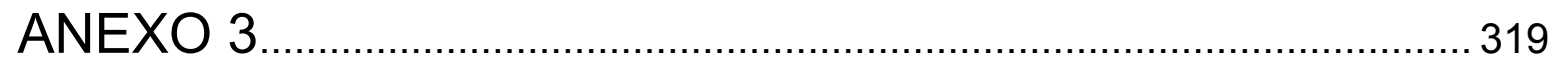

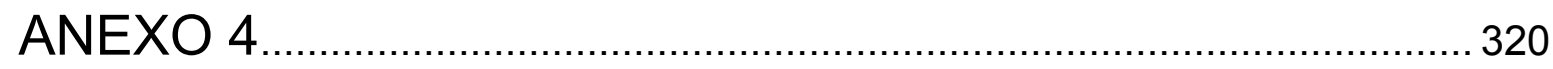

ANEXO 5 


\section{Lista de figuras}

Figura 01: Evolução da frota de veículos leves na RMSP. 6

Figura 02: Tempo de residência e escala espacial de transporte alguns poluentes.10

Figura 03: Smog fotoquímico sobre Quebec, Canadá. 18

Figura 04: Evolução das concentrações dos poluentes (eixo y) durante as horas do dia (eixo x) num típico episódio de smog. 18

Figura 05: Exemplo de dano à vegetação causado pelo ozônio. 20

Figura 06: Índices de qualidade do ar por CO para algumas estações da RMSP, de 2002 a 2006.

Figura 07: Concentrações anuais médias de $\mathrm{NO}_{2}\left(\mathrm{~g} / \mathrm{m}^{3}\right)$ para algumas estações da RMSP, de 1998 a 2006.

Figura 08: Índices de qualidade do ar por MP para algumas estações da RMSP, de 2002 a 2006.

Figura 09: Número de dias com concentrações acima do PQAr de ozônio (colunas) e concentração horária máxima (linha).

Figura 10: Índices de qualidade do ar por $\mathrm{O}_{3}$ para algumas estações da RMSP, de 2002 a 2006.

Figura 11: Número de ultrapassagens do PQAr e níveis críticos de ozônio por mês na RMSP, de 2002 a 2006. 26

Figura 12: Ozônio - RMSP - Alta concentração - 04/03/03 26

Figura 13: Ozônio - RMSP - Baixa concentração - 10/09/03. 27

Figura 14: Localização das estações de monitoramento na RMSP utilizadas neste trabalho 39

Figura 15: Entorno da estação Congonhas. 45

Figura 16: Entorno da estação Lapa. 46

Figura 17: Entorno da estação Osasco. 47

Figura 18: Entorno da estação São Caetano do Sul. 48

Figura 19: Entorno da estação Mooca. 49

Figura 20: Entorno da estação Ibirapuera. 50

Figura 21: Entorno da estação Pico do Jaraguá. A estação está indicada pela seta.51 Figura 22: Entornos da estação Parque D. Pedro II. A localização aproximada é representada pelo quadrado vermelho. 
Figura 23: Entornos da estação Santana. A localização aproximada é representada pelo quadrado vermelho.

Figura 24: Entornos da estação Nossa Senhora do Ó. A localização aproximada é representada pelo quadrado vermelho.

Figura 25: Entornos da estação Diadema. A localização aproximada é representada pelo quadrado vermelho. 55

Figura 26: Entornos da estação Santo Amaro. A localização aproximada é representada pelo quadrado vermelho. 56

Figura 27: Entornos da estação Santo André - Capuava. A localização aproximada é representada pelo quadrado vermelho. 56

Figura 28: Entornos da estação São Miguel Paulista. A localização aproximada é representada pelo quadrado vermelho.

Figura 29: Entornos da estação Mauá. A localização aproximada é representada pelo quadrado vermelho. 58

Figura 30: Entornos da estação Pinheiros. A localização aproximada é representada pelo quadrado vermelho.

Figura 31: Entornos da estação Horto Florestal. A localização aproximada é representada pelo quadrado vermelho.

Figura 32: Concentração anual para as estações com concentração média baixa (< $2 \sigma)$.

Figura 33: Concentração anual para as estações com concentração mediana (entre $1 \sigma \mathrm{e}+1 \sigma)$ 90

Figura 34: Concentração anual para as estações com concentração alta $(>+1 \sigma) .91$ Figura 35: Concentração anual para as estações com concentração muito alta (> $+2 \sigma)$.

Figura 36: Evolução do número de ultrapassagens de padrão e nível de atenção de $\mathrm{O}_{3}$ por estação na RMSP - 2003 a 2007. 94

Figura 37: Evolução das concentrações mensais de ozônio nas estações Parque D. Pedro II, Santana e Pico do Jaraguá. As linhas retas indicam a tendência linear de cada estação. 96

Figura 38: Evolução das concentrações mensais de ozônio na estação Congonhas. A linha reta indica a tendência linear. 
Figuras 39a e 39b: Evolução das concentrações mensais de ozônio para as estações Santo Amaro, Horto Florestal e Osasco. As linhas retas indicam a tendência linear de cada estação. 99

Figura 40: Evolução temporal do valor mensal médio para as 17 estações, de 1996 a 2005. A reta vermelha indica a tendência linear média. Os meses indicados em vermelho e azul demonstram, respectivamente, a maior e a menor concentração registrada no ano. 100

Figura 41: Evolução temporal da concentração mensal de ozônio para as estações Ibirapuera, Mauá, Mooca, Parque D. Pedro II, São Caetano do Sul e São Miguel Paulista, com a respectiva tendência linear. Os meses em vermelho e azul indicam, respectivamente, as concentrações máxima e mínima do ano. 101

Figura 42: Ciclos sazonais médios de ozônio $\left(\mu \mathrm{g} / \mathrm{m}^{3}\right)$, da radiação solar $\left(\mathrm{W} / \mathrm{m}^{2}\right)$ e cobertura de nuvens (\%), para a RMSP, de 1996-2005. Destacam-se os meses de outubro (máximo do ano, em vermelho), junho (mínimo, em azul) e fevereiro (máximo secundário). 104

Figura 43a: Ciclo sazonal da concentração mensal de ozônio, em cada ano, para cada estação apresentada. 106

Figura 43b: Ciclo sazonal da concentração mensal de ozônio, em cada ano, para cada estação apresentada. 107

Figura 43c: Ciclo sazonal da concentração mensal de ozônio, em cada ano, para cada estação apresentada. 108

Figura 43d: Ciclo sazonal da concentração mensal de ozônio, em cada ano, para cada estação apresentada 109

Figura 43e: Ciclo sazonal da concentração mensal de ozônio, em cada ano, para cada estação apresentada. 110

Figura 43f: Ciclo sazonal da concentração mensal de ozônio, em cada ano, para cada estação apresentada. 111

Figura 44: Comportamento sazonal médio da radiação solar na RMSP $\left(\mathrm{W} / \mathrm{m}^{2}\right)$ (curva azul com losangos em laranja) e da concentração de $\mathrm{O}_{3}$ para as estações da RMSP com ciclo sazonal bem definido. 114

Figura 45: Comportamento sazonal médio da radiação solar na RMSP $\left(\mathrm{W} / \mathrm{m}^{2}\right)$ (curva azul com losangos em laranja) e da concentração de $\mathrm{O}_{3}$ para as estações da RMSP com ciclo sazonal diferente. 
Figura 46: Desvio padrão da concentração média diária de $\mathrm{O}_{3}$ para cada estação de monitoramento da RMSP. O valor médio igual a $14,30 \mu \mathrm{g} / \mathrm{m}^{3}$ está indicado pela linha.

Figura 47a: Concentração média diária de $\mathrm{O}_{3}$ para as estações com baixa variabilidade. Os dados inválidos ou faltantes estão indicados em cor azul. ...... 120 Figura 47b: Concentração média diária de $\mathrm{O}_{3}$ para as estações com baixa variabilidade. Os dados inválidos ou faltantes estão indicados em cor azul. 121 Figura 48a: Concentração média diária de $\mathrm{O}_{3}$ para as estações com variabilidade mediana. Os dados inválidos ou faltantes estão indicados em cor azul. 123 Figura 48b: Concentração média diária de $\mathrm{O}_{3}$ para as estações com variabilidade mediana. Os dados inválidos ou faltantes estão indicados em cor azul. 124 Figura 49a: Concentração média diária de $\mathrm{O}_{3}$ para as estações com alta variabilidade. Os dados inválidos ou faltantes estão indicados em cor azul. 125 Figura 49b: Concentração média diária de $\mathrm{O}_{3}$ para as estações com alta variabilidade. Os dados inválidos ou faltantes estão indicados em cor azul. 126 Figura 49c: Concentração média diária de $\mathrm{O}_{3}$ para as estações com alta variabilidade. Os dados inválidos ou faltantes estão indicados em cor azul. 127

Figura 50: Ciclo diurno médio de ozônio das 17 estações na RMSP. 132

Figura 51: Ciclo diurno das médio das concentrações de NOx, estação Cerqueira César, de 12 de agosto a 09 de setembro de 1997. As barras representam o desvio padrão da média horária das concentrações em dias de sol e dias nublados. ... 133 Figura 52: Ciclo diurno de ozônio e $\mathrm{NO}_{2}$ para os dias 03 e 04 de fevereiro de 1998.

Figuras 53a e 53b: Ciclo diurno médio de radiação solar (1999-2001, azul) e da concentração de ozônio (1996-2005) para os meses de outubro e junho, nas estações Ibirapuera (vermelho) e Congonhas (amarelo). 136

Figura 54: Distribuição anual do número de anomalias das concentrações de $\mathrm{O}_{3}$ com valor superior a $1 \sigma$. 147

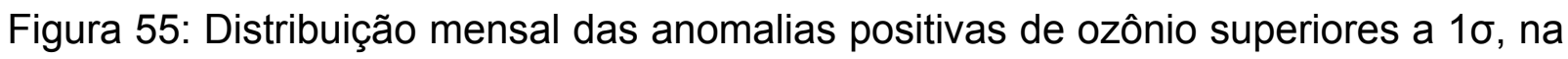
série 1996-2005, considerando as 17 estações. 148

Figura 56: Distribuição anual do número de anomalias das concentrações de $\mathrm{O}_{3}$ com valor inferior $a-1 \sigma$. 154 
Figura 57: Distribuição mensal das anomalias positivas de ozônio superiores a $1 \sigma$, na série 1996-2005, considerando as 17 estações.

Figura 58: Série temporal das anomalias mensais de ozônio, de radiação solar de ondas curtas e umidade relativa. 158

Figura 59: Série Temporal de anomalias das concentrações de $\mathrm{O}_{3}$, considerando as 17 estações. Os meses escolhidos para análise dos padrões atmosféricos estão indicados pelas setas azuis e vermelhas. 159

Figura 60: Atuação das frentes frias no litoral do Brasil, abril de 1998. A cidade de Santos está destacada como representante mais próxima da RMSP. 162

Figura 61a: Umidade relativa e específica do ar em abril de 1998 e suas respectivas anomalias. 163

Figura 61b: Radiação solar de ondas curtas e ROL em abril de 1998 e suas respectivas anomalias. 164

Figura 61c: Temperatura do ar e pressão atmosférica em abril de 1998 e suas respectivas anomalias. 165

Figura 61d: Escoamento atmosférico e sentido do vento em abril de 1998 e sua respectiva anomalia. 166

Figura 61e: Divergência do ar em superfície e altitude em abril de 1998 e suas respectivas anomalias. 167

Figura 62: Atuação das frentes frias no litoral do Brasil, julho de 2005. A cidade de Santos está destacada como representante mais próxima da RMSP. 169

Figura 63a: Umidade relativa e específica do ar em julho de 2005 e suas respectivas anomalias.

Figura 63b: Radiação solar de ondas curtas e ROL em julho de 2005 e suas respectivas anomalias.

Figura 63c: Temperatura do ar e pressão atmosférica em julho de 2005 e suas respectivas anomalias. 172

Figura 63d: Escoamento atmosférico e sentido do vento em julho de 2005 e sua respectiva anomalia.

Figura 63e: Divergência do ar em superfície e altitude em julho de 2005 e suas respectivas anomalias. 174

Figura 64: Atuação das frentes frias no litoral do Brasil, novembro de 1997. A cidade de Santos está destacada como representante mais próxima da RMSP. 175 
Figura 65: Posicionamento da ZCAS no litoral do Sudeste (canal infravermelho), em 18 de novembro de 1997.

Figura 66a: Umidade relativa do ar em novembro de 1997 e a anomalia observada.

Figura 66b: Radiação solar de ondas curtas e ROL em novembro de 1997 e suas respectivas anomalias. 178

Figura 66c: Temperatura do ar e pressão atmosférica em novembro de 1997 e suas respectivas anomalias.

Figura 66d: Escoamento atmosférico e sentido do vento em novembro de 1997 e sua respectiva anomalia.

Figura 66e: Divergência do ar em superfície e altitude em novembro de 1997 e suas respectivas anomalias. 180

Figura 67: atuação das frentes frias no litoral do Brasil, janeiro de 2004. A cidade de Santos está destacada como representante mais próxima da RMSP. 181

Figura 68: Posicionamento da ZCAS no litoral do Sudeste (temperatura de brilho), em 25 de janeiro de 2004 182

Figura 69: Anomalia de precipitação no Brasil, em janeiro de 2004. 183

Figura 70a: Umidade relativa do ar em janeiro de 2004 e a anomalia observada.184 Figura 70b: Radiação solar de ondas curtas e ROL em Janeiro de 2004 e suas respectivas anomalias. 185

Figura 70c: Temperatura do ar e pressão atmosférica em janeiro de 2004 e suas respectivas anomalias. 186

Figura 70d: Escoamento atmosférico e sentido do vento em janeiro de 2004 e sua respectiva anomalia.

Figura 70e: Divergência do ar em superfície e altitude em janeiro de 2004 e suas respectivas anomalias. 188

Figura 71: atuação das frentes frias no litoral do Brasil, agosto de 1999. A cidade de Santos está destacada como representante mais próxima da RMSP. 190

Figura 72a: Umidade relativa e específica do ar em agosto de 1999 e suas respectivas anomalias.

Figura 72b: Radiação solar de ondas curtas e ROL em agosto de 1999 e suas respectivas anomalias. 
Figura 72c: Temperatura do ar e pressão atmosférica em agosto de 1999 e suas respectivas anomalias.

Figura 72d: Escoamento atmosférico e sentido do vento em agosto de 1999 e sua respectiva anomalia.

Figura 72e: Divergência do ar em superfície e altitude em agosto de 1999 e suas respectivas anomalias.

Figura 73: atuação das frentes frias no litoral do Brasil, março de 2002. A cidade de Santos está destacada como representante mais próxima da RMSP. 197

Figura 74a: Umidade relativa e específica do ar em março de 2002 e suas respectivas anomalias. 198

Figura 74b: Radiação solar de ondas curtas e ROL em março de 2002 e suas respectivas anomalias.

Figura 74c: Temperatura do ar e pressão atmosférica em março de 2002 e suas respectivas anomalias. 200

Figura 74d: Escoamento atmosférico e sentido do vento em março de 2002 e sua respectiva anomalia.

Figura 74e: Divergência do ar em superfície e altitude em março de 2002 e suas respectivas anomalias. 202

Figura 75: atuação das frentes frias no litoral do Brasil, fevereiro de 2003. A cidade de Santos está destacada como representante mais próxima da RMSP. 203

Figura 76 : Atuação dos VCANs sobre o Brasil em fevereiro de 2003. 205 Figura 77: posicionamento da alta da Bolívia na América do Sul em fevereiro de 2003. 205

Figura 78a: Umidade relativa e específica do ar em fevereiro de 2003 e suas respectivas anomalias. 206

Figura 78b: Radiação solar de ondas curtas e ROL em fevereiro de 2003 e suas respectivas anomalias. 207

Figura 78c: Temperatura do ar e pressão atmosférica em fevereiro de 2003 e suas respectivas anomalias 208

Figura 78d: Escoamento atmosférico e sentido do vento em fevereiro de 2003 e sua respectiva anomalia. 209

Figura 78e: Divergência do ar em superfície e altitude em fevereiro de 2003 e suas respectivas anomalias. 
Figura 79: Atuação das frentes frias no litoral do Brasil, outubro de 2002. A cidade de Santos está destacada como representante mais próxima da RMSP. 212

Figura 80: Precipitação diária na RMSP no mês de outubro de 2002. 213

Figura 81a: Umidade relativa do ar em outubro de 2002 e a anomalia observada.214 Figura 81b: Radiação solar de ondas curtas e ROL em outubro de 2002 e suas respectivas anomalias. 214

Figura 81c: Temperatura do ar e pressão atmosférica em outubro de 2002 e suas respectivas anomalias. 215

Figura 81d: Escoamento atmosférico e sentido do vento em outubro de 2002 e sua respectiva anomalia.

Figura 81e: Divergência do ar em superfície e altitude em outubro de 2002 e suas respectivas anomalias.

Figura 82: atuação das frentes frias no litoral do Brasil, Janeiro de 2001. A cidade de Santos está destacada como representante mais próxima da RMSP. 219

Figura 83: Precipitação na RMSP em janeiro de 2001. 220

Figura 84: Temperatura de brilho media da América do Sul nos dias 05 e 10 de janeiro de 2001, evidenciando a ocorrência da ZCAS.

Figura 85a: Umidade relativa do ar em janeiro de 2001 e anomalia observada. 221 Figura 85b: Radiação solar de ondas curtas e ROL em janeiro de 2001 e suas respectivas anomalias.

Figura 85c: Temperatura do ar e pressão atmosférica em janeiro de 2001 e suas respectivas anomalias.

Figura 85d: Escoamento atmosférico e sentido do vento em janeiro de 2001 e sua respectiva anomalia.

Figura 85e: Divergência do ar em superfície e altitude em janeiro e 2001 e suas respectivas anomalias. 225

Figura 86: Atuação das frentes frias no litoral do Brasil, abril de 2000. A cidade de Santos está destacada como representante mais próxima da RMSP. 227

Figura 87: Precipitação na RMSP em abril de 2000...................................... 228

Figura 88: Anomalia de precipitação na região SE do Brasil em abril de $2000 \ldots 228$ Figura 89a: Umidade relativa do ar em abril de 2000 e anomalia observada. .... 229 Figura 89b: Radiação solar de ondas curtas e ROL em março de 2002 e suas respectivas anomalias. 230 
Figura 89c: Temperatura do ar e pressão atmosférica em abril de 2000 e suas respectivas anomalias.

Figura 89d: Escoamento atmosférico e sentido do vento em abril de 2000 e sua respectiva anomalia.

Figura 89e: Divergência do ar em superfície e altitude em abril de 2000 e suas respectivas anomalias.

Figura 90: Série temporal de anomalias de ozônio, destacando os meses de classe 2 (azul escuro) associados aos meses anteriores com anomalias negativas (azul claro).

Figura 91: série temporal mensal de anomalias de ozônio, destacando meses com anomalias negativas (verde) e positivas (vermelho) de radiação solar em que não foram observadas anomalias de ozônio acima de 2DP. 235 Figura 92a: Médias diárias de ozônio troposférico e umidade relativa em abril de 1998. Os dias de passagem frontal estão identificados pela seta. 240 Figura 92b: Médias diárias de ROL e temperatura do ar em abril de 1998. Os dias de passagem frontal estão identificados pela seta.

Figura 92c: Médias diárias de pressão atmosférica e velocidade do vento em abril de 1998. Os dias de passagem frontal estão identificados pela seta. 242

Figura 92d: Médias diárias de radiação solar e precipitação diária em abril de 1998. Os dias de passagem frontal estão identificados pela seta. 243 Figura 92e: Médias diárias de ozônio troposférico, radiação solar, ROL e pressão atmosférica em abril de 1998.

Figura 93a: Médias diárias de ozônio troposférico e umidade relativa em julho de 2005. Os dias de passagem frontal estão identificados pela seta. 248

Figura 93b: Médias diárias de ROL e temperatura do ar em julho de 2005. Os dias de passagem frontal estão identificados pela seta. 249

Figura 93c: Médias diárias de pressão atmosférica e velocidade do vento em julho de 2005. Os dias de passagem frontal estão identificados pela seta. 250

Figura 93d: Médias diárias de radiação solar e precipitação diária em julho de 2005. Os dias de passagem frontal estão identificados pela seta.

Figura 93e: Médias diárias de ozônio troposférico, radiação solar, ROL e pressão atmosférica em julho de 2005. 252 
Figura 94a: Evolução mensal de sentido e velocidade do vento nas estações Ibirapuera e Mooca no mês de julho de 2005. A linha pontilhada marca os dias de passagem de sistema frontal 253

Figura 94b: Evolução mensal de sentido e velocidade do vento nas estações Pinheiros, Santana, e Santo Amaro no mês de julho de 2005. A linha pontilhada marca os dias de passagem de sistema frontal.

Figura 94c: evolução mensal de sentido e velocidade do vento nas estação São Caetano do Sul no mês de julho de 2005. A linha pontilhada marca os dias de passagem de sistema frontal

Figura 95a: Médias diárias de ozônio troposférico e umidade relativa em agosto de 1999. Os dias de passagem frontal estão identificados pela seta. 259

Figura 95b: Médias diárias de ROL e temperatura do ar em agosto de 1999. Os dias de passagem frontal estão identificados pela seta. 260

Figura 95c: Médias diárias de pressão atmosférica e velocidade do vento em agosto de 1999. Os dias de passagem frontal estão identificados pela seta.

Figura 95d: Médias diárias de radiação solar e precipitação diária em agosto de 1999. Os dias de passagem frontal estão identificados pela seta. 262

Figura 95e: Médias diárias de ozônio troposférico, radiação solar, ROL e pressão atmosférica em agosto de 1999. 263

Figura 96a: evolução das sentido e velocidade do vento nas estações Ibirapuera e Osasco de 1 a 16 de agosto de 1999. A linha pontilhada marca os dias de passagem de sistema frontal. 264

Figura 96b: evolução mensal de sentido e velocidade do vento na estação Parque D. Pedro II, de 1 a 16 de agosto de 1999. A linha pontilhada marca os dias de passagem de sistema frontal. 265

Figura 96c: evolução mensal de direção e velocidade do vento nas estações Ibirapuera e Osasco de 17 a 1 de setembro de 1999. A linha pontilhada marca os dias de passagem de sistema frontal. 266 Figura 96d: evolução mensal de direção e velocidade do vento na estação Parque D. Pedro II, de 17 de agosto a 1 de setembro de 1999. A linha pontilhada marca os dias de passagem de sistema frontal. 267

Figura 97a: Médias diárias de ozônio troposférico e umidade relativa em março de 2002. Os dias de passagem frontal estão identificados pela seta. 
Figura 97b: Médias diárias de ROL e temperatura do ar em março de 2002. Os dias de passagem frontal estão identificados pela seta.

Figura 97c: Médias diárias de pressão atmosférica e velocidade do vento março de 2002. Os dias de passagem frontal estão identificados pela seta.

Figura 97d: Médias diárias de radiação solar e precipitação diária em março de 2002.

Os dias de passagem frontal estão identificados pela seta.

Figura 97e: Médias diárias de ozônio troposférico, radiação solar, ROL e pressão atmosférica em março de 2002.

Figura 98a: Evolução temporal de sentido e velocidade do vento nas estações Mooca, Parque D. Pedro II no mês de março de 2002. A linha pontilhada marca os dias de passagem de sistema frontal 275

Figura 98b: Evolução temporal de sentido e velocidade do vento nas estações Santana, São Caetano do Sul e São Miguel Paulista no mês de março de 2002. A linha pontilhada marca os dias de passagem de sistema frontal. 276 Figura 98c: Evolução temporal de sentido e velocidade do vento na estação Santo André - Capuava no mês de março de 2002. A linha pontilhada marca os dias de passagem de sistema frontal 277

Figura 99a: Médias diárias de ozônio troposférico e umidade relativa em fevereiro de 2003. Os dias de passagem frontal estão identificados pela seta. 281

Figura 99b: Médias diárias de ROL e temperatura do ar em fevereiro de 2003. Os dias de passagem frontal estão identificados pela seta. 282 Figura 99c: Médias diárias de pressão atmosférica e velocidade do vento em fevereiro de 2003. Os dias de passagem frontal estão identificados pela seta. 283 Figura 99d: Atuação dos VCANs na América do Sul no mês de fevereiro de 2003.284 Figura 99e: Médias diárias de radiação solar e precipitação diária em fevereiro de 2003. Os dias de passagem frontal estão identificados pela seta. 285

Figura 99f: Médias diárias de ozônio troposférico, radiação solar, ROL e pressão atmosférica em fevereiro de 2003 286

Figura 100a: evolução mensal de sentido e velocidade do vento nas estações Mooca e Parque D. Pedro II no mês de fevereiro de 2003. A linha marca os dias de passagem de sistema frontal 287 
Figura 100b: evolução mensal de sentido e velocidade do vento nas estações Santana, Santo Amaro e São Caetano do Sul no mês de fevereiro de 2003. A linha pontilhada marca os dias de passagem de sistema frontal. 288

Figura 100c: evolução mensal de sentido e velocidade do vento na estação São Miguel Paulista no mês de fevereiro de 2003. A linha pontilhada marca os dias de passagem de sistema frontal 


\section{Lista de tabelas}

Tabela 01: Fatores de emissão médios para veículos: 1983-1989 (g/km) .............5

Tabela 02: Fatores médios de emissão dos veículos em uso na RMSP em 2006 ... 5

Tabela 03: Balanço global médio de ozônio troposférico, em $\mathrm{Tg} \mathrm{O}_{3} / \mathrm{ano}^{-1} \ldots \ldots \ldots \ldots . . . .14$

Tabela 04: Estações medidoras utilizadas: configuração e localização ...................41

Tabela 05: Classificação das estações em termos de uso do solo e população

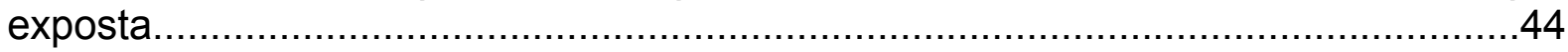

Tabela 06: Classificação das estações em termos de

representatividade..................................................................................... 45

Tabela 07 : Padrões Nacionais de Qualidade do Ar - Resolução CONAMA n 03, de

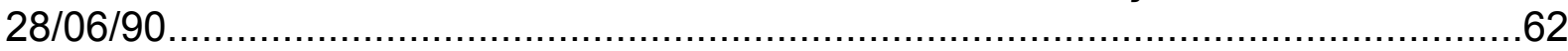

Tabela 08: Índices de qualidade do ar para os principais poluentes do ar segundo a CETESB.

Tabela 09: Principais poluentes do ar segundo a CETESB, índices de qualidade do ar e efeitos na saúde.

Tabela 10: Anos de início e término das séries temporais para cada estação da

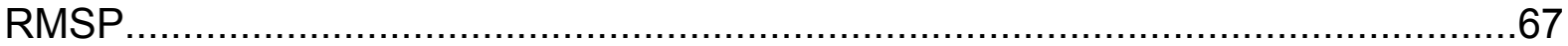

Tabela 11: Número de ultrapassagens do PQAr por ozônio na RMSP em cada mês,

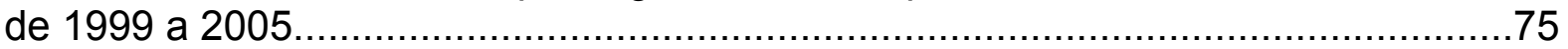

Tabela 12: Critério para classificação dos episódios mensais intensos de

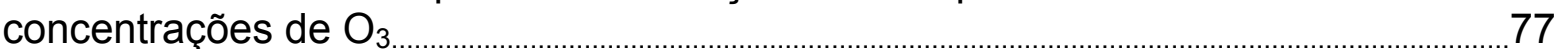

Tabela 13: Classificação das estações por faixa de concentração: baixa (azul), média (verde), alta (vermelho) e muito alta (marrom), em comparação com o desvio padrão médio espacial $(\sigma=3,99)$. 88

Tabela 14: Coeficiente angular da reta de tendência para as 17 estações avaliadas e seus respectivos períodos de avaliação. .95

Tabela 15: Divisão das estações de monitoramento de acordo com o desvio padrão médio da concentração diária de $\mathrm{O}_{3}$ na RMSP...............................................119

Tabela 16: Porcentagem de dados inválidos por ano em algumas estações da CETESB na RMSP. As quadrículas em azul indicam anos em que a estação esteve inativa. 128

Tabela 17: Características de exposição, ciclo sazonal e nível de concentração das estações da CETESB

Tabela 18: Meses com valor médio da anomalia de concentrações de $\mathrm{O}_{3}$ superiores a $1 \sigma$ do mês correspondente (classe 1 ). As anomalias mais intensas para o mês estão destacadas em vermelho e amarelo.

Tabela 19: Meses com valor médio da anomalia das concentrações de $\mathrm{O}_{3}$ superior a $2 \sigma$ do mês correspondente (classe 2 ).

Tabela 20: Anomalias climáticas nos meses em que foram registradas anomalias positivas de $\mathrm{O}_{3}$ superiores a $1 \sigma$.

Tabela 21: Meses com valor médio da anomalia das concentrações de $\mathrm{O}_{3}$ inferior a $1 \sigma$ do mês correspondente (classe -1 ).

Tabela 22:Meses com valor mensal da anomalia das concentrações de $\mathrm{O}_{3}$ inferiores a $-1,5 \sigma$ do mês correspondente (classe -2 ).

Tabela 23: Anomalias climáticas nos meses em que foram registradas anomalias positivas de $\mathrm{O}_{3}$ superiores a $1 \sigma$. 


\section{Introdução}

A segunda metade do século $X X$ representa uma época de profundas mudanças tecnológicas e sociais na história da humanidade. Após o final da $2^{a}$ Guerra Mundial, a produção tecnológica ocorre em um ritmo exponencialmente acelerado. Este momento de grande evolução tecnológica, em parte fomentado por questões políticas, leva também a avanços nas questões de saúde. Todo este quadro influencia positivamente o crescimento populacional no globo, que foi acompanhado também por uma crescente urbanização desta população em ascensão.

As cidades, já consolidadas como centros políticos, científicos, financeiros, e populacionais da vida humana, já ofereciam acesso a estes avanços tecnológicos que levam a uma melhoria da qualidade de vida de sua população. Assim, buscas por melhores condições de vida por parte das populações rurais, que incluem questões como acessibilidade, saúde, transporte, emprego, consumo, entre outras, levaram ao início do fenômeno conhecido como Éxodo Rural (CARAMANO E ABRAMOVAY, 1999), que consiste na saída em massa dos habitantes das zonas rurais em direção às zonas urbanas, onde freqüentemente desempenham o papel de mão-de-obra extra desqualificada ou recorrem à informalidade. Um contingente populacional cada vez maior migrava para as cidades, de forma que a população urbana mundial experimentou um crescimento ininterrupto desde essa época. Claramente, este fenômeno se deu de maneiras diferenciadas conforme a região do globo (ONU, 2004).

Assim, a cidade começou a atrair progressivamente a atenção de pesquisadores de diversas áreas, a fim de estudar e analisar seus diferentes aspectos; dentre eles, o social e o ambiental. Tornou-se então essencial investigar o meio ambiente urbano, onde vivem hoje mais da metade dos mais de 6 bilhões de seres humanos. Esta situação se agrava particularmente nos países em desenvolvimento, como o Brasil. Estes países possuem muitas das maiores metrópoles do mundo, que são também as que apresentam as piores condições sócio-ambientais, com problemas crônicos (a porcentagem da população urbana/rural no Brasil é de $85 \% / 15 \%$ - segundo a ONU em 2004). Assim, os 
problemas ambientais das regiões urbanas tornam-se assunto de importância bastante significativa, em especial nos países em desenvolvimento, uma vez que são capazes de influenciar negativamente a qualidade de vida da maior parte da população mundial, incluindo a brasileira.

A poluição atmosférica surge então neste contexto. Diversas atividades humanas incorporadas no cotidiano social e produtivo hoje têm como subproduto a emissão de substâncias à atmosfera, sejam gases ou partículas, sólidas ou líquidas, que são nocivas à saúde e ao meio ambiente. Estas atividades, ou fontes poluidoras, estão no cerne do desenvolvimento tecnológico-industrial que foi acelerado desde a metade do século $\mathrm{XX}$, e variam desde a utilização de solventes de tintas até grandes complexos de fábricas e frotas automotivas de cidades inteiras. Assim, o aumento das emissões de poluentes acompanhou o crescimento tecnológico e populacional, contextualizando o tema a ser explorado neste trabalho: a poluição atmosférica na região metropolitana de São Paulo - RMSP.

Sabe-se que existem diversos fatores que regulam o impacto dos poluentes do ar nas grandes metrópoles. Dentre eles, podemos citar alguns relacionados à dinâmica social, tais como o tamanho das cidades, suas características e ritmo; a taxa de emissão dos poluentes, que por sua vez é influenciada pela tecnologia disponível e pela implementação de leis que limitem ou reduzam estes valores; o uso do solo e o grau de exposição da população, também relacionado à distribuição espacial da poluição. Outros fatores, no entanto, dependem de processos e estados naturais, tais como as variações topográficas dentro da área urbana e de seu entorno, e a dinâmica da atmosfera, que por sua vez é determinada por fatores de diversas escalas, desde a circulação global até a altitude. Pode-se concluir então que a contaminação do ar nos grandes centros urbanos é um fenômeno bastante complexo, sujeito a diversas interferências, tanto provenientes do quadro natural quanto do social (MONTEIRO,1975). Isto será discutido com maior profundidade posteriormente.

Neste trabalho será avaliada a relação existente entre a dinâmica da atmosfera e as concentrações de ozônio troposférico na atmosfera da RMSP, devido 
à importância da primeira na regulação das concentrações dos últimos, através de processos atmosféricos que podem levar a um acúmulo ou dispersão dos poluentes no ar e seu transporte intra ou extra-urbano (CETESB, 2001; SÁNCHEZ-CCOYLLO et al, 2006, FRUEHAUF, 1998). Para melhor compreensão do fenômeno, será feita uma descrição generalizada de alguns compostos importantes, e em seguida uma descrição um pouco mais detalhada do ozônio troposférico.

Nesta seção, são descritos primeiramente os principais poluentes atmosféricos, suas origens e impactos no meio ambiente. Posteriormente, têm-se uma caracterização mais aprofundada do ozônio troposférico e do clima da RMSP, e por fim, são esclarecidos os objetivos do trabalho. 


\subsection{Os poluentes do ar e suas fontes}

A descrição metódica dos poluentes do ar sempre deve passar pelo crivo de interesse do estudo em questão, pois caso fossem levados em conta todos os compostos, sejam eles orgânicos, inorgânicos, sólidos, líquidos, naturais, antrópicos, etc., uma pretensa lista seria longuíssima, e ainda assim, incompleta (BRASSEUR et al, 1999). Por exemplo, de acordo com a Companhia de Tecnologia de Saneamento Ambiental do estado de São Paulo (CETESB), os poluentes atmosféricos podem ser definidos como "qualquer substância presente no ar que possa torná-lo impróprio, nocivo ou ofensivo à saúde; que seja inconveniente ao bem-estar público, danoso aos materiais, à fauna e à flora e prejudicial ao uso e gozo dos espaços públicos e atividades da comunidade ${ }^{1 "}$. Neste capítulo, serão descritos apenas alguns compostos de importância ambiental significativa nos grandes centros urbanos, e suas fontes.

As principais fontes antropogênicas de poluição hoje podem ser classificadas como fixas ou móveis. As fontes fixas constituem-se principalmente na atividade industrial e na queima de lixo. As fontes móveis incluem os automóveis leves e pesados e motocicletas que circulam em massa pelas grandes cidades; tais como a frota automotiva da RMSP, que atualmente correspondia a cerca de 7,5 milhões de veículos em 2006 (CETESB). Além do tamanho da frota, outra situação que agrava a emissão de poluentes na RMSP é a idade desta: $53 \%$ do total dos veículos é anterior a 1996. Devido à adoção de tecnologias cada vez mais limpas, e a níveis de exigência cada vez mais altos por parte dos órgãos de legislação ambiental e da sociedade, os fatores de emissão de poluentes vêm diminuindo com o tempo, de modo que os veículos mais antigos são significativamente mais poluidores que os novos. Fatores de emissão significam a quantidade de poluentes emitidos (em g) por quilômetro rodado; as tabelas 01 e 02 demonstram a evolução dos fatores, comparando valores da década de 80 com outros mais atuais:

\footnotetext{
${ }^{1}$ Companhia de Tecnologia de Saneamento Ambiental - CETESB, 2001. Relatório de Qualidade do Ar no Estado de São Paulo - 2000. Página 21.
} 
Tabela 01: Fatores de emissão médios para veículos: 1983-1989 (g/km).

\begin{tabular}{|c|c|c|c|c|c|c|}
\hline ANO/ & \multicolumn{3}{|c|}{ ÁLCOOL } & \multicolumn{3}{c|}{ GASOLINA C* } \\
\cline { 2 - 7 } MODELO & $\mathrm{CO}$ & $\mathrm{HC}$ & $\mathrm{NOx}$ & $\mathrm{CO}$ & $\mathrm{HC}$ & NOx \\
\hline Até 83 & 18 & 1,6 & 1,0 & 33 & 3,0 & 1,4 \\
\hline $85 / 85$ & 16,9 & 1,6 & 1,2 & 28 & 2,4 & 1,6 \\
\hline $86 / 87$ & 16 & 1,7 & 1,8 & 22 & 2,0 & 1,9 \\
\hline 88 & 13,3 & 1,6 & 1,4 & 18,5 & 1,7 & 1,8 \\
\hline 89 & 12,8 & 1,6 & 1,1 & 15,2 & 1,6 & 1,6 \\
\hline
\end{tabular}

${ }^{*}$ Composta por $22 \%$ de álcool anidro e $78 \%$ de Gasolina.

Fonte: CETESB, Relatório Anual da Qualidade do Ar do Estado de São Paulo 1990.

Tabela 02: Fatores médios de emissão dos veículos em uso na RMSP em 2006 $(\mathrm{g} / \mathrm{km})$.

\begin{tabular}{|c|c|c|c|c|c|}
\hline \multirow{2}{*}{$\begin{array}{c}\text { TIPO DE } \\
\text { VEÍCULO }\end{array}$} & CO & HC & NOx & SOx & MP \\
\cline { 2 - 6 } GASOLINA C & 10,83 & 1,12 & 0,74 & 0,08 & 0,08 \\
\hline ÁLCOOL & 19,80 & 2,12 & 1,28 & - & - \\
\hline $\begin{array}{c}\text { FLEX } \\
\text { (ÁLCOOL) }\end{array}$ & 0,48 & 0,14 & 0,09 & - & - \\
\hline DIESEL & 14,61 & 2,29 & 10,53 & 0,14 & 0,55 \\
\hline TÁXI & 0,80 & 0,44 & 0,90 & - & - \\
\hline $\begin{array}{c}\text { MOTOCICLETA } \\
\text { E SIMILARES }\end{array}$ & 14,61 & 1,94 & 0,12 & 0,02 & 0,05 \\
\hline
\end{tabular}

Fonte: CETESB, Relatório Anual da Qualidade do Ar do Estado de São Paulo 2006.

Comparando-se as tabelas, percebe-se que os fatores de emissão de veículos a gasolina sofreram acentuada redução desde a década de 80 , enquanto que os veículos a álcool, por outro lado, demonstraram evolução ou estabilidade dos fatores de emissão desde aquela década. No caso dos veículos a gasolina, a diminuição se deve principalmente ao Programa de Controle da Poluição do Ar por Veículos Automotores (PROCONVE), implementando em 1986 pela CETESB, que define limites máximos de emissão para veículos, diretamente limitando a emissão de poluentes. Os veículos a álcool, no entanto, são em sua maioria muito antigos, constituindo uma frota em crescente deterioração, o que compromete a eficiência dos motores e leva a fatores de emissão cada vez mais elevados. Felizmente, estes 
veículos correspondem a cerca de $15 \%$ da frota total de veículos leves na RMSP, como pode ser visto pela figura 01:

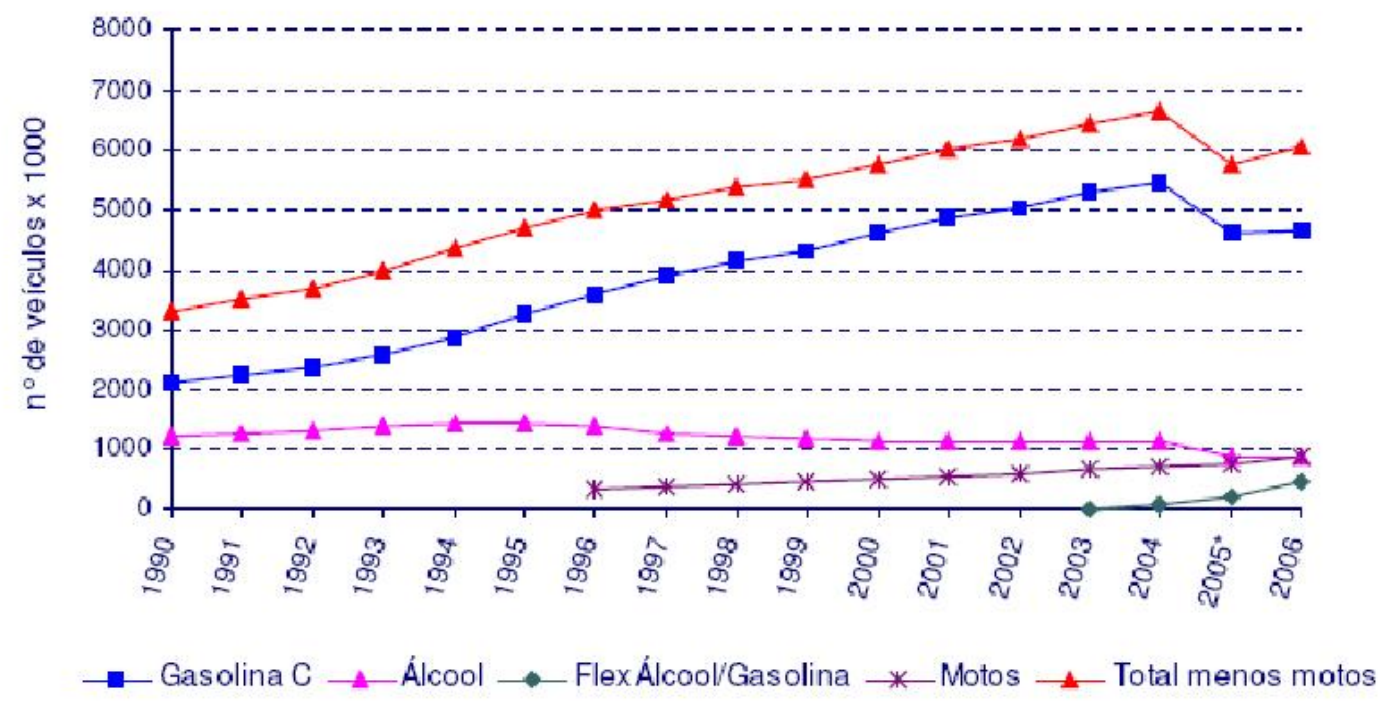

Figura 01: Evolução da frota de veículos leves na RMSP.

Fonte: CETESB, 2006.

* A redução do número de veículos registrados em 2005 se deve à atualização do banco de dados da PRODESP.

Outras fontes antropogênicas de poluentes incluem a queima de biomassa, como lenha, carvão, florestas, plantações e outros materiais orgânicos, que lançam grandes quantidades de COV na atmosfera. Estes também são emitidos por sprays e solventes de tintas. Além da emissão pelo escapamento, devido ao motor de combustão, há outras fontes provenientes dos veículos como emissão do cárter e evaporativa (dos óleos lubrificantes e dos combustíveis - HC) e desgaste dos pneus (partículas). Além disso, áreas próximas de grandes obras de construção civil tendem a apresentar alta concentração de material particulado. Fontes naturais de poluentes que freqüentemente interferem na composição atmosférica das cidades, em especial da RMSP, incluem a brisa marítima (que traz sais do oceano como o Sódio), e a ressuspensão de partículas do solo (Ferro, Alumínio), entre outras. Deste modo, pode-se concluir que as fontes de emissão de poluentes são muito variadas. No entanto, mais variada ainda é a miríade de compostos emitidos por elas, pois muitas vezes uma só fonte pode ser responsável pela emissão de diversos compostos, tais como os veículos automotores, por exemplo. 
Os poluentes emitidos diretamente de uma fonte são chamados primários; e os são formados a partir das reações dos poluentes com outros compostos ou variáveis ambientais (ex. umidade do ar) são denominados secundários. Quanto à sua origem, os poluentes podem ser orgânicos, ligados ao Carbono (C) e ao Hidrogênio $(\mathrm{H})$, como o Metano $\left(\mathrm{CH}_{4}\right)$. Eles são emitidos por processos biológicos, tais como a decomposição de matéria vegetal, no caso do composto escolhido. Os poluentes inorgânicos, obviamente, não possuem relação com tais processos (ex. Chumbo). De acordo com seu estado físico, também pode-se encontrar poluentes em estado sólido e líquido, chamados de aerossóis (ou partículas); existem muitos compostos gasosos ou na forma de vapor (espécies mais leves) (SEINFELD, 2006, BRASSEUR, 1999).

Os principais poluentes primários, sua origem e importância ambiental são:

- $\mathrm{SO}_{2}$ (dióxido de enxofre), produzido pela queima de carvão contendo pirita, da geração de eletricidade e da atividade industrial. Sua importância advém de reações com a umidade do ar, gerando outros compostos sulfurosos importantes para a chuva ácida, como o $\mathrm{SO}_{4}{ }^{-}$, e para o smog industrial (névoa esbranquiçada formada a partir de poluentes industriais em condições de alta umidade do ar e baixa temperatura) (BRASSEUR, 1999).

- $\mathrm{CO}$ (monóxido de carbono) e $\mathrm{CO}_{2}$ (dióxido de carbono), subprodutos principalmente da combustão do motor dos carros; têm como característica a absorção de energia radiante, que é transformada em calor. Os compostos de carbono são muito versáteis e podem reagir com uma infinidade de outros compostos. Combinando sua alta reatividade com a capacidade de absorção de radiação solar, são também parte do processo de formação do smog fotoquímico (névoa cinza-acastanhada formada por poluentes de diversas origens conjugados com a radiação solar, sob condições de alta irradiação, temperatura e estabilidade do ar - Finlayson-Pitts, 2000).

- COV (Compostos Orgânicos Voláteis), uma denominação comum para um grupo de compostos originários do uso de combustíveis fósseis, solventes de tinta e de alguns produtos de limpeza, que evaporam e entram no ar no estado de vapor, assim como "restos" de reações (oxidações incompletas) 
que ocorrem no motor dos carros. Na RMSP, as principais fontes destes poluentes são os veículos movidos à gasolina $\mathrm{C}$ e à diesel, tanto pelo escapamento quanto pela emissão do cárter (onde fica armazenado o óleo do carro) e por processos de evaporação destes combustíveis. Além disso, estão usualmente presentes na atmosfera em áreas caracterizadas pela prática regular de queimadas. São importantes agentes na formação do ozônio troposférico e do Dióxido de Nitrogênio (SEINFELD, 2006).

- Material Particulado (MP ou em inglês PM10), uma mistura complexa de partículas sólidas e líquidas suspensas e muitas vezes visíveis no ar, como restos de poeira, fumaça, pólen, solo e névoas. A composição das partículas varia de acordo com a sua origem, como já exemplificado acima. O Material Particulado pode carregar qualquer outro poluente dissolvido e/ou adsorvido em sua superfície. As partículas menores do que $10 \mu \mathrm{m}$ também podem ser chamadas de PI - Partículas Inaláveis, pois podem ser inaladas e por isso são nocivas ao sistema respiratório (CASTANHO, 1997). Além disso, podem ter efeitos ambientais ligados à supressão ou modificação das nuvens, tais como os mencionados nos estudos de ROSENFELD (2000), ARTAXO (2002, $2004)$ e KOREN et al. $(2002,2004)$.

- Hidrocarbonetos, fazem parte dos COV. São também diversos compostos contendo Hidrogênio e Carbono, emitidos tanto por processos envolvendo agentes orgânicos, como as "sobras" do metabolismo das plantas, como por fontes antropogênicas, como a queima incompleta ou evaporação de combustíveis fósseis e a produção de cimento. Os hidrocarbonetos também contribuem para a formação do ozônio troposférico e do PAN (um aldeído que influencia a formação de compostos fotoquímicos) (PEREIRA, 2004) .

- NO (óxido nítrico), emitido pela combustão do motor dos carros, é a base para formação do Dióxido de Nitrogênio $\left(\mathrm{NO}_{2}\right)$ (MOUVIER,1995).

Muitos poluentes secundários também possuem fortes impactos ambientais. Os poluentes secundários são aqueles formados a partir de reações dos poluentes entre si ou com elementos naturais, como a radiação solar, por exemplo. Alguns dos principais poluentes secundários, sua origem e importância ambiental são: 
- $\mathrm{H}_{2} \mathrm{SO}_{4}$ (ácido sulfúrico), gerado através de reações iniciadas pela oxidação do Enxofre $\left(\mathrm{SO}_{3}+\mathrm{H}_{2} \mathrm{O} \rightarrow \mathrm{H}_{2} \mathrm{SO}_{4}\right)$; partículas de sulfato na atmosfera aumentam o seu albedo, como, por exemplo, em grandes erupções vulcânicas (JACOB, 1999);

- $\mathrm{NO}_{2}$ (dióxido de nitrogênio), aparece como resultado da oxidação do NO numa reação que acontece dentro do motor do carro ou na atmosfera, após a liberação do NO. Conjugado com alguns fatores como a luz solar, é um dos principais precursores do $\mathrm{O}_{3}$ na troposfera e importante componente do smog fotoquímico (NARSTO,2000)

- $\quad \mathbf{O}_{3}$ (ozônio), é benéfico na estratosfera, por bloquear parte da radiação solar ultravioleta que é nociva à vida, mas que na troposfera é um agente extremamente tóxico. É geralmente utilizado para analisar compostos fotoquímicos de uma maneira geral (CETESB,2000). Foco deste trabalho, será descrito com mais detalhes adiante;

- $\mathrm{HNO}_{3}$ (ácido nítrico), formado pela oxidação de $\mathrm{NOx}\left(\mathrm{NO}\right.$ e $\left.\mathrm{NO}_{2}\right) \mathrm{com} \circ \mathrm{OH}$ (hidroxila). Um dos principais componentes da chuva ácida, ele se dissocia completamente em água, aumentando seu PH (CASTRO,1993);

- $\mathrm{OH}$ (hidroxila), formado pela fotólise - dissociação pela radiação solar do $\mathrm{O}_{3}$, caracterizado por baixa concentração na atmosfera, porém por altíssima reatividade. Possui uma posição de destaque, pois, sendo um dos principais agentes de oxidação da atmosfera, ele se liga a uma miríade de outros compostos $\left(\mathrm{NH}_{3}, \mathrm{NOx}, \mathrm{CO}\right.$, etc), dando origem a inúmeros outros compostos e reações. Considerado o "detergente" da atmosfera devido à sua importância de controle da capacidade oxidativa da atmosfera (BRASSEUR, 1999).

O tempo de vida de alguns poluentes pode ser visto na figura 02 : 


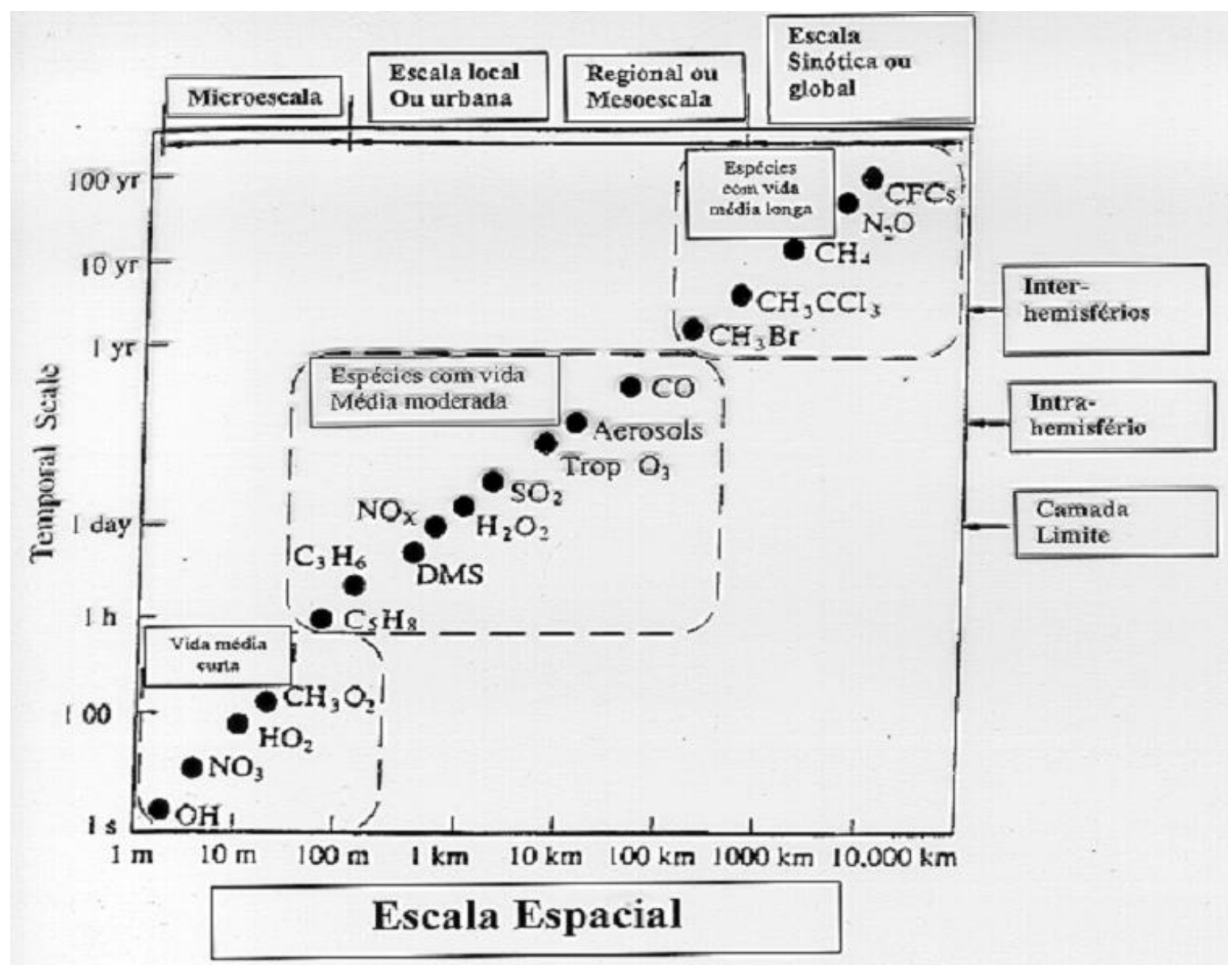

Figura 02: Tempo de residência e escala espacial de transporte alguns poluentes.

Fonte: Adaptado de Seinfeld et al, 1998.

Alguns dos poluentes do ar mais estudados atualmente, inclusive na RMSP, incluem o $\mathrm{SO}_{2}, \mathrm{MP}, \mathrm{CO}, \mathrm{NO}_{2}$ e $\mathrm{O}_{3}$. Para esses poluentes, a Companhia de Tecnologia de Saneamento Ambiental (CETESB) possui uma legislação vigente que define determinadas concentrações como sendo Padrões de Qualidade do $\mathrm{Ar}$ (PQAr); isto significa a existência de concentrações de poluentes que, se excedidas, causam efeitos adversos à saúde e ao meio ambiente. Eles serão explicados mais adiante com maior detalhe.

Atualmente, na RMSP, a maioria dos poluentes é mantida quase totalmente ou, ao menos, parcialmente controlada, principalmente os poluentes primários (CETESB, 2001, 2005, CHIQUETTO, 2005). Mas, para os poluentes secundários, a situação é bastante diferente, uma vez que este grupo de poluentes é formado na atmosfera, por meio de diversas interações que incluem os próprios poluentes primários, poluentes secundários, variáveis atmosféricas (radiação solar, 
temperatura, umidade, etc.), emissões naturais, entre outras. Dos poluentes secundários, um dos mais significativos na RMSP é o ozônio troposférico, cujas concentrações freqüentemente ultrapassam os PQAr, comprometendo a saúde da população que reside e circula na cidade (ANDRADE et al, 2004, CETESB, 2001; SOBRAL, 1997). Dentro deste contexto, podem ainda ser citados como exemplos os estudos sobre variabilidade climática, poluição do ar e saúde realizados por Gonçalves et al (2004), Moseholm et al (1993) e White et al (1993). Gonçalves et al realizaram um estudo sobre o efeito dos poluentes $\mathrm{SO}_{2}, \mathrm{MP}$ e $\mathrm{O}_{3}$ e as variáveis atmosféricas radiação de onda longa (ROL, relacionada à nebulosidade e pluviosidade), temperatura média, radiação solar e densidade do vapor de água sobre a mortalidade infantil, nos meses de verão, através da análise de componentes principais. Neste estudo, concluiu-se que nos meses de maior variabilidade climática (tais como a passagem de um sistema frontal de maior intensidade, dias seguidos com umidade relativa do ar baixa e temperaturas altas), esta era responsável pela maior parte dos casos de mortalidade; no entanto, nos meses em que a variabilidade climática não apontou grandes anomalias, sugeriu-se que a responsabilidade das mortes poderia ser atribuída aos efeitos nocivos da poluição atmosférica sobre a saúde humana. 


\subsection{0 ozônio troposférico}

Durante muito tempo, este gás não era reconhecido como uma substância em si, mas apenas como o "cheiro de eletricidade". Com os avanços da química no século XIX, foi possível detectar sua ocorrência e confirmar sua estrutura. Em 1839, o químico alemão Christian Friedrich Schönbein escreveu sobre um odor que acompanhava a eletrólise da água, e começou a pesquisar as condições de existência deste odor; descobrindo, posteriormente, que se tratava de um composto ligado ao oxigênio. Em 1865, Jacques Louis-Soret determinou sua composição (RUBIN, 2001).

No século XIX, o ozônio troposférico despertava muito interesse quando era, erroneamente, associado à trajetória de epidemias. A partir de 1930, medições em alguns locais do globo realizadas por cientistas já formavam alguns registros significativos de ozônio troposférico (como as do Pic du Midi, na França, entre 1874 e 1909), embora de forma pontual e com métodos ainda não tão precisos. Foi somente a partir da década de 1970 que se iniciou um esforço internacional conjunto para se compreender com maior profundidade sua ocorrência na troposfera, distribuição horizontal e vertical, sazonalidade, formação, destruição, etc.

Sua importância ambiental vem, em parte, de sua propriedade de ampla absorção de radiação, centrada em $9.6 \mu \mathrm{m}$, de modo que o $\mathrm{O}_{3}$ é considerado um gás estufa, particularmente na troposfera superior. Mais importante do que suas propriedades radiativas, contudo, é seu papel no equilíbrio químico da atmosfera. Embora seja apenas um gás traço em termos de quantidade, o ozônio e o $\mathrm{OH}$ (formado, na troposfera livre, pela fotodissociação do $\mathrm{O}_{3}$ e subsequente reação com o vapor d'água ${ }^{1}$ ) são os mais importantes agentes oxidantes da troposfera, sendo responsáveis pela remoção da maioria dos gases reduzidos como $\mathrm{CO}, \mathrm{HC}$ e a maioria dos compostos sulfurosos e nitrosos (SEIFELD, 2006).

$\mathrm{Na}$ troposfera de ambientes naturais, as formação do $\mathrm{O}_{3}$ ocorre principalmente por um conjunto de reações envolvendo reações com a radiação

\footnotetext{
${ }^{1} \mathrm{O}_{3}+\mathrm{hv} \rightarrow \mathrm{O}_{2}+\mathrm{O}\left({ }^{1} \mathrm{D}\right)$

$\mathrm{O}\left({ }^{1} \mathrm{D}\right)+\mathrm{M} \rightarrow \mathrm{O}+\mathrm{M}$

$\mathrm{H}_{2} \mathrm{O}+\mathrm{O} \rightarrow 2 \mathrm{OH}(\mathrm{JACOB}, 1999)$
} 
solar ( $h v, \lambda<420 \mathrm{~nm}$ ) e radicais peróxidos com o $\mathrm{NO}$, dentro do ciclo natural dos NOx (JACOB, 1999):

$$
\mathrm{HO}_{2}+\mathrm{NO} \rightarrow \mathrm{OH}+\mathrm{NO}_{2}
$$

ou

$$
\mathrm{CH}_{3} \mathrm{O}_{2}+\mathrm{NO} \rightarrow \mathrm{CH}_{3} \mathrm{O}+\mathrm{NO}_{2}
$$

Dando origem a

$$
\mathrm{NO}_{2}+h v+\mathrm{O}_{2} \rightarrow \mathrm{NO}+\mathrm{O}_{3}
$$

O ozônio pode então ser consumido pelo NO

$$
\mathrm{NO}+\mathrm{O}_{3} \rightarrow \mathrm{NO} 2+\mathrm{O} 2
$$

Ou pode originar radicais $\mathrm{OH}$ através da fotodissociação e reação com o vapor d'água, conforme descrito anteriormente.

$\mathrm{Na}$ troposfera superior, a produção de $\mathrm{O}_{3}$ se dá pela oxidação do $\mathrm{CO}$

$$
\begin{aligned}
& \mathrm{OH}+\mathrm{CO} \rightarrow \mathrm{CO}_{2}+\mathrm{H} \\
& \mathrm{H}+\mathrm{O}_{2}+M \rightarrow \mathrm{HO}_{2}+M \\
& \mathrm{HO}_{2}+\mathrm{NO} \rightarrow \mathrm{OH}+\mathrm{NO}_{2} \\
& \mathrm{NO}_{2}+h v \rightarrow \mathrm{NO}+\mathrm{O} \\
& \mathrm{O}+\mathrm{O}_{2}+M \rightarrow \mathrm{O}_{3}+M
\end{aligned}
$$

e do metano $\left(\mathrm{CH}_{4}\right)$ (BRASSEUR, 1999)

$$
\begin{aligned}
& \mathrm{OH}+\mathrm{CH}_{4} \rightarrow \mathrm{CH}_{3}+\mathrm{H}_{2} \mathrm{O} \\
& \mathrm{CH}_{3}+\mathrm{O}_{2}+\mathrm{M} \rightarrow \mathrm{CH}_{3} \mathrm{O}_{2}+\mathrm{M} \\
& \mathrm{CH}_{3} \mathrm{O}_{2}+\mathrm{NO} \rightarrow \mathrm{CH}_{3} \mathrm{O}+\mathrm{NO}_{2} \\
& \mathrm{CH}_{3} \mathrm{O}+\mathrm{O}_{2} \rightarrow \mathrm{HO}_{2}+\mathrm{CH}_{2} \mathrm{O} \\
& \mathrm{HO}_{2}+\mathrm{NO} \rightarrow \mathrm{OH}+\mathrm{NO}_{2} \\
& \mathrm{NO}_{2}+h v \rightarrow \mathrm{NO}+\mathrm{O}
\end{aligned}
$$




$$
\mathrm{O}+\mathrm{O}_{2}+M \rightarrow \mathrm{O}_{3}+M
$$

Pode-se perceber que, em ambientes naturais, há um ciclo do ozônio que regula sua formação e consumo, inserido dentro da química da troposfera. As quantidades de ozônio são reguladas dentro do ciclo de outros poluentes, incluindo o $\mathrm{OH}$ e o NOx. Devido à maior disponibilidade de NOx no Hemisfério Norte, poderiase esperar uma concentração de fundo de $\mathrm{O}_{3}$ mais alta neste continente. Por outro lado, a deposição seca do ozônio é mais rápida sobre a terra do que nos oceanos, assim, impede-se que ele se acumule a níveis alarmantes, uma vez que a extensão de terras emersas no Hemisfério Norte é muito maior. De uma maneira geral, no HN há maiores quantidades deste poluente do que no $\mathrm{HS}$, devido às emissões industriais generalizadas. Embora a velocidade de deposição seca sobre a terra seja maior, ela diminui consideravelmente sobre a vegetação sem folhas e com baixa atividade biológica, contribuindo para o transporte do $\mathrm{O}_{3}$ no inverno. No Hemisfério Sul, menos ozônio é produzido, mas o fato da maior parte das emissões ocorrerem em latitudes tropicais, com ampla disponibilidade de radiação solar, pode levar à uma diferença meridional muito maior do que no $\mathrm{HN}$. De qualquer forma, os processos químicos e fotoquímicos dominam o balanço global médio do ozônio troposférico, como pode ser visto na tabela 03:

Tabela 03: Balanço global médio de ozônio troposférico, em $\mathrm{Tg} \mathrm{O}_{3} / a n o$

\begin{tabular}{|l|c|}
\hline \multicolumn{1}{|c|}{ FONTES* $^{*}$} & $3400-7500$ \\
\hline -FORMAÇÃO QUÍMICA IN SITU & $3000-4600$ \\
\hline -TRANSPORTE DA ESTRATOSFERA & $400-1100$ \\
\hline SORVEDOUROS & $3400-7500$ \\
\hline -CONSUMO QUÍMICO IN SITU & $3000-4200$ \\
\hline -DEPOSIÇÃO SECA & $500-1500$ \\
\hline
\end{tabular}

Fonte: JACOB, 1999.

Analisando a tabela 03, pode-se perceber que a produção química de ozônio troposférico em superfície supera o transporte da estratosfera por um fator duas a dez vezes maior. Em se tratando dos sorvedouros de $\mathrm{O}_{3}$ troposférico, as reações químicas na troposfera também são responsáveis pelo seu consumo, de duas a oito vezes mais eficientemente, do que a deposição seca. Claramente, estes valores 
variam de acordo com as características da região considerada. Em termos de distribuição meridional global média, há menos $\mathrm{O}_{3}$ nos trópicos em relação às regiões de latitudes médias, devido à destruição fotoquímica e distribuição vertical mais eficientes e menor interferência estratosférica.

A maior parte das medições deste poluente são realizadas no $\mathrm{HN}$, o que permite conhecer com maior certeza o comportamento deste poluente em superfície em diversos ambientes naquele hemisfério. Por exemplo, segundo BRASSEUR, em 1999, há uma variação sazonal bem definida em latitudes médias no $\mathrm{HN}$, onde a razão de mistura do $\mathrm{O}_{3}$ é $25-50 \%$ maior na primavera-verão do que no outono e inverno devido à maior produção fotoquímica. Esse fator, por sua vez, é maior neste período devido à interação de maior disponibilidade de radiação solar e emissões antropogênicas de áreas urbanizadas e industrializadas, que são também mais numerosas e melhor distribuídas no HN do que no HS. Este ciclo sazonal também é observado nas latitudes médias do HS, embora de forma menos evidente. Uma hipótese levantada por Liu et al (1987) é a de que este máximo na primavera ocorre devido à acumulação dos precursores do $\mathrm{O}_{3}$ no inverno, associada ao maior tempo de residência do $\mathrm{O}_{3}$ no inverno, devido à menor destruição fotoquímica. Enquanto na troposfera do $\mathrm{HN}$ as emissões dos precursores seriam majoritariamente originárias de atividades industriais, no HS elas seriam derivadas da queima de biomassa na África e América do Sul durante a estação seca (inverno), com um máximo no período setembro-novembro.

O tempo de residência do ozônio troposférico na troposfera é de cinco dias a algumas semanas no verão, mas pode chegar a até mais de três meses no inverno em latitudes médias, devido à menor atividade fotoquímica e menor velocidade de deposição sobre vegetação sem folhas.

Nos últimos anos, vem ocorrendo um aumento generalizado deste poluente na troposfera, devido às contínuas emissões de NOx e COV por atividades humanas que interferem no ciclo natural dos constituintes atmosféricos (BRASSEUR, 1999, SEINFELD, 2006, JACOB, 1999, MOUVIER, 1995). 


\subsubsection{O ozônio troposférico nos grandes centros urbanos}

Na seção anterior, foram levantados alguns pontos sobre a distribuição global do $\mathrm{O}_{3}$ troposférico e sua variação sazonal. Mas este quadro é significativamente diferente quando se analisa as concentrações de ozônio troposférico observadas em grandes centros urbanos ou em áreas próximas a elas.

$\mathrm{Na}$ América do Norte, a concentração de $\mathrm{O}_{3}$ em áreas não-urbanas normalmente gira em torno de $40 \mathrm{ppb}$. No entanto, em áreas densamente urbanizadas, caracterizadas por uso do solo industrial e com intenso tráfego de veículos, com alta concentração de NOx e COV emitidos por estas atividades, as concentrações de $\mathrm{O}_{3}$ na troposfera podem ultrapassar de longe este valores, atingindo valores de mais de 100 ppb. Em episódios de poluição agudos, as concentrações podem chegar a mais de 200 ppb. A mais alta concentração deste gás já medidas foi de 680 ppb na região metropolitana de Los Angeles, em 1955, num episódio trágico e memorável de smog fotoquímico (NARSTO, 2000).

Quando presente em alta concentração em superfície, o $\mathrm{O}_{3}$ torna-se um poluente de grande importância ambiental, justamente por sua capacidade altamente oxidante, que acaba por ter efeitos nocivos à saúde da população, aos vegetais, ecossistemas e materiais.

Como visto anteriormente, a produção e o consumo de $\mathrm{O}_{3}$ são regidos pelas quantidades de alguns compostos na troposfera, no caso dos grandes centros urbanos, em especial os NOx. Em grandes centros urbanos, onde a composição atmosférica local é alterada devido à emissão de diversas substâncias poluidoras que degradam a qualidade do ar, a produção do $\mathrm{O}_{3}$ troposférico é regida por complexas interações entre seus precursores e outros fatores ambientais. Além de maiores concentrações de NOx devido a emissões diretas, estes locais também apresentam alta concentração de COV (seção 1.1). Estes compostos, além de serem poluentes do ar em si, também influenciam na produção de mais $\mathrm{O}_{3}$, pois, através da oxidação do $\mathrm{NO}$, geram mais $\mathrm{NO}_{2}$, que por fotodissociação, leva a um aumento na produção de ozônio, como exemplificado anteriormente. No conjunto de 
equações abaixo, RH significa qualquer HC não-metano, $\mathrm{R}$ uma seqüência de HCs e $M$ significa um terceiro composto qualquer $\left(\mathrm{N}_{2}, \mathrm{O}_{2}\right)$ :

$$
\begin{aligned}
& \mathrm{OH}+\mathrm{RH} \rightarrow \mathrm{R}+\mathrm{H}_{2} \mathrm{O} \\
& \mathrm{R}+\mathrm{O}_{2}+M \rightarrow \mathrm{RO}_{2}+M \\
& \mathrm{RO}_{2}+\mathrm{NO} \rightarrow \mathrm{RO}+\mathrm{NO}_{2} \\
& \mathrm{RO}+\mathrm{O}_{2} \rightarrow \mathrm{HO}_{2}+\text { carbonil } \\
& \mathrm{HO}_{2}+\mathrm{NO} \rightarrow \mathrm{OH}+\mathrm{NO}_{2} \\
& 2 \times\left(\mathrm{NO}_{2}+h v \rightarrow \mathrm{NO}+\mathrm{O}\right) \\
& 2 \times\left(\mathrm{O}+\mathrm{O}_{2}+\mathrm{M} \rightarrow \mathrm{O}_{3}+M\right)
\end{aligned}
$$

Este esquema de produção do $\mathrm{O}_{3}$, a partir de NOx e COV na presença da luz solar, foi concebido por Haagen-Smit em 1952, quando estudava o smog fotoquímico em Los Angeles. Ele identificou o ozônio, os óxidos nitrosos, os aldeídos, hidrocarbonetos e o peroxiacetilnitrato (PAN) como os principais componentes do smog fotoquímico, além de alta concentração de material particulado, que lhe confere a característica de reduzir a visibilidade. Assim, o ozônio troposférico pode ser detectado em parte por este fenômeno, que forma uma bruma cinza-acastanhada sobre as cidades, facilmente reconhecível (COLBECK e MACKENZIE, 1994): 


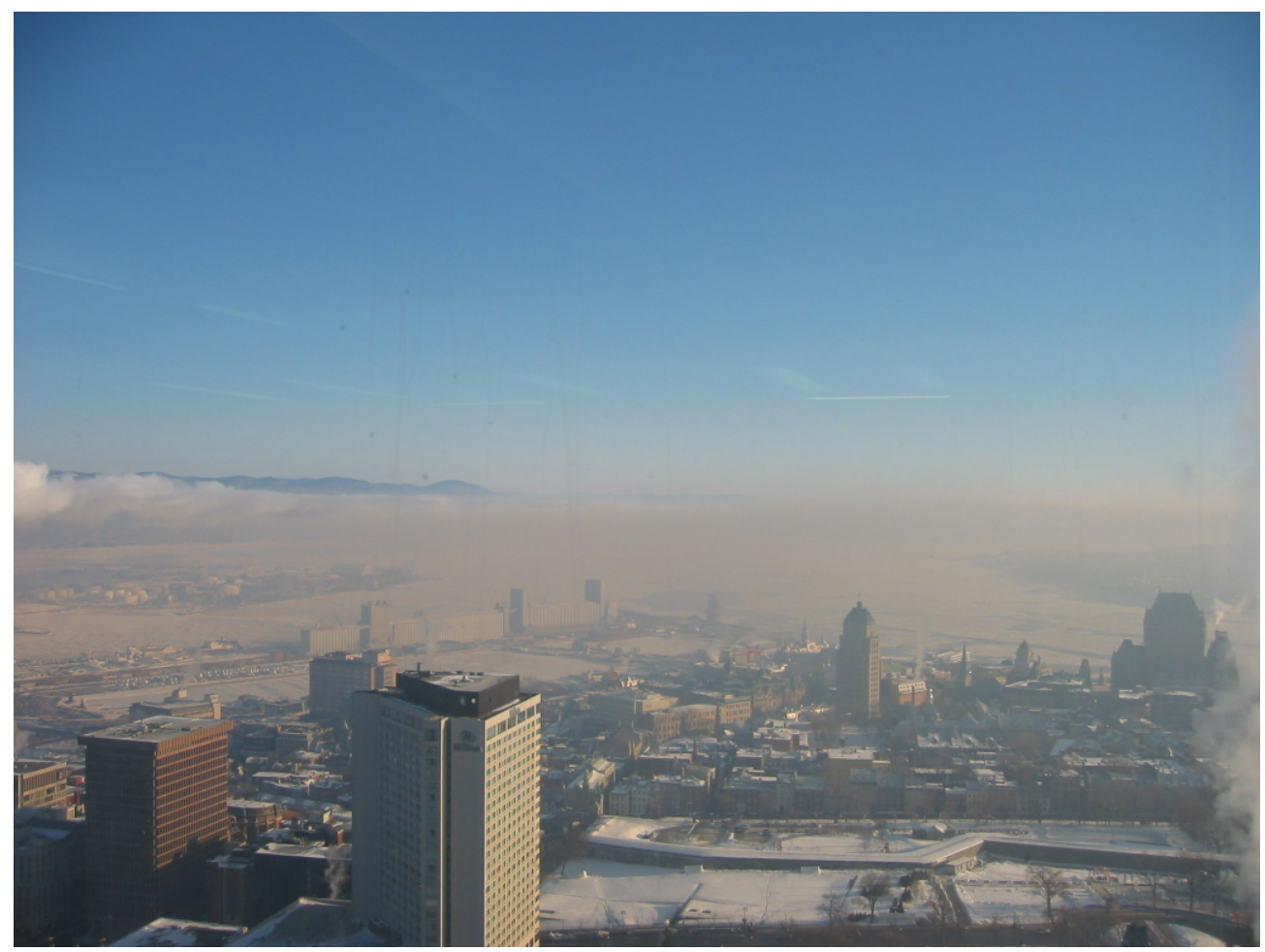

Figura 03: Smog fotoquímico sobre Quebec, Canadá.

Fonte: http://www.criacc.qc.ca

A evolução das concentrações de poluentes ao longo do dia num típico episódio de smog pode ser vista na figura 04:

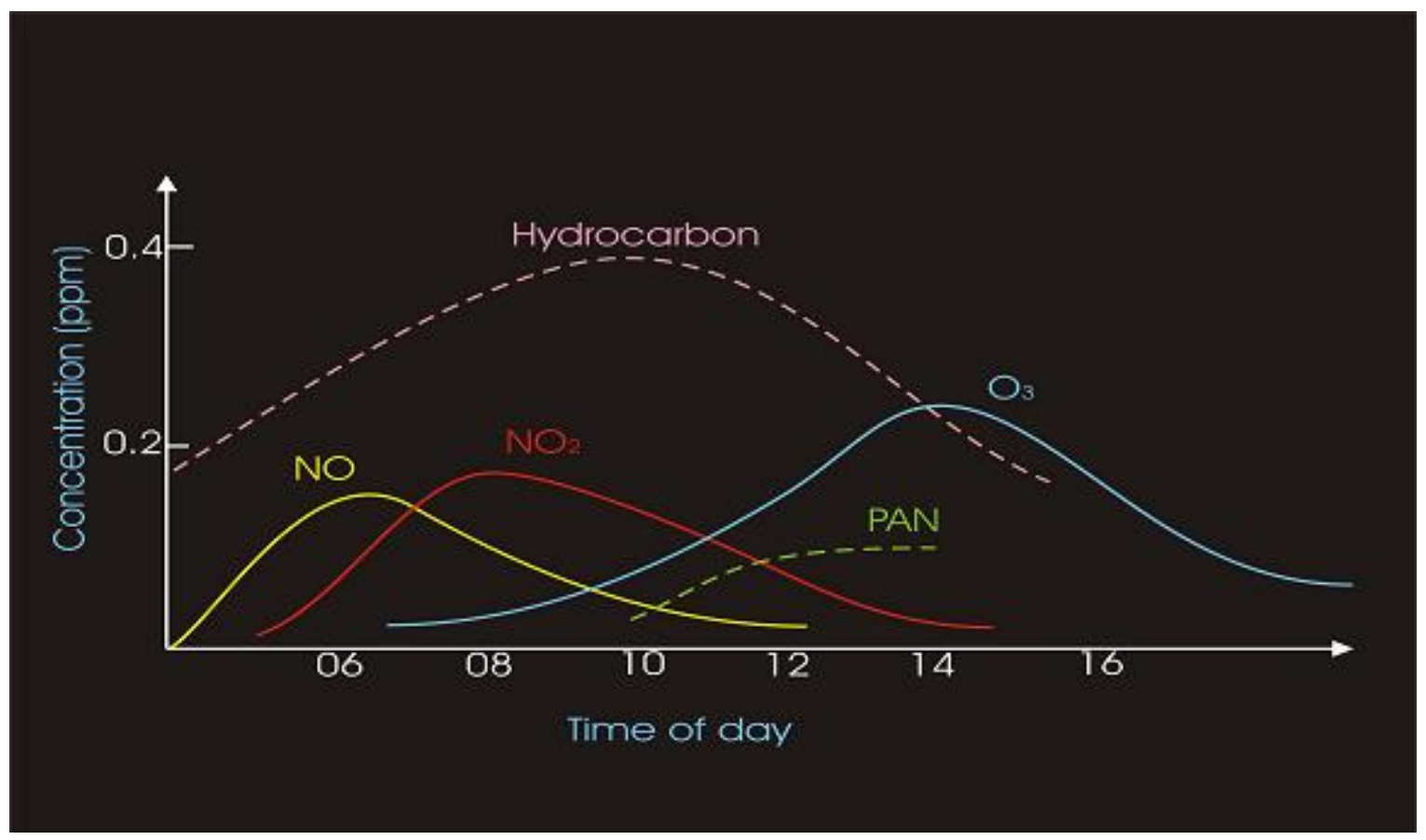

Figura 04: Evolução das concentrações dos poluentes (eixo y) durante as horas do dia (eixo x) num típico episódio de smog.

Fonte: Adaptado de Brasseur, 1999. 
A formação do $\mathrm{O}_{3}$ em ambientes urbanos, então, está ligada à grande disponibilidade de NOx e COV na atmosfera. No entanto, a relação entre o ozônio e seus precursores é significativamente complexa. A quantidade de ozônio produzido depende não só da quantidade, mas principalmente da razão entre os NOx e COV.

Se há maior disponibilidade de $\mathrm{VOC}$ do que $\mathrm{NOx}$, os radicais $\mathrm{OH}$, também presentes em abundância, irão reagir principalmente com os COV; se predominam os NOx, estes reagirão primeiro. Assim, em atmosferas com razão COV/NOx baixa (predominância de NOx), a redução de ozônio é mais eficiente se controlados os COVs; este caso é considerado COV-limitante, ou seja, o ozônio é mais facilmente limitado pela redução de COVs. Isto porque uma concentração excessivamente alta de NOx acaba por reduzir as concentrações de ozônio, seja pela reação com o NO ou pelo aumento das reações $\mathrm{OH}+\mathrm{NO}_{2}$. Com esse aumento, as reações do $\mathrm{OH}$ com $\circ \mathrm{HO}_{2}$ diminuem, e portanto, também a produção de ozônio via $\mathrm{HO}_{2}$ (BRASSEUR, 1999). Mas, em atmosferas com razão COV/NOx alta (predominância de COVs), a redução do ozônio é mais eficiente se controlados os NOx (SEINFELD, 2006). De acordo com estudos da Agência de Proteção Ambiental dos EUA (EPA), um determinado sistema é considerado COV-limitante se a razão COV/NOx é menor do que 8 . Se esta razão for de 8 a 15, o cenário é considerado intermediário, onde tanto o controle de COV como de NOx pode gerar resultados positivos. Caso este número esteja acima de 15, o sistema é considerado NOx-limitante, ou seja, reduzir as concentrações de NOx torna-se mais efetivo para reduzir as concentrações de ozônio (http://www.epa.gov) (NARSTO, 2000).

Além disso, sabe-se que as condições meteorológicas também influenciam este quadro. A maioria dos episódios agudos de poluição do ar ocorrem em condições de significativa estabilidade atmosférica, com pouca mistura vertical do ar. De acordo com um documento elaborado pela North American Research Strategy for Tropospheric Ozone (NARSTO), pode-se ver no anexo 4 que a concentração de $\mathrm{O}_{3}$ aumenta, conforme diminuem as condições de mistura. No entanto, sabe-se que as concentrações de NOx aumentam conforme aumenta a estabilidade vertical da atmosfera; isto afeta diretamente as concentrações de $\mathrm{O}_{3}$. Por isso, condições de estagnação tendem a modificar a razão $\mathrm{VOC/NOx} \mathrm{e} \mathrm{sua} \mathrm{evolução} \mathrm{com} \mathrm{o} \mathrm{tempo.} \mathrm{Se}$ a mistura vertical é extremamente fraca, o sistema permanece como COV-limitante, 
pois o sol se põe antes que quantidades suficientes de NOx sejam processadas para mudar o regime.

Assim, percebe-se que muitas situações e variáveis diferentes afetam as concentrações de ozônio troposférico num determinado local, como a latitude, as características de circulação atmosférica em diversas escalas e a constituição atmosférica, esta mais notadamente modificada em grandes centros urbanos onde há grande emissão de precursores devido às atividades humanas.

As altas concentrações de $\mathrm{O}_{3}$ nestes locais tornam-se nocivas devido à alta capacidade oxidante deste poluente, que é tóxico para os tecidos de organismos vivos. $\mathrm{Na}$ saúde humana, os impactos do $\mathrm{O}_{3}$ incluem envelhecimento precoce da pele, diminuição da resistência a infecções, irritação dos olhos e no trato respiratório superior (MOUVIER, 1995). Além disso, foi provado que ele provoca danos à vegetação, causando queimaduras nas folhas das plantas, podendo interferir até mesmo na produção agrícola (NARSTO, 2000), (conforme pode ser visto na figura 05) o que lhe confere forte conotação sócio-econômica.

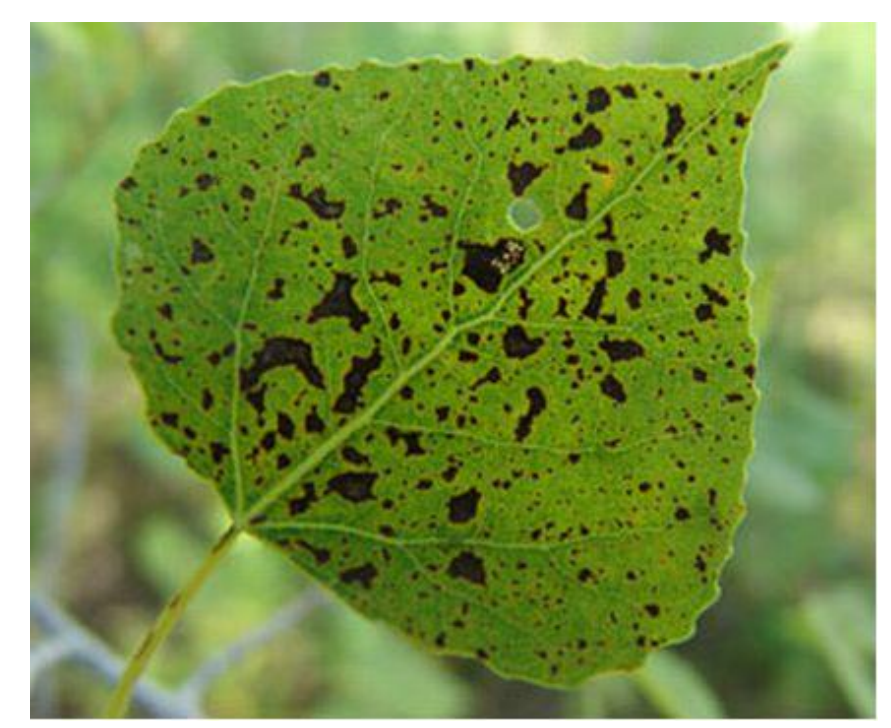

Figura 05: Exemplo de dano à vegetação causado pelo ozônio. Fonte: http://www.treehugger.com

Os relatórios de qualidade do ar da CETESB contêm inclusive a medição e representação dos valores de ozônio de "referência de proteção à vegetação". A metodologia que envolve a medição destes valores é baseada na exposição continuada da vegetação ao ozônio. O valor padrão é 40 ppb/hora. Ou seja, se em 
uma hora forem registradas 50 ppb de ozônio, a ultrapassagem do padrão (denominado AOT40) terá sido de 10 ppb. Segundo a CETESB, ocorrem danos à produtividade agrícola se, num período de 3 meses, o valor acumulado do AOT for igual ou superior a 3000 ppb. Caso o AOT num período de cinco dias for igual ou superior a 200 ppb, ocorrem danos visíveis nas espécies mais sensíveis (CETESB, 2001). Miriam Gutjahr, em sua tese de doutorado pela Universidade de São Paulo (2002), chama a atenção para os problemas causados por este poluente, pois seus danos na vegetação pode afetar desde a agricultura até os mais diversos ecossistemas, uma vez que o ozônio pode ser transportado dos centros urbanos onde é produzido para regiões localizadas em seu entorno.

Por se tratar de um poluente secundário, que é formado na atmosfera devido à emissão de outros poluentes, suas características de origem, transporte e dispersão ou consumo têm um padrão bastante diferenciado de outros poluentes primários. Enquanto que para a maioria dos poluentes há uma tendência definida de queda ou estabilidade de sua concentração na região metropolitana de São Paulo, para o ozônio troposférico esta tendência é menos definida e linear. Suas concentrações são extremamente oscilantes, sendo ainda hoje em dia responsáveis por freqüentes ultrapassagens do padrão de qualidade do ar (CETESB, 2004). Segundo Gutjahr,

\begin{abstract}
"A poluição por $\mathrm{O}_{3}$ ocorre em escalas temporal e espacial múltiplas e sua total compreensão torna-se complicada pela sobreposição de interações químicas e ${ }^{2}$ meteorológicas. Essa complexidade tem confundido os esforços para otimizar estratégias de controle da emissão dos precursores, especialmente aqueles com análises baseadas em limitada quantidade de dados"
\end{abstract}

Nos últimos anos, tem-se observado por meio dos Relatórios da CETESB que as concentrações de alguns poluentes na RMSP têm se mantido estáveis, com mais de $90 \%$ dos dias com qualidade do ar boa, por exemplo, no caso do CO.

\footnotetext{
${ }^{2}$ A Poluição do Ar em Paulínia (SP): Uma Análise Histórico-Geográfica do Clima, GUTJARH, M. R., Tese de Doutoramento pela Universidade de São Paulo, Edição Revisada, 2003, página 164
} 
CO - Evolução das concentraçōes médias das máximas (média de 8 horas)

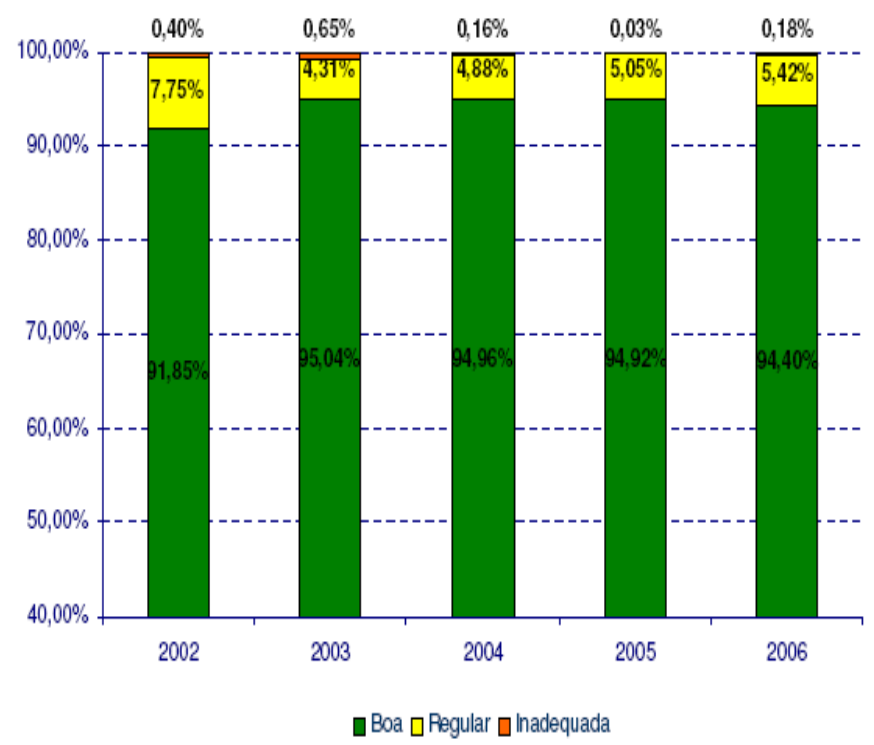

Base: Todas as estaçoes que monitoram este poluente

Figura 06: Índices de qualidade do ar por CO para algumas estações da RMSP, de 2002 a 2006.

Fonte: CETESB, 2007.

Uma situação parecida ocorre comas concentrações de $\mathrm{NO}_{2}$, de acordo com o que pode ser visto na figura 07 :

$\mathrm{NO}_{2}$ - Evolução das concentraçōes médias na RMSP, Cubatão e Interior

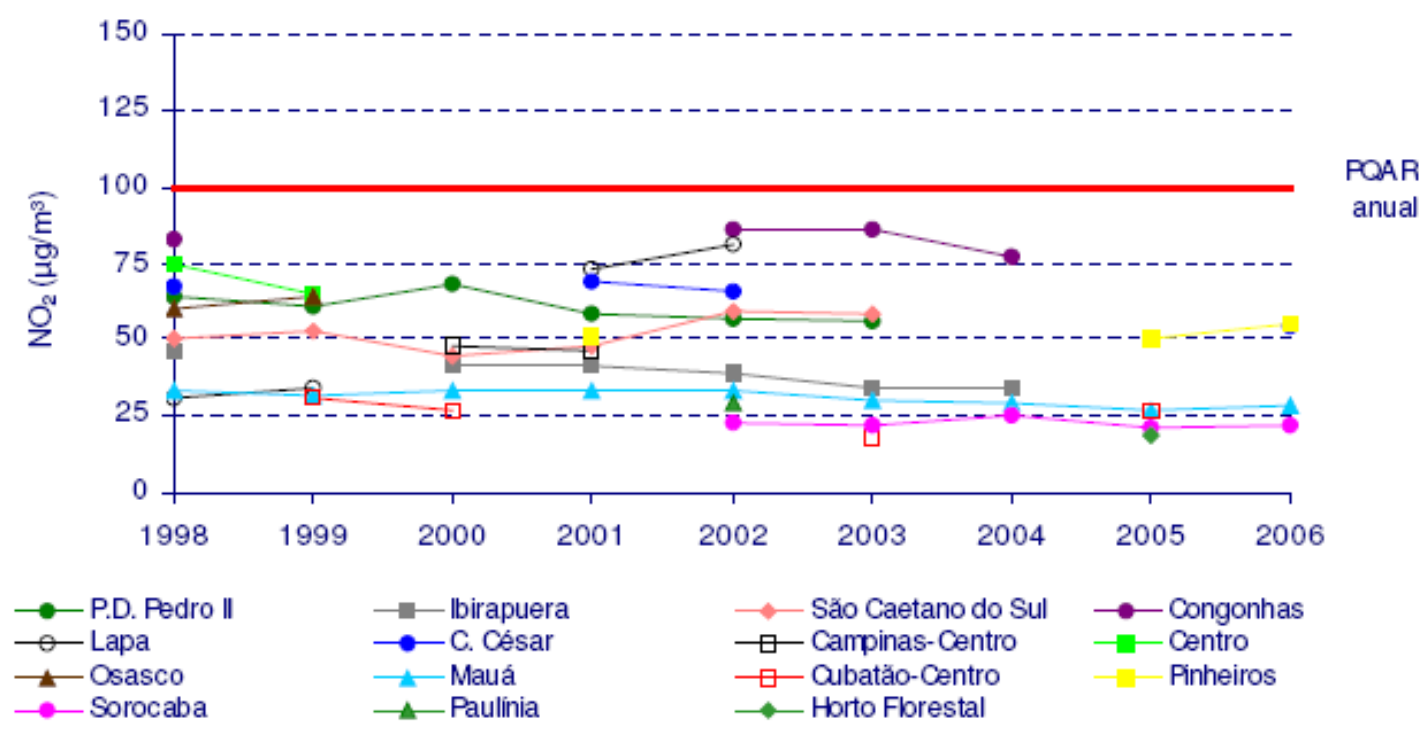

Figura 07: Concentrações anuais médias de $\mathrm{NO}_{2}\left(\mathrm{~g} / \mathrm{m}^{3}\right)$ para algumas estações da RMSP, de 1998 a 2006.

Fonte: CETESB, 2007 
Já as concentrações de MP, apesar de ainda serem responsáveis por qualidade do ar Regular em muitas ocasiões, apresentam importantes tendências de redução, de acordo com a figura 08:

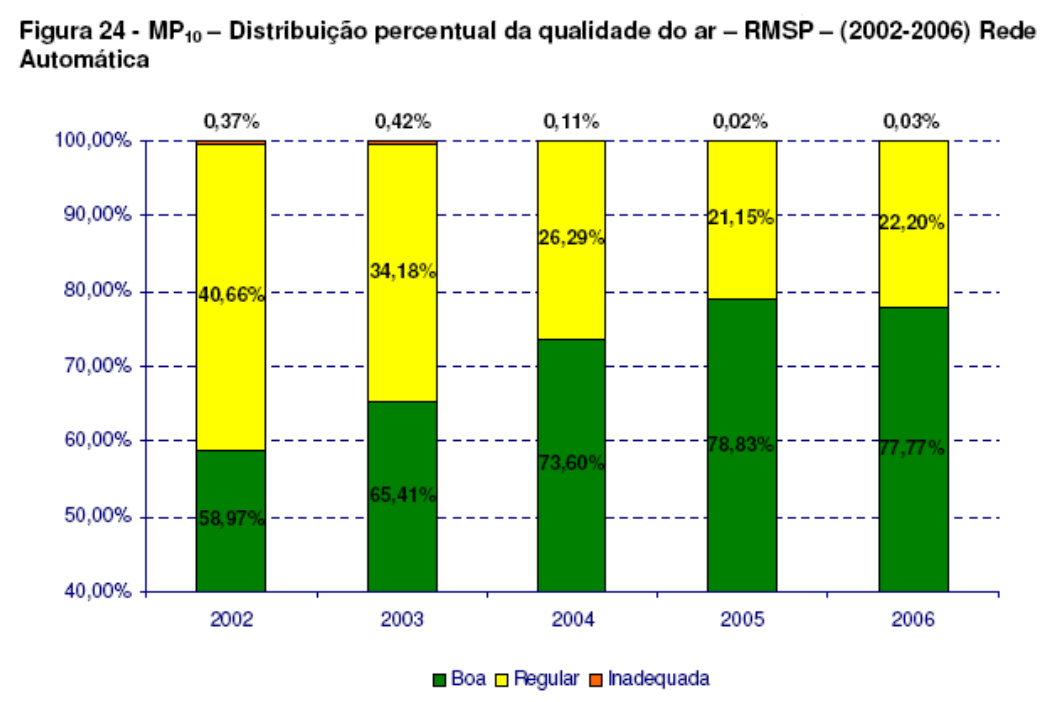

Base: todas as estaçes que monitoram esse poluente(exceto Lapa e São Miquel Paulista)

Figura 08: Índices de qualidade do ar por MP para algumas estações da RMSP, de 2002 a 2006.

Fonte: CETESB, 2007.

No entanto, este cenário não é acompanhado pelas concentrações de ozônio neste período, como se pode verificar pelas figuras 09 e 10:

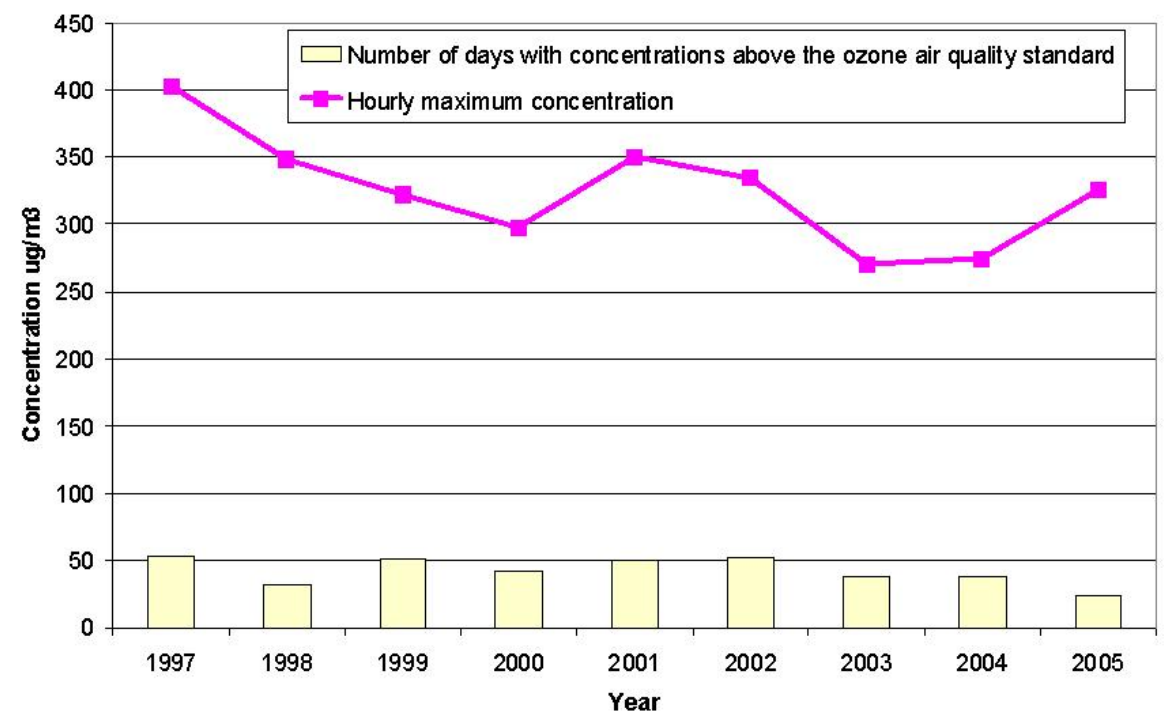

Figura 09: Número de dias com concentrações acima do PQAr de ozônio (colunas) e concentração horária máxima (linha).

Fonte: CETESB, 2006. 


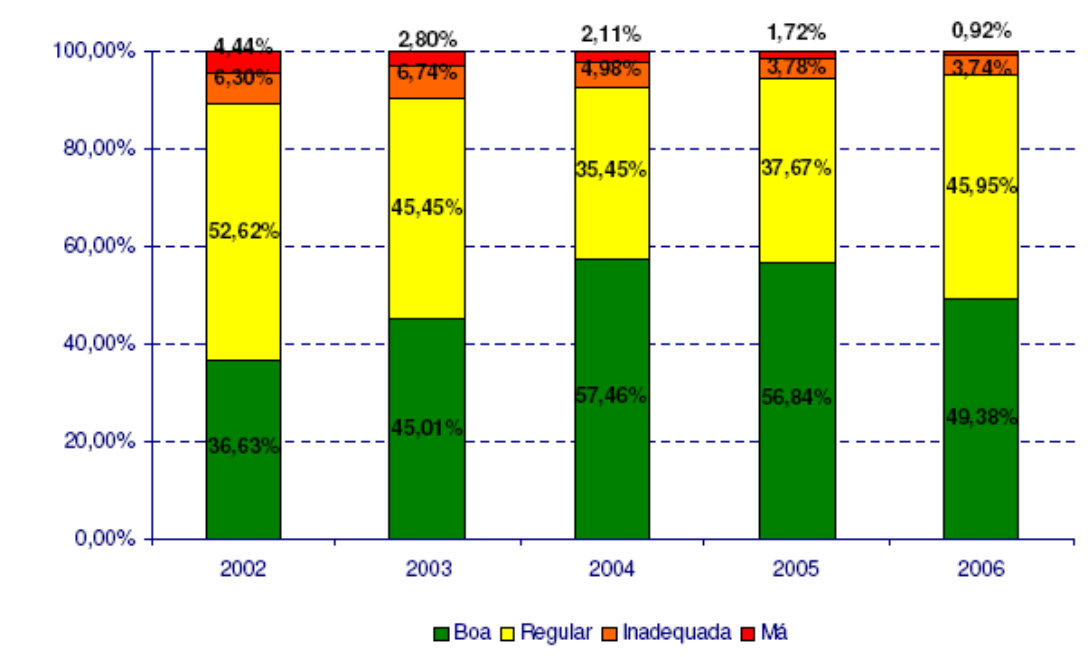

Base: Estaçoes Santana, Moóca, Ibirapuera, Diadema, Santo Amaro, Santo André-Capuava e Mauá

Figura 10: Índices de qualidade do ar por $\mathrm{O}_{3}$ para algumas estações da RMSP, de 2002 a 2006.

Fonte: CETESB, 2007

Uma vez que o ozônio é formado pela emissão de poluentes, que, na RMSP, têm origem majoritariamente veicular (nitrosos e hidrocarbonetos), poderia ser esperado que suas concentrações fossem mais altas em locais com altas concentrações destes poluentes; no entanto, isto não é verificado na realidade com alta correlação (CETESB, 2003; AZEVEDO, 2002; MARTINS, 2006). De fato, muitos locais característicos por apresentarem baixos índices de poluentes veiculares (e, portanto, poderia se assumir que seriam locais menos poluídos), acabam por registrar altas concentrações de ozônio, como o Parque do Ibirapuera e Mauá, na região metropolitana de São Paulo. Particularmente, o Parque do Ibirapuera já chamou a atenção por ser um dos locais mais poluídos por ozônio nesta região (CETESB, 2004, MARTINS, 2006). Uma possível hipótese para este fato é a de que, com a emissão de poluentes veiculares nas avenidas próximas (Av. Ibirapuera, Av. Brasil, Av. Vinte e Três de Maio), estes seriam transportados ao Parque e transformados em ozônio durante esse processo (MARTINS et al, 2004; CETESB, 2004), ou mesmo através do transporte de poluentes de regiões mais afastadas (AZEVEDO, 2002). Uma outra característica do ciclo do ozônio já mencionada é que não só sua formação, mas também seu consumo está associado à presença dos NOx. Assim, para sua formação, seria necessária a presença destes compostos (bem como dos $\mathrm{HC}$ e radiação solar). No entanto, a presença dos NOx na troposfera sem radiação solar acarreta no consumo de ozônio pelos NOx (MOUVIER, 1999; SEINFELD, 2006; AZEVEDO, 2002), como já foi exemplificado. 
Além disso, há o fato de que suas concentrações normalmente apresentam picos diários mais altos no período de outubro a março, justamente quando há maior instabilidade na atmosfera na RMSP (CETESB, 1994, 2006; ANDRADE, 1994). A instabilidade, representada por temperaturas mais elevadas, menor pressão nos baixos níveis atmosféricos, e, conseqüentemente maior possibilidade de precipitação, é pré-requisito para as chamadas "condições favoráveis de dispersão", definidas pela CETESB como condições atmosféricas nas quais a dispersão dos poluentes é facilitada pelas variáveis meteorológicas, evitando que se atinja níveis críticos de poluição do ar. Assim, enquanto que a maioria dos poluentes registra picos maiores no período de outono-inverno, quando há maior estabilidade na atmosfera, menor temperatura do ar, incidência mais baixa de radiação solar e mais inversões térmicas próximas ao solo, verifica-se que o ozônio não tem o mesmo comportamento, pois nesse período é comum que se encontre concentrações baixas desse poluente. Esta conclusão foi mencionada no estudo da CETESB Comportamento Sazonal da Poluição do Ar em São Paulo - Análise de Quatorze Anos de Dados da RMSP e Cubatão: 1981 a 1994 (1994), em que foi avaliada a evolução das concentrações dos poluentes medidos pela rede ao decorrer de alguns anos, numa tentativa de se observar padrões sazonais, bem como no estudo de Andrade (1994).

Estas informações podem ser confirmadas pela figura 11: 


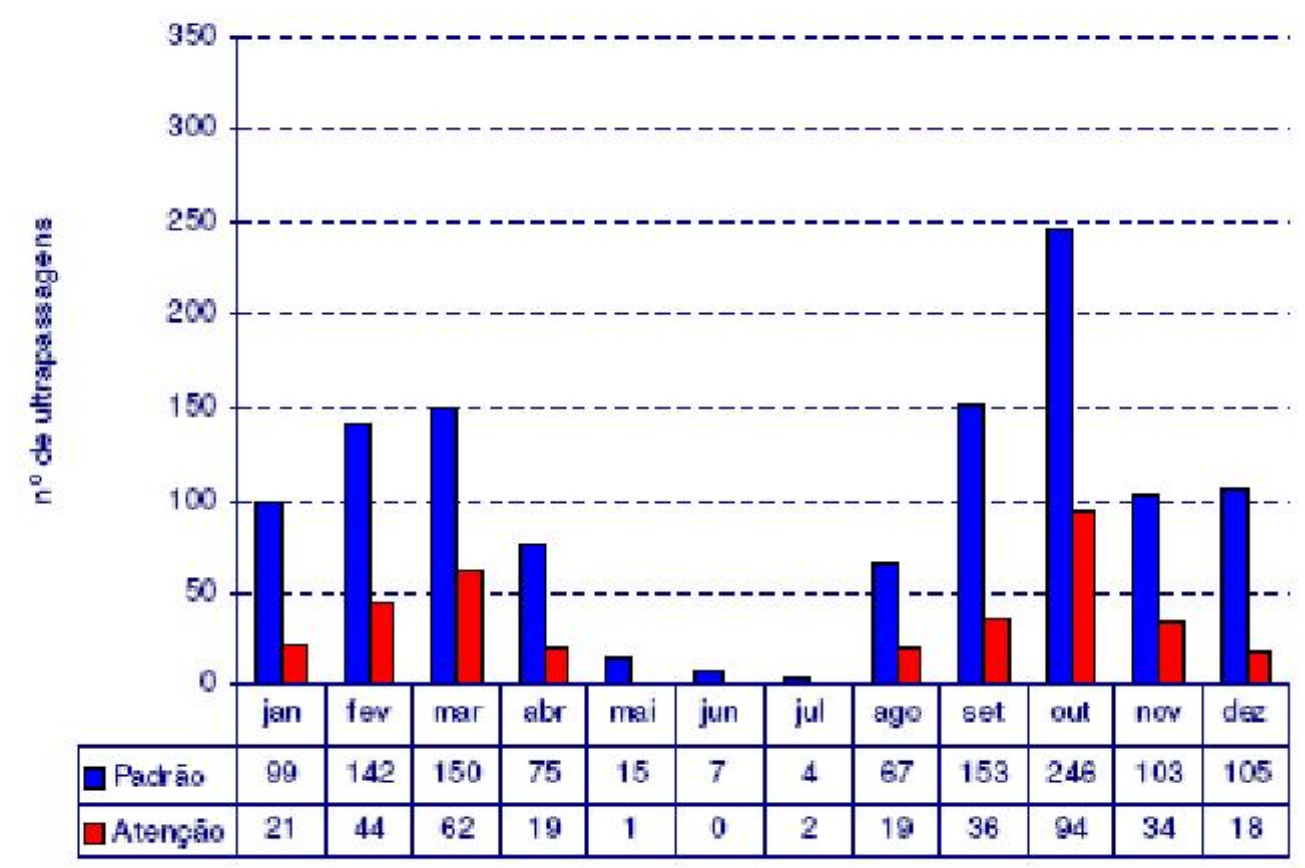

Figura 11: Número de ultrapassagens do PQAr e níveis críticos de ozônio por mês na RMSP, de 2002 a 2006.

Fonte: CETESB, 2007

As figuras 12 e 13 demonstram dias de alta e baixa concentração do $\mathrm{O}_{3}$, respectivamente, na RMSP, para o ano de 2003. As coordenadas são UTM e os valores expressos nas isolinhas são em $\mu \mathrm{g} / \mathrm{m}^{3}$.

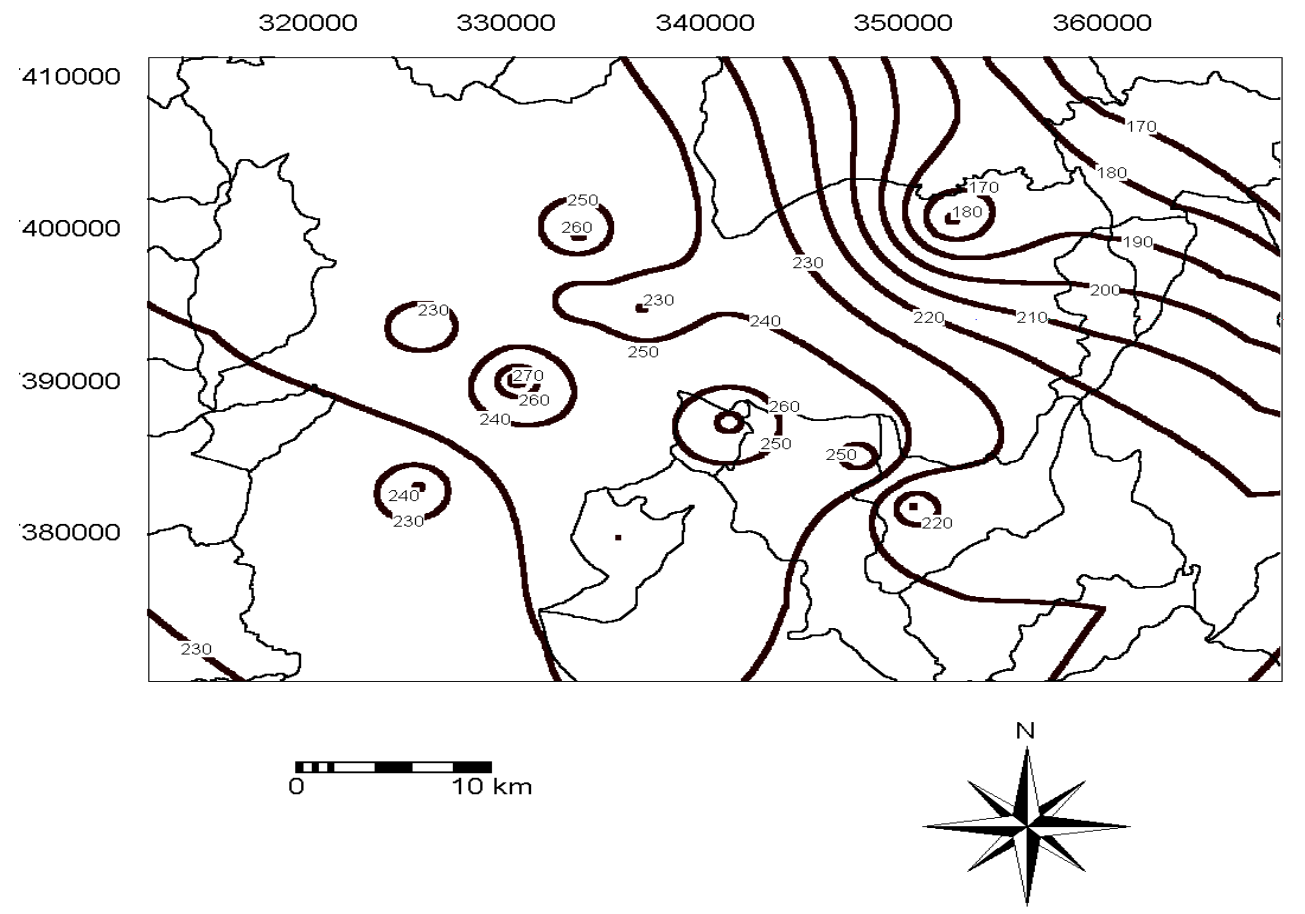

Figura 12: Ozônio - RMSP - Alta concentração - 04/03/03

Fonte: CHIQUETTO, 2005. 


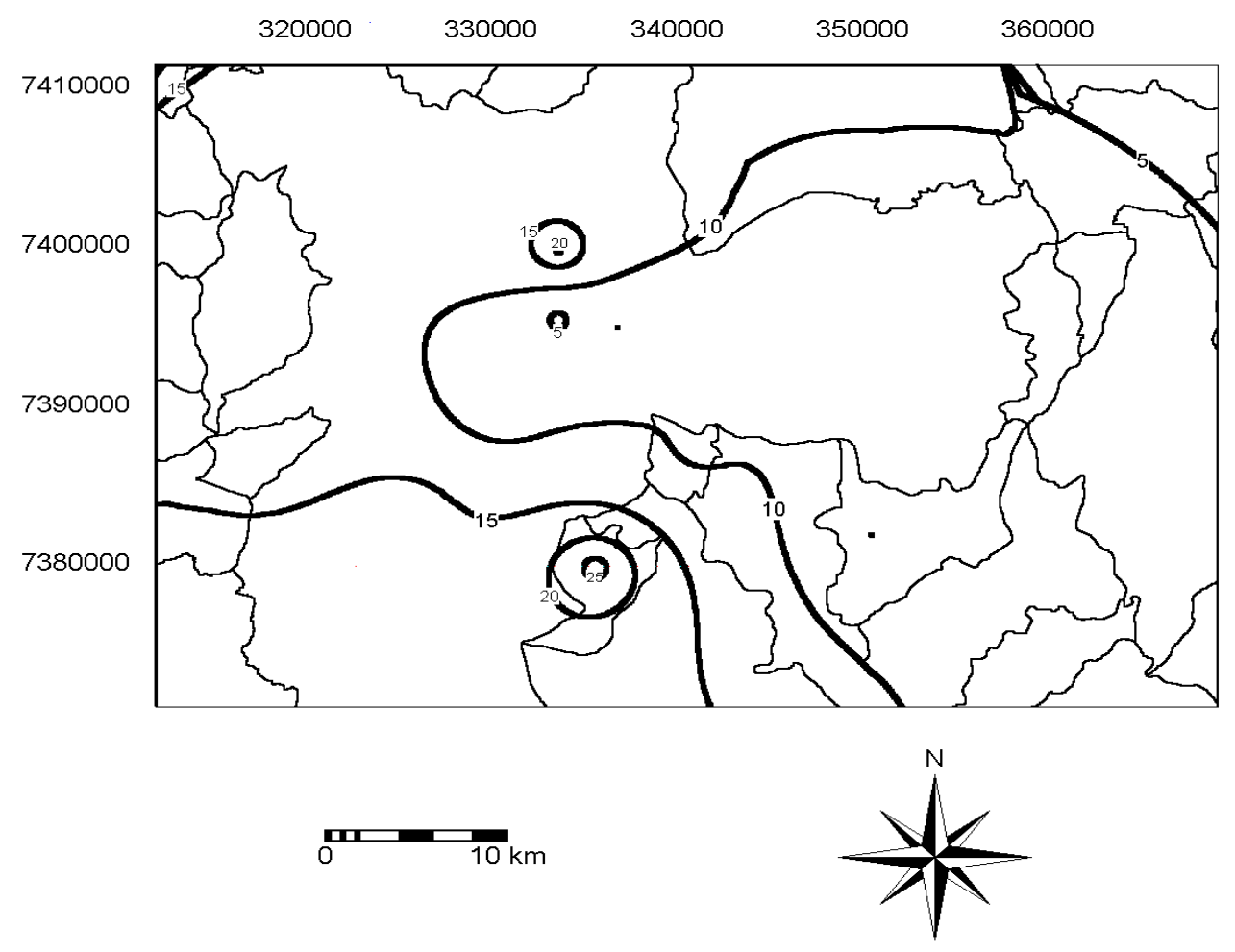

Figura 13: Ozônio - RMSP - Baixa concentração - 10/09/03.

Fonte: CHIQUETTO, 2005.

Estas figuras foram incluídas não por representarem fielmente uma distribuição espacial do poluente na cidade, mas sim como indicativos de uma possível distribuição espacial complexa.

Em vista destas características particulares do ozônio, e de suas relações diferenciadas com as condições atmosféricas e seus precursores, propõe-se estudar neste trabalho a influência dos padrões atmosféricos e as concentrações de ozônio (medidas pela rede de monitoramento de poluentes da CETESB, que cobre diversos bairros da RMSP) em várias escalas temporais, e relacioná-los. Conclui-se então, em vista de alguns fatores, tais como: 1) elevada concentração na atmosfera da RMSP; 2) efeitos nocivos para a saúde humana e o meio ambiente; 3) comportamento diferenciado em relação a outros poluentes, que o estudo da ocorrência do ozônio troposférico na RMSP adquire grande relevância para que futuramente se possa elaborar ações que visem seu controle e, assim, minimizar estes impactos, contribuindo para a melhoria geral do complicado quadro ambiental da RMSP e da qualidade de vida de sua população. Trata-se de uma primeira 
aproximação a este problema, pois embora os padrões atmosféricos identifiquem a escala sinótica, esta não está representada diretamente nos dados de ozônio. No entanto, isto não se constituirá em problema metodológico, dados os objetivos abrangentes do trabalho. 


\subsection{Caracterização climática da RMSP}

A Grande São Paulo está entre as cinco maiores regiões metropolitanas do mundo. Sua população beira aos 20 milhões de habitantes (19,7 milhões estimativa do Instituto Brasileiro de Geografia e Estatística, 2008) - muitos deles de outras regiões do Brasil e também de outros países. Está dividida em 137 distritos de 39 municípios, segundo a Empresa Paulista de Planejamento Metropolitano (EMPLASA, 1994). Está localizada a 2321' de latitude Sul e $46^{\circ} 44^{\prime}$ de longitude Oeste, em uma altitude média de $750 \mathrm{~m}$, podendo variar de $720 \mathrm{~m}$ nos fundos de vale (rios Tietê e Pinheiros) até 830m no Espigão Central (Av. Paulista).

Ela encontra-se na unidade geomorfológica do Planalto Atlântico, sobre uma bacia sedimentar de origem flúvio-lacustre que se originou no período Cenozóico (bacia sedimentar de São Paulo). Seu terreno possui declividades relativamente baixas, o que facilitou intensa ocupação humana. Seus limites incluem a Serra da Cantareira ao norte, Serra de Itapeti a leste, Serra do Mar ao sul e maciços elevados de Itapecerica-São Roque ao oeste e sudoeste (SAMPAIO, 2000). Esta configuração de relevo, um vale cercado por serras, dificulta a dispersão dos poluentes. Este cenário muitas vezes pode ter sido causa ou fator contribuinte aos piores episódios de poluição do ar já registrados na RMSP.

Episódios de ventos de S e SE em São Paulo são freqüentes, o que se deve à freqüente incursão de frentes frias e da brisa marítima, com ventos dirigidos do oceano para o continente; essa direção dos ventos também contribui para o acúmulo de poluentes na cidade, uma vez que muitos poluentes são emitidos na região do ABCD ou de Cubatão, situada justamente a SE da capital (LOMBARDO, 1985, SÁNCHEZ-CCOYLLO, 2000, SAMPAIO, 2000).

A principal característica do clima em São Paulo é sua alta variabilidade, justamente por estar situada em região subtropical (porém ainda muito próxima ao Trópico de Capricórnio), possuindo características dos climas tropicais úmidos de altitude com estação seca definida, quanto dos climas subtropicais permanentemente úmidos do Sul do Brasil. Assim, define-se o clima de São Paulo por uma alternância entre as estações quente e úmida (de outubro a março) e outra 
mais fria e mais seca (de abril a setembro), que podem apresentar características mais marcantes dependendo da intensidade dos sistemas que atingem a região. Em escala temporal menor, essa faixa transitória pode apresentar "variações bruscas do ritmo e da sucessão dos tipos de tempo, em que podem ocorrer estados atmosféricos de intenso aquecimento seguido de intenso resfriamento em segmentos temporais curtos - dias e semanas" ${ }^{3 "}$. Não obstante, em comparação ao restante do território brasileiro e suas regiões metropolitanas, as temperaturas médias na RMSP são de maneira geral brandas, variando entre $15,8^{\circ} \mathrm{C}$ em julho e $22,4^{\circ} \mathrm{C}$ em fevereiro, segundo dados do Instituto Nacional de Meteorologia (INMET) de 1960 a 1991 (anexo 5).

A pluviosidade varia, em média, de 1400 a 1800mm anuais, podendo ocorrer episódios torrenciais de chuvas com precipitação diária acumulada superior a $150 \mathrm{~mm}$, responsáveis por freqüentes enchentes nas marginais dos rios, principalmente nos meses de verão, quando há alta umidade e temperatura do ar. A pressão atmosférica média é de $926 \mathrm{mb}$, com maiores valores nos meses frios e menores nos meses quentes, de acordo com a normal climatológica do INMET de 1961-1990. A climatologia de temperatura e precipitação da cidade de São Paulo de 1960 a 1990 pode ser vista no anexo 5.

Os principais sistemas atmosféricos de tempo em escala sinótica atuantes na região subtropical onde a Grande São Paulo está situada são: Alta Subtropical do Atlântico Sul, Frentes Frias, Alta Pressão transiente na retaguarda das frentes, Zona de Convergência do Atlântico Sul (ZCAS). A composição da atuação dos diferentes sistemas de tempo determina o tipo característico do clima em determinada região. A atuação destes sistemas com suas respectivas freqüências e intensidades definem a variabilidade climática (sazonal, interanual, interdecadal) na região subtropical da América do Sul.

A Alta Subtropical do Atlântico Sul é uma massa de ar proveniente da alta pressão do anticiclone do Atlântico Sul. Possui elevada pressão do ar. Este

\footnotetext{
${ }^{3}$ MATEUS, R. S. A Relação entre o clima e o abastecimento de água na RMSP. Uma proposta de modelagem conceitual da Bacia Hidrográfica da Represa Guarapiranga, Relatório para Exame de Qualificação de Mestrado, Programa de Pós-Graduação em Geografia Física, Departamento de Geografia, Faculdade de Filosofia, Letras e Ciências Humanas, USP, São Paulo, 2005.
} 
anticiclone é praticamente estacionário sobre o Oceano Atlântico Sul, à latitude de $30^{\circ}$ Sul, e sua posição e intensidade variam principalmente de acordo com a estação do ano. No verão ele é menos intenso e tem o seu centro deslocado mais em direção ao oceano, uma vez que as baixas pressões predominam sobre o continente como resultado do maior aquecimento. No inverno, no entanto, sua área de influência expande-se, e o sistema se associa em muitos casos à ocorrência de bloqueios atmosféricos nas regiões Sul e Sudeste do país. O bloqueio atmosférico será explicado posteriormente.

Já as Altas Pressões na retaguarda das frentes frias, por se originarem em áreas mais frias, caracterizam-se pela baixa temperatura e maior estabilidade da atmosfera. As altas pressões durante o inverno são mais intensas e penetram mais a norte devido à grande quantidade de energia potencial associada. Elas são responsáveis pelas grandes quedas de temperatura durante o outono e inverno em grande parte do centro-sul do Brasil e de ocorrência de eventos de geadas nessas áreas, bem como de neve nas áreas serranas do Sul do país (GALVANI e AZEVEDO, 2003).

As Frentes Frias surgem, grosso modo, do contraste entre as condições diferentes dos climas tropicais e temperados, num sentido de equilibrar termodinamicamente as diferenças atmosféricas latitudinais. Elas representam 0 avanço do ar frio sobre as áreas de ar quente, ocasionando grande instabilidade da atmosfera, aumentando a circulação atmosférica e ocasionando nebulosidade e chuvas com sua passagem. A área da RMSP é atingida por Frentes Frias praticamente o ano todo; no inverno elas precedem a incursão de altas pressões que trazem queda de temperatura, como mencionado. Neste processo, provocam chuvas que são importantes atenuadores da estação seca da região. No verão, as frentes provocam chuvas mais intensas devido à grande disponibilidade de calor $\mathrm{e}$ umidade na atmosfera e, em conjunto com a forte atividade convectiva e a Zona de Convergência do Atlântico Sul, contribuem para a maior freqüência das chuvas durante a primavera e o verão. (SAMPAIO, 2000).

A Zona de Convergência do Atlântico Sul (ZCAS) ocorre no verão, e caracteriza-se por uma banda de nebulosidade que se estende desde o sul da 
região amazônica até a região central do Atlântico Sul, responsável por grande atividade convectiva nesta área, afetando principalmente o Sul e o Sudeste do Brasil com ocorrência de enchentes e estiagem prolongadas (Casarim e Kousky, 1986, Kodama, 1991 e 1992). Sua origem e manutenção estão associadas a mecanismos remotos, como a Zona de Convergência do Pacífico Sul, e outros de escala mais regional, como a convecção na região amazônica e a localização do Jato Subtropical, em altitude, que contribui com maior instabilidade atmosférica. A ZCAS também está associada à Baixa do Chaco, uma massa de ar de baixa pressão cujo centro está na região central da América do Sul que se intensifica durante o verão, responsável pela atividade convectiva na região amazônica (Rocha e Gandu, 1996).

Outros sistemas atuam com freqüência ligeiramente menor, no entanto também são importantes na composição climática da região Sudeste. Os Complexos Convectivos de Mesoescala são sistemas de forma aproximadamente circular, compostos inicialmente por cumulonimbi, sendo bastante comum o aparecimento e predominância de nuvens tipo cirrus e stratus nos estágios maduros de desenvolvimento dos sistemas (SILVA DIAS, 1989). Os que atingem a América do Sul formam-se a aproximadamente $25^{\circ}$ Sul, sobre as bacias dos rios Paraná e Paraguai. Segundo Figueiredo e Scolar, em 1996, atingem principalmente a região sul do Brasil ( $70 \%$ do total) ou a região Sudeste (30\%). Ocorrem em sua maioria na primavera e verão, com ciclo de vida de aproximadamente 10 a 20 horas, com o horário de máxima extensão de madrugada (Velasco e Fritsch, 1987). Sua origem está ligada ao escoamento de norte ao leste dos Andes com grande transporte de umidade e calor da região amazônica em direção ao sul, em baixos níveis, que converge com o escoamento local catabático noturno na região das bacias dos rios Paraná e Paraguai e com uma região de velocidade máxima do Jato Subtropical (Silva Dias, 1996).

Os bloqueios atmosféricos acontecem, no Atlântico Sul, durante um período de até 8 a 9 dias. Seu máximo sazonal de freqüência ocorre no final do inverno e início da primavera, com um máximo secundário no outono. Eles são caracterizados pela presença de um anticiclone quase estacionário de grande amplitude e intensidade, e promove condições de alta pressão e temperatura do ar em superfície, com grande estabilidade atmosférica. Uma vez instalados, os bloqueios 
tendem a se fixar na região, desviando a trajetória de ciclones extratropicais e Frentes Frias, que apenas margeiam a área do bloqueio. Sua origem, como demonstram pesquisas de Lejenas e Oakland (1983), está ligada a 1) bifurcação do jato subtropical em altos níveis, que intensifica a subsidência do ar nas latitudes de $50-60^{\circ}$, formando anticiclones em latitudes mais altas que o normal e rompendo com o padrão de circulação zonal de oeste, ou ocasionam a formação de anticiclone em latitudes mais altas do que o normal; e ao 2) desvio padrão da altura geopotencial no nível de $500 \mathrm{hPa}$ a aproximadamente $60^{\circ}$ de latitude. Neste caso, quanto mais intensas as anomalias, mais intensos são os episódios de bloqueio (Marques e Rao, 1996).

Algumas Linhas de Instabilidade também afetam a região na qual a RMSP está inserida. Na verdade, as Linhas de Instabilidade compreendem um tipo de processo convectivo que possui diferentes origens, que afeta tanto latitudes médias quanto tropicais. Elas são caracterizadas por grupos de cumulonimbi de diversos tamanhos, agrupados em formato de linhas ou curvas, cuja origem está associada à circulação de mesoescala. Configurações de brisa marítima, continental, de valemontanha, ou mesmo a circulação pré e pós-frontal podem estar associadas à formação de linhas de instabilidade. Ela se propaga pela convergência do ar subsidente da borda da linha com o ar que vem de fora, dirigido à baixa pressão no centro do sistema (CERQUEIRA, 2006). Elas variam de centenas até milhares de quilômetros de extensão e podem durar de algumas horas até um dia. Nos trópicos elas são caracterizadas principalmente pela intensidade dos eventos de precipitação, com velocidades médias de vento de 12 a $25 \mathrm{~m} / \mathrm{s}$ (www.master.iag.usp.br).

Além da atuação de sistemas atmosféricos com suas variabilidades naturais, o clima da Cidade de São Paulo, devido à magnitude e estrutura da RMSP, sofre interferências antrópicas, levando à concepção de clima urbano. 


\subsection{Objetivos}

O objetivo geral deste trabalho é descrever o comportamento do ozônio troposférico na RMSP em diferentes escalas temporais (diária, mensal e anual), utilizando-se os dados de poluição coletados pela CETESB. Além disso, será feita uma análise dos padrões atmosféricos observados em episódios/situações de concentrações extremas. Para tanto, são analisados os padrões sinóticos de variáveis atmosféricas na região centro-sul do Brasil, em especial na RMSP, na tentativa de generalizar a ocorrência destas concentrações extremas de $\mathrm{O}_{3}$. Por ser um poluente secundário, tal como $\mathrm{HC}$ e aldeídos, com formação que depende de outros processos na atmosfera, sua ocorrência e variabilidade necessitam de profunda investigação. Os resultados obtidos neste estudo devem contribuir para o desenvolvimento de pesquisas associadas ao tema e, como subsídio à elaboração de ações administrativas apropriadas ao seu controle. A formação de poluentes secundários na atmosfera, em especial a do $\mathrm{O}_{3}$, é bastante complexa em termos de química atmosférica, e muitos têm sido os estudos, por parte de cientistas químicos, meteorologistas e físicos, que visam compreender estes processos.

Como objetivos específicos, tem-se o estudo da distribuição espacial do poluente na cidade de São Paulo através da comparação entre as concentrações medidas em diferentes estações de monitoramento da CETESB na RMSP. Este estudo deve contribuir para um melhor conhecimento sobre a ocorrência do ozônio troposférico em diferentes locais da área de estudo. 


\section{Dados e metodologia}

\subsection{Caracterização da fonte de dados de poluição do ar: a CETESB}

Para se caracterizar a poluição atmosférica de São Paulo e sua evolução temporal, serão utilizados dados das redes manual e telemétrica de monitoramento de poluentes da CETESB. A CETESB, seu histórico, funções, sua redes de estações e respectiva serão brevemente descritos nesta seção.

Tendo em vista a grande ameaça à saúde humana, aos animais, às plantas e aos materiais apresentada pelas excessivas concentrações de poluentes nas grandes metrópoles mundiais, faz-se necessário seu contínuo e eficiente monitoramento como forma de se reunir informações e dados suficientes para se tomar as devidas precauções e correções. Em São Paulo, o órgão governamental responsável por tal monitoramento é a CETESB, que faz parte da Secretaria do Meio Ambiente do Estado de São Paulo. Ela foi criada em 1968, a princípio, para lidar com as questões da poluição da água e sanitária. Somente na década de 70 , quando a qualidade do ar estava continuamente piorando em vista do aumento da atividade industrial, é que a CETESB passa a ser o órgão responsável pelo controle e diminuição da poluição atmosférica. Assim, é responsável por elaborar ações para controle da poluição do ar, por criar leis específicas, por restringir as atividades em caso de episódios críticos e por exigir equipamentos mais limpos, elaborar planos de controle a longo prazo, leis de zoneamento, padrões de qualidade do ar e o licenciamento ambiental. Segundo a CETESB,

\footnotetext{
"O licenciamento ambiental, por exemplo, constitui um recurso valioso para o desenvolvimento de uma política de controle preventivo da qualidade ambiental. Mais do que uma simples formalidade legal, o licenciamento permite impor regras para a instalação e funcionamento de loteamentos, indústrias, construções e outros empreendimentos que constituem fontes potenciais de poluição. Autorizações para tais atividade somente são concedidas após o atendimento integral de todas as exigências técnicas estabelecidas em lei" ${ }^{\prime 4}$.
}

Foi então sendo instalada, ao longo das décadas, as redes de estações de monitoramento de poluentes. Os primeiros poluentes a serem medidos foram

\footnotetext{
${ }^{4}$ Extraído do site da CETESB: $\underline{w w w . c e t e s b . s p . g o v . b r}$
} 
fumaça (FMC - que é usado como indicador de materiais carbonáceos) e $\mathrm{SO}_{2}$, que na década de 70 era um dos principais poluentes presentes na atmosfera de São Paulo (CHIQUETTO, 2005). A medição destes dois elementos se iniciou em 1973 (posteriormente essa rede também mediria as Partículas Totais em Suspensão PTS) com estações manuais de monitoramento na cidade, cujos dados possibilitaram a tomada de diversas medidas contra a poluição industrial, que chegou a níveis alarmantes nos anos 70 em São Paulo (enquanto Cubatão vivia uma situação ainda pior). Hoje em dia, a poluição industrial corresponde a aproximadamente apenas $10 \%$ de toda a poluição na capital (CETESB, 2000), o que comprova a efetividade destas ações, sendo raros os casos de ultrapassagens ou mesmo de aproximação dos PQAr por poluentes destas fontes, como o $\mathrm{SO}_{2} \mathrm{e}$ alguns hidrocarbonetos. Durante a década de 70, e até hoje em dia, a CETESB publica um boletim diário de qualidade do ar, que é colocado à disposição da imprensa e para a população, a fim de divulgar os índices de qualidade e a existência ou não de episódios agudos de poluição para o dia em questão, com os dados das concentrações medidas na cidade. Nesses boletins, a CETESB divulga diariamente os níveis de qualidade do ar medidos em todas as estações, para que se possa verificar uma eventual ultrapassagem do padrão, e coloca estas informações à disposição da mídia e da população.

Esses boletins são divididos em dois tipos: os de estações e os de poluentes. Os boletins diários de estações contêm informações a respeito de apenas uma estação específica, sobre os elementos que ela mede. Os boletins diários de poluentes contêm informações sobre as medições de todas as estações sobre um poluente específico, juntamente com informações acerca do índice de qualidade do ar relativo a esse poluente (atualmente, além dos boletins diários, a CETESB também disponibiliza dados horários pela internet, tanto das concentrações dos poluentes como de variáveis meteorológicas, como temperatura do ar, umidade relativa, radiação global etc.). Além disso, algumas publicações, relativas às concentrações dos poluentes, foram publicadas pela CETESB, como por exemplo Formação e ocorrência de oxidantes fotoquímicos na região da Grande São Paulo (1979 - de autoria da própria CETESB), de grande valia no processo de caracterização dos poluentes atmosféricos da época. Além dos boletins diários, a 
partir da década de 80 ela publica os Relatório Anuais de Qualidade do Ar, que resumem as medições dos poluentes do ano vigente, comparando-as com as medições realizadas nos quatro anos anteriores do seu ano de publicação.

No entanto, embora as atenções se voltassem à poluição industrial, que diminuía, nos anos 80 a cidade viu um grande incremento no número de veículos, que praticamente dobrou durante essa década, tal como pode ser visto na Figura 01. Hoje em dia, estima-se que a frota total de veículos na RMSP seja de aproximadamente 7,5 milhões de veículos.

Outras áreas do estado de SP, apesar de não possuírem um número exorbitante de veículos como a RMSP, também apresentam problemas de qualidade do ar, por diversos motivos, como atividade industrial (Cubatão), queima de biomassa (Limeira) e veículos (Campinas). Assim, enquanto aumentavam as estações dentro da RMSP, a CETESB também começou a implantar estações nestas localidades do estado. Elas serão detalhadas posteriormente.

Durante esse período, ocorre um aumento intensivo dos poluentes ligados a emissões veiculares; dos primários, como $\mathrm{CO}$ e $\mathrm{NOx}$, e dos secundários como $\mathrm{O}_{3} \mathrm{e}$ $\mathrm{NO}_{2}$. Surge então, em 1981, as estações da rede automática de monitoramento, que seriam responsáveis pela medição de $\mathrm{PI}$ (Partículas Inaláveis), $\mathrm{CO}, \mathrm{O}_{3}, \mathrm{NO}_{2} \mathrm{e}$ também do $\mathrm{SO}_{2}$. Desde então, a CETESB publica relatórios anuais de qualidade do ar que resumem as concentrações destes poluentes ao longo do ano, e torna-os disponíveis à população em geral, para que se tenha uma melhor informação sobre a situação da poluição atmosférica no Estado. Além disso, diversos estudos foram e continua sendo realizado, tais como "Comportamento Sazonal da Poluição do Ar em São Paulo - análise de 14 anos de dados da RMSP e Cubatão, 1981 a 1994", que são importantes ferramentas no estudo e para a compreensão do fenômeno de poluição em São Paulo. 


\subsubsection{As redes de monitoramento de poluentes}

Existem duas redes de monitoramento de poluentes da CETESB na RMSP: a manual, composta por 18 estações, 8 que medem $\mathrm{SO}_{2}$ e fumaça e 10 que fazem amostragem de grandes volumes (para o Material Particulado), desde 1972, e a rede telemétrica (ou automática), constituída por 22 estações na RMSP, que medem os poluentes $\mathrm{CO}, \mathrm{NO}_{2}, \mathrm{SO}_{2}, \mathrm{PI}$ e $\mathrm{O}_{3}$, e que funciona desde 1981. Todas as estações estão distribuídas em mais de 20 localidades diferentes, concentrando-se na área central da cidade, em seu entorno e na região do $A B C$ - o que reflete a preocupação com as fontes industriais no início de sua instalação. Nem todas as estações medem todos os poluentes - as informações sobre os aspectos medidos por cada estação encontram-se na tabela 04 (página 42). Por exemplo, somente as estações de São Caetano do Sul e a do Parque D. Pedro II mediam as concentrações de MNHC, que são importantes poluentes, emitidos tanto por fontes móveis ou fixas, devido aos efeitos nocivos à saúde humana e à formação do ozônio troposférico como se pode ver na seção 1.2.1. O ozônio troposférico nos grandes centros urbanos. A medição destes compostos na rede da CETESB foi encerrada em 2002 devido à complicações relativas ao custo e manutenção dos equipamentos.

A localização das estações na RMSP utilizadas neste trabalho é demonstrada nas figuras 14 e 15 : 


\section{ESTACOES DE MONITORAMENTO DA CETESB AVALIADAS}

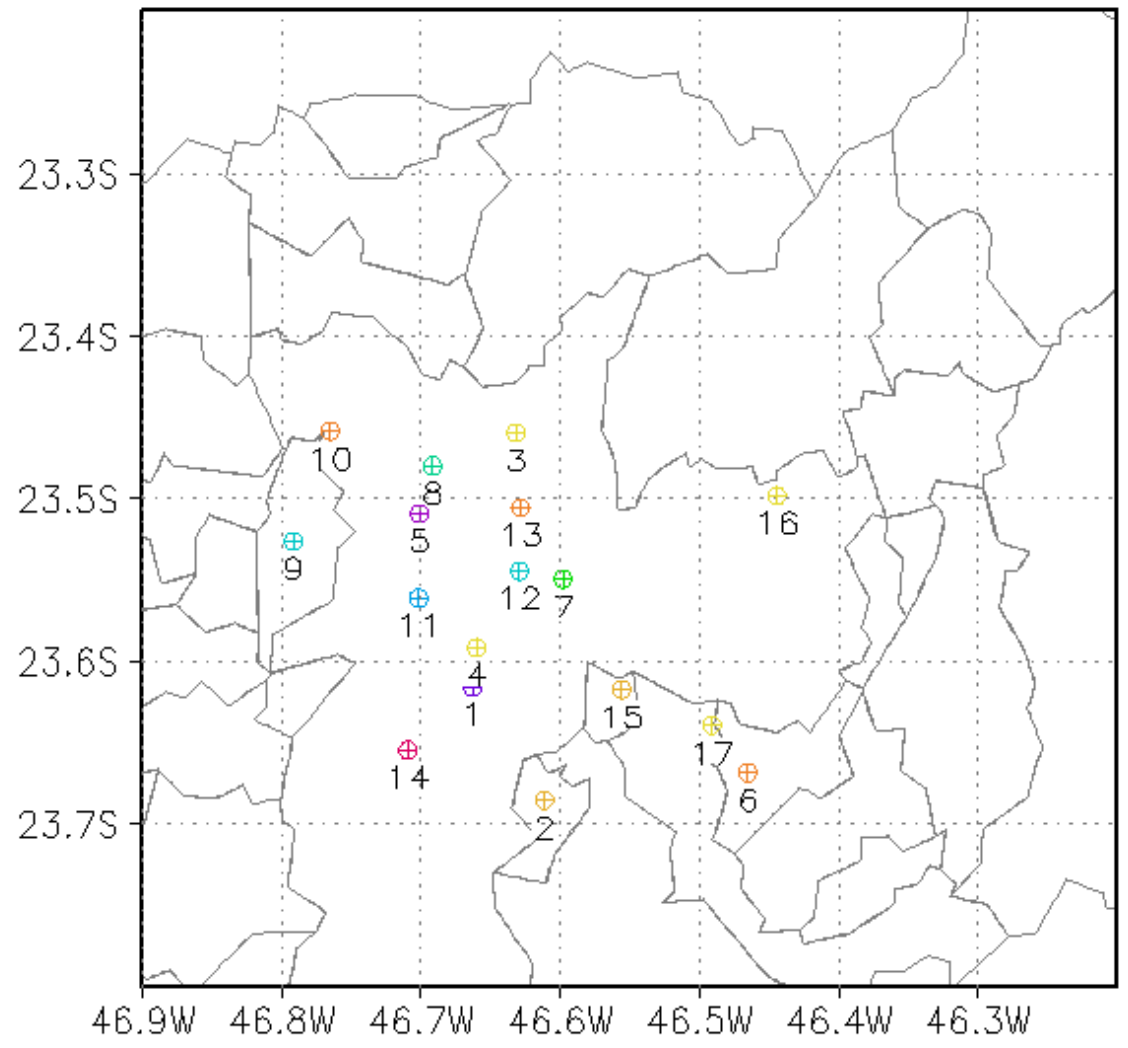

Legenda:

1 - Congonhas

2 - Diadema

3 - Horto Florestal

4 - Ibirapuera

5 - Lapa

6 - Mauá

7 - Mooca

8 - Nossa Senhora do Ó

9 - Osasco

10 - Pico do Jaraguá

11 - Pinheiros

12 - Parque D. Pedro II

13 - Santana

14 - Santo Amaro

15 - São Caetano do Sul

16 - São Miguel Paulista

17 - Santo André - Capuava

Figura 14: Localização das estações de monitoramento na RMSP utilizadas neste trabalho

Fonte: CETESB, 2006

Outras áreas do Estado de São Paulo também apresentaram grande concentração industrial além da região metropolitana de São Paulo. Na década de 70, Cubatão também se consolidava como um pólo industrial regional; isto trouxe um maior grau de desenvolvimento econômico para a região, no entanto acarretou sérios problemas ambientais. Assim, três estações da rede telemétrica foram instaladas na cidade, no centro e em bairros próximos a áreas industriais (Vila Nova e Vila Parisi), para que fosse possível medir a concentração dos poluentes emitidos pela atividade industrial. Outras áreas do Estado que, posteriormente, mereceram atenção devido à elevada poluição do ar foram Campinas, Paulínia, Sorocaba e São José dos Campos. Estas áreas se caracterizaram por uma grande expansão urbana e industrial nos últimos anos, cuja taxa de crescimento foi maior do que a registrada na RMSP, tornando-as, conseqüentemente, vulneráveis aos mesmos problemas de poluição. Além da industrialização, existem problemas ligados a atividades como a queima de cana e de lixo. Mais estações estão sendo instaladas no interior do 
Estado, o que reflete algumas medidas tomadas para se compreender o crescente problema da poluição do ar.

A tabela 04 contém informações acerca da localização de diversas estações da CETESB no Estado de São Paulo e os respectivos itens - poluentes e variáveis atmosféricas - medidos em cada uma delas. 
Tabela 04: Estações medidoras utilizadas: configuração e localização (o ponto vermelho indica o monitoramento do parâmetro considerado, o traço azul indica que o parâmetro não é monitorado).

\begin{tabular}{lll}
$\mathrm{PI}-$ Partículas Inaláveis & NOx - Óxidos de Nitrogênio & $\mathrm{TM}$ - Temperatura \\
$\mathrm{SO}_{2}$ - Dióxido de Enxofre & $\mathrm{CO}-$ Monóxido de Carbono & $\mathrm{VV}$ - Velocidade dos Ventos \\
$\mathrm{NO}$ - Óxido de Nitrogênio & $\mathrm{O}_{3}-$ Ozônio & DV - Direção dos Ventos \\
$\mathrm{NO}_{2}$ - Dióxido de Nitrogênio & UR - Umidade Relativa & \\
\hline
\end{tabular}

\begin{tabular}{|c|c|c|c|c|c|c|c|c|c|c|c|}
\hline \multicolumn{12}{|c|}{ ESTAÇÕES MEDIDORAS } \\
\hline \multicolumn{11}{|c|}{ Configuração } & Localização \\
\hline PI & $\mathrm{SO}_{2} \mid$ & NO & $\mathbf{N O}_{2}$ & $\begin{array}{l}\text { NO } \\
x^{2}\end{array}$ & co & $\mathbf{O}_{3}$ & UR & TM & VV & DV & CAPITAL \\
\hline- & & $\bullet$ & $\cdot$ & $\cdot$ & & • & & & & - & $\begin{array}{l}\text { Horto Florestal }^{*} \\
\text { Rua do Horto, } 931\end{array}$ \\
\hline & & - & $\cdot$ & - & • & • & & . & - & - & $\begin{array}{l}\text { Pico do Jaraguá* } \\
\text { Estrada Pico do Jaraguá, s/n - Parque } \\
\text { Estadual do Jaraguá }\end{array}$ \\
\hline$\cdot$ & • & - & - & & . & . & 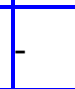 & - & - & . & $\begin{array}{l}\text { Congonhas } \\
\text { Al. Dos Tupiniquins, } 157\end{array}$ \\
\hline & . & . & $\cdot$ & . & - & • & 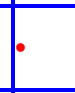 &. & - & - & $\begin{array}{l}\text { Ibirapuera } \\
\text { Parque do Ibirapuera, setor } 25\end{array}$ \\
\hline - & & - & - & - & - & • & & - & . & . & $\begin{array}{l}\text { Santana } \\
\text { Av. Santos Dumont, } 1019\end{array}$ \\
\hline • & & - & 0 & . & - & . & - & - & 0 & - & $\begin{array}{l}\text { Lapa } \\
\text { Av. Embaixador Macedo Soares, } 7995\end{array}$ \\
\hline • & & - & - & - & - & . & - & - & . & - & $\begin{array}{l}\text { Mooca } \\
\text { Rua Bresser, } 2341\end{array}$ \\
\hline . & & - & - & & - & 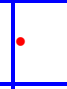 & & - & - & - & $\begin{array}{l}\text { Nossa Senhora do Ó } \\
\text { R. Capitão José Aranha do Amaral, } 80\end{array}$ \\
\hline . & - & • & - & . & • & 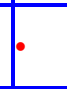 & • & - & . & - & $\begin{array}{l}\text { Parque D. Pedro } \\
\text { Parque Dom Pedro II, } 319\end{array}$ \\
\hline . & & 。 & - & . & . & . & - & - & - & - & $\begin{array}{l}\text { Pinheiros } \\
\text { Rua Frederico Hermann Jr, } 345\end{array}$ \\
\hline • & & - & - & & . & & - & - & . & . & $\begin{array}{l}\text { Santo Amaro } \\
\text { Av. Padre José Maria, } 355\end{array}$ \\
\hline 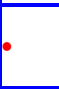 & & & - & & & & & . & . & . & $\begin{array}{l}\text { São Miguel Paulista } \\
\text { Rua Diego Calado, } 166\end{array}$ \\
\hline
\end{tabular}

\begin{tabular}{|c|c|c|c|c|c|c|c|c|c|c|c|}
\hline PI & $\mathbf{S O}_{2}$ & NO & $\mathrm{NO}_{2}$ & $\begin{array}{l}\text { NO } \\
x\end{array}$ & Co & $\mathbf{O}_{3}$ & UR & TM & VV & DV & GRANDE SÃO PAULO \\
\hline - & - & & & & & & & & & & $\begin{array}{l}\text { Diadema } \\
\text { Rua Benjamim Constant, } 3\end{array}$ \\
\hline 1. & - & $\cdot$ & . & & - & & & - & - & - & $\begin{array}{l}\text { Mauá } \\
\text { Rua Vitorino Dell'Antonia, } 150\end{array}$ \\
\hline & - & - & - & & & & & - & - & - & $\begin{array}{l}\text { Santo André - Capuava } \\
\text { Rua Manágua,2 }\end{array}$ \\
\hline & - & 1. & . & & . & . & & . & - & . & $\begin{array}{l}\text { São Caetano do Sul } \\
\text { Rua Aurélia s/n (EMI F. Pessoa V. Paula) }\end{array}$ \\
\hline • & - & . & . & & & & & & & - & $\begin{array}{l}\text { Osasco } \\
\text { Av. dos Autonomistas c/ Rua S. Maurício }\end{array}$ \\
\hline
\end{tabular}

*Estação Móvel

Fonte: CETESB, 2006.

Disponível em: http://www.cetesb.sp.gov.br/Arlar indice padroes.asp 
Como citado anteriormente, as estações em São Paulo estavam inicialmente localizadas próximas ao centro e às áreas de grande concentração industrial. No entanto, sabe-se que enquanto na década de 70 estas eram responsáveis por péssimos quadros de qualidade do ar, hoje em dia são responsáveis apenas por $10 \%$ da poluição em São Paulo, pois muitas e eficazes foram as ações implantadas e tecnologias desenvolvidas para lidar com este problema. Hoje em dia, muitos dos locais cobertos pela rede da CETESB caracterizam-se por apresentarem altos índices de poluição veicular, como as marginais dos rios Pinheiros e Tietê e mesmo o centro de São Paulo. Durante os anos 70, destacava-se o centro da cidade neste contexto, pois além da concentração de poluentes veiculares ser muito intensa, a concentração de poluentes advindos de fontes industriais também costumava apresentar altos índices - uma vez que ventos vindos da direção sudeste podem transportar os poluentes que se originam na região a sudeste da RMSP, como o ABC ou Cubatão, para a cidade de São Paulo (SÁNCHEZ-CCOYLLO,2000). 


\subsubsection{Caracterização de algumas estações medidoras da CETESB}

A quantidade e distribuição espacial das estações de monitoramento de qualidade do ar exercem importante papel na avaliação do mesmo em um dado local. Como pode-se ver nas figuras 07 e 08, as estações de monitoramento da CETESB estão relativamente bem distribuídas pela RMSP. É fato que uma quantidade maior de estações, posicionadas estrategicamente, representaria melhor a qualidade do ar na RMSP, mas existem uma série de detalhes a serem considerados quando da instalação das estações, que dizem respeito à representatividade do local. Por exemplo, se a estação está localizada ao lado de uma via expressa com fluxo intenso de veículos, ela será representativa apenas da poluição gerada neste local. Por outro lado, estações mais afastadas desses grandes centros de emissão tendem a demonstrar a concentração de background, ou concentração de fundo da cidade, ou seja, da área urbana como um todo. Devese considerar adequadamente a topografia do local e a circulação atmosférica em escala urbana predominante, por exemplo, além de uma série de questões práticas. Mouvier (1995), diz que, na França, “...os órgãos públicos especializados instalaram uma rede de estações automáticas em diversos locais supostamente representativos [... $]^{5 ”,}$, chamando a atenção para o fato de que podem ocorrer situações onde a estação de monitoramento não está bem posicionada para representar o que dela se espera. Muitas vezes, a instalação de uma destas estações envolve a satisfação de procedimentos burocráticos e políticos, bem como a segurança dos equipamentos, que acabam também limitando os locais disponíveis para escolha.

Para melhor esclarecer estas questões dentro das redes de monitoramento de qualidade do ar na RMSP, a CETESB aplicou uma escala de representatividade para as estações, que classifica cada estação de acordo com o tipo de informação que ela revela sobre a poluição do ar na cidade, que pode ser vista na tabela 05 :

\footnotetext{
${ }^{5}$ MOUVIER , G. A poluição atmosférica, Biblioteca Básica de Ciência e Cultura, Instituto Piaget, Lisboa, 1995, p 40.
} 
Tabela 05: Classificação das estações em termos de uso do solo e população exposta.

\begin{tabular}{|l|l|}
\hline Característica da estação & Descrição \\
\hline Comercial & $\begin{array}{l}\text { Mede a exposição da população em áreas } \\
\text { urbanas centrais, áreas de comércio, com } \\
\text { grande movimentação de pedestres e veículos. }\end{array}$ \\
\hline Residencial & $\begin{array}{l}\text { Mede a exposição da população em bairros } \\
\text { residenciais e áreas suburbanas das cidades; }\end{array}$ \\
\hline Industrial & $\begin{array}{l}\text { Em áreas onde as fontes industriais têm grande } \\
\text { influência nas concentrações observadas, tanto } \\
\text { em longo prazo quanto para avaliação de picos } \\
\text { de concentração; }\end{array}$ \\
\hline $\begin{array}{l}\text { Urbana/concentração de fundo } \\
\text { (background) }\end{array}$ & $\begin{array}{l}\text { Em áreas urbanas, localizada não próximo de } \\
\text { fontes específicas, representa as concentrações } \\
\text { de fundo da área urbana como um todo; }\end{array}$ \\
\hline $\begin{array}{l}\text { Próxima de vias de tráfego } \\
\text { (veicular) }\end{array}$ & $\begin{array}{l}\text { Localizada próxima de uma via de tráfego, mede } \\
\text { a influência da emissão dos veículos que } \\
\text { circulam na via (rua, estrada etc.); }\end{array}$ \\
\hline Rural & $\begin{array}{l}\text { Mede as concentrações em áreas rurais, deve } \\
\text { estar situada o mais distante possível de fontes } \\
\text { veiculares, industriais e urbanas. }\end{array}$ \\
\hline Ambiente fechado (indoor) & $\begin{array}{l}\text { Mede as concentrações em ambientes } \\
\text { domésticos e de trabalho (exceto ambientes } \\
\text { ocupacionais) }\end{array}$ \\
\hline
\end{tabular}

Esta classificação foi adaptada a partir de diretrizes da Agência de Proteção Ambiental dos EUA (USEPA) e da Organização Mundial da Saúde (OMS). Outra classificação, de mesma origem, aplicada às estações refere-se à representatividade espacial das estações, e pode ser vista na tabela 06: 
Tabela 06: Classificação das estações em termos de representatividade.

\begin{tabular}{|l|l|}
\hline Escala de representatividade & Área de abrangência \\
\hline Microescala & $\begin{array}{l}\text { Concentrações abrangendo áreas de dimensão } \\
\text { de poucos metros até 100 metros; }\end{array}$ \\
\hline Média escala & $\begin{array}{l}\text { Concentrações para blocos de áreas urbanas } \\
\text { (poucos quarteirões com características } \\
\text { semelhantes), com dimensões entre 100 e 500 } \\
\text { metros; }\end{array}$ \\
\hline Escala de bairro & $\begin{array}{l}\text { Concentrações para áreas da cidade (bairros), } \\
\text { com atividade uniforme, com dimensões de 500 } \\
\text { a 4.000 metros; }\end{array}$ \\
\hline Escala urbana & $\begin{array}{l}\text { Concentrações de cidades ou regiões } \\
\text { metropolitanas, da ordem de 4 a 50 km; }\end{array}$ \\
\hline Escala regional & $\begin{array}{l}\text { Concentrações geralmente de uma área rural, } \\
\text { de geografia razoavelmente uniforme e de } \\
\text { dimensões de dezenas a centenas de } \\
\text { quilômetros; }\end{array}$ \\
\hline Escalas nacional e global & $\begin{array}{l}\text { Concentrações de um país e do planeta como } \\
\text { um todo, respectivamente. }\end{array}$ \\
\hline
\end{tabular}

Pode-se inferir, pela localização e disposição das estações da CETESB, que a maioria das estações possui representatividade até escala de bairro, uma vez que a rede é numerosa o suficiente para se ter representações de diversos locais da RMSP.

A estação Congonhas, por exemplo, é considerada veicular, pois sofre influência direta dos fluxo intenso de automóveis das avenidas dos Bandeirantes e Washington Luís, como pode ser visto na figura 16:

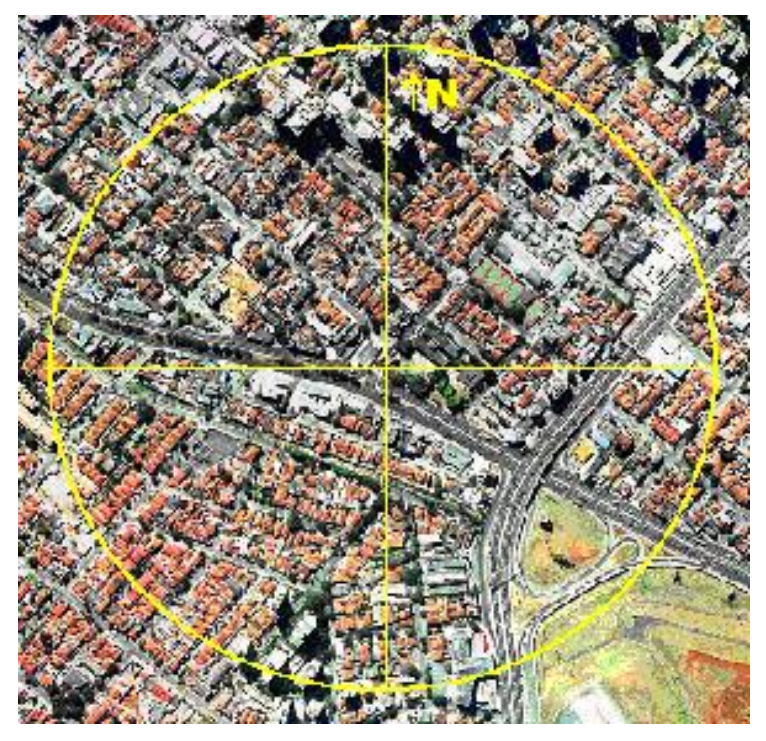

Figura 15: Entorno da estação Congonhas. Fonte: CETESB, 2004. 
Outra estação considerada veicular é a estação Lapa, localizada ao lado da Marginal do Tietê, como pode ser visto na figura 16:

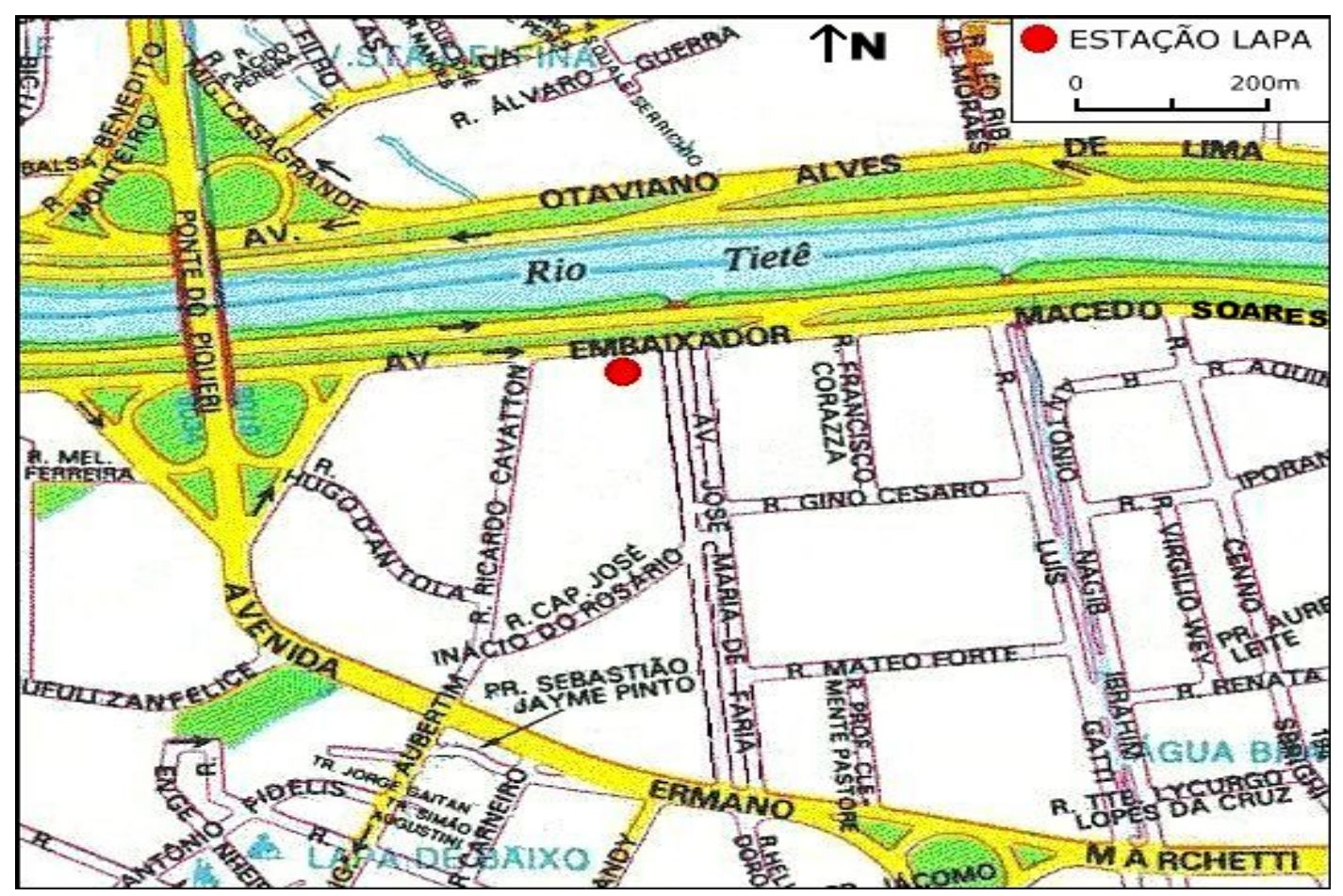

Figura 16: Entorno da estação Lapa.

Fonte CETESB, 2004.

A próxima figura indica a localização de uma outra estação considerada veicular, a estação Osasco. 


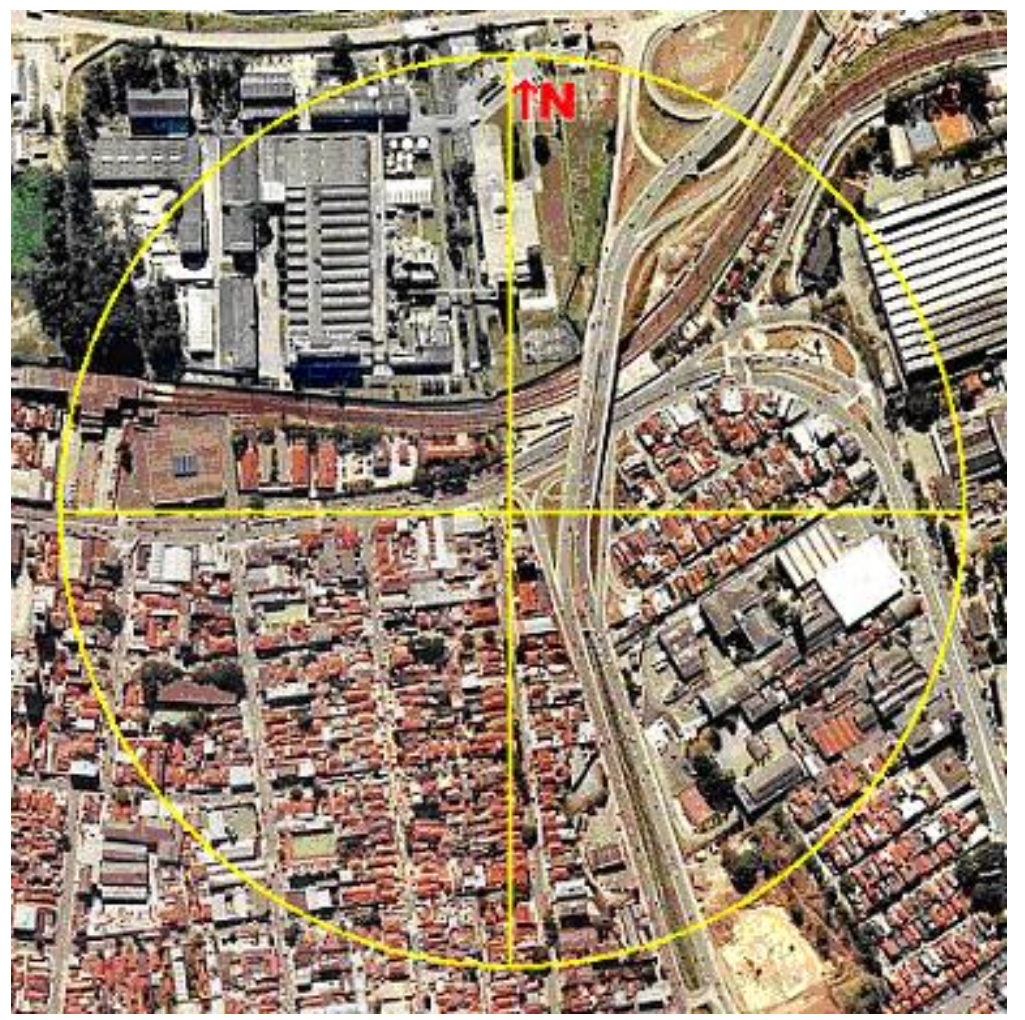

Figura 17: Entorno da estação Osasco.

Fonte: CETESB, 2006.

Esta estação, ao lado da Av. Dos Autonomistas, representa bem a poluição gerada por essa avenida, embora também sofra influência da atividade industrial da região, que é de considerada pela prefeitura de Osasco com Zona de Uso Exclusivamente Industrial (ZI/08). Embora venha ocorrendo expressiva descaracterização da atividade industrial da região nos últimos anos, ainda existem indústrias em funcionamento no local. 


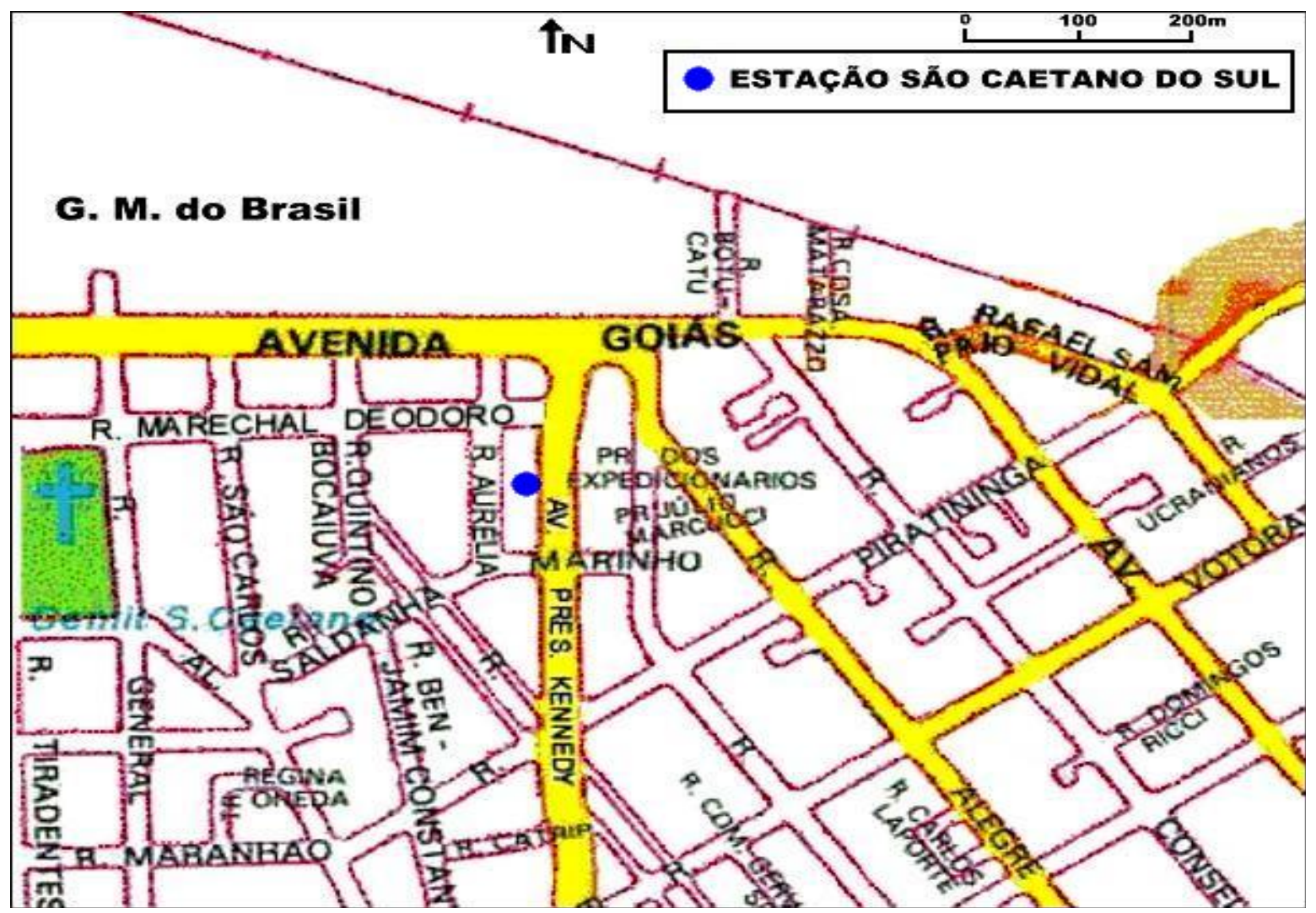

Figura 18: Entorno da estação São Caetano do Sul. Fonte: CETESB, 2003.

A estação São Caetano do Sul, no entanto, não está localizada diretamente nas vias de fluxo intenso, estando a aproximadamente 150m da Av. Goiás, possuindo assim representatividade industrial e residencial. 


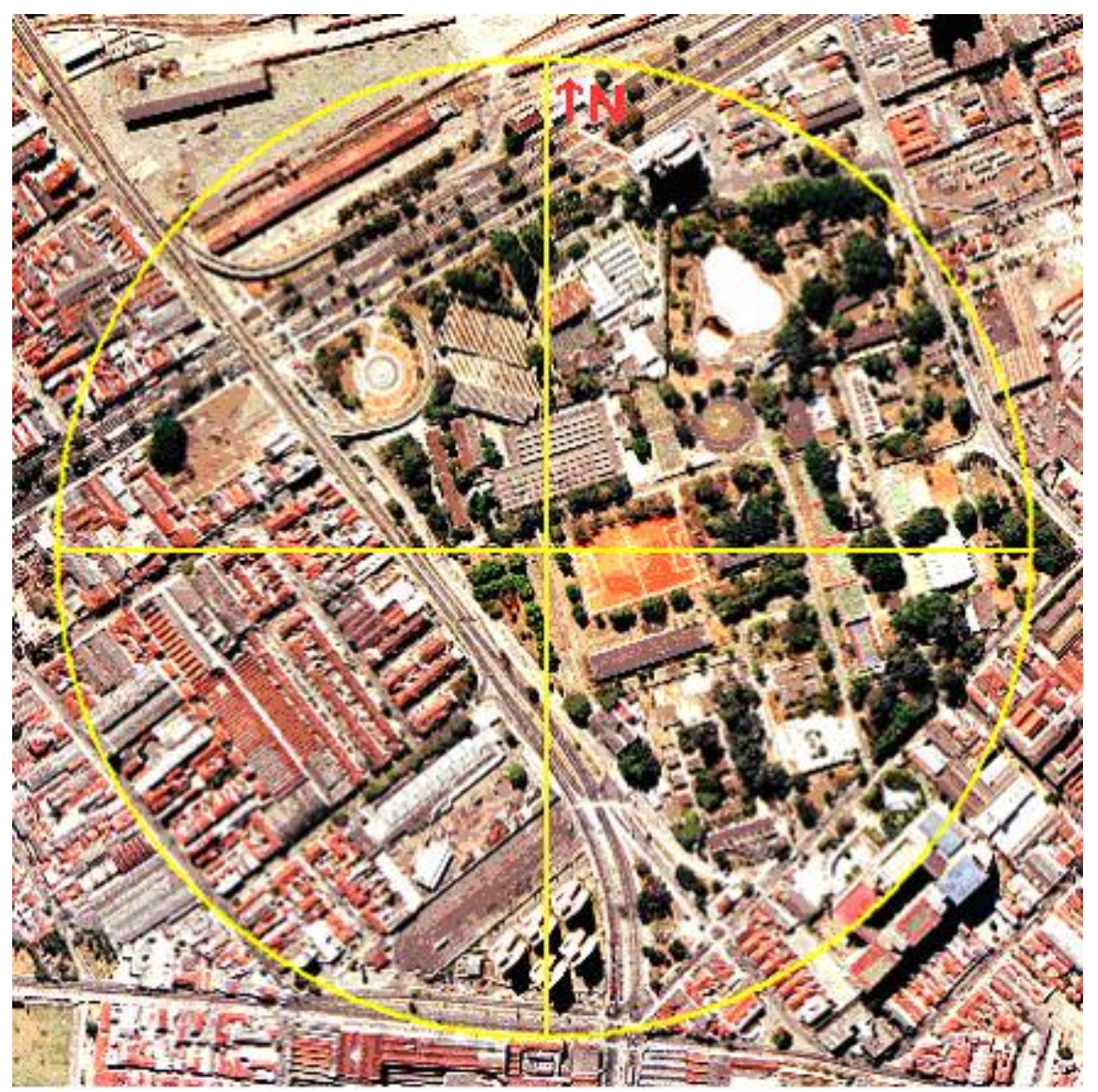

Figura 19: Entorno da estação Mooca.

Fonte: CETESB, 2007.

Outra estação de caráter misto é a estação Mooca, que está localizada numa área de lazer (campo de futebol cercado por área verde), inserida em uma região de uso do solo misto de representatividade industrial, comercial e residencial, a $70 \mathrm{~m}$ da Rua Bresser, com intenso fluxo de veículos. 


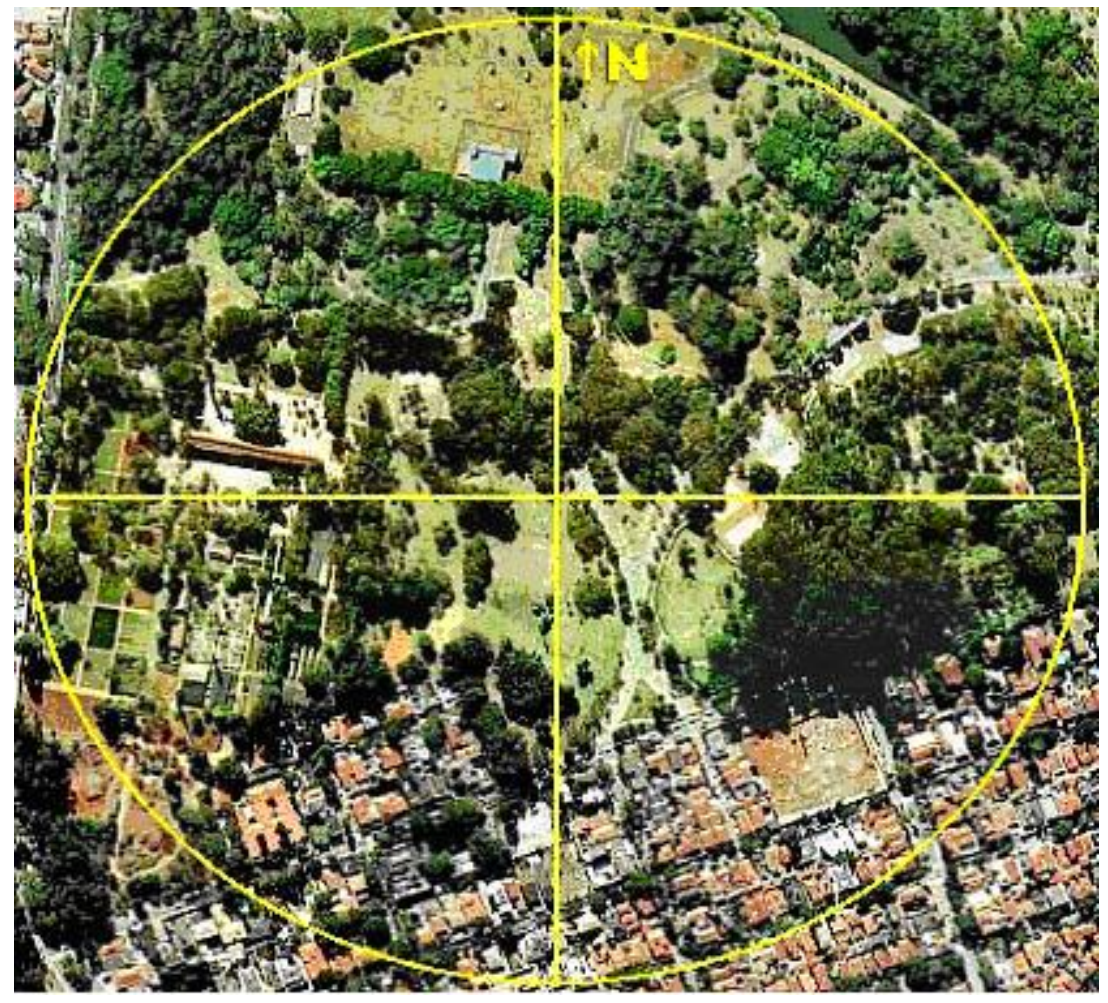

Figura 20: Entorno da estação Ibirapuera.

Fonte: CETESB, 2004.

A estação Ibirapuera, no entanto, é representativa de concentrações de fundo da RMSP, por estar localizada dentro de um parque urbano, a mais de $250 \mathrm{~m}$ de avenidas de fluxo intenso de veículos. O uso do solo nas áreas do entorno do parque, no entanto, é residencial: 


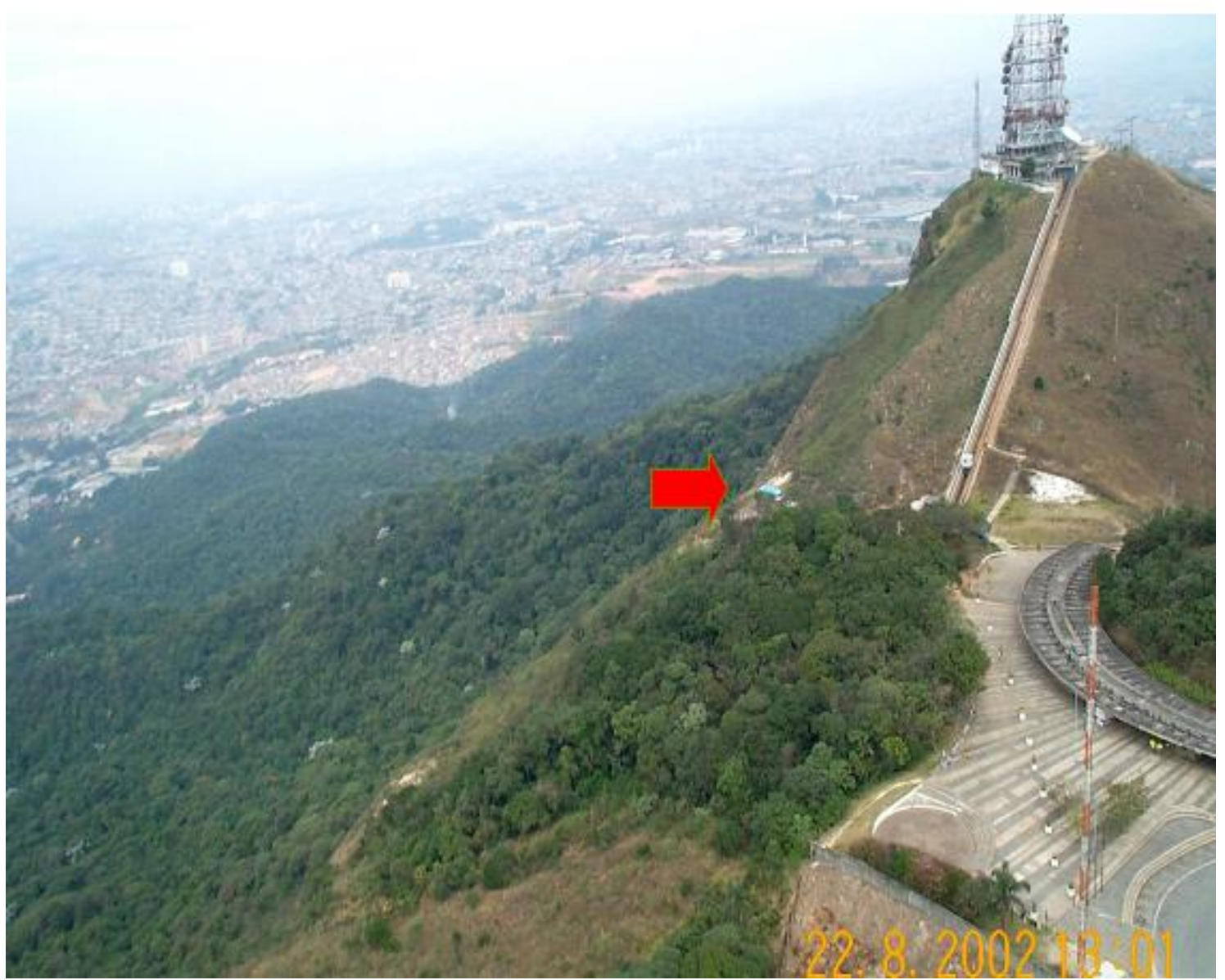

Figura 21: Entorno da estação Pico do Jaraguá. A estação está indicada pela seta. Fonte: CETESB, 2007.

Finalmente, a estação móvel Pico do Jaraguá foi instalada em uma área mais afastada ainda dos grandes centros de emissão, no alto do Pico do Jaraguá, em sua vertente leste, voltada para a RMSP. Ela representa também a poluição de fundo desta grande mancha urbana, e possivelmente sofre influência do transporte de parte dos poluentes da Rodovia dos Bandeirantes e de outros locais.

Há muito ainda a se comentar sobre esta rede de monitoramento de poluentes da CETESB na RMSP, no que se refere à sua disposição, equipamentos, representatividade, etc. Ressalva-se assim a necessidade de se fazer análises e reflexões para a construção de uma rede mais representativa, principalmente em relação à distribuição espacial das estações na cidade e representatividade destas no contexto de cada bairro. A atual rede de estações que monitora a qualidade do ar da RMSP está satisfatoriamente bem distribuída, porém, só recentemente, a partir 
do ano de 2002, os dados gerados pela rede têm maior porcentagem de dados válidos e são organizados de maneira a facilitar a pesquisa científica em torno deles. Além disso, das estações utilizadas neste trabalho, apenas para estas que já foram descritas neste capítulo com maior detalhe é que foi publicado algum tipo de documento de detalhamento e caracterização da estação. Este tipo de documento é importante devido ao conhecimento que se obtém sobre a representatividade da estação considerada, sendo aconselhável que se realize estudos de caracterização para todas as estações da rede de monitoramento para que se possa conhecer com maior profundidade a realidade de cada estação, e assim, aprofundar o conhecimento sobre a evolução temporal e distribuição espacial dos poluentes.

Além dos documentos publicados pela CETESB, outras informações podem ser utilizadas, para se caracterizar algumas estações da rede de monitoramento, tal como os estudos de Sampaio (2000) e Azevedo (2002). Neste contexto, o estudo de Sampaio é importante pois nele foi realizada uma caracterização das estações da rede de monitoramento de qualidade do ar da CETESB, enquanto que no de Azevedo explora-se a relação das concentrações de ozônio e a relação com a intensidade da atividade urbana no entorno das estações. Adicionalmente, foram obtidas do portal Maplink ${ }^{6}$ algumas imagens de satélite das áreas no entorno das estações.

De acordo com o estudo anteriormente mencionado, a estação Parque D. Pedro II situa-se numa área próxima a corredores de tráfego intenso de veículos (Av. Do Estado) e pessoas (R. 25 de Março) e do terminal de ônibus homônimo. Além do terminal de ônibus, a proximidade com o mercado municipal intensifica o tráfego de veículos pesados na área. Assim, esta estação é representativa de uma área de intensa atividade urbana, predominantemente comercial, com algumas residências. Esta estação é importante devido à intensa atividade urbana e emissão de poluição veicular em seu entorno, além de possuir condições topográficas desfavoráveis à dispersão destes poluentes, por estar localizada no vale do Rio Tamanduateí:

\footnotetext{
${ }^{6}$ http://maplink.uol.com.br/
} 


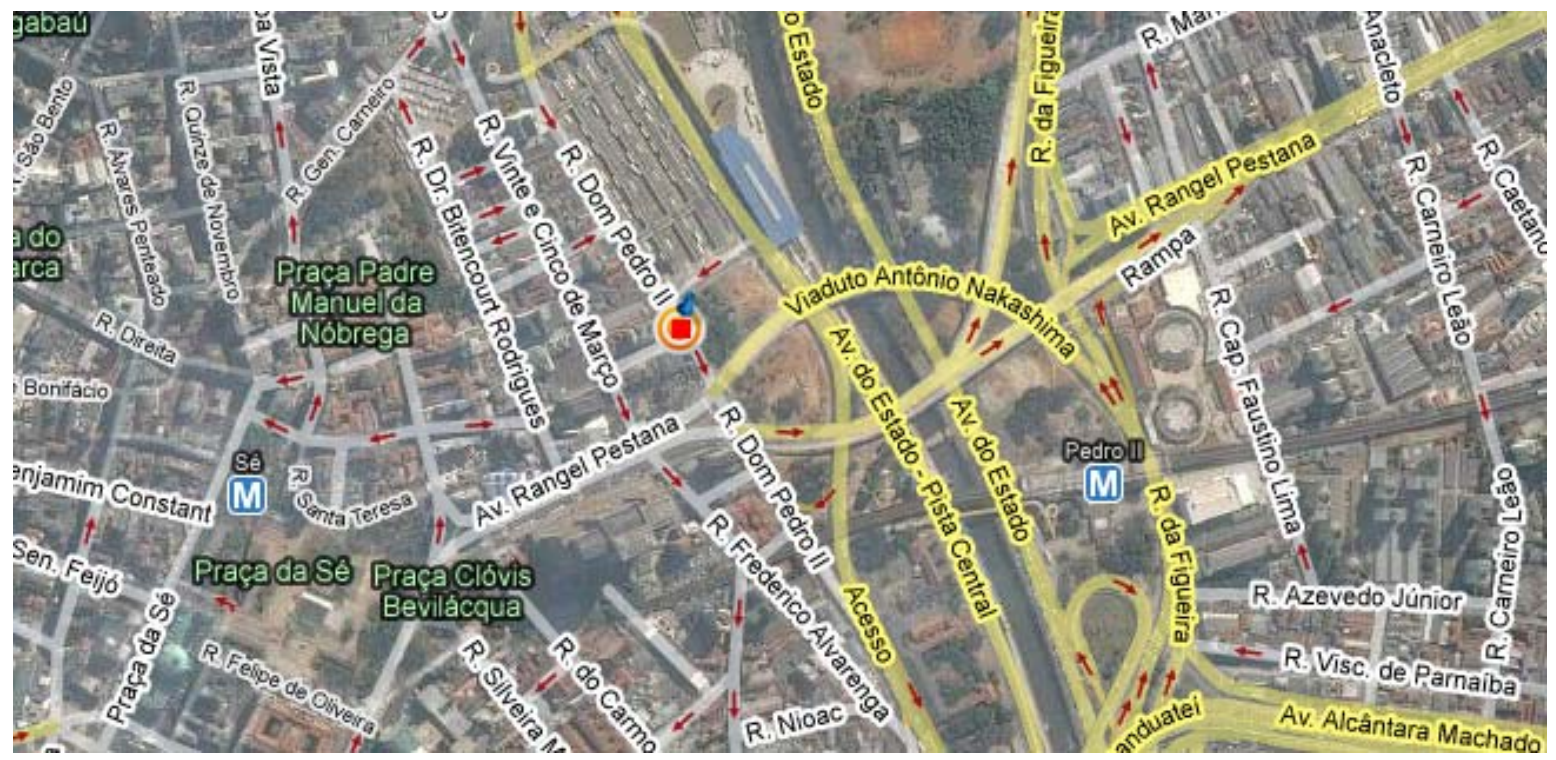

Figura 22: Entornos da estação Parque D. Pedro II. A localização aproximada é representada pelo quadrado vermelho.

Fonte: http://maplink.uol.com.brl

A estação Santana, no entanto, está localizada numa área significativamente diferente. Como pode-se ver pela figura 24, ela não se localiza em uma área diretamente sob a influência das fontes de emissão:

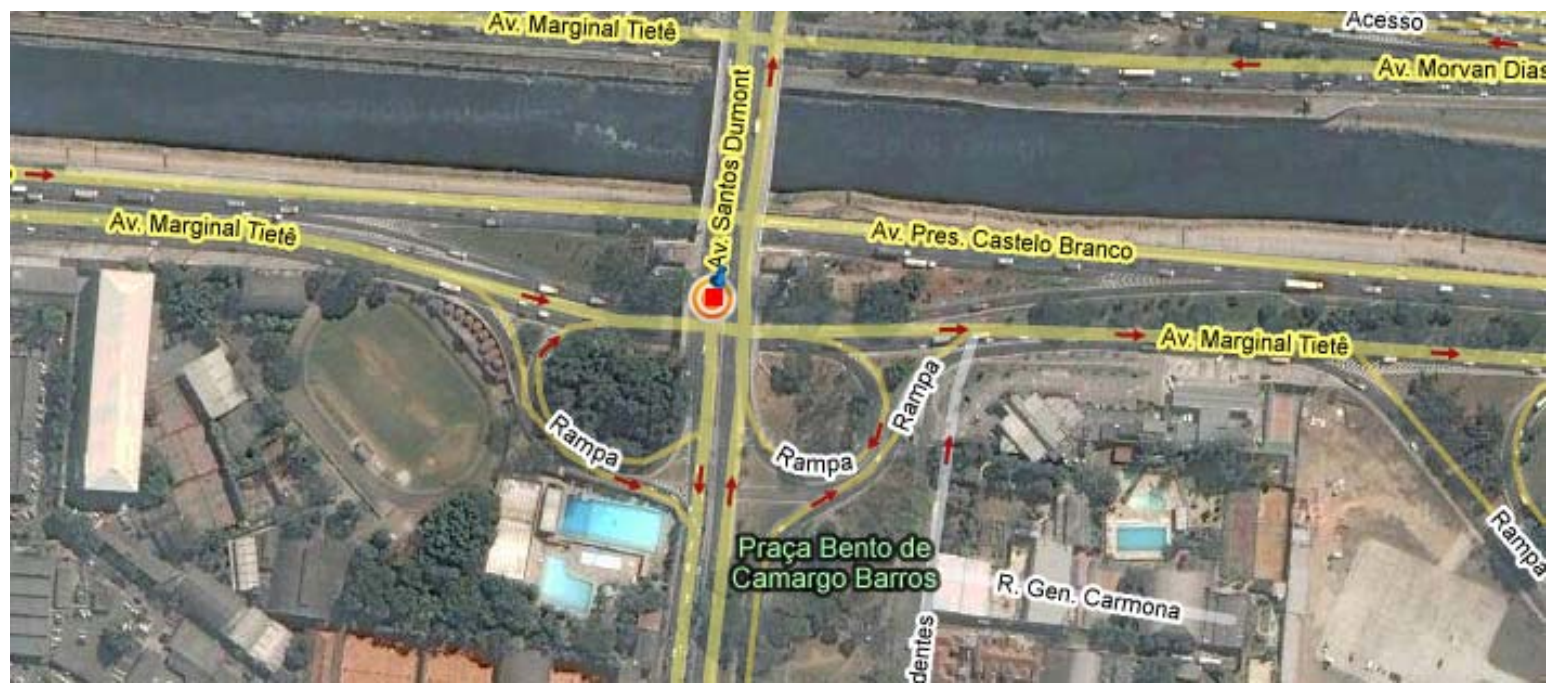

Figura 23: Entornos da estação Santana. A localização aproximada é representada pelo quadrado vermelho.

Fonte: http://maplink.uol.com.brl

A estação situa-se numa área militar, predominantemente residencial mas com algum comércio. Apesar de não estar localizada diretamente numa área de intensa atividade urbana, ela sofre influência da poluição emitida principalmente na Marginal do Tietê e Av. Santos Dumont, bem como da Av. Cruzeiro do Sul. 
"A estação Nossa Senhora do Ó, por outro lado, encontra-se numa área com pouca área verde ao redor, mas com reduzida atividade urbana. Tratase de "um bairro periférico, com pouca vegetação e onde os espaços livres servem muitas vezes de depósito de lixo. Região residencial e comercial, com casas construídas em pequenos lotes ${ }^{7 "}$ :

A estação situa-se numa escola, relativamente afastada das principais fontes de emissão, como a Av. Min. Petrolino Portela, Av. João Paulo I (450m) e Av. Itaberaba $(600 \mathrm{~m})$.

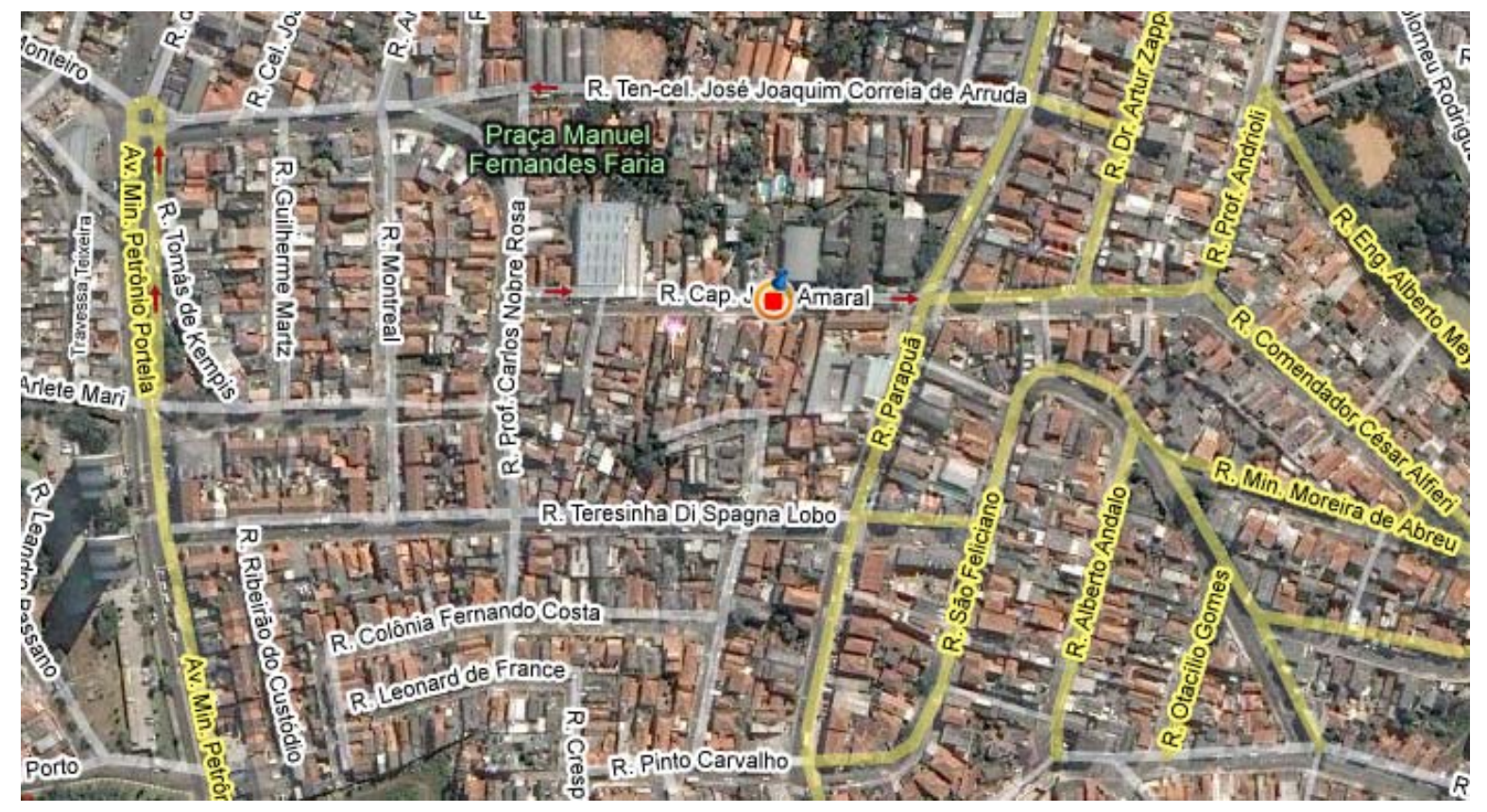

Figura 24: Entornos da estação Nossa Senhora do Ó. A localização aproximada é representada pelo quadrado vermelho.

Fonte: http://maplink.uol.com.brl

A estação Diadema está localizada numa área predominantemente industrial, com reduzida influência de fontes locais. Significativa quantidade de área verde pode ser vista em seus entornos:

\footnotetext{
${ }^{7}$ SAMPAIO SILVA, R. Análise crítica da rede de monitoramento da qualidade do ar da CETESB na Grande São Paulo. Trabalho de Graduação Individual, FFLCH-USP, 2000. p 88.
} 


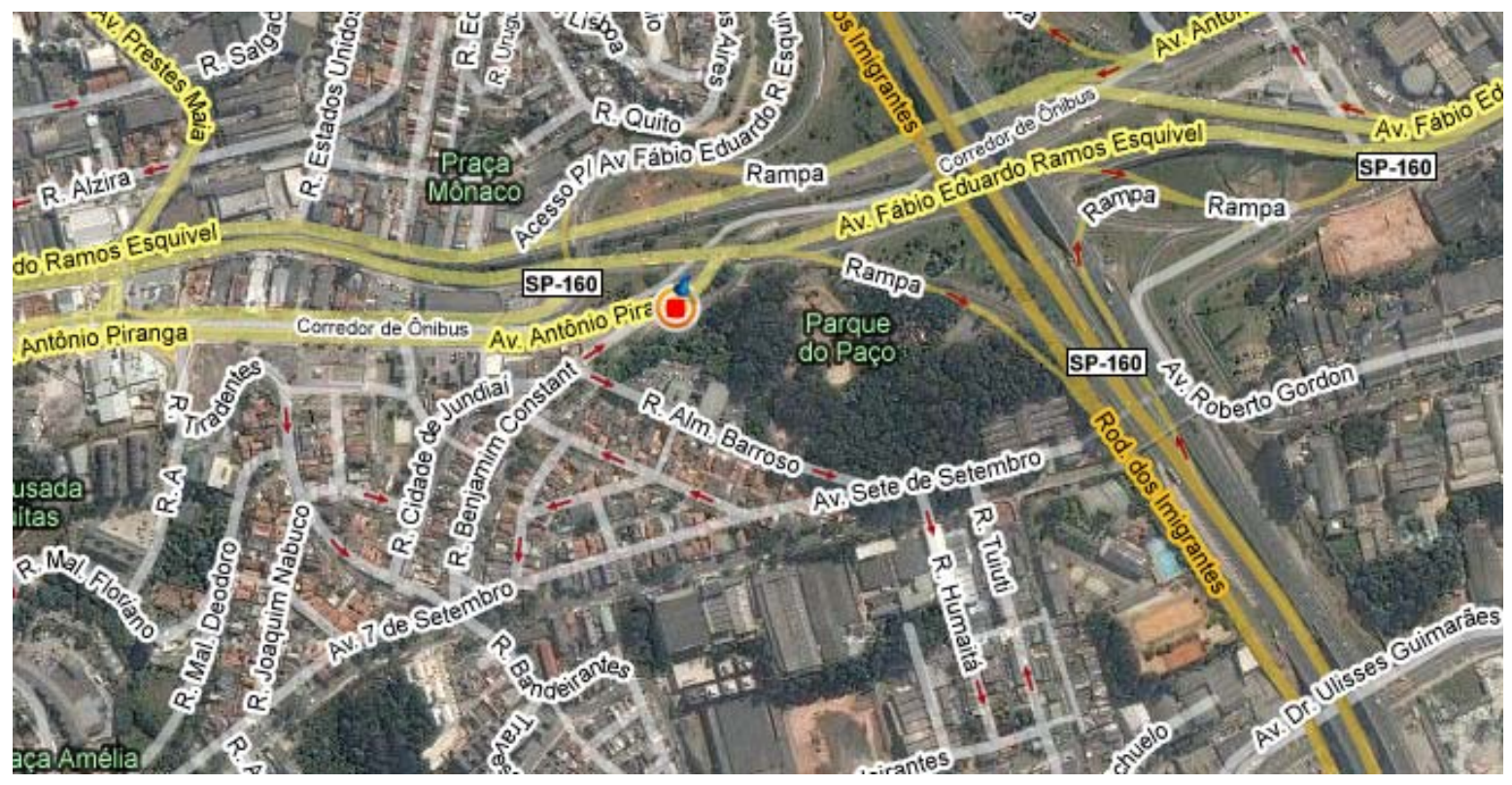

Figura 25: Entornos da estação Diadema. A localização aproximada é representada pelo quadrado vermelho.

Fonte: http://maplink.uol.com.brl

A única fonte significativa de poluição veicular (Rodovia dos Imigrantes) está relativamente afastada, como se pode ver pela figura 26.

Localizada numa área caracterizada por diversos tipos de uso do solo, a estação Santo Amaro é importante devido ao intenso fluxo de veículos e pessoas em seus entornos. Ao mesmo tempo em que ela sofre certa influência do Terminal de Ônibus Santo Amaro, há também intensa atividade comercial no centro comercial local, nos entornos da estação de metrô, além da área verde no Centro Educacional de Santo Amaro Joerg Bruder, onde a estação está localizada. 


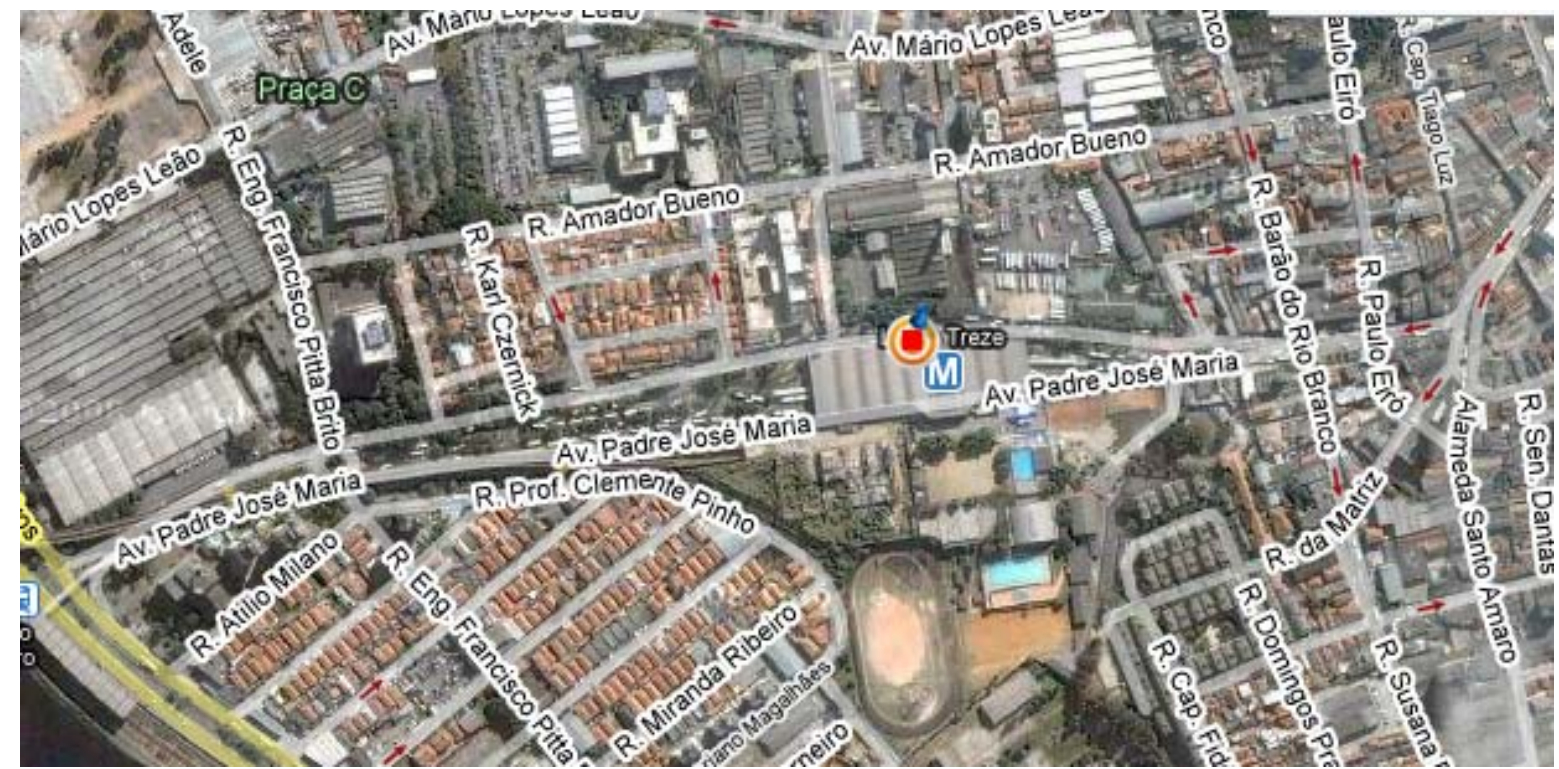

Figura 26: Entornos da estação Santo Amaro. A localização aproximada é representada pelo quadrado vermelho.

Fonte: http://maplink.uol.com.brl

A estação Santo André - Capuava está localizada numa área majoritariamente industrial, assim sofrendo influência direta do pólo petroquímico, mas com algum uso do solo residencial em seu entorno:

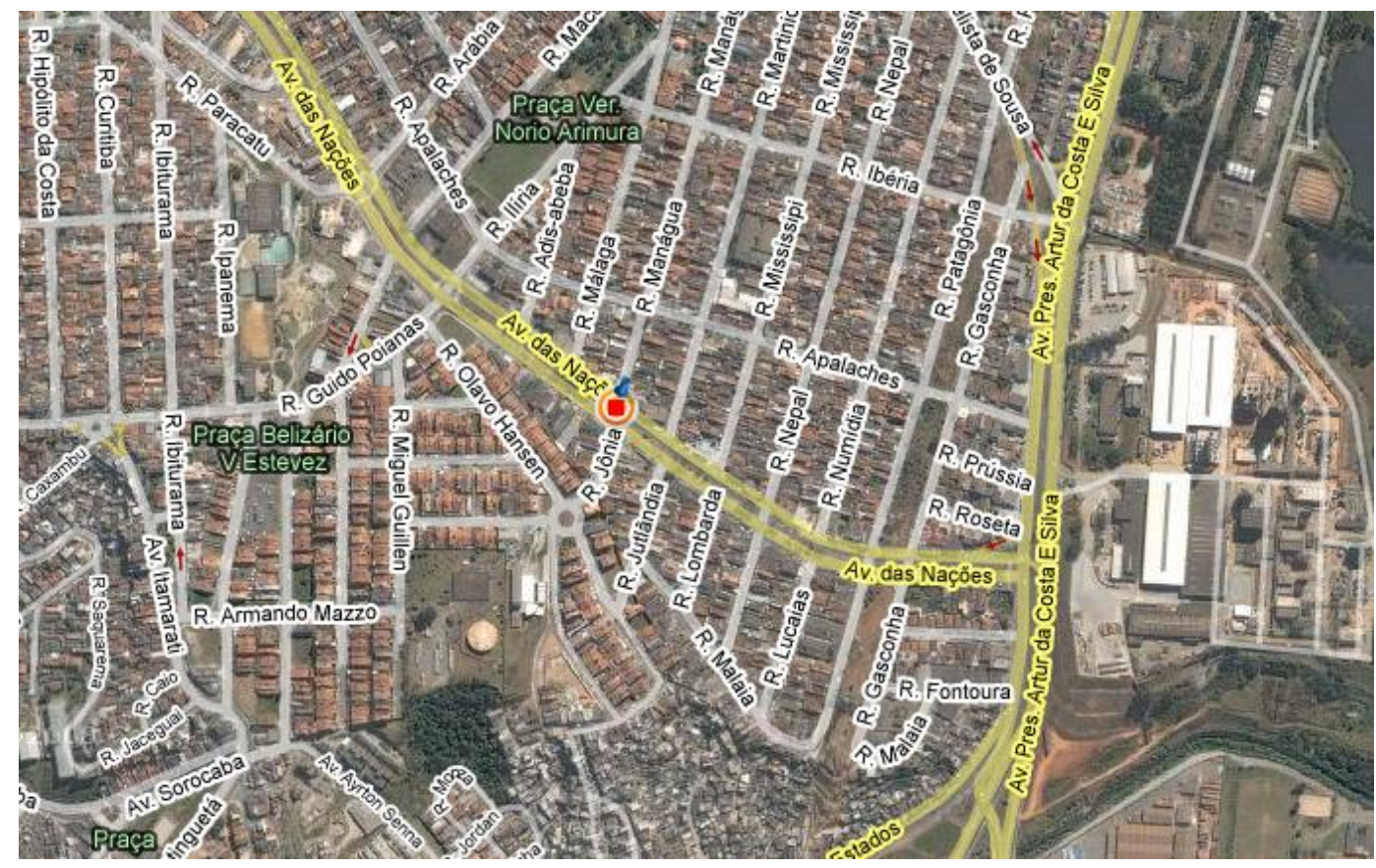

Figura 27: Entornos da estação Santo André - Capuava. A localização aproximada é representada pelo quadrado vermelho.

Fonte: http://maplink.uol.com.brl

$\mathrm{Na}$ figura 27, uma parte do complexo petroquímico pode ser vista à direita da Av. Presidente Arthur da Costa e Silva . 
Na estação São Miguel Paulista, predomina o uso do solo residencial, com alguma atividade industrial no entorno:

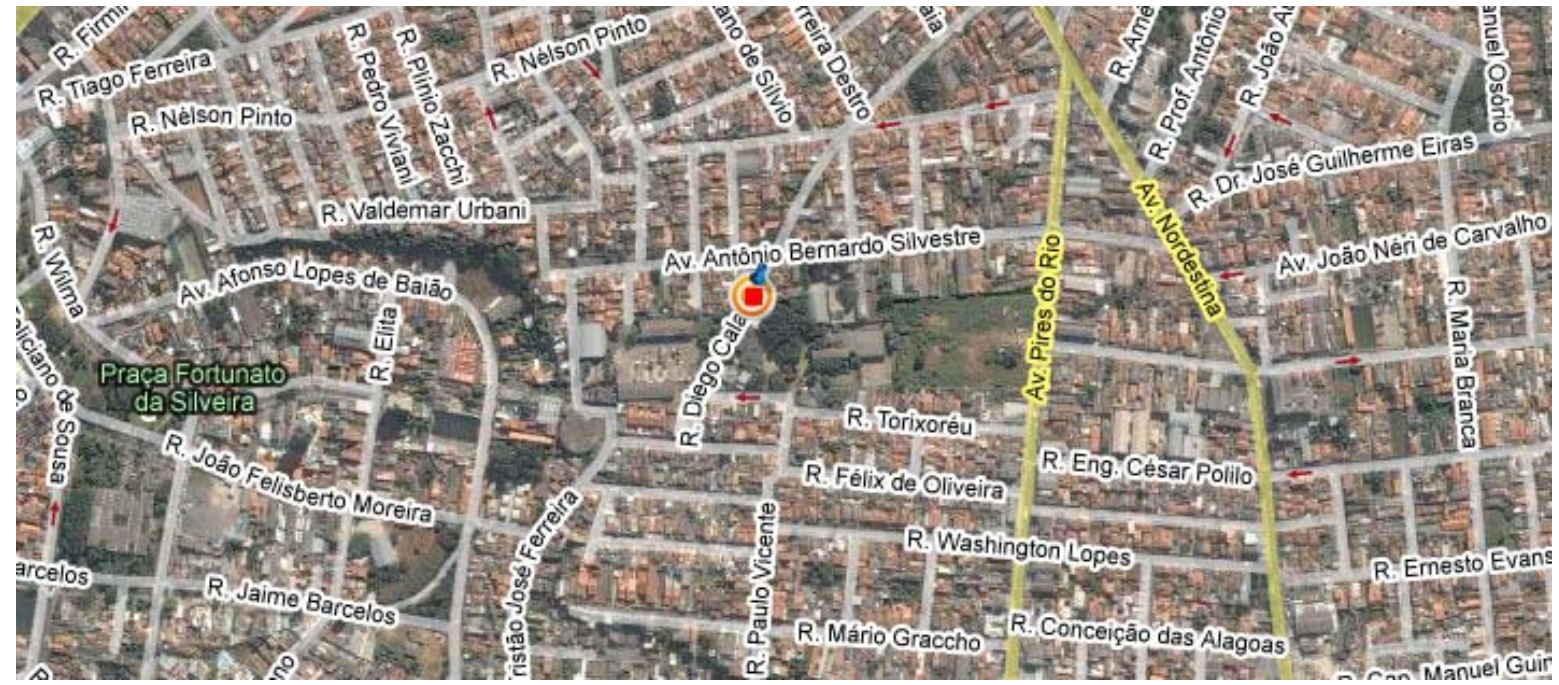

Figura 28: Entornos da estação São Miguel Paulista. A localização aproximada é representada pelo quadrado vermelho.

Fonte: http://maplink.uol.com.brl

Não há variação altimétrica significativa nos entornos da estação, e as avenidas que podem ser vistas na figura 29 são a Av. Pires do Rio e Av. Nordestina; no entanto, devido à relativa distância da estação de monitoramento, sua influência sobre ela é menos significativa.

A estação Mauá está localizada numa área de reduzida atividade urbana, de acordo com o estudo de Azevedo (2002): 


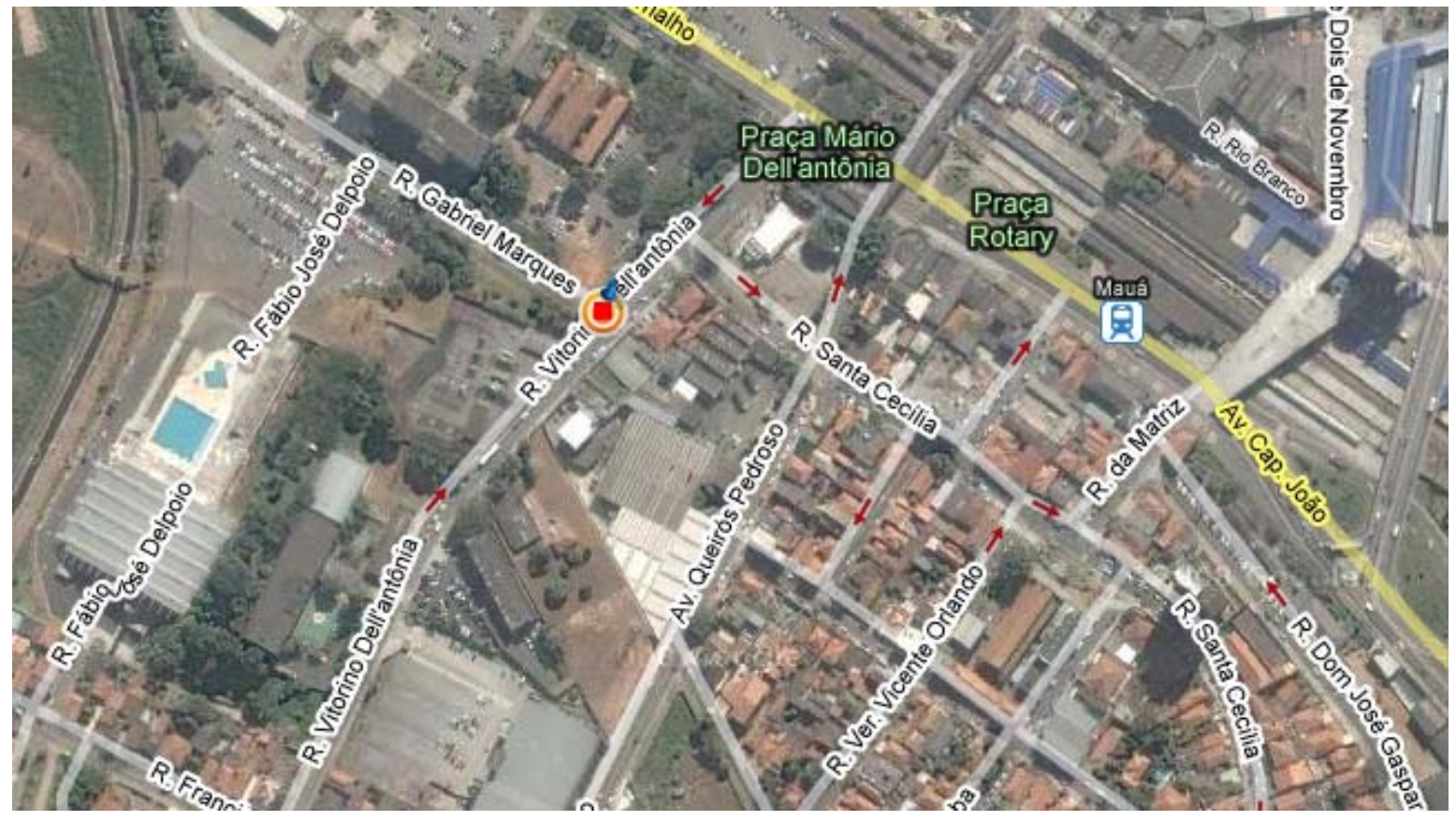

Figura 29: Entornos da estação Mauá. A localização aproximada é representada pelo quadrado vermelho.

Fonte: http://maplink.uol.com.brl

Pode-se notar na figura 30 uma quantidade considerável de área verde e uso do solo predominantemente residencial, sendo que a única avenida mais próxima (Av. Capitão João) não apresenta fluxo tão intenso de veículos quanto as avenidas próximas das estações localizadas no centro da mancha urbana. Ela sofre influência indireta das regiões industrializadas próximas do $A B C$.

Já a estação Pinheiros localiza-se na sede da CETESB em São Paulo, no bairro de Alto de Pinheiros, área residencial de alto padrão, arborizada, sofrendo influência direta do fluxo de veículos da Avenida Frederico Herman Júnior, e relativa influência da Marginal do Pinheiros e Av. Pedroso de Morais. 


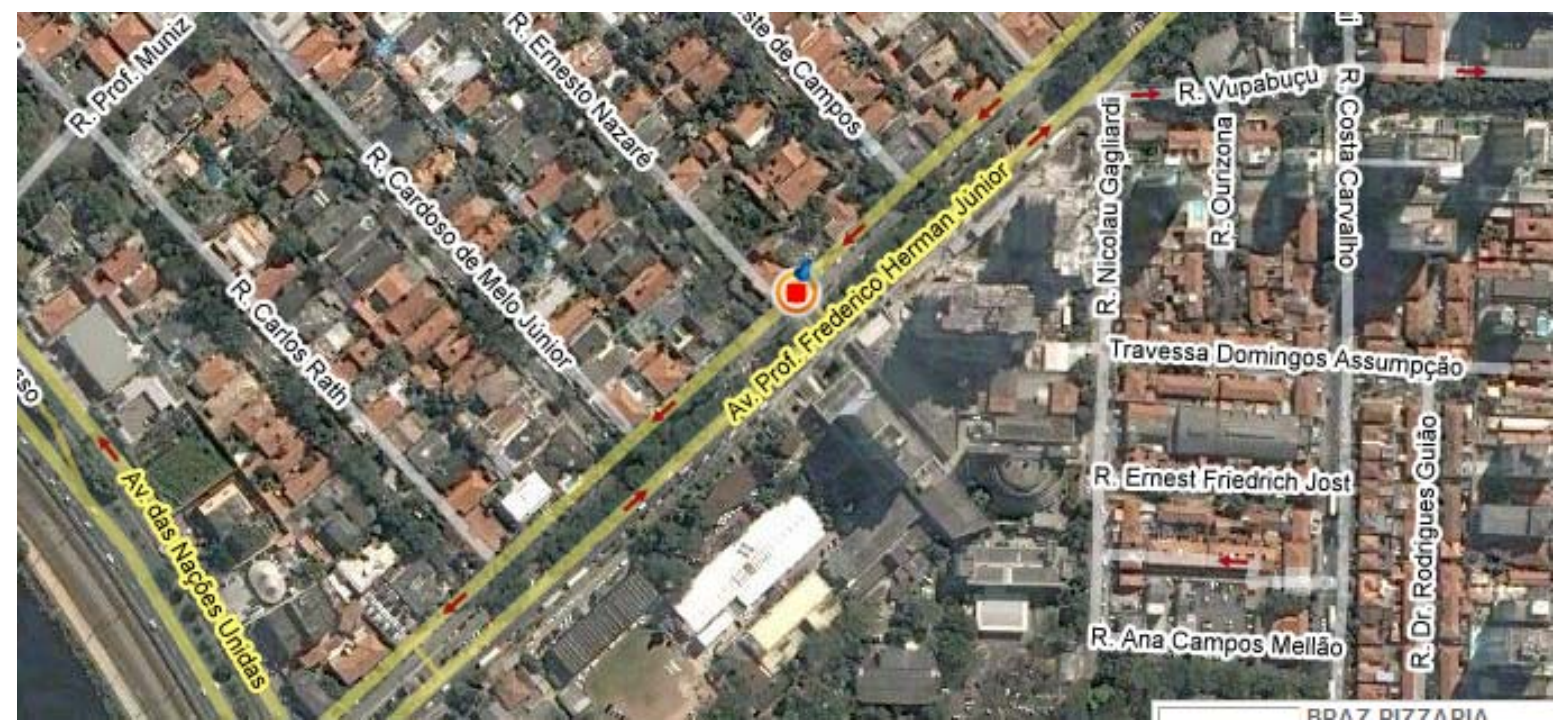

Figura 30: Entornos da estação Pinheiros. A localização aproximada é representada pelo quadrado vermelho.

Fonte: http://maplink.uol.com.brl

Finalmente, a estação Horto Florestal está localizada relativamente distante de grandes fontes de emissão, ao lado de uma grande área verde, com uso do solo predominantemente residencial na área urbanizada que existe nos entornos do Horto Florestal.

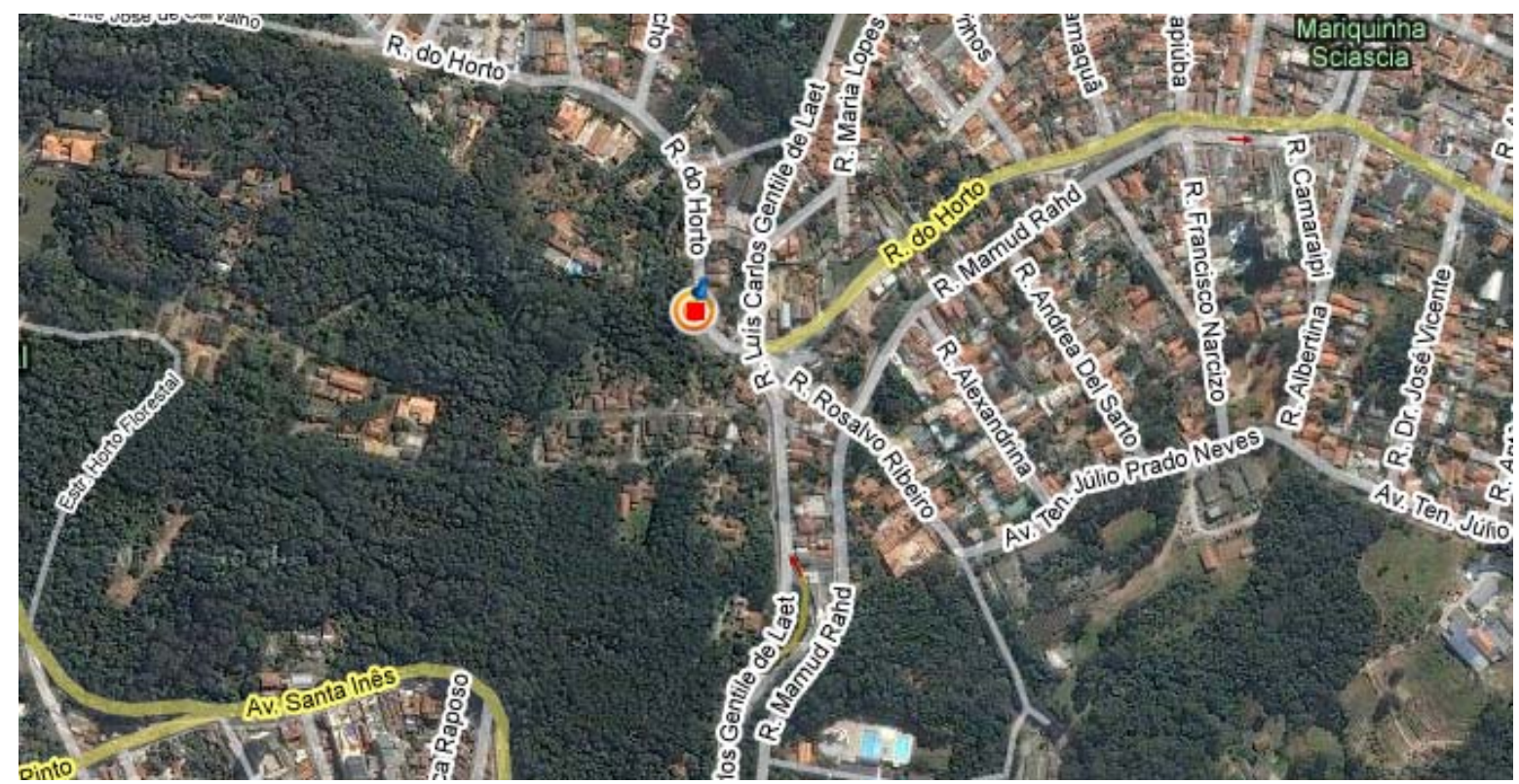

Figura 31: Entornos da estação Horto Florestal. A localização aproximada é representada pelo quadrado vermelho.

Fonte: http://maplink.uol.com.brl

Assim, pode-se perceber que estas estações representam as mais diversas localidades dentro da RMSP. Durante a presente pesquisa, pôde-se associar o uso do solo no entorno das estações com algumas variações no comportamento das 
concentrações de ozônio, o que acaba por afetar as concentrações deste poluente em cada estação de monitoramento. Estes pontos serão discutidos no item 3.1.4 (distribuição espacial do ozônio na RMSP). 


\subsubsection{Os padrões de qualidade do ar}

Segundo a CETESB, os principais objetivos do monitoramento da qualidade do ar são:

\footnotetext{
"Fornecer dados para ativar ações de emergência durante períodos de estagnação atmosférica (falta de vento e chuva), quando os níveis de poluentes na atmosfera possam representar risco à saúde pública;

Avaliar a qualidade do ar à luz de limites estabelecidos para proteger a saúde e o bem estar das pessoas;

Acompanhar as tendências e mudanças na qualidade do ar devidas a alterações nas emissões dos poluentes ${ }^{8}$.
}

Para que se possa melhor lidar com a questão da qualidade do ar em uma cidade como São Paulo, foram estabelecidos os chamados Padrões de Qualidade do $\operatorname{Ar}$ (PQAr). Eles representam uma determinada concentração na qual os poluentes representam pouco ou nenhum risco para a saúde humana, o meio ambiente e os materiais. Estes padrões foram estabelecidos, em nível nacional, pelo Instituto Brasileiro de Meio Ambiente (IBAMA) e aprovados pelo Conselho Nacional de Meio Ambiente (CONAMA). Eles são utilizados para se determinar o nível de urgência representado por determinada concentração de um poluente.

O monitoramento da qualidade do ar passa pela observação das concentrações dos poluentes, comparando-as aos padrões de qualidade do ar, que são determinados de acordo com a concentração máxima permitida para o poluente em questão, as taxas de emissão deste poluente e dos sistemas de remoção atuantes.

Estes padrões podem ser classificados como primários ou secundários. Os padrões primários de qualidade do ar são concentrações de poluentes que, se ultrapassadas, podem afetar a saúde da população, entendidos como níveis máximos de concentração, em metas de curto e médio prazo, normalmente definindo padrões diários ou horários. Os padrões secundários são concentrações de poluentes que apresentam o mínimo dano possível à fauna, flora e ao bem-estar

\footnotetext{
${ }^{8}$ Site da CETESB na Internet - www.cetesb.sp.gov.br
} 
da população, em longo prazo, ou seja, representam padrões médios anuais de qualidade do ar desejáveis de serem atingidos.

Os poluentes escolhidos para serem medidos pela rede de monitoramento da CETESB refletem sua grande importância ambiental e sua maior concentração na atmosfera. São eles: o Dióxido de Enxofre $\left(\mathrm{SO}_{2}\right)$, o Material Particulado (MP), dividido em Partículas Totais em Suspensão (PTS), Fumaça (FMC) e Partículas Inaláveis $(\mathrm{PI})$, ou seja, partículas menores do que $10 \mathrm{~m}$, o Monóxido de Carbono (CO), o ozônio $\left(\mathrm{O}_{3}\right)$ que também é usado para se medir a concentração dos oxidantes fotoquímicos em geral, e o Dióxido de Nitrogênio $\left(\mathrm{NO}_{2}\right)$. Para se divulgar o resultado do índice de qualidade do ar de uma estação, considera-se sempre o pior caso, aquele do poluente de maior concentração medido na estação. Os padrões nacionais primários e secundários de qualidade do ar para os poluentes citados são apresentados na Tabela 07, de acordo com a resolução CONAMA N ${ }^{\circ} 3$, de 28/06/90.

Tabela 07 : Padrões Nacionais de Qualidade do Ar - Resolução CONAMA n 03, de 28/06/90.

\begin{tabular}{|c|c|c|c|c|}
\hline Poluente & $\begin{array}{l}\text { Tempo de } \\
\text { Amostragem }\end{array}$ & $\begin{array}{l}\text { Padrão Primário } \\
\mu \mathrm{g} / \mathrm{m}^{3}\end{array}$ & $\begin{array}{l}\text { Padrão } \\
\text { Secundário } \\
\mu \mathrm{g} / \mathrm{m}^{3}\end{array}$ & Método de Medição \\
\hline $\begin{array}{l}\text { Partículas } \\
\text { totais em } \\
\text { suspensão } \\
\text { (PTS) }\end{array}$ & $\begin{array}{l}24 \text { horas }^{*} \\
\text { MGA }^{* *}\end{array}$ & $\begin{array}{l}240 \\
80\end{array}$ & $\begin{array}{l}150 \\
60\end{array}$ & $\begin{array}{l}\text { Amostrador de grandes } \\
\text { volumes }\end{array}$ \\
\hline Fumaça & $\begin{array}{l}24 \text { horas* }^{*} \\
\text { MMA }^{* * *}\end{array}$ & $\begin{array}{l}150 \\
60\end{array}$ & $\begin{array}{l}100 \\
40\end{array}$ & Refletância \\
\hline $\begin{array}{l}\text { Partículas } \\
\text { Inaláveis }\end{array}$ & $\begin{array}{l}24 \text { horas* } \\
\text { MMA }\end{array}$ & $\begin{array}{l}150 \\
50\end{array}$ & $\begin{array}{l}150 \\
50\end{array}$ & $\begin{array}{l}\text { Separação } \\
\text { inercial/ } \\
\text { filtração }\end{array}$ \\
\hline $\begin{array}{l}\text { Dióxido de } \\
\text { enxofre }\end{array}$ & $\begin{array}{l}24 \text { horas* } \\
\text { MMA }\end{array}$ & $\begin{array}{l}365 \\
80\end{array}$ & $\begin{array}{l}100 \\
40\end{array}$ & Pararosalínica \\
\hline $\begin{array}{l}\text { Monóxido de } \\
\text { carbono }\end{array}$ & $\begin{array}{l}1 \text { hora* } \\
8 \text { horas* }\end{array}$ & $\begin{array}{l}40.000 \\
(35 \mathrm{ppm}) \\
10.000 \\
(9 \mathrm{ppm})\end{array}$ & $\begin{array}{l}40.000 \\
(35 \mathrm{ppm}) \\
10.000 \\
(9 \mathrm{ppm})\end{array}$ & $\begin{array}{l}\text { Infravermelho } \\
\text { não-dispersivo }\end{array}$ \\
\hline Ozônio & 1 hora* & 160 & 160 & Quimiluminescência \\
\hline $\begin{array}{ll}\text { Dióxido } \\
\text { nitrogênio }\end{array}$ & $\begin{array}{l}1 \text { hora } \\
\text { MMA }\end{array}$ & $\begin{array}{l}320 \\
100\end{array}$ & $\begin{array}{l}190 \\
100\end{array}$ & Quimiluminescência \\
\hline
\end{tabular}

Fonte: CETESB, disponível em

http://www.cetesb.sp.gov.br/Ar/ar indice padroes.asp 
A metodologia da CETESB para o monitoramento da qualidade do ar levou à elaboração de índices. Estes índices dependem da concentração do poluente em relação ao padrão primário de qualidade do ar, e são divididos em seis níveis: qualidade do ar Boa (1 a 50\% do PQAr primário), Regular (51 a 100\% do padrão), Inadequada (101 a 199\%), Má qualidade do ar (200 a 299\%), Péssima (300 a 399\%) e Crítica (acima de 400\%). Os três últimos níveis já são graves o suficiente e indicam a necessidade de ações específicas em caso de sua ocorrência, no sentido de diminuir a concentração do poluente. São respectivamente chamados de Estado de Atenção (para qualidade do ar Má), de Alerta (para qualidade do ar Péssima) e de Emergência (para qualidade do ar Crítica). Para o Estado de Atenção, recomenda-se a restrição voluntária de atividades causadoras da poluição, como o rodízio, por exemplo. No Estado de Alerta, porém, é obrigatório que haja diminuição de tais atividades, e no de Emergência, é proibida a concentração de veículos, ocorrendo também a paralisação das atividades industriais. Existe ainda o Estado Crítico, que é caracterizado por uma altíssima concentração em um período curto de tempo em condições desfavoráveis de dispersão.

Em outubro de 2007 ocorreu uma reunião da Organização Mundial da Saúde (OMS) sobre o estabelecimento de PQAr internacionais para os poluentes MP, $\mathrm{NO}_{2}$ e ozônio. De acordo com a organização, os padrões estabelecidos em muitos países, incluindo o Brasil, ainda são prejudiciais à saúde humana e ao meio ambiente, daí a necessidade de sua reformulação. Caso estes padrões mais rígidos sejam adotados pela legislação brasileira, isto não se refletirá em mudança metodológica para esta pesquisa, uma vez que a análise da concentração de ozônio tem não tem objetivos ligados diretamente às ultrapassagens do PQAr.

O índice de qualidade do ar para os diferentes níveis estabelecidos pela CETESB para cada poluente atmosférico está indicado na tabela 08. Os problemas de saúde associados aos principais poluentes na ocorrência desses níveis agudo de poluição estão resumidos na tabela 09. 
Tabela 08: Índices de qualidade do ar para os principais poluentes do ar segundo a CETESB:

\begin{tabular}{|l|l|l|l|l|l|l|}
\hline \multirow{2}{*}{ ELEMENTOS } & \multicolumn{2}{l}{ NÍVEL DE QUALIDADE } \\
\cline { 2 - 8 } & $\begin{array}{l}\text { 50\% } \\
\text { PQAR }\end{array}$ & PQAR & ATENÇÃo & ALERTA & $\begin{array}{l}\text { EMER- } \\
\text { GÊNCIA }\end{array}$ & CRÍTICO \\
\hline $\mathrm{SO}_{2}$ - Dióxido de Enxofre $\left(\mu \mathrm{g} / \mathrm{m}^{3}\right)$ & 80 & 365 & 800 & 1.600 & 2.100 & 2.620 \\
\hline $\mathrm{PI}$ - Partículas Inaláveis $\left(\mu \mathrm{g} / \mathrm{m}^{3}\right)$ & 50 & 150 & 250 & 420 & 500 & 600 \\
\hline $\mathrm{CO}$ - Monóxido de Carbono $(\mathrm{ppm})$ & 4,5 & 9,0 & 15,0 & 30,0 & 40,0 & 50,0 \\
\hline $\mathrm{O}_{3}-$ Ozônio $\left(\mu \mathrm{g} / \mathrm{m}^{3}\right)$ & 80 & 160 & 200 & 800 & 1.000 & 1.200 \\
\hline $\begin{array}{l}\mathrm{NO}_{2}-\text { Dióxido de Nitrogênio }(\mu \mathrm{g} \\
\left./ \mathrm{m}^{3}\right)\end{array}$ & 100 & 320 & 1.130 & 2.260 & 3.000 & 3.750 \\
\hline PQAR - Padrão de qualidade do ar / $\mu \mathrm{g}-$ micrograma / ppm - partes por milhão \\
\hline
\end{tabular}

Fonte: CETESB, disponível em

http://www.cetesb.sp.gov.br/Ar/ar indice padroes.asp 
Tabela 09: Principais poluentes do ar segundo a CETESB, índices de qualidade do ar e efeitos na saúde:

\section{QUALIDADE DO ARE EFEITOS Ȧ SAÚDE}

\begin{tabular}{|c|c|c|c|c|c|c|}
\hline Qualidade & Indice & $\begin{array}{l}\text { MP10 } \\
\left(\mu g / m^{2}\right)\end{array}$ & $\begin{array}{c}03 \\
\left(\mu \mathrm{g} / \mathrm{m}^{\prime}\right)\end{array}$ & $\begin{array}{c}\mathrm{CO} \\
\text { (ppm) }\end{array}$ & $\begin{array}{c}\mathrm{N} 02 \\
\left(\mu g / m^{\prime}\right)\end{array}$ & $\begin{array}{c}\mathrm{SO2} \\
\left(\mu \mathrm{g} / \mathrm{m}^{\prime}\right)\end{array}$ \\
\hline Boa & 0.50 & $\begin{array}{c}0.50 \\
\text { Efeitos despreziveis }\end{array}$ & $\begin{array}{c}0-80 \\
\text { Efeitos despreziveis }\end{array}$ & $\begin{array}{c}0.4,5 \\
\text { Efeitos despreziveis }\end{array}$ & $\begin{array}{c}0-100 \\
\text { Efeitos despreziveis }\end{array}$ & $\begin{array}{c}0-80 \\
\text { Efeitos despreziveis }\end{array}$ \\
\hline Regular & $51-100$ & \begin{tabular}{|l|}
\multicolumn{1}{c|}{$50-150$} \\
Pessoas com doenças \\
respiratórias podem apresentar \\
sintomas como tosse seca e \\
cansaço
\end{tabular} & \begin{tabular}{|l|}
\multicolumn{1}{c|}{$80-160$} \\
Pessoas com doenças \\
respiratórias podem apresentar \\
sintomas como tosse seca e \\
cansaço
\end{tabular} & \begin{tabular}{l}
\multicolumn{1}{c|}{$\quad 4,5-9$} \\
Pessoas com doenças \\
cardiacas podem apresentar \\
sintomas como cansaço e dor \\
no peito
\end{tabular} & \begin{tabular}{l}
\multicolumn{1}{c|}{$100-320$} \\
Pessoas com doenças \\
respiratórias podem apresentar \\
sintomas como tosse seca e \\
cansaço
\end{tabular} & \begin{tabular}{|l|}
\multicolumn{1}{c|}{$\quad 80-365$} \\
Pessoas com doenças \\
respiratórias podem apresentar \\
sintomas como tosse seca e \\
cansaço
\end{tabular} \\
\hline & 101-150 & \begin{tabular}{|l|}
\multicolumn{1}{c|}{$150-200$} \\
Pessoas com doenças \\
respiratórias ou cardiacas, \\
idosos e crianças têm os \\
sintomas agravados. \\
Populaçäo em geral pode \\
apresentar sintomas como \\
ardor nos olhos, nariz e \\
garganta, tosse seca e cansaço
\end{tabular} & \begin{tabular}{|l|}
\multicolumn{1}{|c|}{$160-180$} \\
Pessoas com doenças \\
respiratórias, como asma, e \\
crianças têm os sintomas \\
agravados. Populaçäo em geral \\
pode apresentar sintomas \\
como ardor nos olhos, nariz e \\
garganta, tosse seca e cansaço
\end{tabular} & $\begin{array}{l}\text { Populaçäo em geral pode } \\
\text { apresentar sintomas como } \\
\text { cansaço. Pessoas com doenças } \\
\text { cardiacas têm os sintomas } \\
\text { como cansaço e dor no peito } \\
\text { agravados }\end{array}$ & \begin{tabular}{|l|}
\multicolumn{1}{|c|}{$320-720$} \\
Populaçäo em geral pode \\
apresentar sintomas como \\
ardor nos olhos, nariz e \\
garganta, tosse seca e cansaço. \\
Pessoas com doenças \\
respiratórias e crianças têm os \\
sintomas agravados
\end{tabular} & \begin{tabular}{|l|}
\multicolumn{1}{|c|}{$365-576$} \\
Populaçäo em geral pode \\
apresentar sintomas como \\
ardor nos olhos, nariz e \\
garganta, tosse seca e cansaço. \\
Pessoas com doenças \\
respiratórias ou cardiacas, \\
idosos e crianças têm os \\
sintomas agravados
\end{tabular} \\
\hline Inadequada & 151-199 & \begin{tabular}{l}
\multicolumn{1}{c}{$200-250$} \\
Aumento dos sintomas em \\
crianças e pessoas com \\
doenças pulmonares e \\
cardiovasculares. Aumento de \\
sintomas respiratórios na \\
populaçäo em geral
\end{tabular} & \begin{tabular}{|l|}
\multicolumn{1}{c|}{$180-200$} \\
Aumento dos sintomas \\
respiratórios em crianças e \\
pessoas com doenças \\
pulmonares, como asma. \\
Aumento de sintomas \\
respiratórios na populaçäo em \\
geral
\end{tabular} & \begin{tabular}{|l|}
\multicolumn{1}{c|}{$12-15$} \\
Aumento de sintomas em \\
pessoas cardiacas. Aumento de \\
sintomas cardiovasculares na \\
populaçäo em geral
\end{tabular} & \begin{tabular}{|l|}
\multicolumn{1}{|c|}{$720-1130$} \\
Aumento dos sintomas \\
respiratórios em crianças e \\
pessoas com doenças \\
pulmonares, como asma. \\
Aumento de sintomas \\
respiratórios na populaçăo em \\
geral
\end{tabular} & \begin{tabular}{|l|}
\multicolumn{1}{c|}{$576-800$} \\
Aumento dos sintomas em \\
crianças e pessoas com \\
doenças pulmonares e \\
cardiovasculares. Aumento de \\
sintomas respiratórios na \\
populaçäo em geral
\end{tabular} \\
\hline & $200-250$ & \begin{tabular}{l}
\multicolumn{1}{c}{$250-350$} \\
Agravamento dos sintomas \\
respiratórios. Agravamento de \\
doenças pulmonares, como \\
asma, e cardiovasculares, \\
como infarto do miocárdio
\end{tabular} & \begin{tabular}{|l|}
\multicolumn{1}{|c|}{$200-400$} \\
Agravamento de sintomas \\
respiratórios. Agravamento de \\
doenças pulmonares, como \\
asma, e doença pulmonar \\
obstrutiva crónica
\end{tabular} & \begin{tabular}{|l|}
\multicolumn{1}{c|}{$15-22$} \\
Agravamento das doenças \\
cardiovasculares, como infarto \\
do miocárdio e insuficiència \\
cardiaca congestiva
\end{tabular} & \begin{tabular}{|l|}
\multicolumn{1}{|c|}{$1130-1690$} \\
Agravamento de sintomas \\
respiratórios. Agravamento de \\
doenças pulmonares, como \\
asma, e doença pulmonar \\
obstrutiva crônica
\end{tabular} & \begin{tabular}{|l|}
\multicolumn{1}{|c|}{$800-1200$} \\
Agravamento dos sintomas \\
respiratórios. Agravamento de \\
doenças pulmonares, como \\
asma, e cardiovasculares, \\
como infarto do miocárdio
\end{tabular} \\
\hline Má & $251-299$ & \begin{tabular}{|l|}
\multicolumn{1}{c|}{$350-420$} \\
Agravamento significativo dos \\
sintomas cardiovasculares e \\
respiratórios, como tosse, \\
cansaço, falta de ar e \\
respiraçāo ofegante na \\
populaçäo em geral. Risco de \\
mortes prematuras de pessoas \\
com doenças respiratórias e \\
cardiovasculares. Risco de \\
agravos à gestaçăo
\end{tabular} & \begin{tabular}{|l|}
\multicolumn{1}{|c|}{$400-800$} \\
Agravamento significativo dos \\
sintomas respiratórios e \\
dificuldade de respirar na \\
populaçäo em geral. Risco \\
mortes prematuras de pessoas \\
com doenças respiratórias
\end{tabular} & \begin{tabular}{|l|}
\multicolumn{1}{c|}{$22-30$} \\
Agravamento significativo dos \\
sintomas cardiovasculares, \\
como dores no peito, na \\
populaçäo em geral. Risco de \\
mortes prematuras de pessoas \\
com doenças cardiovasculares.
\end{tabular} & \begin{tabular}{|l|}
\multicolumn{1}{|c|}{$1690-2260$} \\
Agravamento significativo dos \\
sintomas respiratórios e \\
dificuldade de respirar na \\
população em geral. Risco \\
mortes prematuras de pessoas \\
com doenças respiratórias
\end{tabular} & \begin{tabular}{|l|}
\multicolumn{1}{c|}{$1200-1600$} \\
Agravamento significativo dos \\
sintomas respiratórios e \\
cardiovasculares, como tosse, \\
cansaço, falta de ar e \\
respiração ofegante na \\
populaçăo em geral. Risco de \\
mortes prematuras de pessoas \\
com doenças respiratórias e \\
cardiovasculares
\end{tabular} \\
\hline Péssima & $>299$ & \begin{tabular}{|l|}
\multicolumn{1}{|c|}{$>420$} \\
Sérios riscos de manifestaçōes \\
de doenças respiratórias e \\
cardiovasculares. Aumento de \\
mortes prematuras em pessoas \\
com doenças cardiovasculares \\
e respiratórias
\end{tabular} & \begin{tabular}{|l|}
\multicolumn{1}{c|}{$>800$} \\
Sérios riscos de manifestaçōes \\
de doenças respiratórias. \\
Aumento de mortes prematuras \\
de pessoas com doenças \\
respiratórias
\end{tabular} & \begin{tabular}{|l|}
\multicolumn{1}{c|}{$>30$} \\
Sérios riscos de manifestaçöes \\
de doenças cardiovasculares. \\
Aumento de mortes prematuras \\
de pessoas com doenças \\
cardiovasculares
\end{tabular} & \begin{tabular}{|l|}
\multicolumn{1}{c|}{$>2260$} \\
Sérios riscos de manifestaçöes \\
de doenças respiratórias. \\
Aumento de mortes prematuras \\
de pessoas com doenças \\
respiratórias
\end{tabular} & \begin{tabular}{|l|}
\multicolumn{1}{|c|}{$>1600$} \\
Sérios riscos de manifestaçōes \\
de doenças respiratórias e \\
cardiovasculares. Aumento de \\
mortes prematuras em pessoas \\
com doenças cardiovasculares \\
e respiratórias
\end{tabular} \\
\hline
\end{tabular}

Fonte: CETESB, disponível em: http://www.cetesb.sp.gov.br/Ar/anexo/efeitos.pdf 


\subsection{Dados}

\subsubsection{Dados de poluição do ar}

Os dados usados para a determinação da qualidade do ar foram as concentrações de $\mathrm{O}_{3}$ obtidas pela rede de estações medidoras da CETESB instaladas na RMSP (figura 14). Eles foram extraídos dos relatórios anuais e boletins diários publicados pela CETESB, estes últimos contendo medições horárias dos poluentes. Os dados das concentrações do poluente foram utilizados para a determinação de sua variabilidade nas diferentes escalas temporais consideradas e para a identificação dos períodos com concentrações extremas. A leitura dos dados de ozônio, análise da consistência, cálculo de médias anuais, mensais e diárias de suas respectivas anomalias foram obtidos por meio de programas construídos em linguagem computacional FORTRAN ${ }^{9}$ e os gráficos destas séries, traçados com o auxílio do Grid Analysis and Display System (GrADS) e do Excel.

A utilização do software de visualização GrADS permite a leitura de dados em até quatro dimensões: latitude, longitude, altitude e tempo. Podem ser realizadas operações matemáticas entre dados de diferentes fontes (com várias funções aplicadas às ciências atmosféricas). A análise simultânea de dados é bastante utilizada devido à facilidade de se sobrepor "camadas" (overlays) de dados diferentes, gerando diferentes gráficos que podem ser analisados simultaneamente. O GRADS é um visualizador de gráficos e mapas programável em linguagem computacional FORTRAN.

Os dados de poluição de ozônio foram obtidos em formato .txt, para que fossem copiados para os computadores do Laboratório de Climatologia e Biogeografia, do Departamento de Geografia da FFLCH-USP.

No formato original, os dados consistem de medições horárias de ozônio nas 17 estações de medição utilizadas neste trabalho: Congonhas, Diadema, Horto Florestal, Ibirapuera, Lapa, Mauá, Mooca, Nossa Senhora do Ó, Osasco, Pico do

\footnotetext{
${ }^{9}$ A linguagem computacional FORTRAN surgiu em 1956 como a primeira linguagem de programação de alto nível (FREITAS, 2004). Ela foi criada para uso essencialmente científico, e desde então tem
} 
Jaraguá, Pinheiros, Parque D. Pedro II, Santana, Santo Amaro, São Caetano do Sul, São Miguel Paulista e Santo André - Capuava. As estações Horto Florestal e Pico do Jaraguá na verdade não são estações fixas que representam estes locais. A CETESB possui duas estações móveis, que podem ser movidas para a monitoração em diversos locais, de acordo com as necessidades de monitoramento de qualidade do ar. Por exemplo, na estação móvel do Pico do Jaraguá as medidas foram tomadas apenas nos anos de 2002 e 2003. Atualmente, esta estação é denominada de Itaquera, pois localiza-se em bairro com este nome, na zona leste de São Paulo. As datas de início e final das observações variam de acordo com a estação, tal como indicado na tabela 10.

Tabela 10: Anos de início e término das séries temporais para cada estação da RMSP.

\begin{tabular}{|l|c|c|}
\hline \multicolumn{1}{|c|}{ Estação } & Início & Término \\
\hline Congonhas & $24 / 05 / 1996$ & $03 / 03 / 1999$ \\
\hline Diadema & $14 / 04 / 1999$ & $31 / 12 / 2005$ \\
\hline Horto Florestal & $17 / 08 / 2004$ & $31 / 12 / 2005$ \\
\hline Ibirapuera & $22 / 05 / 1996$ & $31 / 12 / 2005$ \\
\hline Lapa & $11 / 08 / 1996$ & $22 / 09 / 2000$ \\
\hline Mauá & $05 / 08 / 1996$ & $31 / 12 / 2005$ \\
\hline Mooca & $01 / 01 / 1997$ & $31 / 12 / 2005$ \\
\hline Nossa Senhora do Ó & $18 / 06 / 2004$ & $31 / 12 / 2005$ \\
\hline Osasco & $05 / 06 / 1996$ & $28 / 09 / 2001$ \\
\hline Pico do Jaraguá & $02 / 01 / 2002$ & $18 / 12 / 2003$ \\
\hline Pinheiros & $01 / 09 / 1999$ & $31 / 12 / 2005$ \\
\hline Parque D. Pedro II & $09 / 05 / 1996$ & $19 / 12 / 2005$ \\
\hline Santana & $01 / 05 / 1999$ & $31 / 12 / 2005$ \\
\hline Santo Amaro & $01 / 01 / 2003$ & $31 / 12 / 2005$ \\
\hline São Caetano do Sul & $30 / 07 / 1996$ & $31 / 12 / 2005$ \\
\hline São Miguel Paulista & $13 / 08 / 1996$ & $17 / 02 / 2005$ \\
\hline Santo André - Capuava & $26 / 10 / 2000$ & $31 / 12 / 2005$ \\
\hline
\end{tabular}

sido largamente utilizada por profissionais de diversas áreas, incluindo a meteorologia. A linguagem FORTRAN foi aprimorada diversas vezes, sendo que uma das principais versões é a FORTRAN-77. 


\subsubsection{Consistência dos dados}

Houve a necessidade de tratamento dos dados para a identificação de dados inválidos e faltantes. Os dados originalmente organizados pela CETESB apresentam indicadores de qualidade como dados válidos e inválidos. Apesar da preexistência deste controle de qualidade, foram eliminados e transformados em dados faltantes os valores horários superiores a $500 \mu \mathrm{g} / \mathrm{m}^{3}$. As médias anuais, mensais e diárias foram calculadas respeitando-se o critério limite adotado neste trabalho de quantidade de dados representativos em cada escala. No caso da média anual, eram necessários no mínimo 8 meses com dados válidos; no caso da mensal, 20 dias no mínimo com dados válidos e, no caso da média diária, este valor correspondeu a no mínimo 16 horas de dados válidos durante o dia.

Para se lidar com uma quantidade grande de dados, foi criado, em linguagem FORTRAN, um programa para a identificação dos valores inválidos e cálculo das médias e anomalias. 


\subsubsection{Dados climáticos}

Os dados climáticos a serem utilizados nesta pesquisa foram obtidos do conjunto de dados da Reanálise II do National Center for Environmental Prediction National Center Atmospheric Reasearch (NCEP/NCAR) (Kanamitsu et al, 2002), com resolução espacial de 2,5 graus. As variáveis utilizadas, em nível de superfície, foram radiação de ondas longas (ROL), pressão atmosférica, radiação solar, temperatura do ar, umidade relativa e específica do ar, nos níveis de $250 \mathrm{hPa}$ e em superfície, direção e intensidade do vento. A partir da direção e intensidade do vento foi possível calcular a convergência e divergência do ar em superfície e no topo da troposfera, bem como o posicionamento das linhas de corrente e identificação dos campos atmosféricos que podem favorecer ou desfavorecer a instabilidade atmosférica, induzindo situações com maior ou menor cobertura de nuvens, precipitação e maior ou menor probabilidade para a dispersão de poluentes em baixos níveis atmosféricos. Os campos atmosféricos foram traçados para a área delimitada pelas coordenadas geográficas $35^{\circ} \mathrm{S} ; 30^{\circ} \mathrm{E}$ e $10^{\circ} \mathrm{S} ; 60^{\circ} \mathrm{O}$. Estas coordenadas foram escolhidas de forma a permitir a representação da circulação atmosférica atuante no centro-sul do Brasil, onde a RMSP está inserida.

Os dados da reanálise são obtidos com a execução do modelo atmosférico T62/28 level NCEP global spectral model (Kalnay et al., 1996) para períodos pretéritos, alimentado com observações. Os modelos atmosféricos são construídos a partir das leis físicas da atmosfera que originam grupos de equações que processam os dados coletados e geram diferentes resultados, dependendo dos dados iniciais que foram inseridos. Isto pode ser feito para se realizar uma previsão (uma aproximação das condições atmosféricas futuras a partir de dados já observados) ou uma análise diagnóstica (simulação de condições atmosféricas num tempo passado a partir de dados já observados). Este conjunto de dados utilizado no trabalho permite, principalmente, o diagnóstico das condições atmosféricas passadas com objetivo de avaliação de simulações ou estudos diagnósticos de variabilidade atmosférica. Os dados da reanálise podem ser obtidos no seguinte endereço na internet: http://www.cdc. noaa.gov/cgi-bin/db search/SearchMenus.pl. 
Adicionalmente aos dados da reanálise, a circulação local da atmosfera foi analisada com base nos dados de velocidade e direção do vento obtidos nas estações da CETESB. Este conjunto de dados permitiu analisar as condições da baixa troposfera com maior detalhamento nos meses com concentrações anômalas de ozônio. Dados de desvio de temperatura mensal do ar do Centro de Previsão de Tempo e Estudos Climáticos (CPTEC) também foram utilizados na elaboração do relatório de qualificação da presente pesquisa.

Além disso, a consulta do Boletim Climanálise, uma publicação mensal disponível no site do CPTEC que avalia os padrões atmosféricos predominantes em cada mês no Brasil, permitiu caracterizar com mais precisão os padrões atmosféricos predominantes em cada situação. Através da análise de imagens de satélite, anomalias de temperatura, precipitação, número de entrada de sistemas frontais na América do Sul e outras de grande escala como a El Niño South Oscillation (ENSO - a variação mensal da temperatura da superfície do Oceano Pacífico Sul), pôde-se obter informações acerca da intensidade dos sistemas frontais, situações de bloqueio, deslocamento dos sistemas atmosféricos, etc. 


\subsection{Metodologia}

\subsubsection{Comportamento do ozônio na RMSP}

Para se tentar compreender o comportamento deste poluente na área de estudo, foram calculadas médias nas três escalas de análise propostas para cada estação.

Para a escala anual, foram calculadas as médias anuais para cada uma das 17 estações, somando-se todos os dados horários dos boletins diários e obtendo um valor médio para aquele ano naquela estação. Foram construídas então séries temporais anuais para todas as 17 estações medidoras de ozônio utilizadas neste trabalho. A partir das comparações entre as diversas séries temporais médias anuais, foram identificadas estações com diferentes níveis de concentração.

Calculou-se o desvio padrão de cada estação, e depois, foi calculada a média dos desvios padrão de todas as estações. Depois o procedimento foi repetido com as médias da concentração de cada estação. Baseando-se na média de todas as estações, calculou-se a anomalia de cada estação e, comparando-se com o desvio padrão médio, pôde-se distinguir quatro grupos de estações: as de concentrações baixas (anomalia duas vezes ou mais menor do que o desvio padrão), médias (anomalias dentro do desvio padrão), altas (anomalia maior que o desvio padrão) e muito altas (anomalia duas vezes maior que o desvio padrão).

Para a escala sazonal ou mensal, no entanto, foram utilizadas médias mensais das concentrações de ozônio. Da mesma maneira que as médias anuais, foram calculadas médias mensais utilizando-se os dados horários, e construi-se séries temporais mensais de $\mathrm{O}_{3}$ para cada estação. A partir destas, foram analisados os meses com anomalias intensas de $\mathrm{O}_{3}$, tanto altas quanto baixas. Além das séries temporais mensais para cada estação, também foram construídos gráficos com as médias mensais ano a ano sobrepostos, ou seja, todos os anos, de janeiro a dezembro, sobrepostos na mesma escala para comparação do comportamento interanual do $\mathrm{O}_{3}$. Isto também permitiu a detecção de seu ciclo sazonal. Dentro deste contexto, índices de correlação linear de Pearson foram calculados entre algumas variáveis analisadas e a média das concentrações de $\mathrm{O}_{3}$ : 
$\mathrm{r}^{2}=\frac{\left[\sum X_{i} Y_{i}\right]^{2}}{\left[\sum X_{i}^{2} \sum Y_{i}^{2}\right]}$

$r=$ coeficiente de correlação de Pearson (Chatfield, 1996)

$\mathrm{x}, \mathrm{y}=$ variáveis correlacionadas

Finalmente, as médias mensais também foram utilizadas para a análise de tendências de lineares da concentração em cada estação. Foram agrupadas estações com tendências de elevação, estabilidade ou redução, de acordo com o valor de seu coeficiente angular na reta de regressão:

$$
Y_{t}=a+b t
$$

onde: $Y_{t}=$ valor predito da série temporal

$$
\begin{aligned}
& a=\text { coeficiente linear da reta } \\
& b=\text { coeficiente angular da reta } \\
& t=\text { tempo }
\end{aligned}
$$

O coeficiente angular b também é chamado de "termo de tendência" e é, essencialmente, a mudança no nível médio por unidade de tempo ${ }^{10}$. Por essa razão, as estações com maior coeficiente angular eram as que apresentavam maior tendência de elevação em suas concentrações.

No caso da escala diária, foram calculadas médias diárias a partir dos dados horários. Foram construídas séries temporais diárias para uma melhor visualização da variabilidade do $\mathrm{O}_{3} \mathrm{e}$, junto a isso, foram traçados os dados faltantes e inválidos, para que se tivesse uma melhor compreensão da distribuição temporal destes dados falhos e da qualidade de medição de cada estação.

Os dados de reanálise selecionados apresentam resolução de 2,5 graus nas direções zonal e meridional. Dessa forma,a RMSP abrange uma área que contém, no máximo, dois pontos de grade. Os dados de concentração de ozônio na RMSP provêm de 17 estações diferentes, sem que haja, desta forma, uma concordância adequada de escalas espaciais para a comparação entre os campos atmosféricos e as concentrações de ozônio. Decidiu-se, então, calcular a média espacial para toda a RMSP, com os dados das 17 estações, e trabalhar com a série temporal média em comparação com os campos atmosféricos. Neste trabalho, busca-se um entendimento mais generalizado sobre a influência das condições atmosféricas e as

\footnotetext{
${ }^{10}$ http://www.icess.ucsb.edu/gem/modulo $1 . h t m$
} 
concentrações de ozônio, sem detalhar o muito o comportamento de cada estação face à variabilidade da atmosfera. Por mais que os dados de $\mathrm{O}_{3}$ das diversas estações sejam divergentes, em geral possuem boa correlação na escala mensal. Este foi o caso, por exemplo, da substituição da estação Congonhas pela estação Ibirapuera, cujas concentrações, apesar de serem muito diferentes em seu nível de concentração absoluta, demonstraram correlação de 0,63 na evolução de suas séries mensais durante o ano de 1996 (CETESB, 1997).

Com a finalidade de se analisar a variabilidade diurna e mensal de $\mathrm{O}_{3}$, foram calculados também ciclos diurnos médios do poluente em cada mês para todo o período. Com os dados provenientes de cada estação, foram somados os valores de um mesmo horário de um mês até obter-se um ciclo diurno médio por mês e, depois, calculou-se a média entre os mesmos meses de diferentes anos.

Um procedimento parecido foi realizado para calcular o ciclo sazonal médio de cada estação: após o cálculo das médias mensais, somou-se todos os valores mensais médios de um determinado mês dentro da série e chegou-se então a um valor médio para aquele mês, obtendo assim uma série anual média, composta por doze meses, para cada estação. Por isso, quanto mais anos de dados uma mesma estação apresenta, menores são seus valores extremos na série anual média. Assim, este procedimento foi realizado apenas para as estações com 5 ou mais anos de medição, o que exclui as estações Horto Florestal, Pico do Jaraguá, Nossa Senhora do Ó e Santo Amaro. Como se nota uma variação sazonal médio no comportamento do ozônio ao longo do ano, esta série anual média será referida posteriormente como o ciclo sazonal médio do ozônio.

Finalmente, foi também elaborado um mapa da distribuição espacial das concentrações de ozônio na RMSP, importante devido a diferentes graus de exposição da população e à variabilidade espacial do $\mathrm{O}_{3}$, aproveitando-se os dados das 17 estações espalhadas pela RMSP.

Primeiro, calculou-se os valores médios para cada estação, somando-se todos os seus valores. Depois, obteve-se as coordenadas da Universal Transversa de Mercator (UTM) e latitude/longitude de cada estação, por meio de boletins 
informativos da CETESB e do endereço das estações (tabela 04). Foi obtida também uma "máscara" da área RMSP (arquivo com os pontos de latitude e longitude que delimitam uma determinada área), com um mapa político da região para o GrADS, sobre o qual foram inseridas as coordenadas de localização de cada estação, criando pontos sobre o mapa que representam a localização das estações. Cada ponto então está associado à determinada concentração média de $\mathrm{O}_{3}$.

A técnica da Análise de Cressman (CRESSMAN, 1959) foi utilizada para uma melhor visualização da ocorrência espacial deste poluente na RMSP. Esta técnica de interpolação consiste em estimar um valor aproximado em um ponto em que não há dados, levando-se em conta os valores próximos; no entanto, diferente da interpolação comum, a Análise Objetiva de Cressman permite obter um resultado mais criterioso para a distribuição espacial de uma variável, por levar em consideração a quantidade de pontos e a distância entre eles.

\begin{abstract}
"Para cada estação, um erro é definido como a diferença entre o valor da estação e um valor conseguido pela interpolação da grade para aquela estação. $O$ fator de correção é baseado em uma fórmula ponderada de distância aplicada para todos os tais erros dentro do raio de influência. Os fatores de correção são aplicados para cada ponto de grade antes da próxima etapa ser realizada. ${ }^{11}$ "
\end{abstract}

Por meio deste mapa, não se pretende caracterizar com exatidão a concentração de ozônio em cada local da RMSP, mas sim permitir uma compreensão geral da distribuição espacial do poluente pelas diferentes localidades representadas por cada estação, de acordo com o que foi apresentado na seção 4.1.2.

\footnotetext{
${ }^{11}$ DOTY, B, 2006 The Grid Analysis and Display System, Edição revisada por Tom Holt da University of East Anglia e Mike Fiorino do Lawrence Livermore National Laboratory, 1995. Disponível em: http://www.master.iag.usp.br/ind.php?inic=00\&prod=mapa
} 


\subsubsection{Análise da influência dos padrões atmosféricos nas concentrações de ozônio da RMSP}

Por meio das análises do comportamento anual do ozônio na RMSP, detectouse uma tendência de aumento do poluente para o período estudado. Mais precisamente, a tendência de aumento linear é observada no período entre 1996 e 2003; no final da série, é observada uma tendência linear negativa dos valores de concentração de $\mathrm{O}_{3}$. Tal aspecto indica que ao final da série houve um decréscimo dos valores anuais, o que, de acordo com o Relatório de Qualidade do Ar do Estado de São Paulo, pode estar ligado às condições meteorológicas. Independentemente da razão, observou-se um número de ultrapassagens do PQAr menor em 2005.

Tabela 11: Número de ultrapassagens do PQAr por ozônio na RMSP em cada mês, de 1999 a 2005.

\begin{tabular}{rrrrrrrrrrrrrr} 
MÊS & JAN FEV MAR ABR MAI JUN JUL AGO SET OUT NOV DEZ TOTAL \\
\hline 1999 & 18 & 11 & 8 & 6 & 3 & 3 & 0 & 16 & 16 & 6 & 7 & 15 & 109 \\
2000 & 9 & 2 & 1 & 8 & 0 & 2 & 2 & 6 & 4 & 19 & 11 & 11 & 75 \\
2001 & 12 & 8 & 17 & 2 & 0 & 2 & 3 & 6 & 8 & 11 & 13 & 4 & 86 \\
2002 & 5 & 5 & 17 & 7 & 4 & 0 & 0 & 7 & 5 & 23 & 6 & 11 & 90 \\
2003 & 6 & 19 & 9 & 9 & 1 & 4 & 2 & 5 & 6 & 8 & 4 & 4 & 77 \\
2004 & 3 & 6 & 10 & 4 & 0 & 0 & 0 & 6 & 17 & 3 & 7 & 7 & 63 \\
2005 & 2 & 10 & 6 & 7 & 0 & 1 & 0 & 2 & 3 & 10 & 4 & 6 & 51 \\
\hline
\end{tabular}

Fonte:CETESB, 2006.

Assim, antes de se iniciar a análise de interpretação entre o comportamento da atmosfera e do ozônio, optou-se por remover a tendência observada nos dados originais de $\mathrm{O}_{3}$, com o objetivo de se capturar as variações legítimas do comportamento do poluente. Para tal, utilizou-se a equação da reta de regressão linear, explanada na seção anterior. Para a remoção da tendência da série temporal, multiplica-se o coeficiente angular pelo tempo e subtrai-se o resultado do valor observado em cada tempo. Desta maneira, a tendência temporal é removida da série de dados.

Após a obtenção da série temporal mensal de ozônio sem a tendência, iniciouse a análise da relação entre os padrões atmosféricos nas concentrações de ozônio 
na RMSP, que foi feita em três etapas. A primeira consistiu na detecção de períodos com anomalias positivas e negativas de ozônio para se definir os meses de interesse. Foram observadas anomalias climáticas mensais específicas associadas a esses meses de concentração anômala alta e baixa de ozônio. Depois disso, os meses com anomalias positivas e negativas foram subdivididos em novas duas classes, de acordo com a intensidade da anomalia de $\mathrm{O}_{3}$.

A segunda etapa consistiu na interpretação do comportamento espacial de médias e anomalias mensais das variáveis atmosféricas escolhidas por meio da construção de mapas para análise dos padrões atmosféricos vigentes nos meses de interesse que haviam sido identificados na seção anterior.

A última etapa consistiu na interpretação de valores diários médios do poluente e das variáveis atmosféricas analisadas, numa tentativa de compreensão mais aprofundada das possíveis interferências atmosféricas nas suas concentrações na escala de tempo sinótica. 


\subsubsection{Seleção de meses com anomalias de ozônio e as anomalias atmosféricas observadas}

Obteve-se a série temporal de anomalias mensais das concentrações de $\mathrm{O}_{3}$ para o período 1996-2005. Detectou-se os meses com anomalias positivas e negativas extremas de $\mathrm{O}_{3}$, com base no desvio padrão mensal. Assim, foram selecionados os meses cujo valor absoluto da anomalia de $\mathrm{O}_{3}$ foi maior ou menor do que um desvio padrão $(1 \sigma)$. A anomalia mensal é calculada como a diferença entre o valor médio mensal e sua média climatológica, tal como indicado a seguir:

$$
\operatorname{var}_{i}^{\prime}=\operatorname{var}_{i}-\operatorname{var}_{\text {clim }}
$$

onde var ${ }_{i}^{\prime}$ indica a anomalia, var $_{i}$ o valor observado mensal e var $_{c l i m}$ a média climatológica.

Os episódios mensais com diferentes intensidades de concentração de $\mathrm{O}_{3}$ foram subdivididos em quatro classes: duas classes com anomalias positivas, com valor da anomalia de concentração de $\mathrm{O}_{3}$ superior a $1 \sigma$ e a $2 \sigma$ e duas classes com anomalias negativas, com valor da anomalia inferior a $-1 \sigma$ e a $-1,5 \sigma$, tal como indicado na tabela 12. O critério para seleção de meses com anomalias negativas inferiores a $-2 \sigma$ não foi satisfeito; percebeu-se então que as anomalias negativas de $\mathrm{O}_{3}$ são menos intensas. As anomalias atmosféricas e de $\mathrm{O}_{3}$, para todas as classes estabelecidas (1, 2, -1 e -2), foram analisadas a fim de se estabelecer uma relação de variação conjunta.

Tabela 12: Critério para classificação dos episódios mensais intensos de concentrações de $\mathrm{O}_{3}$.

\begin{tabular}{|c|c|}
\hline classe & critério \\
\hline 1 & {$\left[\mathrm{O}_{3}\right]>1 \sigma$} \\
\hline 2 & {$\left[\mathrm{O}_{3}\right]>2 \sigma$} \\
\hline-1 & {$\left[\mathrm{O}_{3}\right]<-1 \sigma$} \\
\hline-2 & {$\left[\mathrm{O}_{3}\right]<-1,5 \sigma$} \\
\hline
\end{tabular}


Com o intuito de se obter uma primeira interpretação (menos refinada) da relação entre o comportamento atmosférico e do $\mathrm{O}_{3}$, decidiu-se analisar os períodos com anomalias de $\mathrm{O}_{3}$. Supõe-se naturalmente que anomalias intensas de $\mathrm{O}_{3}$ devam apresentar alguma interferência causada pela atmosfera. Embora sejam as concentrações mais altas e positivas as que ultrapassem o PQAr e, por conseguinte, representem maiores danos para o meio ambiente e para a saúde da população, a análise de episódios com anomalias negativas de concentrações de $\mathrm{O}_{3}$ permite elaborar uma interpretação mais abrangente sobre as informações e hipóteses levantadas associadas à variabilidade do poluente. Estes critérios de análise permitem afirmar com maior precisão a influência da atmosfera sobre as concentrações de ozônio.

Para os meses de classe 1, 2, -1 e -2, foi construída uma tabela com as anomalias climáticas presentes em cada mês, das variáveis radiação solar, temperatura do ar, pressão, umidade relativa do ar e radiação de ondas longas (ROL). Foi então realizada uma contagem e calculou-se a porcentagem de anomalias climáticas positivas e negativas que acompanhavam os meses destas classes. 


\subsubsection{Associação de padrões atmosféricos às concentrações de ozônio}

Para os meses de anomalias mais intensas (2 e -2), utilizou-se também de composições atmosféricas regionais sem tentar inferir quais sistemas atmosféricos e padrões atmosféricos mensais poderiam estar mais associados às concentrações de ozônio na RMSP.

Estas composições foram traçadas no GrADS para o conjunto de dados obtidos da Reanálise II, para as variáveis sentido e intensidade do vento e campo de divergência do ar em baixos e altos níveis, linhas de corrente, temperatura do ar, radiação solar de ondas curtas, umidade relativa do ar (bem como umidade específica para os meses agosto de 1999, março de 2002, fevereiro de 2003, abril de 1998 e julho de 2005), pressão atmosférica em superfície e radiação de ondas longas, na área definida pelas coordenadas geográficas $\left(60^{\circ} \mathrm{O} ; 35^{\circ} \mathrm{S}\right)$ e $\left(30^{\circ} \mathrm{O} ; 10^{\circ} \mathrm{S}\right)$, de modo a representar os principais sistemas atmosféricos atuantes em escala sinótica na área de estudo.

Foram escolhidas opções dentro do programa de visualização (GrADS) que permitissem uma visão clara da distribuição da variável pelo espaço, como o efeito de preenchimento (shaded), além da opção de suavização da variável (smooth9) para eliminar dados considerados como ruído. Foram traçados mapas com as médias mensais das variáveis e com suas respectivas anomalias, estas obtidas diretamente da reanálise ou pela subtração do valor observado da média da série temporal (ver seção anterior).

Além dos dados da reanálise II, foram também incluídas algumas informações advindas dos boletins da climanálise, tais como a freqüência e intensidade dos sistemas frontais que atingiram áreas na latitude da RMSP (neste caso, o município de Santos), anomalias de precipitação no Brasil, posicionamento e duração dos episódios da ZCAS e taxa de precipitação mensal. Estas informações contribuem para uma análise mais completa dos padrões atmosféricos vigentes em cada mês de análise. Alguns meses também muito poluídos por ozônio, discriminados posteriormente, aproximaram-se dos limiares das classes 2 e -2 e 
também foram incluídos nesta análise no sentido de aumentar o número de casos observados e conferir maior legitimidade às conclusões.

Uma significativa influência das condições atmosféricas sobre as concentrações de ozônio já era mencionada no estudo de Andrade e Massambani (1994), quando da caracterização do comportamento sazonal deste poluente na RMSP. Diversas publicações da CETESB, principalmente os relatórios de qualidade do ar do Estado de São Paulo, atentam para o fato de que os dados de ozônio devem "ser analisados com cuidado, já que representam em grande parte variações das condições meteorológicas, o que pode ser confirmado pelas diferenças significativas entre os mesmos meses em diferentes anos ${ }^{3 \prime}$.

Mesmo a redução das concentrações de ozônio nos anos de 2004 e 2006 foram influenciadas por maior freqüência de dias nublados, com temperaturas máximas mais baixas (CETESB 2004, 2006). Já em 2007, o Relatório de Qualidade do Ar no Estado de São Paulo indica que houve um período de muitos dias quentes e secos nos meses de setembro e outubro, ocasionando maior ocorrência de eventos de altas concentrações de ozônio na RMSP em relação aos anos anteriores.

Outros estudos realizados para uma escala espacial maior que inclui a região metropolitana de São Paulo (FREITAS, 2003; SANCHÉZ-CCOYLLO et al, 2006; RECUERO, 2003; BOIAN et al, 2005) e outras regiões do país indicam que não só as condições meteorológicas locais, mas também a circulação atmosférica em escala regional podem influenciar as concentrações de ozônio, seja através do transporte em escala regional de poluentes precursores emitidos pela queima de biomassa no Centro-Oeste e Brasil central (escoamento de Noroeste), ou pelo transporte de poluentes veiculares ou industriais provenientes da própria região metropolitana ou de outras áreas próximas (fluxo de Noroeste).

Para a Região Sudoeste dos EUA, em particular Los Angeles, alguns estudos apontam a importância das condições atmosféricas sobre as concentrações de ozônio, principalmente a radiação solar, temperatura do ar, taxa de mistura vertical e direção da circulação em superfície. Segundo Wise et al, (2005), a variabilidade

\footnotetext{
${ }^{3}$ Relatório da Qualidade do Ar no Estado de São Paulo, CETESB, 2006, p.59.
} 
atmosférica corresponde a cerca de 40-70\% da variabilidade do ozônio, refletindo-se principalmente na taxa de mistura vertical, uma vez que a variabilidade atmosférica na escala sinótica nesta região é menor do que o observado em outras regiões dos EUA, diminuindo o peso das variações na radiação e na temperatura nesta escala de análise. Outros estudos (NARSTO, 2000) reforçam tanto a importância da estabilidade atmosférica como do transporte em escala local e regional. 


\subsubsection{Influência da atmosfera na variabilidade diária do ozônio troposférico}

No sentido de se complementar a análise realizada para as composições atmosféricas, optou-se por utilizar médias diárias do poluente nos meses de classe 2 e -2. Assim, foram traçadas séries temporais diárias médias de $\mathrm{O}_{3}$, utilizando-se os dados horários de todas as estações. As variáveis temperatura do ar, umidade relativa do ar, pressão atmosférica, radiação solar de ondas curtas, radiação de onda longa, velocidade do vento e taxa de precipitação foram obtidas da reanálise II na escala diária para a região da RMSP e então utilizadas para a construção de gráficos no Excel e no GrADS. Além deste conjunto de dados, foram também utilizados dados de precipitação diários provenientes do LCB para o mês de março de 2002, de direção e intensidade do vento horários de algumas estações da CETESB. Imagens ilustrando o posicionamento da Alta da Bolívia e a atuação e duração dos vórtices ciclônicos de altos níveis (VCANs) também foram obtidas para alguns meses, além de imagens de satélite evidenciando o posicionamento destes sistemas e a atuação da ZCAs.

Os gráficos foram construídos e organizados de maneira a facilitar a visualização e análise da evolução das concentrações de ozônio dia a dia e da variabilidade diária das variáveis atmosféricas no mesmo período, comparando-se os gráficos de diferentes variáveis em eixos temporais semelhantes, de certa maneira inspirada na análise rítmica de Monteiro (1976), no entanto sem citar o sistema atmosférico predominante. A variabilidade atmosférica na escala sinótica pôde ser percebida e então pode-se avaliar subjetivamente a influência desta no comportamento do poluente que, como será visto na seção 3.3, difere bastante para os meses avaliados. Os dados horários de direção e intensidade do vento da medidas nas estações da CETESB foram organizados em linguagem computacional FORTRAN para eliminação dos dados falhos e visualização em forma de vetores. Assim, pode-se acompanhar a direção predominante do vento, em diversas estações ao mesmo tempo, bem como as mudanças nesta variável no decorrer do mês. As mudanças na direção do vento são claramente percebidas após os dias de passagem dos sistemas frontais, identificados nos gráficos por uma seta ou linha azul. 
Índices de correlação linear de Pearson foram calculados entre o ozônio e algumas variáveis atmosféricas nesta escala de análise no sentido de dar mais suporte teórico às análises realizadas. 


\section{Resultados}

\subsection{Comportamento do ozônio na RMSP}

A medição do ozônio na RMSP iniciou em 1983, com quatro estações da rede automática: Parque Dom Pedro II, Lapa, Congonhas e Mooca (CETESB, 1985). Os primeiros anos de medição são caracterizados por uma quantidade significativa de dados inválidos, mas a qualidade da medição deste poluente melhora com o passar dos anos, principalmente devido à expansão de seu monitoramento. Inicialmente, a estação Mooca era a que apresentava os índices mais altos de poluição por ozônio; no entanto, com a expansão e atualização da rede de monitoramento no ano de 1996, diversas outras estações passaram também a medi-lo - Mauá, São Miguel Paulista, Osasco, São Caetano do Sul e Ibirapuera. Estas novas estações, formando uma rede mais representativa espacialmente, permitiram perceber que o problema do ozônio troposférico se dava de maneira generalizada em diversas áreas da RMSP. Em 1999 as estações Santana, Pinheiros e Diadema passam também a medir este composto, bem como em Santo André-Capuava no ano de 2000, e Santo Amaro em 2002. Maiores detalhes sobre o monitoramento de ozônio entre 1996 e 2005 podem ser vistos na tabela 10.

Desde o início de sua medição, este poluente apresentou freqüentes ultrapassagens do PQAr, tornando-se motivo de preocupação para as autoridades. Por exemplo, em 1986, houve 103 horas de ultrapassagem do PQAr na estação Mooca por ozônio e, em 1990, a máxima anual foi de $587 \mu \mathrm{g} / \mathrm{m}^{3}$, que caracteriza um estado de atenção (CETESB, 1990). As concentrações oscilaram consideravelmente desde o início das medições, sendo que parte destas oscilações respondem às diferentes condições atmosféricas e parte devido a mudanças nas leis de trânsito com relação aos limites de emissão dos veículos e devido à introdução de novos combustíveis ou modificação dos existentes (CETESB, 1994, ANDRADE, 1994). A introdução do álcool como combustível e a modificação da gasolina (que passa a ser chamada de "gasolina C" ou "gasool", com até 22\% de álcool em sua composição) provocaram modificações no tipo e quantidade de substâncias que são emitidas dos escapamentos dos carros (maiores detalhes na seção 1.1). De qualquer forma, não há um conjunto de razões conhecido que explique a variabilidade do ozônio troposférico por inteiro. Mas ao analisar as concentrações da década de 80 com as 
atuais, percebe-se que elas sofreram alguma redução em relação aos níveis observados desde a década de 80 , no entanto ainda hoje permanecem em níveis prejudiciais à população e ao meio ambiente. Por exemplo, analisando os dados dos relatórios de qualidade do ar da CETESB de 2000 e 2003, não há tendência definida para o ozônio neste período (ver as figuras 09 e 10 na seção 1.2.1.). O estudo de Chiquetto, em 2005, contém maiores detalhes sobre a evolução histórica da poluição atmosférica medida na RMSP. 


\subsubsection{Médias anuais}

Para o ano de 1996, nenhuma estação atingiu o critério de representatividade adotado neste trabalho, que estabelece um mínimo de oito meses com dados válidos. Isto ocorreu em 1996, pois este foi um ano de reformulação da rede de monitoramento de poluentes da CETESB (CETESB, 2000).

Pode-se notar pelas figuras 32 a 36 que há relativa variabilidade dos dados entre as diversas estações; no entanto, por se tratar de médias anuais, muitos detalhes como períodos extremos, maior variabilidade das estações, comportamento sazonal, entre outros, permanecem ocultos. Além disso, uma vez que não há PQAr anual para o ozônio, o objetivo de se analisar estes dados é somente o de registrar as tendências de longo prazo dessas concentrações (CETESB, 2007), na tentativa de se identificar anos com valores extremos e classificar as estações de acordo com sua média anual (este aspecto também será discutido na análise da distribuição espacial do poluente na RMSP, seção 3.4.1). As diversas estações da rede automática que medem a concentração de ozônio troposférico começaram sua operação em períodos diferentes, daí a diferença na disponibilidade dos dados (tabela 10). Durante a análise dos dados, percebeu-se que as médias anuais representavam bem as diferenças entre as estações; para melhor visualização destas diferenças, as séries temporais anuais de ozônio apresentadas nesta seção são agrupadas em quatro figuras com o mesmo eixo temporal.

A média dos desvios padrão $(\sigma)$ de todas as estações foi calculada com base no desvio padrão individual de cada uma delas. O cálculo da diferença entre a média anual de concentração de $\mathrm{O}_{3}$ para cada estação e o desvio padrão médio permitiu a classificação das estações com relação à concentração. Desta forma, pôde-se distinguir quatro classes de concentrações distintas (tabela 13):

- Concentrações baixas, em que o valor de anomalia da estação foi igual ou inferior a $-2 \sigma$;

- Concentrações médias, em que o valor da anomalia da estação ficou no intervalo entre $-1 \sigma \mathrm{e}+1 \sigma$;

- Concentrações altas, em que o valor da anomalia foi maior do que $+1 \sigma$ e 
- Concentrações muito altas, em que a anomalia da estação foi maior do que $+2 \sigma$. 
Tabela 13: Classificação das estações por faixa de concentração: baixa (azul), média (verde), alta (vermelho) e muito alta (marrom), em comparação com o desvio padrão médio espacial $(\sigma=3,99)$.

\begin{tabular}{|l|l|}
\hline Estação & Anomalia \\
\hline Lapa & $-18,09$ \\
\hline Congonhas & $-17,53$ \\
\hline Pinheiros & $-10,27$ \\
\hline Osasco & $-9,62$ \\
\hline Parque D. Pedro II & $-8,39$ \\
\hline Nossa Sra. Do Ó & $-7,56$ \\
\hline Mooca & $-1,14$ \\
\hline Horto Florestal & 1,95 \\
\hline Santo André - Capuava & 2,39 \\
\hline Ibirapuera & 3,79 \\
\hline São Miguel Paulista & 4,01 \\
\hline Diadema & 4,66 \\
\hline São Caetano do Sul & 4,74 \\
\hline Mauá & 7,68 \\
\hline Pico do Jaraguá & $\mathbf{1 0 , 1 8}$ \\
\hline Santana & $\mathbf{1 1 , 1 4}$ \\
\hline Santo Amaro & $\mathbf{1 6 , 2 4}$ \\
\hline
\end{tabular}

As estações Congonhas, Lapa, Osasco, Pinheiros, Parque Dom Pedro II e Nossa Senhora do Ó apresentam média anual de $\mathrm{O}_{3}$ mais baixa, sendo que os menores valores giram em torno de $10 \mu \mathrm{g} / \mathrm{m}^{3}$, e os valores mais altos não ultrapassam $25 \mu \mathrm{g} / \mathrm{m}^{3}$, exceto pela estação Parque Dom Pedro II que nos anos de 1999, 2002 e 2003 apresentou médias anuais de entre 25 a $28 \mu \mathrm{g} / \mathrm{m}^{3}$. 


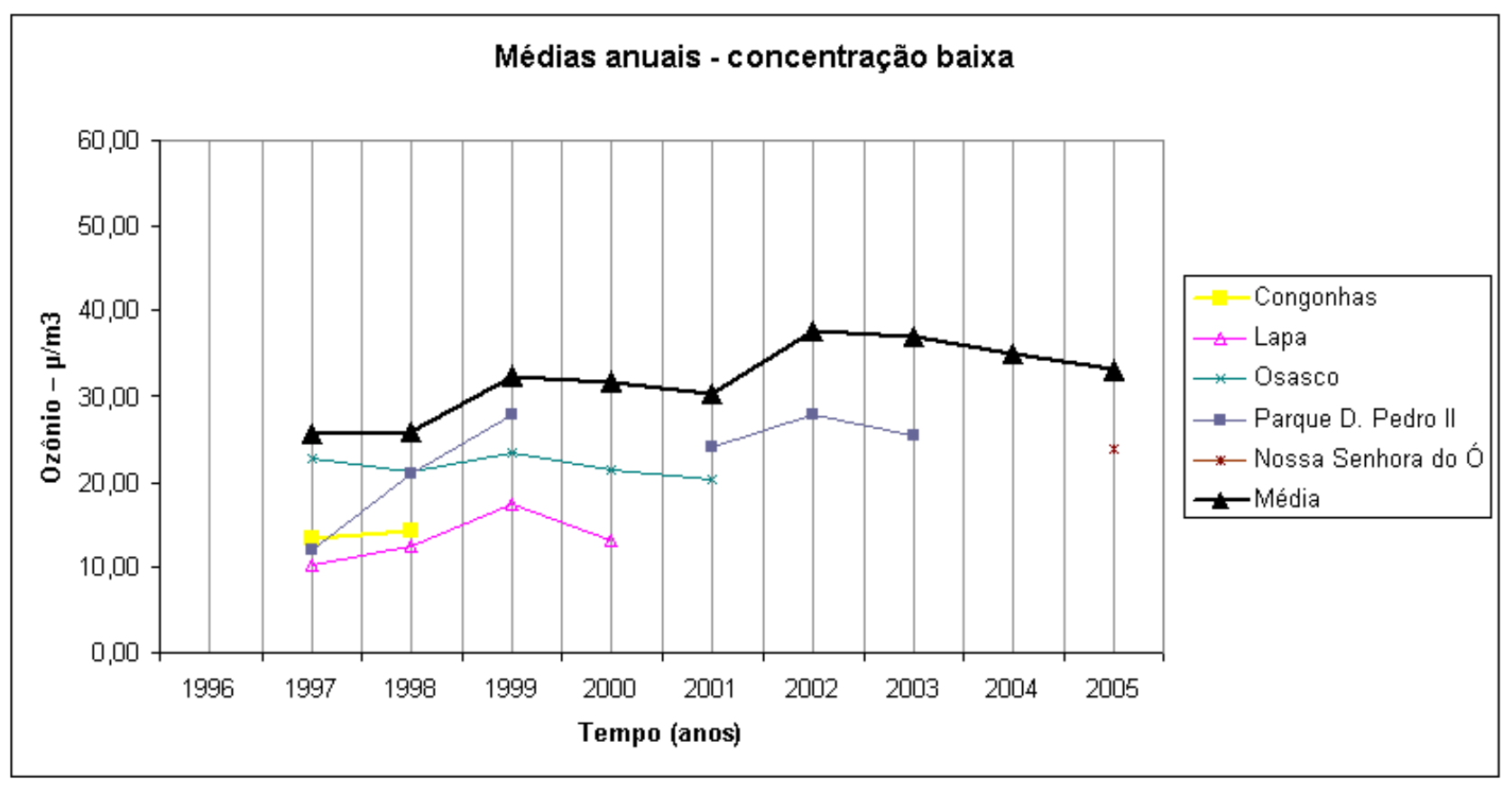

Figura 32: Concentração anual para as estações com concentração média baixa (< $-2 \sigma)$.

Pode-se notar que as séries temporais anuais destas estações permanecem abaixo da média relativa a todas as estações em todos os anos, representada pela linha preta mais espessa na figura 32. A estação Nossa Senhora do Ó apresenta dados representativos na escala anual somente no ano 2005.

As estações Mooca, Ibirapuera, Santo André-Capuava e Horto Florestal apresentam médias anuais maiores em comparação às estações anteriores. No geral, suas médias anuais ficam em torno de $20-40 \mu \mathrm{g} / \mathrm{m} 3$. Surpreendentemente, a estação Ibirapuera, conhecida por suas altas concentrações de ozônio na literatura (CETESB, 2004), tem um comportamento semelhante a estas estações no que concerne à evolução temporal de suas médias anuais, com média anual mínima de $28 \mu \mathrm{g} / \mathrm{m}^{3}$, em 2004 e picos de aproximadamente $42 \mu \mathrm{g} / \mathrm{m}^{3}$, em 1997 e 2002. 


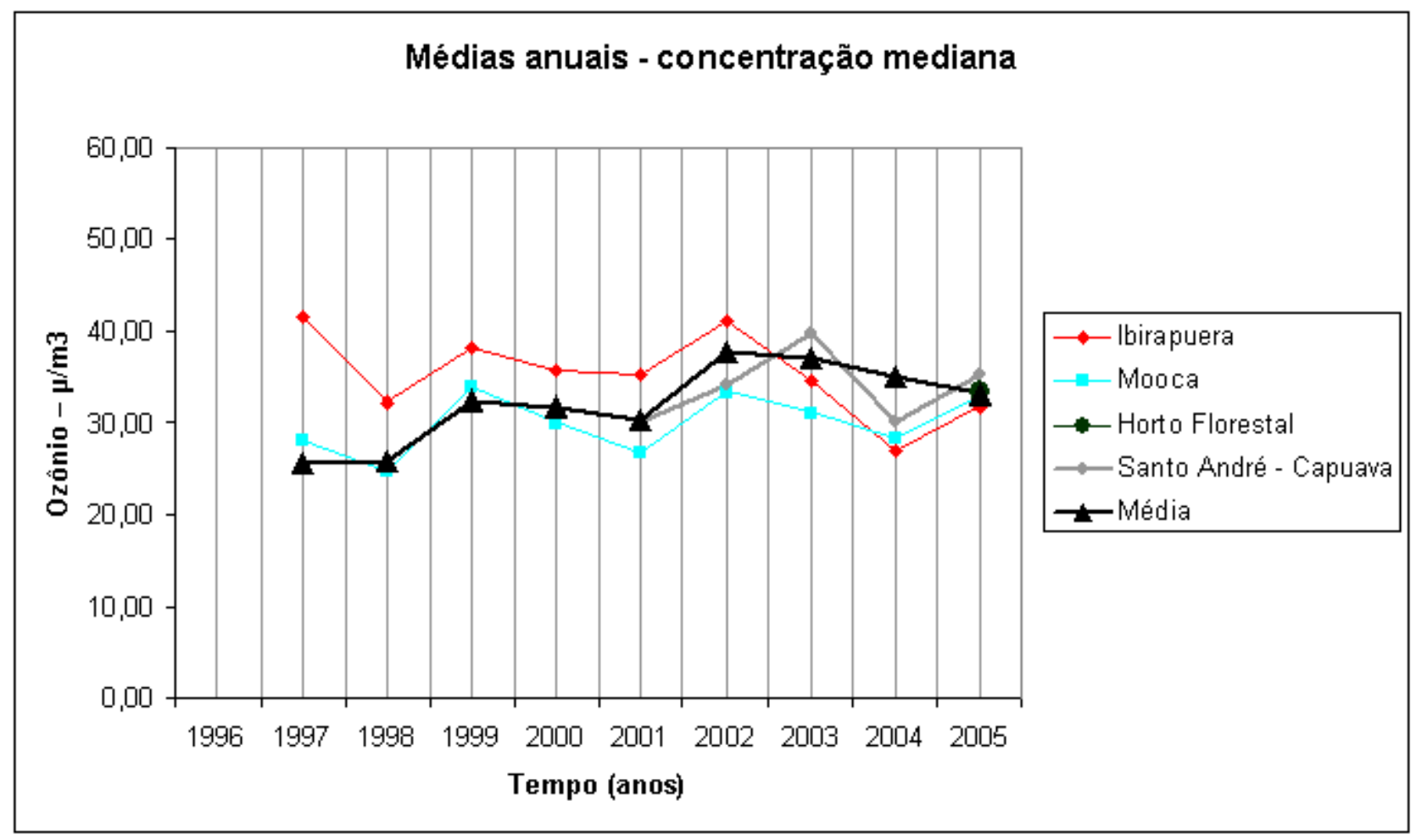

Figura 33: Concentração anual para as estações com concentração mediana (entre $-1 \sigma e+1 \sigma)$.

No entanto, percebe-se pela figura 33 que, na maior parte da série temporal, as concentrações anuais médias da estação Ibirapuera permanecem acima da média espacial dentre todas as estações, identificada pela linha preta. A metodologia empregada no trabalho para dividir as estações por concentração baixa, mediana, alta, e muito alta foi a comparação com o desvio padrão médio espacial; o que fez com que, neste conjunto de estações e recorte temporal analisados, a estação Ibirapuera figurasse entre as estações de concentração mediana, embora o valor de seu desvio padrão seja mais próximo numericamente do calculado para as estações de alta concentração (tabela XX). No entanto, decidiu-se por mantê-la agrupada com as estações Horto Florestal, Santo André-Capuava e Nossa Senhora do Ó, pois ainda assim o desvio padrão da estação Ibirapuera era menor do que o limite proposto. Diferentemente desta estação, as outras estações deste grupo apresentam concentrações com valores próximos à média. A estação Horto Florestal possui dados representativos na escala anual apenas para o ano de 2005, com valor bem próximo da média de todas as estações para este ano. 
Já a estações São Miguel Paulista, Diadema, São Caetano do Sul e Mauá apresentaram médias anuais consideradas altas com base na metodologia empregada, com médias anuais mínimas em torno de $30 \mu \mathrm{g} / \mathrm{m}^{3}$ e, máximas de 40 a $45 \mu \mathrm{g} / \mathrm{m}^{3}$, como pode ser verificado na figura 34 .

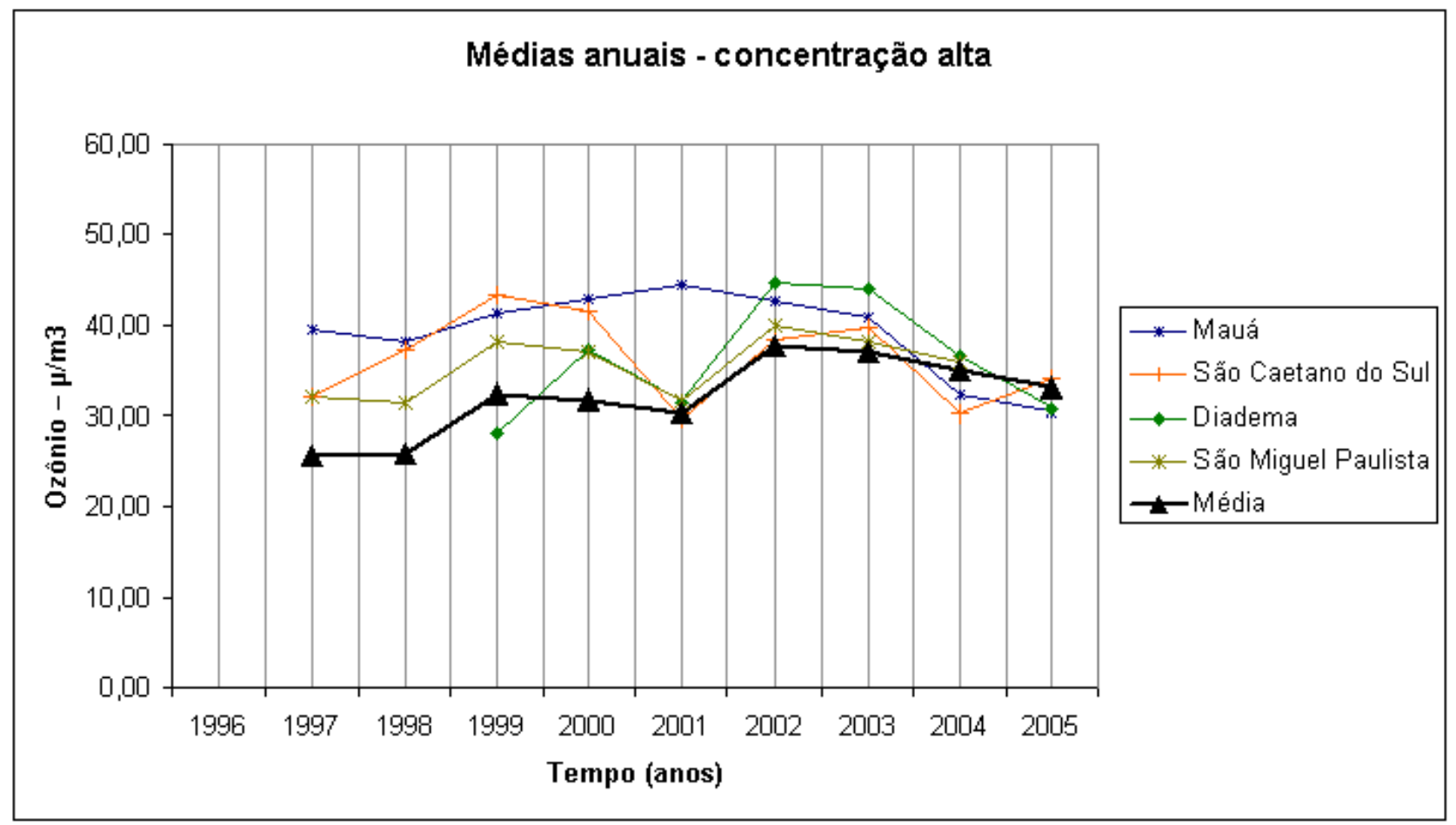

Figura 34: Concentração anual para as estações com concentração alta $(>+1 \sigma)$.

Estas estações apresentam valores anuais superiores à média de todas as estações na maioria dos anos. Distingue-se das demais o comportamento da estação Mauá no ano de 2001, enquanto todas as outras estações demonstram queda da concentração neste ano, a estação Mauá registrou um ligeiro aumento.

O último grupo de estações, constituído por Pico do Jaraguá, Santo Amaro e Santana, apresenta os valores anuais mais elevados dentre as demais estações analisadas, como pode ser visto na figura 35. As médias anuais mínimas ficam em torno de $40 \mu \mathrm{g} / \mathrm{m}^{3}$ e as maiores chegam a $55 \mu \mathrm{g} / \mathrm{m}^{3}$, como nas estações Santo Amaro, em 2004, e Santana, em 2005. No entanto, Santo Amaro e Pico do Jaraguá apresentam, respectivamente, para esse período analisado, apenas três e dois anos de dados. Portanto, buscou-se, no Relatório de Qualidade do Ar do Estado de São Paulo de 2007 (CETESB, 2008), informações acerca das concentrações de ozônio, nestas e em outras estações, para os anos de 2006 e 2007, numa tentativa de se 
identificar as tendências de concentração em anos posteriores aos da série temporal estudada (1996-2005).

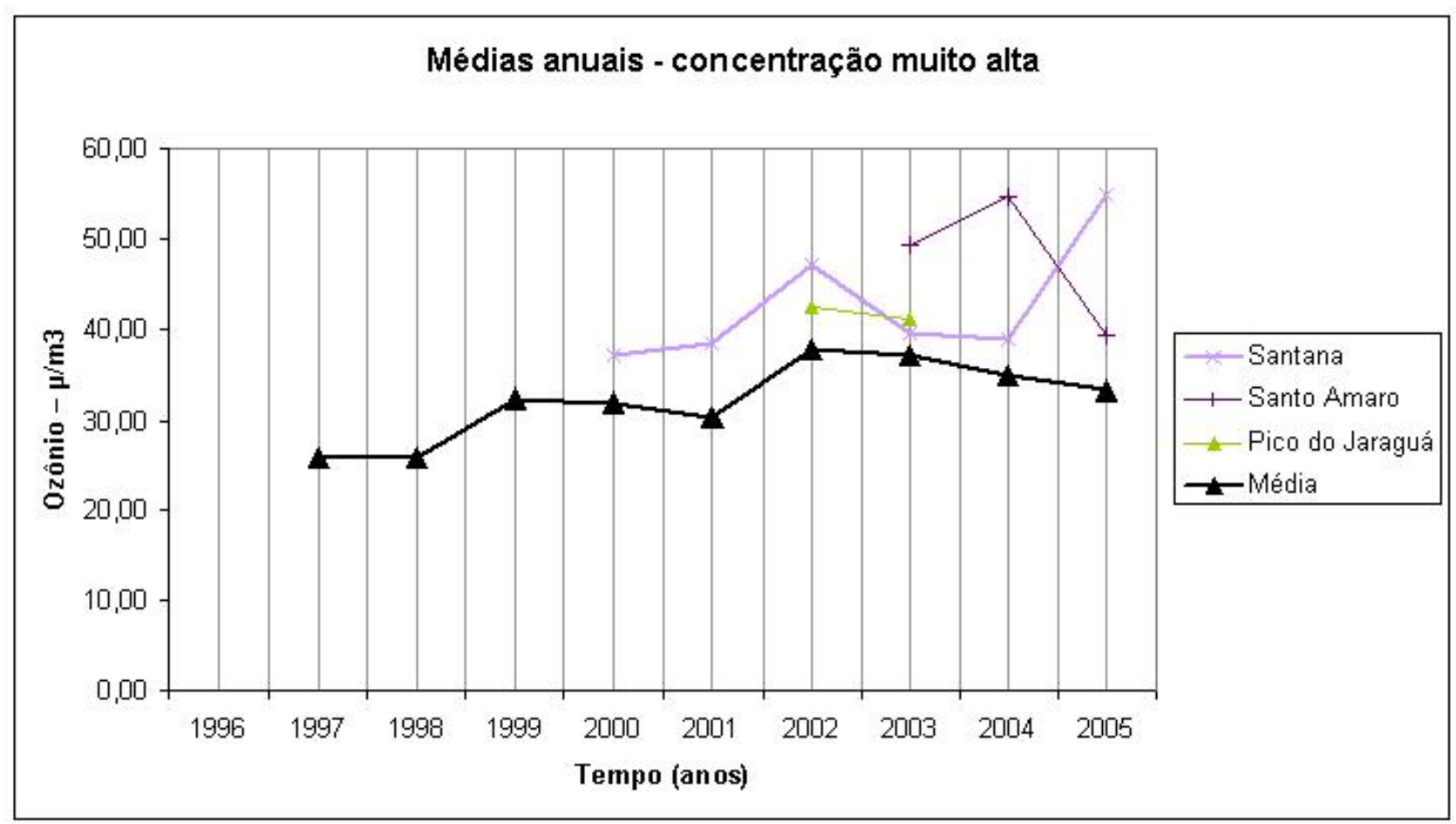

Figura 35: Concentração anual para as estações com concentração muito alta (> $+2 \sigma)$.

As informações contidas no relatório da CETESB de 2007 (figura 36) mostram a evolução das concentrações de ozônio de 2003 a 2007, para diversas estações da RMSP, de acordo com o número de ultrapassagens do PQAr por ano. De qualquer forma, pode-se tomar estes dados como medida do nível de concentração de ozônio em cada estação, pois eles variam de maneira parecida com a média aritmética anual. Segundo os dados deste relatório, as estações Diadema, Ibirapuera, Santo Amaro, Santo André-Capuava, Mooca, Santana e São Caetano do Sul continuam a apresentar patamares de concentrações parecidos com os dos anos anteriores, de forma que, mesmo que suas tendências de aumento ou diminuição de concentração tenham mudado nos últimos anos, ainda podem ser agrupadas de maneira similar ao elaborado neste estudo, enquanto o critério de análise for o de médias anuais. Por outro lado, as estações Pinheiros, Nossa Senhora do Ó e Mauá apresentam um número diferente de ultrapassagens do PQAr em comparação aos anos anteriores, com maiores níveis de concentração nas estações Pinheiros e Nossa Senhora do Ó em relação aos anteriores e menores em Mauá, tal como visto na figura 36 . A 
tendência temporal da concentração de $\mathrm{O}_{3}$ em cada estação pode ser melhor avaliada na próxima seção, que evidencia a evolução das médias mensais. 

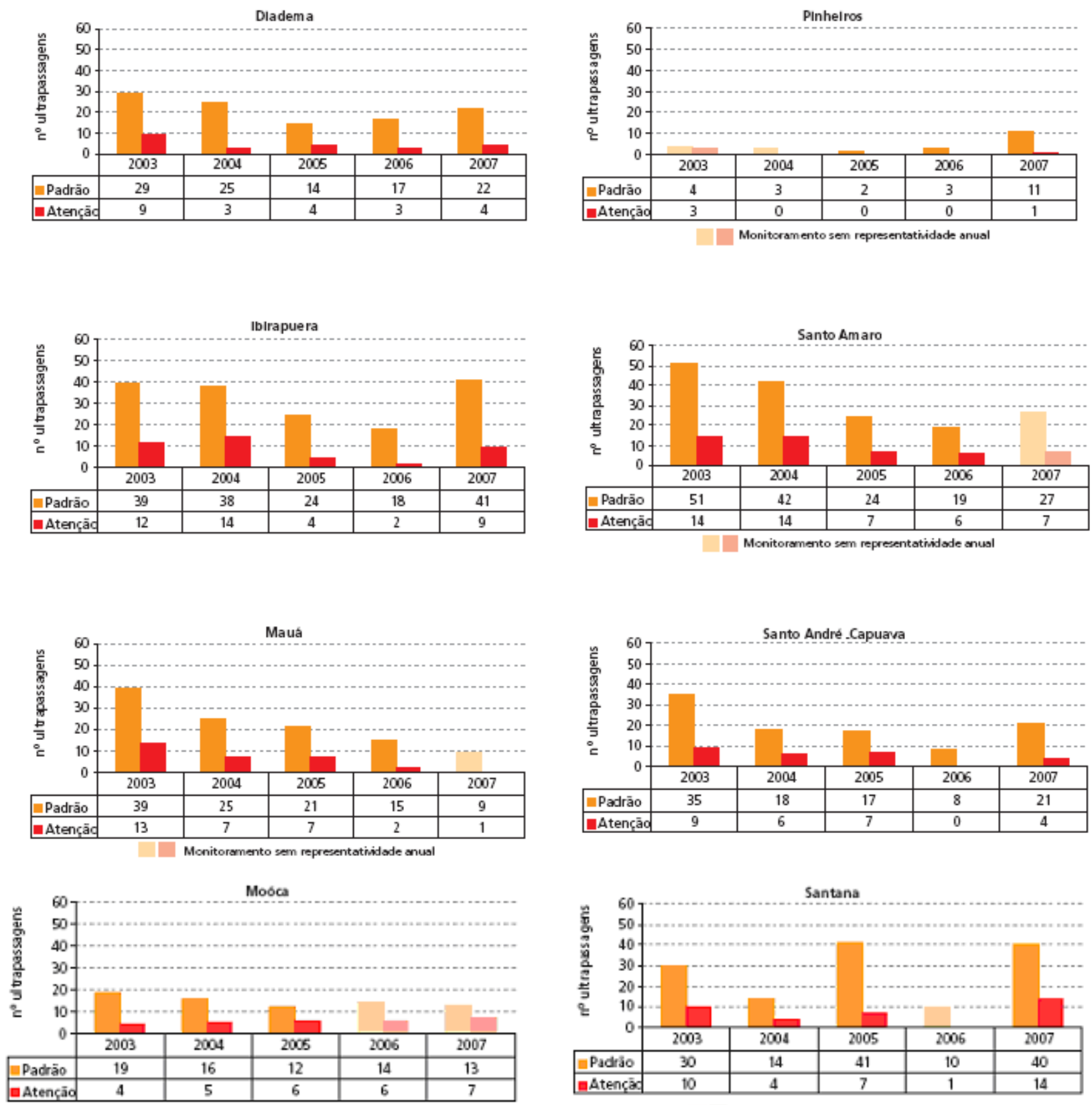

DIII Monitcramento sen repesentatividede anual
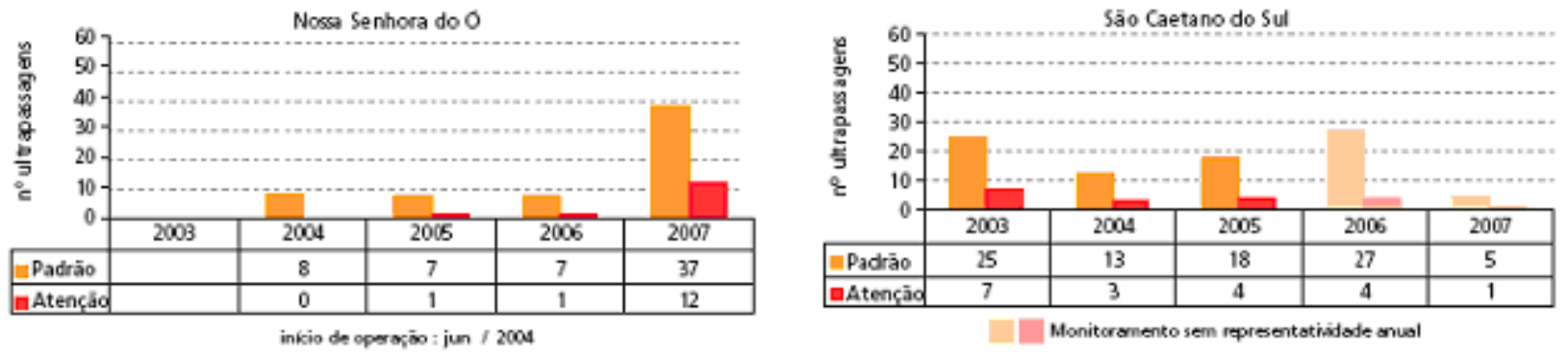

1- Monitcramento sem representatinidode anual

Figura 36: Evolução do número de ultrapassagens de padrão e nível de atenção de $\mathrm{O}_{3}$ por estação na RMSP - 2003 a 2007. Fonte: CETESB (2008). 


\subsubsection{Médias mensais}

As médias anuais analisadas anteriormente facilitam a leitura das diferenças de concentrações médias das estações analisadas, por suprimirem as variações sazonais e mensais. As médias mensais, por outro lado, permitem observar a evolução das concentrações de $\mathrm{O}_{3}$ ao longo do ano, em períodos/estações diferentes, em que predominam condições atmosféricas distintas, permitindo a identificação, com certa facilidade, do ciclo sazonal deste poluente. O critério de representatividade para as médias mensais (20 dias ou mais com dados válidos em cada mês) foi atingido pela maioria dos meses em todas as estações.

Para cada estação, foi calculada a tendência linear da concentração mensal de ozônio, conforme descrito na seção 2.3. Dentre as 17 estações estudadas, 8 estações apresentaram tendências de elevação, 7 de redução e 2 de estabilidade em suas concentrações mensais, tal como visto na tabela 14, figuras 37 a 39 e o anexo 1.

Tabela 14: Coeficiente angular da reta de tendência para as 17 estações avaliadas e seus respectivos períodos de avaliação.

\begin{tabular}{|l|l|l|}
\hline Estação & $\begin{array}{l}\text { Coeficiente } \\
\text { angular }\end{array}$ & $\begin{array}{l}\text { Período de } \\
\text { avaliação }\end{array}$ \\
\hline Horto Florestal & $-0,4$ & $2004-2005$ \\
\hline Santo Amaro & $-0,3$ & $2003-2005$ \\
\hline Osasco & $-0,1$ & $1996-2001$ \\
\hline Ibirapuera & $-0,09$ & $1996-2005$ \\
\hline Pinheiros & $-0,09$ & $1999-2005$ \\
\hline Mauá & $-0,06$ & $1996-2005$ \\
\hline São Caetano do Sul & $-0,02$ & $1996-2005$ \\
\hline Congonhas & $-0,01$ & $1996-1999$ \\
\hline Nossa Senhora do Ó & $-0,01$ & $2004-2005$ \\
\hline Mooca & 0,04 & $1997-2005$ \\
\hline Diadema & 0,05 & $1999-2005$ \\
\hline Santo André - Capuava & 0,06 & $2001-2005$ \\
\hline Lapa & 0,06 & $1996-2000$ \\
\hline São Miguel Paulista & 0,07 & $1996-2005$ \\
\hline Parque D. Pedro II & 0,1 & $1996-2005$ \\
\hline Santana & 0,2 & $1999-2005$ \\
\hline Pico do Jaraguá & 0,3 & $2002-2003$ \\
\hline
\end{tabular}


Embora pela análise da tabela 14 pode-se perceber que há mais estações com coeficientes negativos do que positivos - o que indica mais estações com tendência de redução da concentração de $\mathrm{O}_{3}$ - a média espacial das 17 estações indica tendência geral de aumento, tal como será visto na figura 40. As estações Congonhas e Nossa Senhora do Ó apresentam tendência de redução pouco significativa, que não é percebida na média final.

Figuras com a tendência linear para todas as estações fazem parte do anexo 1.

No geral, não se percebe nenhuma lógica na distribuição de estações com tendência de aumento ou redução, seja no nível de concentração das estações, de sua distribuição espacial e uso do solo no entorno ou do período estudado.

As estações que apresentam as maiores tendências de elevação da concentração de $\mathrm{O}_{3}$, dentre as 17 estações estudadas na RMSP, são: Santana, Pico do Jaraguá e Parque D. Pedro II, tal como observado na figura 37.

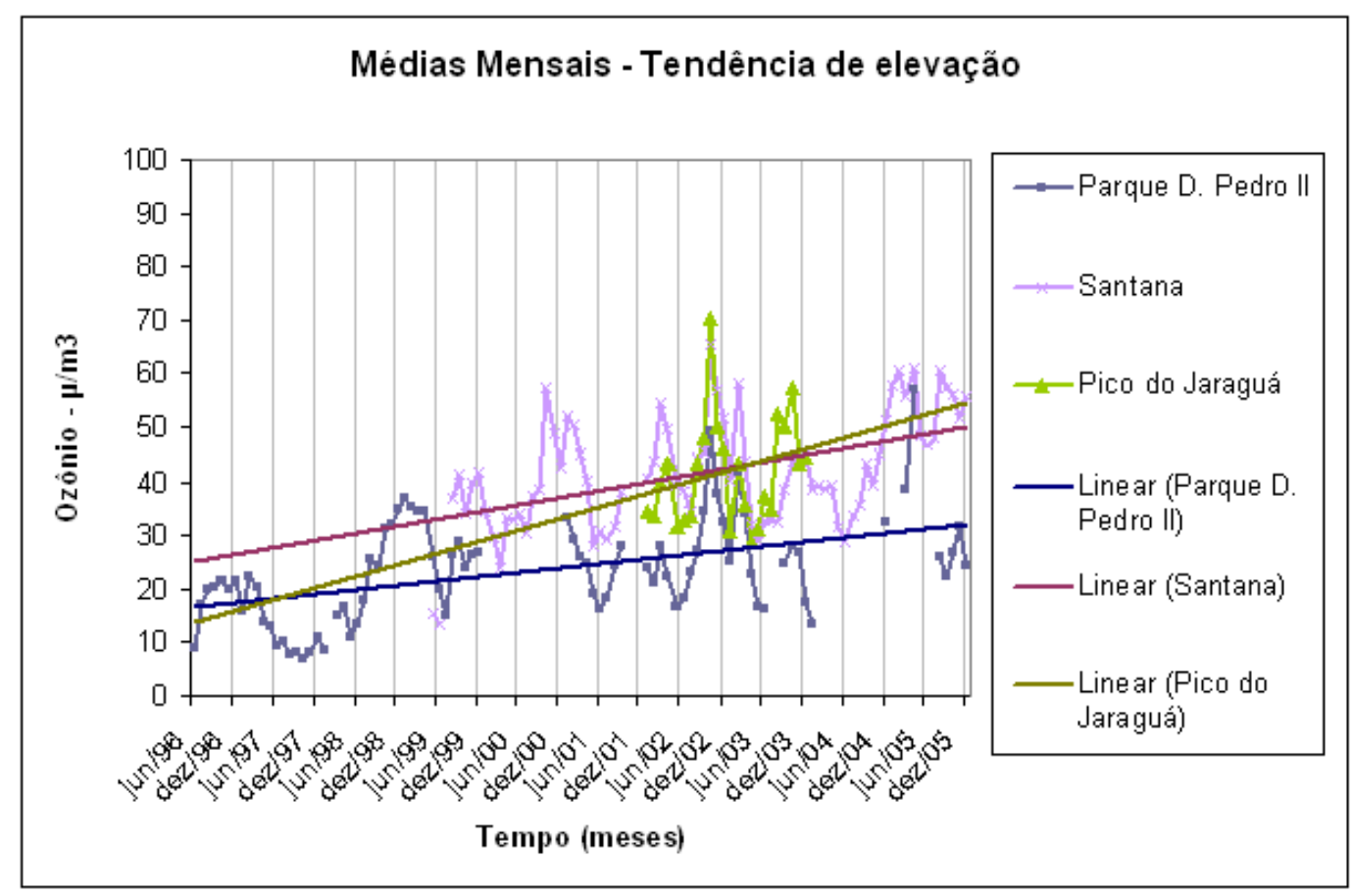

Figura 37: Evolução das concentrações mensais de ozônio nas estações Parque D. Pedro II, Santana e Pico do Jaraguá. As linhas retas indicam a tendência linear de cada estação. 
Como se pode ver pela figura 37, a evolução temporal das concentrações da estação Parque D. Pedro II é clara e constante ao longo de sua série temporal. Pode-se notar que nos anos de 1996 e 1997 suas médias encontram-se num patamar bem mais baixo do que nos anos seguintes, principalmente em relação a 1998, 2002 e 2005. Neste último ano, suas concentrações já atingem níveis semelhantes aos das outras duas estações, classificadas como de alta concentração de $\mathrm{O}_{3}$ (seção 2.3.2). Por outro lado, nota-se que há uma grande ausência de dados válidos nesta estação, principalmente no final de sua série temporal, o que compromete uma análise mais detalhada da evolução temporal.

A estação Santana apresenta uma série temporal menor, mas também revela claramente uma tendência de elevação em suas concentrações mensais, de 1999 a 2005. Contudo, estação Pico do Jaraguá conta com apenas dois anos de análise, 2002 e 2003. Nestes dois anos, diversas estações da RMSP apresentam altas concentrações de ozônio, como poderá ser visto na análise do ciclo sazonal. A tendência de elevação das concentrações mensais, neste caso, é influenciada pelas altas concentrações de ozônio registradas no segundo semestre, principalmente no mês de outubro de 2002, e pelo pequeno número de valores mensais, estando associada à baixa significância estatística (não calculada). Apesar de estatisticamente pouco significativa, as altas concentrações de $\mathrm{O}_{3}$ na estação Pico do Jaraguá são relevantes devido ao fato desta estação estar localizada em área de lazer e proteção ambiental relativamente afastada do centro da mancha urbana.

A estação Congonhas apresenta estabilidade das concentrações mensais durante o período analisado, de 1996 a 1999 (figura 38). 


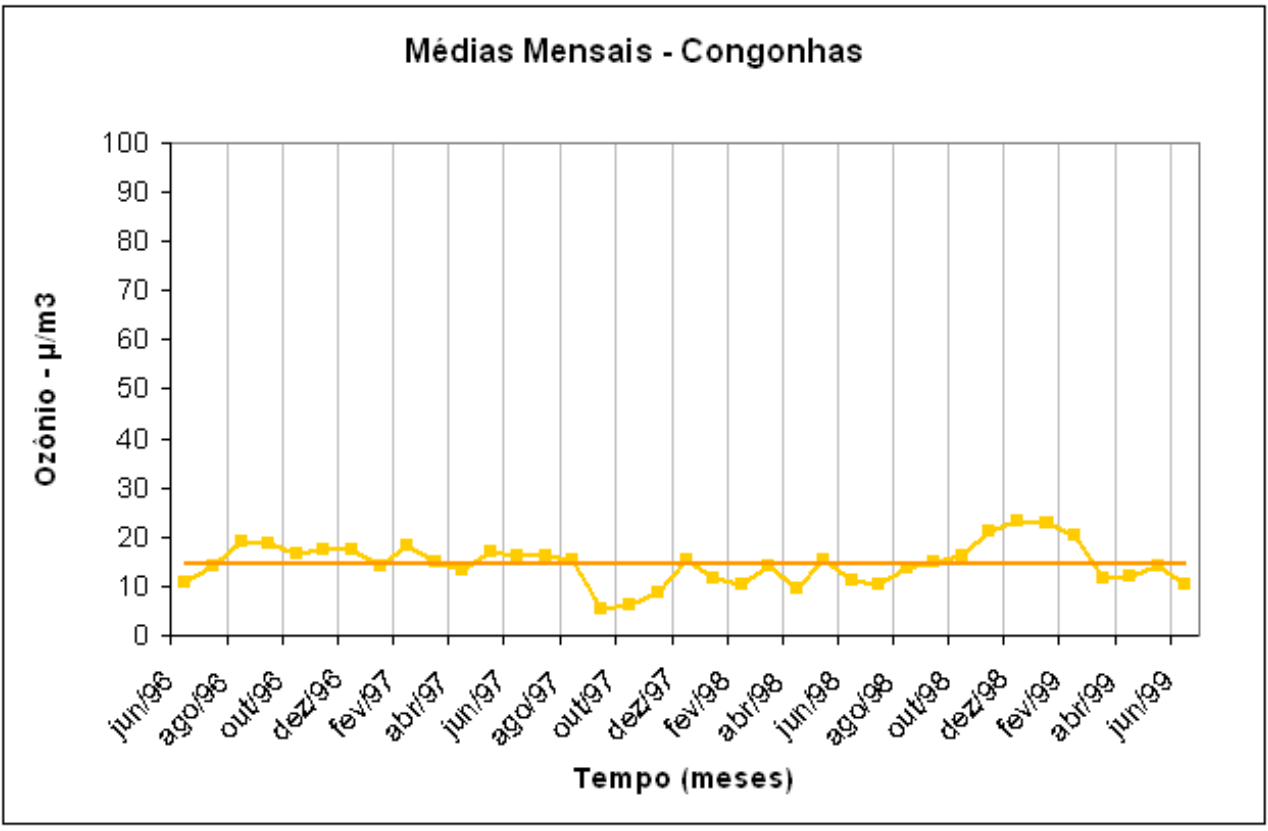

Figura 38: Evolução das concentrações mensais de ozônio na estação Congonhas. A linha reta indica a tendência linear.

Apenas Congonhas e a estação Nossa Senhora do Ó apresentam estabilidade em suas concentrações; todas as outras estações apresentam tendência de elevação ou redução, com diferentes graus de intensidade, como pode ser conferido na tabela 14. A seguir, são apresentadas as séries temporais de algumas estações com tendências significativas de redução em suas concentrações, como é o caso de Santo Amaro, Horto Florestal (figura 39a) e Osasco (figura 39b).

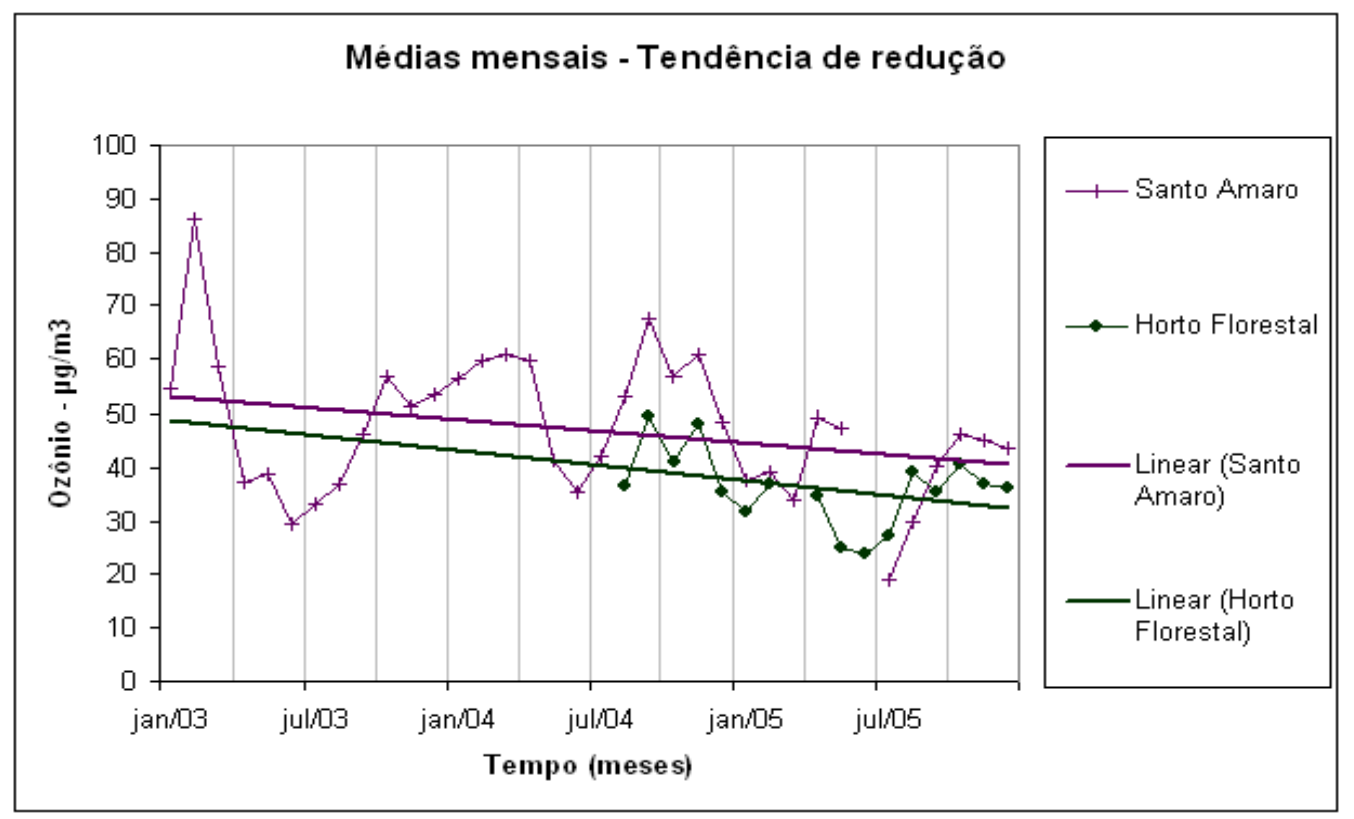




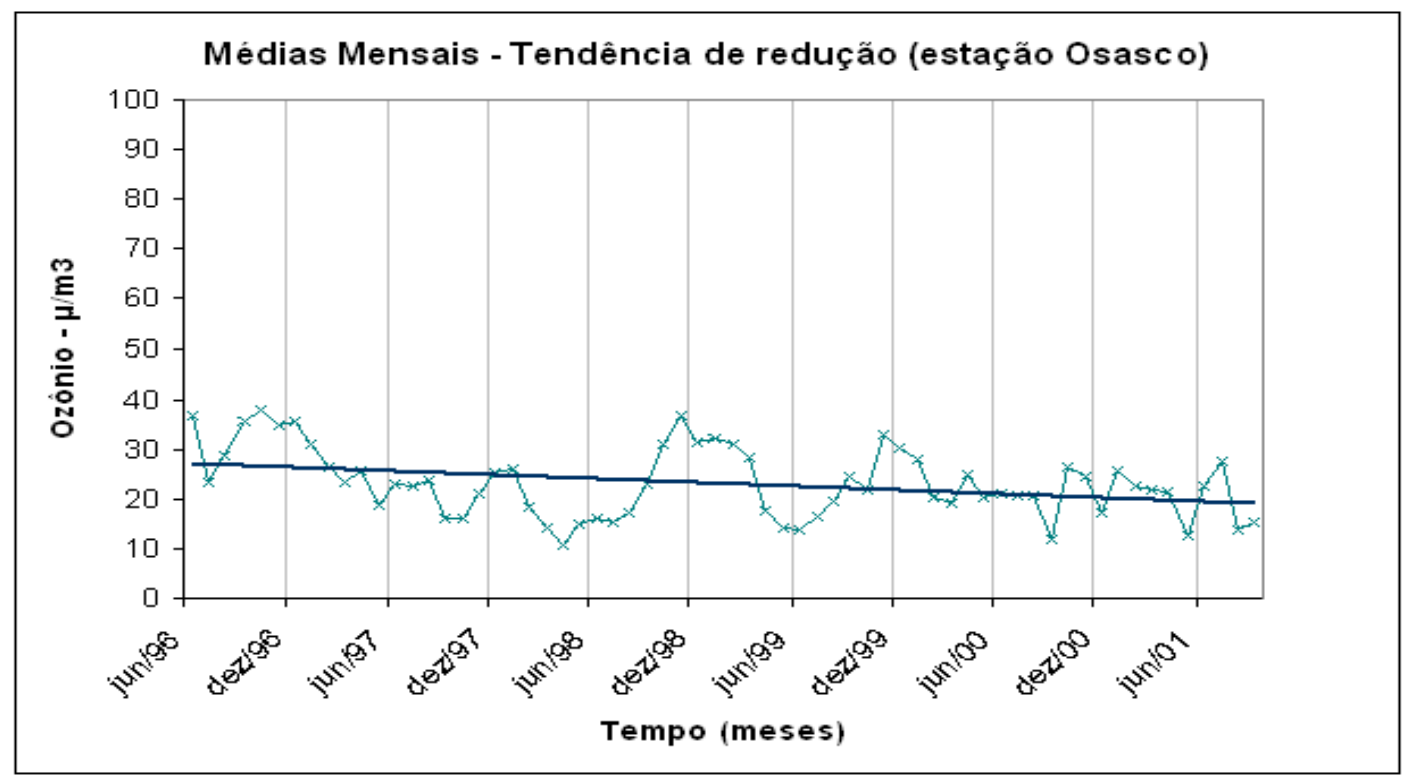

Figuras 39a e 39b: Evolução das concentrações mensais de ozônio para as estações Santo Amaro, Horto Florestal e Osasco. As linhas retas indicam a tendência linear de cada estação.

As estações Santo Amaro, Horto Florestal (figura 39a) e Osasco (figura 39b) apresentam as maiores tendências de redução. Estas séries foram agrupadas em gráficos diferentes devido à defasagem temporal no período de suas medições: enquanto Santo Amaro e Horto Florestal apresentam observações no período de 2003 a 2005, Osasco apresenta observações de 1996 a 2001. Esta última estação também apresenta tendência negativa não muito alta (coeficiente angular $=-0,1$, representando redução de aproximadamente $1,2 \mu \mathrm{g} / \mathrm{m}^{3}$ ao ano) e a estação de Santo Amaro, entre o início e o final da série, apresenta valores médios bastante diferentes (coeficiente angular= $-0,3$, representando redução de aproximadamente $3,6 \mu \mathrm{g} / \mathrm{m}^{3}$ ao ano). A estação Santo Amaro apresenta um pico de concentração no mês de fevereiro de 2003 (aproximadamente $86 \mu \mathrm{g} / \mathrm{m}^{3}$ ), e um mínimo em julho de 2005 (aproximadamente $25 \mu \mathrm{g} / \mathrm{m}^{3}$ ). Os meses com concentrações atípicas são discutidos com mais detalhe nas seções 3.3 e 3.4. A estação Horto Florestal conta com valores medidos em apenas em três anos (2004 a 2006), sendo que 2005 apresenta menores concentrações, tal como o observado na tabela 11. 


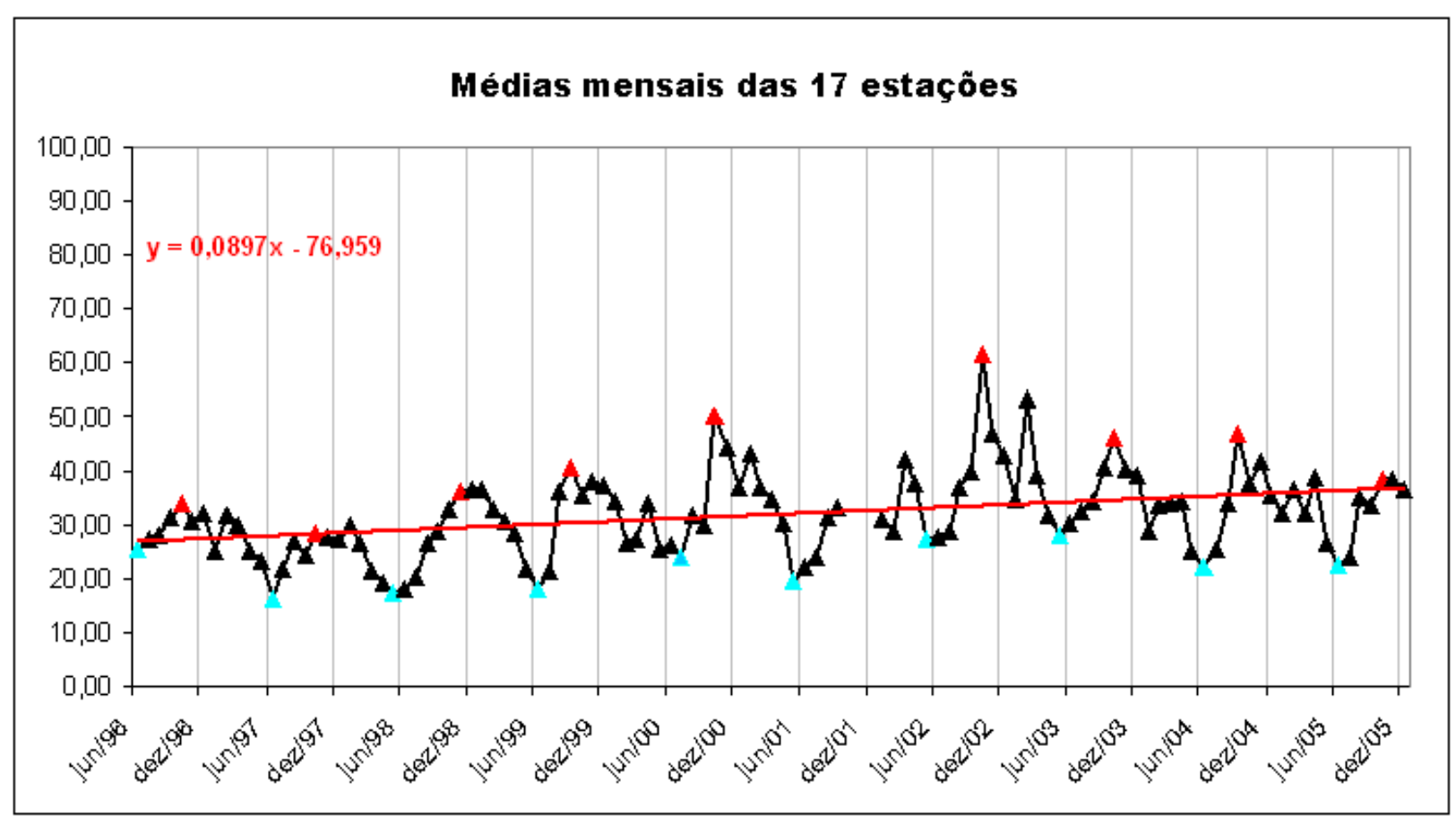

Figura 40: Evolução temporal do valor mensal médio para as 17 estações, de 1996 a 2005. A reta vermelha indica a tendência linear média. Os meses indicados em vermelho e azul demonstram, respectivamente, a maior e a menor concentração registrada no ano.

Considerando-se a média de todas as 17 estações da RMSP nota-se que há uma tendência média de aumento da concentração de ozônio. No entanto, isto não significa que esteja havendo um aumento generalizado do poluente na RMSP, ou seja, em todas as estações. A média espacial é resultado das observações em diversas estações que estão localizadas em áreas distintas, funcionam (ou funcionaram) em épocas específicas e representando diferentes períodos. Estas médias refletem então determinados recortes espaço-temporais significativamente diferentes. Por isso, uma análise da média de todo este conjunto de estações não deve ser tomada como única fonte de dados quando se quer avaliar a evolução temporal das concentrações de ozônio na RMSP.

Para se tentar inferir uma tendência mais legítima da concentração deste poluente, calculou-se também a média da concentração mensal apenas para as estações que contam com séries temporais mais longas (figura 41). As estações escolhidas para este cálculo foram Ibirapuera, Mauá, Mooca, Parque D. Pedro II, São Caetano do Sul e São Miguel Paulista, cujos períodos de análise são os 
mesmos (1996-2005, exceto pela estação Mooca, com período de observação de 1997 a 2005).

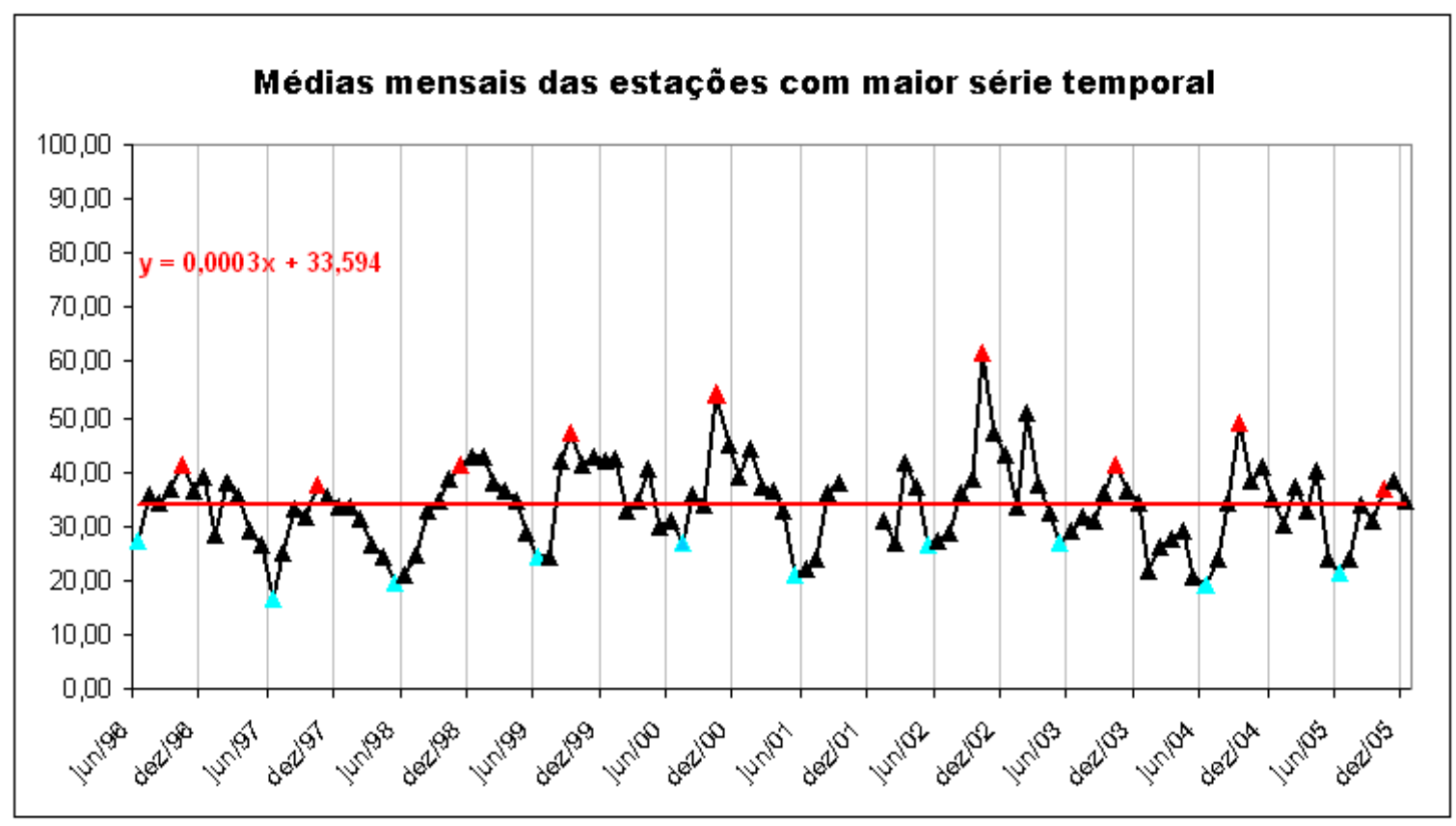

Figura 41: Evolução temporal da concentração mensal de ozônio para as estações Ibirapuera, Mauá, Mooca, Parque D. Pedro II, São Caetano do Sul e São Miguel Paulista, com a respectiva tendência linear. Os meses em vermelho e azul indicam, respectivamente, as concentrações máxima e mínima do ano.

Pode-se concluir com base nos dados apresentados por esta figura que a tendência de redução ou aumento da concentração média de $\mathrm{O}_{3}$ para as estações com as maiores séries temporais (1996-2005) é praticamente inexistente.

Assim sendo, é mais provável que o aumento na média de ozônio quando se utiliza a média das 17 estações seja decorrente do aumento do número de estações de monitoramento na RMSP e não que haja realmente aumento do poluente. Outra conclusão que pode ser retirada desta comparação é que provavelmente as concentrações do poluente na RMSP em 1996 eram mais altas do que o representado pelas estações em funcionamento na época, que não representavam a RMSP como a rede em 2005, ano em que contava com mais do que o dobro (13) das estações utilizadas em 1996 (6). À medida que novos pontos passam a ser monitorados, a real distribuição e concentração do poluente na cidade vai sendo aos poucos revelada. Este pensamento também pode ser aplicado a épocas anteriores às melhorias realizadas na rede de monitoramento em 1996. 
Pode-se supor então que o ozônio não é um problema recente de poluição do ar na RMSP, mas anteriormente a 1996, era um problema pouco conhecido devido a restrições principalmente tecnológicas e financeiras, oriundas dos custos envolvidos na implantação de uma rede adequada de monitoramento da qualidade do ar e outras prioridades existentes nessas épocas, como a poluição por outros compostos, conforme pode ser verificado nos diversos relatórios anuais de qualidade do ar da CETESB desde 1983 e outros estudos que abordam a poluição atmosférica na RMSP em épocas anteriores à 1996 (FRUEHAUF, 1988; SOBRAL, 1988; CHIQUETTO, 2005). O que pode ser considerado recente (de 1996 em diante) é apenas um conhecimento mais próximo da real extensão da contaminação por ozônio do ar que a população da RMSP respira. 


\subsubsection{O ciclo sazonal do ozônio troposférico na RMSP}

Outro aspecto importante revelado pelas médias mensais é o ciclo sazonal do ozônio. Monteiro, em 1976, esclarecia que a poluição atmosférica é, em grande parte, originária das atividades humanas, entretanto é influenciada pelos fenômenos atmosféricos. Assim, supõe-se que a sucessão dos diferentes escoamentos atmosféricos ao longo do ano interaja de diferentes maneiras com a distribuição espacial dos poluentes, resultando também em uma sazonalidade das concentrações dos poluentes ao longo do ano. Como foi explicado no capítulo $1^{\circ}$ (Introdução), o ozônio troposférico depende de uma combinação de poluentes precursores, principalmente óxidos de nitrogênio e compostos orgânicos voláteis, sob o efeito de fotodissociação da radiação solar. Assim, a intensidade e freqüência da radiação solar que atinge as camadas atmosféricas mais próximas à superfície é de extrema importância na determinação das concentrações de ozônio. Pode-se notar pelas figuras demonstradas nesta seção (em especial a figura 42) que as máximas e mínimas concentrações do ano obedecem a um padrão, sendo as mínimas concentrações mensais freqüentemente observadas no trimestre maiojunho-julho e as máximas no trimestre setembro-outubro-novembro. A variação sazonal do ozônio está relacionada à quantidade de radiação solar incidente nas baixas camadas da atmosfera, tal como discutido por Andrade et al. (1993) e CETESB (1994). A radiação solar apresenta um valor mínimo por volta do final de outono e um valor máximo no início da primavera, tal como observado na figura 42 . . 


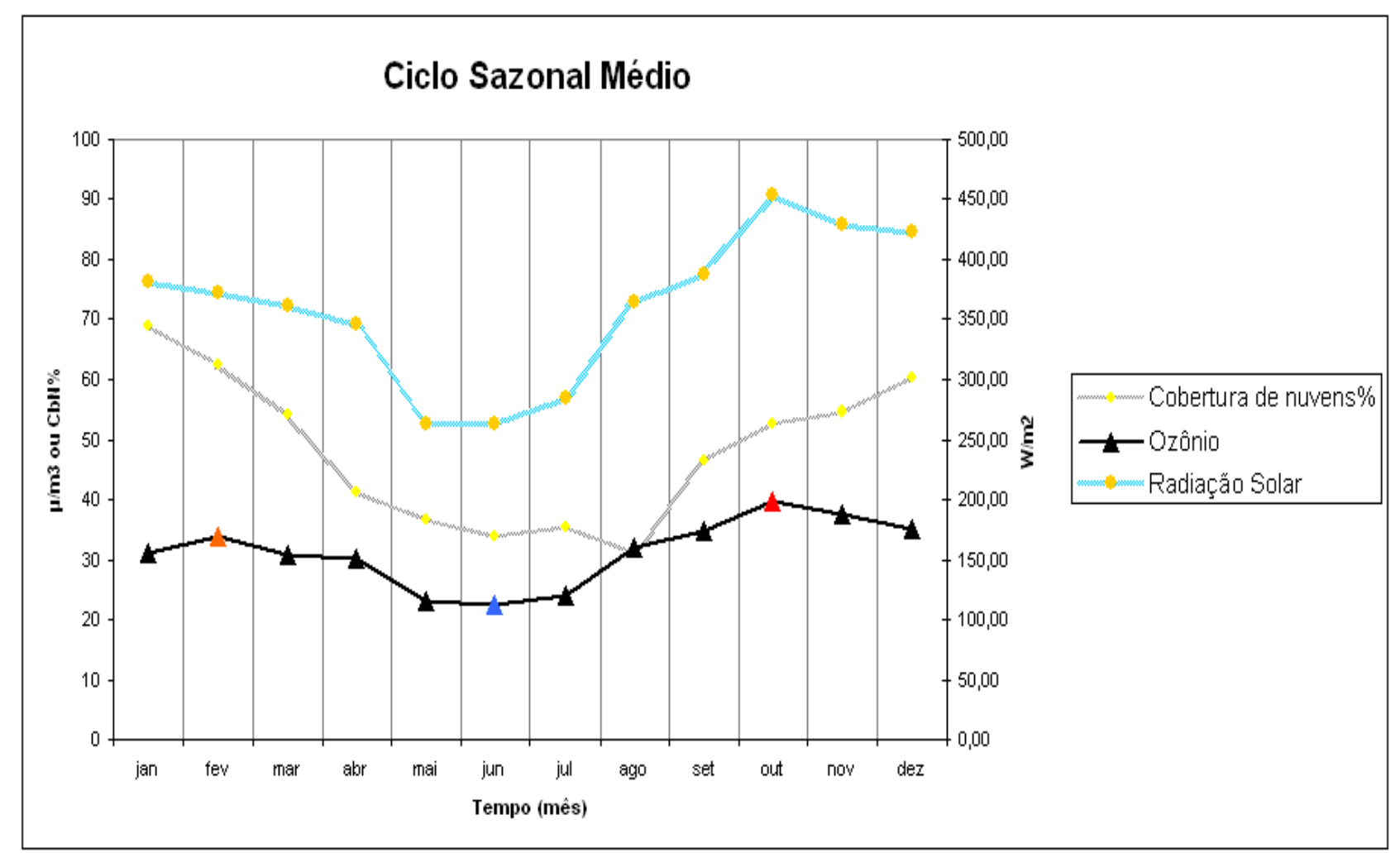

Figura 42: Ciclos sazonais médios de ozônio $\left(\mu \mathrm{g} / \mathrm{m}^{3}\right)$, da radiação solar $\left(\mathrm{W} / \mathrm{m}^{2}\right)$ e cobertura de nuvens (\%), para a RMSP, de 1996-2005. Destacam-se os meses de outubro (máximo do ano, em vermelho), junho (mínimo, em azul) e fevereiro (máximo secundário).

Pode-se perceber por esta figura que os ciclos sazonais de radiação solar incidente e da cobertura de nuvens influenciam, de forma visível, o ciclo sazonal do ozônio troposférico. O coeficiente de correlação linear de Pearson entre os valores médio mensais de ozônio e da radiação solar (1996-2005), é igual a 0,98 e entre ozônio e cobertura de nuvens, é igual a -0,6. Percebe-se na figura 42 que, conforme a quantidade de radiação solar recebida aumenta e a cobertura de nuvens diminui, aumentam as condições propícias para a formação de ozônio em superfície. A maior diferença entre a radiação solar e a cobertura de nuvens ocorre nos meses de agosto, setembro e outubro, quando se nota um significativo incremento na concentração média de ozônio. No entanto, a partir de novembro, como a cobertura de nuvens aumenta, esta diferença volta a cair, implicando assim numa redução das concentrações médias do poluente. Contudo, nos meses de verão são registrados episódios com alta concentração, como é o caso do mês de fevereiro que acusa um máximo secundário da concentração do poluente. A partir do mês de maio, entretanto, as concentrações caem com a queda de radiação solar, mesmo com 
baixa cobertura de nuvens. A correlação entre o ozônio e outras variáveis atmosféricas não é tão expressiva nesta escala de análise.

Apesar deste comportamento sazonal ser observado na média, nem todas as estações da rede de monitoramento demonstram este ciclo sazonal em suas concentrações anuais. Além da variabilidade anual do ciclo sazonal, as condições de cada localidade são fundamentais para definir a concentração de $\mathrm{O}_{3}$. As figuras $43 a$ a $43 f$ evidenciam o ciclo sazonal de cada estação em cada ano de registros e sua média temporal. 

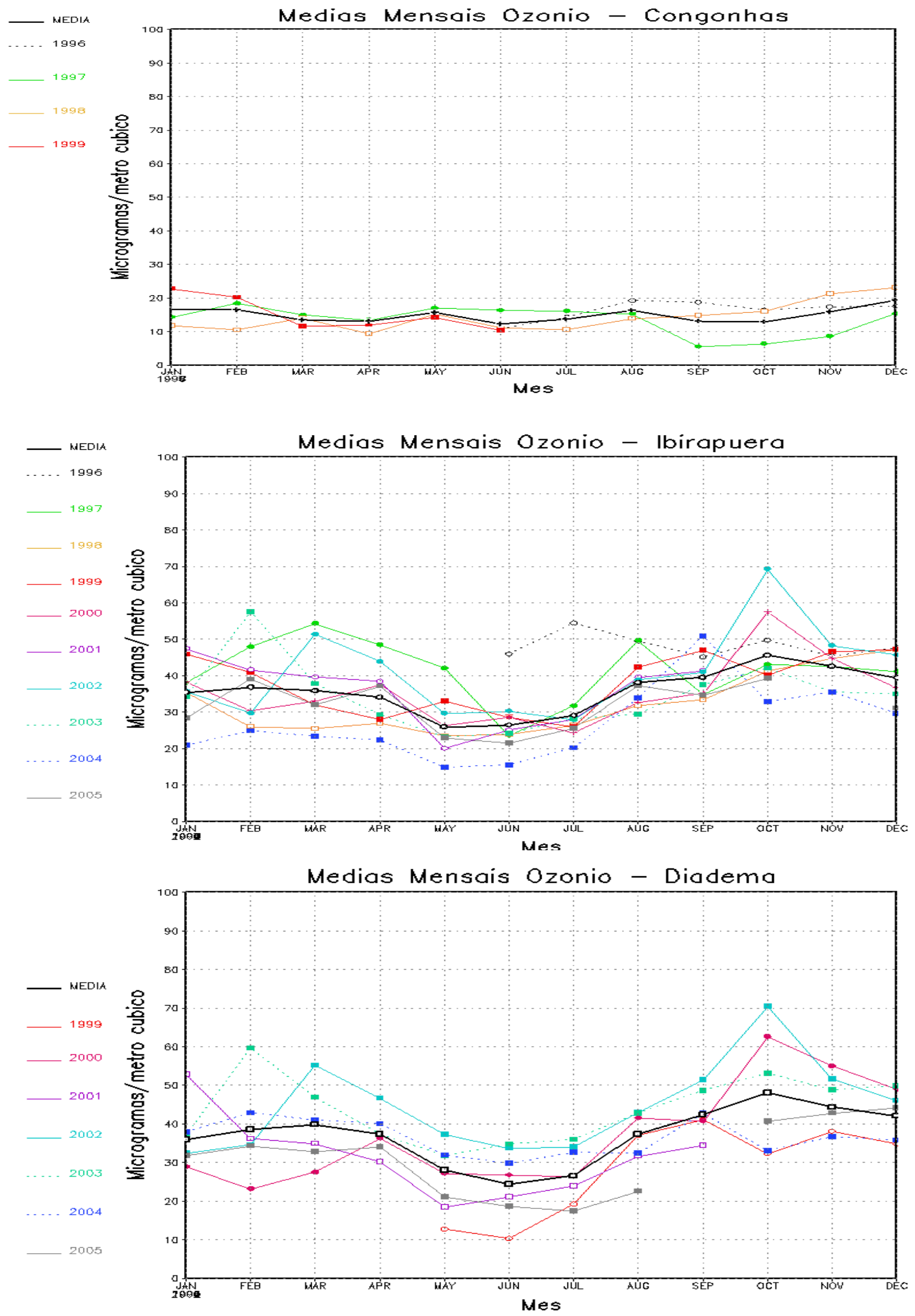

Figura 43a: Ciclo sazonal da concentração mensal de ozônio, em cada ano, para cada estação apresentada. 

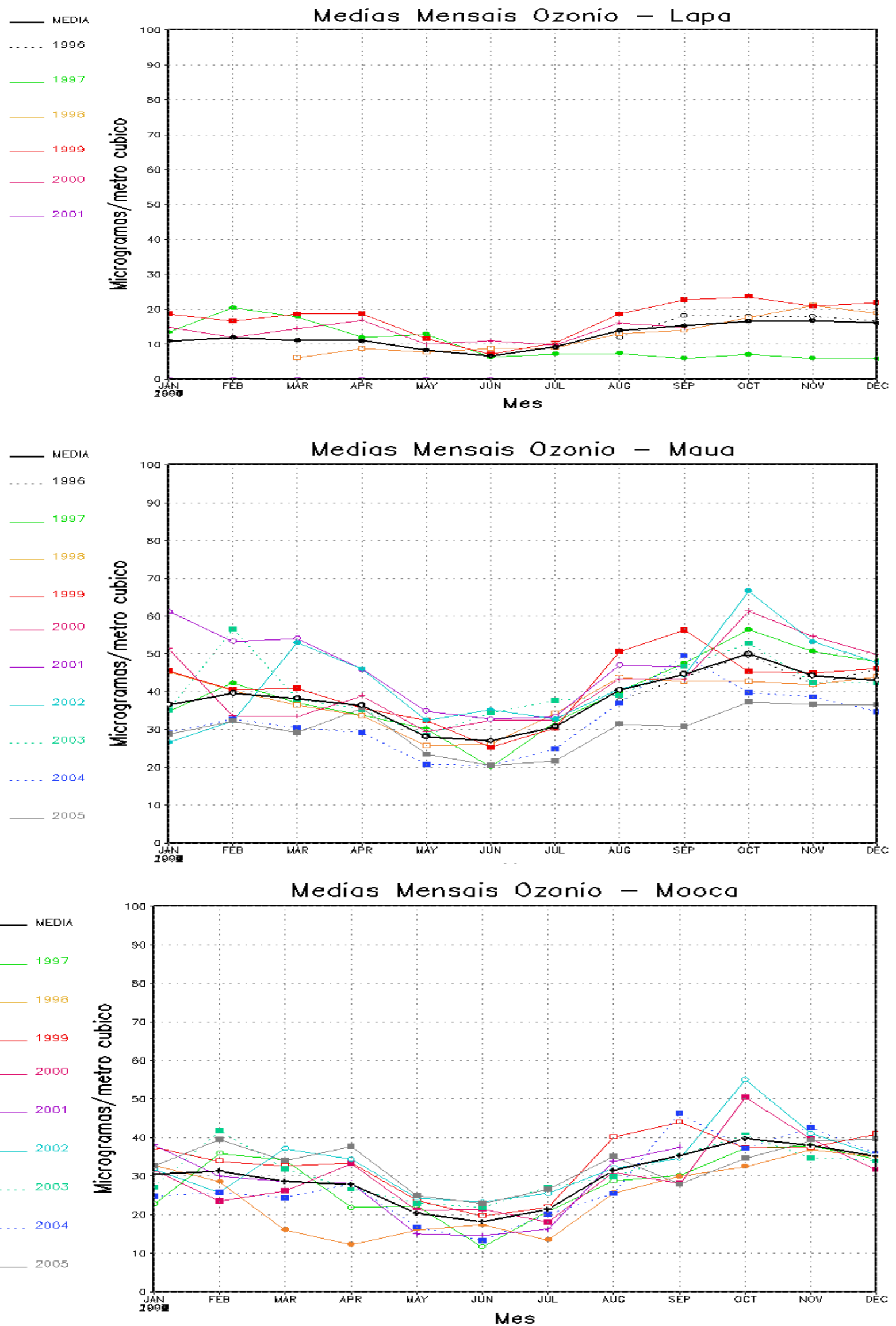

Figura 43b: Ciclo sazonal da concentração mensal de ozônio, em cada ano, para cada estação apresentada. 


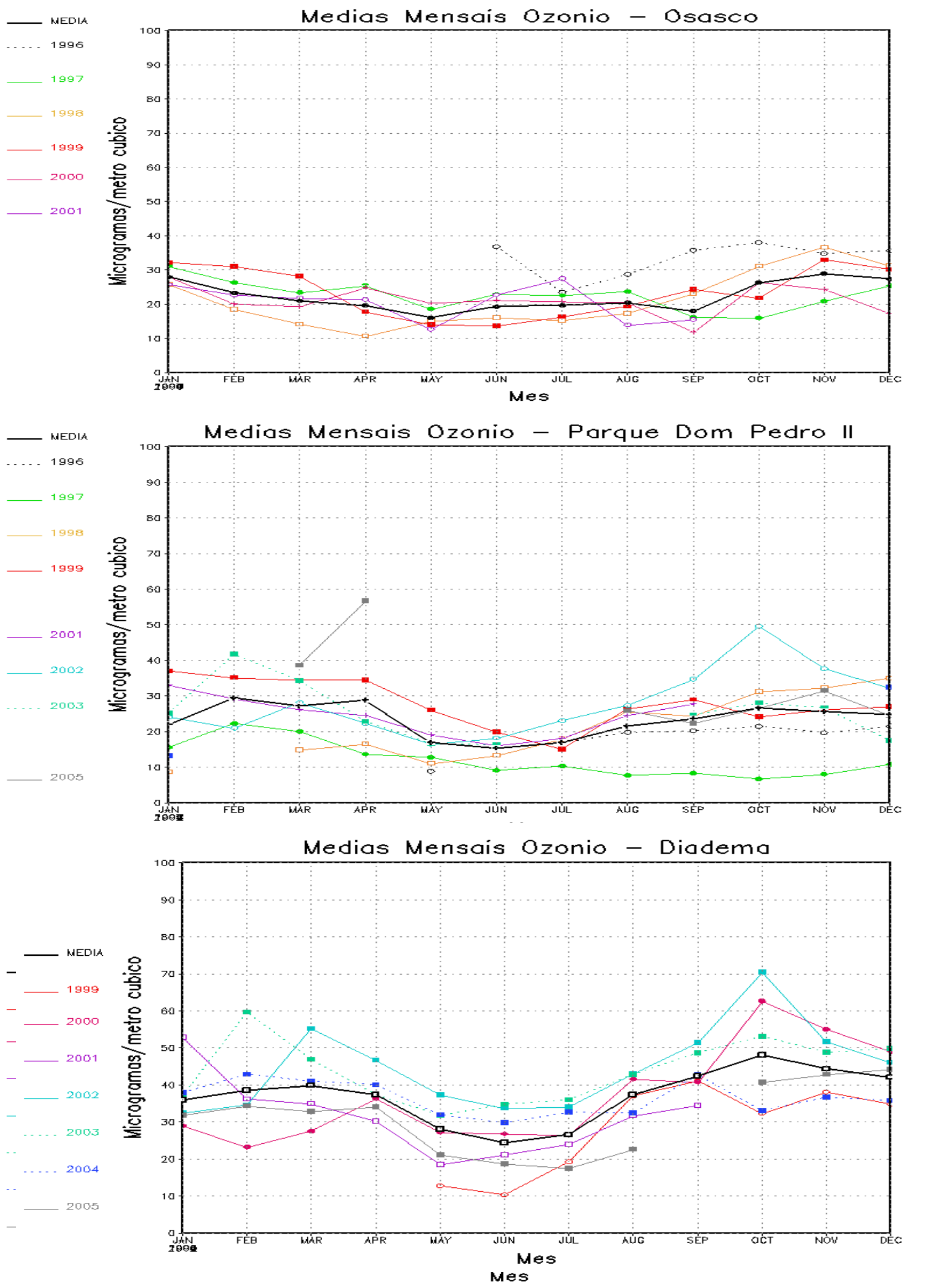

Figura 43c: Ciclo sazonal da concentração mensal de ozônio, em cada ano, para cada estação apresentada. 

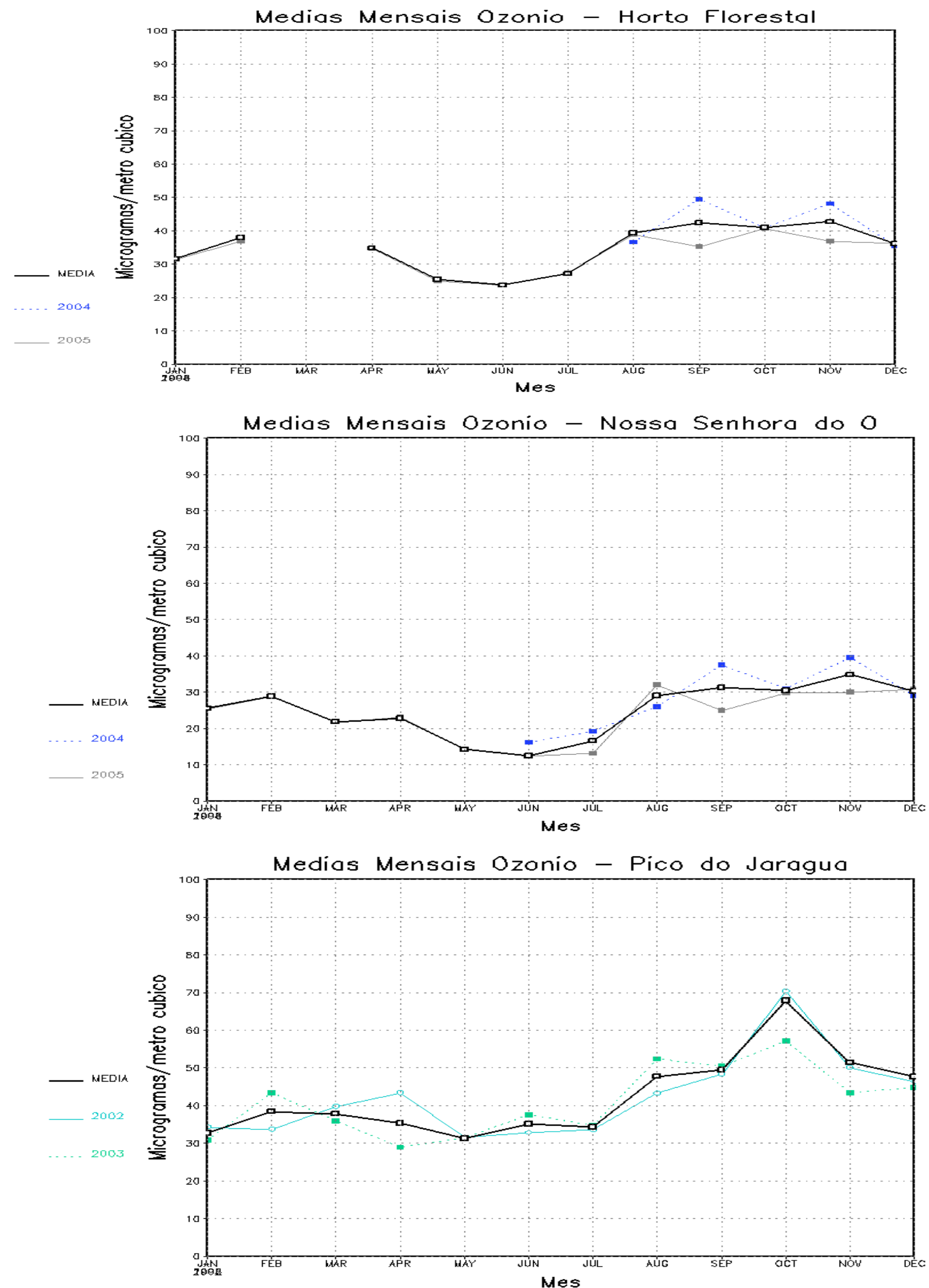

Figura 43d: Ciclo sazonal da concentração mensal de ozônio, em cada ano, para cada estação apresentada . 

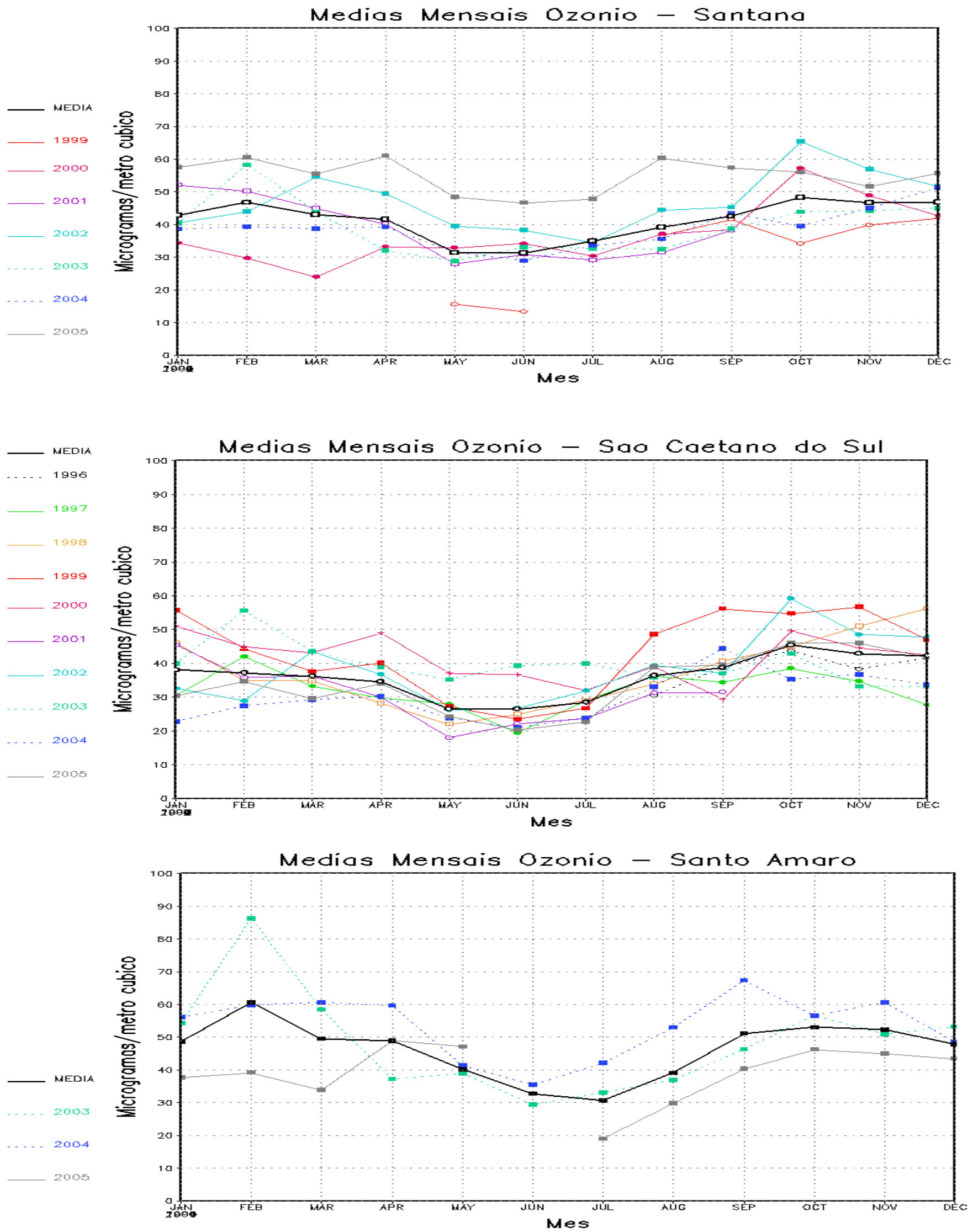

Figura 43e: Ciclo sazonal da concentração mensal de ozônio, em cada ano, para cada estação apresentada. 
Figura 43f: Ciclo sazonal da concentração mensal de ozônio, em cada ano, para cada estação apresentada.

Os dados da figuras $43 \mathrm{a}$ à $43 \mathrm{f}$ foram organizados de maneira a facilitar a leitura do ciclo sazonal de ozônio. Todos os anos de monitoramento das estações

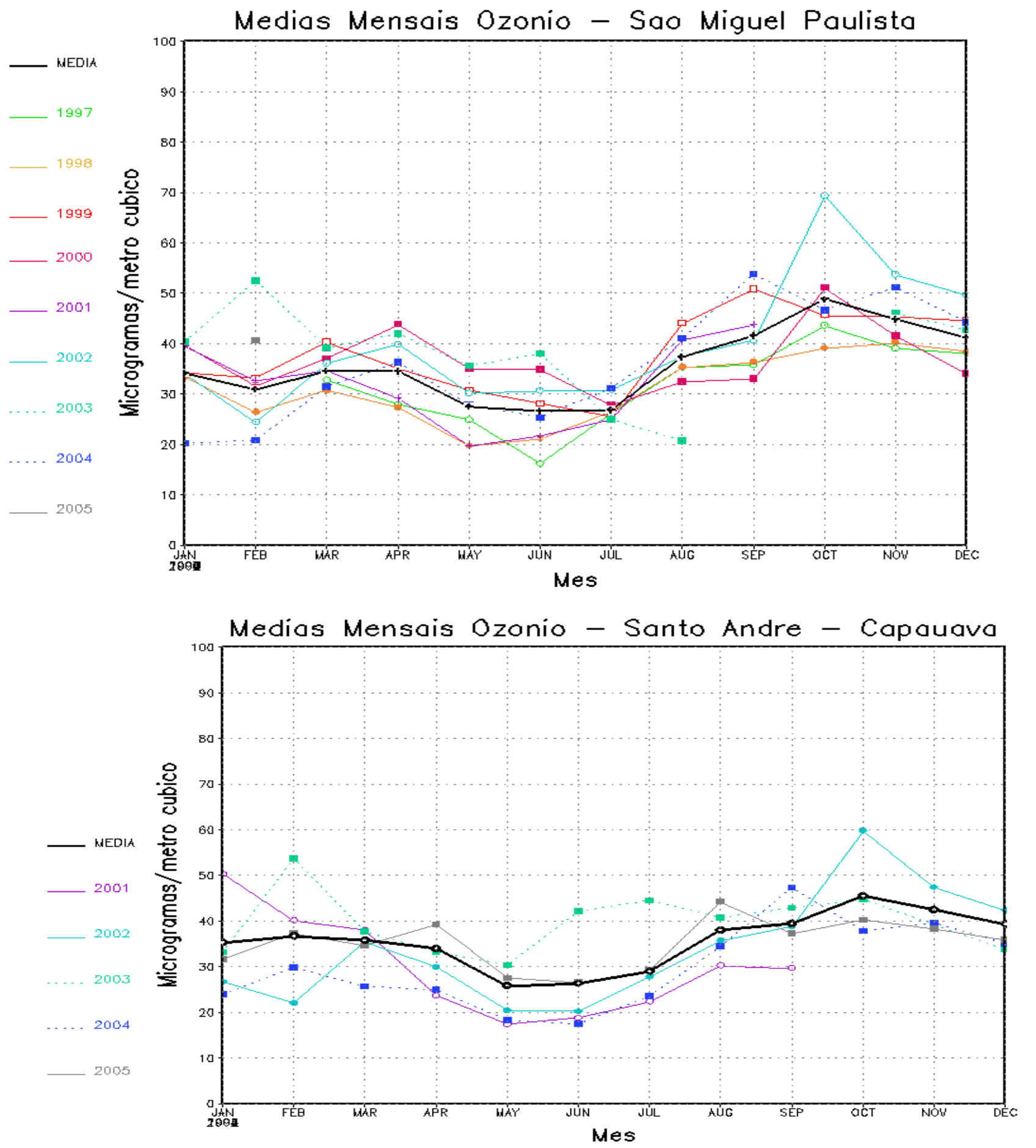

são representados sempre da mesma cor, em todas as figuras. A média da referida 
estação é representada na linha contínua de cor preta e mais espessa. Em primeira aproximação, pode-se perceber, na maioria das estações, os mínimos de junho e os máximos de outubro e fevereiro já mencionados anteriormente, principalmente quando se analisa os valores médios (curva preta), que eliminam a variabilidade interanual. Esta forma de representação também é bastante conveniente para se perceber as diferenças de concentração entre os diferentes meses e diferentes anos, além das diferenças entre as estações, já que todos os gráficos estão na mesma escala.

A análise interanual da concentração de $\mathrm{O}_{3}$ na RMSP evidencia que o ano de 2002 (curva azul clara) é um ano com valores mais altos (figuras 43a a 43f). Ocorre um máximo da concentração de $\mathrm{O}_{3}$ no mês de outubro deste ano, em todas as estações em que houve monitoramento. Outros meses relevantes são: março de 2003 (curva verde-água pontilhada), em que se destaca em todas as estações, setembro de 2004 (curva azul-escuro pontilhada), com valores altos na maioria das estações, bem como janeiro de 2001 (curva roxa) e março de 2002 (curva azulclaro). Alguns meses que apresentam concentrações mais baixas são abril de 1998 e alguns meses do segundo semestre de 1997 e o ano de 2004, de forma geral. No entanto, estes meses de concentração mais baixa não apresentam a mesma uniformidade de ocorrência espacial, em comparação aos meses de concentrações mais altas. Alguns destes meses são mais bem explorados nas seções seguintes, em que se investiga a associação de padrões atmosféricos às concentrações extremas de ozônio.

Com relação ao ciclo sazonal, outras observações podem ser feitas com base na figuras apresentadas. O ciclo sazonal não varia apenas de acordo com o ano, mas também de acordo com a estação considerada. Ou seja, existe uma variabilidade temporal e espacial do ciclo sazonal. Adicionalmente, é possível verificar que nem todas as estações representam o ciclo sazonal de maneira bem definida, com mínimos em junho e máximos em outubro e fevereiro tal como pode ser observado nas estações Congonhas, Lapa e Osasco.

Na estação Congonhas, nos anos de 1997 e 1998, os valores máximos de concentração ocorrem nos meses de fevereiro e dezembro, respectivamente. Os 
anos de 1996 e 1999, em Congonhas, não possuem dados suficientes para essa verificação. Na estação Lapa, somente os anos de 1999 e 2000 apresentam um ciclo sazonal mais bem definido. Em 1997, a maior média ocorre em fevereiro e, a partir daí, as concentrações decrescem até atingirem um valor mínimo em junho, que é repetido em setembro e novembro; em 1998, a maior média mensal ocorre em dezembro. A estação Osasco mostra o ciclo sazonal de maneira mais bem definida somente em 1999; no ano de 1997, o valor médio das concentrações no trimestre junho-agosto é maior do que o do trimestre seguinte, setembro-novembro. Em 1998, as menores médias ocorrem em março e abril, já em 2000 e 2001, o comportamento sazonal médio de ozônio é mais variável. Por exemplo, em 2001, a maior média mensal ocorre em julho. Nas estações Parque Dom Pedro II e Pinheiros, o ciclo sazonal médio também não aparece de maneira bem definida, a não ser no ano de 2002. Na estação Parque D. Pedro II a análise dos anos de 1996 e 2005 fica comprometida devido a pouca disponibilidade de dados e, na estação Pinheiros, este mesmo fato ocorre nos anos de 1999 e 2003.

A situação é significativamente diferente em outras estações de monitoramento de ozônio. Por exemplo, na estação Ibirapuera, o ciclo sazonal é bem definido na maioria dos anos, exceto em 1997, quando as médias do período fevereiro-maio são mais altas do que no trimestre compreendido entre setembro e novembro e em 1998, pois nesse ano as concentrações mais altas ocorrem a partir de agosto, sem a presença do máximo secundário no primeiro semestre. Em São Miguel Paulista e Santo André-Capuava o ciclo sazonal também é bem definido em praticamente todos os anos. Somente em 2003, em ambas as estações, a média mensal de fevereiro foi a mais alta do ano, como já mencionado anteriormente. Nas estações Horto Florestal e Nossa Senhora do Ó, há poucos dados disponíveis para se avaliar a boa definição do ciclo sazonal. No Horto Florestal, o máximo de 50 $\mu \mathrm{g} / \mathrm{m} 3$ ocorre em setembro de 2004, sugerindo que este ano apresentou um dos setembros mais poluídos da série, tal como pode ser verificado no ciclo sazonal da outras estações, inclusive em Nossa Senhora do Ó. As estações Mooca e Santo André-Capuava refletem de maneira clara o ciclo sazonal. Exceto em 1998, pela estação Mooca, cujo trimestre compreendido entre os meses maio, junho e julho apresentou concentração de $\mathrm{O}_{3}$ mais alta do que os meses de março e abril e, em 2003, pela estação Santo André que apresentou maiores médias nos meses de 
fevereiro, julho e outubro. Observa-se claramente os picos de concentração de $\mathrm{O}_{3}$ em setembro de 2004 e outubro de 2002, em ambas as estações.

Nas estação Diadema o ciclo sazonal é bem representado em todos os anos. Nas estações Santo Amaro e Pico do Jaraguá há poucos dados para boa representação do ciclo sazonal médio em si, mas pode-se notar os já citados meses de fevereiro de 2003 e outubro de 2002. Na estação Santana, o ciclo sazonal é bem definido também na maioria dos anos, exceto em 2000, quando a concentração média de junho é mais alta do que as verificadas em diversos meses anteriores, inclusive em fevereiro de 2003. Em Mauá, diversos máximos apontados anteriormente em outras estações se confirmam nesta estação, tais como outubro de 2002, setembro de 2004, fevereiro de 2003, março de 2002 e janeiro de 2001.

Para a parte final desta análise, dividiu-se as estações entre um grupo com ciclo sazonal médio bem definido e influenciado pela radiação solar (figura 44), e outro com ciclo sazonal médio diferente (45). As figuras 44 e 45 resumem o que foi descrito anteriormente sobre o ciclo sazonal médio, sobre sua variabilidade espacial e representatividade de um ciclo sazonal bem definido.

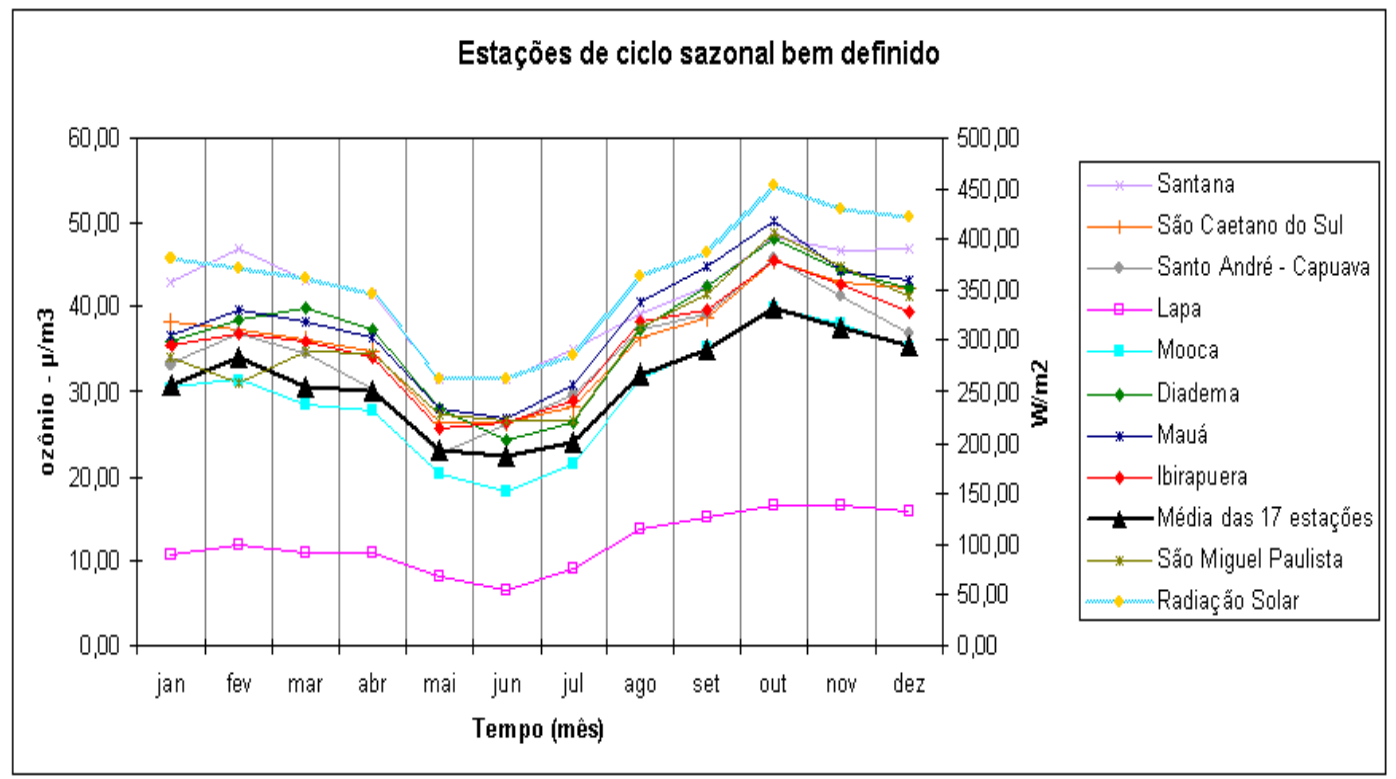

Figura 44: Comportamento sazonal médio da radiação solar na RMSP $\left(\mathrm{W} / \mathrm{m}^{2}\right)$ (curva azul com losangos em laranja) e da concentração de $\mathrm{O}_{3}$ para as estações da RMSP com ciclo sazonal bem definido. 
Verifica-se que nove estações representam bem o ciclo sazonal médio: Ibirapuera, São Caetano do Sul, Mooca, Santana, Diadema, São Miguel Paulista, Santo André-Capuava, Lapa e Mauá. Praticamente todas apresentam valor médio mensal superior à média das 17 estações, exceto a estação Lapa, com concentrações bem mais baixas do que a média e a estação Mooca, que apresenta valores muito similares à média. Nota-se que o ciclo médio de radiação solar no decorrer do ano exerce significativa influência no comportamento sazonal da concentração de ozônio nestas estações. Como já descrito anteriormente, há uma alta correlação entre o ciclo sazonal médio do ozônio e a radiação solar, mas nem todas as estações seguem este padrão. Algumas estações apresentam um ciclo diferente do padrão da maioria das estações. O ciclo sazonal médio das estações Pinheiros, Parque D. Pedro II, Osasco e Congonhas, diferentemente das demais estações, não apresentam o mesmo grau de correlação com a radiação solar na escala mensal, tal como mostrado na figura 45.

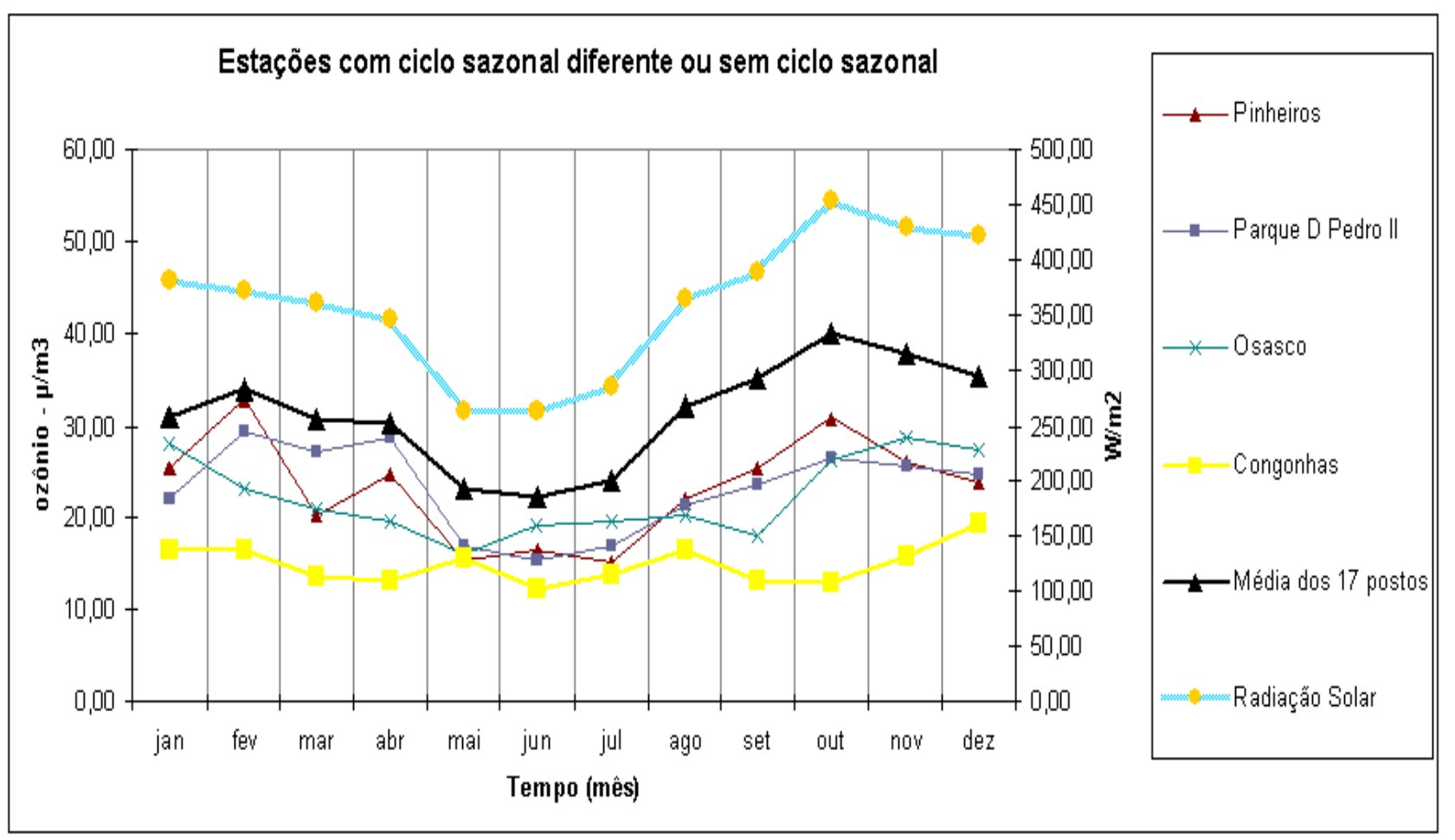

Figura 45: Comportamento sazonal médio da radiação solar na RMSP $\left(\mathrm{W} / \mathrm{m}^{2}\right)$ (curva azul com losangos em laranja) e da concentração de $\mathrm{O}_{3}$ para as estações da RMSP com ciclo sazonal diferente.

Estas estações apresentam um ciclo sazonal ligeiramente diferente (Pinheiros) ou completamente distintos (Congonhas) do ciclo médio sazonal da média das 17 
estações da RMSP. O ciclo sazonal médio das estações Horto Florestal, Santo Amaro, Pico do Jaraguá e Nossa Senhora do Ó não foram incluídos nestes gráficos, pois apresentam menos de três anos de dados e foram considerados estatisticamente inapropriados, sendo necessárias séries mais longas para se poder analisá-los.

Possíveis razões para o comportamento diferenciado da concentração de $\mathrm{O}_{3}$ em estações específicas, tal como apresentado nas figuras 43.a a 45, são apresentadas e discutidas na seção 3.1.4. 


\subsubsection{Médias diárias}

A análise das médias diárias da concentração de ozônio nos permite conhecer com maior profundidade a variabilidade temporal dos dados de cada estação de medição. Nas figuras de 46 a 49c verifica-se visualmente a freqüência de dados válidos e faltantes na escala horária. Optou-se por demonstrar as séries temporais completas, cujos períodos variam de acordo com a estação, conforme indicado na tabela 10. Isto resulta em 365 ou 366 dados por ano, incluindo valores válidos e inválidos (estes últimos representando dados inválidos ou faltantes). Esta maneira de representação permite a visualização da variabilidade diária e da quantidade de dados inválidos em diferentes períodos, bem como a identificação de longos períodos sem dados.

Nas análises dos dados nas escalas anual e mensal, as estações medidoras de ozônio foram classificadas conforme o valor médio da concentração do poluente ou de acordo com sua tendência e representação do ciclo sazonal, respectivamente. $\mathrm{Na}$ análise dos dados em escala diária, propõe-se verificar a diferença de variabilidade entre as estações e a existência de dados faltantes e inválidos. $O$ primeiro aspecto analisado foi o desvio padrão diário, como pode ser visto na figura 46. 


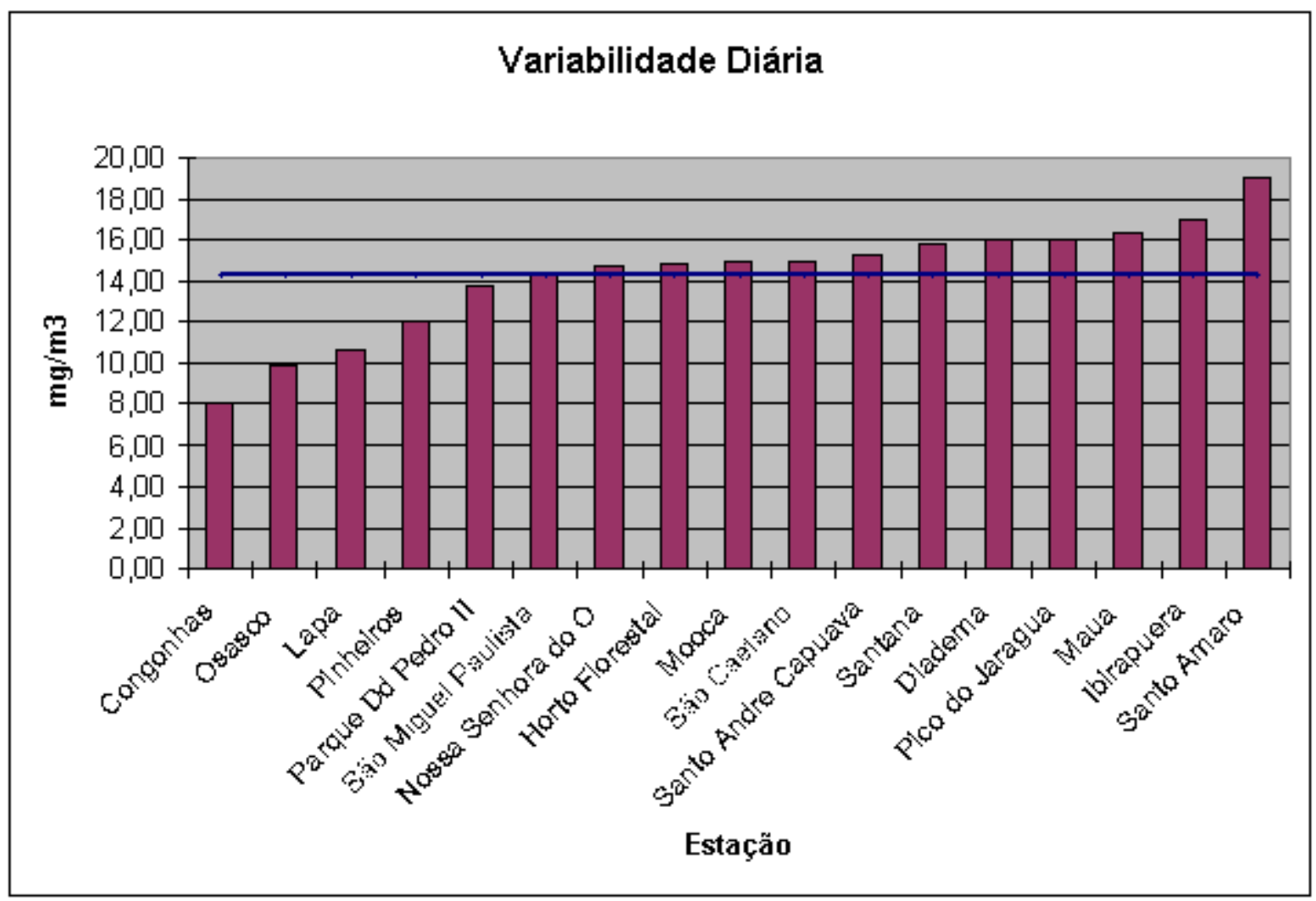

Figura 46: Desvio padrão da concentração média diária de $\mathrm{O}_{3}$ para cada estação de monitoramento da RMSP. O valor médio igual a $14,30 \mu \mathrm{g} / \mathrm{m}^{3}$ está indicado pela linha.

Os dados das estações refletem de maneira mais clara diferentes graus de variabilidade diária. Pode-se notar que a estação Congonhas é a que demonstra menor variabilidade, enquanto que Santo Amaro é a estação em que a concentração de ozônio tem maior variabilidade na escala diária. A estação Mooca ocupa uma posição mediana. Na escala anual, a estação Congonhas apresenta a segunda menor concentração e a estação Santo Amaro, a maior. A estação Mooca também está numa posição intermediária no que diz respeito à média anual. Assim, por meio dos dados da tabela 13 (seção 3.1.1) e da tabela 15 apresentada abaixo, pode-se pensar que a maior parte das estações com baixa variabilidade também apresenta baixa concentração média. 
Tabela 15: Divisão das estações de monitoramento de acordo com o desvio padrão médio da concentração diária de $\mathrm{O}_{3}$ na RMSP.

\begin{tabular}{|l|l|}
\hline Estação & $\begin{array}{l}\text { Desvio padrão } \\
\text { diário }\end{array}$ \\
\hline Congonhas & 8,01 \\
\hline Osasco & 9,81 \\
\hline Lapa & 10,59 \\
\hline Pinheiros & 11,97 \\
\hline Parque D. Pedro II & 13,72 \\
\hline São Miguel Paulista & 14,35 \\
\hline Nossa Senhora do Ó & 14,74 \\
\hline Horto Florestal & 14,77 \\
\hline Mooca & 14,87 \\
\hline São Caetano do Sul & 14,97 \\
\hline Santo André - Capuava & $\mathbf{1 5 , 2 7}$ \\
\hline Santana & $\mathbf{1 5 , 8 0}$ \\
\hline Diadema & $\mathbf{1 5 , 9 7}$ \\
\hline Pico do Jaraguá & $\mathbf{1 5 , 9 9}$ \\
\hline Mauá & $\mathbf{1 6 , 3 3}$ \\
\hline Ibirapuera & $\mathbf{1 7 , 0 2}$ \\
\hline Santo Amaro & \\
\hline & $\mathbf{1 9}, 00$ \\
\hline
\end{tabular}

As estações de monitoramento podem ser agrupadas quanto ao valor do desvio padrão calculado com base na concentração média diária de $\mathrm{O}_{3}$ em estações com baixa variabilidade, cujo desvio padrão de cada estação é inferior à média espacial (cor verde na tabela 15), em estações com variabilidade mediana, cujo desvio padrão apresenta valor próximo da média (cor vermelha na tabela 15) e em estações com alta variabilidade, cujo desvio padrão apresenta valores significativamente superiores à média espacial (cor marrom na tabela 15).

Proporcionalmente ao volume de dados em cada estação, Parque D. Pedro II é a que apresenta o maior número de dados faltantes dentre as estações com variabilidade diária baixa, tal como visto na figura 47b. O valor do dado faltante (em azul na figura) varia entre 0 e 24, de acordo com o número de horas inválidas para um determinado dia. 


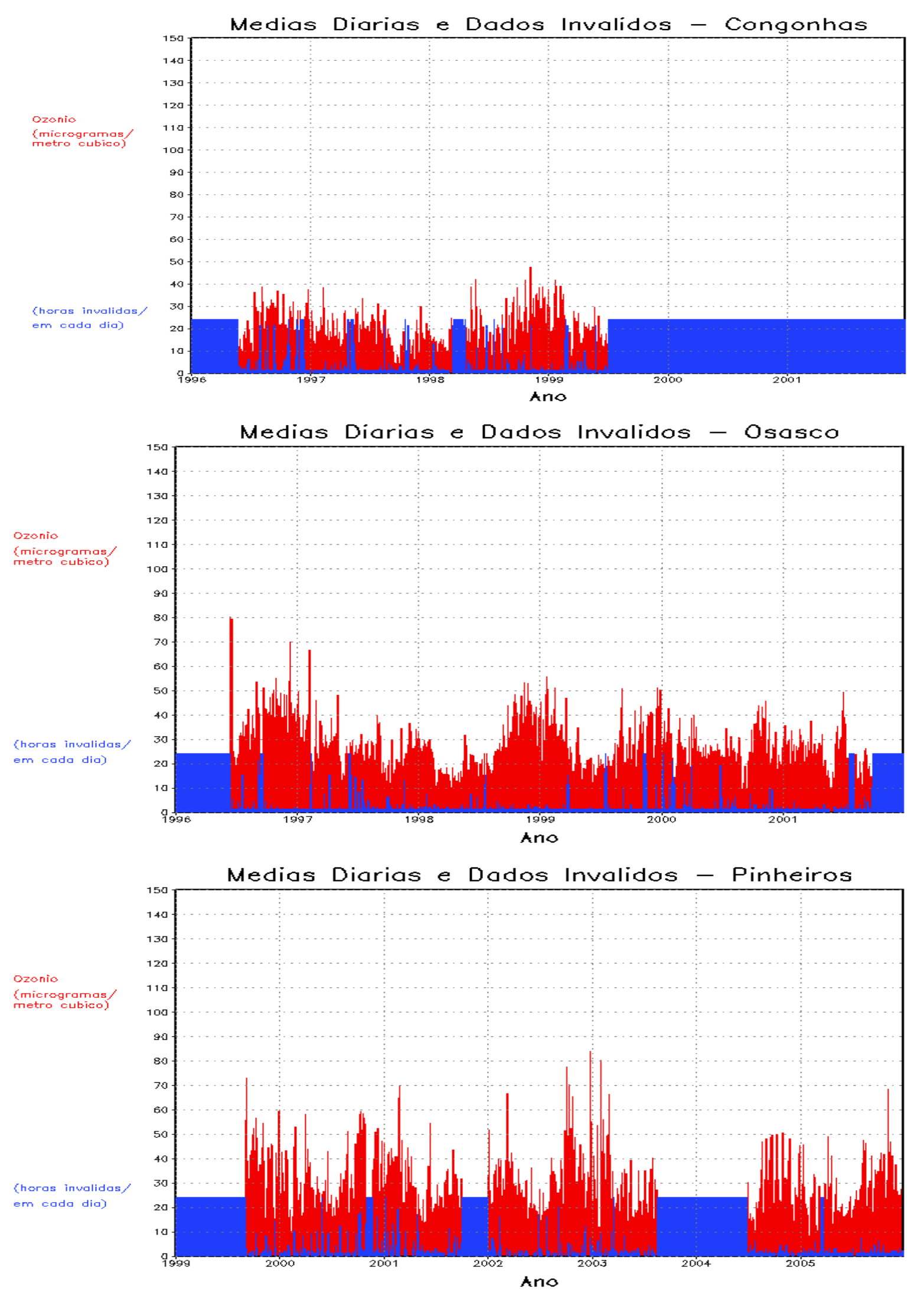

Figura 47a: Concentração média diária de $\mathrm{O}_{3}$ para as estações com baixa variabilidade. Os dados inválidos ou faltantes estão indicados em cor azul. 

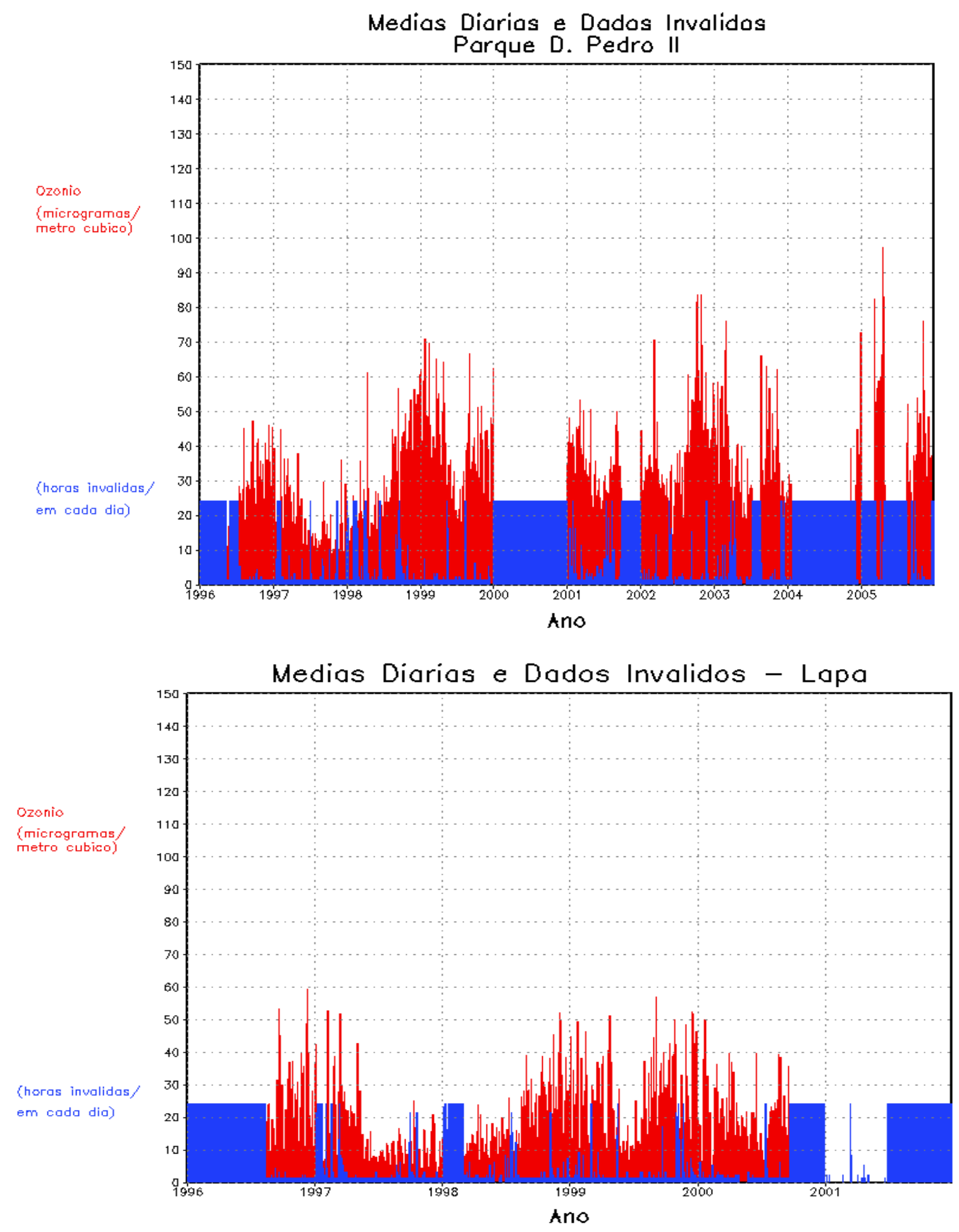

Figura 47b: Concentração média diária de $\mathrm{O}_{3}$ para as estações com baixa variabilidade. Os dados inválidos ou faltantes estão indicados em cor azul.

A estação Congonhas não apresenta nenhum dado válido a partir de meados de 1999, mas sua série temporal vai até 2001, quando a estação é desativada (CETESB, 2001). O mesmo ocorre com a estação Lapa, que a partir do final do ano de 2000 também não apresenta mais dados válidos. A estação Parque D. Pedro II 
também conta com quantidade significativa de dados inválidos, principalmente nos anos de 2000, 2004 e 2005. Dentre estas estações, as que apresentam melhor qualidade dos dados são Osasco e Pinheiros, em especial a estação Osasco, pois existe considerável quantidade de dados inválidos em Pinheiros, principalmente nos anos de 1999, 2003 e 2004.

Em relação à variabilidade diária, as concentrações máximas raramente ultrapassam $80 \mu \mathrm{g} / \mathrm{m}^{3}$ (figuras $47 \mathrm{a}$ e 47b), exceto pela estação Parque Dom Pedro II, ao final de sua série temporal, que apresenta alguns valores próximos a $100 \mu \mathrm{g} / \mathrm{m}^{3}$. De fato, esta estação possui maior variabilidade do que as outras deste grupo, com desvio padrão igual a $13,72 \mu \mathrm{g} / \mathrm{m}^{3}$ (tabela 15). Na análise de médias mensais, observa-se que esta estação apresenta uma das maiores tendências de elevação na série temporal de 1996 a 2005. No entanto, a grande presença de dados inválidos no final da série desta estação (figura 47b) compromete uma melhor avaliação desta tendência.

As estações classificadas como de variabilidade mediana foram: Horto Florestal, São Miguel Paulista, São Caetano do Sul, Mooca, Nossa Senhora do Ó. Dentre elas nota-se uma presença menor de dados inválidos (figuras 48a e 48b) em relação às estações de baixa variabilidade (figuras 47a e 47b), exceto pela estação Nossa Senhora do Ó e Horto Florestal, cujos períodos de medição se iniciam em janeiro de 2004, mas que só passam a ter dados válidos a partir de julho (Nossa Senhora do Ó) ou setembro (Horto Florestal) deste mesmo ano. 

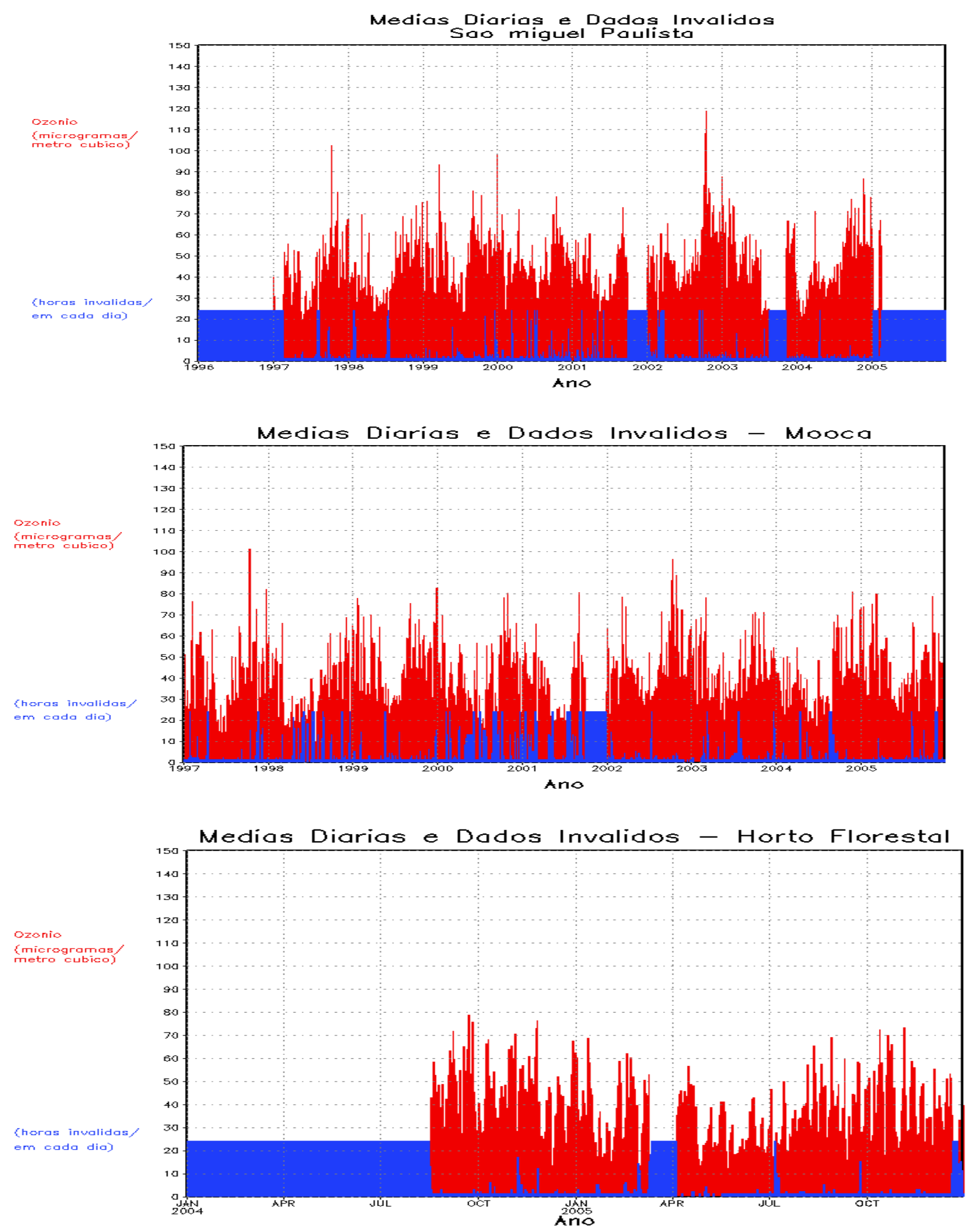

Figura 48a: Concentração média diária de $\mathrm{O}_{3}$ para as estações com variabilidade mediana. Os dados inválidos ou faltantes estão indicados em cor azul. 


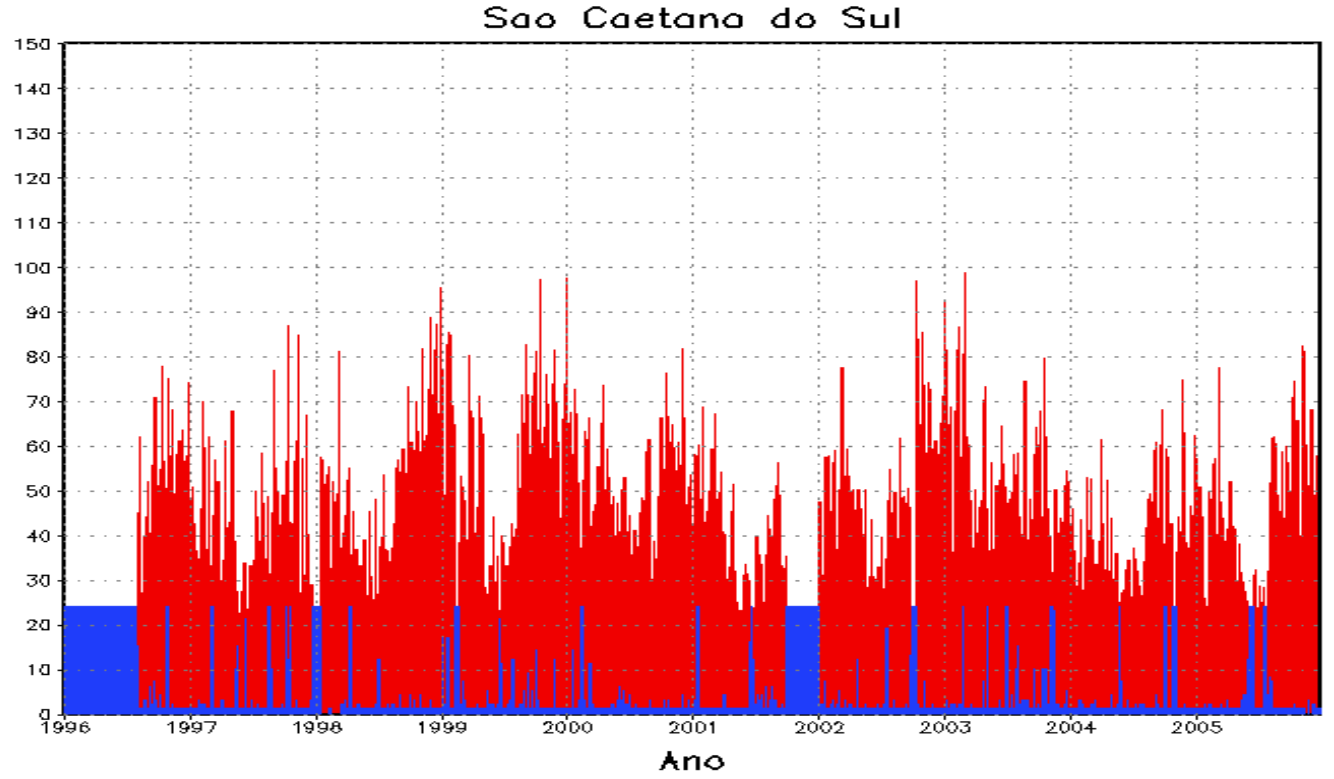

Medias Diarias e Dadas Invalidas

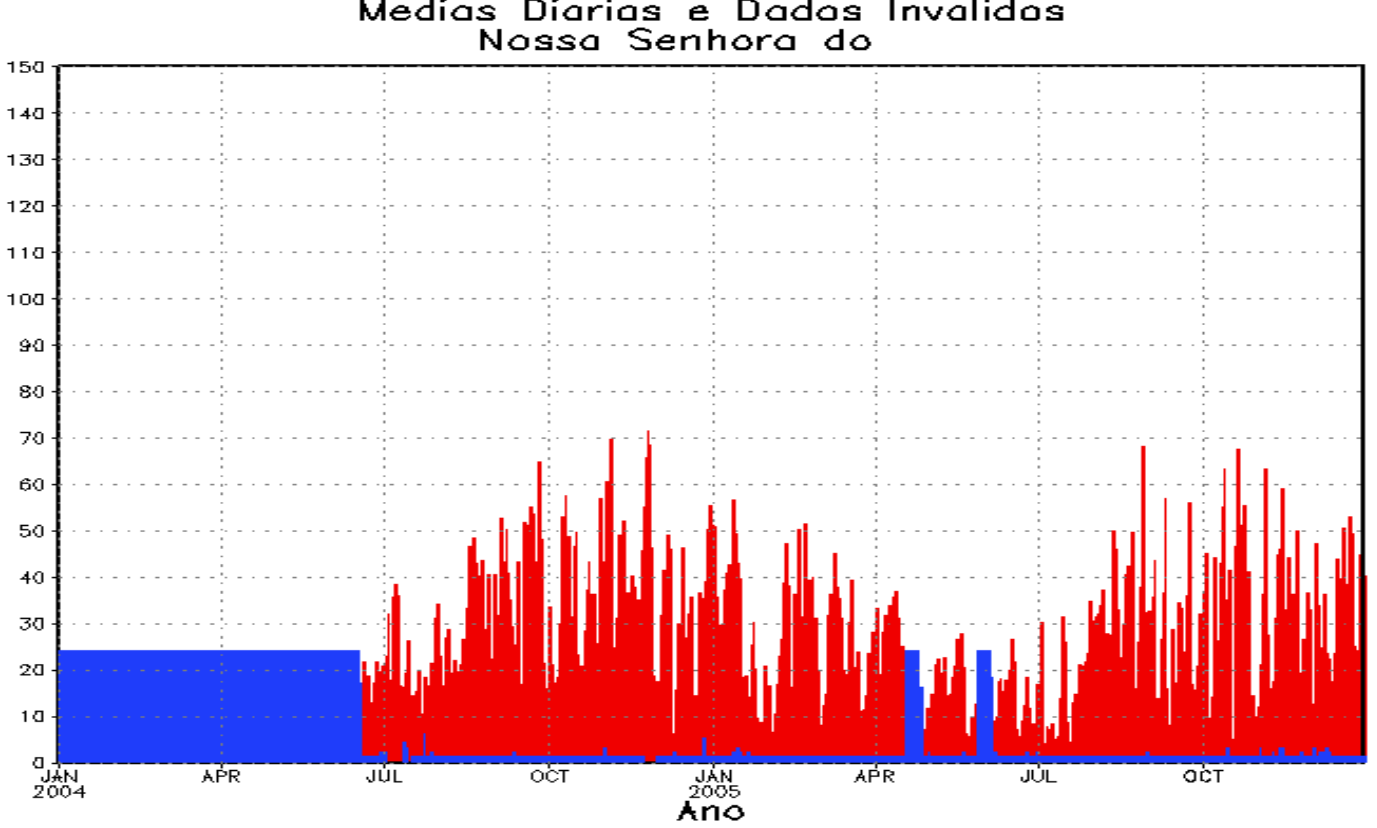

Figura 48b: Concentração média diária de $\mathrm{O}_{3}$ para as estações com variabilidade mediana. Os dados inválidos ou faltantes estão indicados em cor azul.

De qualquer maneira, nota-se a presença de mais dados inválidos no início ou final das séries temporais. Embora a estação Horto Florestal apresente valores máximos diários em torno de $70 \mu \mathrm{g} / \mathrm{m}^{3}$, as outras estações deste grupo contam com diversos valores entre 80 e $100 \mu \mathrm{g} / \mathrm{m}^{3}$, com máximos em torno de $120 \mu \mathrm{g} / \mathrm{m}^{3}$, na estação São Miguel Paulista, em outubro de 2002 (48a).

As estações Santo André-Capuava, Ibirapuera, Mauá, Diadema, Santo Amaro, Santana e Pico do Jaraguá foram classificadas como as que apresentam as maiores variabilidades na concentração diária de ozônio (figuras 49a, 49b e 49c): 

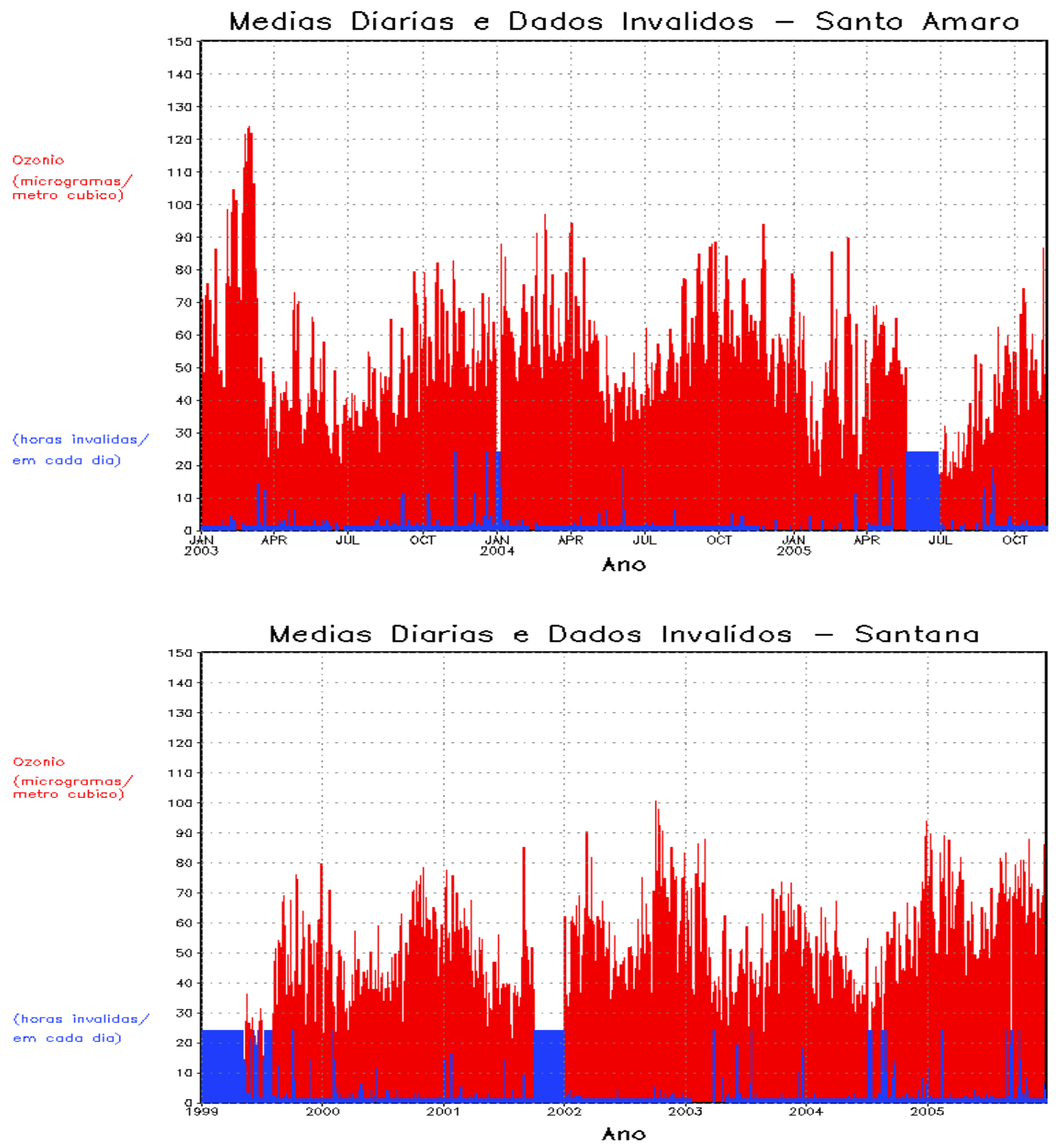

Figura 49a: Concentração média diária de $\mathrm{O}_{3}$ para as estações com alta variabilidade. Os dados inválidos ou faltantes estão indicados em cor azul. 

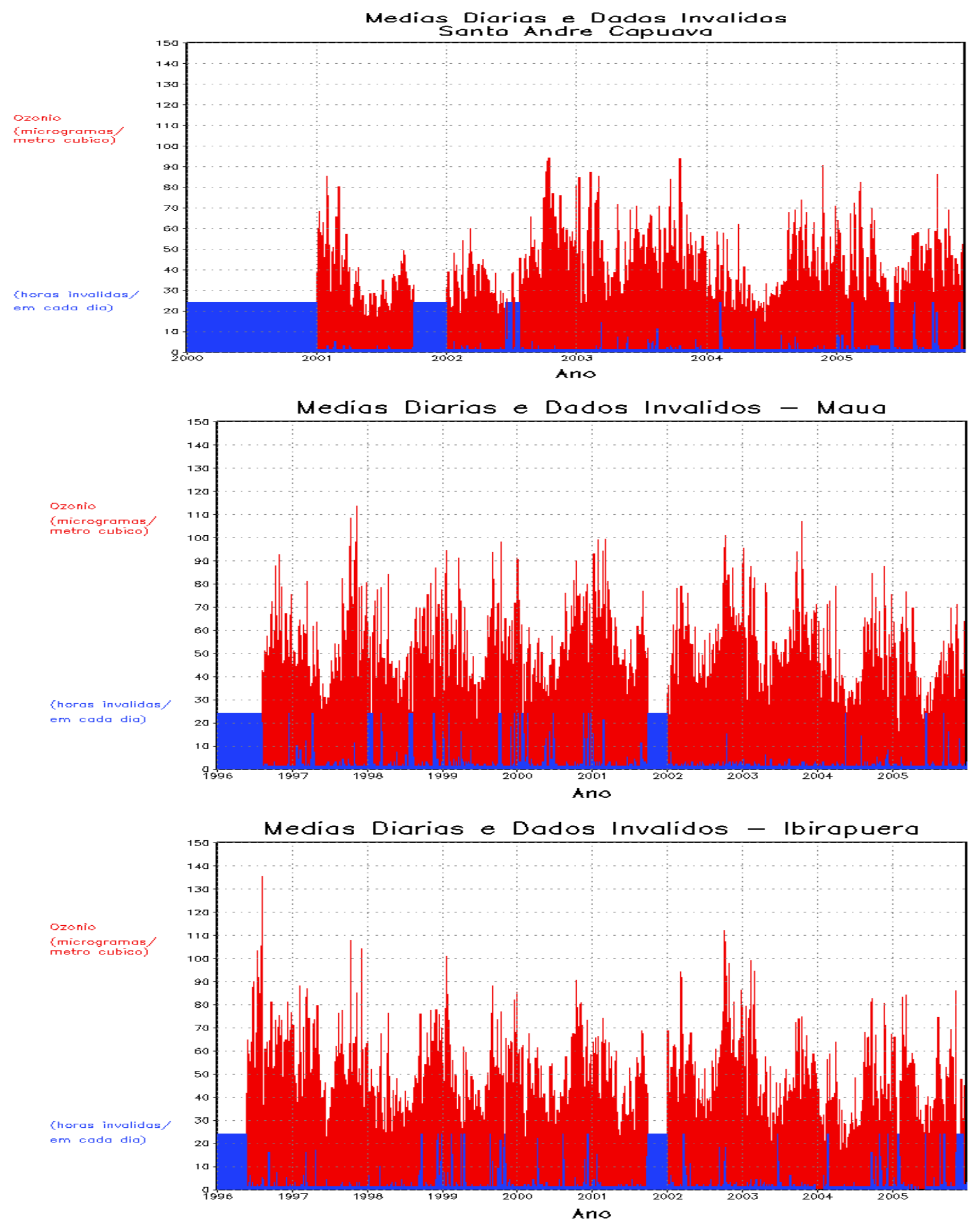

Figura 49b: Concentração média diária de $\mathrm{O}_{3}$ para as estações com alta variabilidade. Os dados inválidos ou faltantes estão indicados em cor azul. 

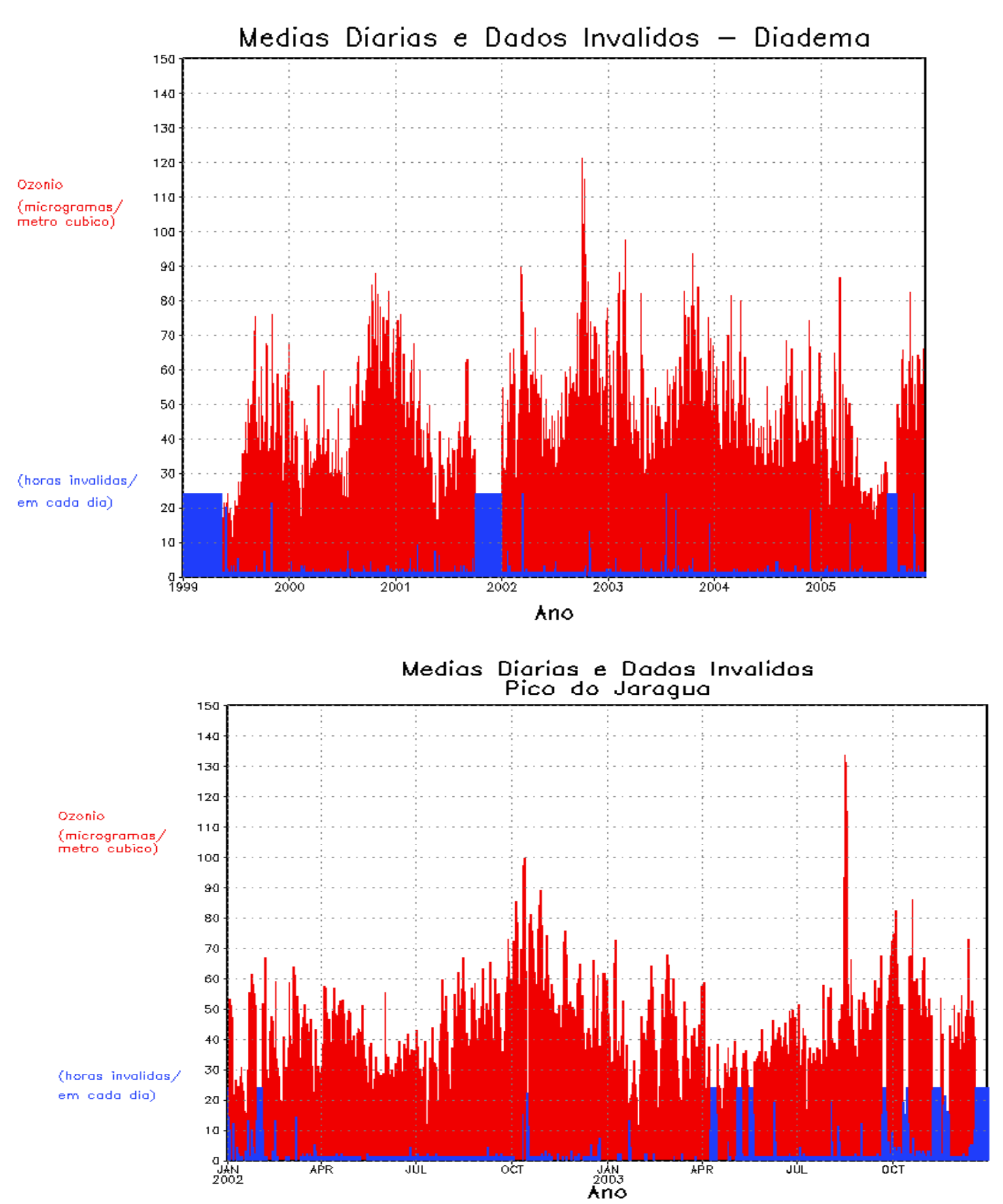

Figura 49c: Concentração média diária de $\mathrm{O}_{3}$ para as estações com alta variabilidade. Os dados inválidos ou faltantes estão indicados em cor azul.

Em relação às concentrações das estações do grupo com alta variabilidade, os episódios de maior concentração de ozônio ultrapassam $100 \mu \mathrm{g} / \mathrm{m}^{3}$ em Mauá e Santana, chegando a valores diários maiores do que $120 \mu \mathrm{g} / \mathrm{m}^{3}$ na estação Diadema em 2002 e Santo Amaro, em 2003. Nota-se que a estação Ibirapuera também apresenta um pico de $130 \mu \mathrm{g} / \mathrm{m}^{3}$ no início da série (em 1996), cujo valor é similar ao das estações Diadema (outubro/2002), Pico do Jaraguá (setembro/2003) e Santo Amaro (fevereiro e março/2003). A tendência de queda nas concentrações da 
estação Ibirapuera não é tão evidente nos dados diários (figura 49b) como é nas médias anuais e mensais (figura 33 e anexo 1). As estações Mauá e Santana também apresentam concentrações altas, mas não mostram tantos episódios agudos de poluição como as outras estações deste mesmo grupo. A maior variabilidade nos dados é encontrada na estação Santo Amaro.

Em relação à existência de dados inválidos, percebe-se que, quanto maior a variabilidade dos valores diários, menor é a quantidade de dados inválidos. Uma possível explicação para isto seria o fato de que estas estações apresentam também as maiores médias de concentração, sendo mais representativas das medidas do ozônio troposférico na RMSP. Algumas delas (como Pico do Jaraguá e Ibirapuera) pertencem à categoria "estação urbana", que medem a concentração de fundo da cidade, longe da influência das emissões veiculares ou industriais pontuais (CETESB, 2004, 2007). Assim, devido à maior importância destas estações na representação das concentrações de ozônio na RMSP, seus equipamentos podem ter sido mantidos em melhores condições. Ocorre também que as estações agrupadas como as de maior variabilidade diária iniciaram suas medições em períodos posteriores, com tecnologia mais recente, o que contribui para uma melhor qualidade nos dados. O oposto ocorre com as de menor variabilidade.

A partir de ano de 2002, praticamente não há dados inválidos nas estações da RMSP, como pode ser notado na tabela 16 :

Tabela 16: Porcentagem de dados inválidos por ano em algumas estações da CETESB na RMSP. As quadrículas em azul indicam anos em que a estação esteve inativa.

\begin{tabular}{|l|l|l|l|l|l|l|l|l|l|l|l|}
\hline Ano/Estação & $\mathbf{1 9 9 6}$ & $\mathbf{1 9 9 7}$ & $\mathbf{1 9 9 8}$ & $\mathbf{1 9 9 9}$ & $\mathbf{2 0 0 0}$ & $\mathbf{2 0 0 1}$ & $\mathbf{2 0 0 2}$ & $\mathbf{2 0 0 3}$ & $\mathbf{2 0 0 4}$ & $\mathbf{2 0 0 5}$ & Total \\
\hline Congonhas & ND & 9,0 & 12,3 & 52,4 & 9,7 & 0,4 & & & & & 16,7 \\
\hline Diadema & & & & 5,1 & 4,5 & 2,1 & 0,0 & 0,0 & 0,0 & 0,0 & 1,6 \\
\hline Horto Florestal & & & & & & & & & 0,0 & 0,0 & 0,0 \\
\hline Ibirapuera & 0,0 & 4,4 & 6,5 & 8,7 & 6,6 & 2,4 & 0,0 & 0,0 & 0,0 & 0,0 & 2,8 \\
\hline Lapa & 0,0 & 9,6 & 14,0 & 7,8 & 30,4 & 0,0 & & & & & 10,3 \\
\hline Mauá & 0,0 & 5,2 & 9,4 & 9,0 & 10,4 & 2,9 & 0,0 & 0,0 & 0,0 & 0,0 & 3,6 \\
\hline Mooca & & 4,2 & 6,7 & 5,3 & 9,3 & 4,0 & 0,0 & 0,0 & 0,0 & 0,0 & 3,2 \\
\hline $\begin{array}{l}\text { Nossa Senhora do } \\
\text { Ó }\end{array}$ & & & & & & & & 0,0 & 0,0 & 0,0 \\
\hline Osasco & 0,0 & 4,5 & 4,5 & 7,2 & 6,6 & 2,1 & & & & & 4,1 \\
\hline Parque D. Pedro II & 0,0 & 4,2 & 11,8 & 5,0 & ND & 3,0 & 0,0 & 0,0 & 0,0 & 0,0 & 2,6 \\
\hline
\end{tabular}




\begin{tabular}{|l|l|l|l|l|l|l|l|l|l|l|l|}
\hline Pico do Jaraguá & & & & & & & 0,0 & 0,0 & & & 0,0 \\
\hline Pinheiros & & & & 0,9 & 3,0 & 3,3 & 0,0 & 0,0 & 0,0 & 0,0 & 1,0 \\
\hline Santana & & & & 12,9 & 4,6 & 2,0 & 0,0 & 0,0 & 0,0 & 0,0 & 3,2 \\
\hline Santo Amaro & & & & & & & & 0,0 & 0,0 & 0,0 & 0,0 \\
\hline São Caetano do Sul & 0,0 & 11,7 & 7,8 & 8,5 & 4,8 & 1,9 & 0,0 & 0,0 & 0,0 & 0,0 & 3,4 \\
\hline $\begin{array}{l}\text { São Miguel Paulista } \\
\text { Santo André - } \\
\text { Capuava }\end{array}$ & & 15,0 & 7,8 & 5,4 & 5,6 & 2,5 & 1,1 & 0,0 & 0,0 & 0,0 & 3,7 \\
\hline
\end{tabular}

*ND: não disponível

As porcentagens indicadas na tabela 16 levam em conta apenas os dados propriamente inválidos e não os inválidos mais os faltantes, como foi representado nas figuras 47a a 49c. Assim, pode-se concluir que, a partir do ano de 2002, praticamente todos os dados representados como inválidos nas figuras $47 \mathrm{a}$ a $49 \mathrm{c}$ indicam, na verdade, valores faltantes. Os valores faltantes ocorrem quando há um determinado período em que a estação, por alguma razão, como manutenção, reposição de peças, etc., não funciona. Já os dados inválidos, ocorridos antes de 2002, são originários de medições consideradas incorretas pelos equipamentos. Desta forma, percebe-se que a manutenção e a atualização da rede de monitoramento de poluentes da CETESB está associada à melhoria da qualidade dos dados disponíveis. No entanto, a falta de dados ainda é consideravelmente perceptível em alguns períodos, para algumas estações, de modo que este conjunto de dados poderia ser ainda mais completo.

Algumas considerações finais podem ser feitas sobre a validade dos dados. $O$ período de dados inválidos ou faltantes no início do período de análise (1996 a 2005) refere-se, em grande parte das vezes, à falta de informação pelo nãofuncionamento da estação, uma vez que as séries temporais foram completadas com valores indicativos de dados faltantes para que se pudesse trabalhar com todas as estações numa mesma base de dados. Por exemplo, de acordo com o Relatório Anual de Qualidade do Ar da RMPS e do Interior de 2000, da CETESB, a estação Santana começou a funcionar no dia 06/05/1999, embora os dados de ozônio obtidos registrem valores desde o primeiro dia deste mês, e a série temporal apresentada nas figuras vá desde 01/01/1999 até 31/12/2005. Algo parecido ocorre com as estações Congonhas e Lapa. O final de suas séries mostra um número elevado de dados inválidos, uma vez que estas estações apresentam concentrações 
de ozônio inexpressivas se comparadas com os valores das outras estações, tendo sido gradativamente desativadas. Tal procedimento permitiu focar a atenção em outras regiões da RMSP com pior qualidade do ar, relativamente ao ozônio (CETESB, 2004). Não foi possível obter os dados dos meses de outubro, novembro e dezembro de 2001. 


\subsubsection{O ciclo diurno do ozônio troposférico na RMSP}

Na escala diária, além das séries temporais de médias diárias, optou-se por realizar um estudo com a variação diurna de concentrações do ozônio troposférico. Os poluentes normalmente seguem um ciclo diurno, com variações em suas concentrações de acordo com diferentes configurações atmosféricas e o seu padrão de emissão; sendo este último influenciado diretamente pelo fluxo das atividades humanas que os originam (MONTEIRO, 1976). Assim, espera-se que um poluente de origem veicular terá picos característicos de concentração regido pelos horários de maior fluxo de automóveis, como nos horários de pico nos rushes da manhã (aproximadamente das $7 \mathrm{~h}$ às $10 \mathrm{~h}$ ) e do fim da tarde (aproximadamente das $5 \mathrm{~h}$ às 8h), em locais com grandes vias de circulação. Estes horários são justamente os de vigor do rodízio de automóveis, afim de diminuir o trânsito e a emissão de poluentes nestes horários, pois a emissão de poluentes é menos concentrada nos outros horários do dia (CETESB, 2006).

O ciclo do ozônio troposférico, sendo este um poluente secundário, é certamente influenciado pelas diferentes taxas de emissão de precursores durante o dia (MARTINS, 2006). Seu ciclo diurno foi calculado de acordo com o descrito em 2.3 Metodologia.

A climatologia diurna média do $\mathrm{O}_{3}$ já foi estudada anteriormente por Qin et al (2004) em um estudo em Los Angeles, no qual se compara a quantidade de ozônio presente na atmosfera em dias da semana e em finais de semana, sugerindo diferentes quantidades médias de ozônio para esses períodos. A hipótese sugere que haja menor espalhamento da luz nos finais de semana ligada à menor quantidade de material particulado na atmosfera nesses dias, bem como menor emissão de NOx, levando a um aumento nas concentrações de ozônio no final de semana devido a razões já expostas anteriormente neste trabalho. Outro estudo, já citado, foi conduzido por Azevedo (2002) na RMSP, no qual o ciclo diurno do $\mathrm{O}_{3}$ é analisado com conclusões semelhantes: a variação semanal do ozônio troposférico seria inversamente proporcional à intensidade da atividade urbana. 
Os resultados obtidos na presente pesquisa sobre o ciclo diurno do ozônio foram bastante similares, corroborando as informações obtidas nas referidas pesquisas. De acordo com os resultados exibidos na figura 50 , o ciclo diurno médio do ozônio na RMSP apresenta um padrão característico: as concentrações são no geral mais baixas durante a noite e aumentam progressivamente a partir das $7 \mathrm{~h}$ em direção ao meio da tarde. Por volta das $15 \mathrm{~h}$, ocorre um máximo na concentração do poluente, de acordo com os resultados obtidos por 13 estações, em pelo menos oito meses do ano. A partir das $15 \mathrm{~h}$, as concentrações começam a cair. Elas chegam a um mínimo secundário por volta da meia-noite e apresentam um ligeiro aumento a partir desse horário, culminando com um máximo noturno por volta das $4 \mathrm{~h}$. Este máximo da madrugada também foi apresentado por 13 estações, em pelo menos oito meses do ano. De acordo com dez das estações analisadas, as concentrações voltam a cair e atingem um mínimo por volta das $7 \mathrm{~h}$, quando começam a subir novamente, fechando o ciclo. Para facilitar a visão do comportamento do ozônio aqui descrito na escala diurna, foi calculado um ciclo diurno médio, que pode ser verificado na figura 50 :

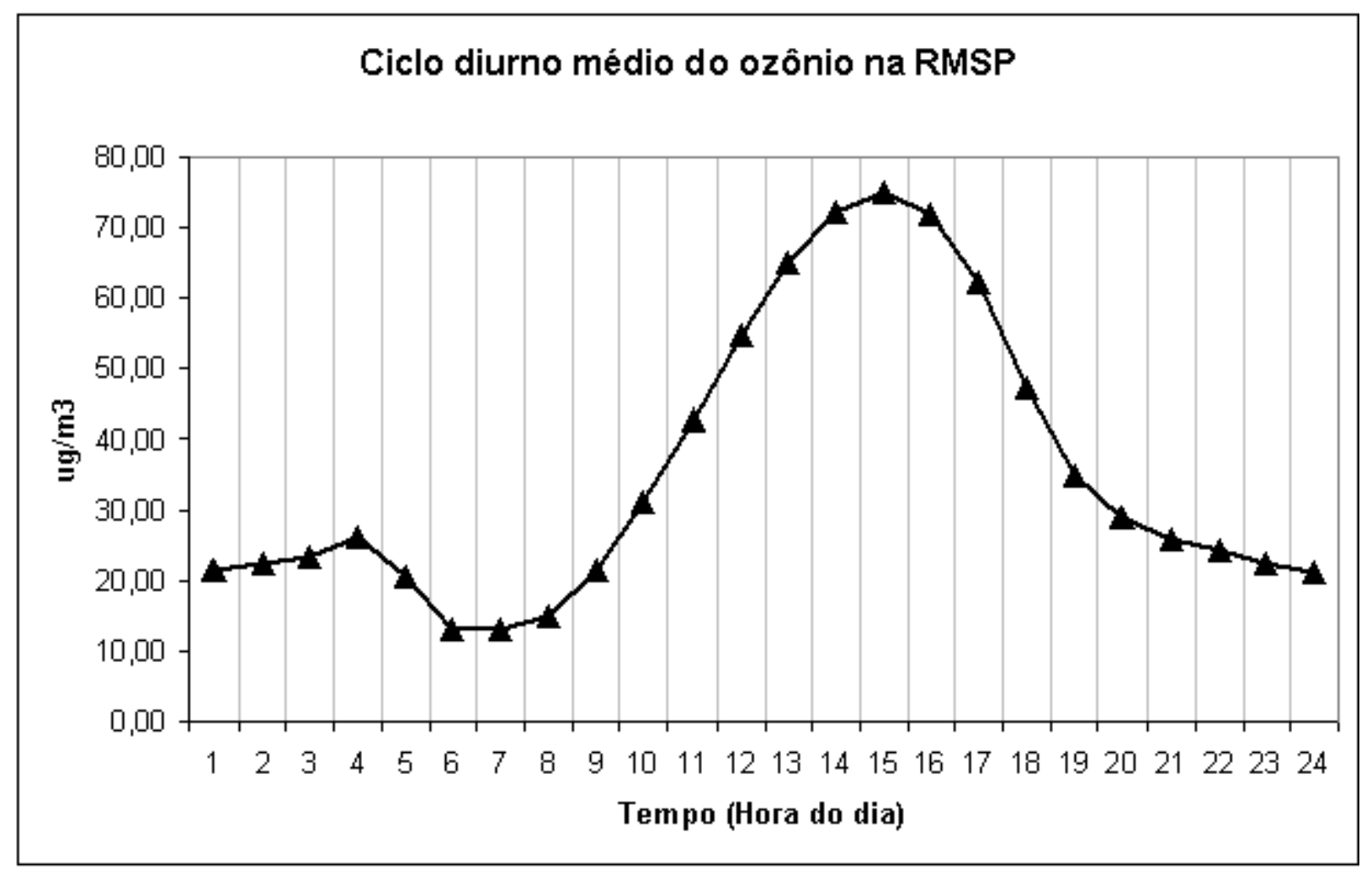

Figura 50: Ciclo diurno médio de ozônio das 17 estações na RMSP 
Algumas observações podem ser feitas acerca desse comportamento típico que reflete a natureza do $\mathrm{O}_{3}$ como poluente secundário e fotoquímico. Uma vez que a quantidade de radiação solar que atinge a superfície determina a formação do ozônio troposférico, são esperadas maiores concentrações nos horários de insolação mais intensa. Assim, o pico das concentrações de ozônio, em média, ocorre por volta das 15h na RMSP, algumas horas após o pico de radiação recebida pela superfície, num dia claro. Além disso, nestes horários, a quantidade de precursores também atinge um valor mínimo, pois a maioria dos NOx já se converteu em ozônio. Esse mínimo de NOx também contribui, secundariamente, para o máximo de ozônio, pois uma menor quantidade de NOx implica num menor consumo de ozônio:

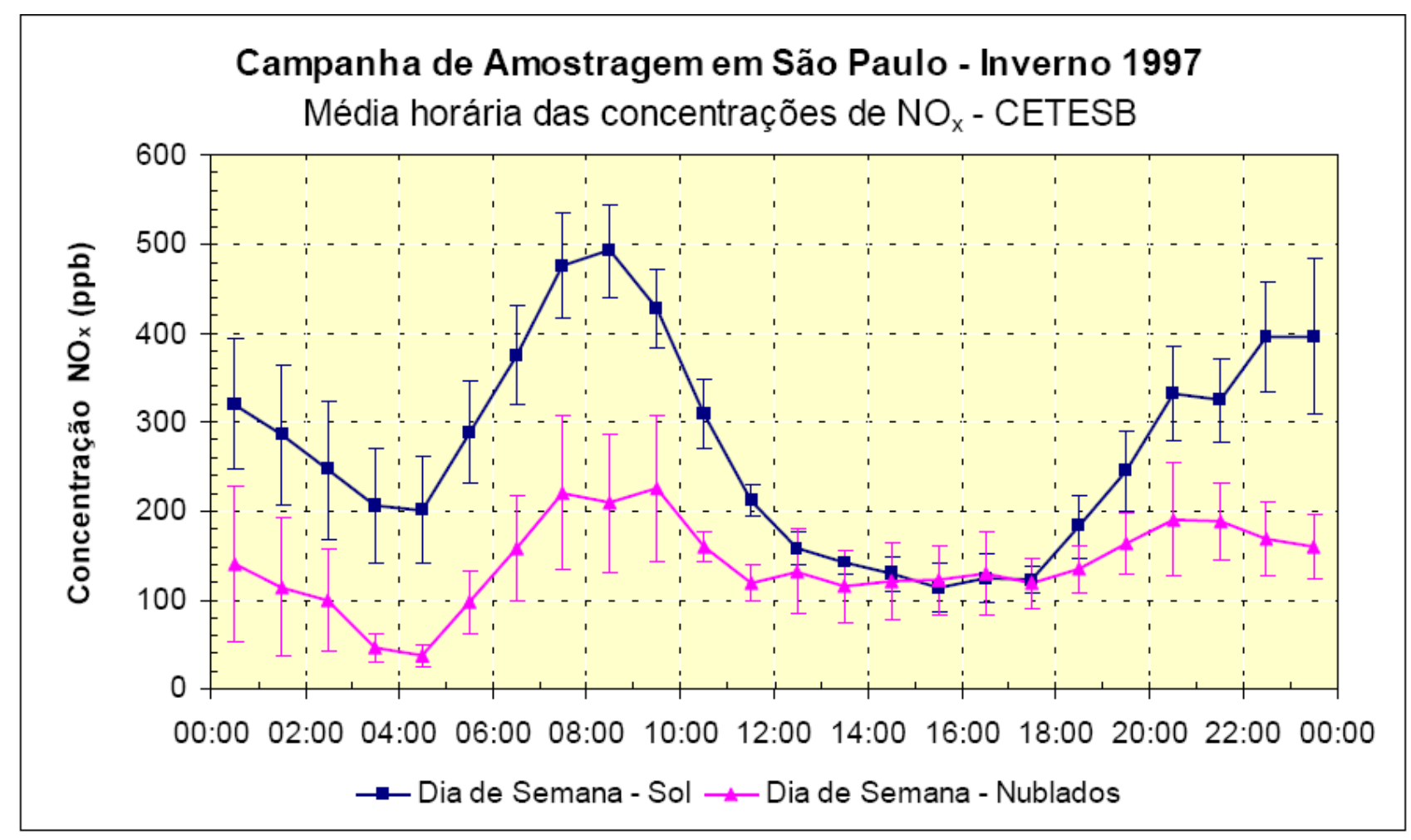

Figura 51: Ciclo diurno das médio das concentrações de NOx, estação Cerqueira César, de 12 de agosto a 09 de setembro de 1997. As barras representam o desvio padrão da média horária das concentrações em dias de sol e dias nublados.

Fonte: Castanho, 1999

Assim, dada a abundante disponibilidade de precursores do ozônio na camada de mistura da RMSP, a quantidade de ozônio troposférico na escala diária também é fortemente influenciada pela incidência de radiação solar de ondas curtas. 
De manhã, após o rush de veículos que ocorre por volta das $7 \mathrm{~h}$ ou $8 \mathrm{~h}$, as condições começam a favorecer a formação deste poluente. De acordo com as explicações anteriores (seção 1.2), o NO lentamente começa a se transformar em $\mathrm{NO}_{2}$, e este a sofrer fotodissociação e formar o ozônio (ANDRADE ET AL, 2004). Um exemplo da evolução diária destes poluentes pode ser visto na figura 04.

Esse atraso ocorre devido ao tempo da reação de fotólise dos NOx (MASSAMBANI ET AL, 2004). Desta forma, por volta das 15h, após várias horas com alto índice de radiação solar, as quantidades acumuladas de ozônio atingem um ápice. Devido à rotação da Terra, a quantidade de radiação solar incidente passa a diminuir. Essa redução da quantidade de radiação que chega à superfície incorre numa diminuição da taxa de formação do $\mathrm{O}_{3}$. Além disso, a emissão de NOx no período do rush do início da noite, que tem início por volta das $17 \mathrm{~h}$, contribui para um maior consumo do ozônio. As concentrações permanecem baixas durante o período noturno. O ozônio atinge uma concentração mínima por volta das $6 \mathrm{~h}-7 \mathrm{~h}$, por se tratar de um horário onde já começa a ocorrer uma maior emissão de poluentes que consomem o ozônio presente no ar. Além disso, a radiação solar incidente nesse horário ainda é baixa em relação aos outros horários do dia. Portanto, o ozônio é formado em taxas mais lentas e ocorre um déficit em sua concentração, que já está baixa devido a diversas horas de ausência de radiação solar durante a noite. A partir das $9 \mathrm{~h}$, a maior quantidade de insolação contribui duplamente para aumentar a concentração desse poluente, retirando o NOx do ar e aumentando a concentração de ozônio simultaneamente através do processo de fotodissociação.

O único ponto que permanece sem explicação é o aumento noturno de ozônio, o pequeno máximo de madrugada que ocorre em 14 estações por volta das $3 \mathrm{~h}$ ou $4 \mathrm{~h}$. Uma vez que não há radiação solar neste horário, outros processos devem ser responsáveis pelo aumento nas concentrações deste gás de madrugada, tais como o transporte de outras substâncias, por exemplo. Uma sugestão é a de que as concentrações de ozônio troposférico aumente nesse horário devido ao mínimo dos precursores observado nesse horário, como pode ser visto na figura 52. 


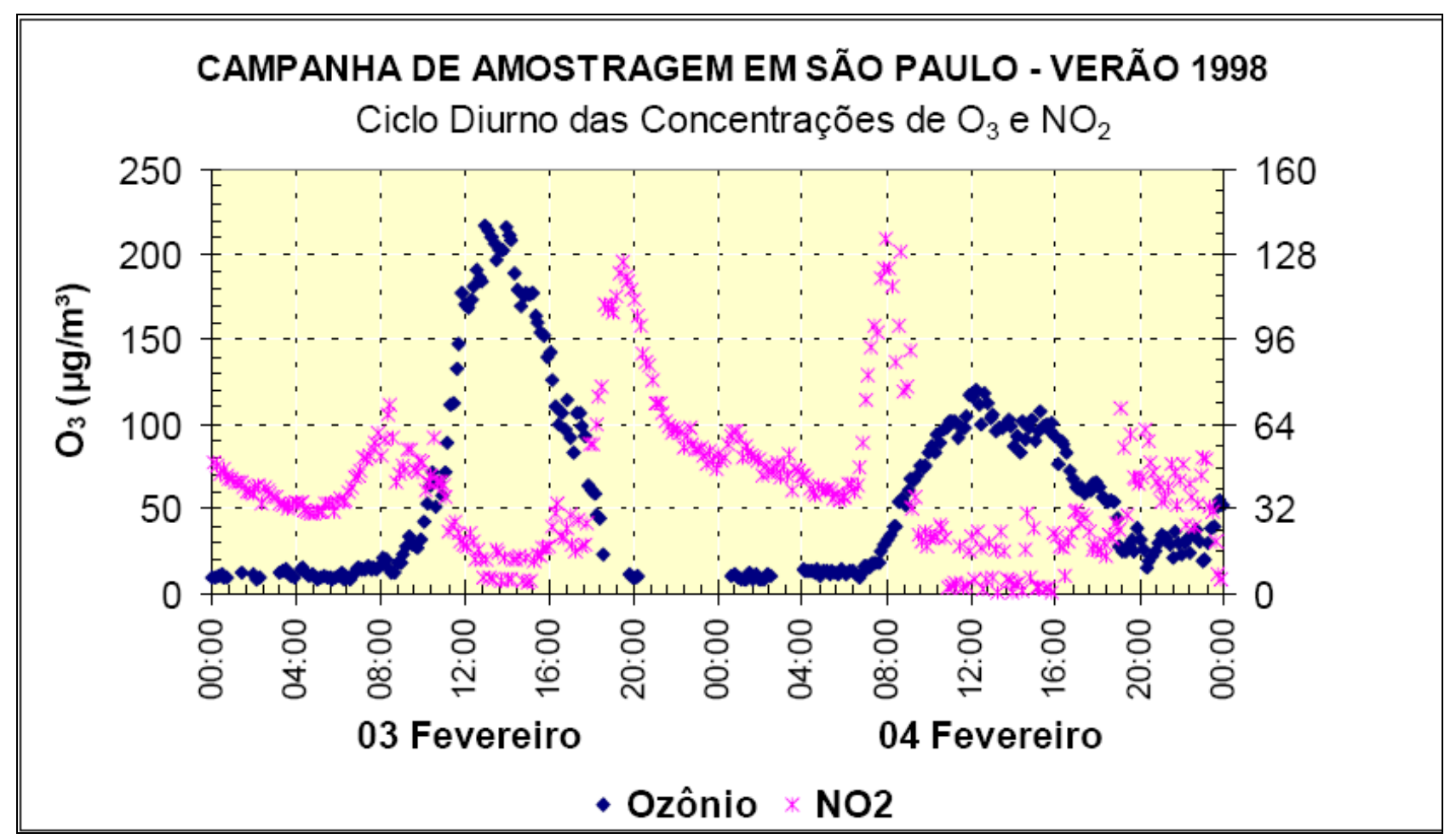

Figura 52: Ciclo diurno de ozônio e $\mathrm{NO}_{2}$ para os dias 03 e 04 de fevereiro de 1998. Fonte: Castanho, 1999

Em linhas gerais, este é o comportamento apresentado pela maioria dos postos, para a maioria dos meses. Existem variações de acordo com o mês do ano e o posto considerado. Por exemplo, a maioria dos postos exibe curvas diárias médias mais altas nos meses de setembro a novembro, confirmando a idéia do ciclo sazonal do poluente levantada anteriormente. Pode-se perceber esta diferença comparando a figura $53 a$ e $53 b$ abaixo. 

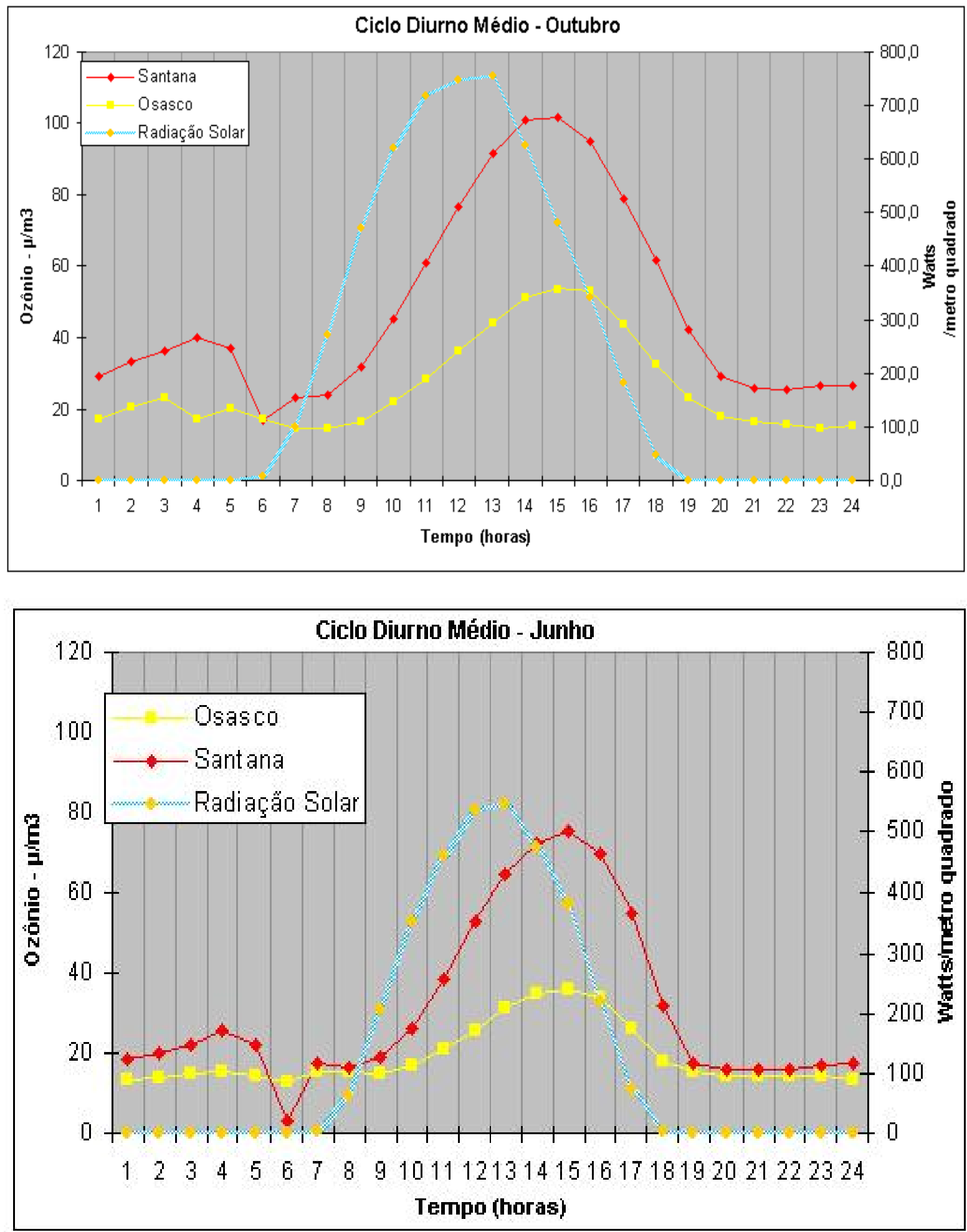

Figuras 53a e 53b: Ciclo diurno médio de radiação solar (1999-2001, azul) e da concentração de ozônio (1996-2005) para os meses de outubro e junho, nas estações Ibirapuera (vermelho) e Congonhas (amarelo).

Fonte: CHIQUETTO et al, 2007

Pode-se notar que tanto na escala diária quanto na escala sazonal, a variabilidade da radiação solar seja determinante para uma maior concentração de 
ozônio. O máximo noturno por volta das $3 \mathrm{~h}$ ou $4 \mathrm{~h}$ pode ser visto nas figuras $52,53 \mathrm{a}$ e 53b. Ele ocorre principalmente de setembro a novembro, nos meses de maior concentração do poluente, na maioria das estações, como foi mencionado anteriormente. A estação Congonhas não apresentou quantidade significativa de dados válidos no horário das $4 \mathrm{~h}$. A estação Lapa não apresenta este máximo secundário de maneira bem consistente, e na estação Pico do Jaraguá ele ocorre por volta das $2 \mathrm{~h}$ ou $3 \mathrm{~h}$. 


\subsubsection{Análise da distribuição espacial do ozônio troposférico na RMSP}

Foi discutido nas seções 3.1.1 a 3.1.3 sobre as diferentes concentrações de ozônio medidas nas estações de monitoramento. A análise do comportamento do poluente nestas três escalas permitiu que se notasse significativas diferenças entre os níveis de concentração médio, a variabilidade nos dados e expressividade do ciclo sazonal do ozônio na RMSP nas diferentes estações analisadas. Assim, pôdese concluir, com base nos resultados até agora obtidos, que devido a essas diferenças entre as concentrações de ozônio nas estações analisadas, esta não é homogênea na RMSP. Esta distribuição espacial do poluente será brevemente discutida nesta seção.

Na seção 2.1.2 foram evidenciadas algumas diferenças entre as estações no que concerne à localização da estação, o uso do solo em seu entorno (residencial, industrial, comercial, etc.), e sua exposição às fontes de emissão próximas, por meio da análise de alguns documentos publicados pela CETESB, trabalhos anteriores realizados por outros pesquisadores (SAMPAIO, 2000, AZEVEDO, 2002) e de fotos de satélite contendo a localização aproximada da estação e sua área de entorno. Estas informações estão resumidas na tabela 17: 
Tabela 17: Características de exposição, ciclo sazonal e nível de concentração das estações da CETESB.

\begin{tabular}{|l|l|l|l|}
\hline Estação & $\begin{array}{l}\text { Exposição direta e característica } \\
\text { das fontes locais }\end{array}$ & $\begin{array}{l}\text { Ciclo } \\
\text { sazonal }\end{array}$ & $\begin{array}{l}\text { Nível de } \\
\text { concentração }\end{array}$ \\
\hline Congonhas & Sim - veicular & Não & Baixo \\
\hline Diadema & Não - veicular & Sim & Alto \\
\hline Ibirapuera & Não fontes locais próximas & Sim & Médio \\
\hline Horto Florestal & Não - veicular & - & Médio \\
\hline Lapa & Sim - veicular e industrial & Sim & Baixo \\
\hline Mauá & Não - industrial & Sim & Alto \\
\hline Mooca & Não - veicular e industrial & Sim & Médio \\
\hline Nossa Senhora do Ó & Não - veicular & - & Baixo \\
\hline Osasco & Sim - veicular e não- industrial & Não & Baixo \\
\hline Pico do Jaraguá & Não há fontes locais próximas & - & Muito Alto \\
\hline Pinheiros & Sim - veicular & Não & Baixo \\
\hline Parque D. Pedro II & Sim - veicular & Não & Baixo \\
\hline Santana & Não - veicular & Sim & Muito Alto \\
\hline Santo Amaro & Não - veicular & - & Muito Alto \\
\hline São Caetano do Sul & Não - veicular e industrial & Sim & Médio \\
\hline São Miguel Paulista & Não - veicular & Sim & Alto \\
\hline Santo André - Capuava & Sim - veicular e industrial & Sim & Médio \\
\hline
\end{tabular}

Fonte: SAMPAIO (2000), CETESB $(2004,2006,2007)$ e AZEVEDO (2002)

Conforme citado em 2.2.1, as estações Horto Florestal, Pico do Jaraguá, Nossa Senhora do Ó e Santo Amaro contavam com menos de três anos no banco de dados utilizados neste estudo, por isso foram consideradas inapropriadas para estudo do ciclo sazonal médio.

Ao se analisar a tabela 17, percebe-se que as estações que foram classificadas como de baixa concentração (de acordo com a metodologia empregada em 3.1.1: Congonhas, Lapa, Osasco, Pinheiros e Parque D. Pedro II) estão todas localizadas em áreas com intensa atividade urbana e expostas à direta influência de emissões veiculares. As outras estações apresentam variados graus de exposição à poluição veicular e industrial, mas é interessante notar que, mesmo estações localizadas próximas de significativa quantidade de área verde, tais como Pico do Jaraguá, Parque do Ibirapuera e Horto Florestal, ou mesmo de áreas de lazer ou outras áreas com alguma quantidade de vegetação (Mauá, Santo Amaro, 
Santana) apresentam concentrações de ozônio mais altas do que as inseridas diretamente em avenidas. É importante frisar que as estações Diadema e Santana (que possuem concentrações altas e muito altas de acordo com a metodologia empregada neste estudo), apesar de se situarem próximas às vias de intenso tráfego de veículos, não estão expostas diretamente à poluição emitida por eles, uma vez que se não se localizam na avenida, mas dentro das áreas verdes próximas a elas (figuras 15 a 31). Embora isto não possa ser compreendido num primeiro olhar sobre a foto, buscou-se estas informações acerca da localização aproximada da estação em outros estudos, já mencionados anteriormente, que esclarecem melhor esta questão, uma vez que a CETESB não publicou documentos sobre todas as estações de monitoramento.

Assim, percebe-se que as estações localizadas em áreas de menor atividade urbana, essencialmente, com tráfego de veículos menos intenso em seus arredores, apresentam maior concentração de ozônio e um ciclo sazonal mais bem definido.

Já foi abordado anteriormente que a formação do ozônio em superfície nos grandes centros urbanos depende de certos gases precursores, principalmente NOx e COV (majoritariamente emitidos por veículos) e do efeito de fotodissociação induzido pela radiação solar de ondas curtas. Assim, pode-se perceber que, nas proximidades das grandes avenidas, as condições para acúmulo de ozônio em superfície são menos propícias, justamente pela excessiva quantidade de NOx que consomem este gás, de acordo com as reações dadas na seção 1.2 e 1.2.1.

Assim, conclui-se que as maiores concentrações de ozônio medidas estão justamente em locais com significativa quantidade de área verde ou mesmo áreas de lazer. As estações Ibirapuera, Horto Florestal, Diadema e Pico do Jaraguá encontram-se em parques urbanos dentro da RMSP, verdadeiras ilhas de vegetação numa região metropolitana carente de áreas verdes e com inchaço populacional. A estação Santana está localizada no Campo de Marte, aeroporto militar próximo da Marginal Tietê mas com quantidade significativa de área verde. Outras estações, como Santo Amaro, Mooca e São Caetano do Sul estão localizadas em áreas de lazer ou educacionais, como centros esportivos e educacionais (CEEls) e escolas de ensino fundamental e médio. Já as estações São Miguel Paulista, Nossa Senhora do 
Ó, Santo André-Capuava e Mauá estão localizadas em áreas predominantemente residenciais, sendo representações mais próximas do ar que a população respira em suas residências nestes locais. As concentrações medidas em áreas de lazer, escolas e parques são igualmente preocupantes, uma vez que o senso comum diz que estas áreas teriam um ar menos contaminado. Ironicamente, essa situação é exatamente o inverso no que diz respeito às concentrações de ozônio troposférico: as avenidas possuem menor concentração deste poluente do que os parques, áreas verdes e áreas de lazer. Isso porque as camadas atmosféricas superficiais destes locais já estão saturadas com outro tipo de poluição. É importante lembrar também que as estações localizadas mais distante das fontes de emissão são consideradas pela CETESB como medidoras da concentração de fundo, ou de background, à concentração aproximada mais comum da área urbana como um todo.

Como conclusão do que foi apresentado com este conjunto de dados, podese dizer que não existem "ilhas de ar puro" dentro da RMSP. O inchaço populacional, a demanda por produtos e serviços, a intensidade frenética da atividade urbana, tudo isso leva à uma emissão muito significativa de substâncias nocivas à saúde humana, ao meio ambiente, além de materiais para a atmosfera, que contaminam o ar de maneira generalizada em escala local. Dentro deste contexto, as condições atmosféricas desempenham papel crucial na variabilidade da concentração destas substâncias.

Nas figuras demonstradas pelo anexo 3, fez-se uma tentativa de compreensão da distribuição espacial média deste poluente na RMSP. De acordo com o que foi descrito na seção 2.3.1, utilizou-se a ferramenta de interpolação do GrADS para gerar este mapa, que é baseada na análise de Cressman (CRESSMAN, 1959).

Nestas figuras, os números verdes indicam a localização e o número de identificação das estações, enquanto que os brancos representam o valor das isolinhas de concentração de ozônio, em $\mu \mathrm{g} / \mathrm{m}^{3}$. As estações Congonhas, Lapa e Ibirapuera correspondem na figura aos números 1, 5 e 4, respectivamente. Sua análise permite perceber que há maior concentração deste poluente, representada pelas cores verde, amarelo, laranja e vermelho, nas áreas mais afastadas do centro 
da mancha urbana e da densa circulação de veículos. A estação Osasco $\left(\mathrm{N}^{\circ} 9\right)$ seria exceção à essa regra, por estar relativamente mais afastada e apresentar baixas concentrações; no entanto sabe-se que ela sofre a influência direta dos poluentes da Av. dos Autonomistas (Figura 15), o que acaba por diminuir sua concentração média de acordo com o que foi explicado anteriormente.

As estações do Pico do Jaraguá $\left(\mathrm{N}^{\circ} 10\right)$ e Santo Amaro $\left(\mathrm{N}^{\circ} 14\right)$ são as que apresentam as maiores concentrações médias de ozônio. Embora o bairro de Santo Amaro seja bastante urbanizado e tenha avenidas com intenso fluxo de veículos (Marginal do Pinheiros, Av. Santo Amaro), a estação está localizada dentro da área de um Centro Esportivo e Educacional (CEE), por isso distante das fontes de poluentes primários. Assim, este mapa conta com maior relevância somente na demonstração da quantidade de ozônio presente nas estações de monitoramento, mas não para demonstrar este poluente nas áreas entre as estações, que podem sofrer influência direta do uso do solo em cada localidade. A estação móvel Pico do Jaraguá foi instalada no alto do Pico do Jaraguá (figura 21), em sua vertente leste, sendo então representativa de sua região de entorno, que é menos urbanizada e mais afastada do centro urbano. As altas concentrações médias de ozônio podem ser derivadas do transporte deste poluente e de seus precursores emitidos na Rodovia dos Bandeirantes ou outras vias por ventos de sudeste, que, segundo diversos estudos realizados pela CETESB $(2003,2004,2005,2006,2007)$, são os mais freqüentes em diversas estações da rede na RMSP e estão associados com concentrações altas de ozônio em diversas delas (CETESB 2003, 2004, 2005, 2006, 2007).

Como última observação a ser feita sobre uma melhor compreensão da distribuição do ozônio troposférico na RMSP, pode-se dizer que, para atingir um conhecimento mais apropriado e aprofundado desta questão, faz-se necessário acoplar as medidas em estação de monitoramento que se tem disponíveis com informações sobre o uso do solo da RMSP, em especial da quantidade de veículos que circulam nas grandes avenidas (AZEVEDO, 2002) e dos padrões de circulação atmosférica em escala intra-urbana. O estudo de Tarifa e Azevedo (2001), sobre a divisão da RMSP em diversas unidades micro-climáticas urbanas, de acordo com fatores como por exemplo o uso do solo adquire importância num contexto como 
este aonde a composição atmosférica local pode exercer influência determinante nas concentrações do poluente. 
3.2 Meses de anomalias de ozônio e as anomalias atmosféricas observadas

Conforme foi explicado na seção anterior, foram selecionados meses de concentração anômala de ozônio para análise das anomalias atmosféricas observadas neles. A comparação com o desvio padrão permitiu a classificação dos meses em duas classes, confirme indicado na seção anterior. Estas informações estão resumidas nas tabelas 18, 19,21 e 22 : 
Tabela 18: Meses com valor médio da anomalia de concentrações de $\mathrm{O}_{3}$ superiores a $1 \sigma$ do mês correspondente (classe 1). As anomalias mais intensas para o mês estão destacadas em vermelho e amarelo:

\begin{tabular}{|c|c|c|c|c|c|c|c|c|c|c|c|c|}
\hline Mês & $\begin{array}{l}{\left[\mathrm{O}_{3}\right]} \\
\mu \mathrm{g} / \mathrm{m}^{3}\end{array}$ & $\begin{array}{l}\text { Anom } \\
{\left[\mathrm{O}_{3}\right]}\end{array}$ & $\begin{array}{l}\text { Rad } \\
\mathrm{W} / \mathrm{m}^{2}\end{array}$ & $\begin{array}{l}\text { Anom } \\
\text { Rad }\end{array}$ & $\begin{array}{l}\text { Temp } \\
{ }^{\circ} \mathrm{C}\end{array}$ & $\begin{array}{l}\text { Anom } \\
\text { Temp }\end{array}$ & $\begin{array}{l}\text { UR } \\
\%\end{array}$ & $\begin{array}{l}\text { Anom } \\
\text { UR }\end{array}$ & $\begin{array}{l}\text { Pres } \\
m b\end{array}$ & $\begin{array}{l}\text { Anom } \\
\text { Pres }\end{array}$ & $\begin{array}{l}\mathrm{ROL} \\
\mathrm{W} / \mathrm{m}^{2}\end{array}$ & $\begin{array}{l}\text { Anom } \\
\text { ROL }\end{array}$ \\
\hline $\begin{array}{l}\text { Mai } \\
1997\end{array}$ & 21,7 & $+4,9$ & 184,2 & $+11,8$ & 17,0 & $-0,8$ & 81,2 & $-3,2$ & 954,5 & $+1,7$ & 265,9 & $+1,5$ \\
\hline $\begin{array}{l}\text { Jan } \\
1999\end{array}$ & 33,3 & $+5,9$ & 234,9 & $-24,7$ & 22,3 & $+0,5$ & 91,6 & $+3,4$ & 947,9 & $-0,4$ & 219,0 & $-16,4$ \\
\hline $\begin{array}{l}\text { Ago } \\
1999\end{array}$ & 32,5 & $+5,8$ & 218,0 & $+76,3$ & 16,5 & $-0,8$ & 73,3 & $-3,7$ & 955,8 & $+1,3$ & 283,1 & $+75,6$ \\
\hline $\begin{array}{l}\text { Set } \\
1999\end{array}$ & 36,7 & $+7,3$ & 243,8 & $+78,5$ & 18,6 & $+0,6$ & 73,3 & $-6,1$ & 951,7 & $-1,1$ & 270,3 & $+11,8$ \\
\hline $\begin{array}{l}\text { Abr } \\
2000\end{array}$ & 29,3 & $+5,9$ & 238,8 & $+33,7$ & 19,5 & $-0,1$ & 80,0 & $-6,2$ & 951,9 & $+0,5$ & 283,0 & $+27,6$ \\
\hline $\begin{array}{l}\text { Mai } \\
2000\end{array}$ & 20,9 & $+4,2$ & 187,0 & $+14,7$ & 17,3 & $-0,5$ & 79,4 & $-5,0$ & 952,4 & $-0,3$ & 269,4 & $+5,1$ \\
\hline $\begin{array}{l}\text { Out } \\
2000\end{array}$ & 45,3 & $+10,4$ & 279,2 & $+20,0$ & 21,7 & $+1,7$ & 78,2 & $-4,7$ & 950,9 & $+0,1$ & 265,4 & $+8,9$ \\
\hline $\begin{array}{l}\text { Nov } \\
2000\end{array}$ & 38,9 & $+6,4$ & 278,1 & $-7,5$ & 20,1 & $-0,3$ & 87,9 & $+4,9$ & 948,4 & $-0,6$ & 239,9 & $-15,7$ \\
\hline $\begin{array}{l}\text { Jan } \\
2001\end{array}$ & 38,0 & $+10,5$ & 292,1 & $+32,4$ & 22,5 & $+0,6$ & 87,1 & $-2,0$ & 950,4 & $+2,0$ & 243,1 & $+7,6$ \\
\hline $\begin{array}{l}\text { Mar } \\
2002\end{array}$ & 35,3 & $+70,5$ & 256,1 & $+25,1$ & 22,9 & $+1,8$ & 86,4 & $-4,1$ & 950,4 & $+0,5$ & 259,2 & $+70,5$ \\
\hline $\begin{array}{l}\text { Abr } \\
2002\end{array}$ & 31,0 & $+7,6$ & 210,9 & $+5,7$ & 21,2 & $+1,6$ & 84,3 & $-4,2$ & 951,2 & $-0,1$ & 266,9 & $+5,5$ \\
\hline $\begin{array}{l}\text { Ago } \\
2002\end{array}$ & 29,7 & $+3,0$ & 206,5 & $+4,8$ & 19,7 & $+2,2$ & 73,2 & $-6,3$ & 954,3 & $-0,2$ & 266,8 & $-0,6$ \\
\hline $\begin{array}{l}\text { Out } \\
2002\end{array}$ & 53,9 & $+79,0$ & 268,7 & $+9,5$ & 22,9 & $+3,5$ & 68,4 & $-13,8$ & 949,9 & $-0,8$ & 264,3 & $+7,9$ \\
\hline $\begin{array}{l}\text { Nov } \\
2002\end{array}$ & 39,4 & $+6,9$ & 280,9 & $-4,7$ & 21,4 & $+0,9$ & 81,4 & $-2,0$ & 950,0 & $+0,8$ & 257,2 & $+1,5$ \\
\hline $\begin{array}{l}\text { Dez } \\
2002\end{array}$ & 35,4 & $+5,1$ & 289,4 & $+13,6$ & 22,0 & $+0,6$ & 85,2 & $-0,5$ & 949,1 & $+0,9$ & 253,7 & $+8,7$ \\
\hline $\begin{array}{l}\text { Fev } \\
2003\end{array}$ & 45,7 & $+19,3$ & 281,6 & $+31,1$ & 23,91 & $+1,8$ & 84,1 & $-7,6$ & 950,5 & $+1,1$ & 246,4 & $+7,2$ \\
\hline $\begin{array}{l}\text { Mar } \\
2003\end{array}$ & 31,3 & $+6,5$ & 234,5 & $+3,5$ & 21,3 & $+0,2$ & 87,9 & $-0,8$ & 950,7 & $+0,8$ & 249,2 & $+0,5$ \\
\hline $\begin{array}{l}\text { Mai } \\
2003\end{array}$ & 20,3 & $+3,5$ & 187,3 & $+15,0$ & 16,9 & $-0,9$ & 76,8 & $-8,1$ & 953,7 & $+0,9$ & 275,3 & $+11,0$ \\
\hline $\begin{array}{l}\text { Jun } \\
2003\end{array}$ & 22,4 & $+4,8$ & 166,0 & $+7,9$ & 18,3 & $+2,0$ & 77,4 & $-8,1$ & 954,0 & $-0,4$ & 275,0 & $+9,7$ \\
\hline $\begin{array}{l}\text { Jul } \\
2003\end{array}$ & 24,3 & $+4,8$ & 176,5 & $+11,7$ & 16,8 & $+0,5$ & 73,3 & $-9,3$ & 956,3 & $+1,0$ & 271,4 & $+7,1$ \\
\hline $\begin{array}{l}\text { Set } \\
2004\end{array}$ & 37,5 & $+8,1$ & 255,4 & $+30,1$ & 20,3 & $+2,4$ & 68,9 & $-12,6$ & 952,9 & $+0,0$ & 272,4 & $+13,9$ \\
\hline $\begin{array}{l}\text { Abr } \\
2005\end{array}$ & 28,7 & $+5,3$ & 205,1 & 0,0 & 20,7 & $+1,0$ & 83,5 & $-4,6$ & 952,0 & $+0,6$ & 263,4 & $+2,0$ \\
\hline
\end{tabular}


Tabela 19: Meses com valor médio da anomalia das concentrações de $\mathrm{O}_{3}$ superior a $2 \sigma$ do mês correspondente (classe 2 ).

\begin{tabular}{|l|l|l|l|l|l|l|l|l|l|l|l|l|}
\hline Mês & $\begin{array}{l}{\left[\mathrm{O}_{3}\right]} \\
\mathrm{\mu g} / \mathrm{m}^{3}\end{array}$ & $\begin{array}{l}\text { Anom } \\
{\left[\mathrm{O}_{3}\right]}\end{array}$ & $\begin{array}{l}\text { Rad } \\
\mathrm{W} / \mathrm{m}^{2}\end{array}$ & $\begin{array}{l}\text { Anom } \\
\mathrm{Rad}\end{array}$ & $\begin{array}{l}\text { Temp } \\
{ }^{\circ} \mathrm{C}\end{array}$ & $\begin{array}{l}\text { Anom } \\
\text { Temp }\end{array}$ & $\begin{array}{l}\text { UR } \\
\%\end{array}$ & $\begin{array}{l}\text { Anom } \\
\text { UR }\end{array}$ & $\begin{array}{l}\text { Pres } \\
\mathrm{mb}\end{array}$ & $\begin{array}{l}\text { Anom } \\
\text { Pres }\end{array}$ & $\begin{array}{l}\text { ROL } \\
\text { W/m }\end{array}$ & $\begin{array}{l}\text { Anom } \\
R O L\end{array}$ \\
\hline Ago 1999 & 32,5 & $+5,8$ & 218,0 & $+16,3$ & 16,5 & $-0,8$ & 73,3 & $-3,7$ & 955,8 & $+1,3$ & 283,1 & $+15,6$ \\
\hline Mar 2002 & 35,3 & $+10,5$ & 256,1 & $+25,1$ & 22,9 & $+1,8$ & 86,4 & $-4,1$ & 950,4 & $+0,5$ & 259,2 & $+10,5$ \\
\hline Fev 2003 & 45,7 & $+19,3$ & 281,6 & $+31,1$ & 23,9 & $+1,8$ & 84,1 & $-7,6$ & 950,5 & $+1,1$ & 246,4 & $+7,2$ \\
\hline
\end{tabular}

Do período avaliado (1996-2005), 22 meses apresentaram anomalias positivas de $\mathrm{O}_{3}$ superiores a $1 \sigma$, considerando-se como critério de classificação o desvio padrão mensal, o que pode ser visto na Tabela 18(acima). O maior número de casos ocorreu entre 2002 e 2003. Três meses da série, agosto de 1999, março de 2002, fevereiro de 2003 (em vermelho), apresentaram valores de anomalia das concentrações de $\mathrm{O}_{3}$ superiores a $2 \sigma$, tal como observado na Tabela 19. Outros meses com concentrações altas, muito próximas deste limiar, são abril de 2000, janeiro de 2001, outubro de 2002 e setembro de 2004, identificados em amarelo.

No período de 1996 a 1998 não foram observados casos de anomalias de

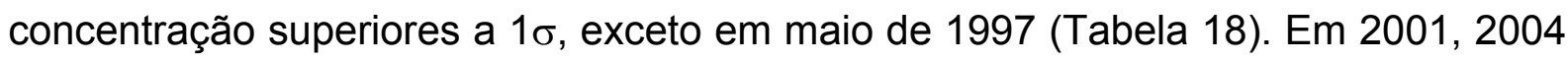
e 2005 foi registrado apenas um evento com concentração superior a $1 \sigma$ em cada ano. A maior quantidade de casos de anomalias superiores a $1 \sigma$ foi observada entre 1999 e 2003. 


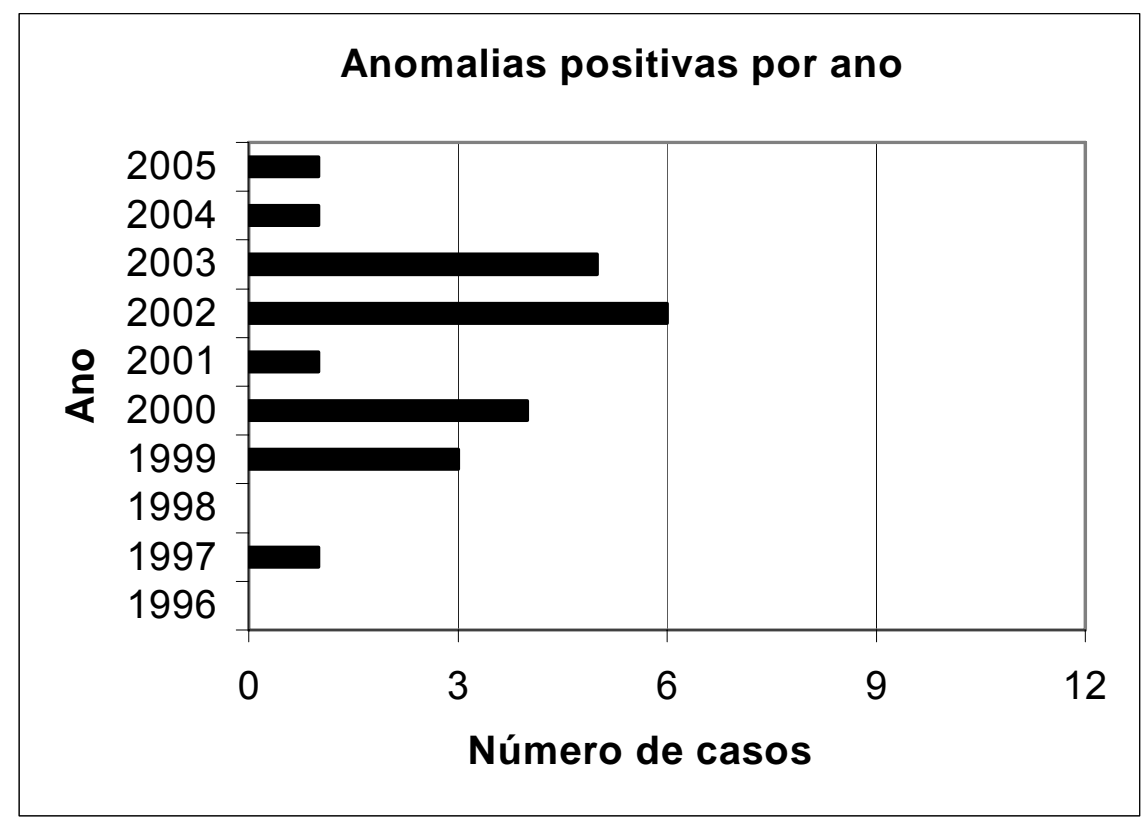

Figura 54: Distribuição anual do número de anomalias das concentrações de $\mathrm{O}_{3}$ com valor superior a $1 \sigma$.

Em particular, no ano de 2002 foram registrados seis casos e, em 2003, cinco casos. Ainda com uma quantidade significativa de casos com anomalias superiores a $1 \sigma$ aparece o ano de 2000, com quatro casos, e 1999, com três casos. Destas anomalias positivas, apenas três da série considerada são superiores $2 \sigma$ : agosto de 1999, março de 2002 e fevereiro de 2003, que serão discutidos com maior detalhamento adiante. 


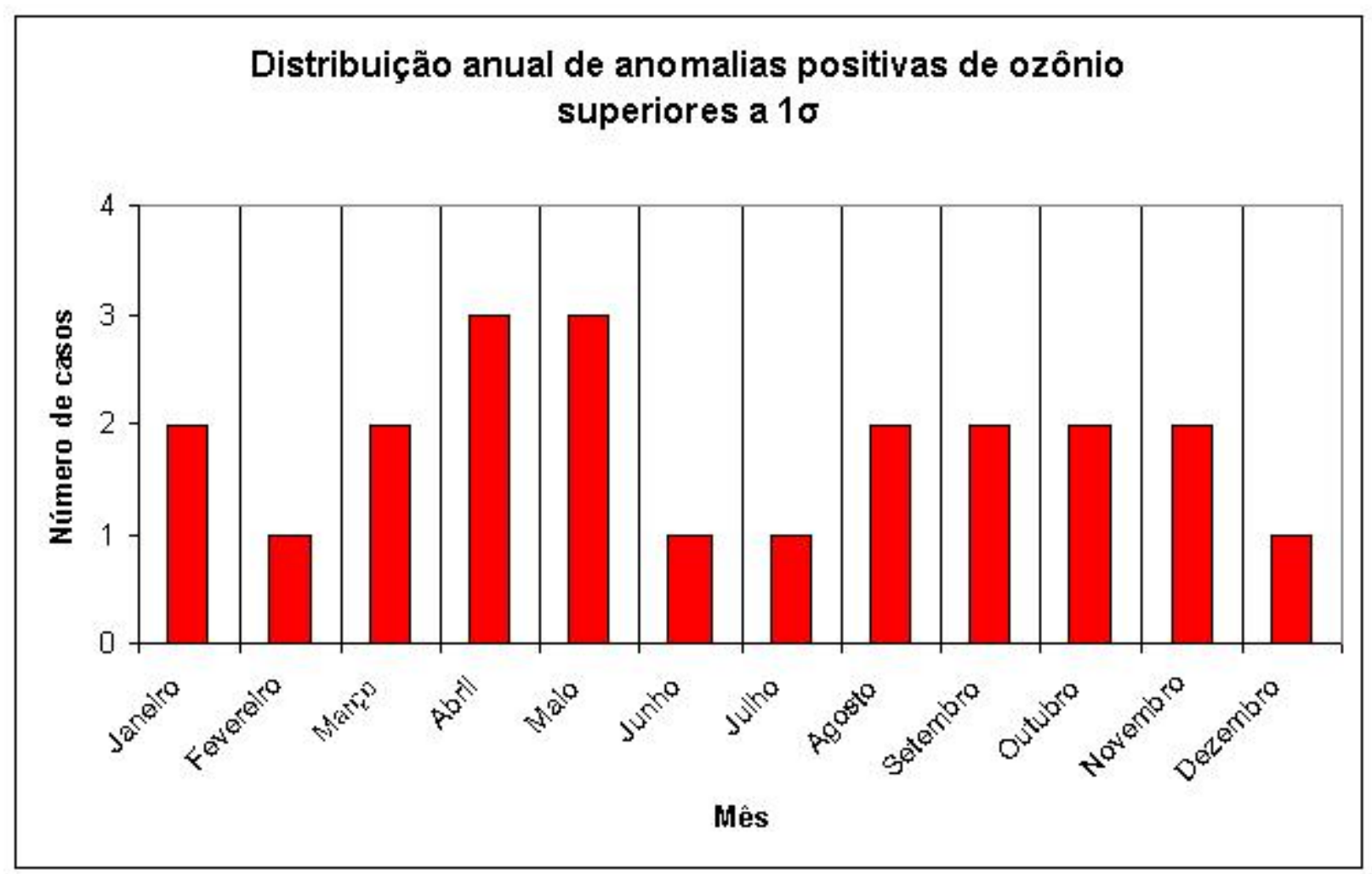

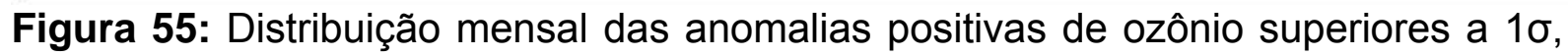
na série 1996-2005, considerando as 17 estações.

Pode-se ver pela figura 55 que, no período estudado, houve maior ocorrência de anomalias de ozônio superiores à $1 \sigma$ nos meses de abril e maio. Nenhum destes meses, no entanto, foi classificado como de classe 2, o que demonstrou que as anomalias observadas nestes meses, apesar de mais frequentes, foram menos intensas.

Ao se analisar a ocorrência de anomalias positivas das concentrações de $\mathrm{O}_{3}$ juntamente às anomalias climáticas, observa-se que há padrões atmosféricos predominantes em situações de anomalias positivas significativas das concentrações de $\mathrm{O}_{3}$, superiores a $1 \sigma . \mathrm{O}$ número de anomalias positivas e negativas das condições climáticas nestes casos extremos (para o total de 22 casos) está indicado na Tabela 20. 
Tabela 20: Anomalias climáticas nos meses em que foram registradas anomalias positivas de $\mathrm{O}_{3}$ superiores a $1 \sigma$.

\begin{tabular}{|l|l|l|l|}
\hline Variável Climática & Positiva & Negativa & Nula \\
\hline Radiação Solar & 18 & 03 & 01 \\
\hline Temperatura do ar & 16 & 06 & - \\
\hline Umidade Relativa & 02 & 20 & - \\
\hline Pressão Atmosférica & 14 & 08 & - \\
\hline Radiação de Onda Longa & 19 & 03 & - \\
\hline $\begin{array}{l}\text { Total de anomalias das concentrações de } \mathrm{O}_{3} \text { positivas } \\
\text { superiores a 10: } 22\end{array}$ \\
\hline
\end{tabular}

As anomalias positivas significativas de ozônio (superiores a $1 \sigma$ ) estão associadas muitas vezes à ocorrência de anomalias também positivas das variáveis radiação solar (RAD), temperatura do ar (TEMP), pressão atmosférica em superfície (PNM) e radiação de ondas longas (ROL), e de anomalias negativas de umidade do ar (UR). Quatorze (63,3\%) dos 22 casos observados de anomalias positivas superiores a $1 \sigma$ estiveram associados a anomalias positivas de RAD, TEMP, PNM e ROL e a anomalias negativas de UR. Dentre o total de 22 casos observados de anomalias positivas superiores a $1 \sigma, 18$ casos (80\%), estiveram associados a anomalias positivas de RAD e ROL e a anomalias negativas de UR. Assim, verificase que variáveis associadas à radiação, tanto solar quanto terrestre, e à umidade do ar estão bem mais associadas aos altos índices das concentrações de $\mathrm{O}_{3}$ do que temperatura e pressão à superfície, embora estas ainda possuam alguma relação com desvios positivos de concentrações de $\mathrm{O}_{3}$.

Nos meses em que foram identificadas anomalias positivas das concentrações de $\mathrm{O}_{3}$ superiores a $1 \sigma$, os valores extremos relativos às anomalias climáticas foram os seguintes (Tabela 18): radiação solar, maior valor em abril de 2000 , com $+33,70 \mathrm{~W} / \mathrm{m}^{2}$, e o mais baixo, em janeiro de 1999 , com anomalia negativa de $-24,70 \mathrm{~W} / \mathrm{m}^{2}$; temperatura do ar, mais alta em outubro de 2002 , com $+3,53^{\circ} \mathrm{C}$, e a menor, em maio de 2003 , com $-0,91^{\circ} \mathrm{C}$; pressão atmosférica - a anomalia mais alta foi observada em janeiro de $2001,+2,03 \mathrm{hPa}$, e a mais baixa, em setembro de 1999 , - 1,14 $\mathrm{hPa}$; radiação de onda longa - o valor mais alto observado ocorreu também em abril de $2000,+21,61 \mathrm{~W} / \mathrm{m}^{2}$, e o mais baixo em janeiro de $1999,-16,40 \mathrm{~W} / \mathrm{m}^{2}$. 
Destes valores, percebe-se que as anomalias climáticas positivas extremas que acompanham desvios positivos das concentrações de $\mathrm{O}_{3}$ são sempre mais intensas do que as negativas, para as variáveis RAD, TEMP, PNM, ROL (tabela 18). A UR apresentou a menor anomalia em outubro de $2002,-13,46 \%$, e a maior anomalia em novembro de $2000,+4,98 \%$.

As anomalias negativas de RAD, TEMP, PNM e ROL (e positivas de UR) que acompanham anomalias positivas das concentrações de $\mathrm{O}_{3}$ superiores a $1 \sigma$ são muito menos freqüentes e menos intensas do que as positivas (no caso da UR, o sinal oposto prevalece - as anomalias positivas são mais freqüentes e intensas que as negativas para UR). Estas anomalias negativas (e positivas de UR) correspondem por apenas $37 \%$ dos casos, considerando-se todas as variáveis e, $20 \%$ dos casos, considerando-se somente RAD, ROL e UR, com intensidade 35\% inferior, em média, em relação às anomalias com sinal contrário.

Como conclusão para este conjunto de dados analisados, pode-se dizer que quando ocorrem situações atmosféricas em que há maior intensidade de radiação solar, maior temperatura do ar, maior pressão atmosférica, menor nebulosidade (ROL mais alta) e menor umidade relativa do ar, há maiores chances de que a concentração de ozônio seja mais alta do que o valor médio do mês. Particularmente, a anomalia de umidade do ar foi negativa em 20 dos 22 casos em que a anomalia de concentração de ozônio foi superior a $1 \sigma$, o que equivale a $90 \%$ dos casos.

Nos meses em que foi observada anomalia positiva das concentrações de $\mathrm{O}_{3}$ superiores a $2 \sigma$ (classe 2) (agosto/1999, março/2002 e fevereiro/2003, Tabela 12), pode-se observar a segunda maior anomalia de $\mathrm{ROL},+15,63 \mathrm{~W} / \mathrm{m}^{2}$, em agosto de 1999. Em fevereiro de 2003, ocorreu uma significativa anomalia de RAD, $+31,11$ $\mathrm{W} / \mathrm{m}^{2}$, que, embora seja a terceira maior anomalia da série para esta variável, tratase de valor muito próximo do observado em abril de 2000 e janeiro de 2001 (+33,7 e $32,48 \mathrm{~W} / \mathrm{m}^{2}$, respectivamente, tabela 18). Outros meses em que ocorreram anomalias altas de variáveis atmosféricas foram janeiro de 2001 (RAD e PNM) e 
outubro de 2002 (TEMP e UR), que, embora não sejam de classe 2, também são destacados na Tabela 18 como meses com concentração alta.

A classificação preliminar dos meses realizada sem a remoção da tendência de aumento das concentrações de $\mathrm{O}_{3}$ ao longo do período considerado apontou estes mesmos meses como sendo de classe 2. Entretanto, após a remoção da tendência e revisão dos cálculos, pôde-se verificar que as concentrações altas observadas em janeiro de 2001 e outubro de 2002 foram influenciadas não só pelas condições atmosféricas como pela tendência de aumento da concentração de $\mathrm{O}_{3}$ na RMSP. Por outro lado, os meses de agosto de 1999 e março de 2002, anteriormente considerados como da classe 1 , após a remoção da tendência no período, passaram a constituir a classe 2 . Assim, pode-se concluir a partir desta análise que a tendência de aumento do poluente na RMSP mascara não só a real variabilidade mensal das concentrações de $\mathrm{O}_{3}$ como também a importância relativa das altas concentrações de cada mês na série temporal estudada.

Já para as anomalias negativas (classes -1 e -2 ), foram observados um número menor de casos, como se pode ver pela tabela 21 : 
Tabela 21: Meses com valor médio da anomalia das concentrações de $\mathrm{O}_{3}$ inferior a $-1 \sigma$ do mês correspondente (classe -1 ).

\begin{tabular}{|l|l|l|l|l|l|l|l|l|l|l|l|l|}
\hline Mês & $\begin{array}{l}{\left[\mathrm{O}_{3}\right]} \\
\mathrm{Hg} / \mathrm{m}^{3}\end{array}$ & $\begin{array}{l}\text { Anom } \\
{\left[\mathrm{O}_{3}\right]}\end{array}$ & $\begin{array}{l}\text { Rad } \\
\text { W/m }\end{array}$ & $\begin{array}{l}\text { Anom } \\
\text { Rad }\end{array}$ & $\begin{array}{l}\text { Temp } \\
{ }^{\circ} \mathrm{C}\end{array}$ & $\begin{array}{l}\text { Anom } \\
\text { Temp }\end{array}$ & $\begin{array}{l}\text { UR } \\
\%\end{array}$ & $\begin{array}{l}\text { Anom } \\
\text { UR }\end{array}$ & $\begin{array}{l}\text { Pres } \\
\text { Mb }\end{array}$ & $\begin{array}{l}\text { Anom } \\
\text { Pres }\end{array}$ & $\begin{array}{l}\mathrm{ROL} \\
\text { W/m }\end{array}$ & $\begin{array}{l}\text { Anom } \\
R O L\end{array}$ \\
\hline $\begin{array}{l}\text { Set } \\
\mathbf{1 9 9 7}\end{array}$ & 22,4 & $-6,9$ & 232,4 & $+7,1$ & 19,9 & $+2,0$ & 71,6 & $-8,2$ & 950,2 & $-2,6$ & 259,1 & $+0,6$ \\
\hline $\begin{array}{l}\text { Nov } \\
\mathbf{1 9 9 7}\end{array}$ & 25,5 & $-6,9$ & 254,3 & $-31,2$ & 21,6 & $+1,7$ & 84,1 & $+2,7$ & 949,1 & $+0,0$ & 238,4 & $-17,1$ \\
\hline $\begin{array}{l}\text { Dez } \\
\mathbf{1 9 9 7}\end{array}$ & 25,3 & $-4,9$ & 274,2 & $-1,61$ & 22,6 & $+1,2$ & 82,9 & $-1,0$ & 948,8 & $+0,6$ & 241,0 & $-3,8$ \\
\hline $\begin{array}{l}\text { Mar } \\
\mathbf{1 9 9 8}\end{array}$ & 19,0 & $-5,7$ & 211,2 & $-19,74$ & 22,0 & $+0,9$ & 87,6 & $+1,7$ & 950,5 & $+0,6$ & 235,5 & $-13,1$ \\
\hline $\begin{array}{l}\text { Abr } \\
\mathbf{1 9 9 8}\end{array}$ & 16,8 & $-6,5$ & 207,4 & $+2,2$ & 20,4 & $+0,8$ & 86,8 & $+0,4$ & 951,1 & $-0,3$ & 262,6 & $+1,2$ \\
\hline $\begin{array}{l}\text { Ago } \\
\mathbf{1 9 9 8}\end{array}$ & 23,8 & $-2,8$ & 180,5 & $-21,21$ & 18,8 & $+1,4$ & 80,5 & $+4,4$ & 953,2 & $-1,3$ & 257,0 & $-10,4$ \\
\hline $\begin{array}{l}\text { Mai } \\
\mathbf{2 0 0 1}\end{array}$ & 13,8 & $-2,9$ & 160,4 & $-11,83$ & 17,0 & $-0,8$ & 84,7 & $+0,2$ & 952,1 & $-0,6$ & 256,2 & $-8,0$ \\
\hline $\begin{array}{l}\text { Jan } \\
\mathbf{2 0 0 4}\end{array}$ & 20,0 & $-7,3$ & 236,0 & $-23,6$ & 20,7 & $-1,1$ & 85,3 & $+0,3$ & 948,2 & $-0,0$ & 233,6 & $-1,8$ \\
\hline $\begin{array}{l}\text { Jun } \\
\mathbf{2 0 0 4}\end{array}$ & 13,2 & $-4,4$ & 155,3 & $-2,7$ & 15,8 & $-0,4$ & 80,2 & $-2,1$ & 956,2 & $+1,7$ & 260,3 & $-4,9$ \\
\hline $\begin{array}{l}\text { Dez } \\
\mathbf{2 0 0 4}\end{array}$ & 25,9 & $-4,3$ & 288,5 & $+12,7$ & 20,5 & $-0,8$ & 82,8 & $-1,1$ & 949,1 & $+0,9$ & 248,5 & $+3,5$ \\
\hline $\begin{array}{l}\text { Jun } \\
\mathbf{2 0 0 5}\end{array}$ & 12,3 & $-5,2$ & 163,5 & $+5,3$ & 17,6 & $+1,2$ & 74,6 & $-7,7$ & 955,0 & $+0,5$ & 263,9 & $-1,41$ \\
\hline $\begin{array}{l}\text { Jul } \\
\mathbf{2 0 0 5}\end{array}$ & 13,7 & $-5,7$ & 176,3 & $+11,4$ & 15,7 & $-0,53$ & 76,2 & $-3,4$ & 956,7 & $+1,4$ & 274,1 & $+9,4$ \\
\hline $\begin{array}{l}\text { Set } \\
\mathbf{2 0 0 5}\end{array}$ & 23,2 & $-6,1$ & 216,0 & $-9,2$ & 17,4 & $-0,4$ & 82,1 & $+2,2$ & 953,5 & $+0,6$ & 252,5 & $-6,0$ \\
\hline $\begin{array}{l}\text { Dez } \\
\mathbf{2 0 0 5}\end{array}$ & 26,0 & $-4,2$ & 297,6 & $+21,8$ & 19,9 & $-1,4$ & 83,7 & $-0,2$ & 948,7 & $+0,5$ & 260,6 & $+15,7$ \\
\hline
\end{tabular}

Tabela 22: Meses com valor mensal da anomalia das concentrações de $\mathrm{O}_{3}$ inferiores $a-1,5 \sigma$ do mês correspondente (classe -2 ). 


\begin{tabular}{|l|l|l|l|l|l|l|l|l|l|l|l|l|}
\hline Whês & {$\left[\begin{array}{l}{\left[\mathrm{O}_{3}\right]} \\
\mu \mathrm{g} / \mathrm{m}^{3}\end{array}\right.$} & $\begin{array}{l}\text { Anom } \\
{\left[\mathrm{O}_{3}\right]}\end{array}$ & $\begin{array}{l}\text { Rad } \\
\text { W/m }\end{array}$ & $\begin{array}{l}\text { Anom } \\
\text { Rad }\end{array}$ & $\begin{array}{l}\text { Temp } \\
\circ \mathrm{C}\end{array}$ & $\begin{array}{l}\text { Anom } \\
\text { Temp }\end{array}$ & $\begin{array}{l}\text { UR } \\
\%\end{array}$ & $\begin{array}{l}\text { An } \\
\text { UR }\end{array}$ & $\begin{array}{l}\text { Pres } \\
\mathrm{mb}\end{array}$ & $\begin{array}{l}\text { Anom } \\
\text { Pres }\end{array}$ & $\begin{array}{l}\mathrm{ROL} \\
\mathrm{W} / \mathrm{m}^{2}\end{array}$ & $\begin{array}{l}\text { Anom } \\
\mathrm{ROL}\end{array}$ \\
\hline $\begin{array}{l}\text { Abr } \\
\mathbf{1 9 9 8}\end{array}$ & 16,8 & $-6,5$ & 207,4 & $+2,2$ & 20,4 & $+0,8$ & 86,8 & $+0,4$ & 951,1 & $-0,3$ & 262,6 & $+1,2$ \\
\hline $\begin{array}{l}\mathrm{Jul} \\
\mathbf{2 0 0 5}\end{array}$ & 13,7 & $-5,7$ & 176,3 & $+11,4$ & 15,7 & $-0,5$ & 76,2 & $-3,4$ & 956,7 & $+1,4$ & 274,1 & $+9,4$ \\
\hline
\end{tabular}

A análise de intensidade das anomalias negativas das concentrações de $\mathrm{O}_{3}$ permitiu verificar que em nenhum dos meses foi observada anomalia inferior a $-2 \sigma$, desta forma, o rigor para se classificar os meses de acordo com a intensidade da anomalia foi reduzido. Os meses que apresentaram anomalias negativas inferiores a $-1,5 \sigma$ foram enquadrados na classe -2 . Mesmo assim, apenas dois meses foram classificados como tal: abril de 1998 e julho de 2005. Esses dois meses serão discutidos posteriormente com mais detalhes.

Do período avaliado (1996-2005), 14 meses foram enquadrados como de classe -1 , ou seja, com anomalias das concentrações de $\mathrm{O}_{3}$ inferiores a $-1 \sigma$, o que equivaleu a $12 \%$ do total de meses da série temporal. Os casos da classe -1 foram $35 \%$ menos freqüentes do que os da classe 1 . Assim como foi feito com os meses com anomalias positivas, foi adotada uma classificação interna para diferenciar os meses com anomalias negativas mais intensas. Os meses de abril/1998 e julho/2005, identificados em azul, foram considerados de classe -2 (tabela 22). Outros meses com desvio negativo significativo são novembro/1997 e janeiro/2004, identificados em verde na tabela 21.

A Figura 56 evidencia um maior número de casos da classe -1 nos anos em que foi observada a menor quantidade de casos na classe 1 , o que aconteceu nos extremos da série temporal (anos 1997, 1998, 2004 e 2005). Observa-se que os casos da classe -1 são inferiores aos da classe 1 , indicando que no caso de anomalias negativas das concentrações de $\mathrm{O}_{3}$, parte considerável dos casos apresenta valores entre a média e $-1 \sigma$. 


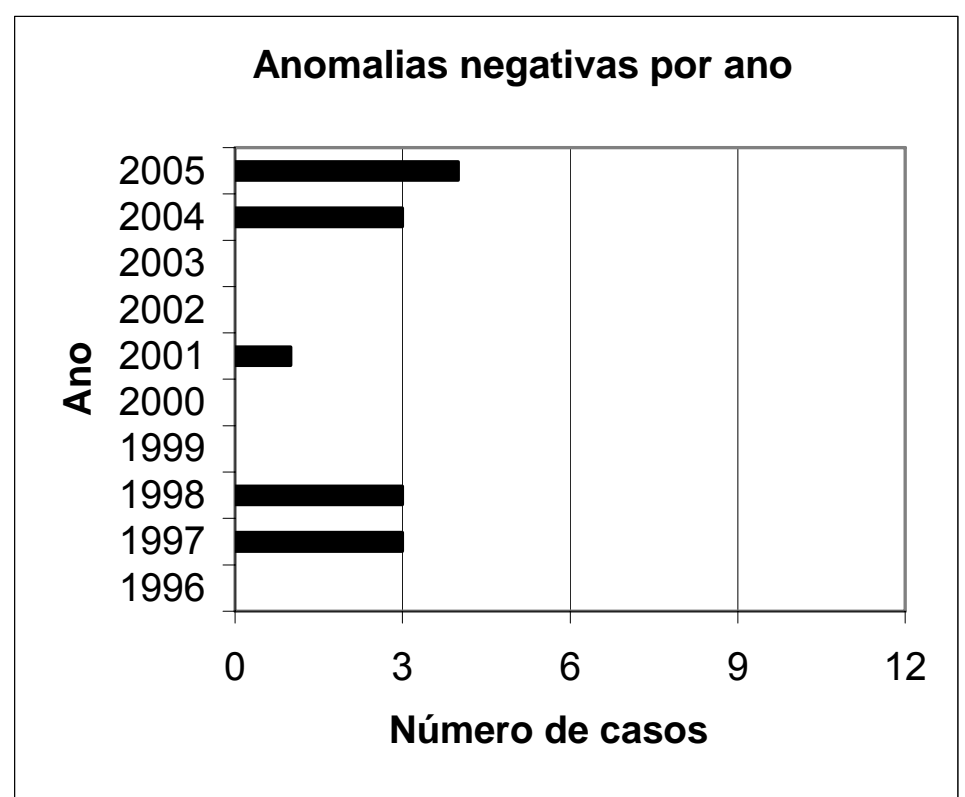

Figura 56: Distribuição anual do número de anomalias das concentrações de $\mathrm{O}_{3}$ com valor inferior $a-1 \sigma$.

Foram registrados três casos de anomalias negativas inferiores a $-1 \sigma$ nos anos extremos da série temporal, 1997, 1998, 2004, e 4 casos em 2005 (Figura 56), em contraste com as anomalias positivas, que foram registradas principalmente entre os anos de 1999 e 2003 (Figura 56). Em 2001 foi observado um único caso de anomalia inferior a $-1 \sigma$, no mês de maio. Nos demais anos não foram registradas anomalias negativas das concentrações de $\mathrm{O}_{3}$ inferiores $\mathrm{a}-1 \sigma$, ou seja, não houve $o$ registro de nenhum caso nas classes -1 e -2 , tal como mostrado na Tabela 21 .

O mês com o maior número de casos é dezembro. Não houve ocorrência de anomalias inferior a $-1 \sigma$ nos meses de outubro e fevereiro, como se pode ver pela figura 57 : 


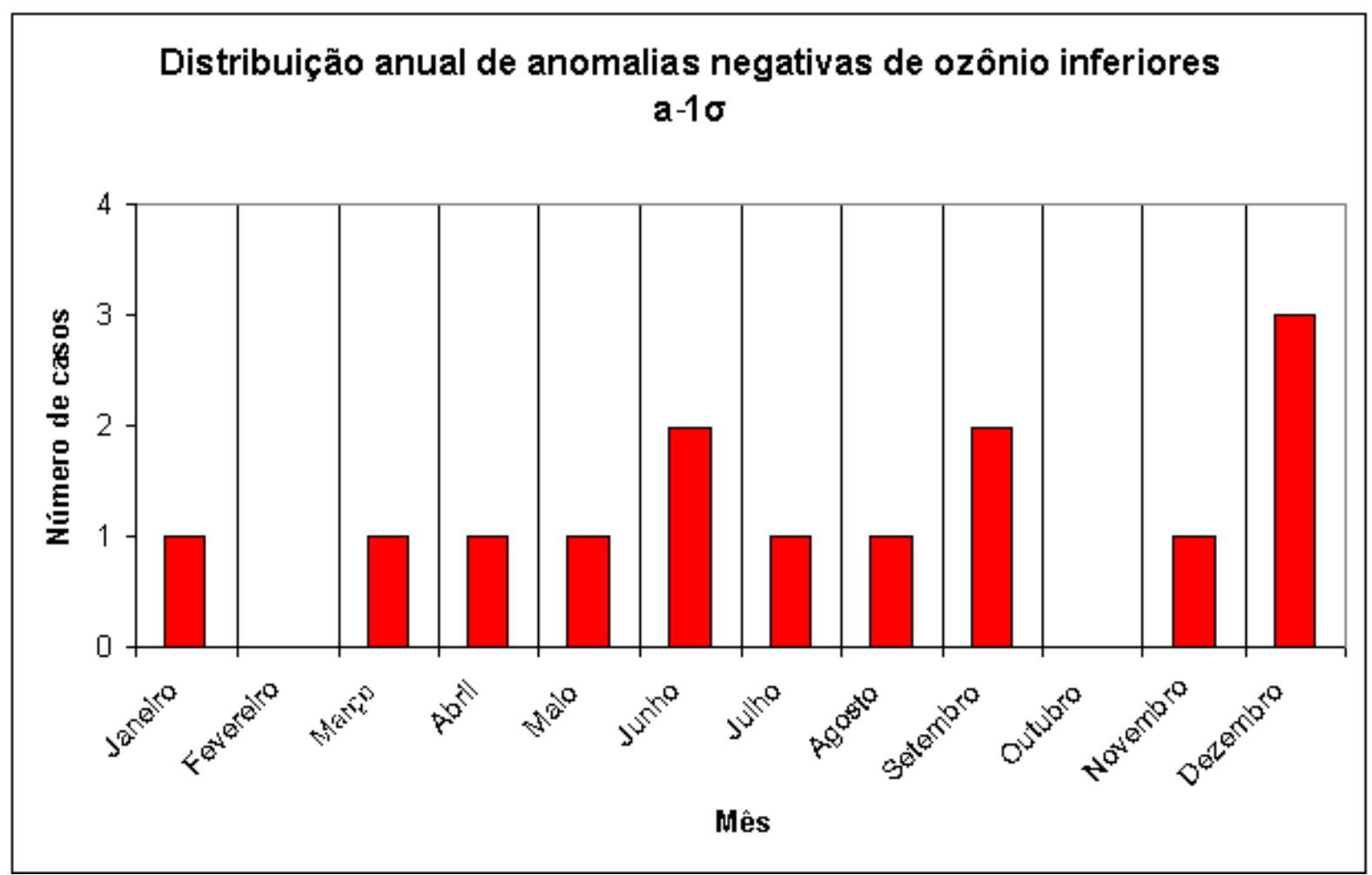

Figura 57: Distribuição mensal das anomalias positivas de ozônio superiores a $1 \sigma$, na série 1996-2005, considerando as 17 estações.

A Tabela 23 mostra a ocorrência das anomalias climáticas que acompanham as anomalias de classe -1 das concentrações de $\mathrm{O}_{3}$ :

Tabela 23: Anomalias climáticas nos meses em que foram registradas anomalias positivas de $\mathrm{O}_{3}$ superiores a $1 \sigma$.

\begin{tabular}{|c|c|c|c|}
\hline Variável Climâtíca & Positiva & Negativa & Nula \\
\hline Radiação Solar & 06 & 08 & - \\
\hline Temperatura do ar & 07 & 07 & - \\
\hline Umidade Relativa & 07 & 07 & - \\
\hline Pressão Atmosférica & 08 & 05 & - \\
\hline Radiação de Onda Longa & 05 & 09 & - \\
\hline
\end{tabular}

Em primeira aproximação, observa-se que as anomalias das variáveis climáticas associadas aos casos de anomalias negativas das concentrações de $\mathrm{O}_{3}$ inferiores a $-1 \sigma$ não sugerem uma influência tão significativa nas concentrações de ozônio, em relação ao que foi observado no caso das anomalias positivas das concentrações de $\mathrm{O}_{3}$. As variáveis TEMP e UR, por exemplo, apresentam a mesma quantidade de anomalias positivas e negativas (7 casos) quando da ocorrência de 
anomalias negativas das concentrações de $\mathrm{O}_{3}$ inferiores a $-1 \sigma$. O número de casos com anomalia de RAD negativa é ligeiramente maior (8 casos; $57 \%$ ) do que o número de casos com anomalia positiva desta variável ( 6 casos). Para a variável PNM, foram registrados 8 casos com anomalias positivas e 5 casos com anomalias negativas, indicando um padrão de comportamento semelhante ao observado com as anomalias positivas de ozônio, e, portanto, contrário ao esperado com relação às menores concentrações de $\mathrm{O}_{3}$ observadas nestes casos. A variável que se comportou de maneira mais definida em relação às menores concentrações de $\mathrm{O}_{3}$ foi ROL, que apresentou anomalias negativas em 9 dos 14 casos, ou seja, em 64\% dos casos, indicando a maior presença de nebulosidade. Isso, por sua vez, pode ter provocado um impacto mais significativo na formação e concentração de $\mathrm{O}_{3}$.

De acordo com a tabela 23 , percebe-se que a anomalia mais baixa de RAD ocorreu em novembro de 1997, com $-31,27 \mathrm{~W} / \mathrm{m}^{2}$, e a mais alta, em dezembro de 2005, com $+21,85 \mathrm{~W} / \mathrm{m}^{2}$. A PNM apresentou a anomalia mais baixa, $-2,65 \mathrm{hPa}$, em setembro de 1997 , e a mais alta, $+1,75 \mathrm{hPa}$, em junho de 2004. Para a ROL, a anomalia mais baixa da série ocorreu em novembro de 1997 , com $-17,19 \mathrm{~W} / \mathrm{m}^{2}$, e a mais alta em dezembro de 2005 , com $+15,7 \mathrm{~W} / \mathrm{m}^{2}$.

A anomalia de UR mais alta ocorreu em agosto de $1998,+4,49 \%$, e a mais baixa, em setembro de $1997,-8,28 \%$. A TEMP apresentou a anomalia mais baixa em dezembro de $2005,-1,46^{\circ} \mathrm{C}$, e a mais alta em setembro de $1997,+2,04^{\circ} \mathrm{C}$. As anomalias negativas de RAD, PNM, ROL e UR são mais intensas do que as positivas nos casos de anomalia negativa das concentrações de $\mathrm{O}_{3}$ inferiores a $-1 \sigma$, e as anomalias positivas de TEMP são mais intensas do que as negativas. Assim, estas observações sugerem que as anomalias negativas de RAD e ROL influenciem de maneira mais significativa as anomalias negativas das concentrações de $\mathrm{O}_{3}$, concordando com o que foi observado para as anomalias positivas.

Ainda dentre os casos com anomalias negativas das concentrações de $\mathrm{O}_{3}$ inferiores a $-1 \sigma$, foi observado o mesmo número de casos de anomalias positivas $\mathrm{e}$ negativas de UR e TEMP. Contudo, as anomalias positivas de TEMP são mais 
intensas que as negativas e no caso da UR, as anomalias negativas são mais intensas.

De todos os meses enquadrados na classe -2 anteriormente à remoção da tendência de aumento das concentrações de $\mathrm{O}_{3}$ da série temporal, o mês de abril de 1998 foi o único que permaneceu com esta classificação. Isso significa que neste mês as concentrações foram realmente baixas, independentemente da tendência positiva. Com a remoção da tendência existente na série, além da permanência deste mês como anômalamente negativo, percebeu-se que o mês julho de 2005 pôde ser enquadrado na classe -2, cujo comportamento anômalo e negativo esteve anteriormente mascarado pela tendência de aumento da concentração de $\mathrm{O}_{3}$ na série temporal analisada.

Quando foi analisado o comportamento das variáveis atmosféricas no caso das anomalias positivas das concentrações de $\mathrm{O}_{3}$, chegou-se à conclusão de que as anomalias positivas das concentrações de $\mathrm{O}_{3}$ estão, na maioria das vezes, associadas a anomalias positivas de TEMP, RAD, ROL e PNM, e negativas de UR. Poderia-se esperar então que as anomalias negativas deste poluente fossem acompanhadas por padrões atmosféricos opostos, ou seja, negativos de TEMP, RAD, ROL e PNM e positivos de UR. No entanto, as variáveis atmosféricas nos meses de abril de 1998 e julho de 2005, de classe -2, não se comportam da maneira supostamente esperada, exceto quando se trata das variáveis ROL e RAD, que apresentaram anomalias positivas em ambos os meses. Assim, sugere-se que o aumento da nebulosidade e a diminuição da RAD em superfície têm maior importância na ocorrência de anomalias negativas de ozônio em superfície; contudo, somente o comportamento destas variáveis não é responsável pela determinação das anomalias negativas das concentrações de $\mathrm{O}_{3}$, devendo existir outros mecanismos de remoção do ozônio que atuam no sentido de diminuir sua concentração nestas condições.

A figura 58 ilustra a evolução temporal das anomalias de ozônio, radiação solar e umidade relativa, uma vez que estas foram as variáveis que melhor se correlacionaram com o ozônio nesta escala temporal. 


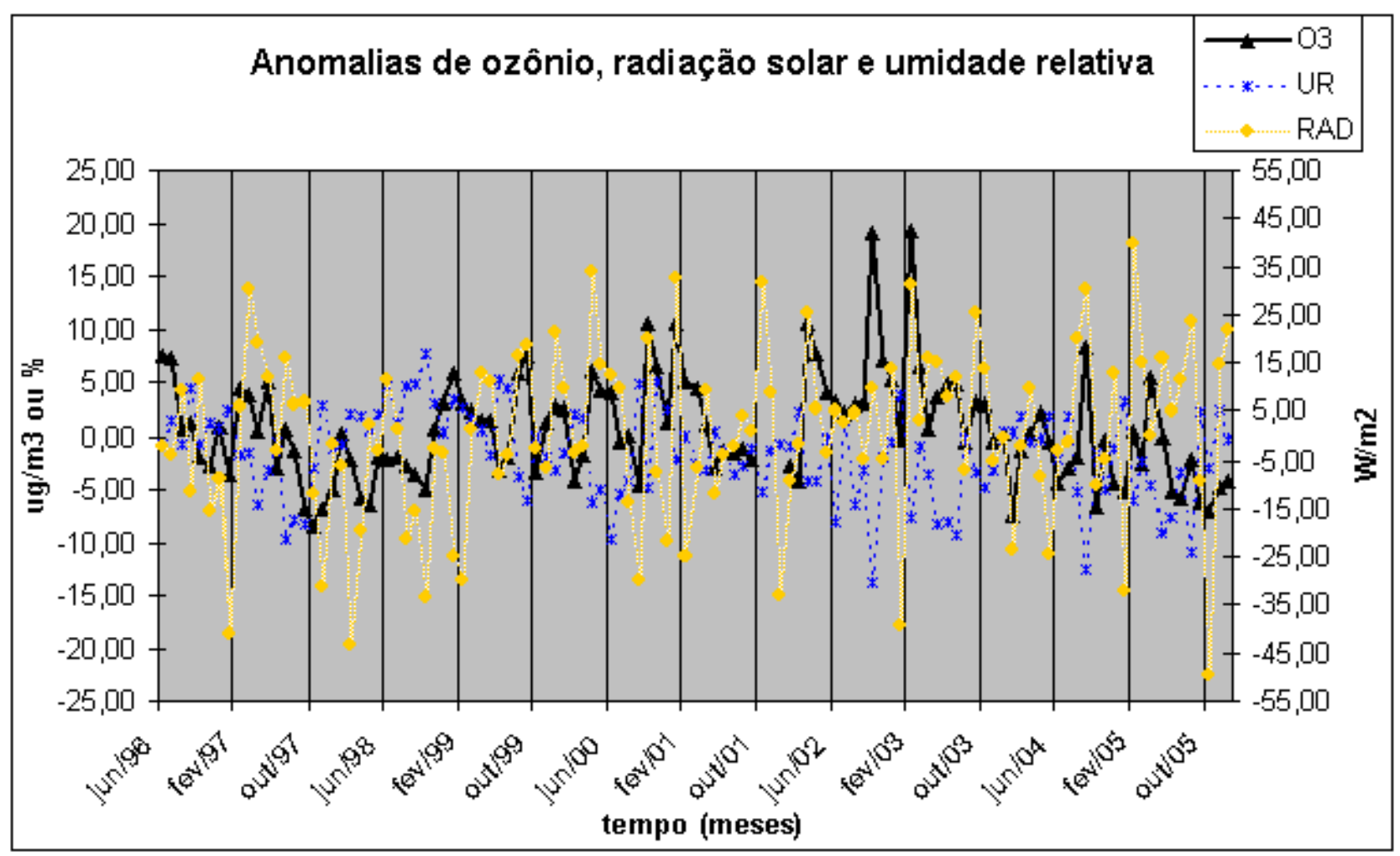

Figura 58: Série temporal das anomalias mensais de ozônio, de radiação solar de ondas curtas e umidade relativa.

Verifica-se pela análise da figura 58 que a maior parte das anomalias positivas de ozônio ocorrem juntamente à anomalias positivas de radiação solar e negativas de umidade relativa. Um padrão oposto pode ser percebido para as anomalias negativas de ozônio - anomalias negativas de radiação solar simultaneamente a anomalias positivas de umidade relativa. $O$ índice de correlação linear de Pearson entre as anomalias mensais de ozônio troposférico e radiação solar foi de 0,42 e de ozônio troposférico e umidade relativa foi de -0,4.

Como conclusão final desta seção, pode-se dizer que a variabilidade de $\mathrm{O}_{3}$ é decorrente, em parte, das condições atmosféricas observadas, principalmente no tocante às anomalias positivas do poluente. Entretanto, também deve-se considerar a tendência da série temporal considerada, que pode mascarar anomalias importantes e suas respectivas interpretações. Por outro lado, em relação às anomalias negativas de ozônio, existem outros processos, provavelmente na química da atmosfera, envolvidos em sua ocorrência. Estes processos estão citados na seção 1.2.1 O ozônio troposférico nas grandes cidades. 
A figura 59 demonstra a série temporal das anomalias mensais de ozônio, após a remoção da tendência.

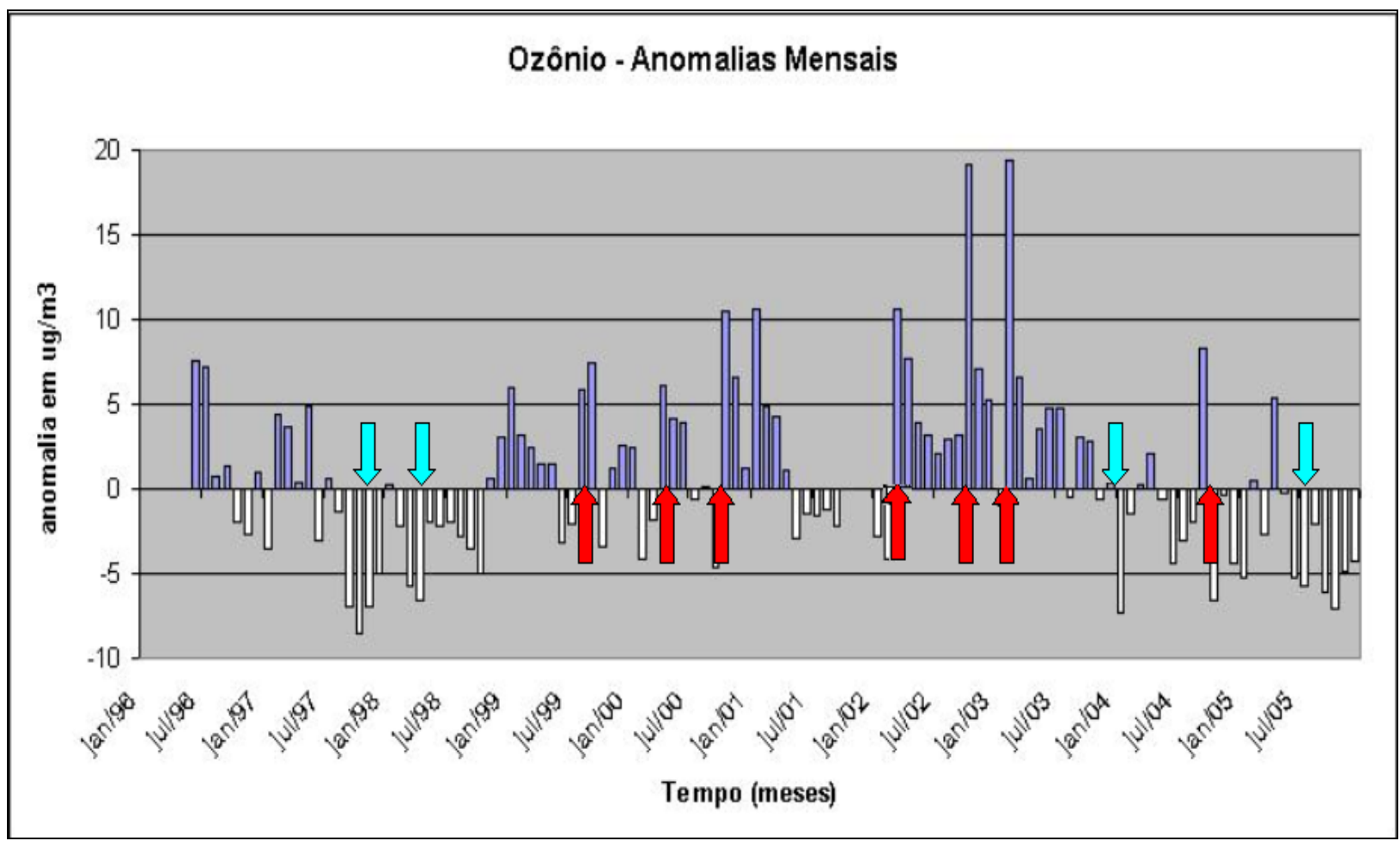

Figura 59: Série Temporal de anomalias das concentrações de $\mathrm{O}_{3}$, considerando as 17 estações. Os meses escolhidos para análise dos padrões atmosféricos estão indicados pelas setas azuis e vermelhas.

Os meses identificados nesta figura são os meses de classe 2 (setas vermelhas) e -2 (azuis), além de alguns cuja anomalia se aproximou bastante dos limiares definidos para estas classes. Para as anomalias negativas, estes meses são novembro de 1997, abril de 1998, janeiro de 2004 e julho de 2005. Para as positivas, são agosto de 1999, abril de 2000, janeiro de 2001, março de 2002, outubro de 2002, fevereiro de 2003 e setembro de 2004. Eles serão discutidos em maiores detalhes na próxima sessão. 


\subsection{Associação de padrões atmosféricos às concentrações de ozônio}

A seguinte seção tem por objetivo analisar os campos atmosféricos mensais médios durante os meses com anomalias positivas e negativas das concentrações de $\mathrm{O}_{3}$ superiores a $2 \sigma$ organizadas nos grupos 2 e -2 , além de alguns meses específicos que serão mencionados. A avaliação destes campos permite um olhar mais completo sobre o comportamento médio da atmosfera nos meses escolhidos, inserindo-os num contexto. Tem o sentido de aprofundar a análise feita na seção anterior, em que foram somente apontadas as anomalias climáticas pontuais que acompanharam as anomalias positivas e negativas das concentrações de $\mathrm{O}_{3}$ sobre a região metropolitana de São Paulo.

Além dos meses de classe 2 e -2, foram também escolhidos os meses de outubro de 2002, janeiro de 2001, abril de 2000 e setembro de 2004, pois embora eles se enquadrem na classe 1 , suas concentrações foram mais altas do que a média do mês e suas anomalias se aproximaram daquelas observadas nos meses de classe 2. Em especial, as excessivas concentrações de ozônio no mês de outubro de 2002 foram responsáveis pela ultrapassagem do PQAr (qualidade do ar Inadequada) e do nível de atenção (qualidade do ar Má) em diversas estações de monitoramento da CETESB, em diversos dias, inclusive nos finais de semana (CETESB, 2003). Além disso, a anomalia das concentrações de $\mathrm{O}_{3}$ registrada neste mês de outubro é mais do que $1,9 \sigma$, aproximando-se bastante das anomalias registradas nos meses de classe 2. De fato, anterior à remoção da tendência da série temporal, este mês pertencia à classe 2. Além destes, os meses de novembro de 1997 e janeiro de 2004 também foram incluídos por apresentarem concentrações baixas, com $\sigma$ próximo dos observados nos meses de classe -2 , num sentido de aumentar o número de casos para análise de meses com concentrações baixas de ozônio.

As seguintes composições foram traçadas em sua maioria para o nível de superfície. Nos casos em que não há indicação na legenda da figura, assume-se que o campo foi traçado para a superfície. A única exceção diz respeito aos campos de divergência do ar e sua respectiva anomalia, que foram traçados para os níveis de 850 e $250 \mathrm{hPa}$, de acordo com o indicado na legenda da figura. 


\title{
3.3.1 Meses com anomalias negativas intensas de ozônio.
}

\begin{abstract}
Abril de 1998
Analisando os campos das variáveis atmosféricas para o mês de abril de 1998 (figuras 61a a 61e) nota-se que não ocorreram grandes anomalias climáticas neste mês, em comparação aos outros meses das classes -2 e +2 . Entretanto, este mês foi caracterizado por anomalias negativas de ROL e pressão em superfície, tal como indicado pelas figuras $61 \mathrm{~b}$ e $61 \mathrm{c}$. Estas anomalias negativas estiveram associadas à maior intensidade das frentes frias ${ }^{8}$ sobre a Região Sul, onde foram observados os maiores valores de anomalia negativa, além do Sudeste do Brasil. Para a região da RMSP, houve ligeira anomalia positiva, de $+2,28 \mathrm{~W} / \mathrm{m}^{2}$, de acordo com a tabela 18 na seção anterior. Embora tenham ocorrido algumas anomalias das variáveis citadas, na região da RMSP as anomalias de todas as variáveis analisadas foram próximas de zero, o que significa uma situação atmosférica mais próxima do esperado para esta região.
\end{abstract}

Não obstante, observa-se uma grande região com anomalias negativas de ROL sobre todo o sul do Brasil, estando associadas à maior estacionariedade de sistemas frontais do que a normal climatológica, de acordo com o boletim da Climanálise de abril de $1998^{12}$.

\footnotetext{
${ }^{12}$ http://www.cptec.inpe.br/products/climanalise/0498/index.html
} 


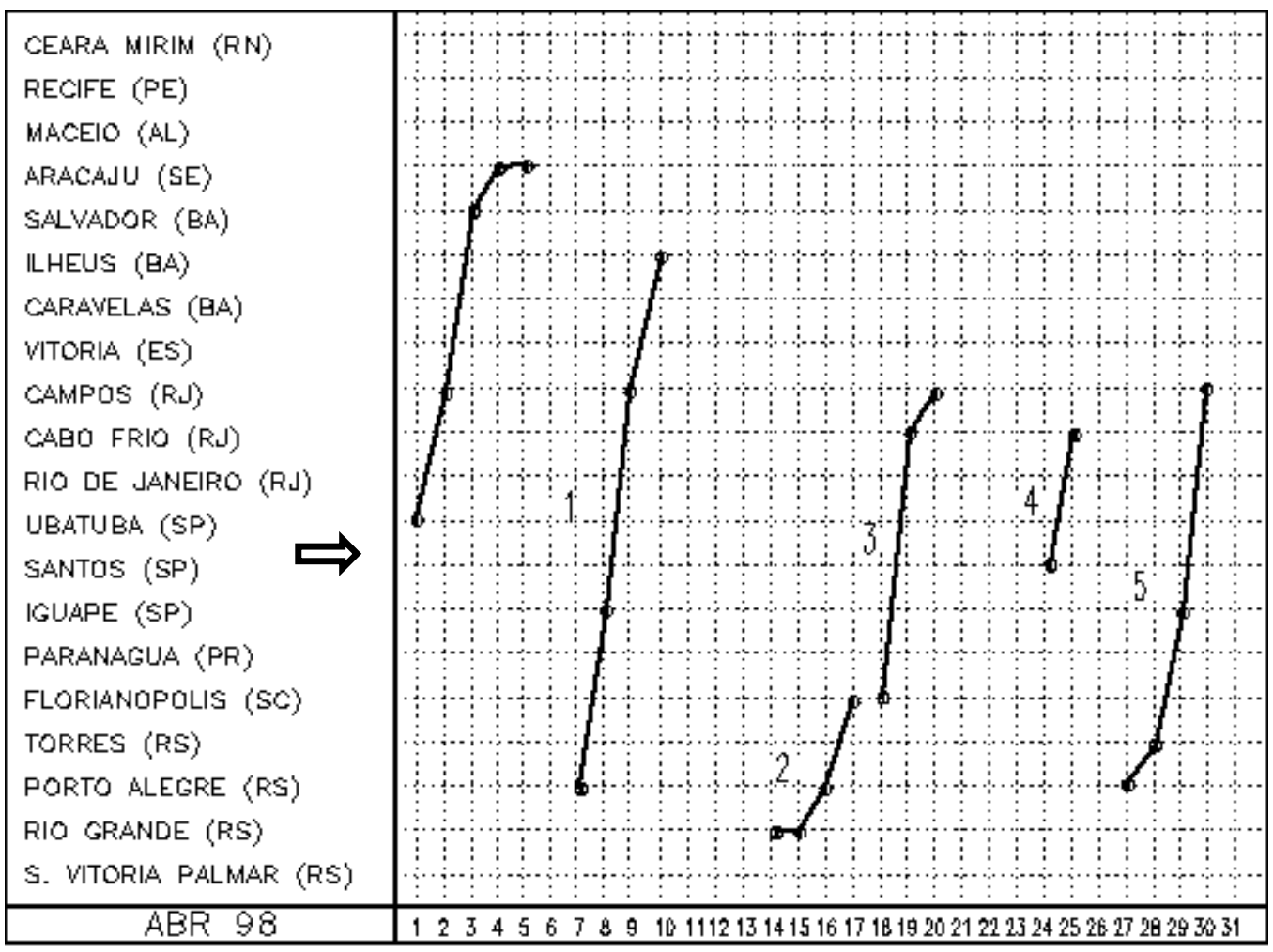

Figura 60: Atuação das frentes frias no litoral do Brasil, abril de 1998. A cidade de Santos está destacada como representante mais próxima da RMSP.

Fonte: http://www.cptec.inpe.br/products/climanalise/0498/index.html

Esta região com anomalias negativas de ROL estende-se até o Estado de São Paulo, indicando maior passagem de sistemas frontais neste mês específico, para esta área. De acordo com o boletim da Climanálise para este mês, quatro sistemas frontais atuaram entre as latitudes $20^{\circ} \mathrm{S}$ e $25^{\circ} \mathrm{S}$, onde se encontra a RMSP. Apesar da média climatológica deste mês para estas latitudes ser de seis sistemas, a maior intensidade destes foi responsável pela ocorrência de maior nebulosidade e chuvas no centro-sul do Brasil neste mês.

Tais aspectos podem ter influenciado os valores negativos de anomalia da concentração de $\mathrm{O}_{3}$ observados neste mês, tal como indicado na tabela 18. A circulação do ar em altitude durante este mês (figura 61e) sustenta as características anômalas de instabilidade atmosférica em baixos níveis. Observa-se que a atmosfera sobre o Estado de São Paulo, particularmente neste mês, é caracterizada como uma região de transição entre os padrões de umidade, ROL e temperatura observados ao Sul (Paraná) e ao Norte(Bahia). 


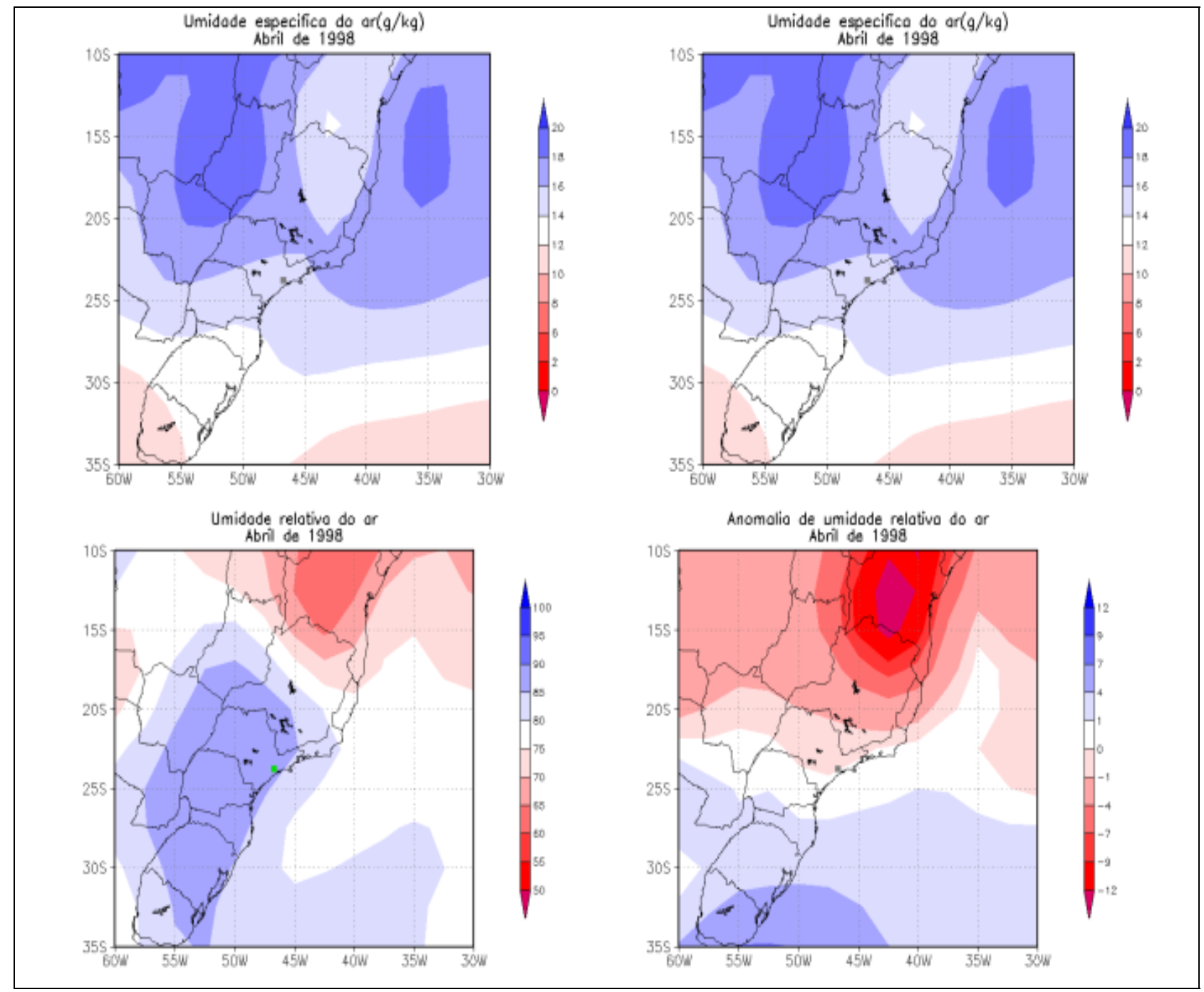

Figura 61a: Umidade relativa e específica do ar em abril de 1998 e suas respectivas anomalias. 


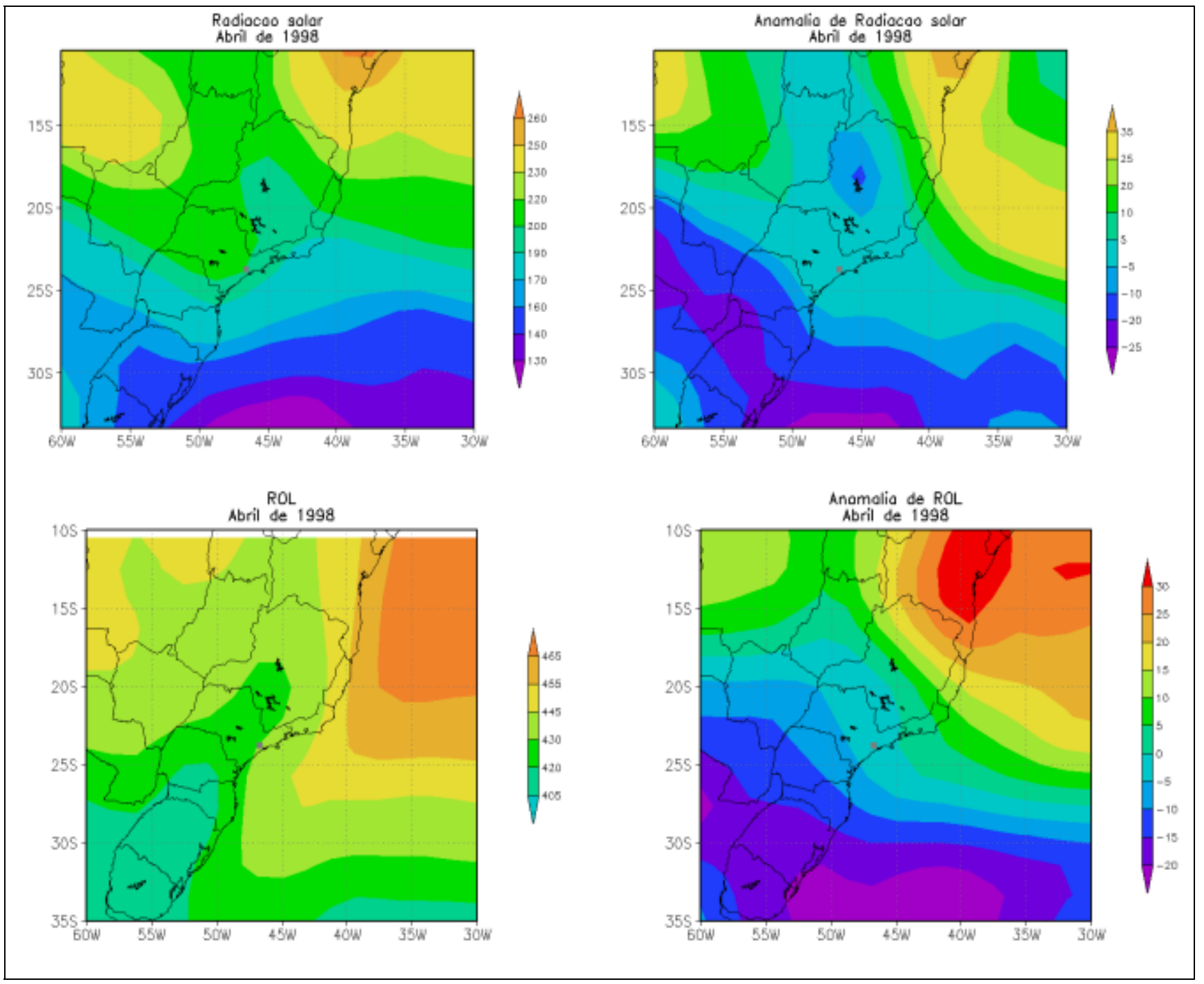

Figura 61b: Radiação solar de ondas curtas e ROL em abril de 1998 e suas respectivas anomalias. 


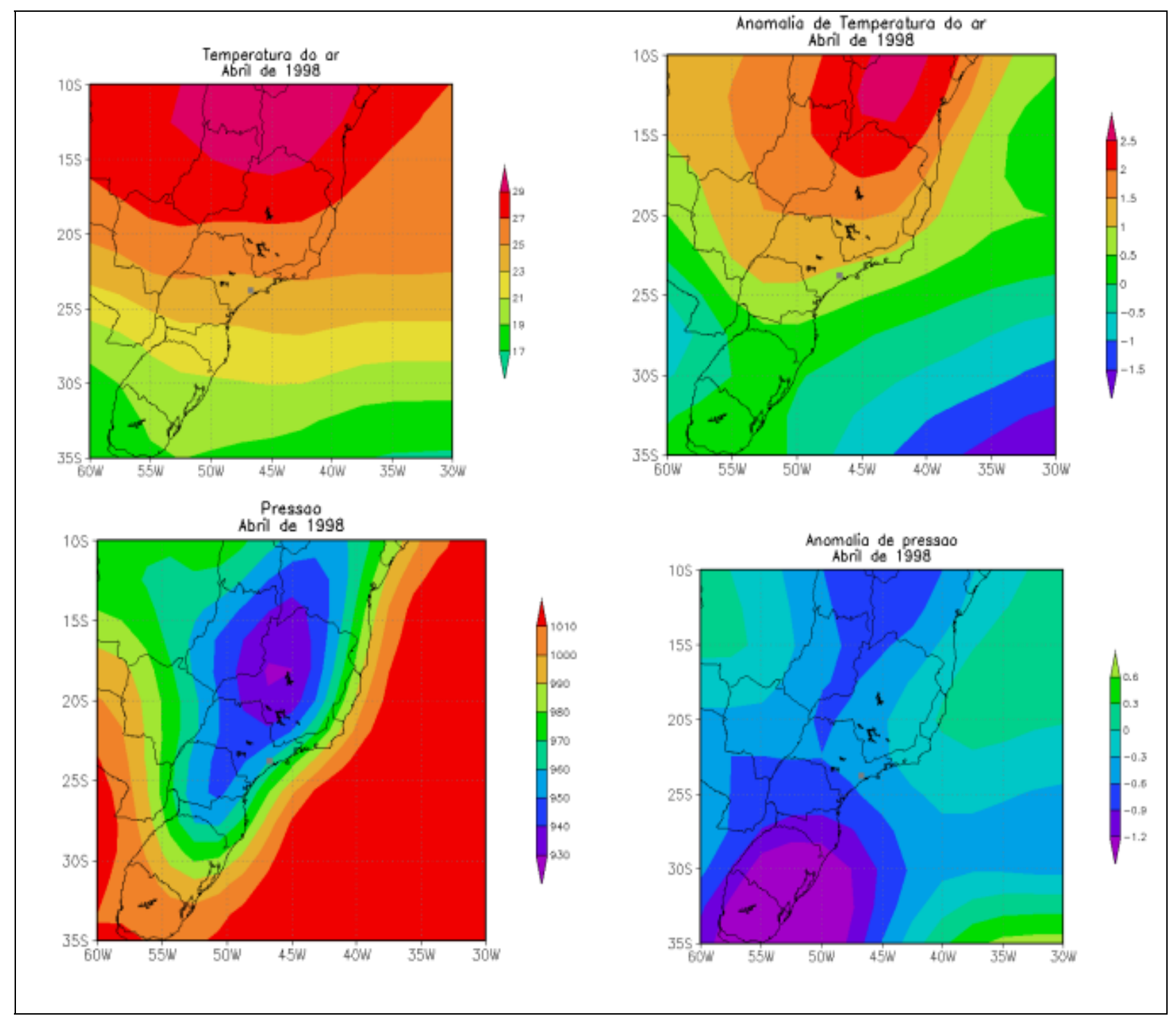

Figura 61c: Temperatura do ar e pressão atmosférica em abril de 1998 e suas respectivas anomalias. 


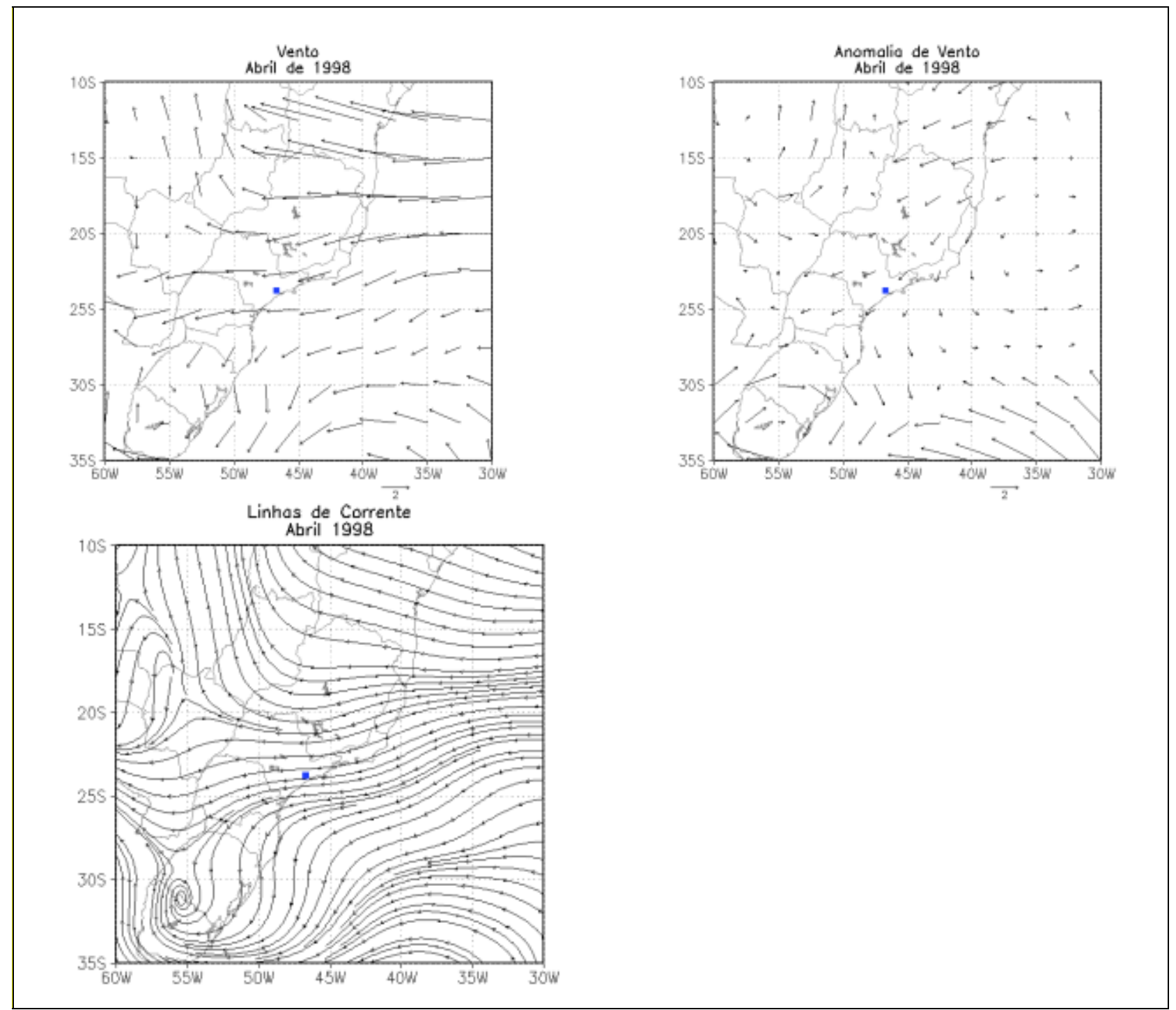

Figura 61d: Escoamento atmosférico e sentido do vento em abril de 1998 e sua respectiva anomalia. 


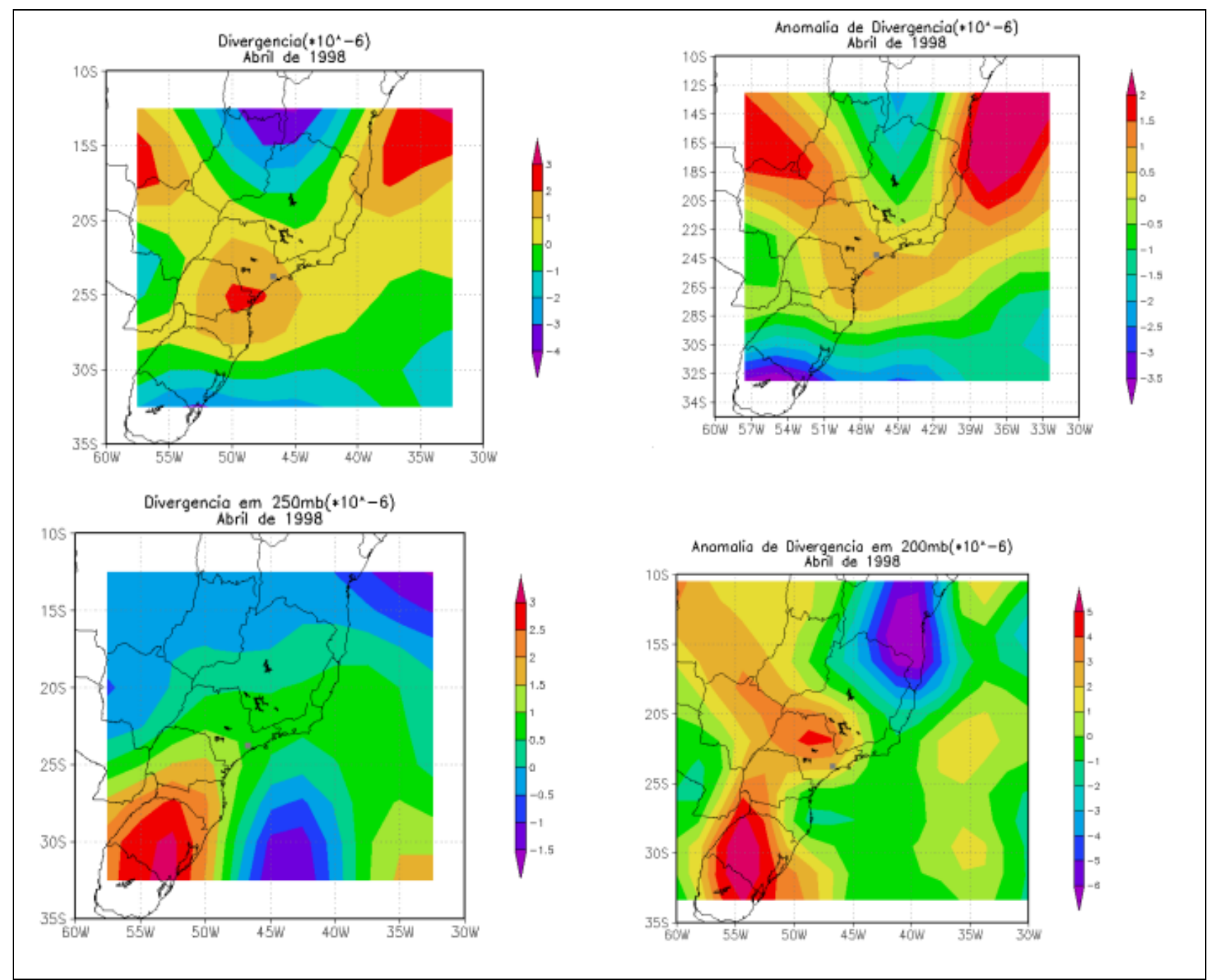

Figura 61e: Divergência do ar em superfície e altitude em abril de 1998 e suas respectivas anomalias. 


\section{Julho de 2005}

As frentes frias que passaram por sobre as Regiões Sul e Sudeste do Brasil no mês de julho de 2005 estiveram associadas a anomalias positivas de divergência em superfície sobre a Região Sul do Brasil, enquanto que nas regiões ao norte do estado do Paraná estas anomalias permanecem próximas de zero (RMSP) ou se tornam negativas (figuras 62e). Este comportamento indica que a Região Sul do País esteve mais associada à atuação de movimentos divergentes em baixos níveis. Os campos de pressão em superfície, ROL e radiação solar sobre o Estado de São Paulo apresentaram neste mês anomalias positivas, e os de temperatura e umidade, anomalias negativas, o que foi determinado pela intensidade das massas de ar frio, com pressões mais altas na retaguarda das frentes frias. Todas as variáveis atmosféricas analisadas para o mês de julho de 2005 estão associadas à maior intensidade dos sistemas frontais que atuaram na Região Sul e Sudeste do País (figuras 62a a 62e).

De fato, segundo o boletim Climanálise para este mês ${ }^{13}$, foram observadas anomalias positivas de precipitação a oeste de São Paulo, causada pela incursão freqüente de sistemas frontais que foram intensos o suficiente para atingirem o interior do Estado. No caso da RMSP, observa-se a passagem de quatro frentes frias pelo mês, bem distribuídas (figura 62).

\footnotetext{
${ }^{13}$ http://www.cptec.inpe.br/products/climanalise/0705/index.html
} 


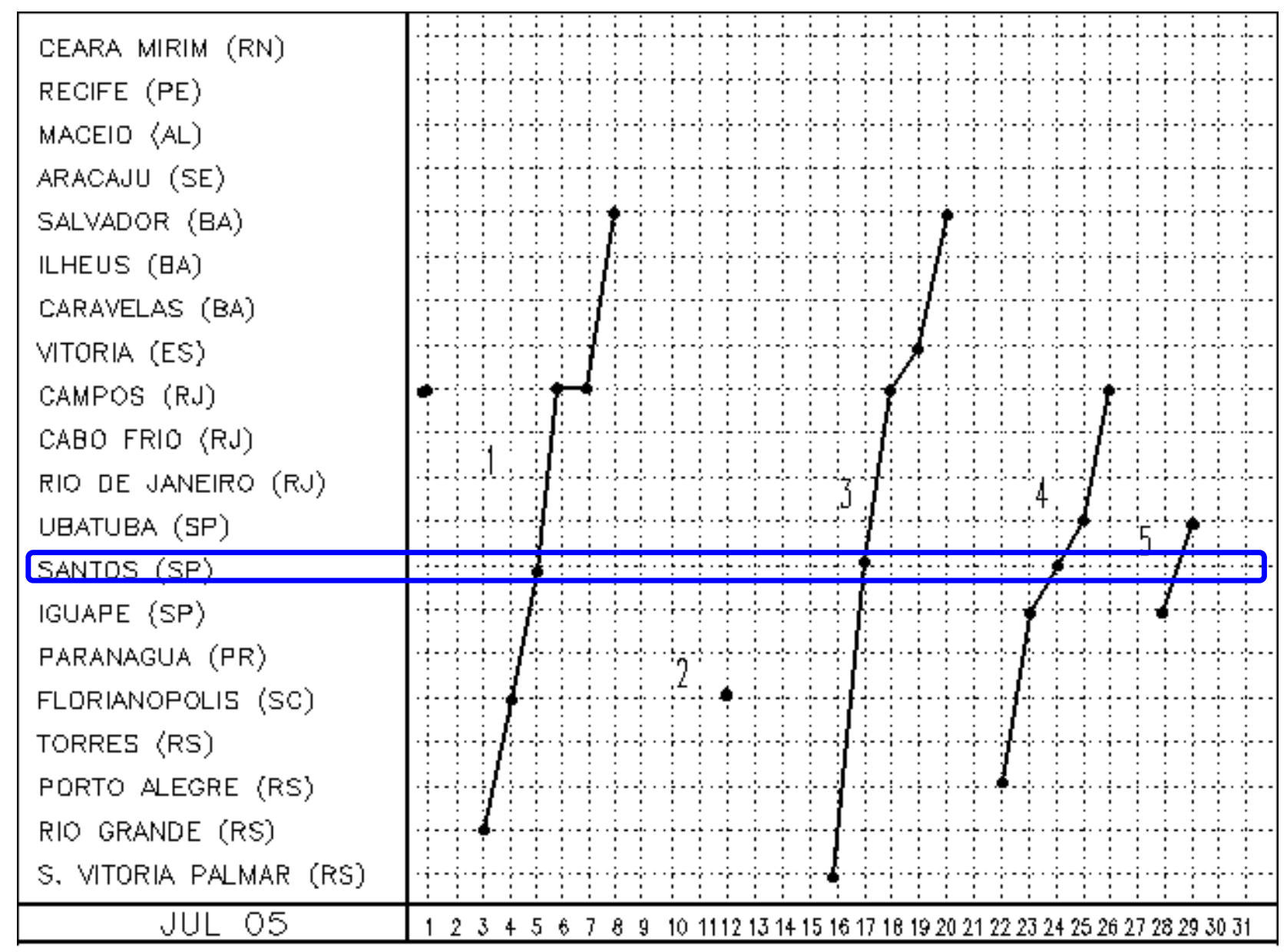

Figura 62: Atuação das frentes frias no litoral do Brasil, julho de 2005. A cidade de Santos está destacada como representante mais próxima da RMSP.

Fonte: http://www.cptec.inpe.br/products/climanalise/0705/index.html

Semelhante ao que foi observado em abril de 1998, houve a atuação de um número inferior ao da média climatológica de frentes frias neste mês (que é de sete sistemas), mas de considerável intensidade, de acordo com o boletim da climanálise para este mês.

Sabe-se que o ciclo anual do $\mathrm{O}_{3}$ inclui um mínimo no período entre maio e julho, que está associado principalmente à diminuição da temperatura e da radiação solar incidente nestes meses. Assim, conclui-se que, mesmo havendo uma pequena anomalia positiva de radiação solar e pouca nebulosidade nestes meses, estes fatores isoladamente não contribuíram para o aumento da concentração de $\mathrm{O}_{3}$ em baixos níveis. Como este mês esteve também associado à freqüente instabilidade em níveis baixos associada às passagens frontais, é mais provável que este aspecto atmosférico tenha contribuído de forma mais determinante para as anomalias negativas de $\mathrm{O}_{3}$. Lembramos aqui que a sugestão das possíveis causas da 
variabilidade do $\mathrm{O}_{3}$ troposférico é feita apenas da ótica do comportamento dos aspectos físico-dinâmicos da atmosfera.
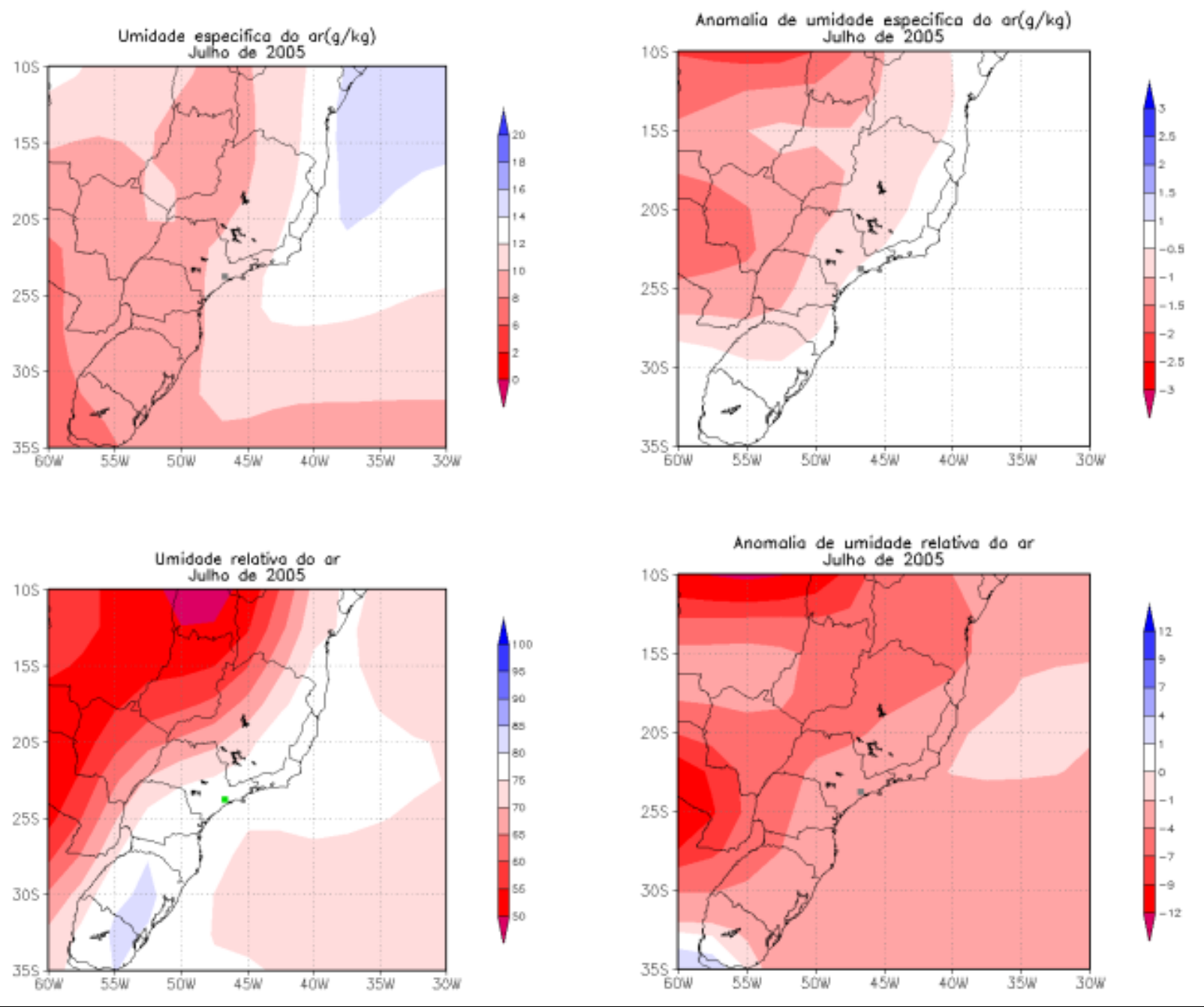

Figura 63a: Umidade relativa e específica do ar em julho de 2005 e suas respectivas anomalias. 

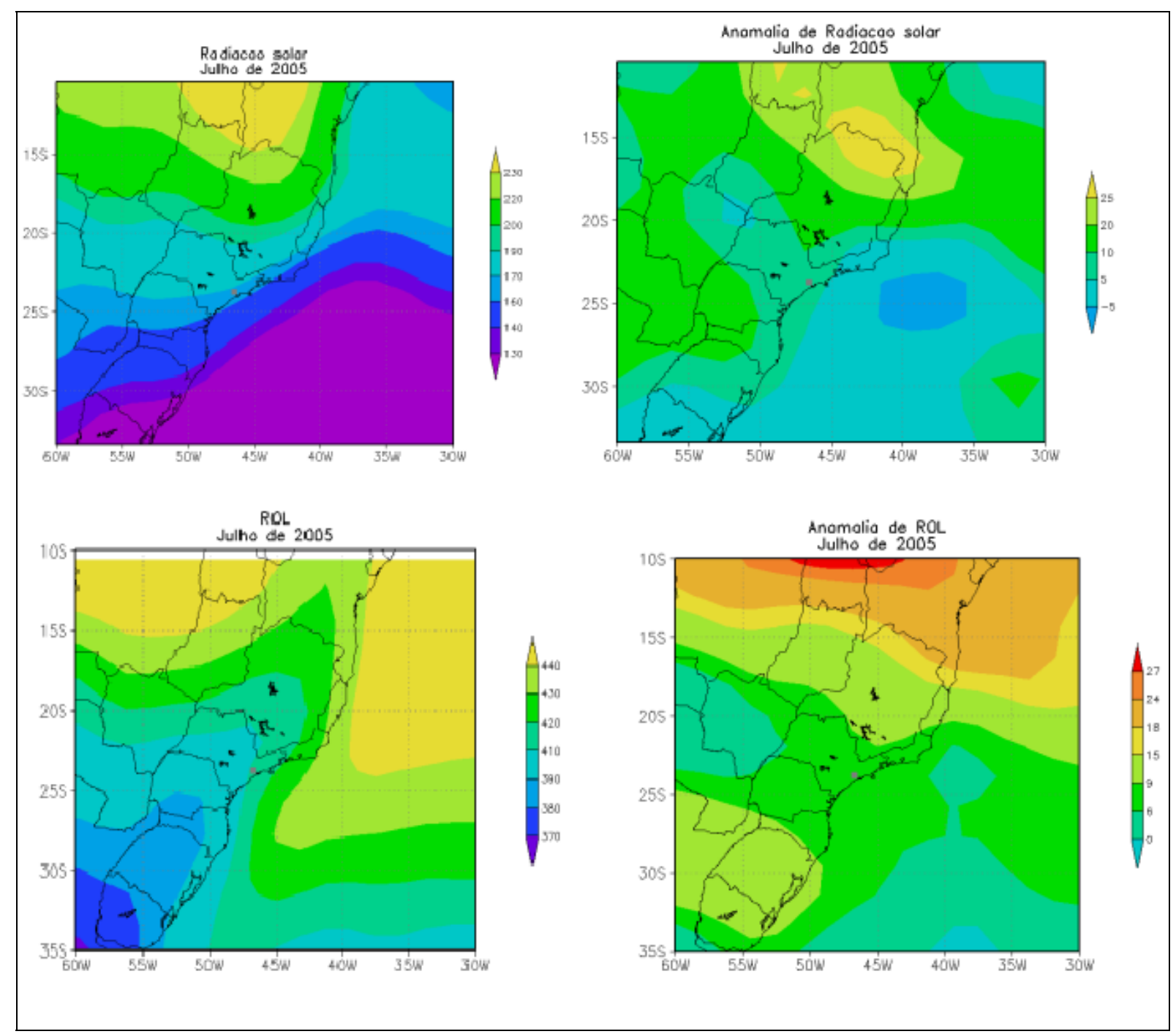

Figura 63b: Radiação solar de ondas curtas e ROL em julho de 2005 e suas respectivas anomalias. 


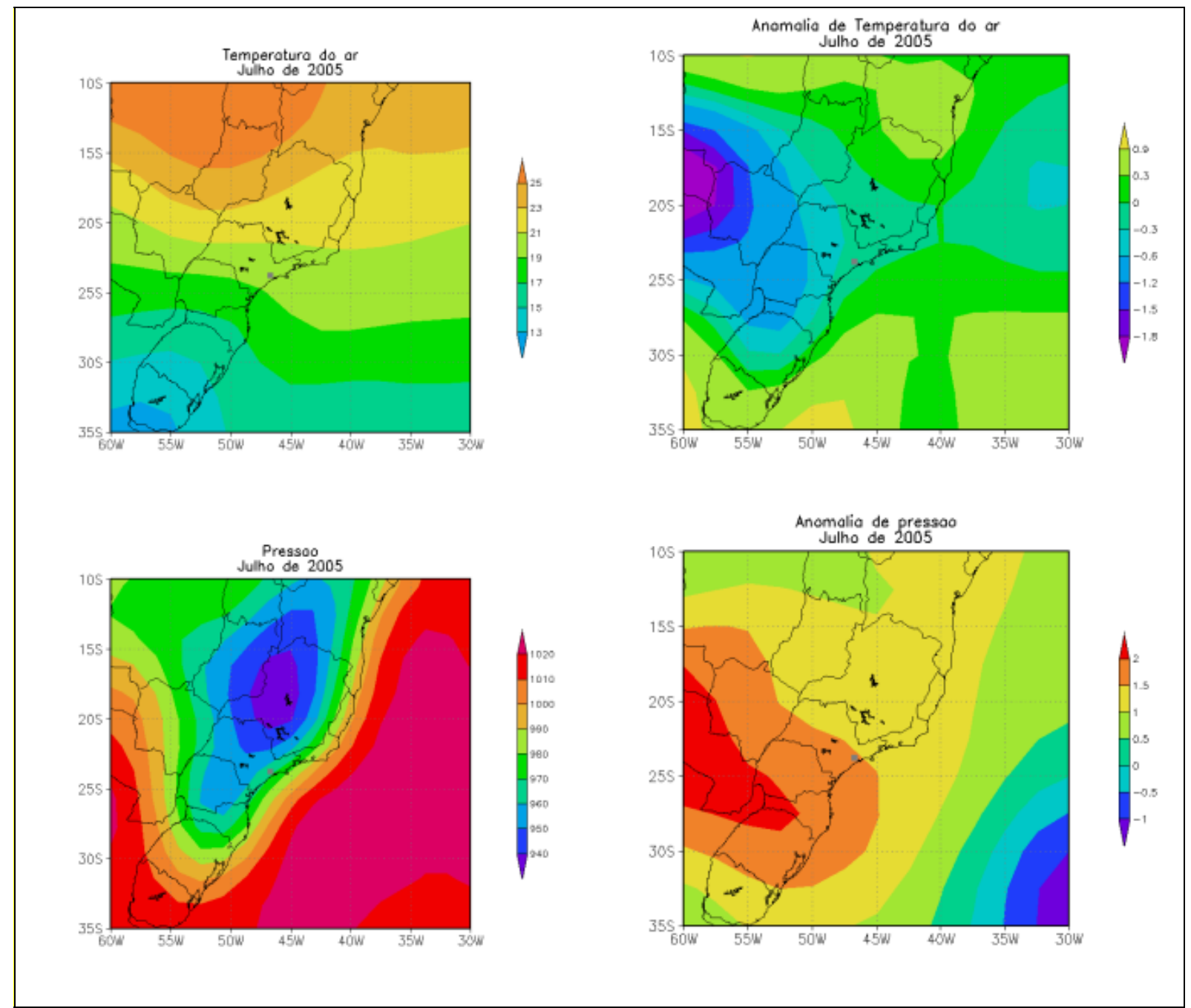

Figura 63c: Temperatura do ar e pressão atmosférica em julho de 2005 e suas respectivas anomalias. 


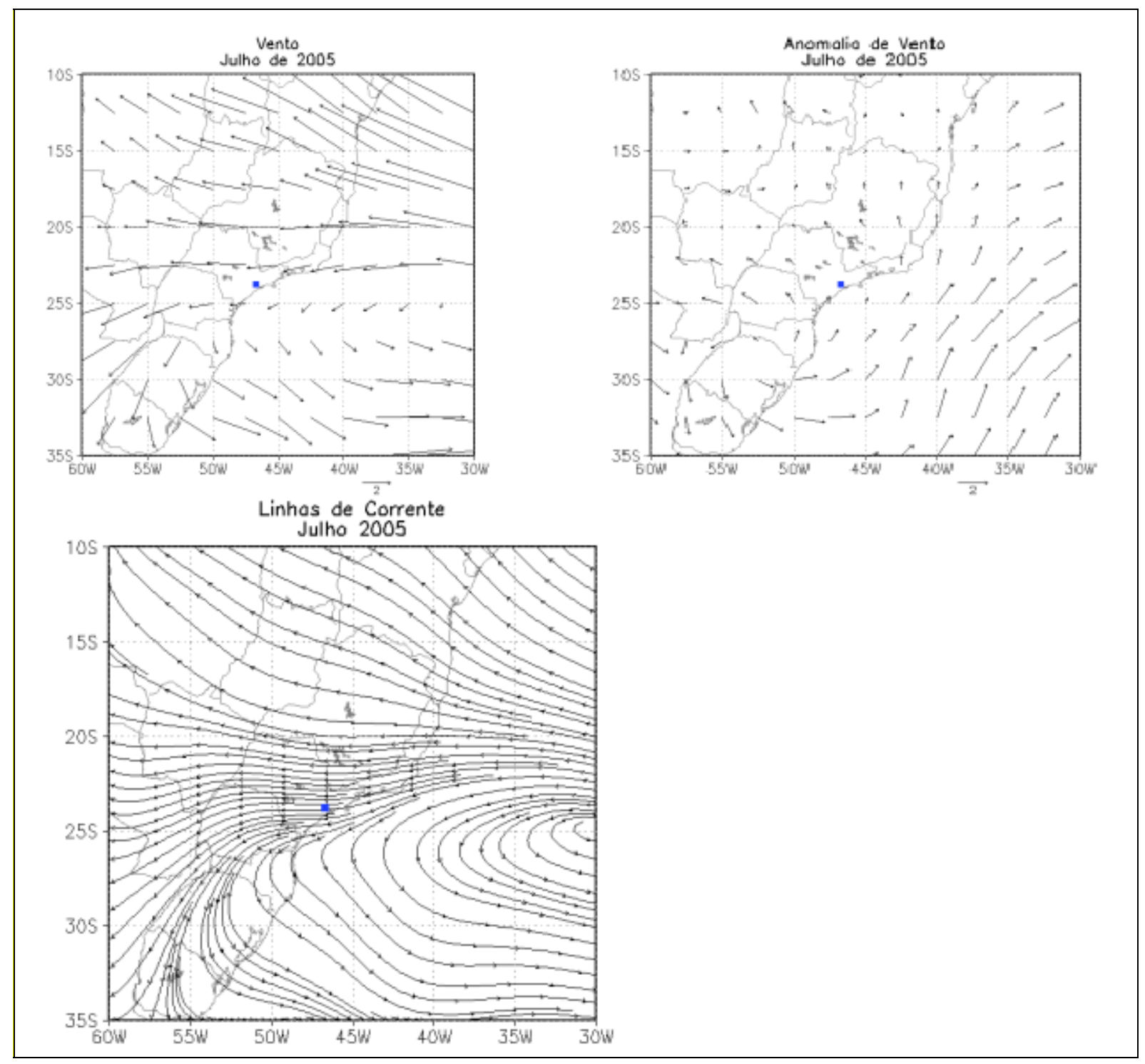

Figura 63d: Escoamento atmosférico e sentido do vento em julho de 2005 e sua respectiva anomalia. 


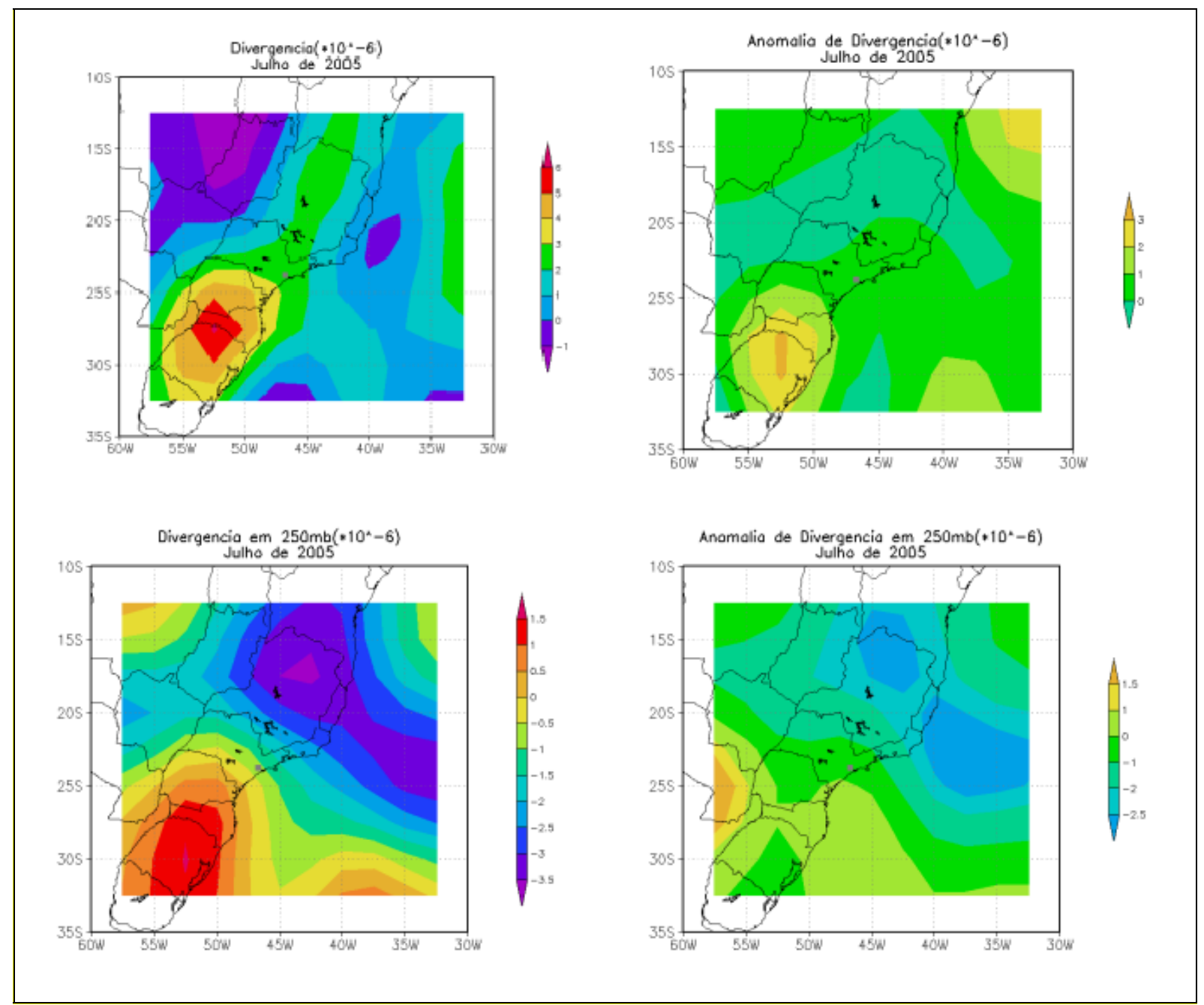

Figura 63e: Divergência do ar em superfície e altitude em julho de 2005 e suas respectivas anomalias. 


\section{Novembro de 1997}

Durante o mês de novembro de 1997 também foram registradas concentrações significativamente baixas, com anomalias próximas do limiar de $1,5 \sigma$, critério adotado para classificação de eventos mais intensos (classe -2 ). Notase pela figura 64 que houve a passagem de sete sistemas frontais neste mês na altura da cidade de Santos que, provavelmente, influenciaram as condições atmosféricas na RMSP, pois a maioria deles deslocou-se para norte da latitude de $23^{\circ} \mathrm{S}$. Este número coincide com a média climatológica do mês.

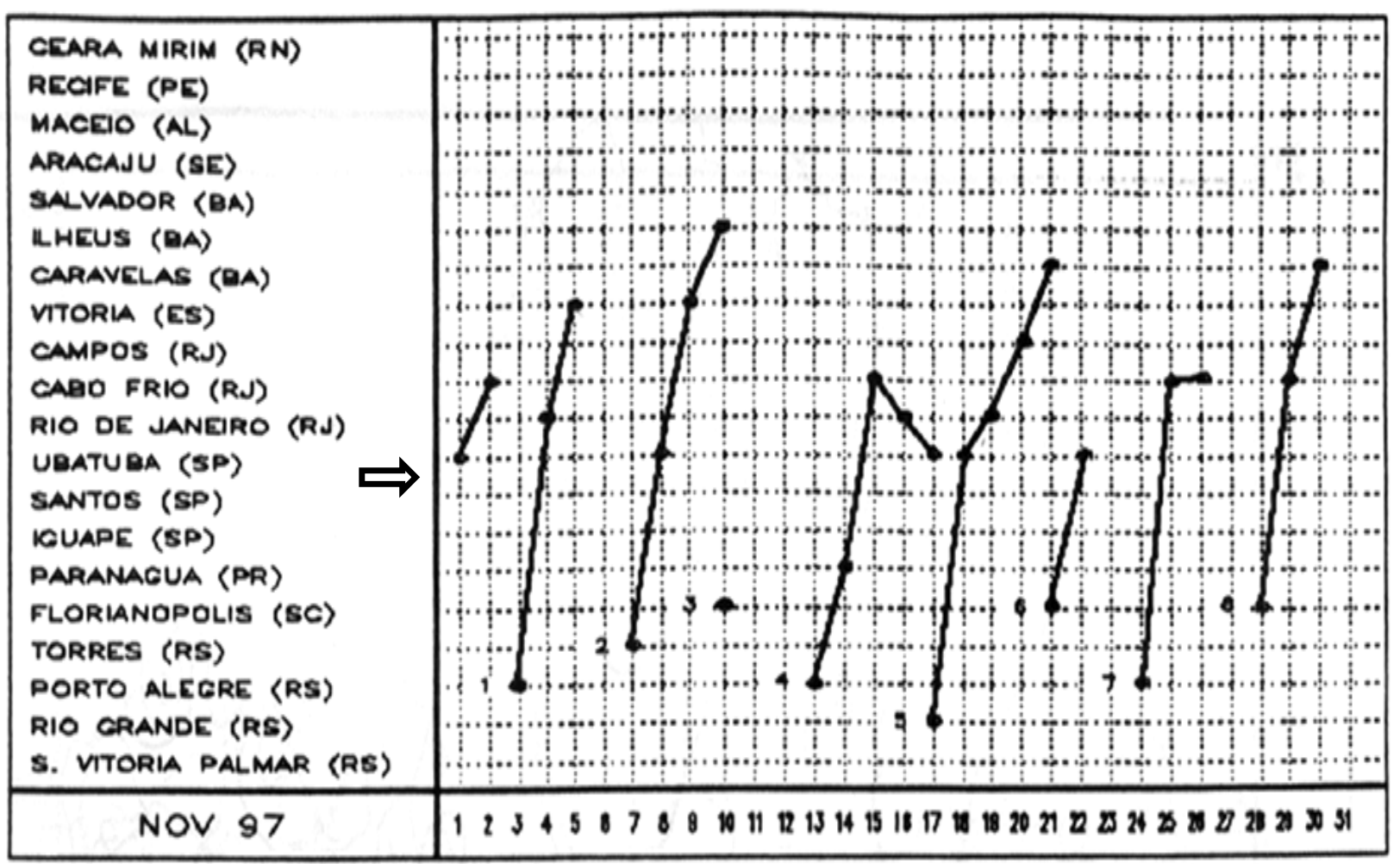

Figura 64: Atuação das frentes frias no litoral do Brasil, novembro de 1997. A cidade de Santos está destacada como representante mais próxima da RMSP. Fonte: http://www.cptec.inpe.br/products/climanalise/1197/index.html

Com base no campo de radiação solar (figura 66b), verifica-se que as anomalias foram negativas em praticamente todo o centro-sul do Brasil. As anomalias de pressão em superfície (figura 66c) indicam também a alta freqüência de passagens frontais associadas à formação de regiões com baixas pressões. Tal situação sinótica foi caracterizada pela formação de ZCAS em meados do mês, o que é evidenciado pela figura 65 : 


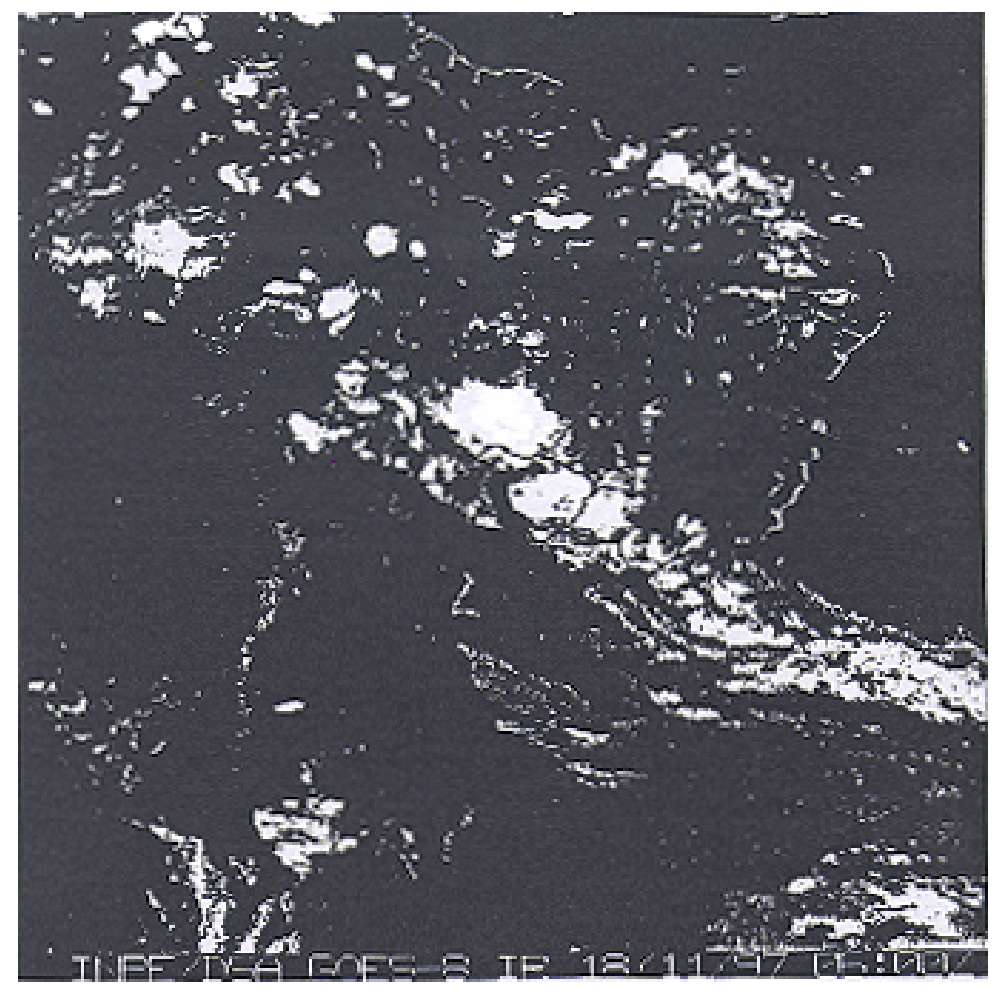

Figura 65: Posicionamento da ZCAS no litoral do Sudeste (canal infravermelho), em 18 de novembro de 1997.

Fonte: http://www.cptec.inpe.br/products/climanalise/1197/figlV.html

Segundo o boletim Climanálise deste mês ${ }^{14}$, o episódio de ZCAS se estendeu de 14 a 19 de novembro. Acompanhando a ocorrência da ZCAS, este mês apresentou anomalias positivas de umidade (figura 66a). Grande parte da Região Sudeste, inclusive o Estado de São Paulo, foi caracterizada por uma situação de convergência do ar em baixos níveis (figura 66e), com valores máximos a noroeste de Minas Gerais, sudoeste da Bahia e leste de Goiás, aspecto este reforçado por anomalias negativas de divergência. Em altos níveis, observam-se anomalias positivas de divergência do ar sobre os Estados de São Paulo e Paraná, dando suporte dinâmico às condições de baixos níveis.

Assim, percebe-se que as condições atmosféricas neste mês desfavoreceram a produção e acúmulo de $\mathrm{O}_{3}$ em níveis mais baixos da atmosfera, tanto pelas anomalias negativas de radiação solar, causadas pela freqüente passagem de sistemas frontais e atuação da ZCAS, como pela instabilidade dinâmica instalada em baixos níveis troposféricos, contribuindo para a dispersão de poluentes e a diminuição do acúmulo de precursores.

${ }^{14}$ http://www.cptec.inpe.br/products/climanalise/1197/index.html 


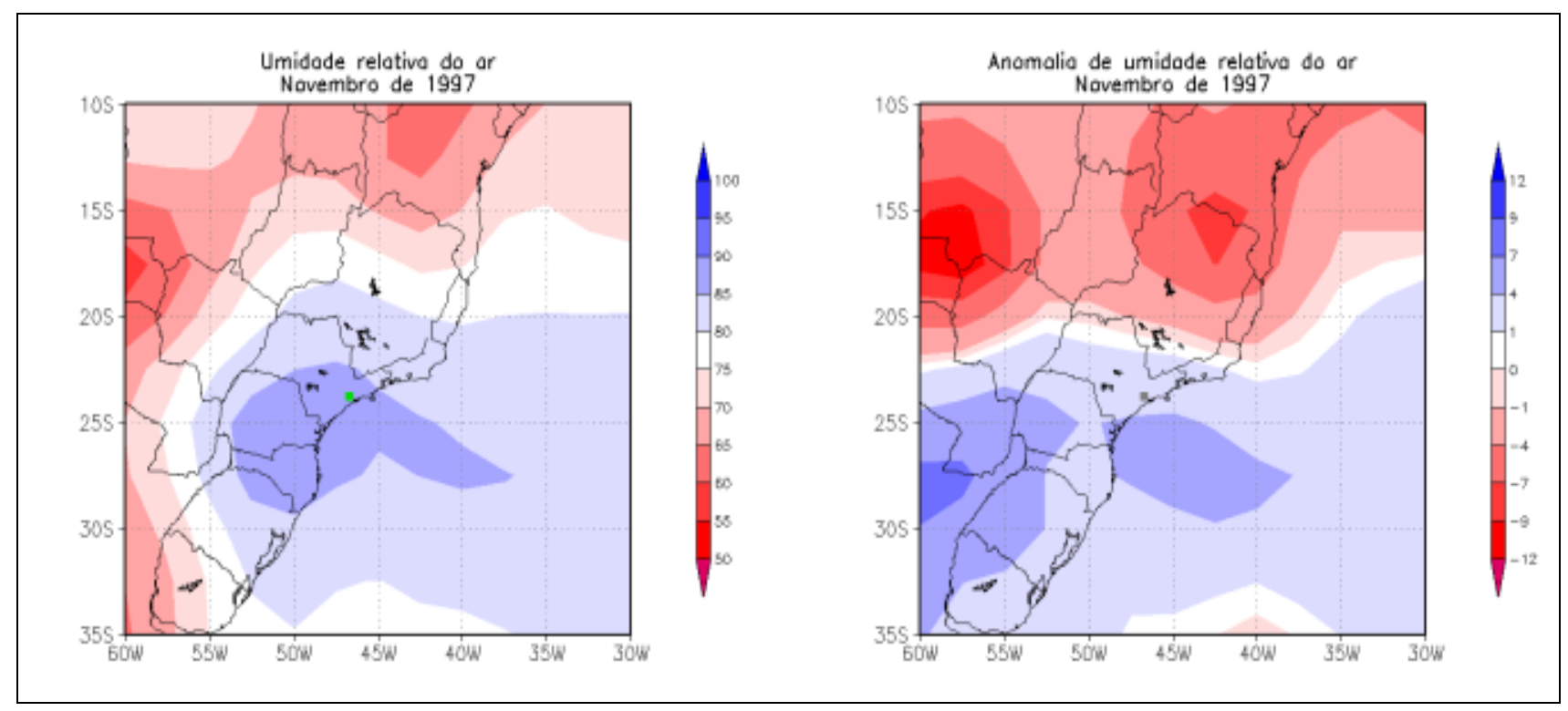

Figura 66a: Umidade relativa do ar em novembro de 1997 e a anomalia observada.

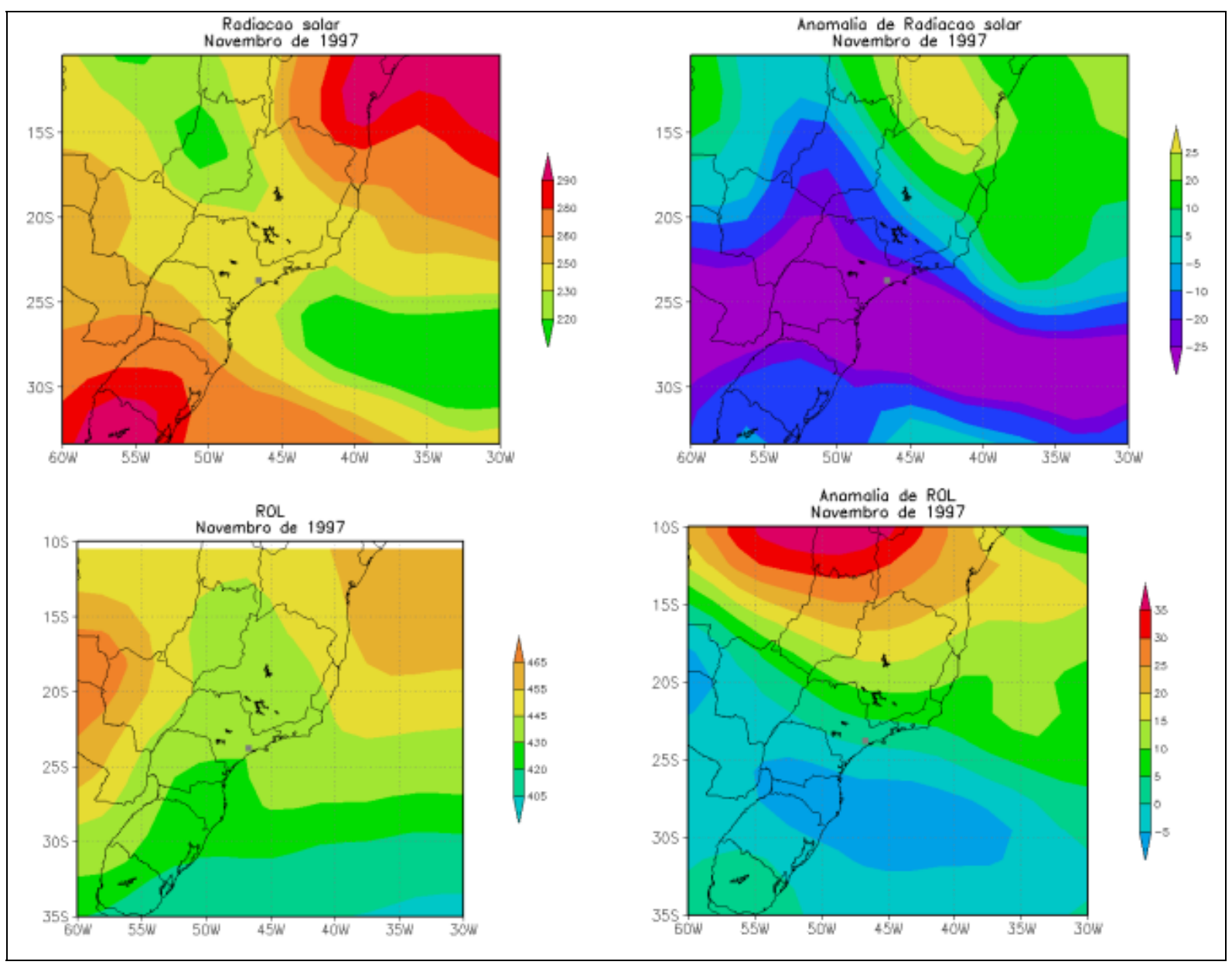


Figura 66b: Radiação solar de ondas curtas e ROL em novembro de 1997 e suas respectivas anomalias.

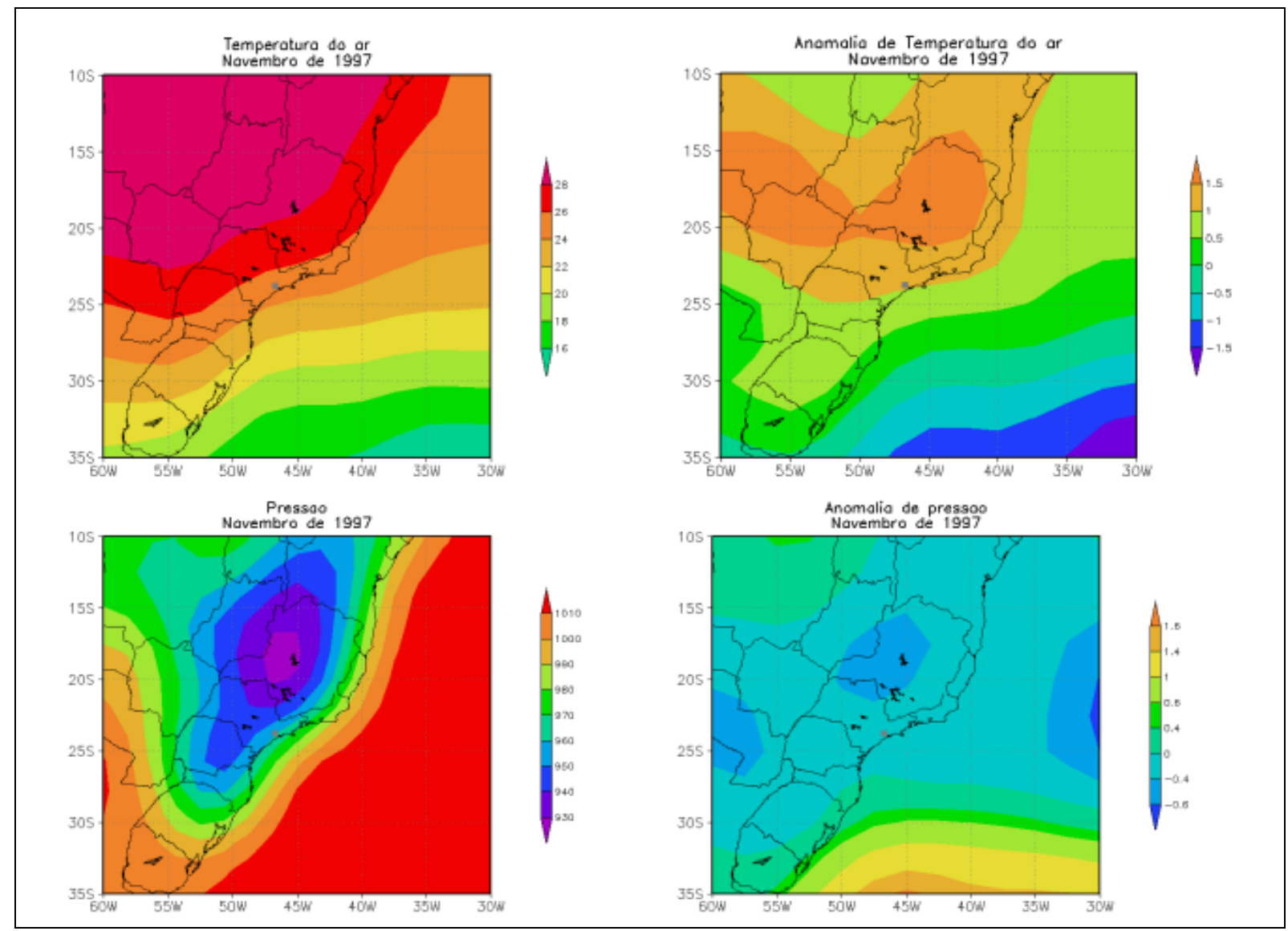

Figura 66c: Temperatura do ar e pressão atmosférica em novembro de 1997 e suas respectivas anomalias. 


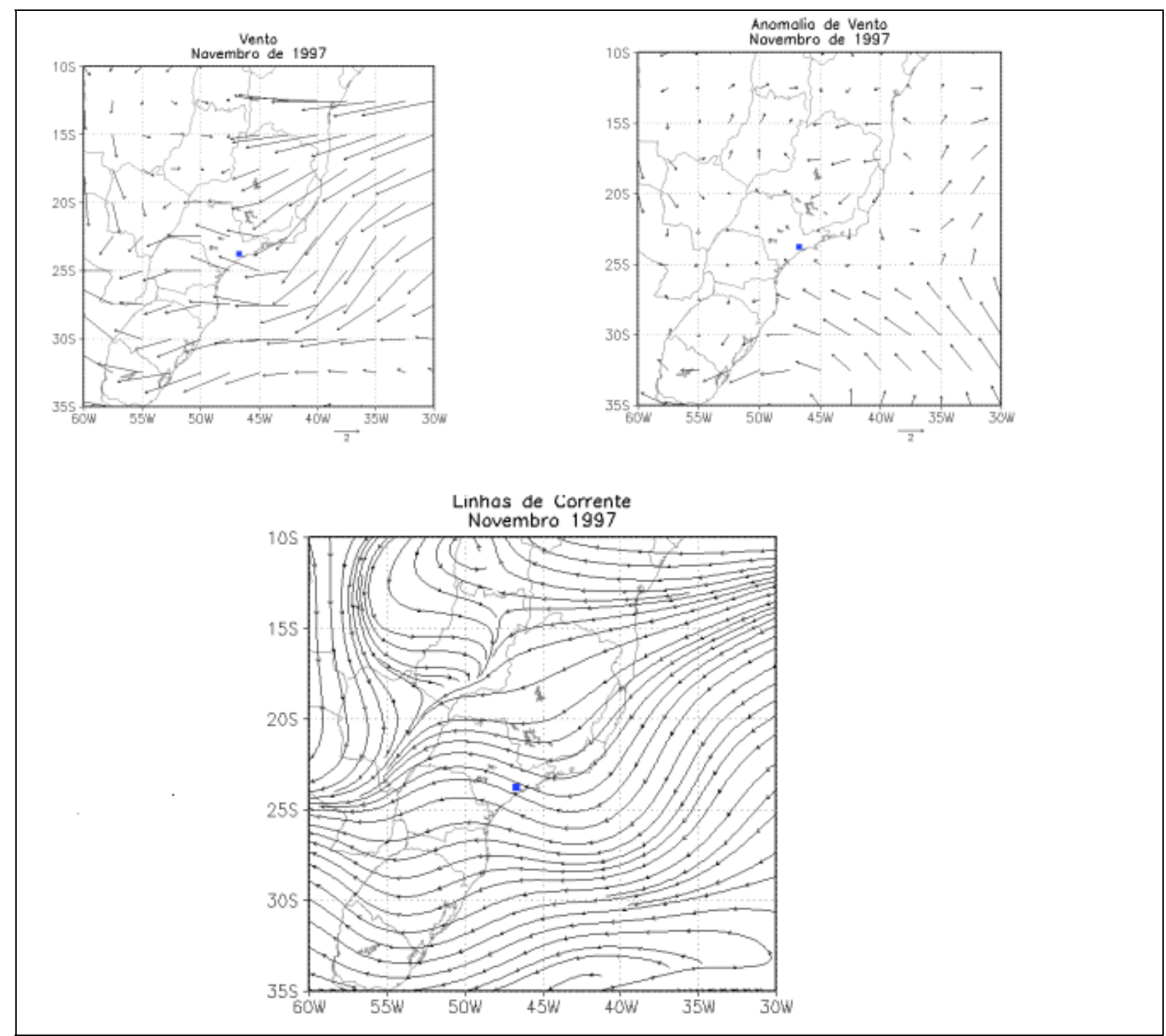

Figura 66d: Escoamento atmosférico e sentido do vento em novembro de 1997 e sua respectiva anomalia. 


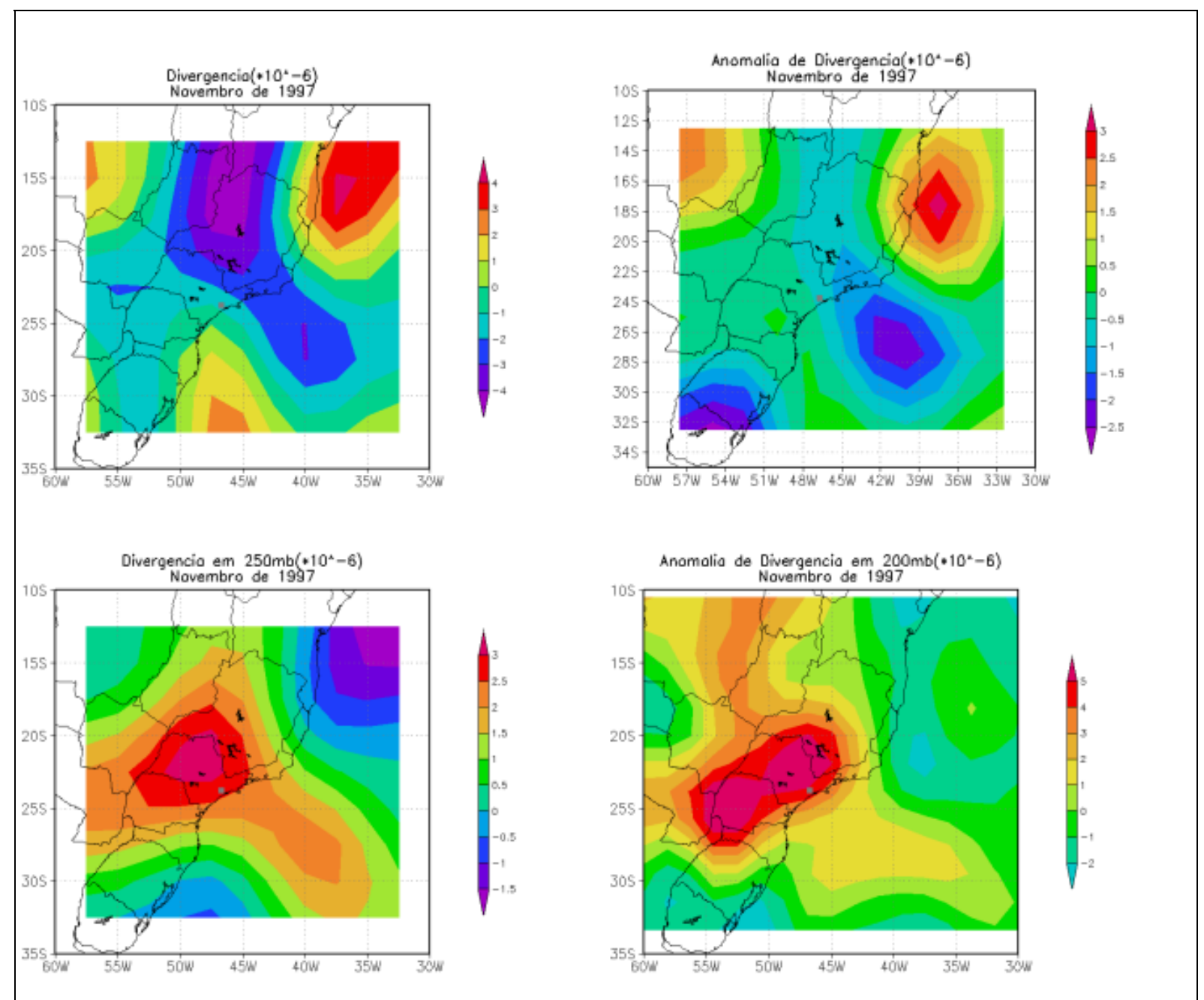

Figura 66e: Divergência do ar em superfície e altitude em novembro de 1997 e suas respectivas anomalias. 


\section{Janeiro de 2004}

Por meio da análise da figura 67 , percebe-se que não houve nenhuma passagem frontal próxima à latitude da RMSP no mês de janeiro de 2004 (a média climatológica é de seis sistemas):

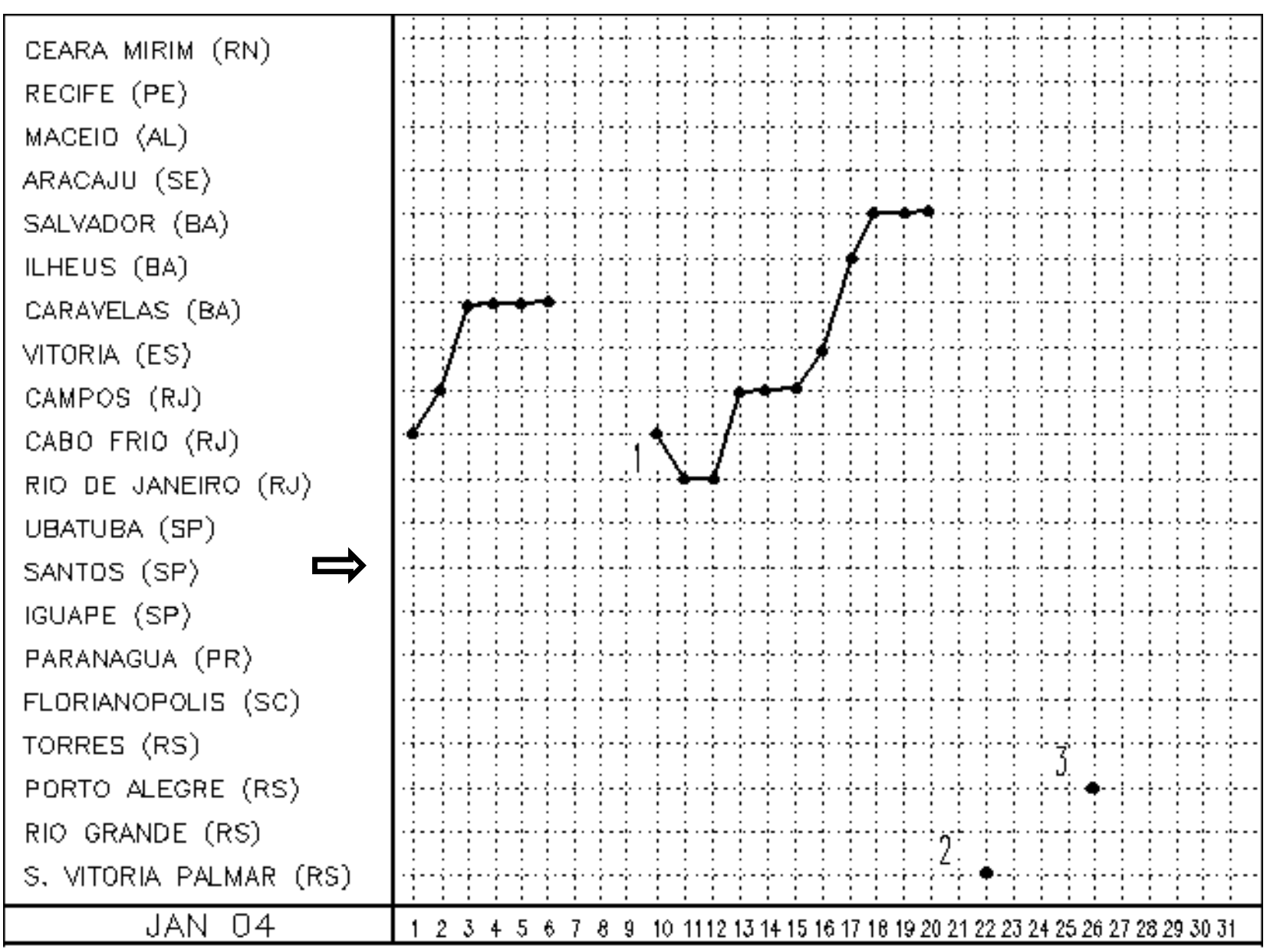

Figura 67: atuação das frentes frias no litoral do Brasil, janeiro de 2004. A cidade de Santos está destacada como representante mais próxima da RMSP. Fonte: http://www.cptec.inpe.br/products/climanalise/0104/index.html

No entanto, observa-se pela análise da tabela 21 que as concentrações de ozônio foram inferiores a $-1 \sigma$. Isto ocorre não devido à passagem freqüente de sistemas frontais, como foi observado em outros meses de classe -2 ou similares, mas pode ter sido influenciado devido à atuação persistente da ZCAS durante o mês. De acordo com o boletim da Climanálise para este mês, houve no Brasil três episódios da ZCAs em janeiro de 2004, sendo que dois atingiram a latitude da 
RMSP. Em particular, o último episódio do mês teve uma posição mais verticalizada, como se pode observar na figura 68 :

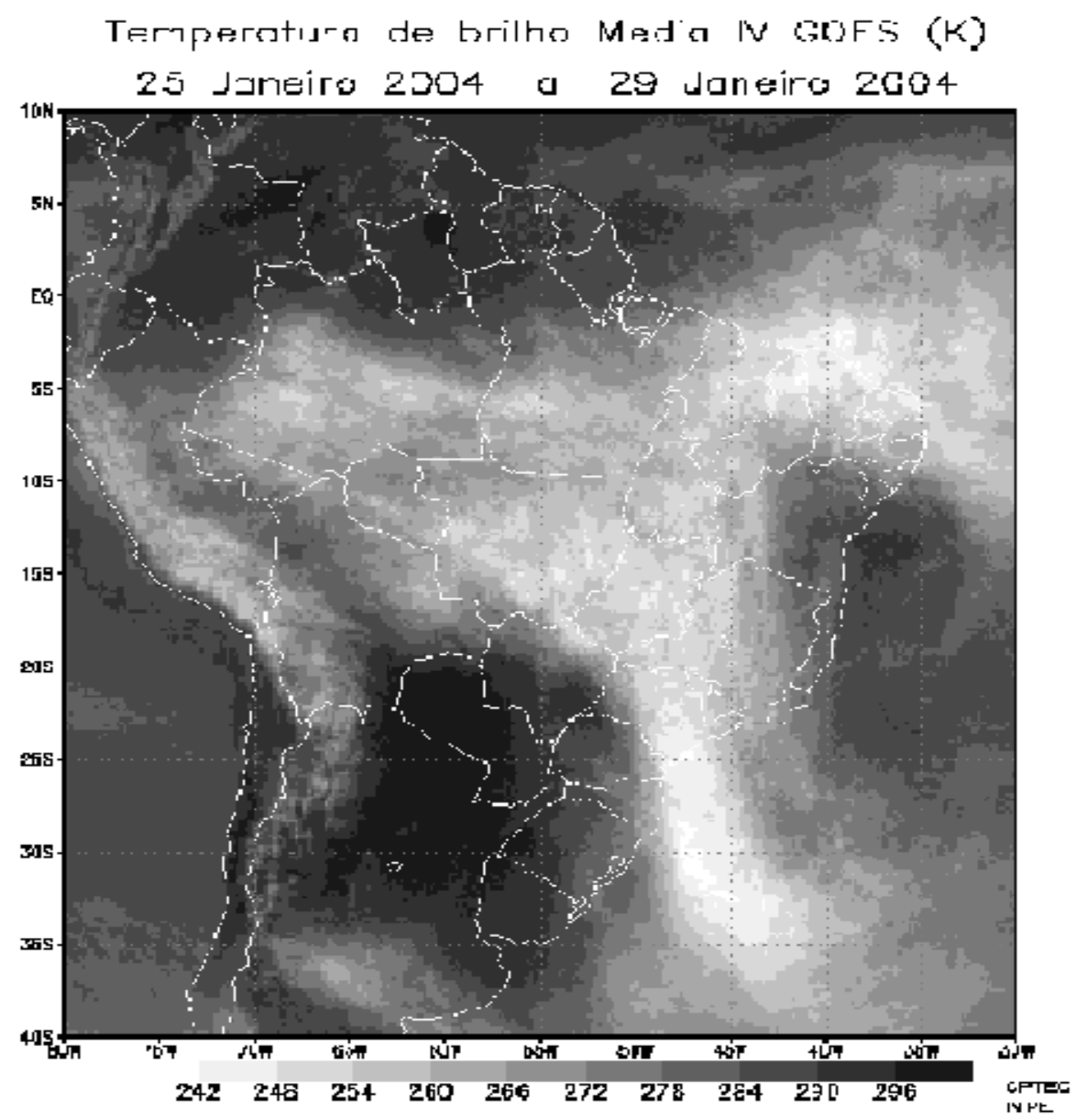

Figura 68: Posicionamento da ZCAS no litoral do Sudeste (temperatura de brilho), em 25 de janeiro de 2004.

Fonte: http://www.cptec.inpe.br/products/climanalise/0104/zcas.html

Estas ocorrências da ZCAS levaram a anomalias positivas de precipitação em diversas áreas do centro-sul do País, havendo, inclusive, ocorrência de alagamentos na cidade e outras regiões metropolitanas atingidas por estes episódios de precipitação intensa ${ }^{15}$. As anomalias de precipitação no Brasil podem ser vistas na figura 69:

\footnotetext{
${ }^{15}$ http://www.cptec.inpe.br/products/climanalise/0104/index.html
} 


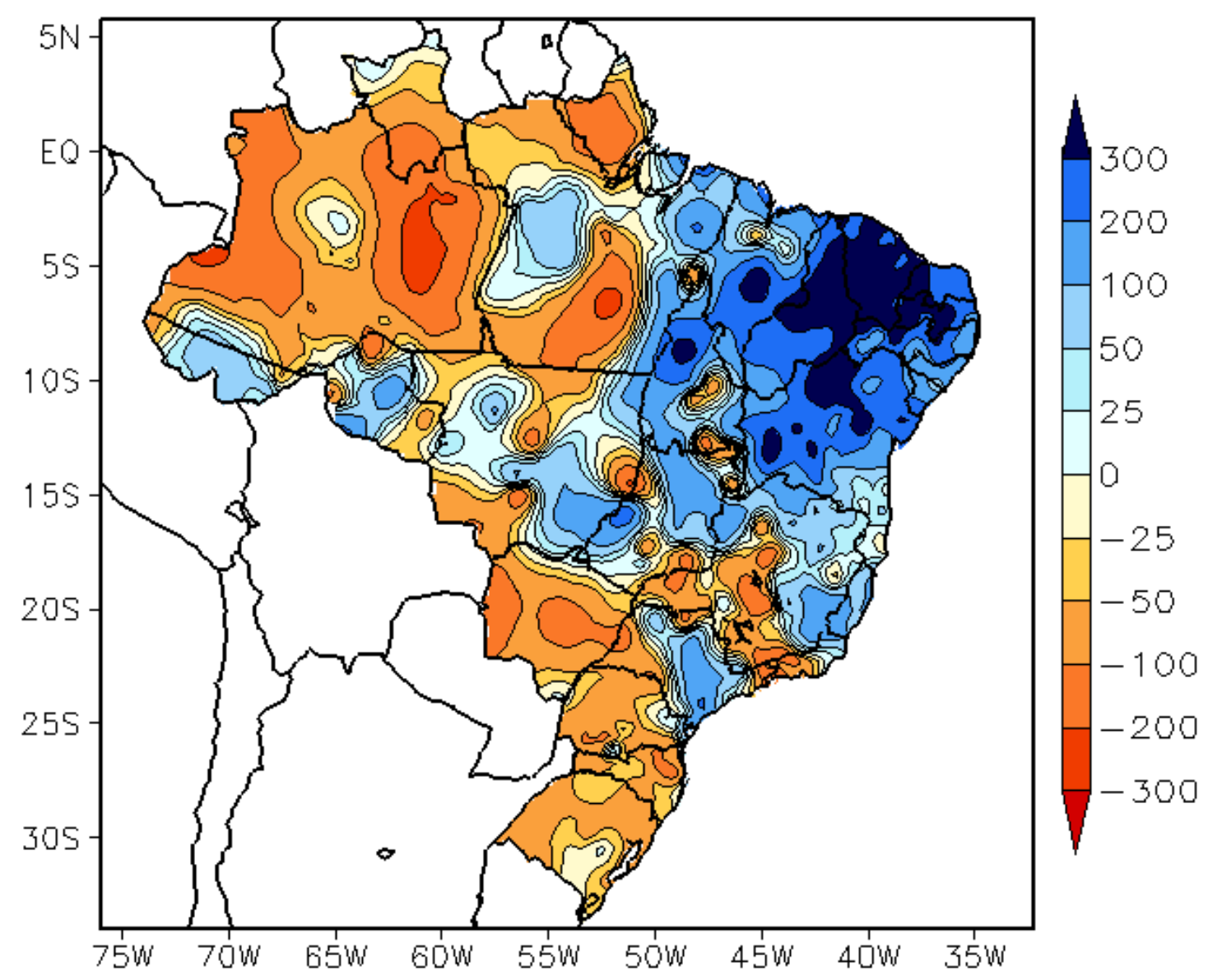

Figura 69: Anomalia de precipitação no Brasil, em janeiro de 2004.

Fonte: http://www.cptec.inpe.br/products/climanalise/0104/analise prec.html

Pode-se ver uma anomalia positiva de aproximadamente $100 \mathrm{~mm}$ para a região da RMSP. A precipitação originada por qualquer processo termodinâmico (frontal, convectiva, orográfica), apesar de não remover diretamente o ozônio da atmosfera, remove os poluentes precursores do ozônio, contribuindo para a remoção do ozônio da atmosfera. Adicionalmente, a formação de nebulosidade associada à precipitação, que bloqueia parcialmente a radiação solar que chega à superfície, também contribui para a remoção do ozônio da atmosfera. Assim, pôde-se concluir que, em geral, situações atmosféricas associadas à modificação dos padrões de nebulosidade e precipitação podem interferir na produção e concentração de $\mathrm{O}_{3}$.

As composições atmosféricas não indicam anomalia de umidade relativa no mês (figura 70a), bem como nebulosidade próxima do normal (fraca anomalia positiva de ROL - figura 70b), mas há uma anomalia negativa de radiação solar mais intensa. A temperatura do ar apresentou desvios negativos, bem como a pressão atmosférica (figura 70c), o que pode ter contribuído para a dispersão do ozônio formado em superfície. A atuação da ZCAS também pode estar associada às 
anomalias de SE no padrão dos ventos, que tiveram anomalia positiva de aproximadamente $2 \mathrm{~m} / \mathrm{s}$ (figura $70 \mathrm{~d}$ ).

O posicionamento das linhas de corrente indica uma zona de convergência do ar no interior do continente, e as figura 70e indicam convergência do ar em superfície e divergência em altitude, um pouco menos intensas do que a média na região, mas ainda assim contribuindo para a situação de constante instabilidade atmosférica observada neste mês na RMSP.

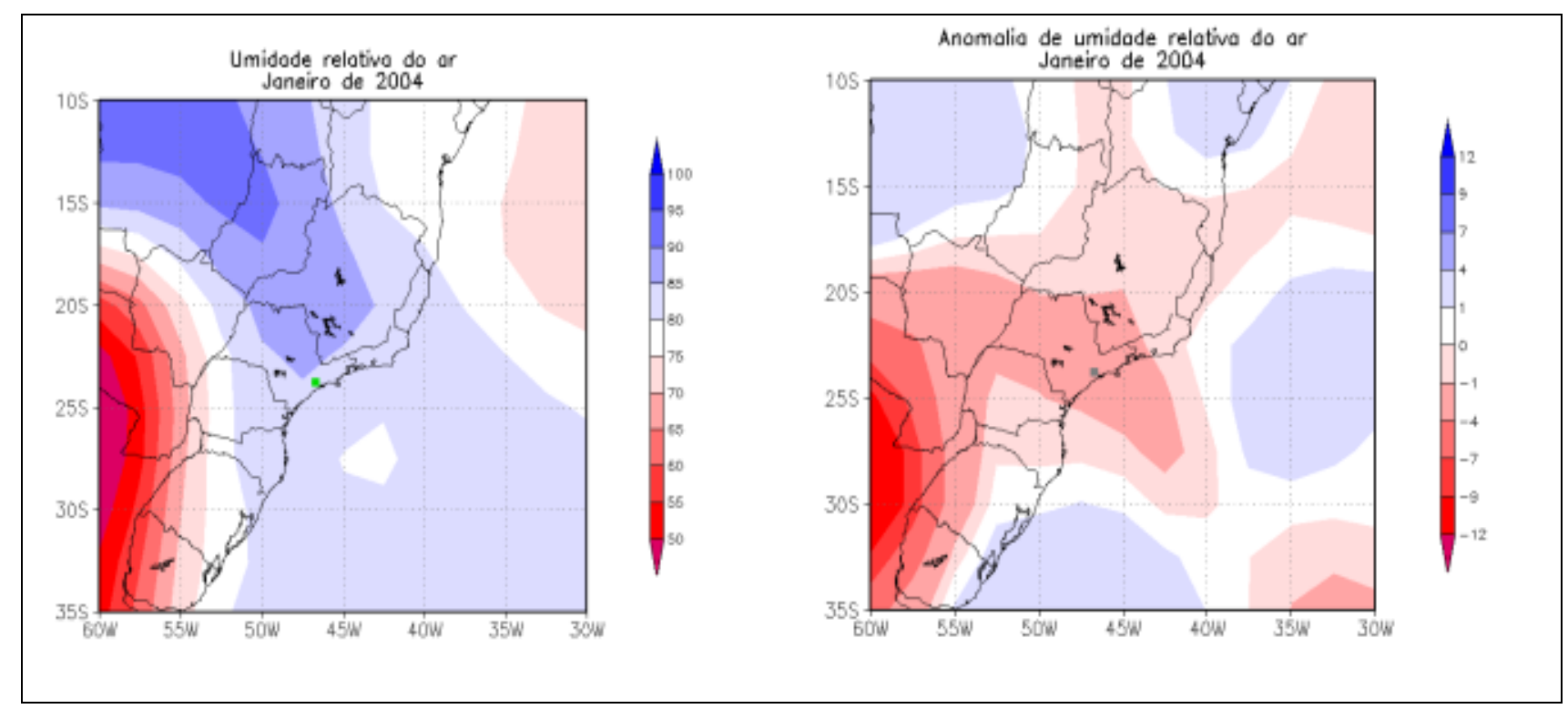

Figura 70a: Umidade relativa do ar em janeiro de 2004 e a anomalia observada. 

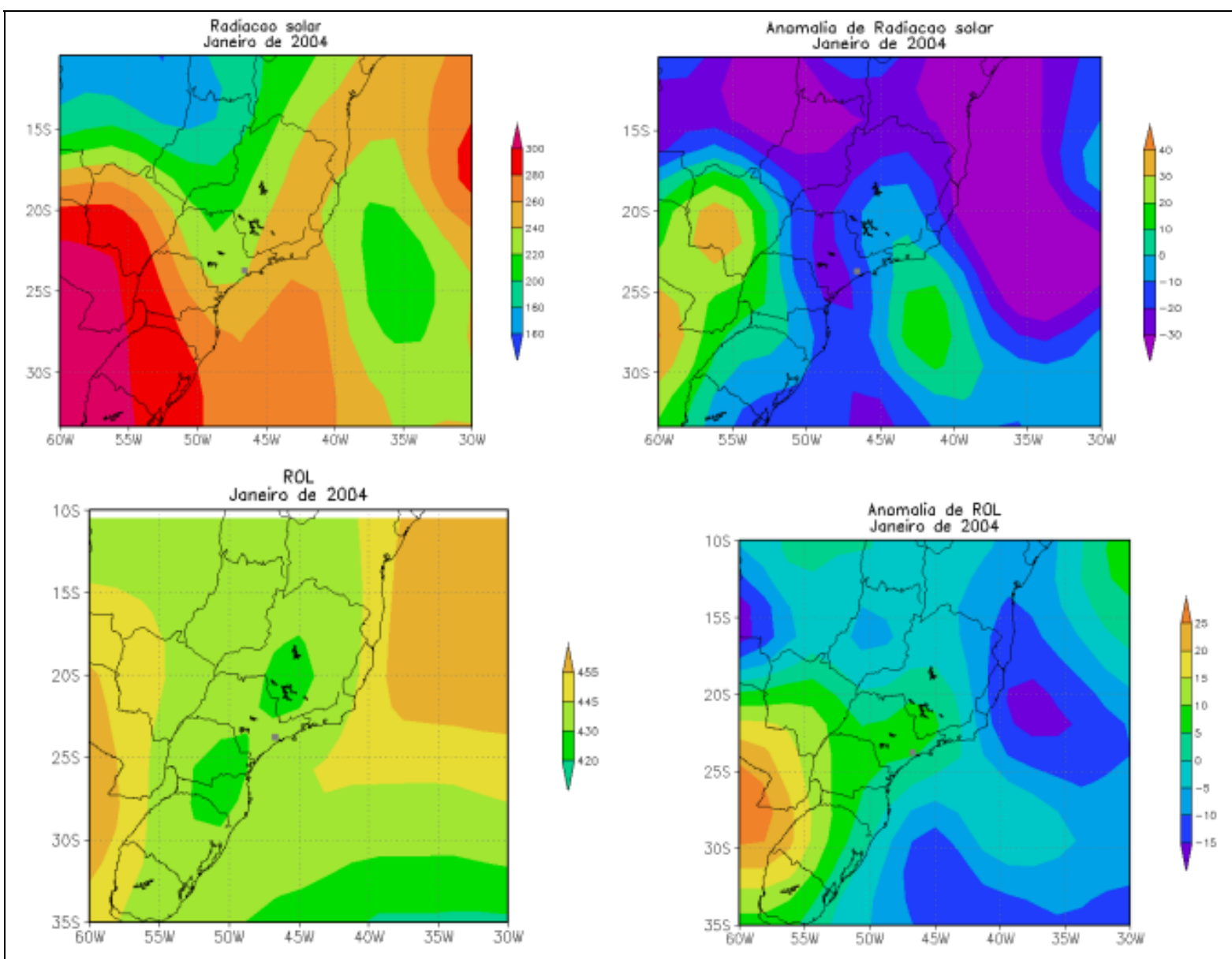

Figura 70b: Radiação solar de ondas curtas e ROL em Janeiro de 2004 e suas respectivas anomalias. 


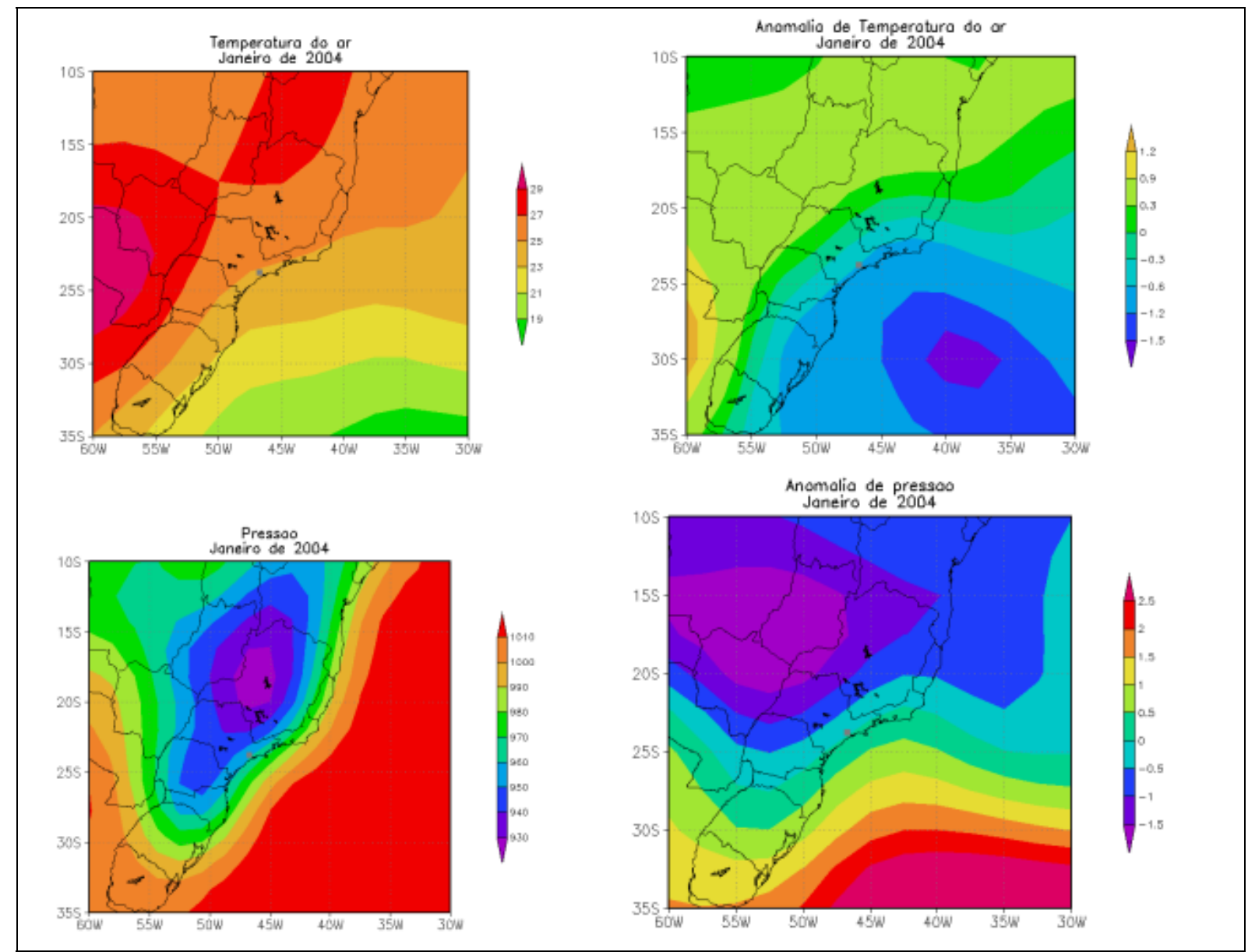

Figura 70c: Temperatura do ar e pressão atmosférica em janeiro de 2004 e suas respectivas anomalias. 


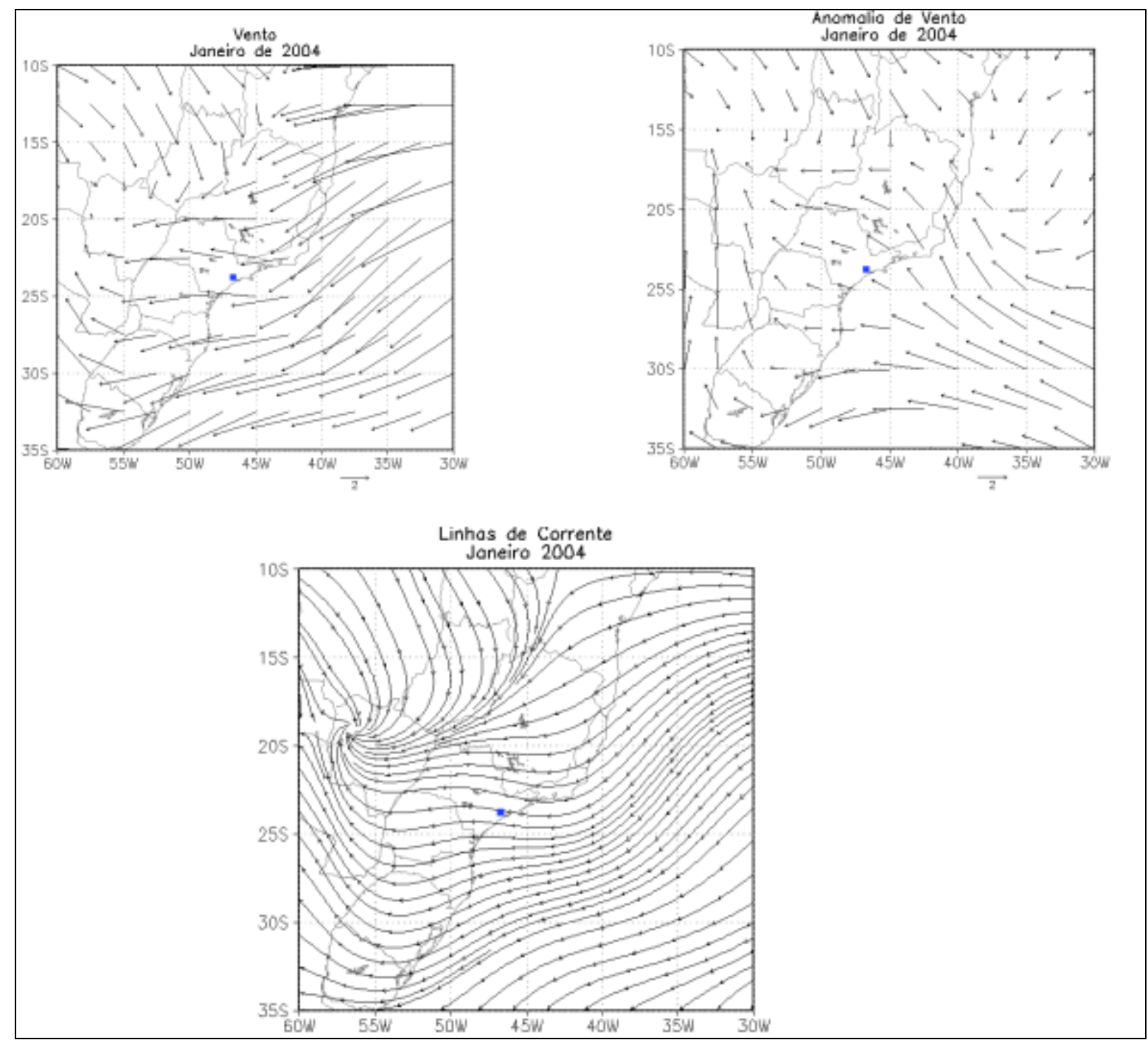

Figura 70d: Escoamento atmosférico e sentido do vento em janeiro de 2004 e sua respectiva anomalia. 


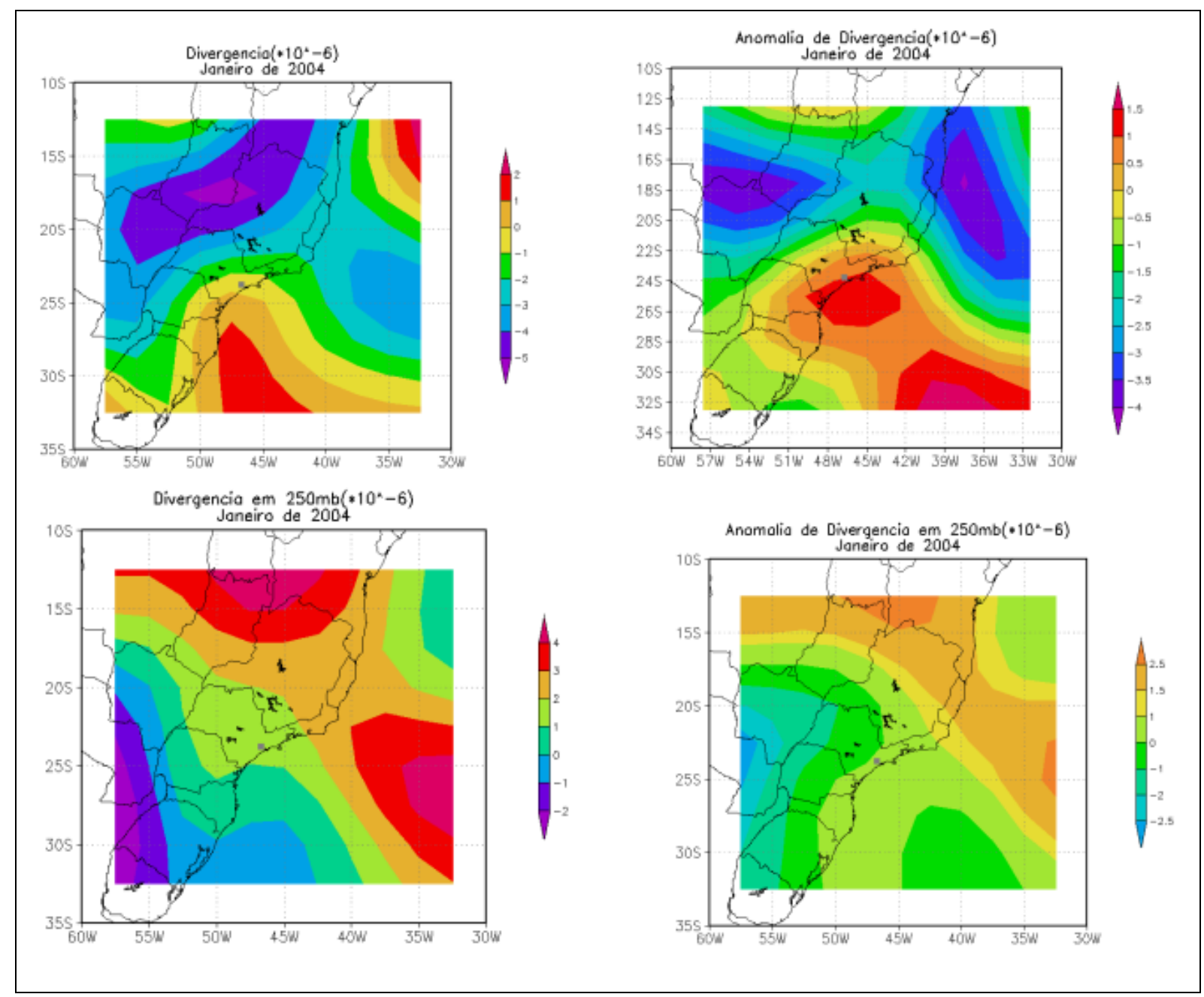

Figura 70e: Divergência do ar em superfície e altitude em janeiro de 2004 e suas respectivas anomalias. 


\title{
3.3.2 Meses com anomalias positivas intensas de ozônio.
}

\section{Agosto de 1999}

Por meio da análise das figuras $72 \mathrm{a}$ a $72 \mathrm{e}$, nota-se que as anomalias positivas de ROL, radiação de ondas curtas, pressão em superfície e negativas de umidade relativa e específica do ar configuram o sistema de alta pressão localizado no interior do continente, conforme descrito no boletim da Climanálise de agosto de 1999. Este boletim também informa que a média climatológica de passagem de sistemas frontais para a latitude da RMSP no mês de agosto é de sete sistemas; no entanto, verifica-se na figura 71 que em agosto de 1999 ocorreu a passagem de apenas 3 sistemas. Ocorrem anomalias positivas de pressão em todo o interior do continente e uma anomalia ainda mais intensa pode ser observada sobre o oceano, que corresponde grosseiramente ao anticiclone do Atlântico Sul. Na figura 72d, pode-se notar o posicionamento deste sistema e sua influência, bem como a existência de uma região de divergência do ar no interior do continente.

\begin{abstract}
"Em agosto, na maior parte dessa Região (Sudeste), não foram registradas precipitações. A passagem de sistemas frontais pelo Oceano Atlântico devido à presença de um sistema de alta pressão no Brasil Central, contribuiu para a pouca formação de nuvens, inclusive no leste da região. Além disso, ocorreram baixos índices de umidade relativa do ar, que no período da tarde foram inferiores a $20 \%$ em algumas áreas, principalmente no final do mês. Essa situação contribuiu para o aumento do número de focos de queimadas na região. Foram observados desvios negativos de precipitação em São Paulo, Rio de Janeiro e Espírito Santo.
\end{abstract}

A temperatura média variou entre 16 e $20^{\circ} \mathrm{C}$, caracterizando desvios positivos em praticamente toda a região, com valores de até $2^{\circ} \mathrm{C}$ no sul de São Paulo. No campo de temperatura máxima pode-se observar que as temperaturas variaram entre 24 e $30^{\circ} \mathrm{C}$. Foram observados altos valores de temperatura máxima e baixa umidade relativa do ar, principalmente durante o final do mês ${ }^{16}$."

Pode-se notar que há divergência do ar na região da RMSP (figura 72e). Essa divergência, no entanto, está próxima da média. Em altitude, dando suporte dinâmico à estas condições, pode-se perceber forte convergência do ar, significativamente anômala para essa região neste período, com anomalias de até $4.5^{*} 10^{-6} \mathrm{~m} / \mathrm{s}$.

\footnotetext{
${ }^{16}$ http://www.cptec.inpe.br/products/climanalise/0899/index.html
} 
A influência de uma área de alta pressão sobre a RMSP, representada pela massa de ar mais seco no interior do continente, em particular para a região de Goiás, que, segundo o boletim Climanálise migra para o e outra, representada pelo anticiclone do Atlântico Sul, provavelmente foram responsáveis pela maior estabilidade do ar na região, dificultando tanto a incursão de sistemas frontais quanto a dispersão de poluentes, em particular, segundo o boletim da Climanálise para este mês, a partir da segunda quinzena do mês:

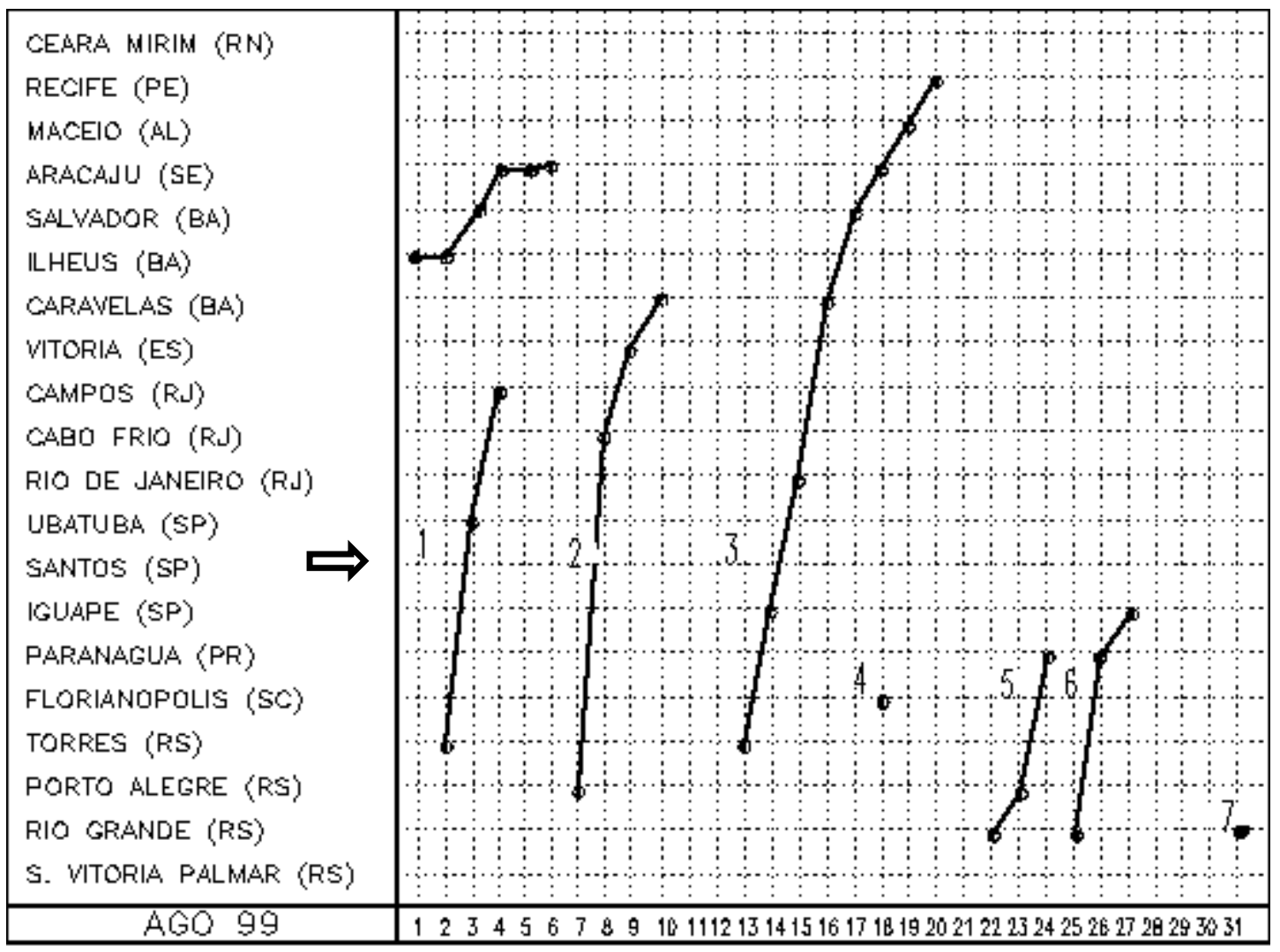

Figura 71: atuação das frentes frias no litoral do Brasil, agosto de 1999. A cidade de Santos está destacada como representante mais próxima da RMSP.

Fonte: http://www.cptec.inpe.br/products/climanalise/0899/index.html

Concomitantemente a estas condições, as anomalias positivas de ROL e radiação (figura $70 b$ ) favoreceram a produção e acúmulo de ozônio na troposfera da RMSP. 


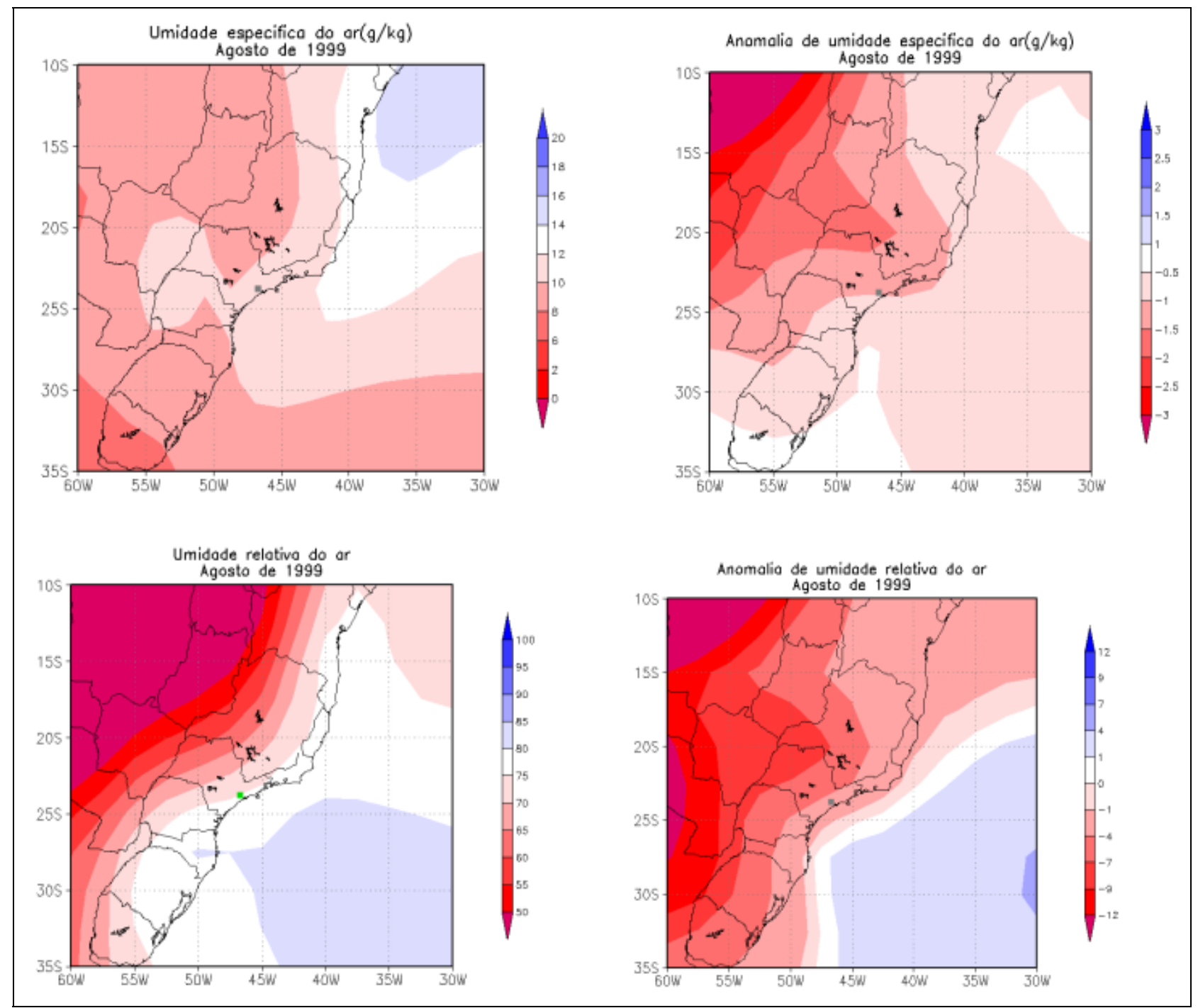

Figura 72a: Umidade relativa e específica do ar em agosto de 1999 e suas respectivas anomalias. 


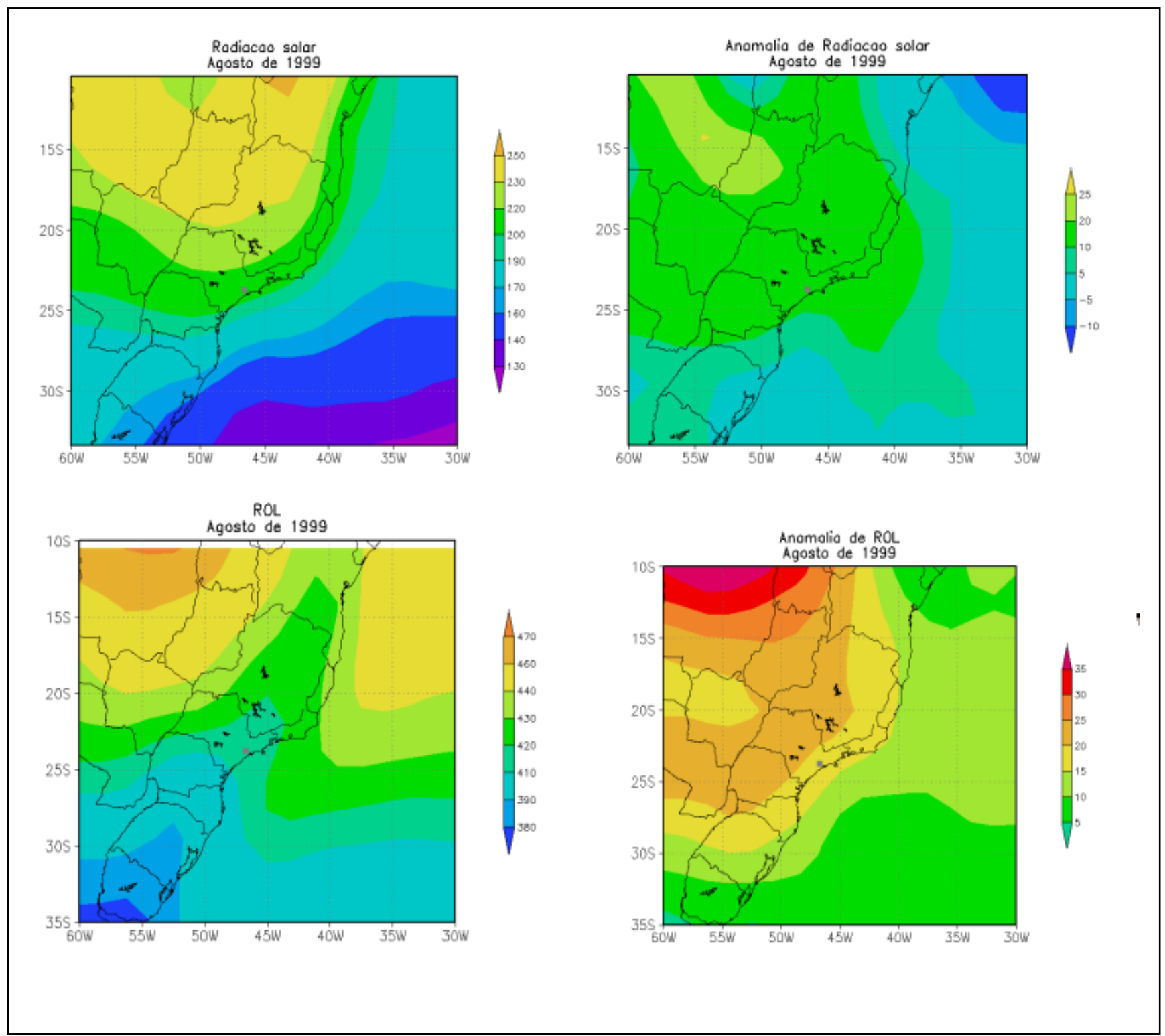

Figura 72b: Radiação solar de ondas curtas e ROL em agosto de 1999 e suas respectivas anomalias. 


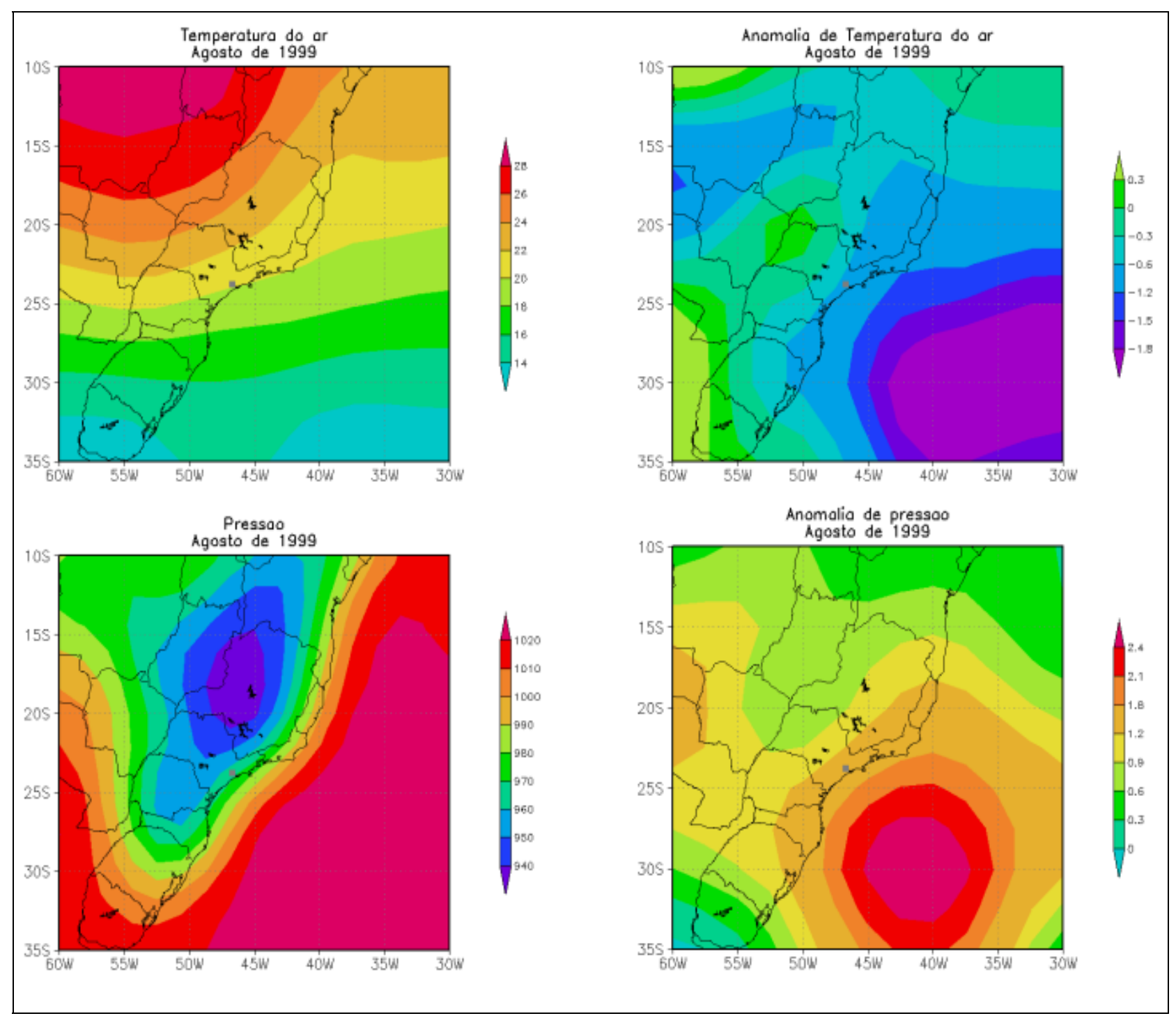

Figura 72c: Temperatura do ar e pressão atmosférica em agosto de 1999 e suas respectivas anomalias. 


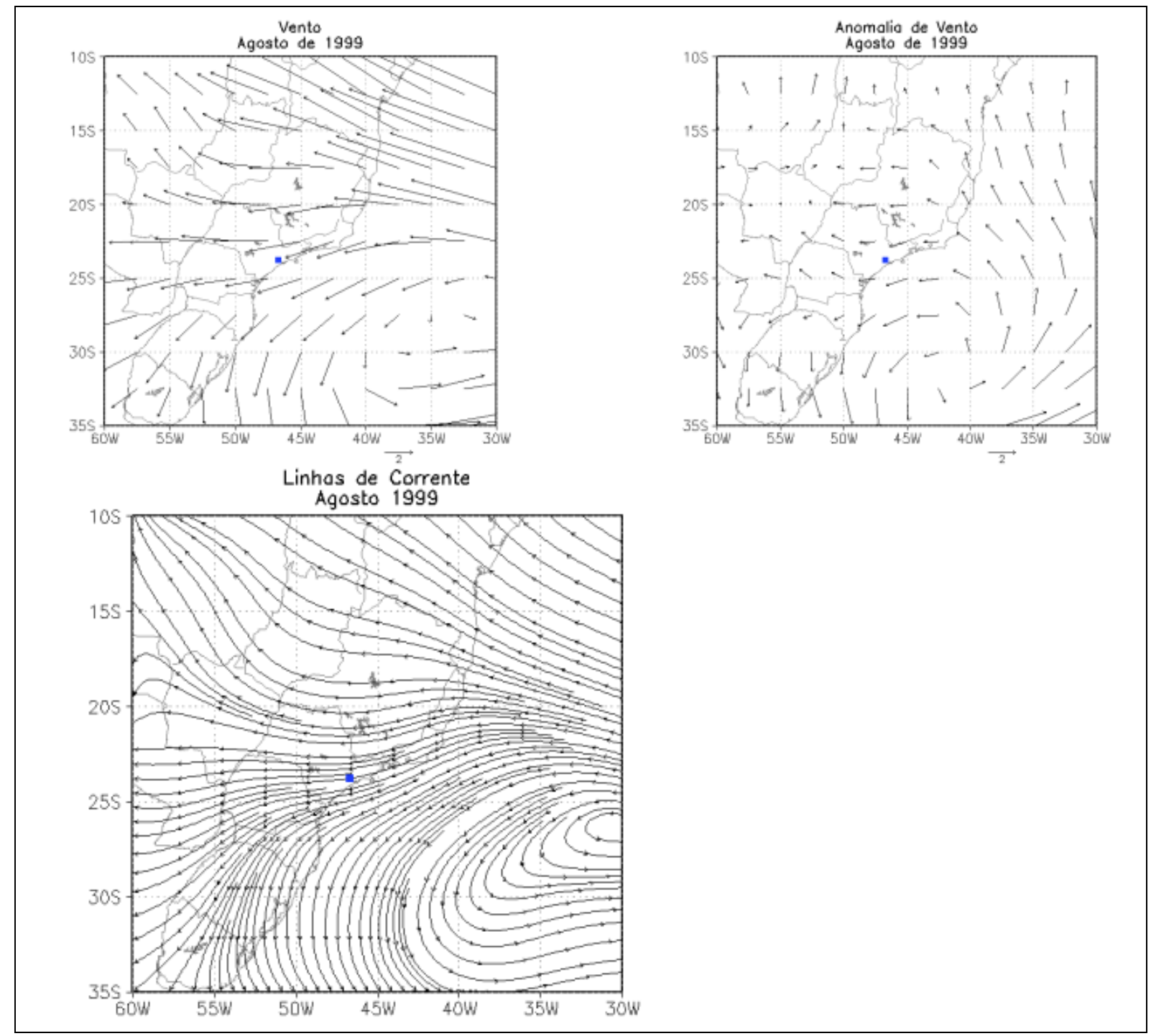

Figura 72d: Escoamento atmosférico e sentido do vento em agosto de 1999 e sua respectiva anomalia. 


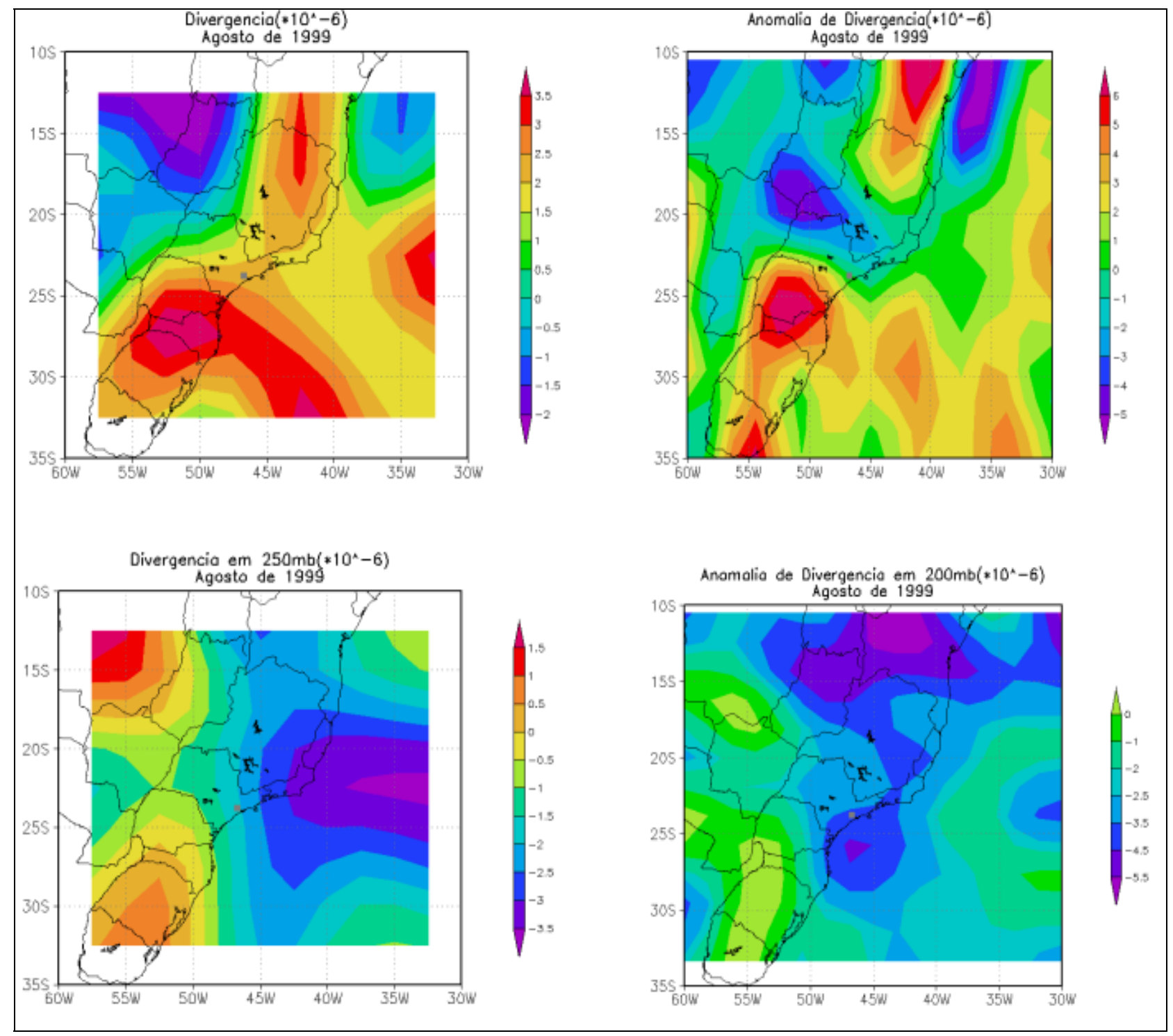

Figura 72e: Divergência do ar em superfície e altitude em agosto de 1999 e suas respectivas anomalias. 


\section{Marco de 2002}

Analisando os campos atmosféricos, pode-se perceber anomalias negativas de umidade relativa do ar na RMSP (figura 74a). Embora haja uma anomalia positiva de umidade específica para a região, a umidade relativa teve anomalias negativas, provavelmente em conseqüência das anomalias positivas de temperatura (figura 74c). Percebe-se anomalias positivas de radiação e ROL para a RMSP (figura 74b), que podem estar ligadas à maior produção do ozônio em superfície. Observa-se também anomalias ligeiramente positivas de pressão em superfície e ventos predominantes de NE (figura 74d). Por meio da análise das linhas de corrente e de divergência em superfície, pode-se perceber que havia leve divergência em superfície na RMSP, bem como em altitude (figura 74e), mas com anomalias próximas de zero para ambas.

Estas condições sugerem um mês com predominância de dias ensolarados, temperaturas mais altas e baixa umidade relativa do ar, em especial quando se analisa a figura 73 : 


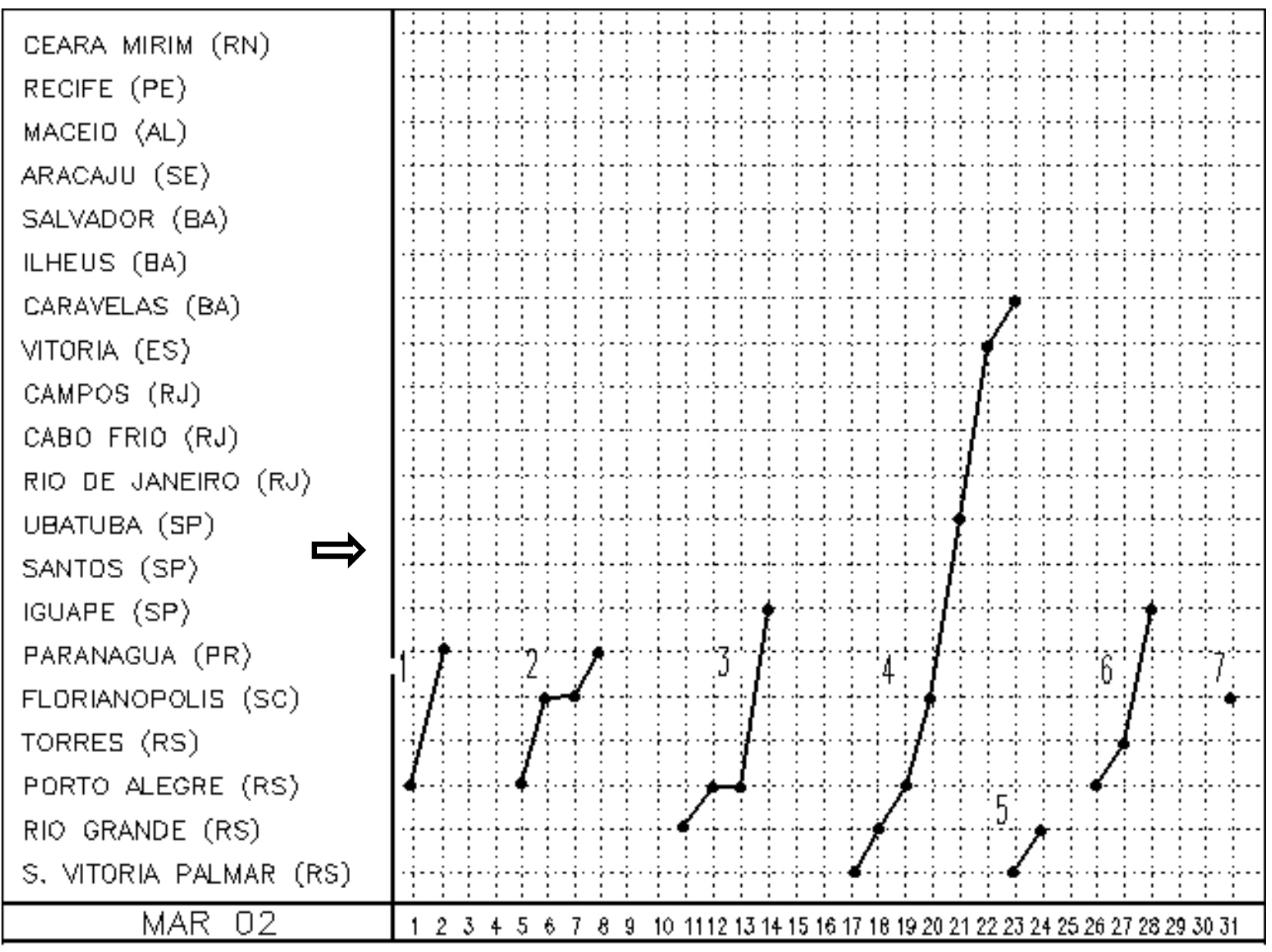

Figura 73: atuação das frentes frias no litoral do Brasil, março de 2002. A cidade de Santos está destacada como representante mais próxima da RMSP.

Fonte: http://www.cptec.inpe.br/products/climanalise/0302/index.html

Pode-se perceber que apenas uma frente fria atingiu a latitude da RMSP, enquanto que a média climatológica é de seis sistemas para essa latitude (de acordo com o boletim climanálise). Considerando-se que os sistemas frontais são importantes contribuintes para ocorrência de episódios de precipitação nesta época do ano na RMSP, reforça-se a hipótese de diversos dias seguidos com alta incidência de radiação solar e pressão atmosférica elevada, baixa umidade relativa do ar e poucas chuvas provavelmente influenciaram para que a anomalia de concentração de ozônio neste mês fosse positiva e atingisse a classe 2 verificada na tabela 12. Esta hipótese será verificada com maior precisão na seção 3.4 . 


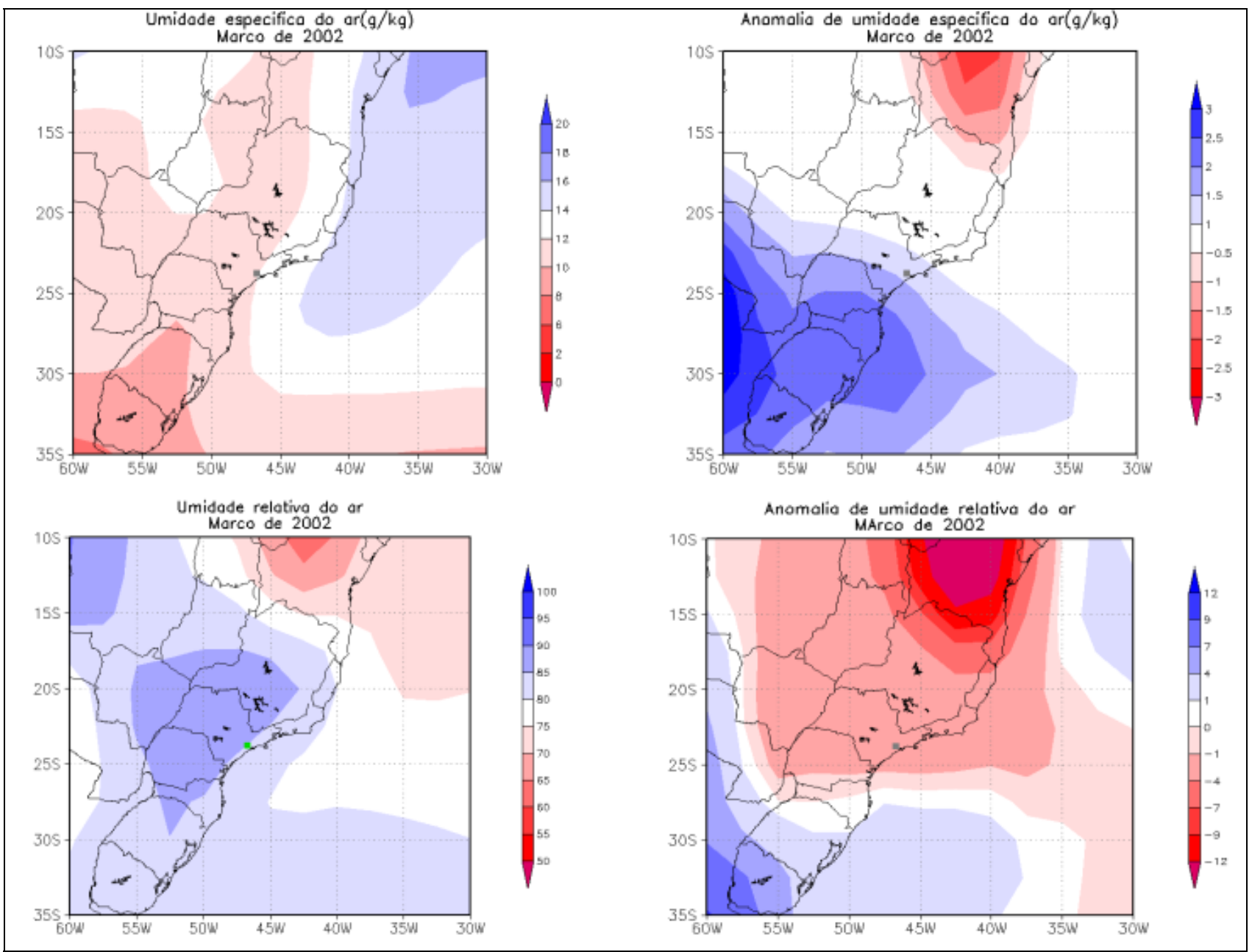

Figura 74a: Umidade relativa e específica do ar em março de 2002 e suas respectivas anomalias. 


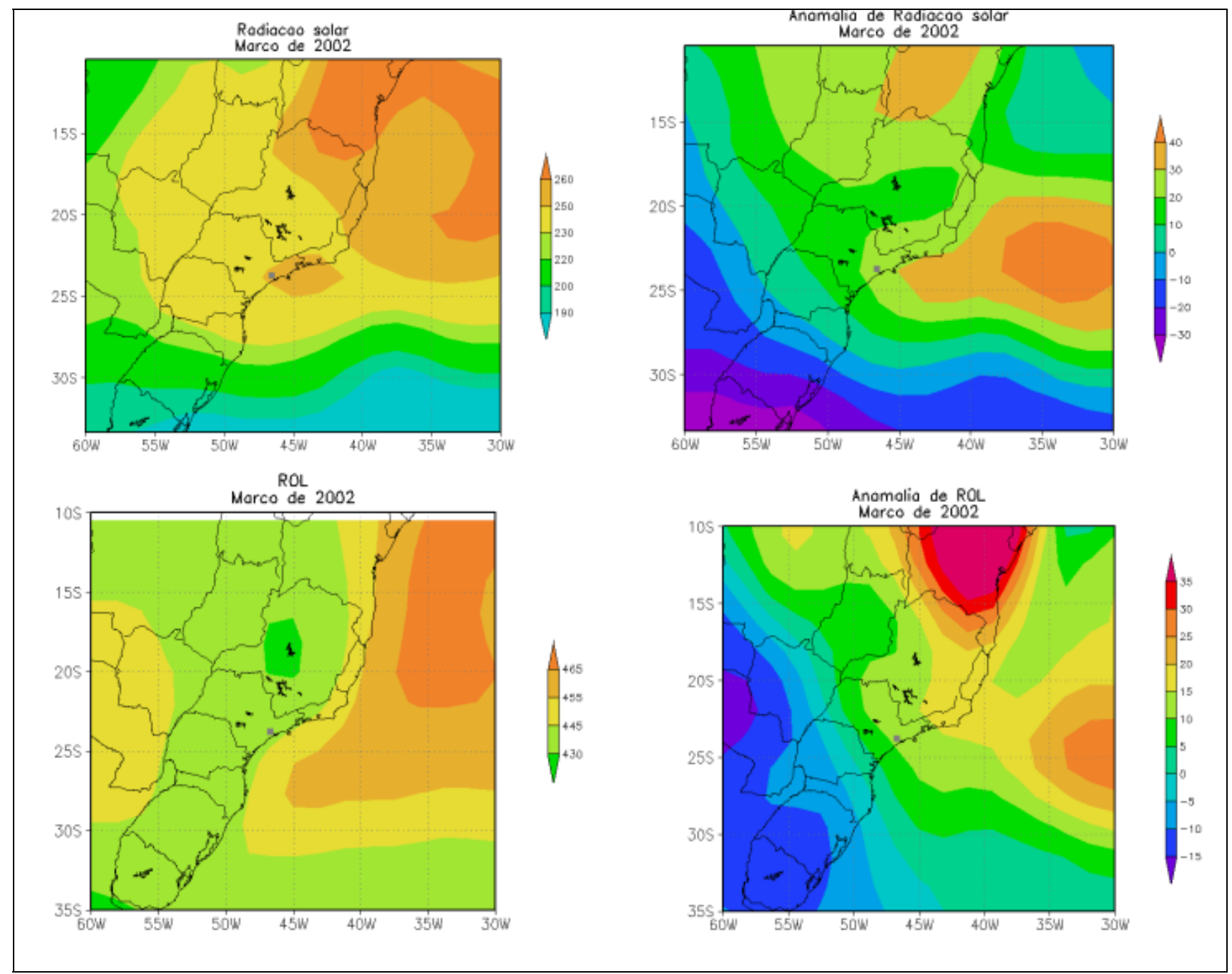

Figura 74b: Radiação solar de ondas curtas e ROL em março de 2002 e suas respectivas anomalias. 


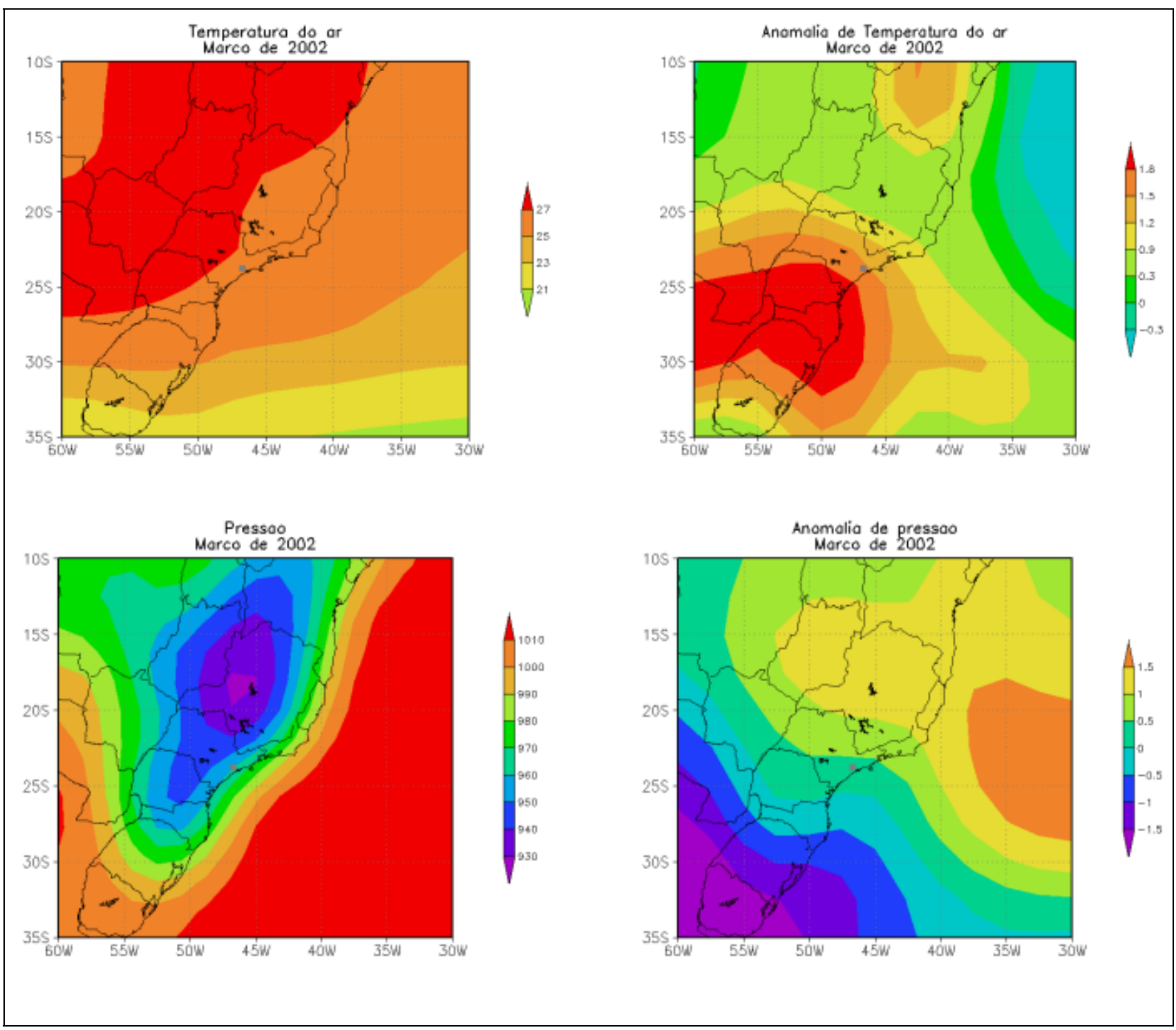

Figura 74c: Temperatura do ar e pressão atmosférica em março de 2002 e suas respectivas anomalias. 


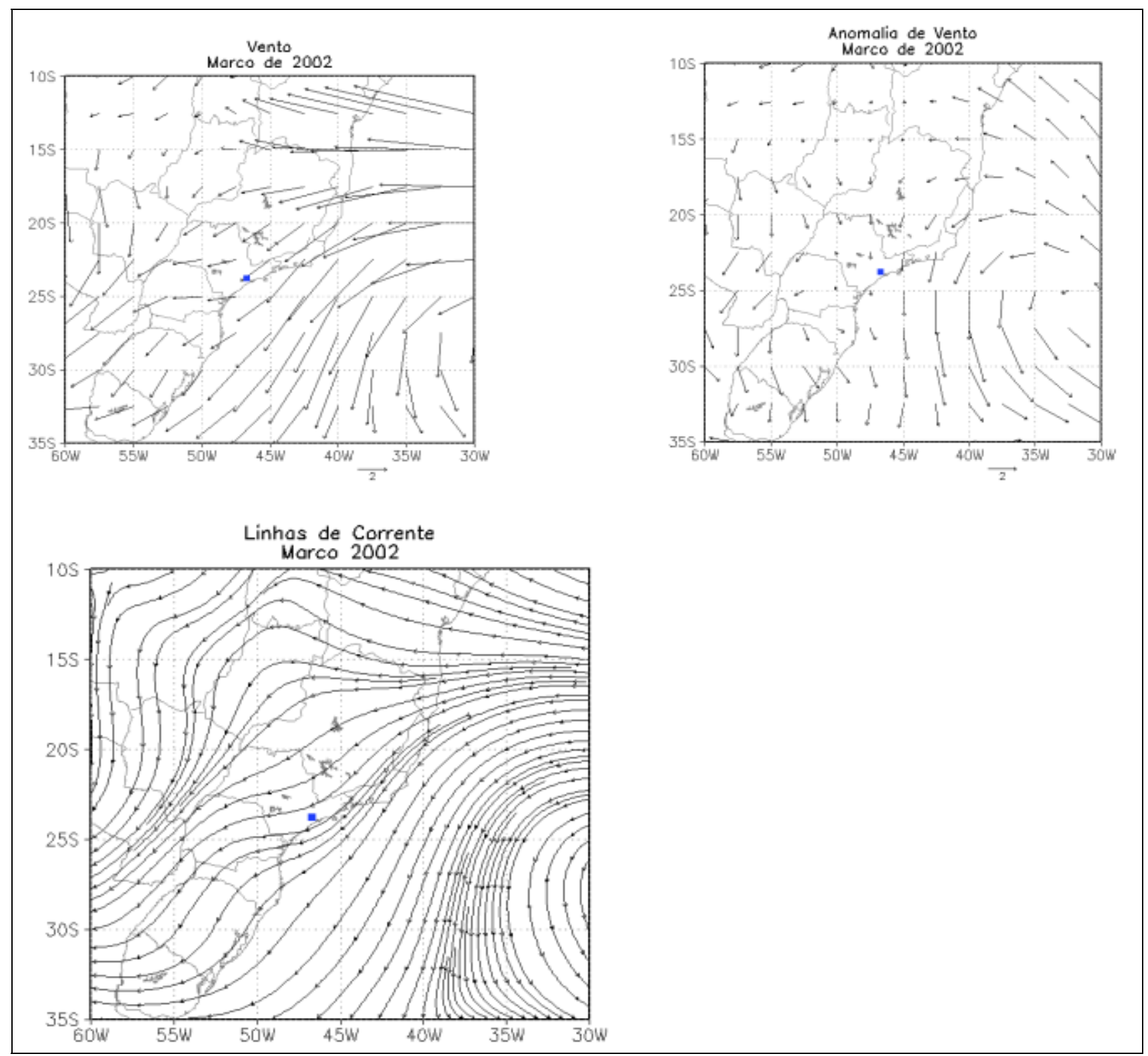

Figura 74d: Escoamento atmosférico e sentido do vento em março de 2002 e sua respectiva anomalia. 


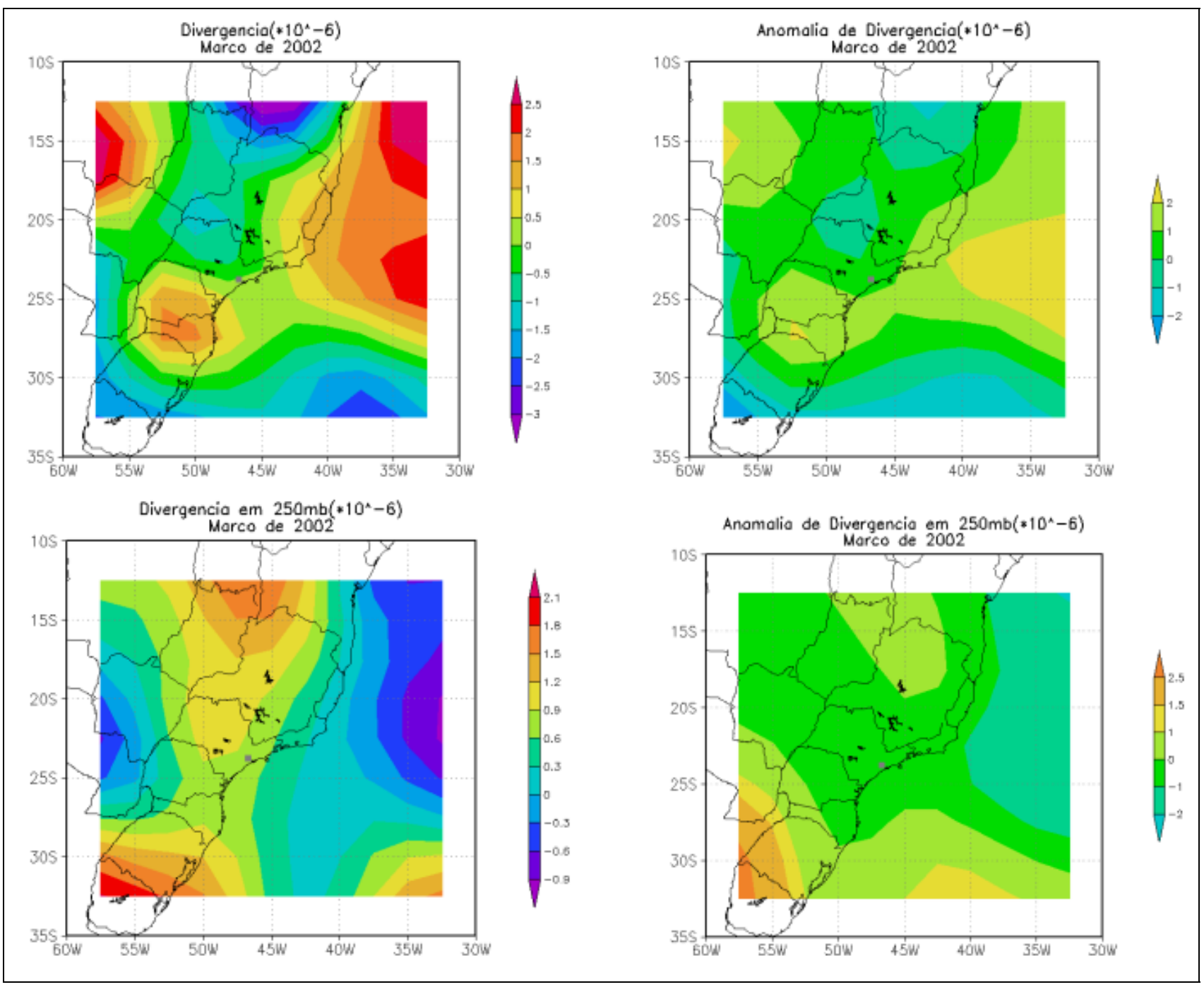

Figura 74e: Divergência do ar em superfície e altitude em março de 2002 e suas respectivas anomalias. 


\section{Fevereiro de 2003}

No que diz respeito aos campos atmosféricos, o mês de fevereiro de 2003 foi bastante semelhante ao de março de 2002, com anomalias positivas de pressão, temperatura, radiação, $\mathrm{ROL}$ e negativas para umidade relativa, além de divergência do ar em superfície (figuras 78a a 78e), juntamente com ventos de NE. Houve a atuação de diversos vórtices ciclônicos de altos níveis no Brasil, sendo que um deles se deslocou da Bahia até o Estado de São Paulo, onde inibiu a chegada de frentes frias; assim, houve fraca atividade frontal. Finalmente, nenhuma atividade foi verificada por parte da ZCAS:

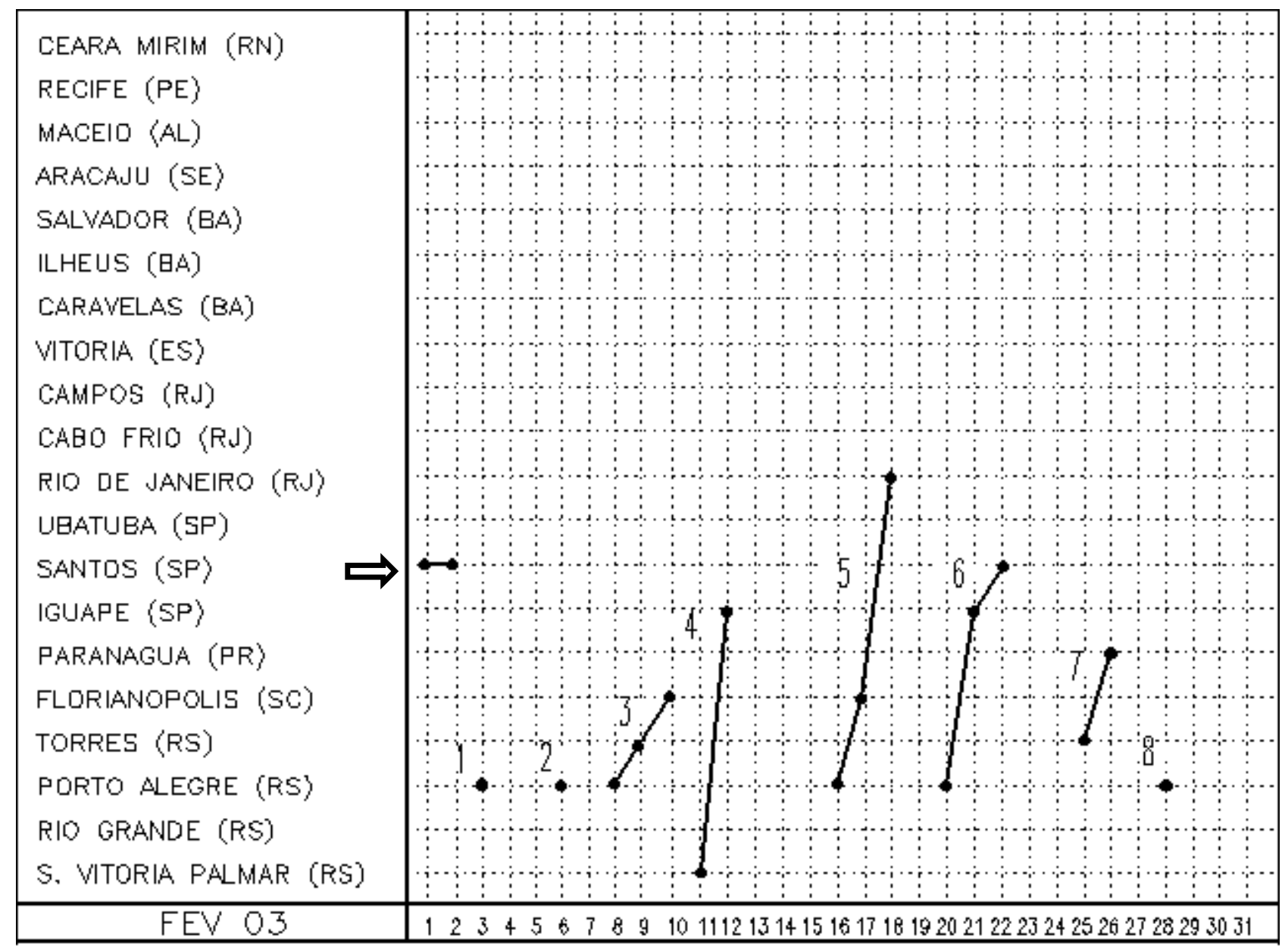

Figura 75: atuação das frentes frias no litoral do Brasil, fevereiro de 2003. A cidade de Santos está destacada como representante mais próxima da RMSP.

Fonte: $\underline{\text { http://www.cptec.inpe.br/products/climanalise/0203/index.html }}$

A figura 75 demonstra que apenas duas frentes frias atuaram na RMSP neste mês (a média climatológica pra fevereiro na latitude da RMSP é de seis sistemas), nos dias 17 e 21, de modo que a primeira quinzena do mês e a última semana não 
tiveram influência destes sistemas. De acordo com o boletim da Climanálise para este mês ${ }^{16}$,

"a atuação de vórtices ciclônicos em altos níveis, associada ao aumento da pressão à superfície, impediu o avanço das frentes frias, o que foi desfavorável à ocorrência de chuvas. Considerando os desvios em relação à média histórica, com exceção de áreas isoladas, predominaram desvios negativos em toda a Região (SE)".

Na figura 76, pode-se perceber a influência dos VCANs sobre boa parte do Brasil:

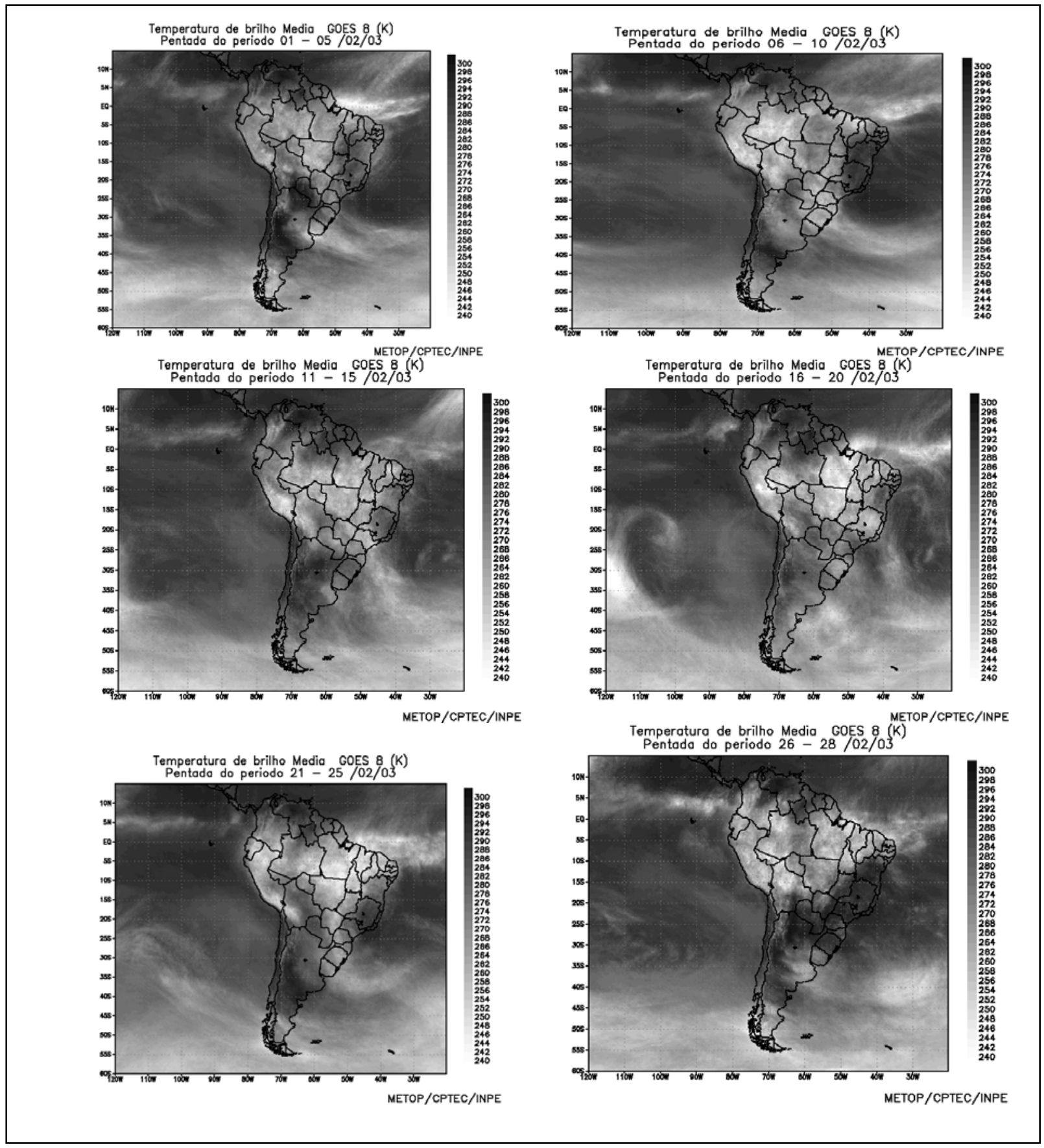

${ }^{16}$ http://www.cptec.inpe.br/products/climanalise/0203/index.html 
Figura 76 : Atuação dos VCANs sobre o Brasil em fevereiro de 2003. Fonte: http://www.cptec.inpe.br/products/climanalise/0203/index.html

Embora a análise da figura 76 indique significativa nebulosidade sobre a área da RMSP, os VCANs foram muito intensos e abrangentes, atuando em escala sinótica no oceano e dificultando a entrada de frentes frias sobre a RMSP, em especial no final do mês.

Segundo o boletim Climanálise mencionado, a ocorrência destes VCANs foi favorecida devido à mudança do posicionamento da alta da Bolívia, que influenciou no posicionamento de uma área de convergência do ar em altitude sobre a Região Nordeste do Brasil, causando divergência em superfície.

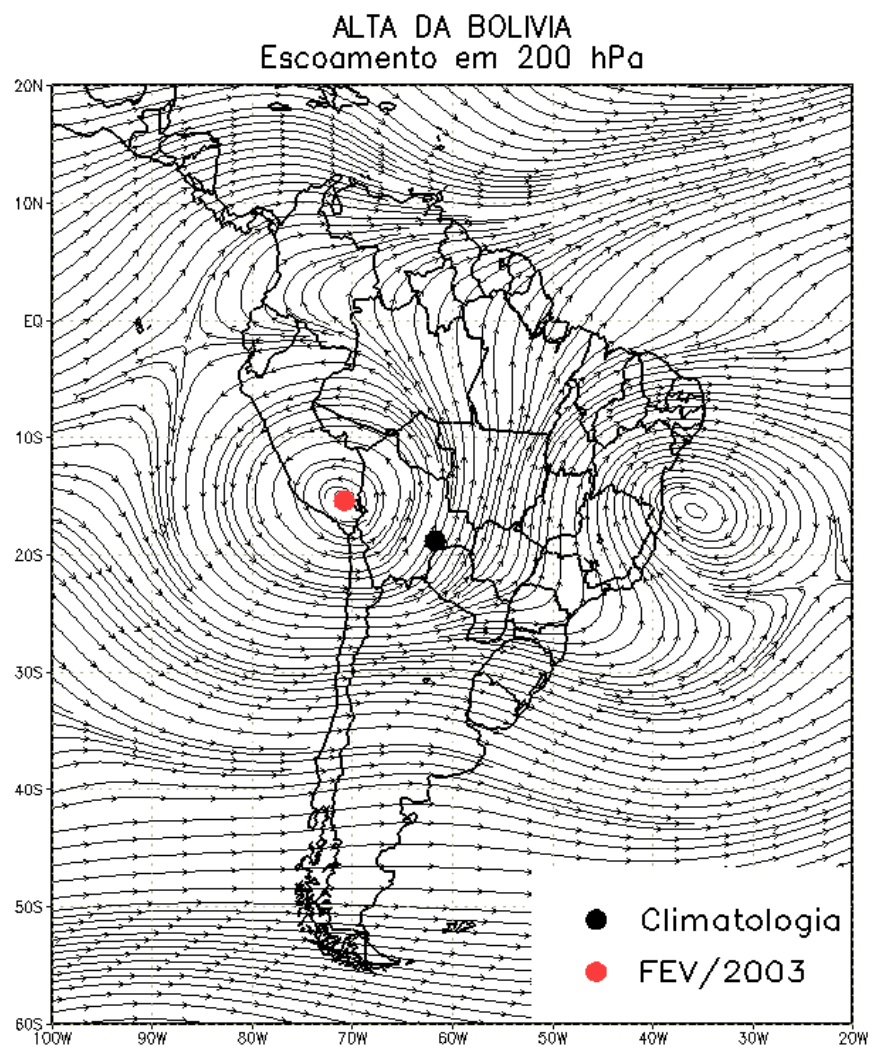

Figura 77: posicionamento da alta da Bolívia na América do Sul em fevereiro de 2003.

Fonte: http://www.cptec.inpe.br/products/climanalise/0203/altabolivia.html

Assim, as anomalias positivas de ROL, radiação, temperatura, pressão e negativas de UR observadas na figura evidenciam a atuação dos VCANs, influenciados pelo posicionamento anômalo da alta da Bolívia, que contribuíram para o acúmulo do poluente neste mês. 


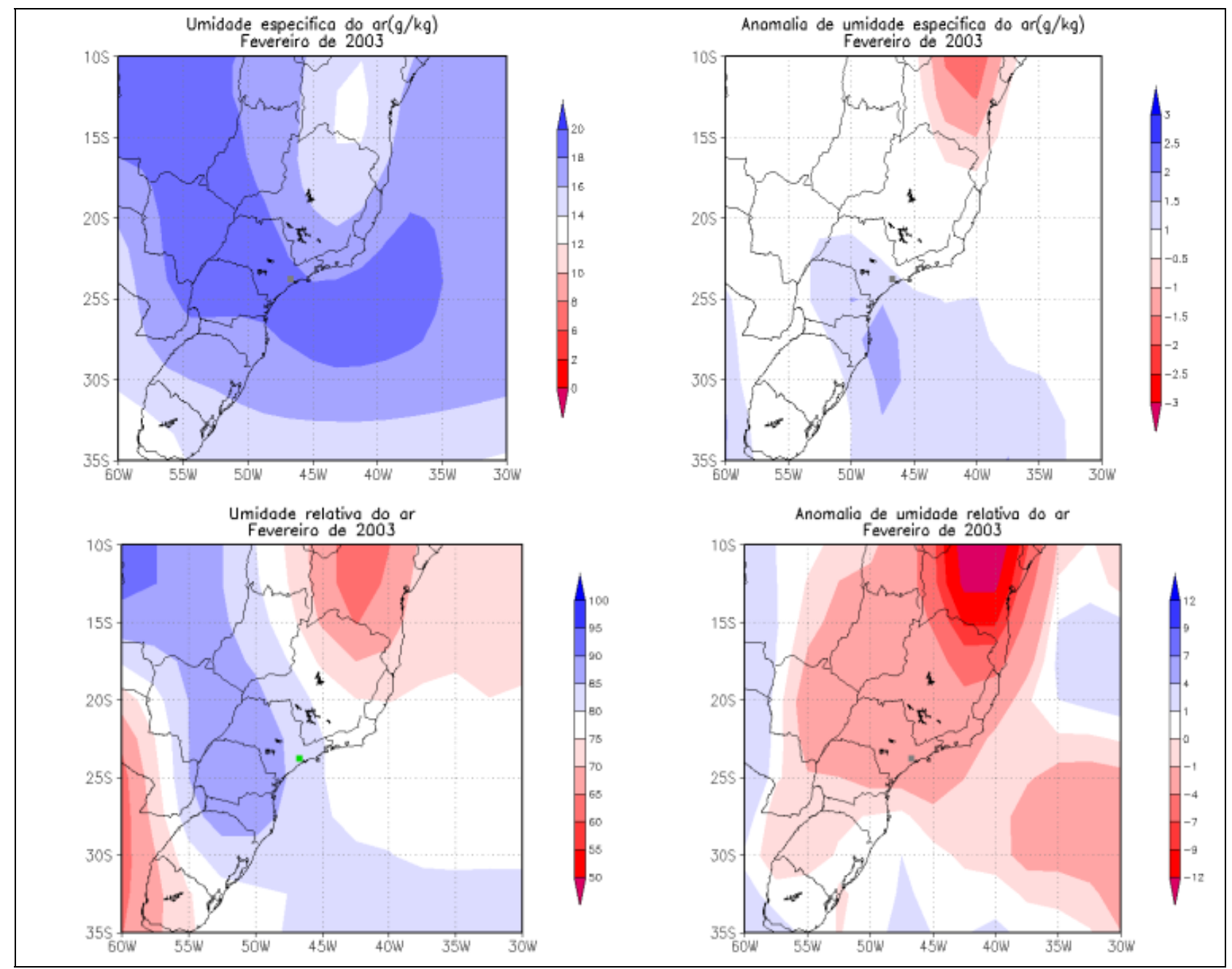

Figura 78a: Umidade relativa e específica do ar em fevereiro de 2003 e suas respectivas anomalias. 


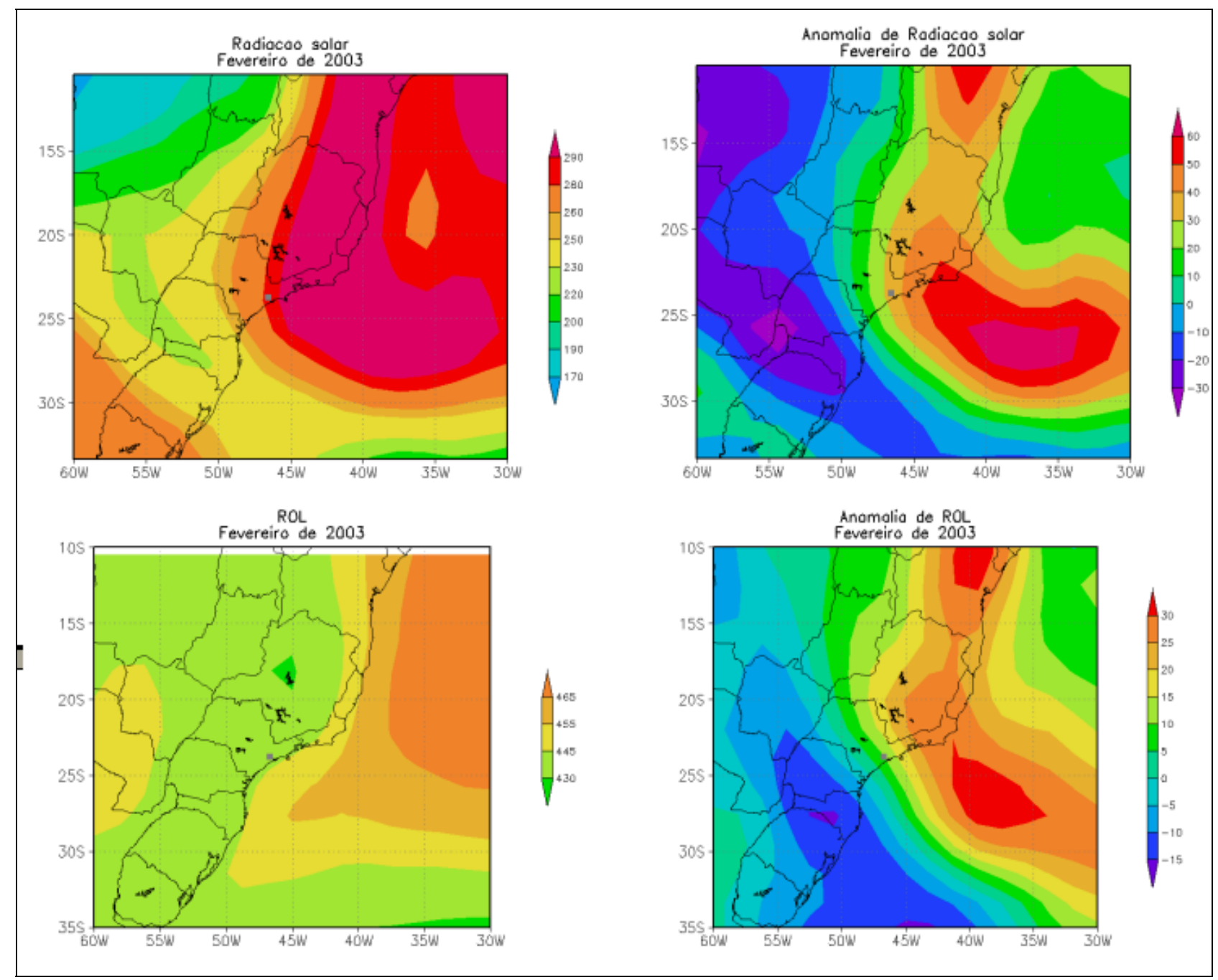

Figura 78b: Radiação solar de ondas curtas e ROL em fevereiro de 2003 e suas respectivas anomalias. 


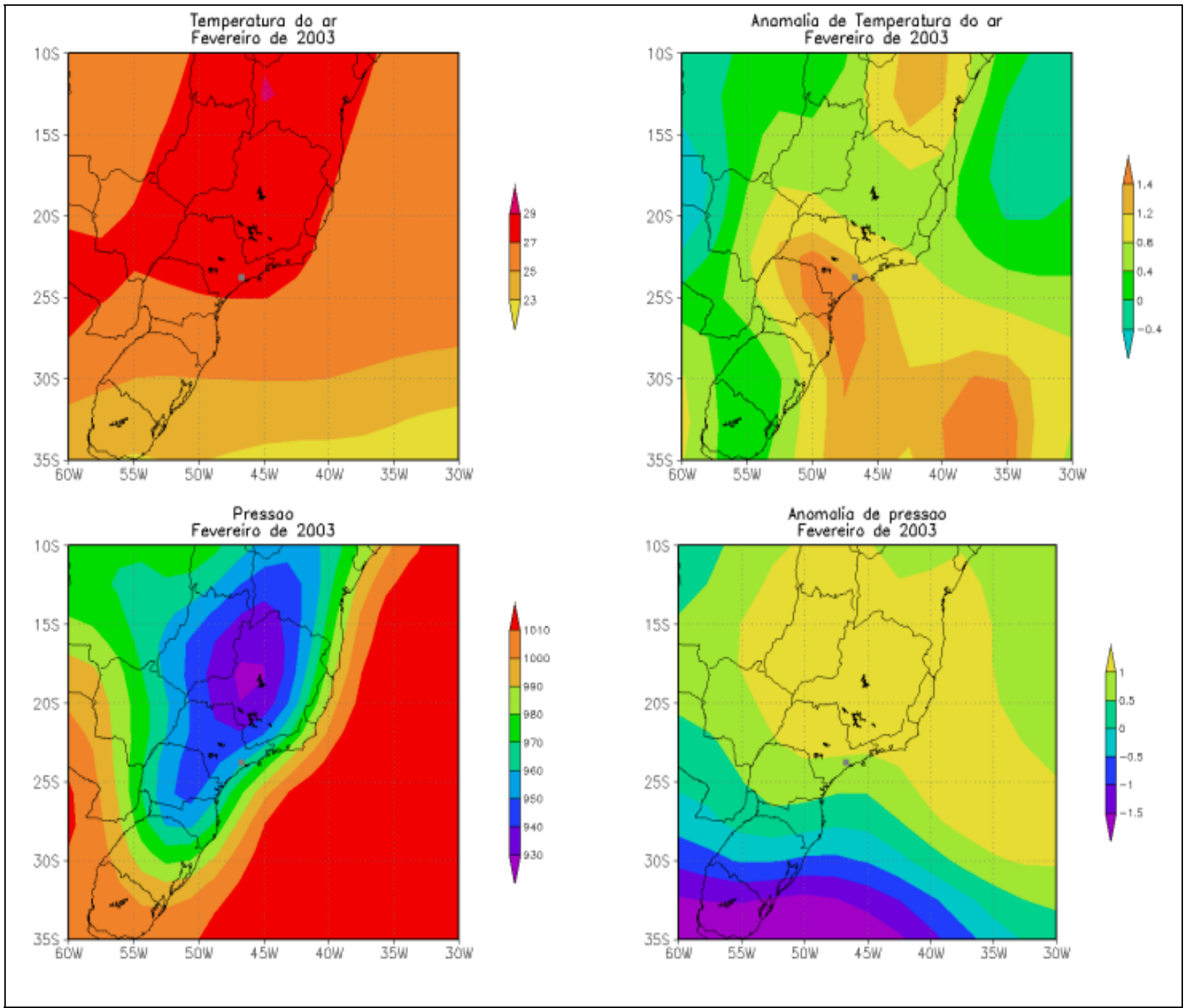

Figura 78c: Temperatura do ar e pressão atmosférica em fevereiro de 2003 e suas respectivas anomalias 


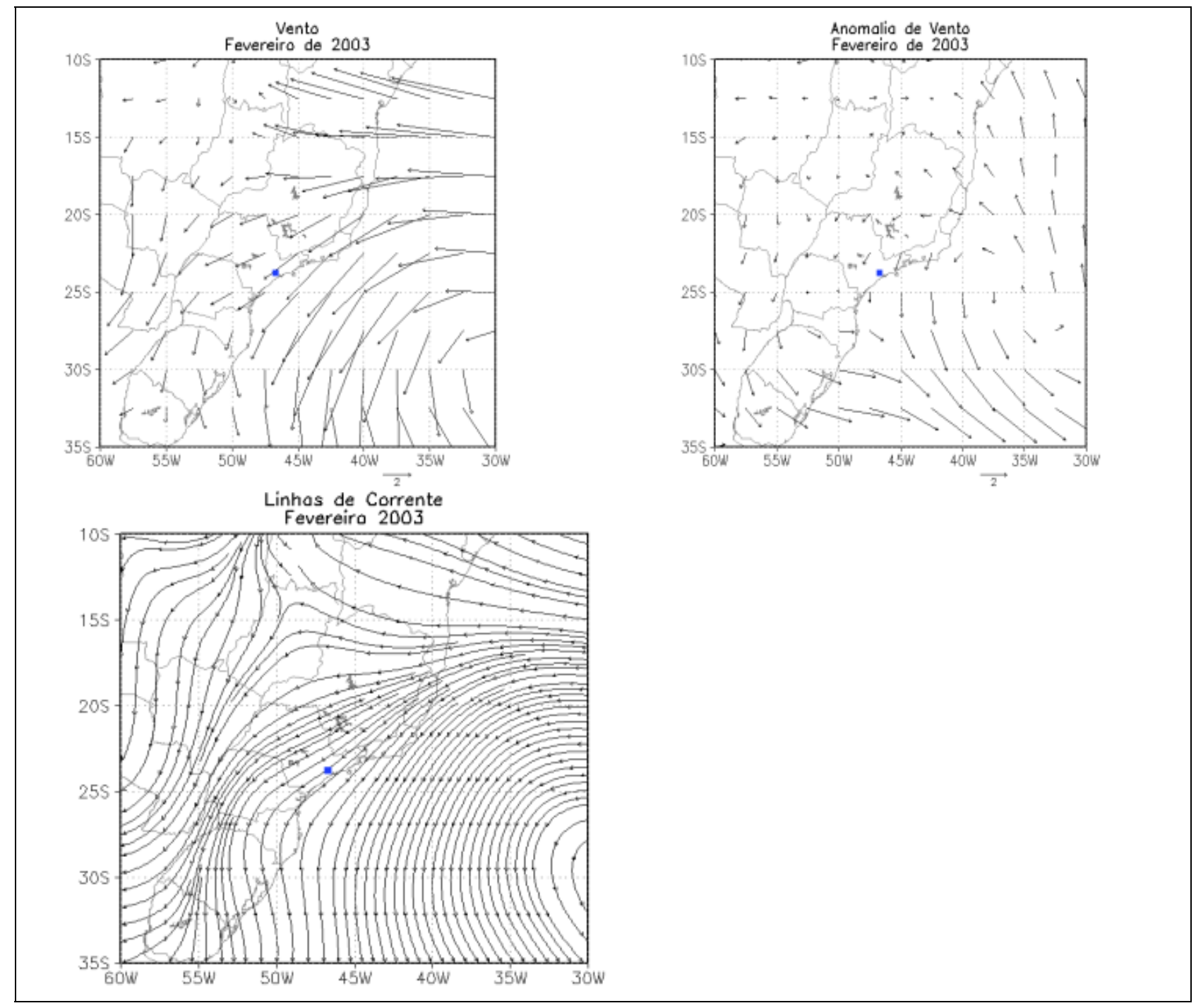

Figura 78d: Escoamento atmosférico e sentido do vento em fevereiro de 2003 e sua respectiva anomalia. 


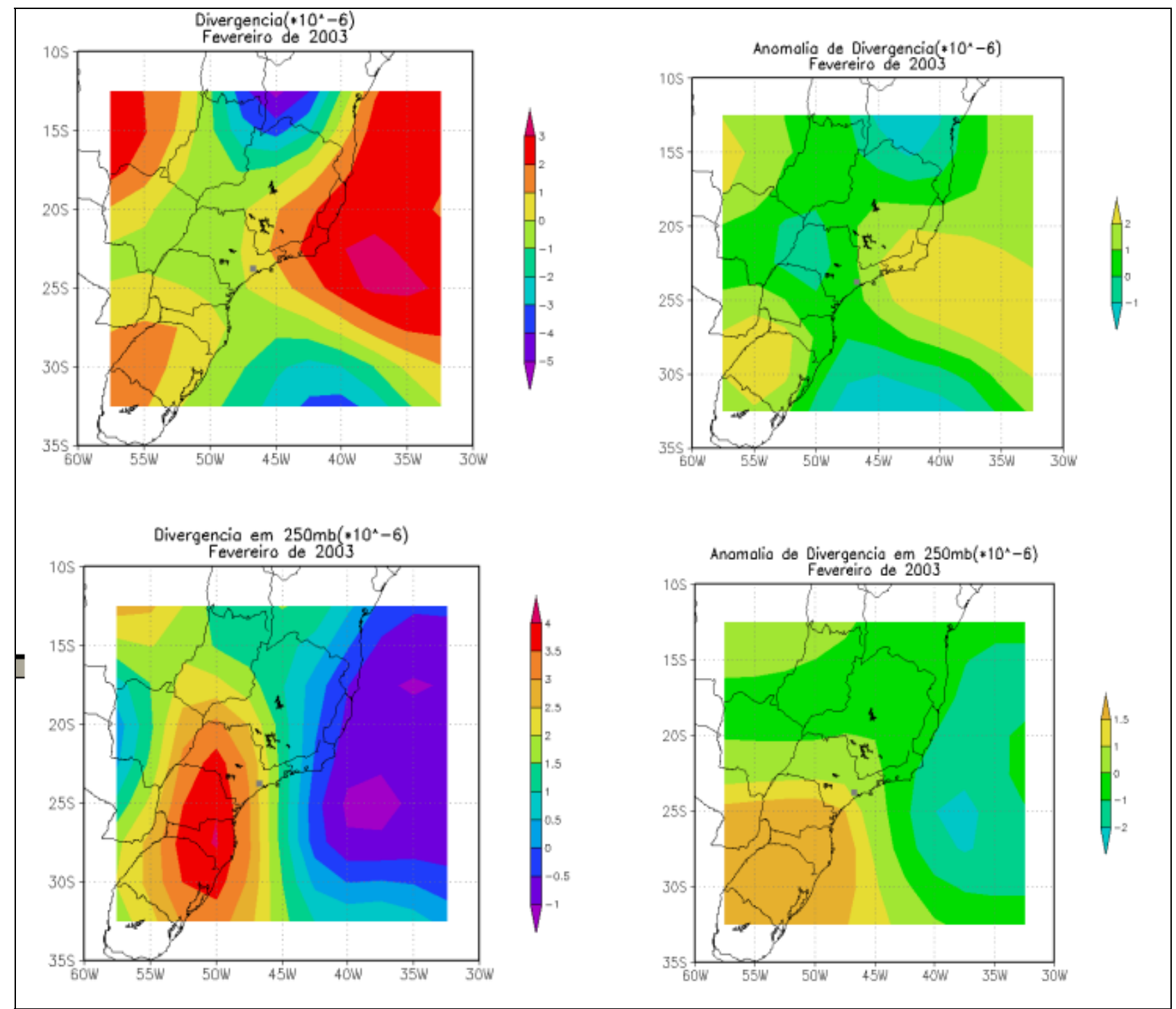

Figura 78e: Divergência do ar em superfície e altitude em fevereiro de 2003 e suas respectivas anomalias. 


\section{Outubro de 2002}

Já foi discutido anteriormente como o ciclo sazonal do ozônio troposférico apresenta um mínimo por volta de junho e um máximo no mês de outubro. O mês de outubro de 2002 é, em termos absolutos, um dos mais poluído da série temporal estudada (1996 a 2005). Excessivamente altas concentrações de ozônio na RMSP em qualquer escala temporal foram observadas neste mês, como pode ser visto nas figuras 32 a 35 na seção 3.1.1 e nas figuras 43a a 43f na seção 3.1.2.1. Além da tendência de aumento do poluente no período estudado, as condições atmosféricas também contribuíram para este episódio de poluição na RMSP, como poderá ser avaliado nas figuras 81 a a 81 e.

A umidade relativa do ar apresenta intensa anomalia negativa no centro do País, com valores de anomalia negativa inferiores a $-10 \%$ numa grande área que se estende desde a RMSP para além da latitude $10^{\circ} \mathrm{S}$ (interior do Estado do Tocantins), limite dos mapas utilizados nesta seção (figura 81a). Pelas figuras $81 \mathrm{~b}$ e 81c, também percebe-se anomalias intensas de radiação solar, ROL e temperatura do ar nesta área, indicando a predominância de dias muito secos, quentes e ensolarados. A pressão atmosférica, contudo, está próxima do normal na RMSP.

O escoamento atmosférico predominante indica uma área de convergência no continente, com centro sobre o Estado de Goiás. A RMSP é levemente influenciada por esta área, como se pode ver na figura $81 \mathrm{~d}$.

Um dado interessante sobre este mês é que sete sistemas frontais chegaram até a latitude de Santos (figura 79): 


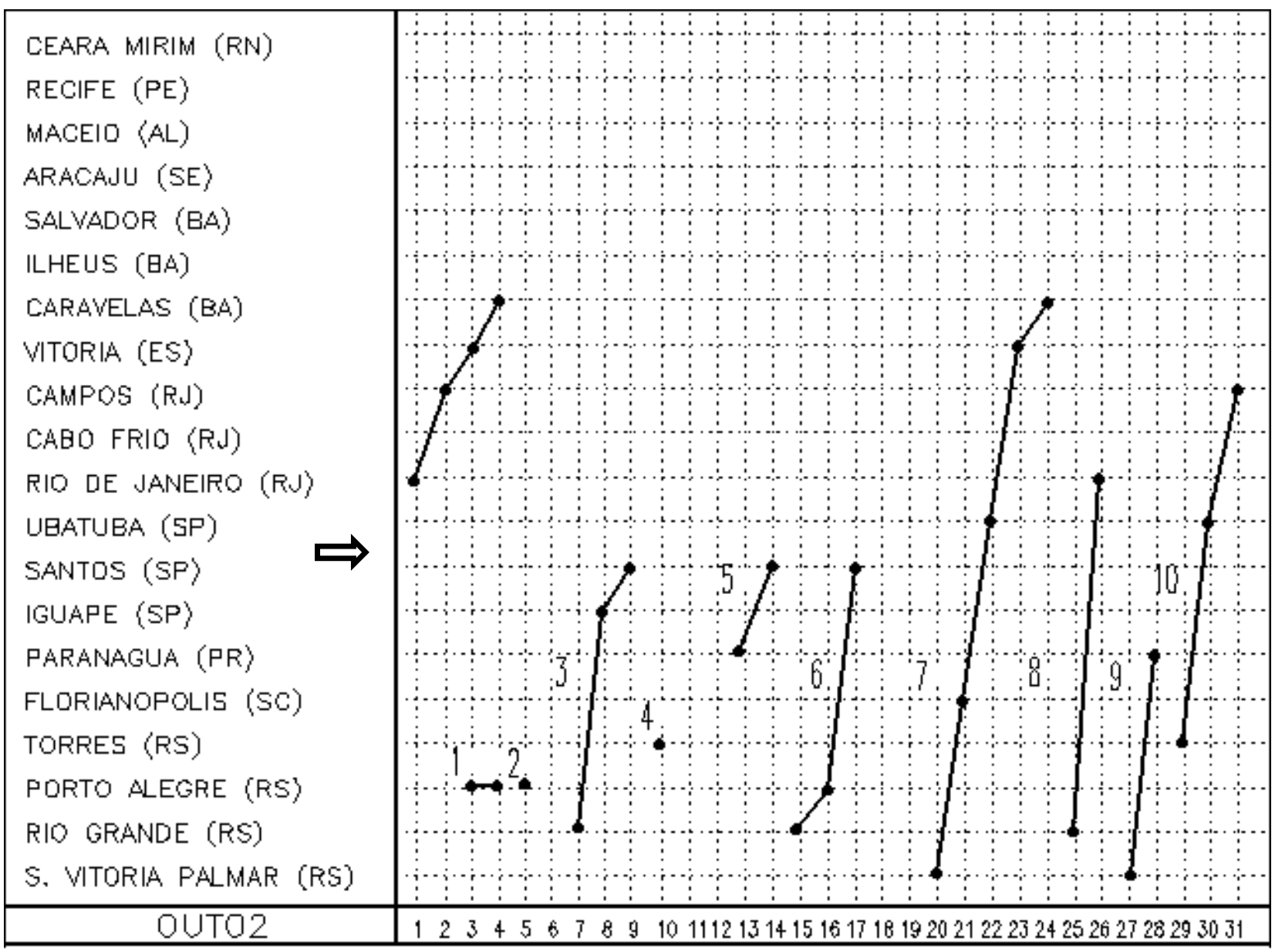

Figura 79: Atuação das frentes frias no litoral do Brasil, outubro de 2002. A cidade de Santos está destacada como representante mais próxima da RMSP.

Fonte: http://www.cptec.inpe.br/products/climanalise/1002/index.html

Entretanto, de acordo com o boletim da Climanálise para este mês: "Foram observados dez sistemas frontais no mês de outubro, no País, embora a maior parte deles tenha atuado apenas até o sul do Estado de São Paulo ${ }^{17 "}$.

Além disso, este mesmo documento informa que houve desvio negativo de precipitação em toda a Região Sudeste. Pode-se observar que, de fato, os três primeiros sistemas do mês não ultrapassaram esta latitude, podendo indicar menor intensidade. Assim, assumindo então que apenas os sistemas frontais dos dias 21, 25 e 29 influenciaram significativamente a RMSP neste mês, houveram praticamente vinte dias sem a atuação de sistemas frontais significativos (figura 79). Esta hipótese pode ser reforçada pelos dados da figura 80 :

\footnotetext{
${ }^{17}$ http://www.cptec.inpe.br/products/climanalise/1002/index.html
} 


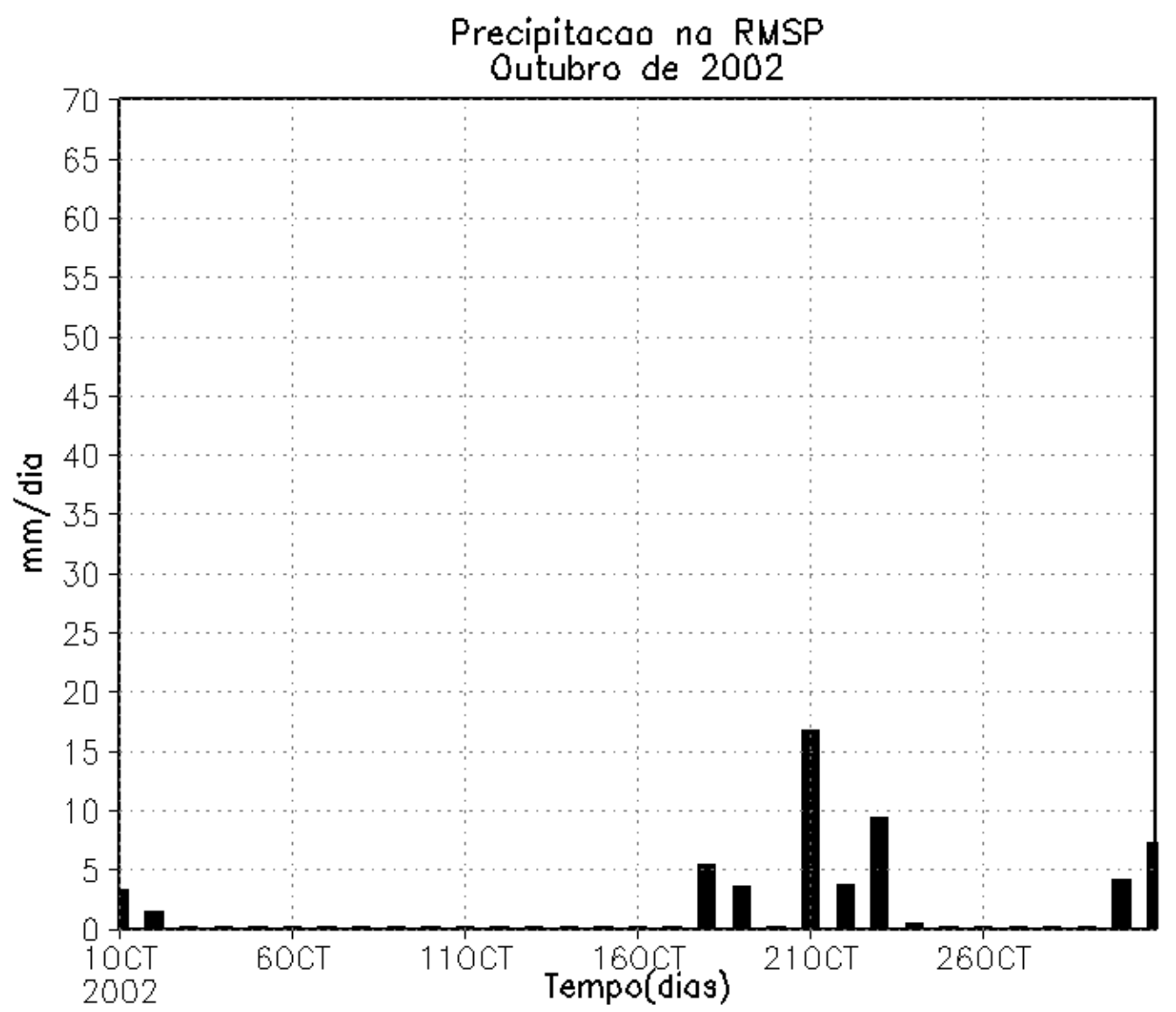

Figura 80: Precipitação diária na RMSP no mês de outubro de 2002. Fonte: Reanálise 2.

Pode-se perceber que houve ocorrência de precipitação neste mês em nove dias, mas que em apenas quatro os volumes foram superiores a $5 \mathrm{~mm}$. O maior episódio precipitação, de $17 \mathrm{~mm}$, ocorreu no dia da passagem de um sistema frontal, o mais intenso do mês (figura 79). Nota-se a baixa frequência de sistemas frontais significativos neste mês, uma vez que a média climatológica de outubro pra as latitudes de $20^{\circ}$ a $25^{\circ} \mathrm{S}$ é de sete sistemas (boletim climanálise).

Assim, embora em um primeiro olhar sobre estas figuras possa-se imaginar que houve boas condições de dispersão de poluentes, o que se constata é uma situação inversa, devido à fraca intensidade dos sistemas que atingiram a RMSP neste mês. Assim, mais uma vez temos a predominância dos padrões atmosféricos parecidos com os de outros meses da classe 2 que provavelmente facilitaram a produção e concentração de ozônio próximo à superfície na RMSP. 


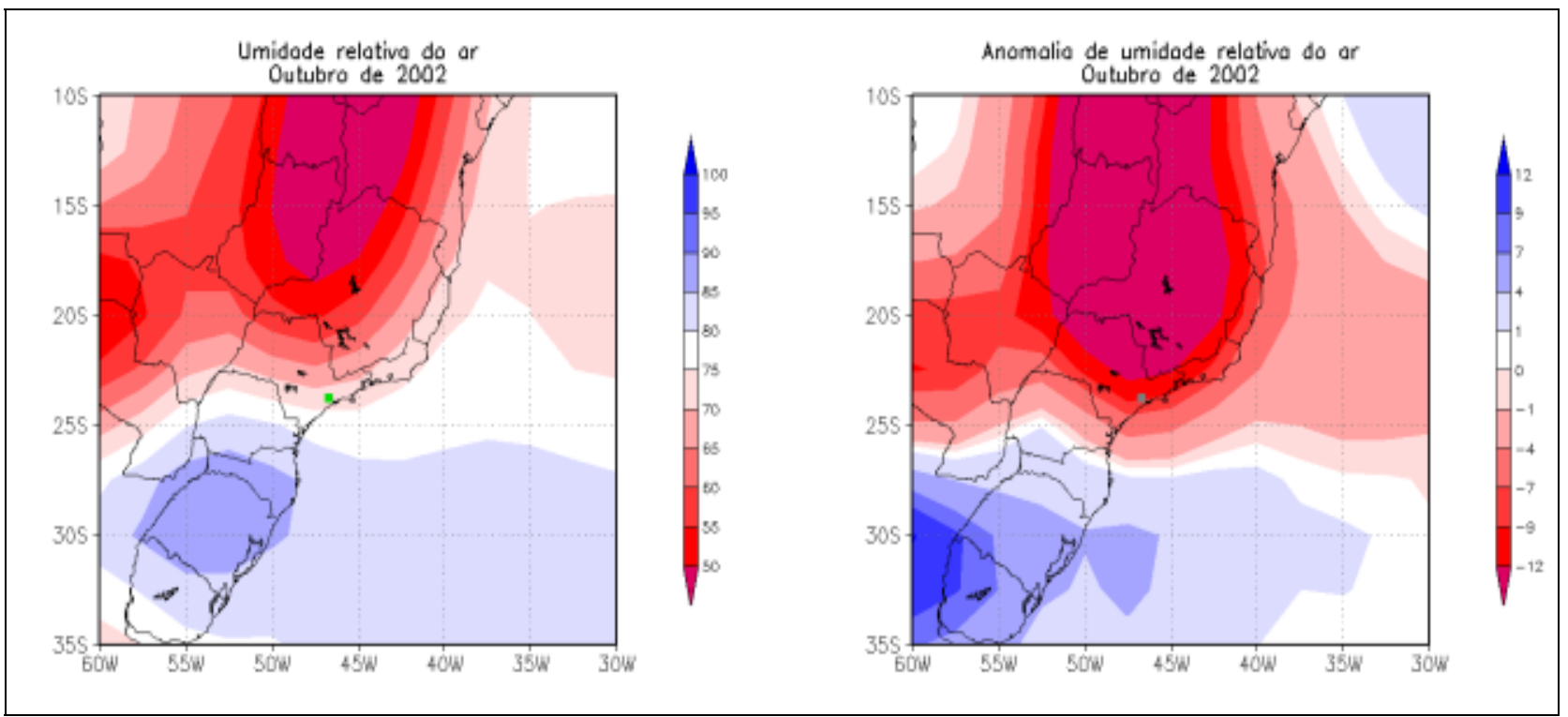

Figura 81a: Umidade relativa do ar em outubro de 2002 e a anomalia observada.

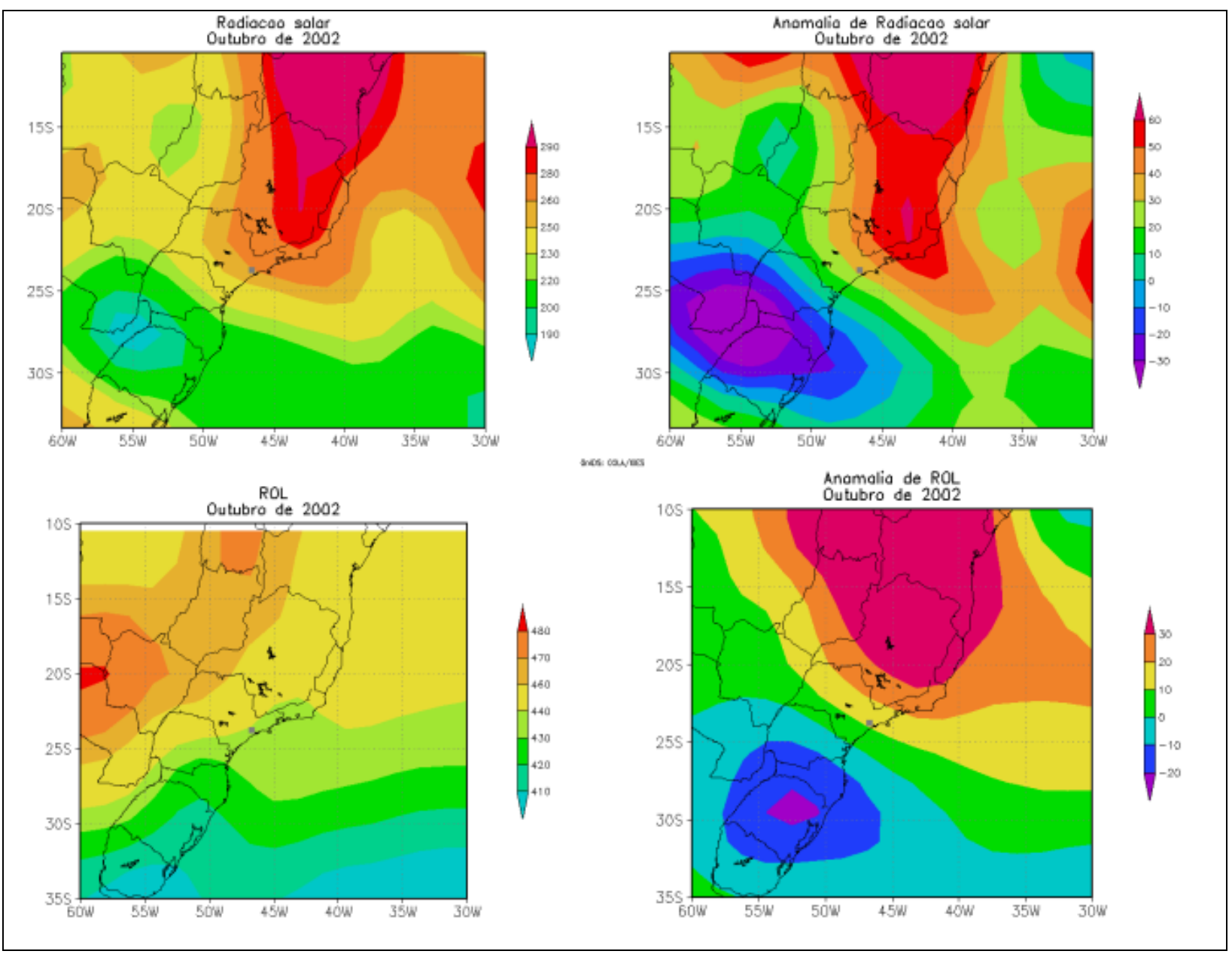

Figura 81b: Radiação solar de ondas curtas e ROL em outubro de 2002 e suas respectivas anomalias. 


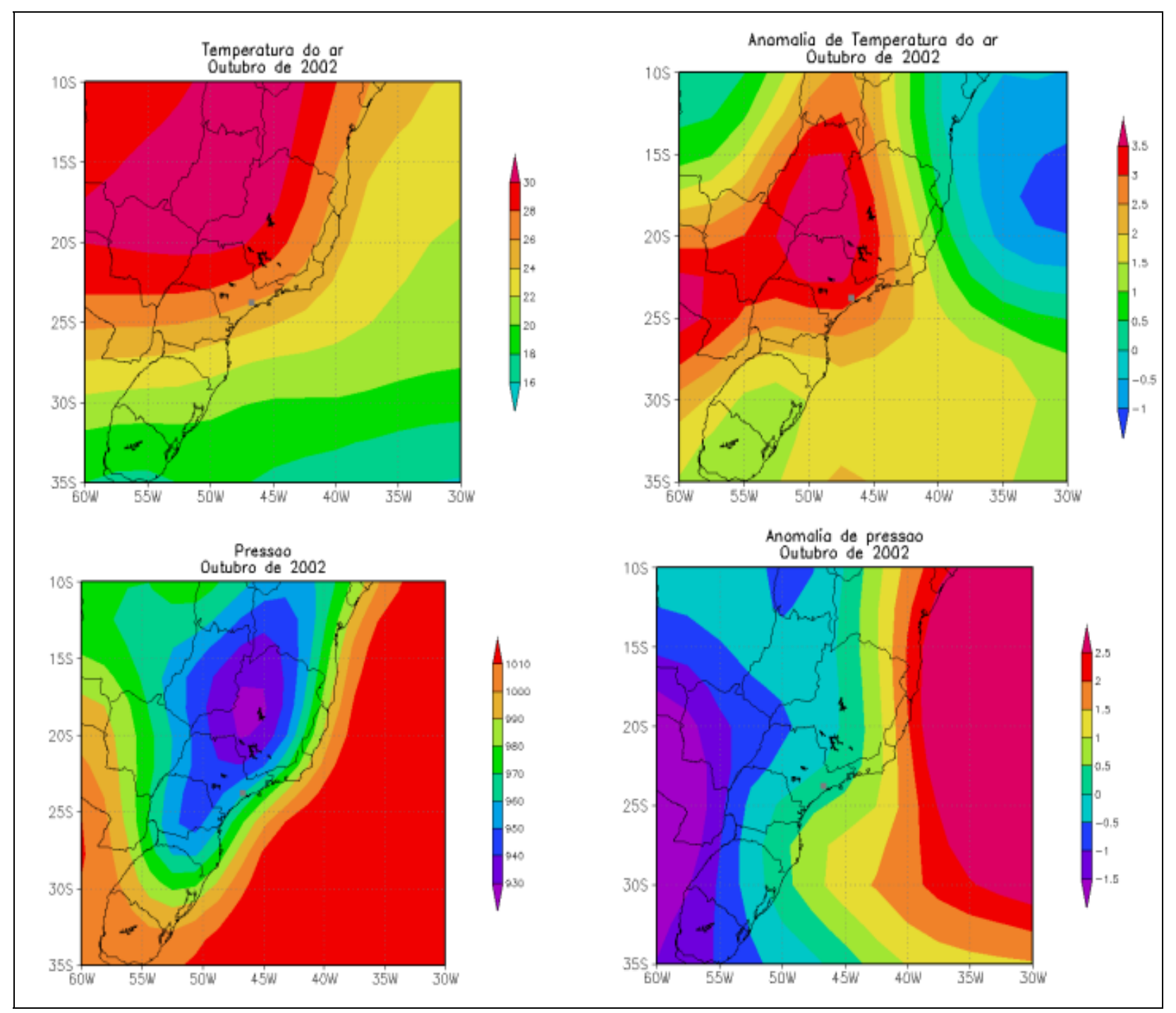

Figura 81c: Temperatura do ar e pressão atmosférica em outubro de 2002 e suas respectivas anomalias. 


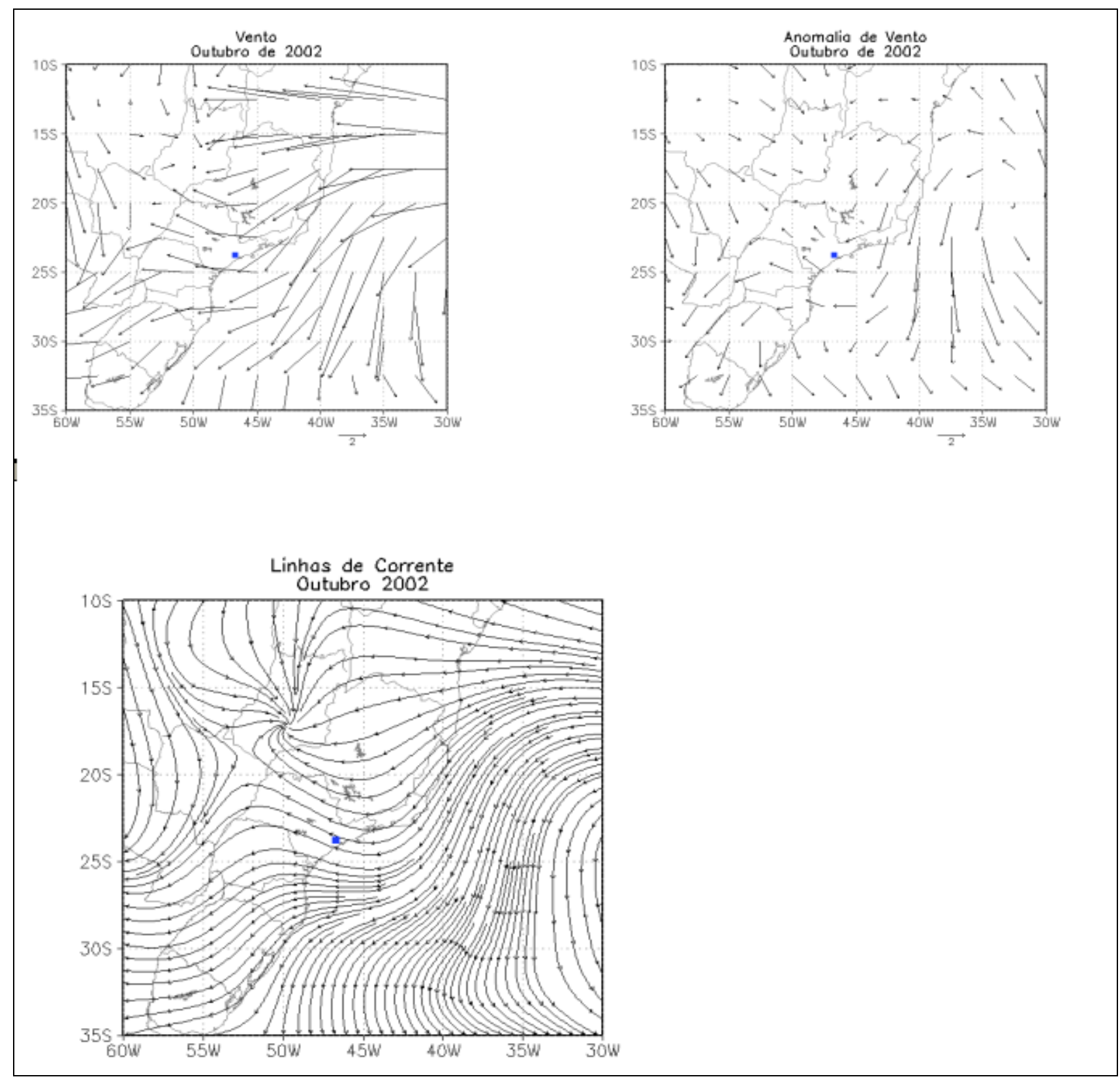

Figura 81d: Escoamento atmosférico e sentido do vento em outubro de 2002 e sua respectiva anomalia. 


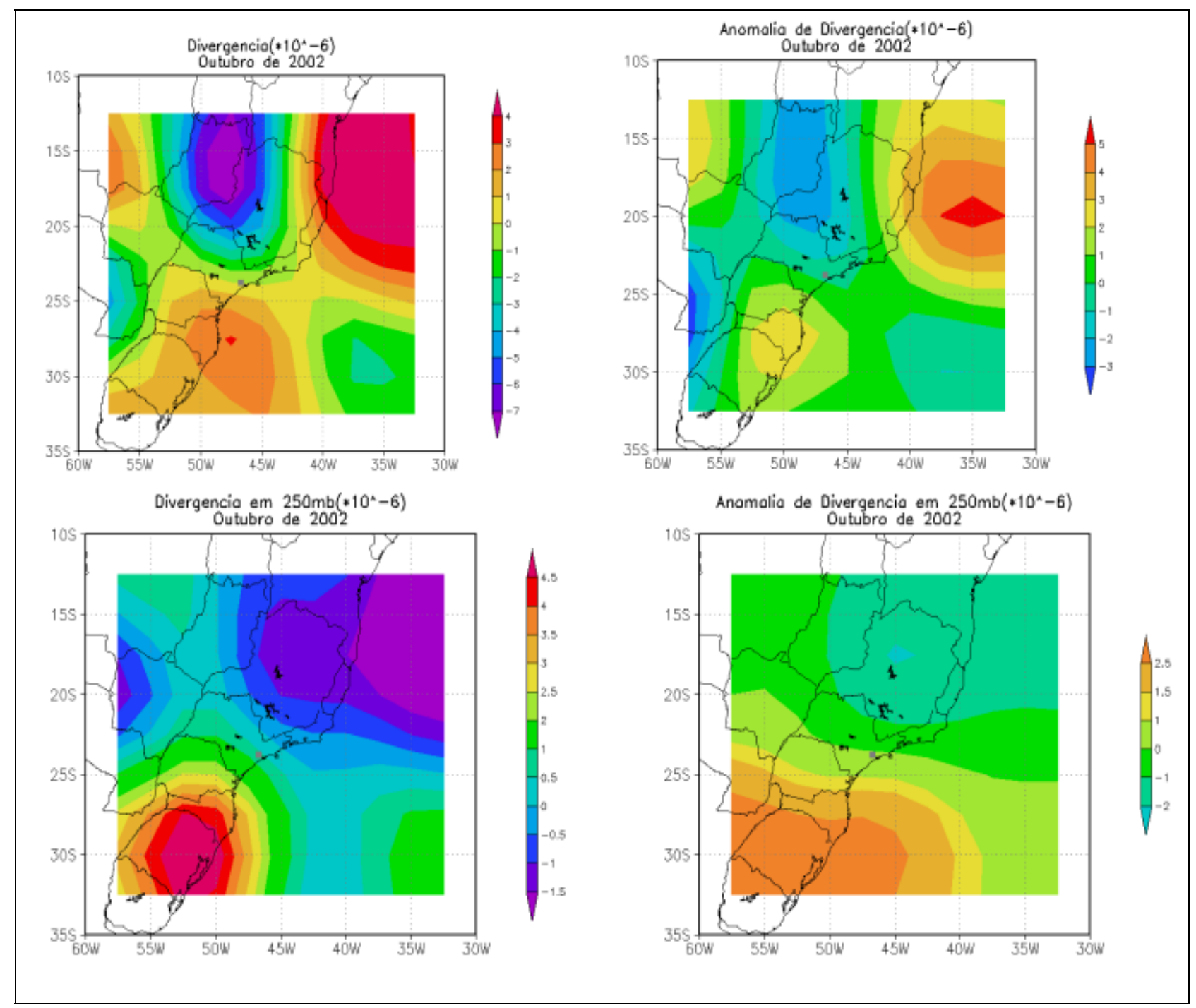

Figura 81e: Divergência do ar em superfície e altitude em outubro de 2002 e suas respectivas anomalias. 


\section{Janeiro de 2001}

Este mês apresentou desvios positivos de radiação solar, ROL, pressão e pequenos desvios positivos de temperatura do ar, além de desvios negativos de umidade relativa (figuras 85 a a $85 \mathrm{e}$ ).

Essas anomalias se configuraram espacialmente de uma maneira semelhante à observada no mês de abril de 1998, ou seja, o Estado de São Paulo sendo caracterizado como uma região de transição entre as condições predominantes no Sul do País e em regiões da Bahia. No Sul, encontram-se áreas com anomalias positivas de umidade relativa do ar (figura 85a), negativas de radiação solar e ROL (figura 85b), com convergência do ar em superfície menos intensa do que o normal (figura 85e). Nota-se, portanto, predominância de baixa umidade do ar, temperatura mais elevada e menor nebulosidade neste mês, o que pode ter influenciado as anomalias positivas de ozônio verificadas. A direção do vento foi de NE (figura 85d), como observada em vários outros meses de concentração alta analisados anteriormente.

Com relação à atividade frontal e à precipitação, os boletins da Climanálise para este mês indicam a ocorrência de quatro sistemas frontais em janeiro de 2001 que atingiram a latitude da RMSP, mas que foram caracterizados por fraca intensidade (figura 82): 


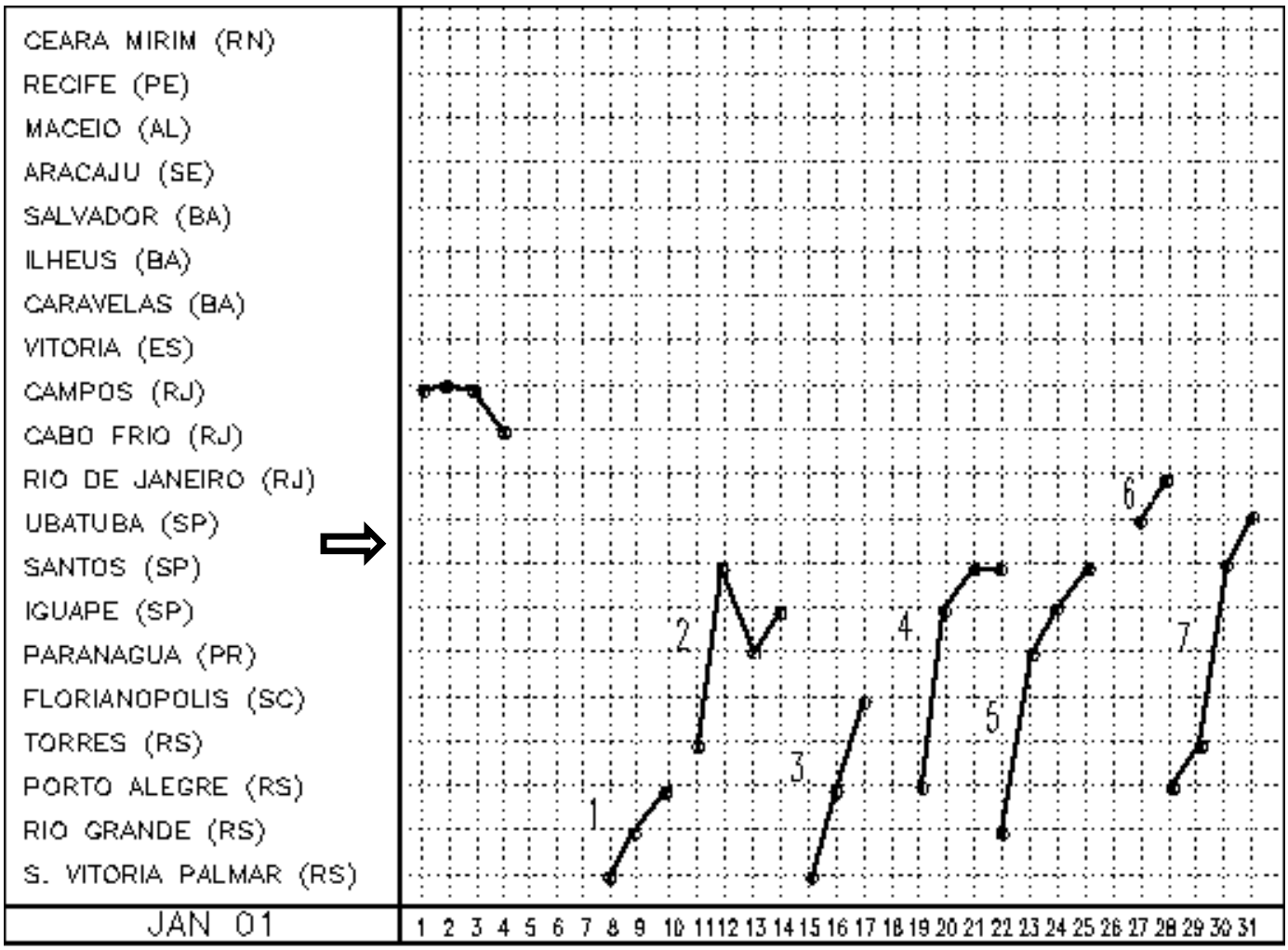

Figura 82: atuação das frentes frias no litoral do Brasil, Janeiro de 2001. A cidade de Santos está destacada como representante mais próxima da RMSP.

Fonte: http://www.cptec.inpe.br/products/climanalise/0101/index.html

Segundo o boletim Climanálise deste mês, "[...]sete sistemas frontais atuaram neste mês[...]estes sistemas foram de fraca intensidade e organizaram pouca convecção no interior do continente ${ }^{18}$ ". Este número equivale à média climatológica do mês, contudo, apenas quatro deles atingiram latitude da RMSP. É possível deduzir que, mesmo que estes sistemas atingissem a latitude de Santos, não interferiram significativamente na RMSP a ponto de dispersar de maneira decisiva as altas concentrações de ozônio verificadas. A influência dos sistemas frontais sobre as condições atmosféricas no continente foi reduzida devido à atuação do anticiclone do Atlântico Sul ${ }^{19}$, que também influenciou negativamente o desenvolvimento de convecção local. Pode-se perceber que, apesar da ocorrência de eventos de precipitação em diversos dias do mês (figura 83), esta ainda ficou abaixo da média ${ }^{20}$ devido aos fatores supracitados:

\footnotetext{
${ }^{18} \mathrm{http}: / /$ www.cptec.inpe.br/products/climanalise/0101/index.html

${ }_{19} \mathrm{http://www.cptec.inpe.br/products/climanalise/0101/ativ} \mathrm{convectiva.html}$

${ }^{20}$ http://www.cptec.inpe.br/products/climanalise/0101/sistemas frontais.html
} 


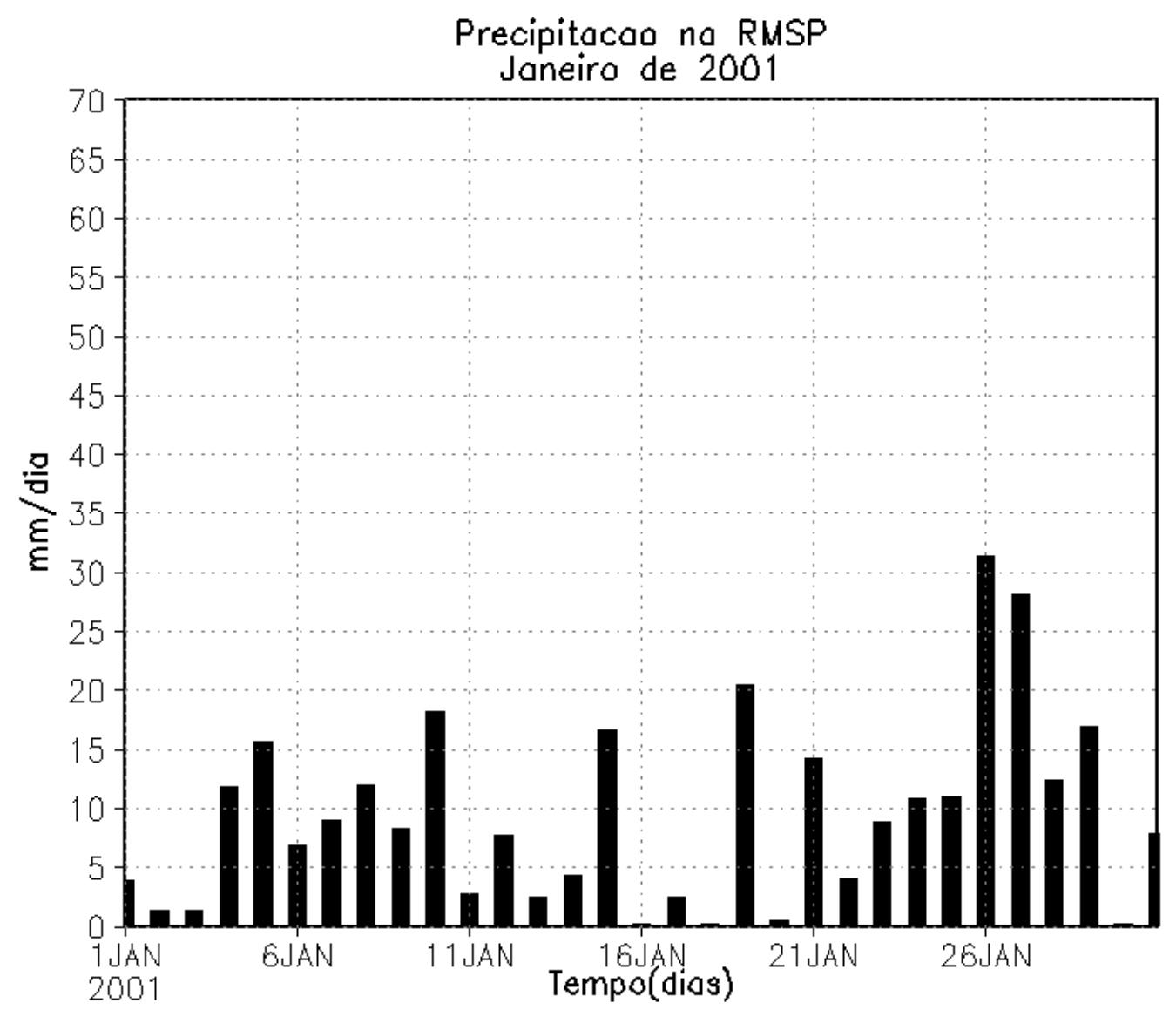

Figura 83: Precipitação na RMSP em janeiro de 2001. Fonte: Reanálise 2.

Comparando as figuras de precipitação e de passagem das frentes frias, notase que apenas a frente fria do dia 25 esteve relacionada a um episódio de intensa precipitação no mês, ao contrário dos sistemas anteriores, dias 12, 21-22 e 30. As anomalias negativas de precipitação ocorreram mesmo com a presença de um episódio da ZCAS no início de janeiro de 2001, que não atuou diretamente sobre a RMSP e, portanto, não compensou os baixos índices de precipitação verificados no restante do mês: 


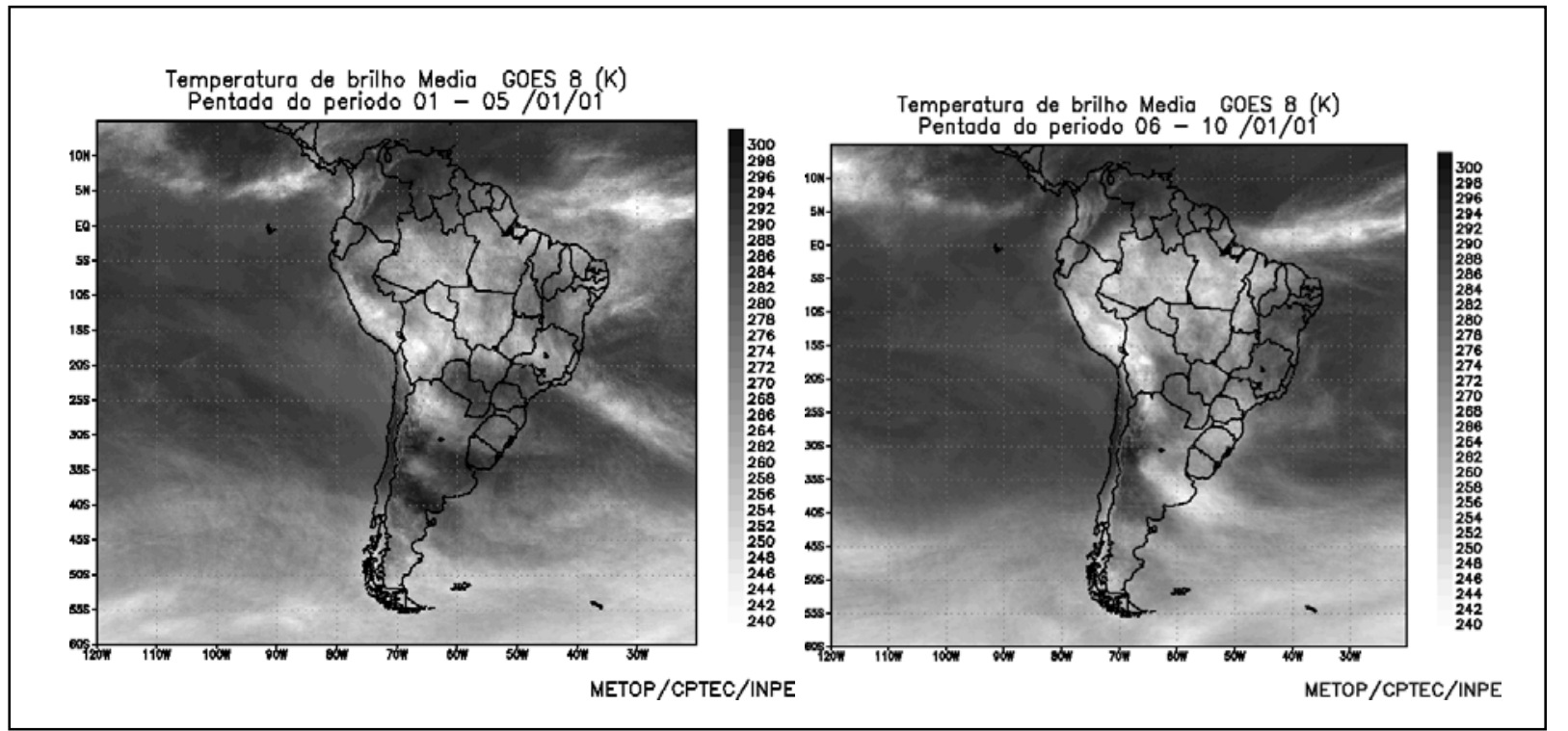

Figura 84: Temperatura de brilho media da América do Sul nos dias 05 e 10 de janeiro de 2001, evidenciando a ocorrência da ZCAS.

Fonte:www.cptec.inpe.br

Assim, sugere-se que as condições atmosféricas predominantes neste mês, com anomalias positivas de radiação solar, temperatura, pressão em superfície e negativas para umidade relativa e divergência do ar; desvios negativos de precipitação e fraca intensidade de sistemas frontais influenciados pela intensificação do anticiclone do Atlântico Sul configuraram uma situação sinótica favorável à produção e acúmulo de ozônio em superfície na RMSP.

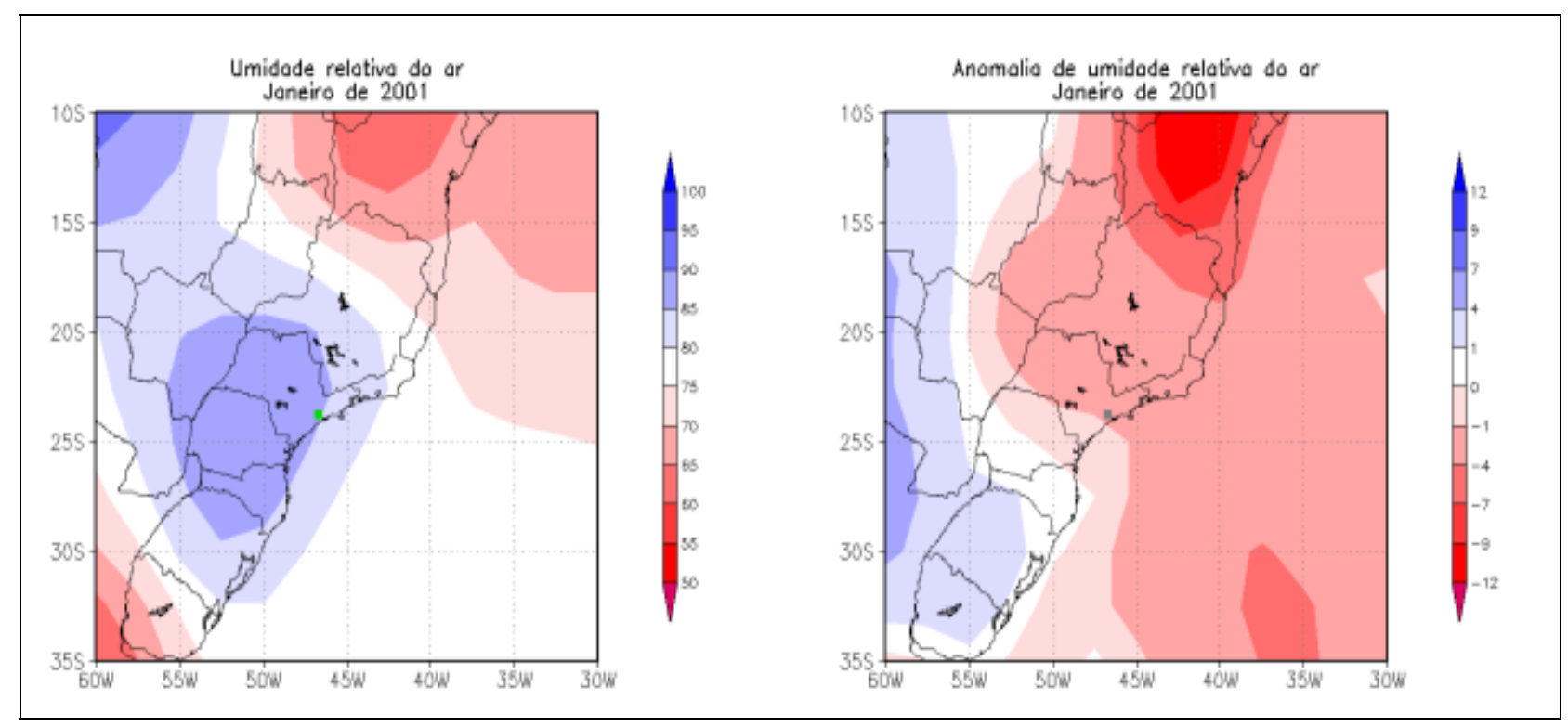

Figura 85a: Umidade relativa do ar em janeiro de 2001 e anomalia observada. 


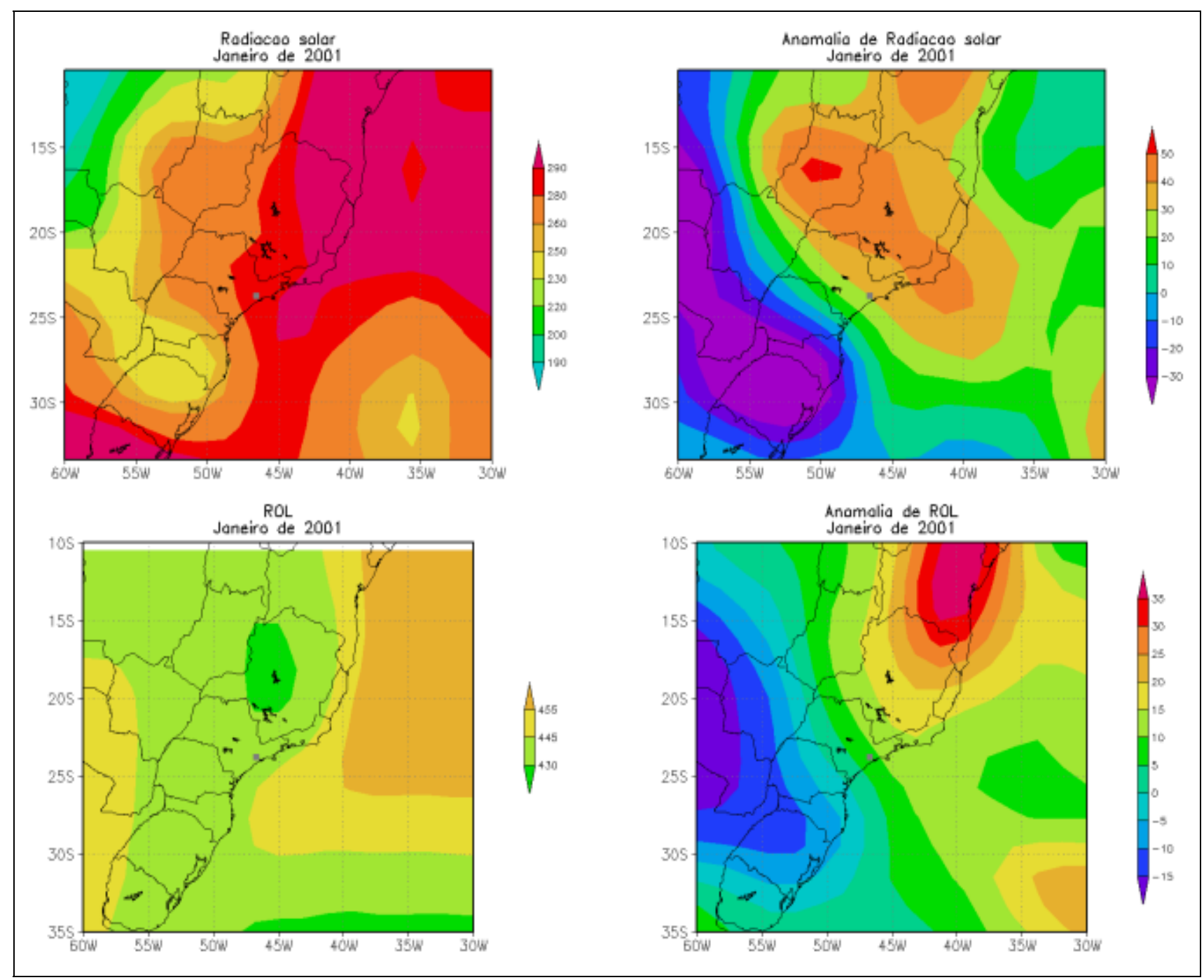

Figura 85b: Radiação solar de ondas curtas e ROL em janeiro de 2001 e suas respectivas anomalias. 

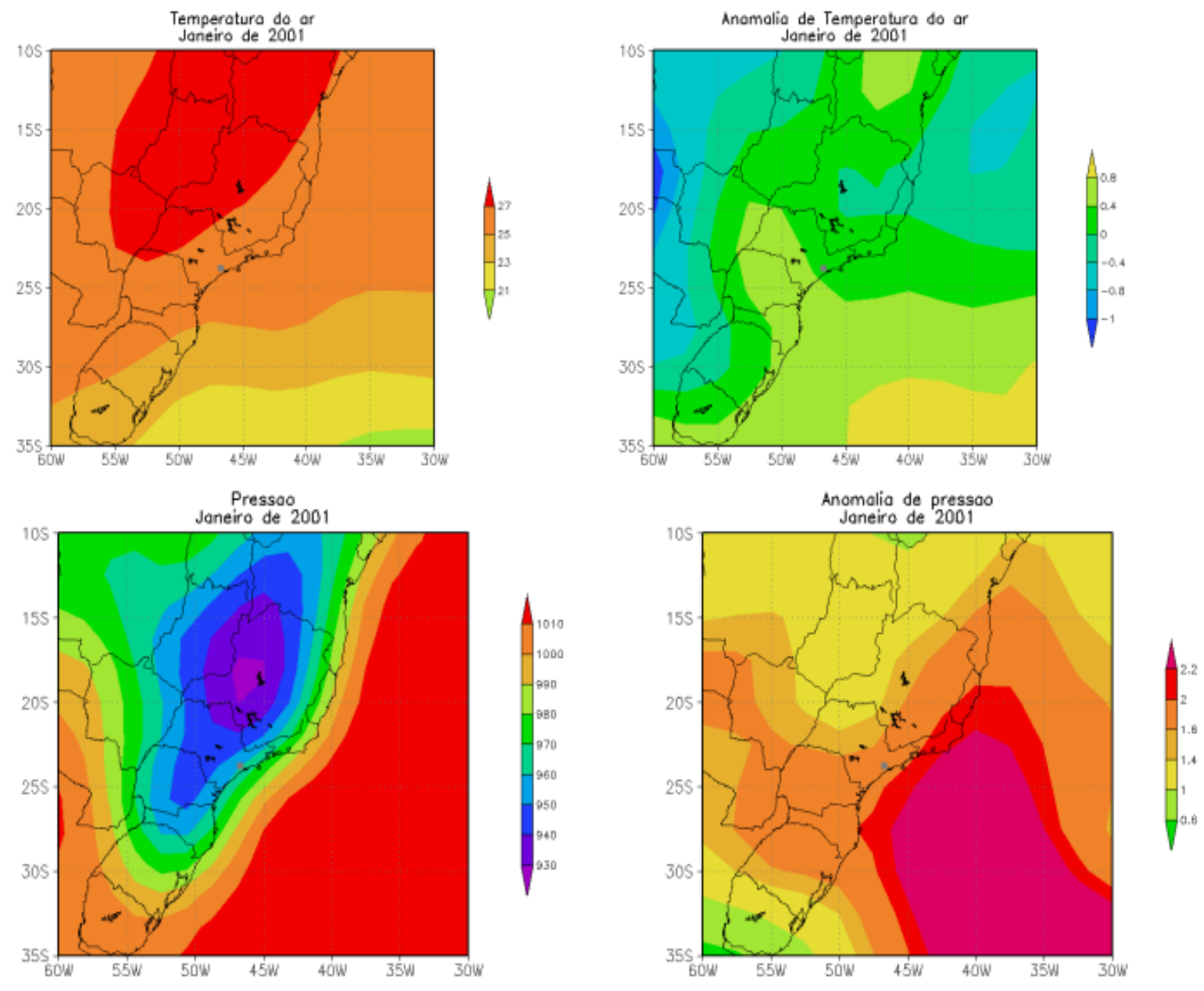

Figura 85c: Temperatura do ar e pressão atmosférica em janeiro de 2001 e suas respectivas anomalias. 

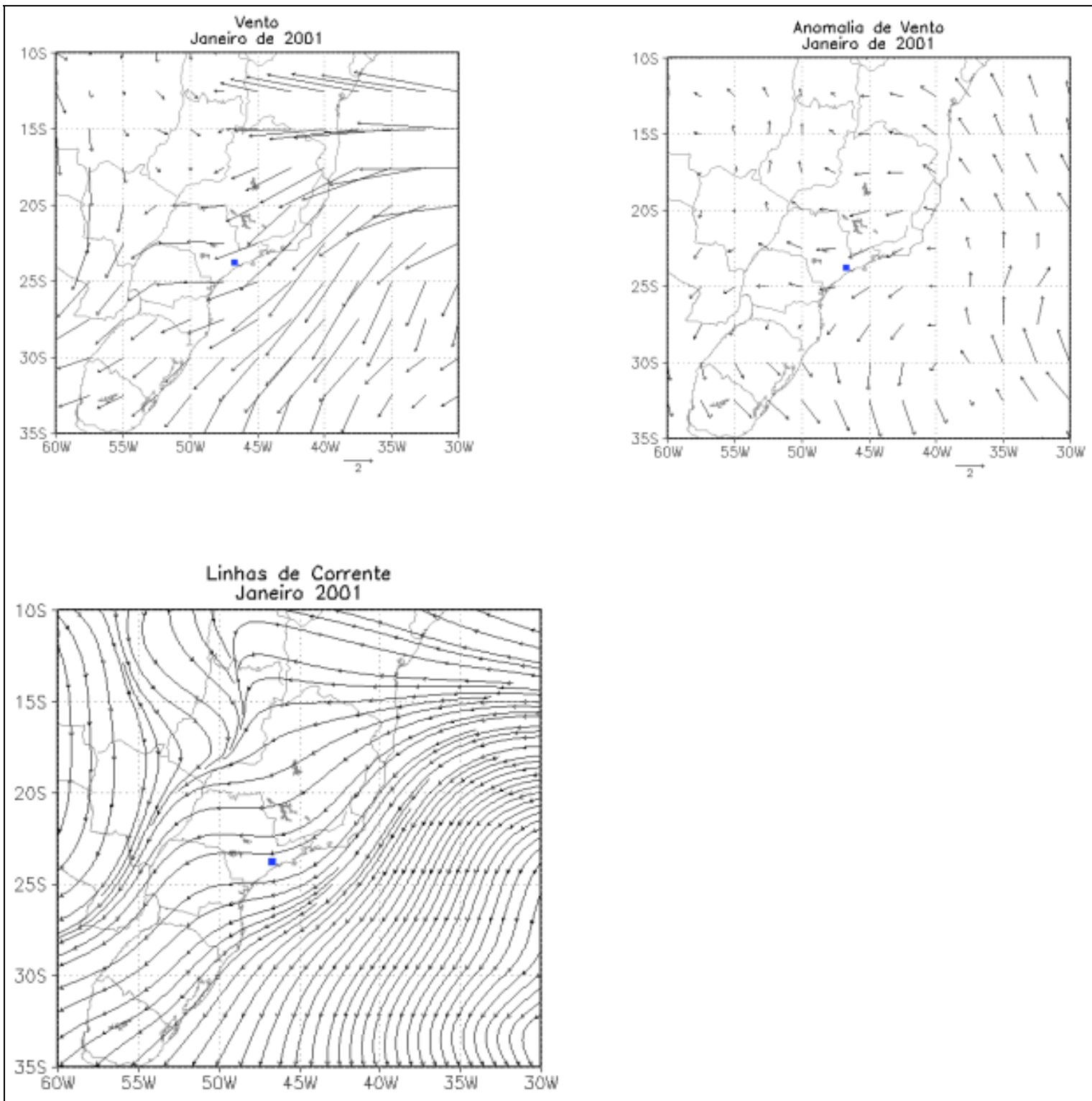

Figura 85d: Escoamento atmosférico e sentido do vento em janeiro de 2001 e sua respectiva anomalia. 


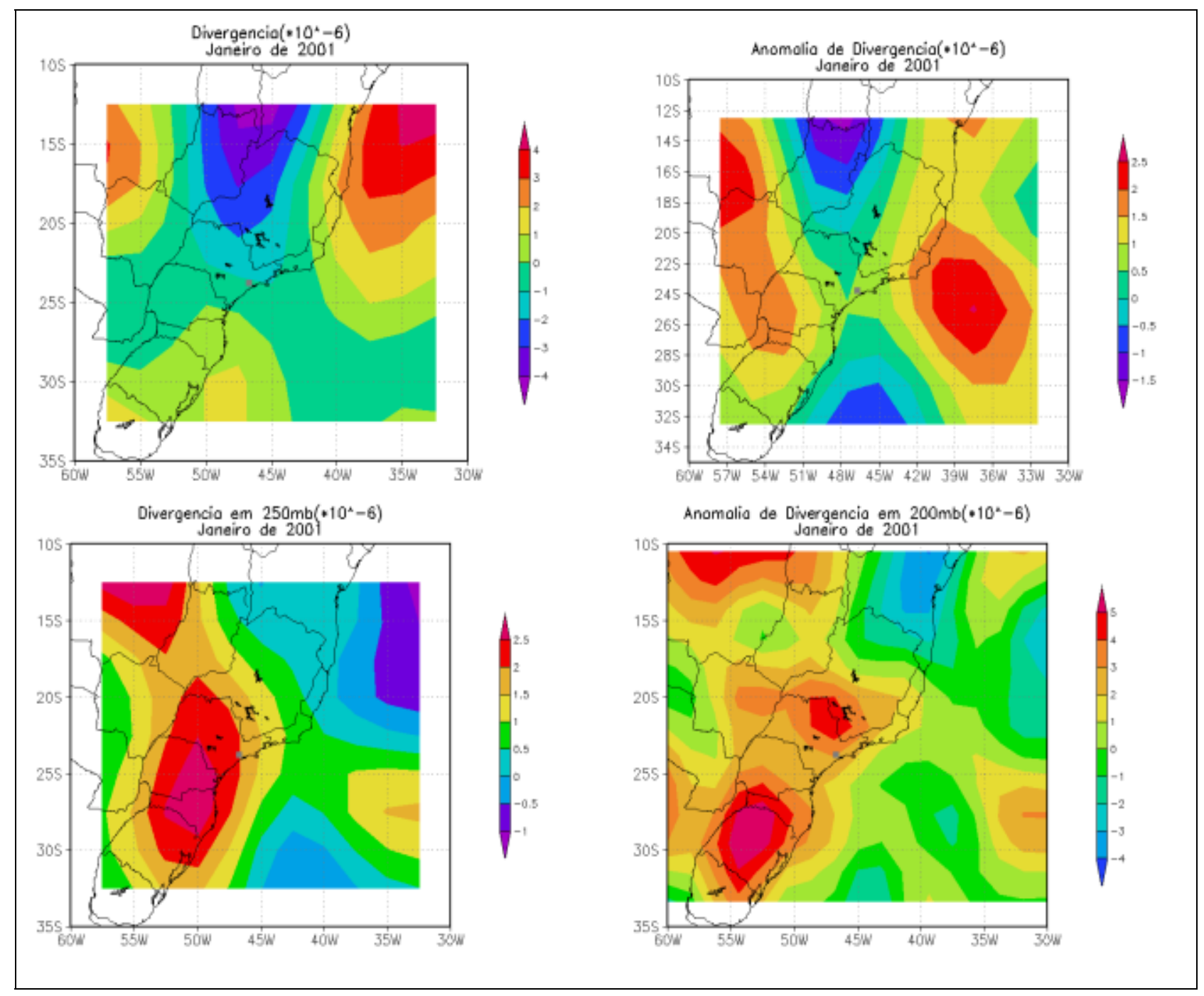

Figura 85e: Divergência do ar em superfície e altitude em janeiro e 2001 e suas respectivas anomalias. 


\begin{abstract}
Abril de 2000
Em abril de 2000, observa-se que há também desvios positivos de radiação solar, ROL, pressão e pequenos desvios positivos de temperatura do ar, além de desvios negativos de umidade relativa (figuras 89a a 89c), mas com o centro sobre o Estado de São Paulo. Nota-se, porém, forte divergência do ar em superfície (figura 89e), com o centro das anomalias positivas sobre o Estado do Paraná, que estendem sua influência sobre a área da RMSP, reforçadas inclusive pela forte convergência do ar em altitude para esta região. Também a direção do vento demonstrou padrão parecido com outros meses de classe 2 e similares, de direção NE (89d).
\end{abstract}

Nota-se, novamente, predominância no mês de dias com menor nebulosidade, baixa umidade do ar e temperatura mais elevada, provavelmente favorecendo anomalias positivas de ozônio troposférico na RMSP.

A atividade frontal em abril de 2000 indicou a passagem de somente três sistemas frontais na latitude da RMSP, sendo que a média para a latitude da RMSP no mês de abril é de seis sistemas (segundo o boletim climanálise). Embora estes sistemas tenham atingido latitudes mais baixas, até alguns estados do NE, sua influência não foi suficiente para interferir de maneira significativa nas condições atmosféricas da RMSP: 


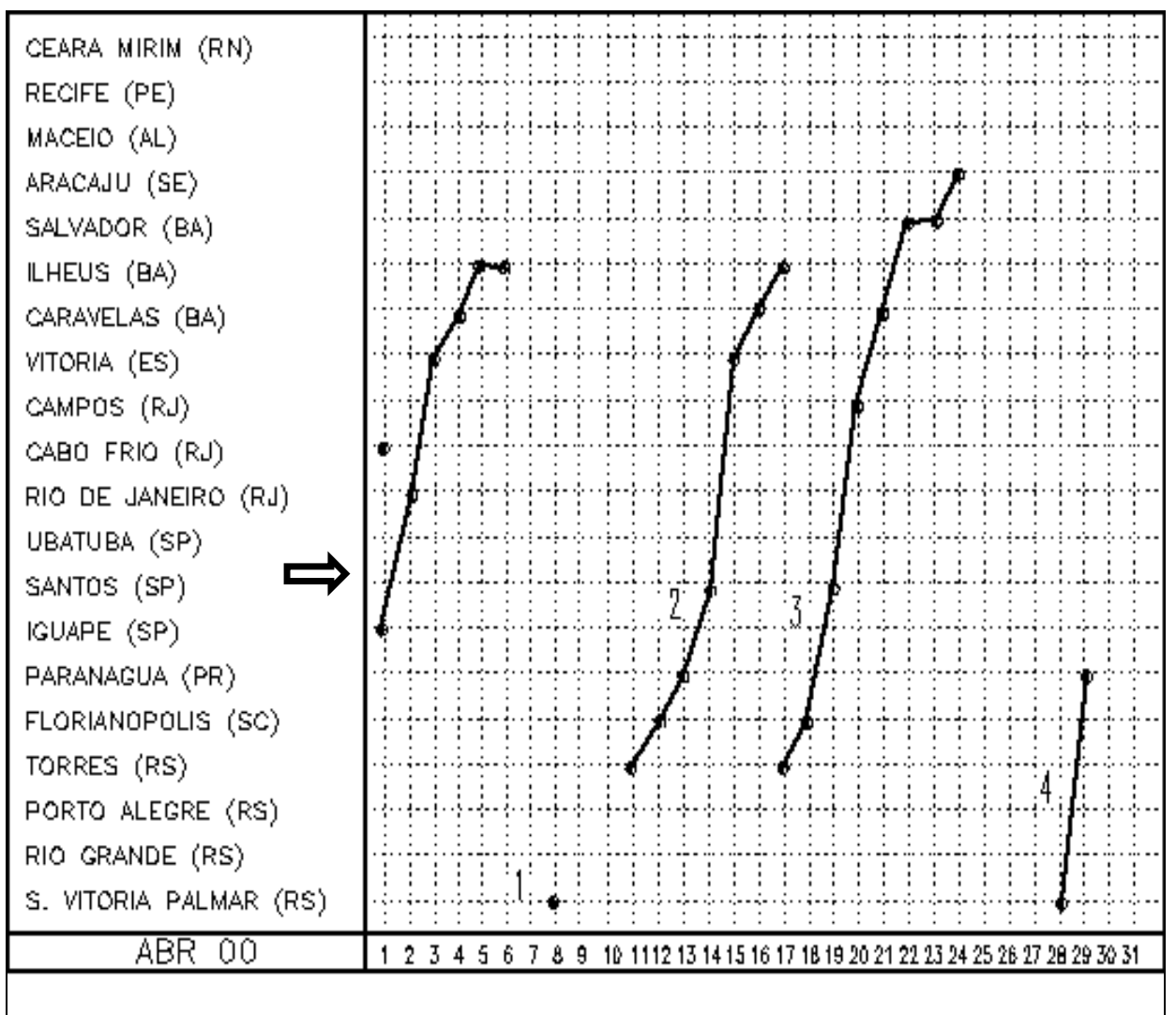

Figura 86: Atuação das frentes frias no litoral do Brasil, abril de 2000. A cidade de Santos está destacada como representante mais próxima da RMSP.

Fonte: http://www.cptec.inpe.br/products/climanalise/0400/index.html

De acordo com o boletim Climanálise deste mês, "os sistemas frontais do mês de abril (de 2000) foram de fraca intensidade, causando apenas nebulosidade no litoral e mudança de ventos e temperatura no interior das Regiões Centro-Oeste e Sudeste ${ }^{21 ، .}$

As figuras 87 e 88, que exibe precipitação e anomalia de precipitação, indicam que ocorreu alguma precipitação principalmente nos dias de passagem frontal (1 e 19) do mês, mas a precipitação ainda permaneceu em níveis abaixo da média, com anomalias negativas em toda a Região Sudeste, inclusive com valores próximos a $-100 \mathrm{~mm}$ na RMSP, não contribuindo para a dispersão do ozônio ou de seus precursores:

${ }^{21}$ http://www.cptec.inpe.br/products/climanalise/0400/index.html 


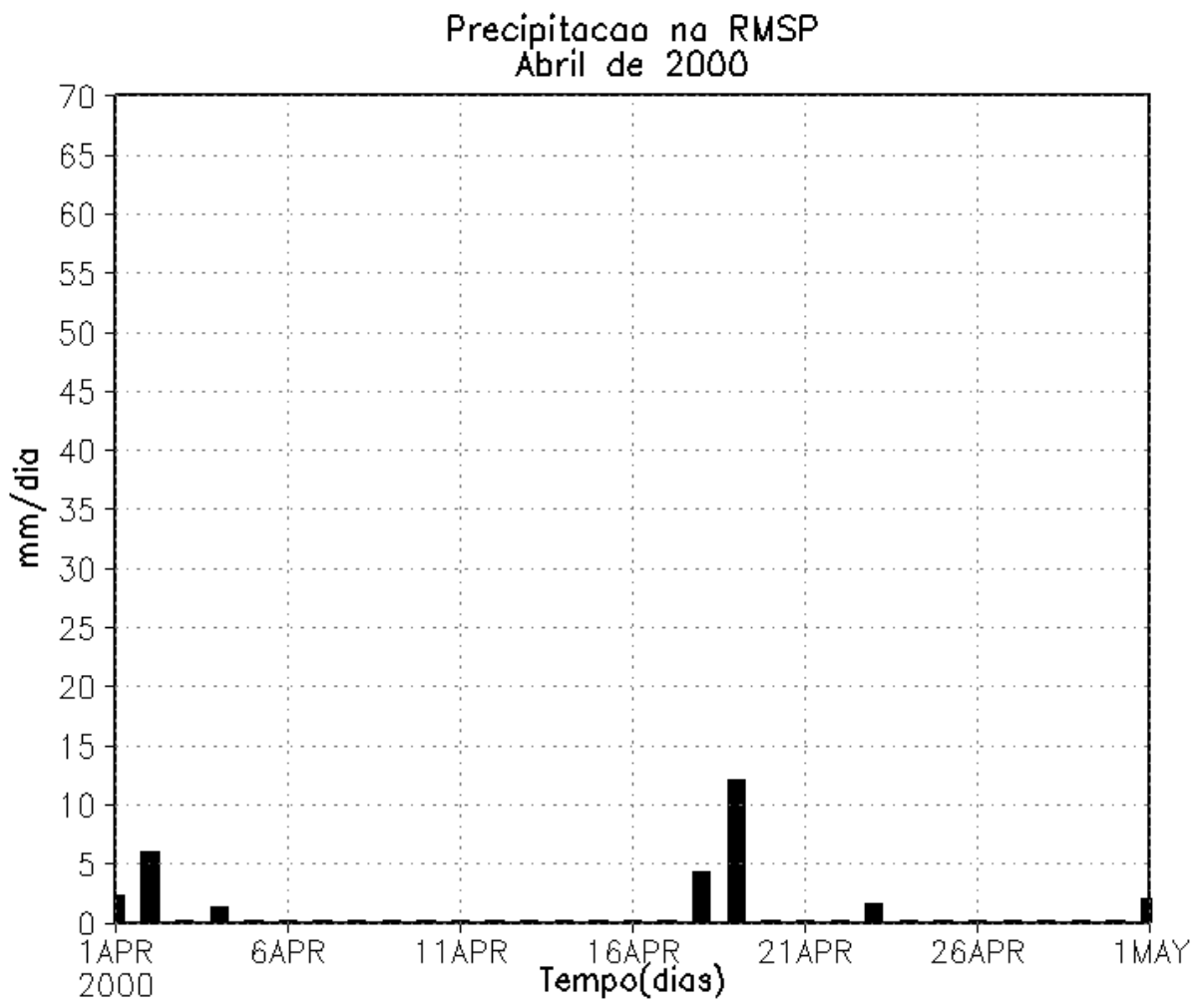

Figura 87: Precipitação na RMSP em abril de 2000.

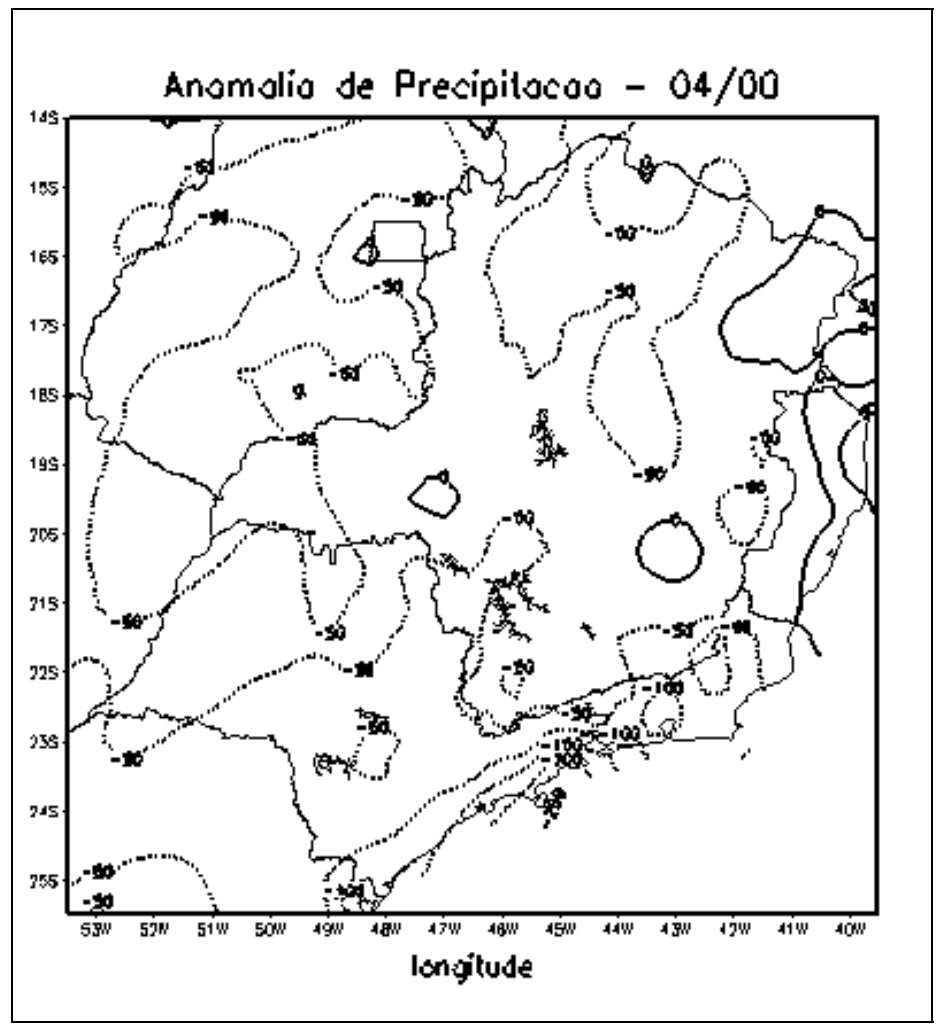

Figura 88: Anomalia de precipitação na região SE do Brasil em abril de 2000. Fonte: http://www.cptec.inpe.br/products/climanalise/0400/index.html 
Mesmo o terceiro sistema frontal de abril de 2000, que atingiu até o litoral da Bahia, originou chuvas intensas apenas na região Sul do Brasil, causando somente nebulosidade no Sudeste.

Assim, pode-se concluir que tanto a intensidade quanto a freqüência dos sistemas frontais influencia nos níveis mensais de concentração de ozônio na RMSP. Em particular, nos meses de janeiro de 2001 e abril de 2000, foram observadas anomalias positivas significativamente altas de $\mathrm{O}_{3}$, cuja concentração na superfície se favoreceu devido às anomalias de radiação solar e ineficiência de mecanismos de remoção de poluentes da atmosfera em diversas escalas temporais.

A evolução diária das concentrações de ozônio nos meses de classe 2 e -2 (abril de 1998, julho de 2005, agosto de 1999, março de 2002, fevereiro de 2003) será descrita em maior detalhe na próxima seção.

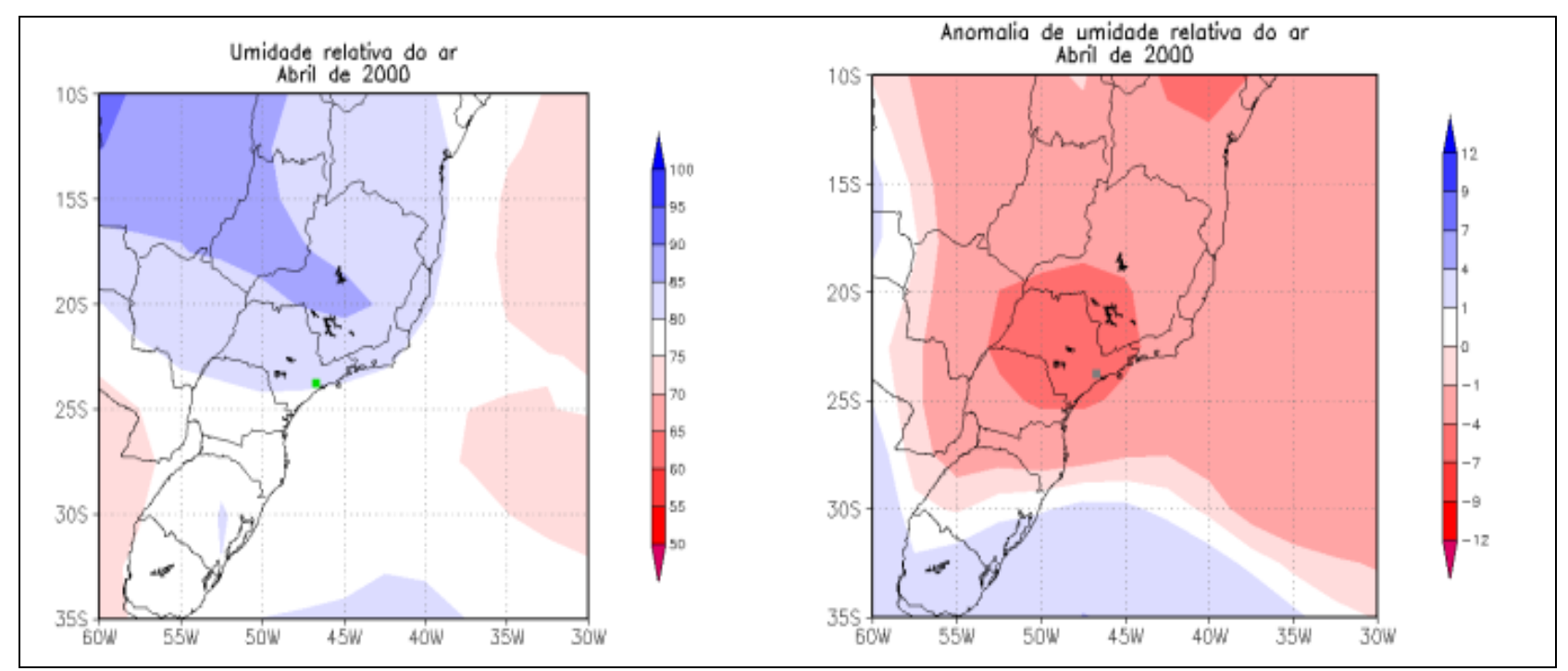

Figura 89a: Umidade relativa do ar em abril de 2000 e anomalia observada. 


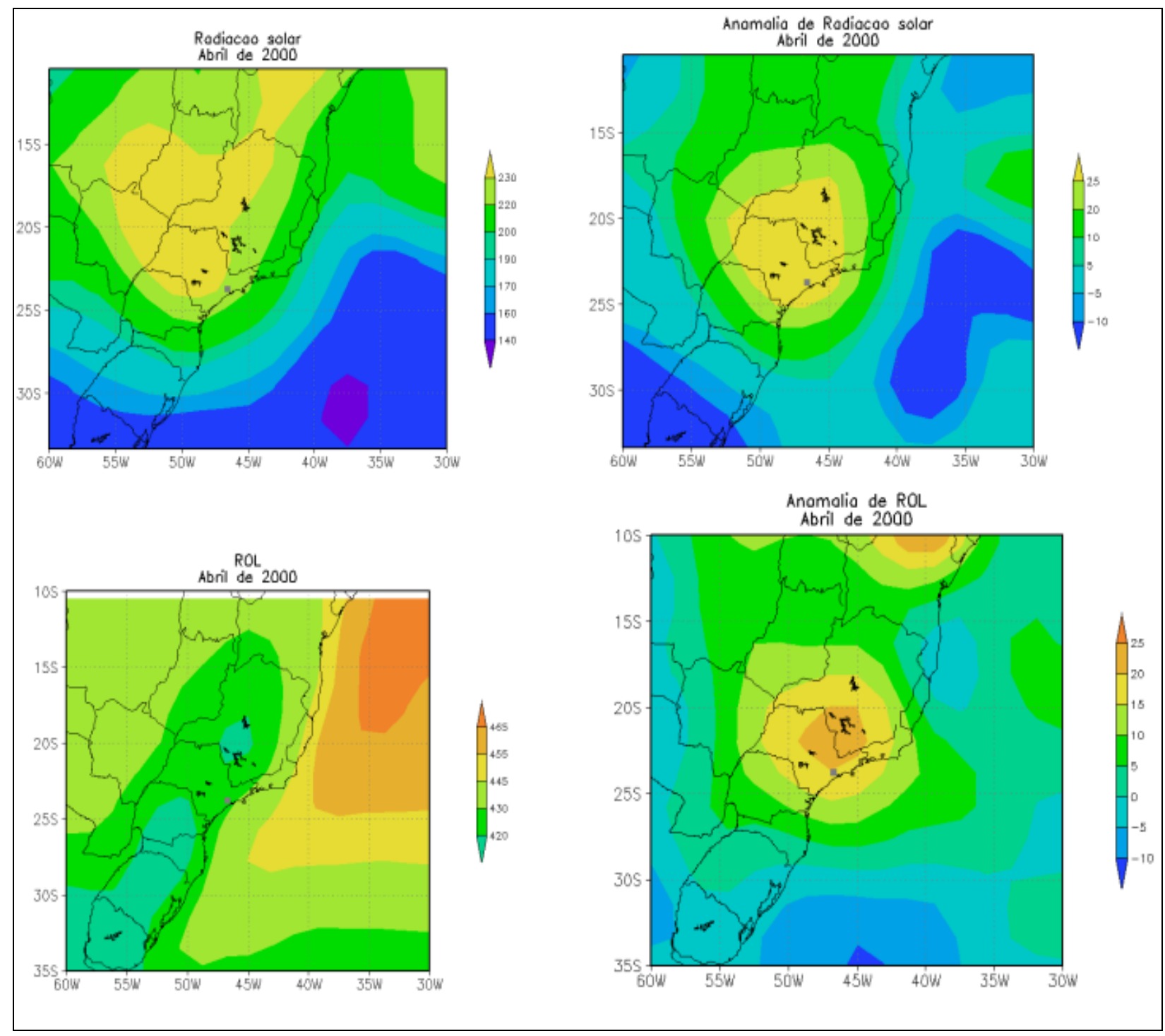

Figura 89b: Radiação solar de ondas curtas e ROL em março de 2002 e suas respectivas anomalias. 


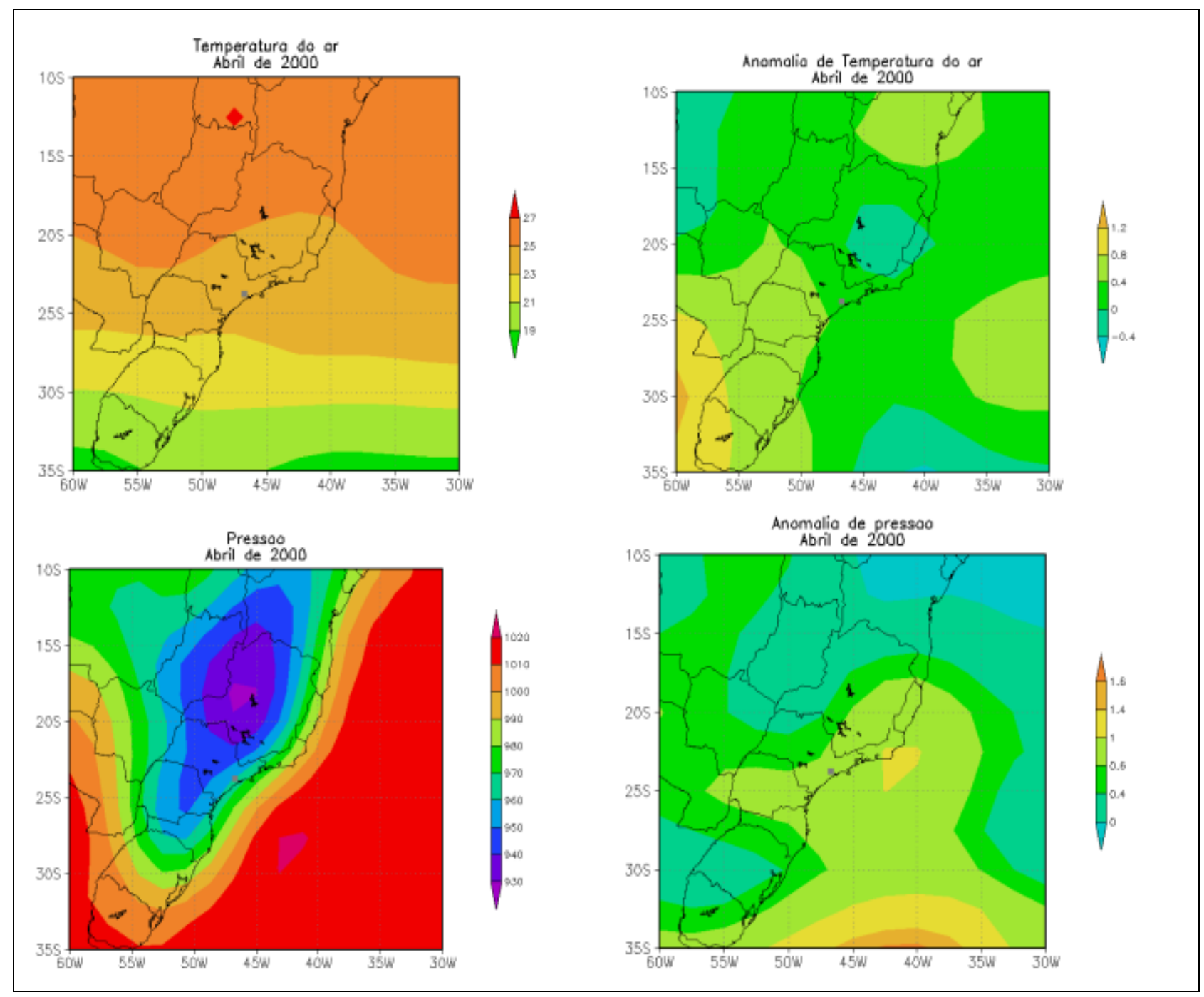

Figura 89c: Temperatura do ar e pressão atmosférica em abril de 2000 e suas respectivas anomalias. 


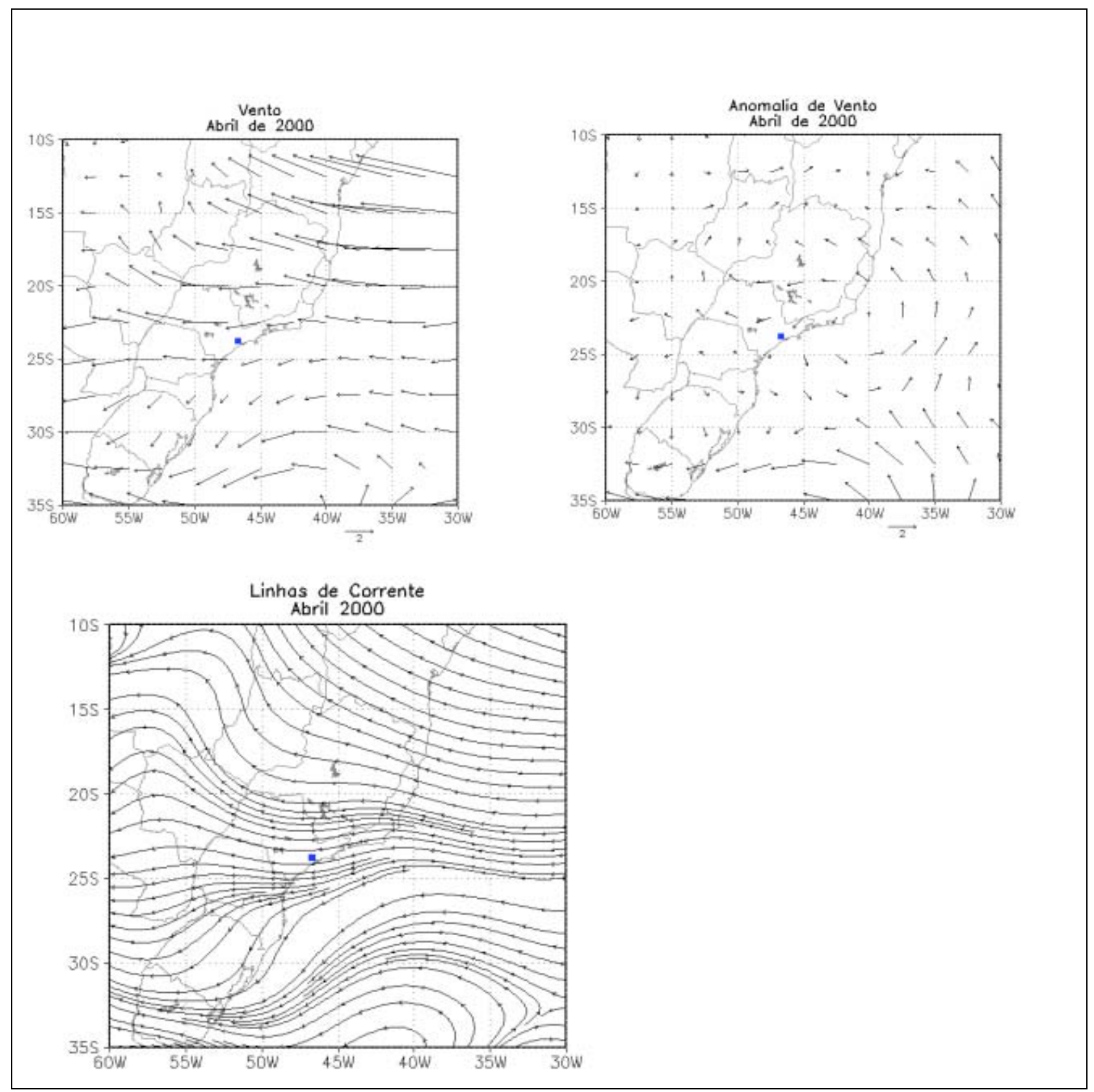

Figura 89d: Escoamento atmosférico e sentido do vento em abril de 2000 e sua respectiva anomalia. 


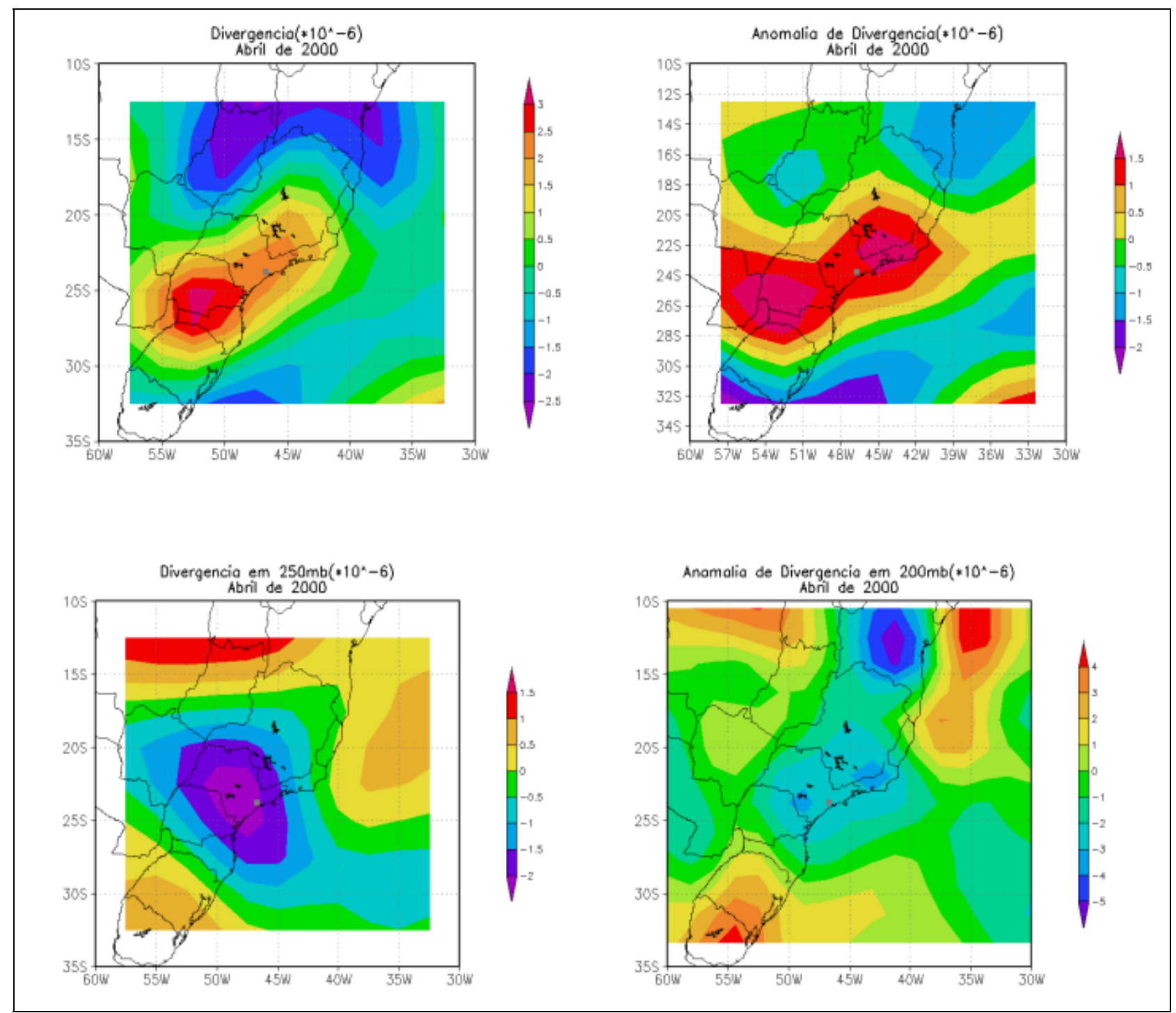

Figura 89e: Divergência do ar em superfície e altitude em abril de 2000 e suas respectivas anomalias.

Finalmente, concluindo que os padrões atmosféricos regulavam com maior precisão os meses com desvio positivo de ozônio, buscou-se outras razões que pudessem influir na ocorrência de anomalias negativas. Dentro deste contexto, observou-se as concentrações de ozônio em meses anteriores próximos aos escolhidos para a análise, a fim de verificar se haveria alguma influência dos meses anteriores nos desvios apresentados pelos meses de classe 2 e -2. Para os meses de classe 2, não foi observado nenhum padrão, mas para os meses de classe -2 , notou-se que no geral as concentrações de ozônio já apresentavam anomalias negativas ou tendência de queda nos meses anteriores aos do desvio negativo mais intenso, como se pode verificar na figura 90: 


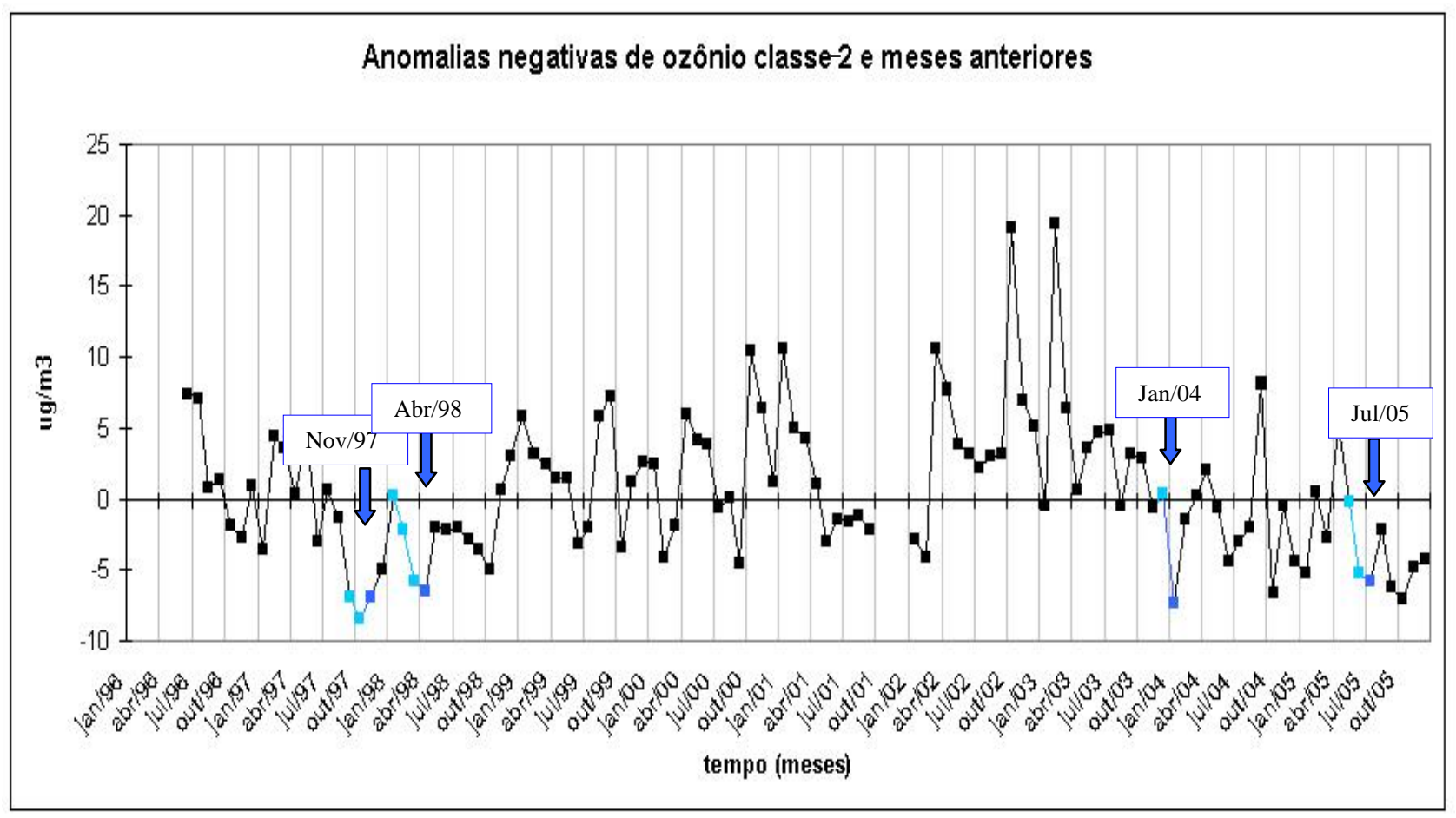

Figura 90: Série temporal de anomalias de ozônio, destacando os meses de classe -2 (azul escuro) associados aos meses anteriores com anomalias negativas (azul claro).

Pode-se perceber pela análise da figura que os meses identificados em azul escuro (classe -2) são sempre precedidos de outros meses com anomalias negativas, próximas de zero ou com tendência de queda, identificados em azul claro. Assim, pode-se sugerir que também as concentrações de ozônio do mês anterior podem contribuir para que um determinado mês tenha desvio negativos intensos, principalmente quando se tem em mente o que foi citado na seção 1.1 e de acordo com os dados da figura 02 (tempo de residência dos poluentes), que o tempo de residência do ozônio troposférico na atmosfera é de cinco dias a algumas semanas no verão do Hemisfério Norte (podendo chegar a até três meses no inverno em latitudes médias). Claramente isto não ocorre em todas as áreas da RMSP, devido à diferentes padrões climáticos e também à intensa circulação de veículos, tal como explicado na seção 1.2.1, mas sugere-se que as concentrações registradas, principalmente nas estações de background, sejam influenciadas em algum grau pelas concentrações observadas no mês anterior, uma vez que a variabilidade atmosférica existe independentemente do calendário convencionado pelos seres humanos. 
Partindo-se do princípio que a variável com melhor correlação com o ozônio na escala mensal foi a radiação solar de ondas curtas, buscou-se também analisar os meses com intensas anomalias negativas e positivas de radiação solar (acima ou abaixo de $30 \mathrm{~W} / \mathrm{m}^{2}$ ) que não apresentavam anomalias intensas de ozônio.

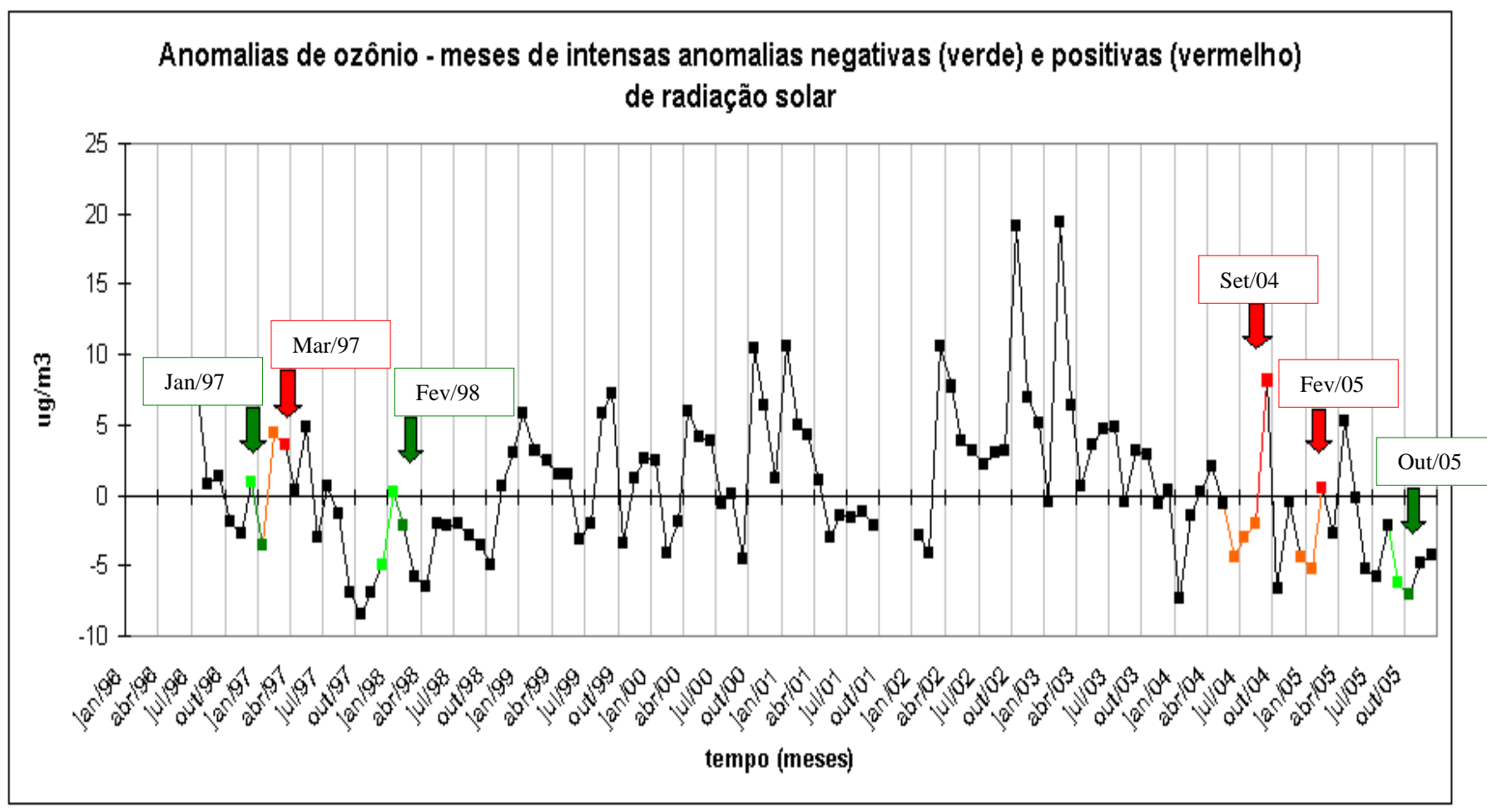

Figura 91: série temporal mensal de anomalias de ozônio, destacando meses com anomalias negativas (verde) e positivas (vermelho) de radiação solar em que não foram observadas anomalias de ozônio acima de 2DP.

Ao se analisar a figura 91, percebe-se que em dois (setembro de 2004 e fevereiro de 2005) dos três meses em que houve anomalias positivas de radiação solar também houveram anomalias positivas de ozônio, mas que não atingiram a classe 2. Na verdade somente o mês de setembro de 2004 apresentou anomalias de ozônio superiores a $1 \sigma$. Pode-se sugerir então, que apesar dos meses identificados em vermelho na figura tenham apresentado anomalias intensas de radiação solar (superiores $a+30 \mathrm{w} / \mathrm{m}^{2}$ ), estes não apresentaram desvios positivos de ozônio da mesma intensidade dos meses de classe 2 pois ocorreram logo após meses com anomalias negativas, realçados em laranja. Não obstante, pode-se observar que para estes dois meses ocorre elevação nas anomalias. O único mês com intensa anomalia de radiação solar mas que não apresentou elevação da anomalia de 
ozônio foi março de 1997, que por alguma razão, registrou anomalias de ozônio menores do que o mês anterior. Já os meses identificados em verde escuro (janeiro de 1997, fevereiro de 1998 e outubro de 2005) correspondem a meses com intensas anomalias negativas de radiação solar (menores do que $-30 \mathrm{~W} / \mathrm{m}^{2}$ ), mas que não apresentaram anomalias de ozônio de classe -2 . Não se encontrou razão aparente, em um primeiro olhar, para que as anomalias de ozônio destes meses não fossem baixas como os observados na tabela 21 , ficando a investigação destes casos como sugestão para pesquisas futuras. Possíveis razões para a ocorrência de anomalias negativas de ozônio relativamente brandas nestes meses podem residir no comportamento de outras variáveis atmosféricas, principalmente precipitação e umidade relativa, e das intrincadas reações da química atmosférica que participam da produção e consumo deste poluente. 


\subsection{Interferência da atmosfera na variabilidade diária do ozônio troposférico}

Nesta seção é analisada a variabilidade diária, tanto atmosférica quanto da concentração de $\mathrm{O}_{3}$, nos meses com anomalias negativas e positivas intensas de $\mathrm{O}_{3}$, representantes das classes -2 e 2 (indicados nas tabelas 19 e 22), respectivamente. É feita uma análise comparativa com base na evolução diária dos valores da concentração de $\mathrm{O}_{3}$ e das variáveis atmosféricas consideradas, construindo séries temporais diárias para os meses de interesse. O estudo da variabilidade diária é importante por permitir a verificação mais detalhada da influência da atmosfera na variabilidade da concentração de ozônio troposférico na escala sinótica, aprofundando as considerações feitas no capítulo anterior (análise dos campos atmosféricos).

Serão avaliados primeiramente os meses de classe -2 , seguidos pelos de classe +2 


\subsubsection{Meses de classe -2}

\section{Abril de 1998}

Este mês foi caracterizado por concentrações bem mais baixas que a média observada no período, enquadrado na classe -2 , tal como discutido na seção 3.2 e indicado na tabela 22. Os campos atmosféricos analisados (figuras 61a a 61e, seção 3.3) indicam um comportamento atmosférico que reflete a atuação de frentes frias de considerável intensidade nas Regiões Sul e Sudeste do Brasil, ocasionando anomalias negativas de ROL e pressão atmosférica generalizadas para estas regiões, principalmente sobre o Estado do Paraná. De acordo com o boletim da climanálise para este mês, estes sistemas foram intensificados pela presença de cavados em todos os níveis atmosféricos e vórtices ciclônicos de altos níveis.

Em uma análise preliminar, nota-se pela figura 92a que, embora em oito dias no mês a concentração de $\mathrm{O}_{3}$ superou a média do mês $\left(23,36 \mu \mathrm{g} / \mathrm{m}^{3}\right)$, na maior parte dos dias a concentração esteve baixa, sendo que nos dias 29 e 30 de abril a média diária ficou por volta de $4,0 \mu \mathrm{g} / \mathrm{m}^{3}$. Durante o mês, a concentração de $\mathrm{O}_{3}$ apresentou pequenos picos nos dias 06, 12 e 21 que, no entanto, não contribuíram significativamente no cálculo da média mensal, fazendo com que esta permanecesse baixa.

Com base na análise mensal da penetração de frentes frias na Região Sudeste do Brasil, informações obtidas do Climanálise (figura 60 - área de atuação e número de frentes frias no litoral do Brasil), para abril de 1998, verificou-se que, neste mês, quatro frentes frias passaram pela latitude do município de Santos, nos dias 8, 18, 24 e 29 e que provavelmente interferiram nas condições atmosféricas na RMSP. Apesar de em número inferior à média climatológica, que são de seis sistemas, este sistemas aturam com maior intensidade sobre as regiões Sul, Sudeste e no estado de Mato Grosso do Sul. Pelos valores diários de precipitação (figura 92d) nota-se que ocorreram episódios de chuva em São Paulo próximos das datas das passagens frontais. Além disso, nestes mesmos dias foram registradas as menores concentrações de $\mathrm{O}_{3}$, tal como indicado na figura 92a. Os valores diários de ROL (figura 92b) permitem verificar que os períodos (de três a seis dias) que 
antecederam as duas passagens frontais em meados do mês de abril de 1998, nos dias 18 e 24, foram os que apresentaram as maiores concentrações de $\mathrm{O}_{3}$ (com picos nos dias 12 e 21, figura 92a). Uma vez que a cobertura de nuvens nestes períodos era menor (oito dias com ROL superior a $250 \mathrm{~W} / \mathrm{m}^{2}$ no período anterior à segunda passagem frontal e seis dias com ROL superior a $250 \mathrm{~W} / \mathrm{m}^{2}$ no período anterior à terceira passagem frontal), sugere-se assim, fortemente, a associação da formação de $\mathrm{O}_{3}$ à disponibilidade de radiação solar. O período anterior à primeira passagem frontal do mês (dia 08/04) foi caracterizado por nebulosidade variável, o que pode ter inibido a produção e concentração excessivas de $\mathrm{O}_{3}$, tal como pode ser observado pelos valores de concentração atingidos neste período, com máximo no dia 6. Por outro lado, do dia 11 ao dia 15, ocorre aumento de pressão e as médias diárias de ROL se mantêm elevadas e estáveis, indicando a predominância de vários dias seguidos com significativa incidência de radiação solar. É justamente neste período que ocorre a maior média de concentração de $\mathrm{O}_{3}$ do mês, no dia 12 . $\mathrm{O}$ último pico de $\mathrm{O}_{3}$ do mês, em 21/04, também está inserido em mais um período de dias seguidos de tempo com pouca nebulosidade, em que as médias de ROL se mantêm altas e estáveis em relação ao demais valores do mês (19 a 22/04).

A última passagem frontal do mês (em 29/04) foi antecedida por um período com muita cobertura de nuvens, desfavorecendo a formação de $\mathrm{O}_{3}$. As passagens frontais também podem ser identificadas pelos dados de pressão em superfície e temperatura do ar, tal como indicado pelas setas nas figuras 92b e 92c. 0 coeficiente de correlação linear entre os valores diários de $\mathrm{O}_{3}$ e ROL em abril de 1998 foi 0,48 .

Todos os períodos deste mês em que foi observado declínio de $\mathrm{O}_{3}$ estiveram, ao mesmo tempo, acompanhados pela diminuição da pressão em superfície, o que está associado à maior instabilização dinâmica da atmosfera e, portanto, a situações mais favoráveis à dispersão de poluentes. Adicionalmente, a presença de maior nebulosidade em períodos caracterizados por atuação frontal inibe a incidência de radiação solar, contribuindo também para a diminuição da produção de ozônio. Pelos dados de precipitação (figura 92d) nota-se que houve um episódio com alta de intensidade no último dia do mês anterior, em março 1998, sugerindo que as 
anomalias negativas deste poluente para o mês de abril tenham sofrido influência adicional das condições atmosféricas do mês anterior.
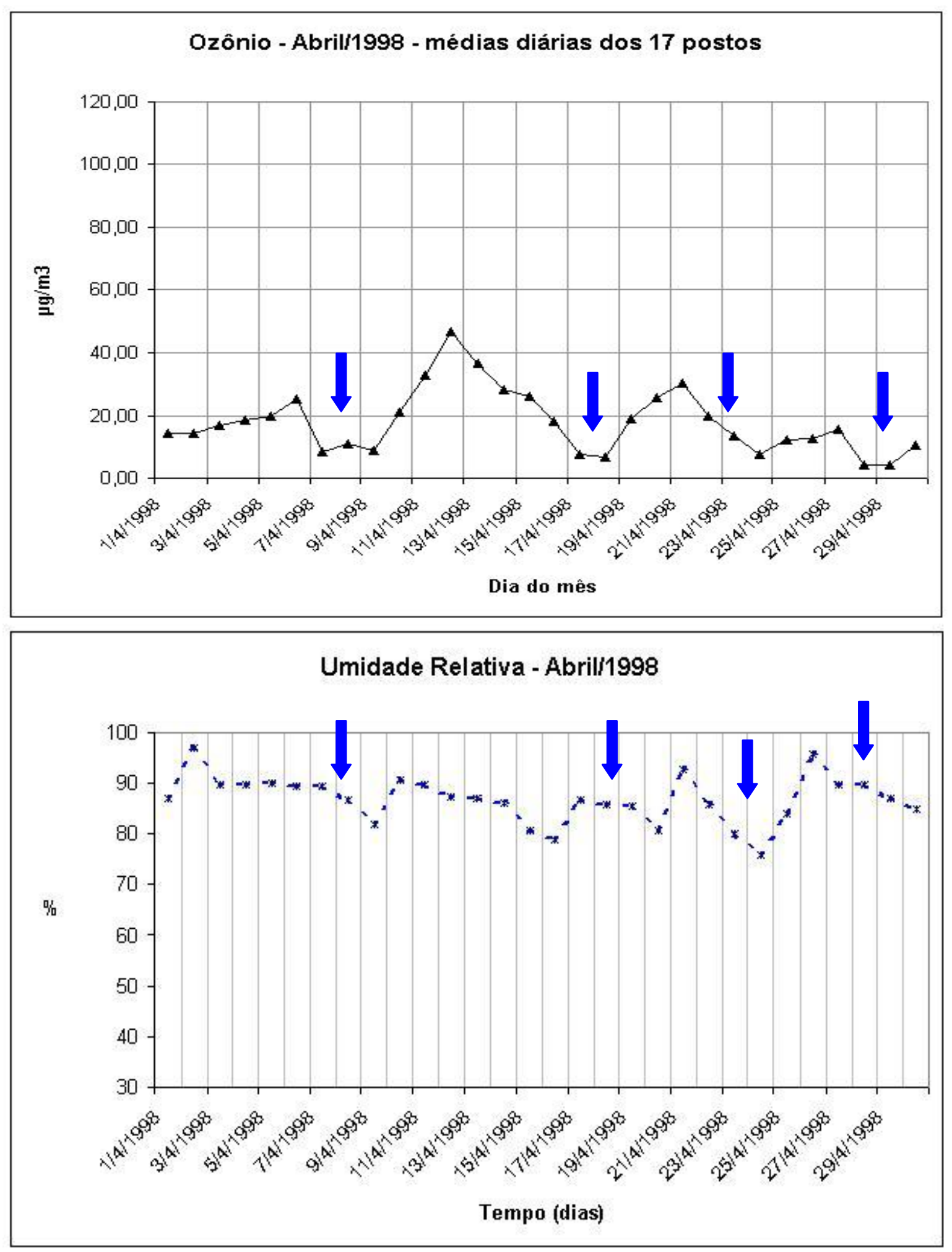

Figura 92a: Médias diárias de ozônio troposférico e umidade relativa em abril de 1998. Os dias de passagem frontal estão identificados pela seta. 

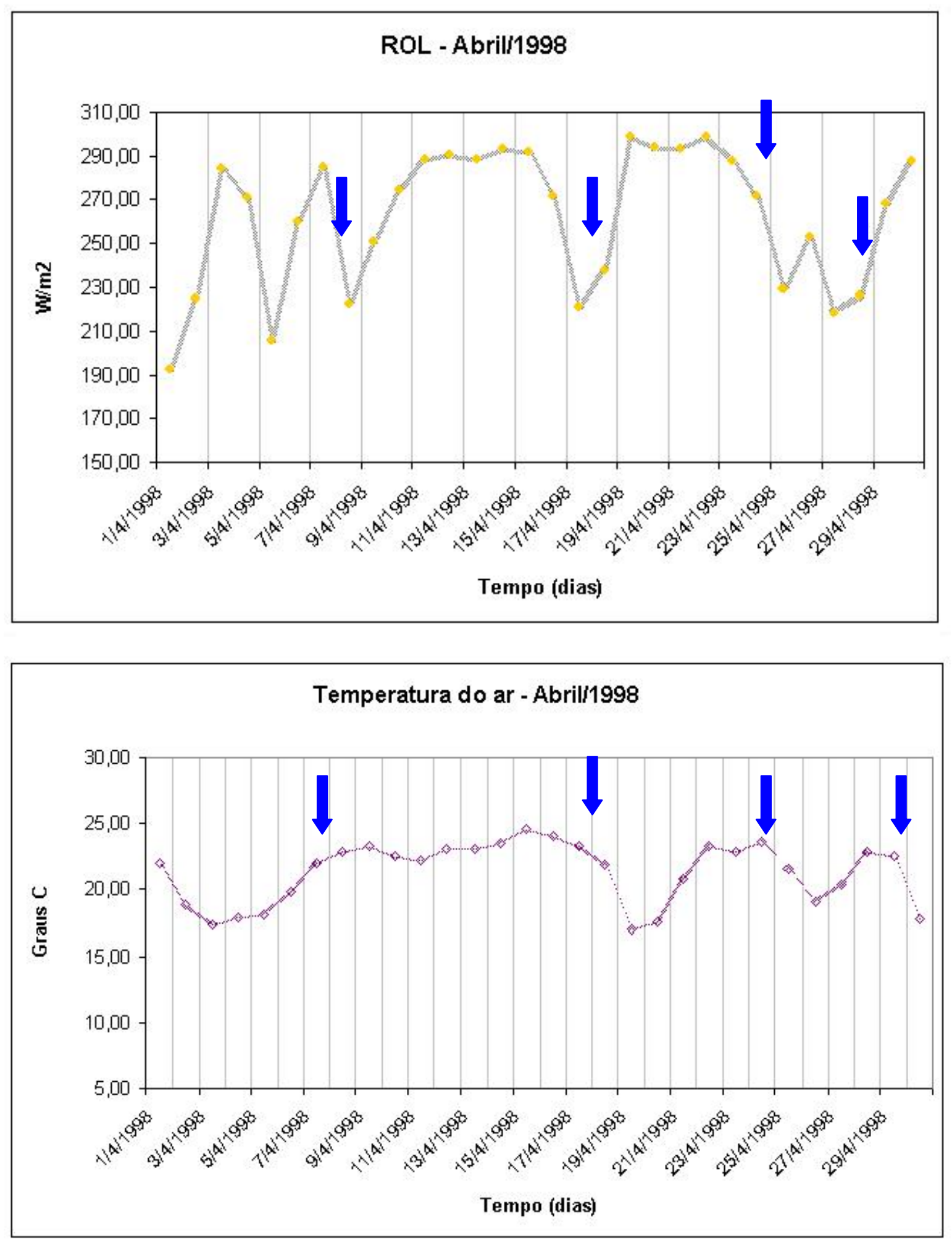

Figura 92b: Médias diárias de ROL e temperatura do ar em abril de 1998. Os dias de passagem frontal estão identificados pela seta. 

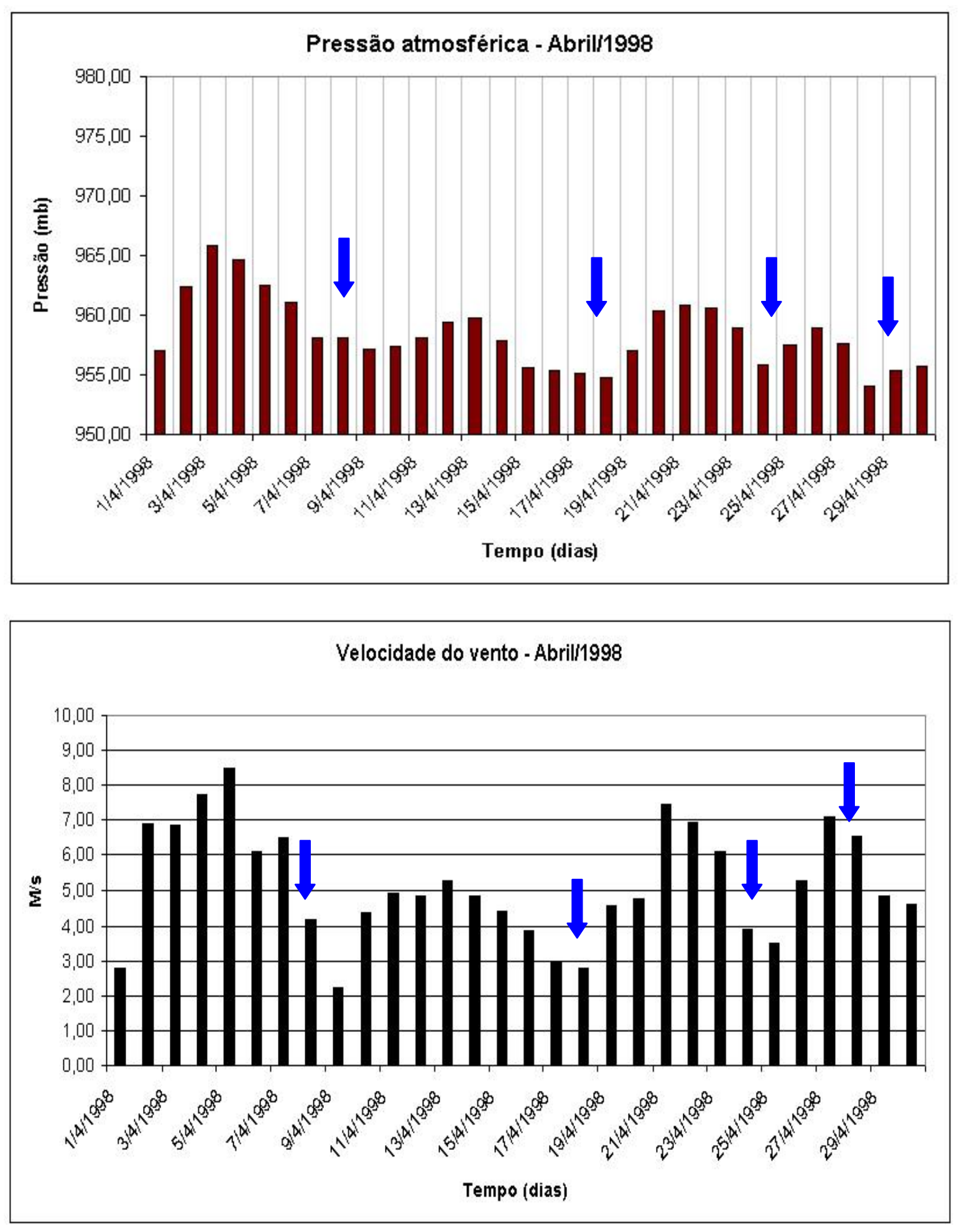

Figura 92c: Médias diárias de pressão atmosférica e velocidade do vento em abril de 1998. Os dias de passagem frontal estão identificados pela seta. 

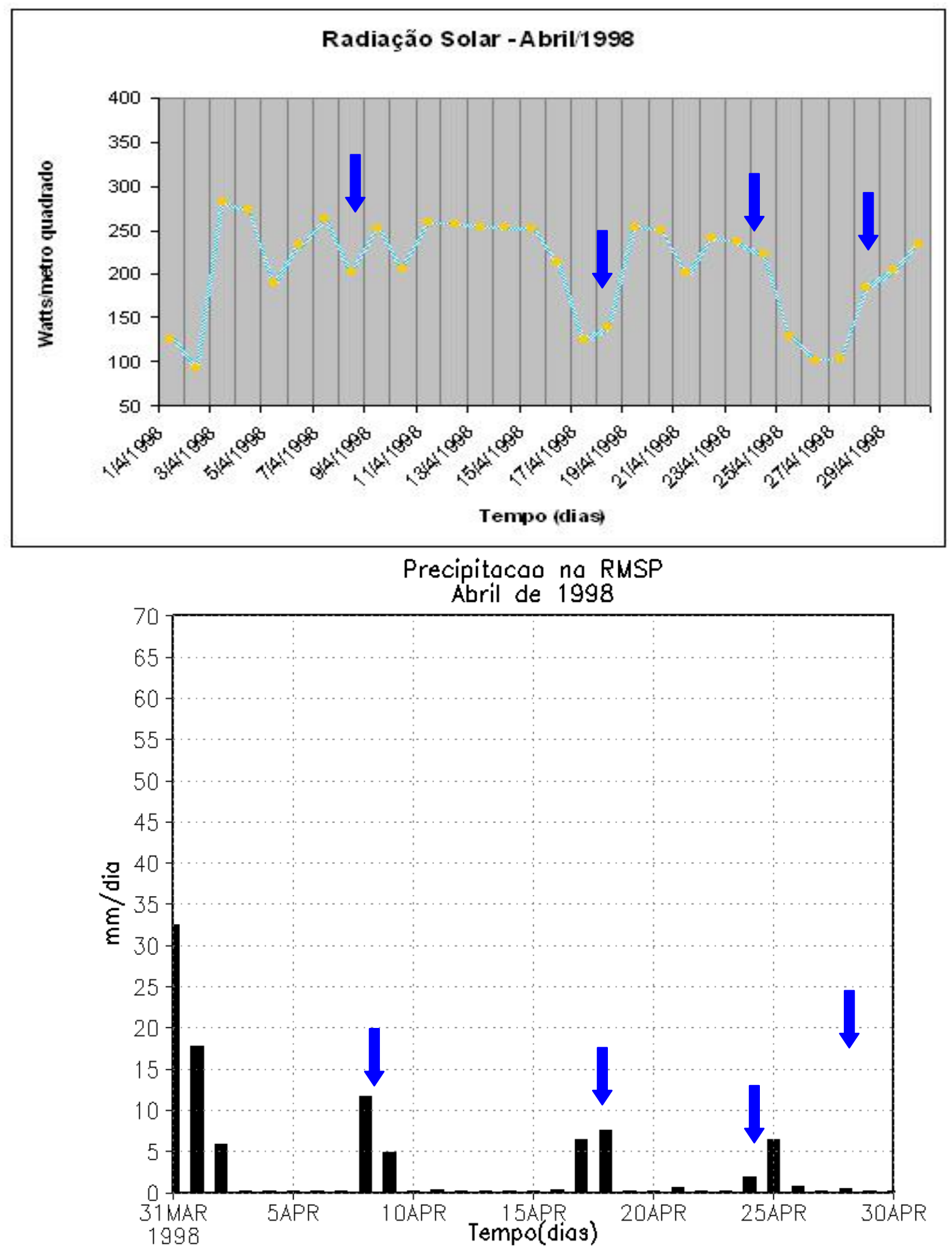

Figura 92d: Médias diárias de radiação solar e precipitação diária em abril de 1998. Os dias de passagem frontal estão identificados pela seta. 


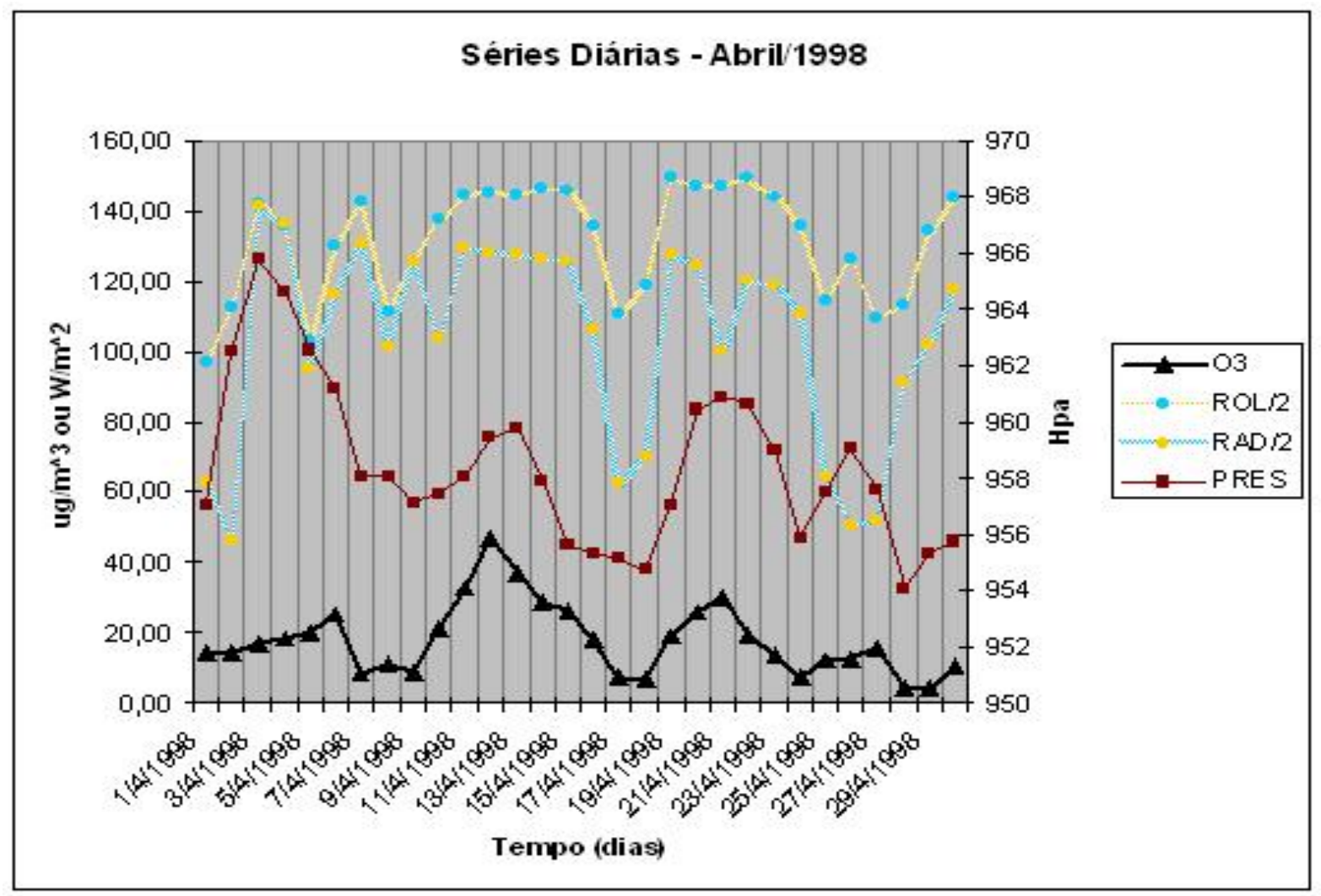

Figura 92e: Médias diárias de ozônio troposférico, radiação solar, ROL e pressão atmosférica em abril de 1998. 


\section{Julho de 2005}

O mês de julho de 2005 foi também considerado como de classe -2 devido às baixas concentrações apresentadas (tabela 18). Foram observadas durante este mês anomalias positivas de pressão em superfície, ROL, radiação solar e de velocidade do vento, bem como anomalias negativas de temperatura e umidade relativa, sugerindo significativa influência das massas de ar de latitudes mais altas associadas aos quatro sistemas frontais que atingiram a latitude da RMSP, de acordo com o boletim Climanálise deste mês. Corroborando a intensidade dos sistemas frontais, este mesmo boletim associa a intensidade destes sistemas com anomalias positivas de precipitação no oeste do Estado de São Paulo.

Em apenas quatro dias do mês foram observadas concentrações acima da média de julho, que é de $19,5 \mu \mathrm{g} / \mathrm{m}^{3}$, indicando que neste período de tempo possivelmente as condições atmosféricas não tenham sido propícias para a formação e concentração do $\mathrm{O}_{3}$ (figura 93a). Destacam-se neste mês a predominância de ventos de sul (figuras 94a a 94c) e a incursão freqüente de sistemas frontais, bem distribuídos no decorrer do período. Os dados das figuras 93a a 93 e revelam a passagem dos sistemas frontais nos dias $05,17,24$, e 28 , indicadas por uma seta.

A entrada do sistema frontal no dia 5 é evidenciada pela mudança no sentido do vento (figuras 94a a 94c - ventos predominantemente de norte que passam, após o dia 5, a ser de SE e S), pela queda nos valores de radiação solar, ROL e temperatura e pela elevação da umidade relativa (figuras 93a a 93d). A concentração de $\mathrm{O}_{3}$ na RMSP também sofre queda neste dia. A partir desta data, a pressão atmosférica aumenta, indicando o deslocamento da região caracterizada com altas pressões na retaguarda da frente, tal como tipicamente observado (GALVANI e AZEVEDO, 2003). É observado um aumento gradativo de $\mathrm{O}_{3}$ neste período, entre a primeira e a segunda passagem frontal, concomitantemente a valores altos de ROL. No entanto, pode-se observar que a ocorrência de ventos fortes e a contínua queda de temperatura provavelmente contribuem para que a concentração do poluente não se eleve tanto. Ocorre um valor máximo de ozônio que é observado no dia anterior à passagem do segundo sistema frontal (dia 17). A partir deste dia, as variáveis atmosféricas indicam condições características à 
passagem frontal, sem grande disponibilidade de radiação solar, o que novamente parece sugerir a queda das concentrações de $\mathrm{O}_{3}$. Este comportamento se repete com a chegada de nova frente fria, no dia 24: elevação das concentrações no período antecedente à entrada da frente, e redução e estabilidade da concentração de $\mathrm{O}_{3}$ após sua passagem, o que está associado à predominância de muita nebulosidade, pouca incidência de radiação solar e valores baixos de ROL e temperatura.

Por outro lado, pode-se perceber pela figura 62 que a última frente fria do mês provavelmente não tenha contribuído para a modificação das concentrações de $\mathrm{O}_{3}$ troposférico na RMSP. Este sistema não teve a mesma trajetória que as outras frentes frias do mês, tampouco a mesma intensidade, como pode ser verificado nas figuras 93a a 93e e pela pouca mudança na direção do vento (figuras 94a a 94c). Apesar de ter provocado uma pequena queda da pressão atmosférica, este sistema causou posterior diminuição da umidade relativa, associada a valores relativamente altos de radiação solar e ROL. Dessa forma, a manutenção de valores altos de radiação solar associados aos de $\mathrm{ROL}$ sugerem que estas variáveis atmosféricas sejam importantes na produção de $\mathrm{O}_{3}$. Além disso, não houve grande mudança na direção e velocidade do vento e tampouco queda de temperatura como ocorreu em outras passagens frontais neste mês. Esta situação provocou aumento das concentrações de $\mathrm{O}_{3}$ no fim do mês, fazendo com que a maior média diária do mês fosse alcançada no dia 31 , com $25,83 \mu \mathrm{g} / \mathrm{m}^{3}$.

No início do mês nota-se o predomínio de ventos de sentido NE na maioria das estações da CETESB. Pode-se ver pela figura 93a que as concentrações de $\mathrm{O}_{3}$ permanecem estáveis, com ligeira tendência de elevação, e sofrem uma queda quando ocorre a passagem do primeiro sistema frontal do mês, no dia 05/07, quando todas as estações registram ventos de S. Na próxima semana, o vento predominante registrado continua a ser deste sentido, porém pode-se notar que gradualmente adquire componentes de SO e O, principalmente a partir do dia 11. As concentrações de $\mathrm{O}_{3}$ neste período não apresentam tendência definida; no entanto, nos dias 16 e 17, elevam-se e atingem o máximo do mês, podendo-se verificar que o sentido do vento medido nas estações nestes dois dias muda para N/NE. No dia 17 ocorre a segunda passagem de sistema frontal do mês; as concentrações de $\mathrm{O}_{3}$ exibem tendência de queda no dia 17 até o dia 21 , enquanto a direção do vento se 
mantém de SO para NE em todas as estações da CETESB. O restante do mês não é marcado por sentido predominante do vento, mas nota-se um aumento gradativo das concentrações de $\mathrm{O}_{3}$ a partir do dia 27 . 

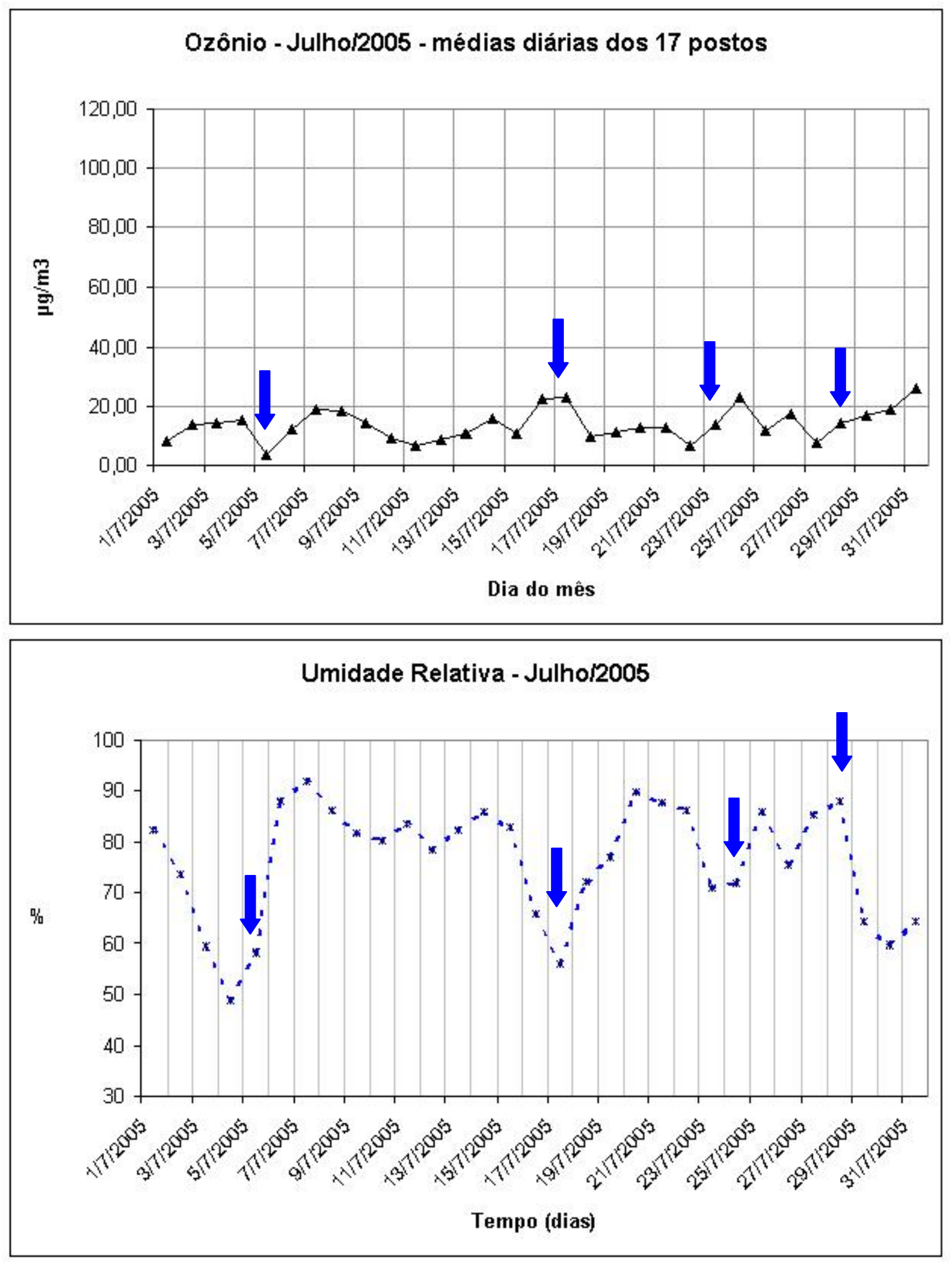

Figura 93a: Médias diárias de ozônio troposférico e umidade relativa em julho de 2005. Os dias de passagem frontal estão identificados pela seta. 

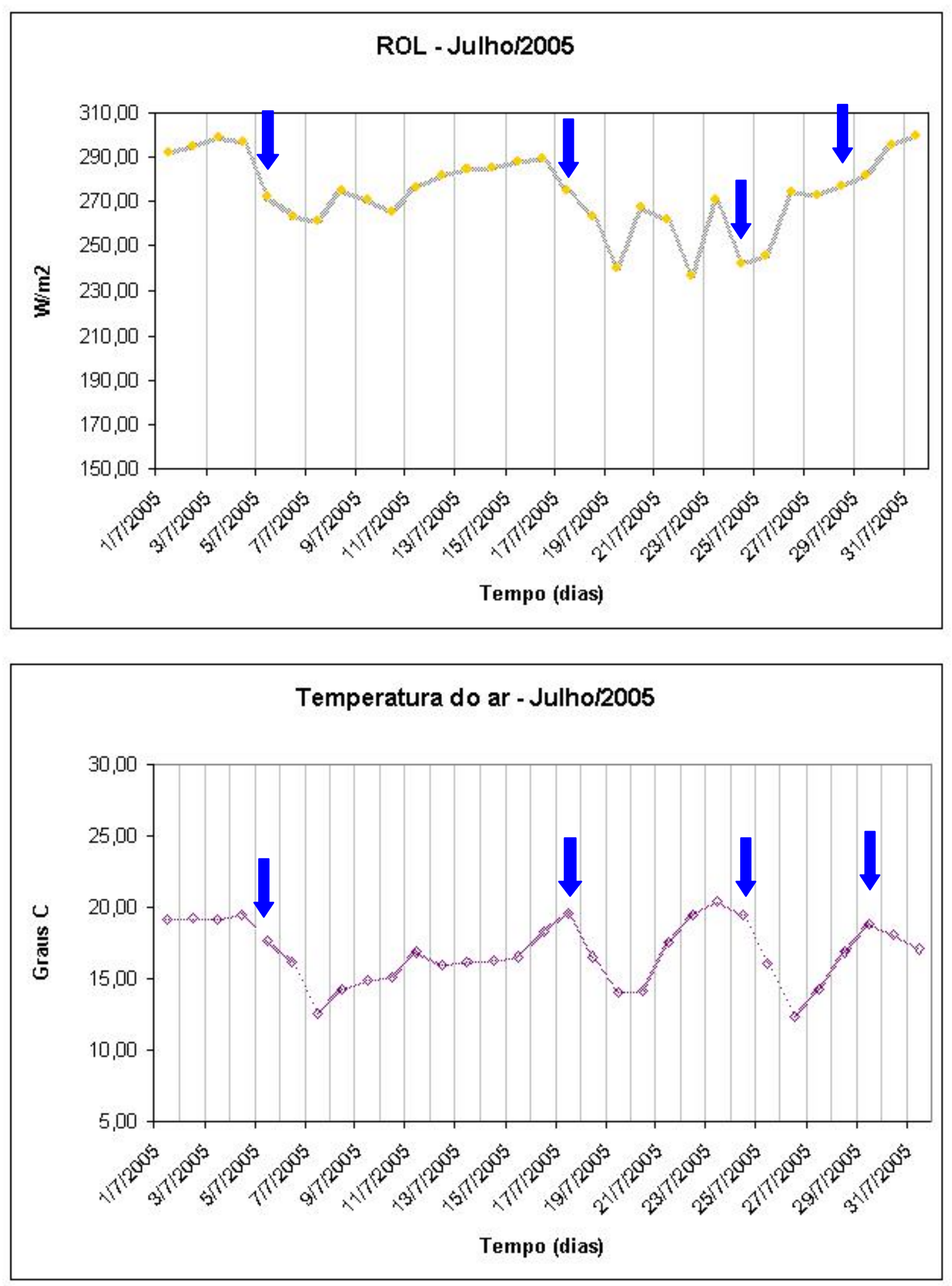

Figura 93b: Médias diárias de ROL e temperatura do ar em julho de 2005. Os dias de passagem frontal estão identificados pela seta. 

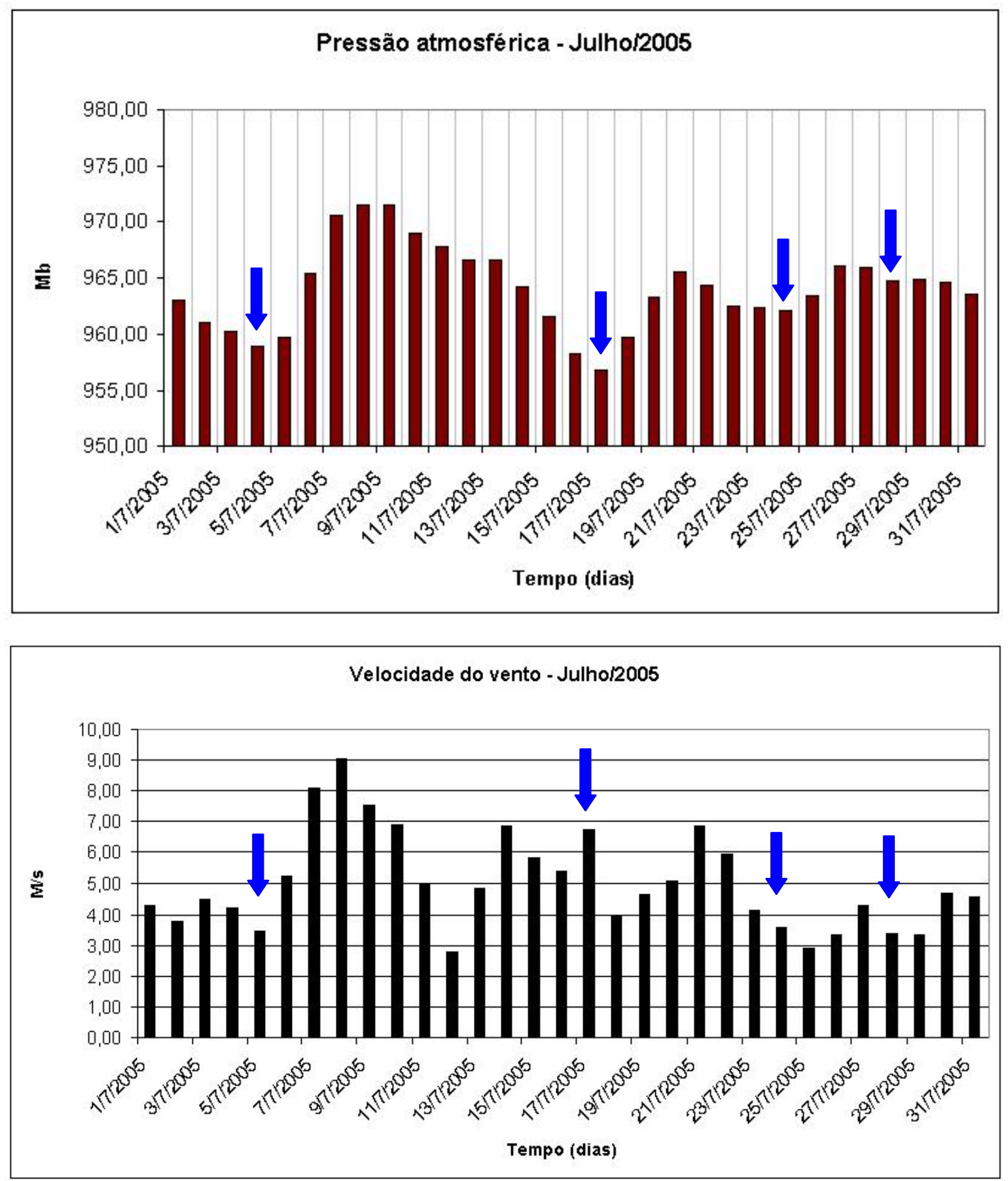

Figura 93c: Médias diárias de pressão atmosférica e velocidade do vento em julho de 2005. Os dias de passagem frontal estão identificados pela seta. 

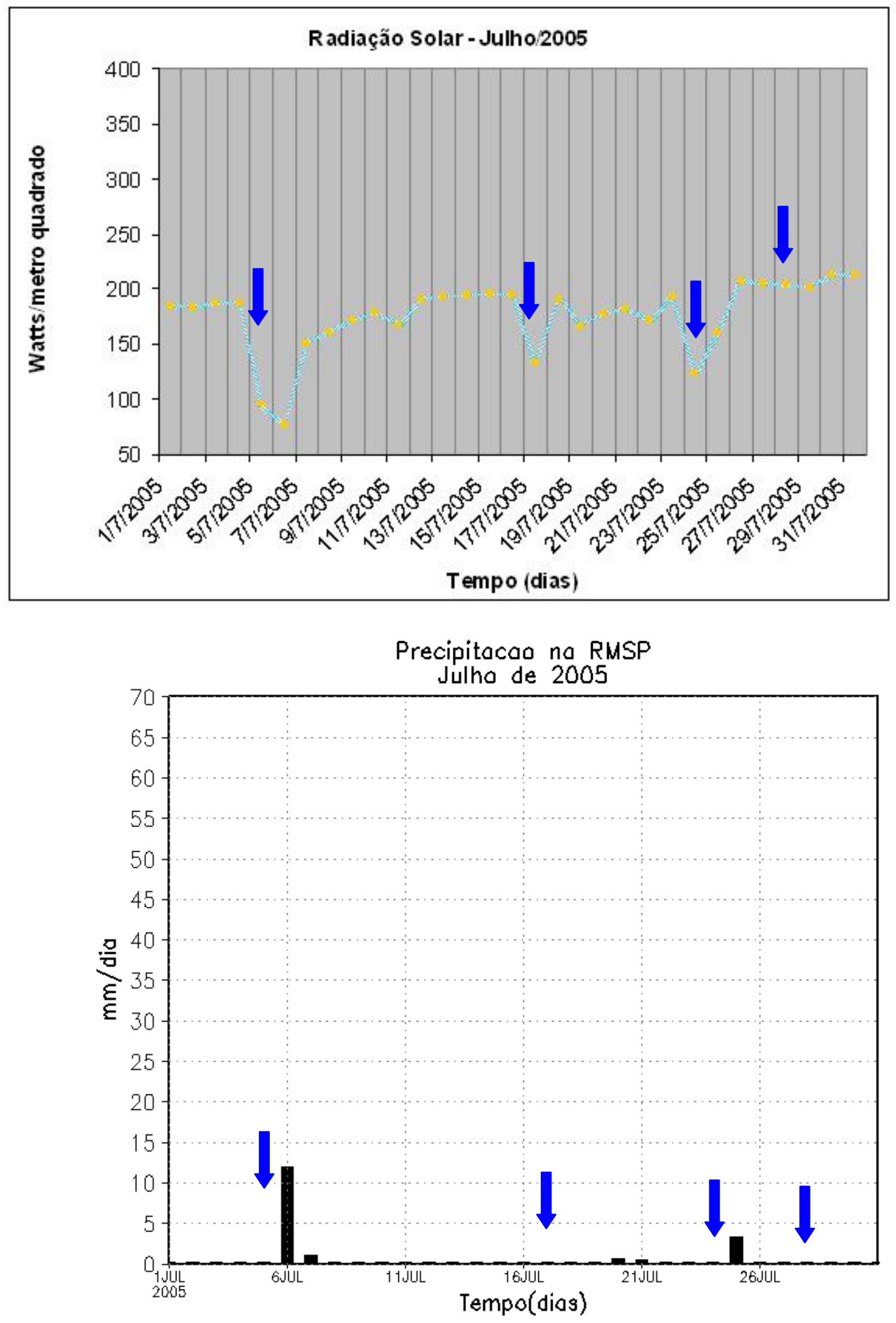

Figura 93d: Médias diárias de radiação solar e precipitação diária em julho de 2005. Os dias de passagem frontal estão identificados pela seta. 


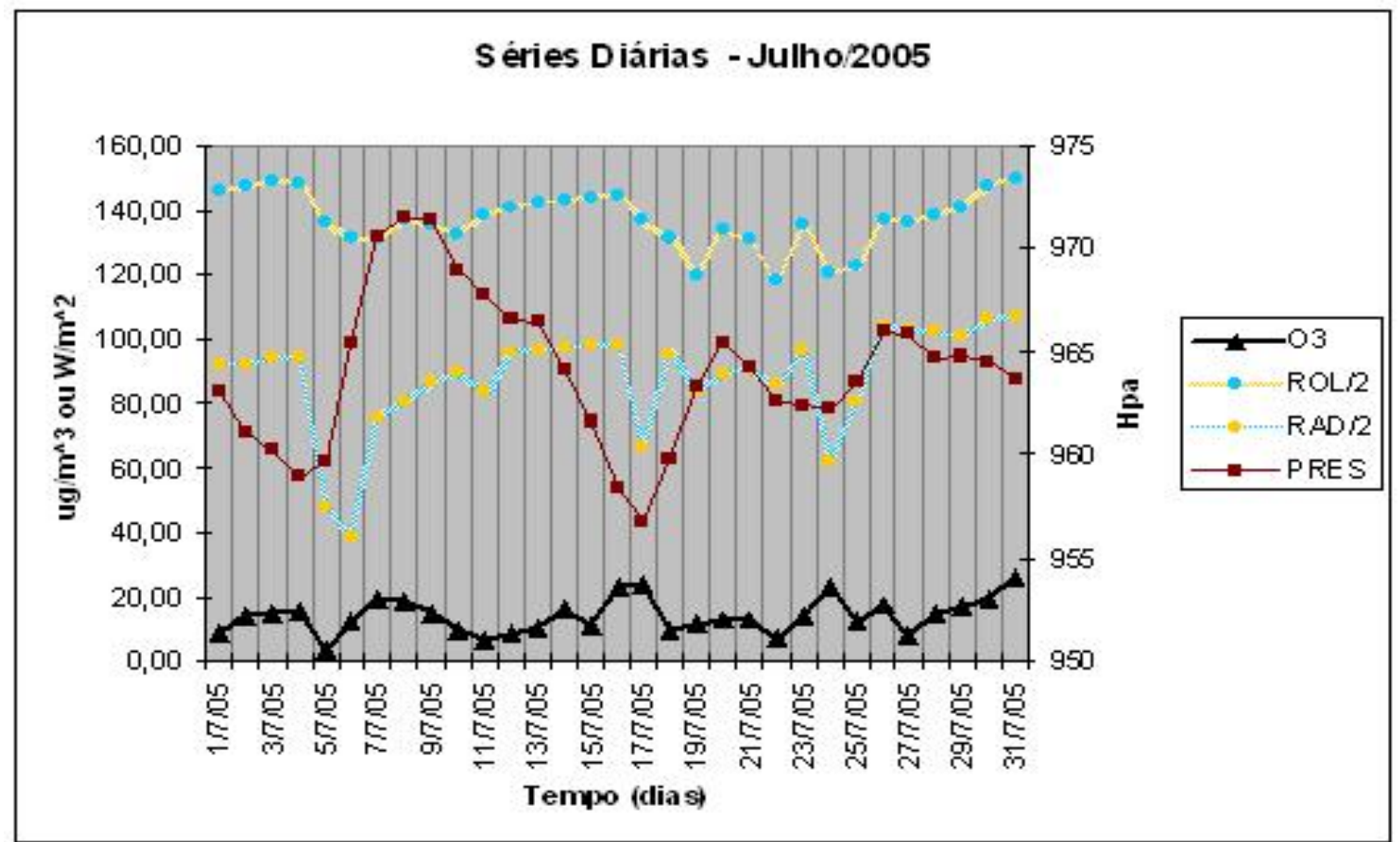

Figura 93e: Médias diárias de ozônio troposférico, radiação solar, ROL e pressão atmosférica em julho de 2005. 


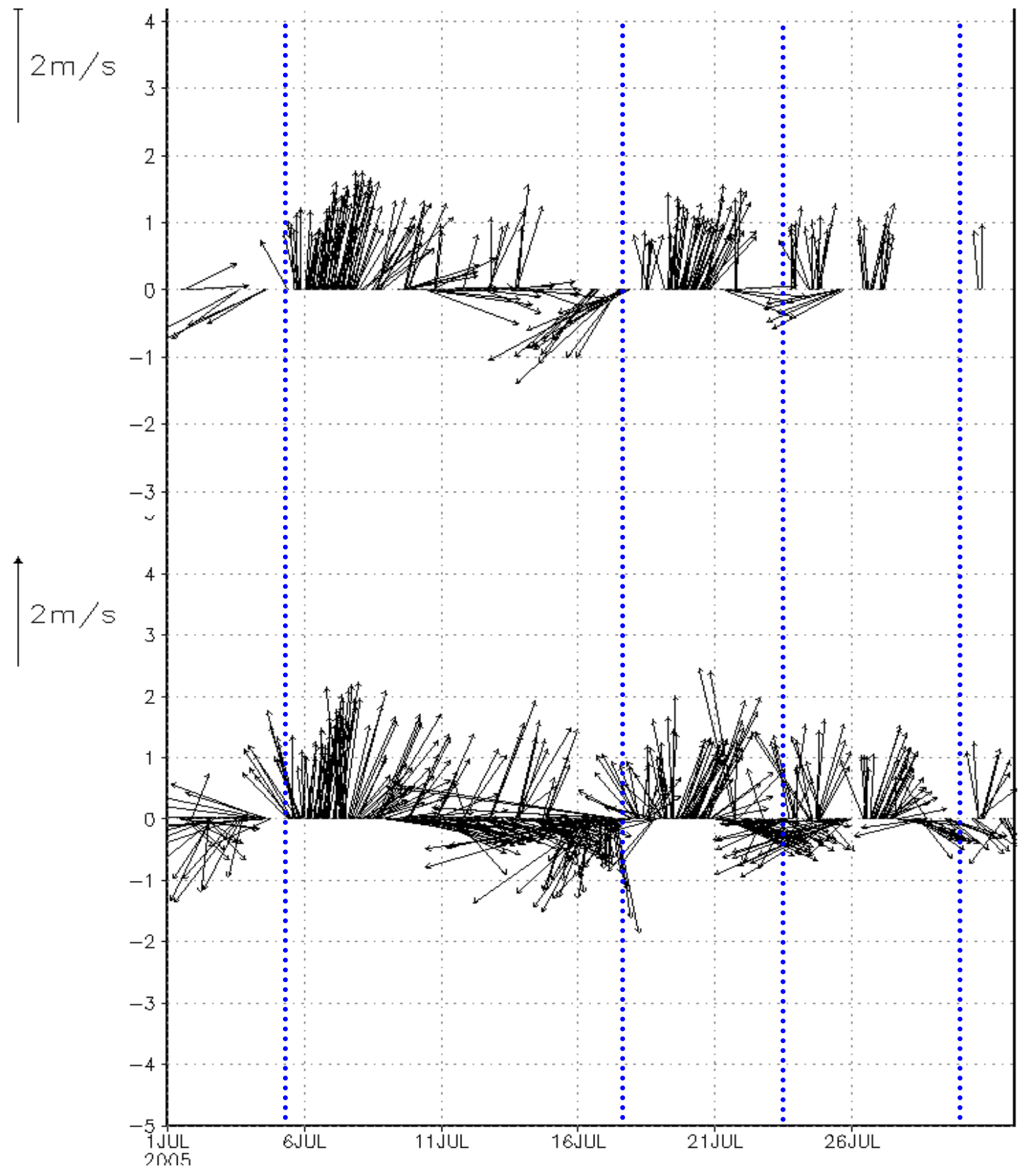

Figura 94a: Evolução mensal de sentido e velocidade do vento nas estações Ibirapuera e Mooca no mês de julho de 2005. A linha pontilhada marca os dias de passagem de sistema frontal. 


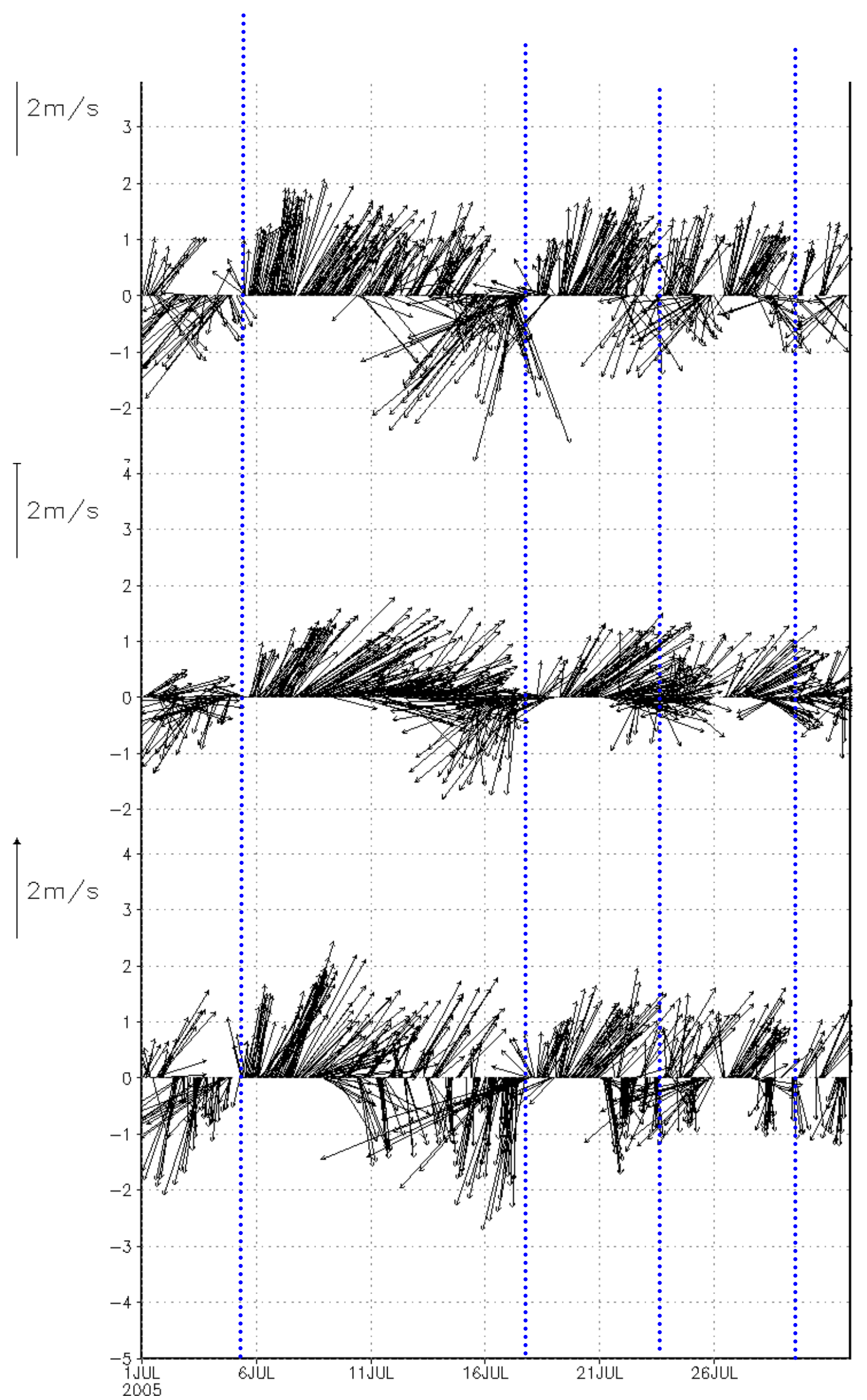

Figura 94b: Evolução mensal de sentido e velocidade do vento nas estações Pinheiros, Santana, e Santo Amaro no mês de julho de 2005. A linha pontilhada marca os dias de passagem de sistema frontal. 


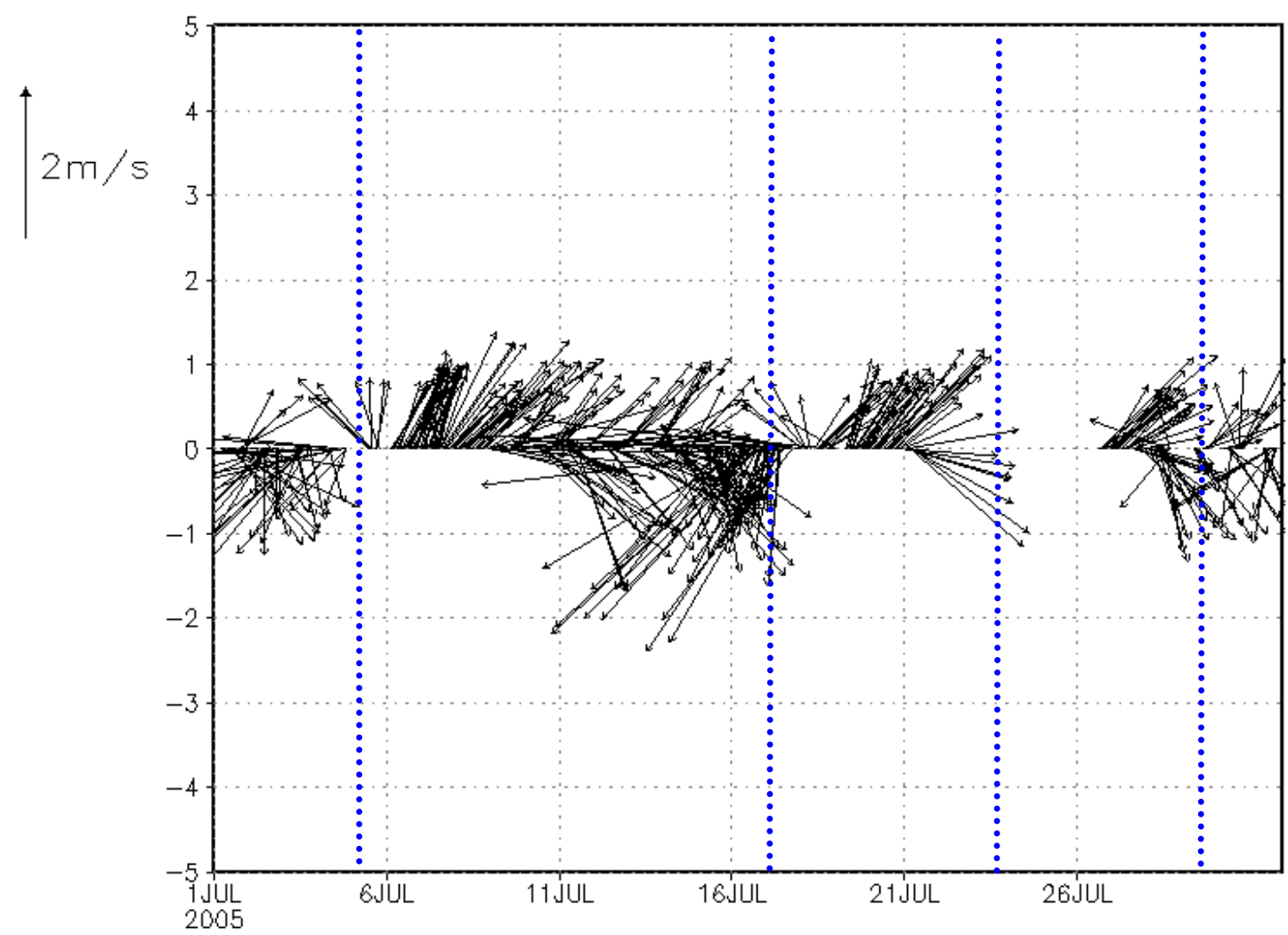

Figura 94c: evolução mensal de sentido e velocidade do vento nas estação São Caetano do Sul no mês de julho de 2005. A linha pontilhada marca os dias de passagem de sistema frontal. 


\subsubsection{Meses de classe 2}

\section{Agosto de 1999}

O mês de agosto de 1999 foi enquadrado na classe +2 com relação à concentração de $\mathrm{O}_{3}$, como se pode ver pela tabela 18. A análise dos padrões atmosféricos deste mês feita na seção anterior apontou a presença de um sistema de alta pressão atmosférica localizado no interior do continente que foi responsável por anomalias positivas de temperatura, radiação solar, ROL, PNM e negativas de umidade relativa e específica. Também foram registrados desvios negativos de precipitação em diversas áreas do Brasil, com intensificação do anticiclone do Atlântico Sul (figuras 72a a 72e).

Durante este mês, foi observada a passagem de três frentes frias sobre o Sudeste do Brasil, conforme indicado na figura 71 (passagem de frentes frias), nos dias 2, 7 e 14, número inferior à média climatológica para esta latitude (sete sistemas). Os demais sistemas frontais que alcançaram o sul do Brasil deslocaramse para o Oceano Atlântico sem atingir a Região Sudeste. Com base nos dados de pressão, temperatura, umidade e radiação solar é possível identificar a ocasião de cada passagem frontal e que a passagem frontal do dia 14 foi a mais intensa, com forte queda de pressão atmosférica (com valor mínimo próximo a $955 \mathrm{hPa}$ ) e entrada de massa de ar de latitudes mais altas com pressão mais elevada (> $970 \mathrm{hPa}$ ) e temperaturas baixas no Município de São Paulo $\left(<8^{\circ} \mathrm{C}\right)$, em comparação aos valores registrados no restante do mês. Nos dias 2, 3 e 7 do mês de agosto de 1999 é possível verificar mínimos relativos de pressão, associados a duas passagens frontais de menor intensidade. Os dados de temperatura do ar evidenciam queda bastante pronunciada no dia 15 e quedas relativas nos dias 3, 4, 8 e 9, o que esteve associado à entrada de massa de ar frio de menor intensidade do que a observada no dia 14. Entre os dias 13 e 18, é possível identificar uma queda significativa dos valores de ROL que está associada à maior nebulosidade presente pela passagem da frente fria. Nas passagens frontais anteriores, é possível notar apenas uma pequena queda no valor de ROL no dia 7. Os valores de umidade relativa evidenciam a passagens frontais com valores contrastantes entre os dias 7 e 9 ( $2^{\text {a }}$ passagem frontal) e 13 e 15 (3- passagem frontal). 
Como o início do mês foi caracterizado por uma instabilidade atmosférica maior (passagem de três frentes frias) e, a partir da terceira passagem frontal, a atmosfera na Região Sudeste tornou-se, em média, mais estável. É esperado o aumento da concentração de poluentes, em particular o de $\mathrm{O}_{3}$, de meados até o final do mês, como observado na figura $95 a$, em que se verifica esta tendência. $A$ concentração de $\mathrm{O}_{3}$ nos dois primeiros dias do mês é baixa, apresentando seu valor mínimo $\left(20 \mu \mathrm{g} / \mathrm{m}^{3}\right)$ no dia 2 . Na segunda metade do mês, a partir do dia 18 , as concentrações se elevam consideravelmente, variando entre 20 e $50 \mu \mathrm{g} / \mathrm{m}^{3}$ e atingem a maior média diária no dia 30 , com $57 \mu \mathrm{g} / \mathrm{m}^{3}$, enquanto que na primeira metade do mês os valores de $\mathrm{O}_{3}$ variaram entre 20 e $40 \mu \mathrm{g} / \mathrm{m}^{3}$. A média diária máxima é verificada ao final do mês, no dia 30 , com $57 \mu \mathrm{g} / \mathrm{m} 3$.

Pode-se relacionar a variabilidade da concentração de $\mathrm{O}_{3}$ e das varáveis atmosféricas no primeiro período. Com base nos dados de concentração de $\mathrm{O}_{3}$, verifica-se que há uma concordância entre os valores máximos e a diminuição de nebulosidade. $\mathrm{O}$ valor máximo de $\mathrm{O}_{3}$ na primeira quinzena do mês é registrado nos dias 11 e 12, concordando com o período de valores altos de ROL. Entre os dias 13 e 17, observa-se uma queda de $\mathrm{O}_{3}$ que esteve associada ao período da passagem da terceira frente fria e de menores valores de ROL, tal como observado nas figuras 95a a 95e. A temperatura cai acentuadamente do dia 15 ao dia 17 e ocorrem aumentos consideráveis na umidade relativa após o dia 13, pela própria diminuição da temperatura, e da pressão em superfície. Também é verificada a queda dos valores de ROL a partir do dia 12, indicando a presença de aumento de nebulosidade. Após a passagem frontal, nota-se a presença de ventos de SE, na estação de Ibirapuera, e de SO, em Osasco e Parque D. Pedro II (figuras 96a a 96d), com a entrada da massa de ar com circulação anticiclônica.

Neste mês, fez-se necessária a divisão da série temporal de vento em duas partes para facilitar a visualização dos diferentes sentidos de vento citados. No início do mês, pode-se notar pelas figuras 96a a 96d uma predominância de ventos de $\mathrm{S} / \mathrm{SO}$, até o dia 6 . As concentrações de $\mathrm{O}_{3}$ (figura 95a) elevam-se após a passagem do primeiro sistema frontal, provavelmente devido à manutenção de condições de alta incidência de radiação solar e baixa velocidade do vento nestes dias. Durante a 
semana seguinte, não se pode verificar uma direção predominante do vento e as concentrações de $\mathrm{O}_{3}$ permanecem estáveis, sem sofrer redução, mesmo com a passagem do segundo sistema frontal (07/08). No entanto, observa-se um máximo secundário entre os dias 11 e 12, que coincide com valores altos de ROL e ventos de sentido NE na estação Osasco. Nas outras estações, não há dados de vento representativos para estes dois dias. Após a passagem do último sistema frontal (dia 14), nota-se uma predominância de ventos de sentido $S$, com progressiva atuação de uma componente de $\mathrm{O}$ a partir do dia 17 . Verifica-se na série temporal de ozônio que este período coincide com uma tendência de aumento nas concentrações do poluente. Na última semana do mês, as concentrações não sofrem queda; elas permanecem altas e estáveis, e não há uma direção predominante do vento. 

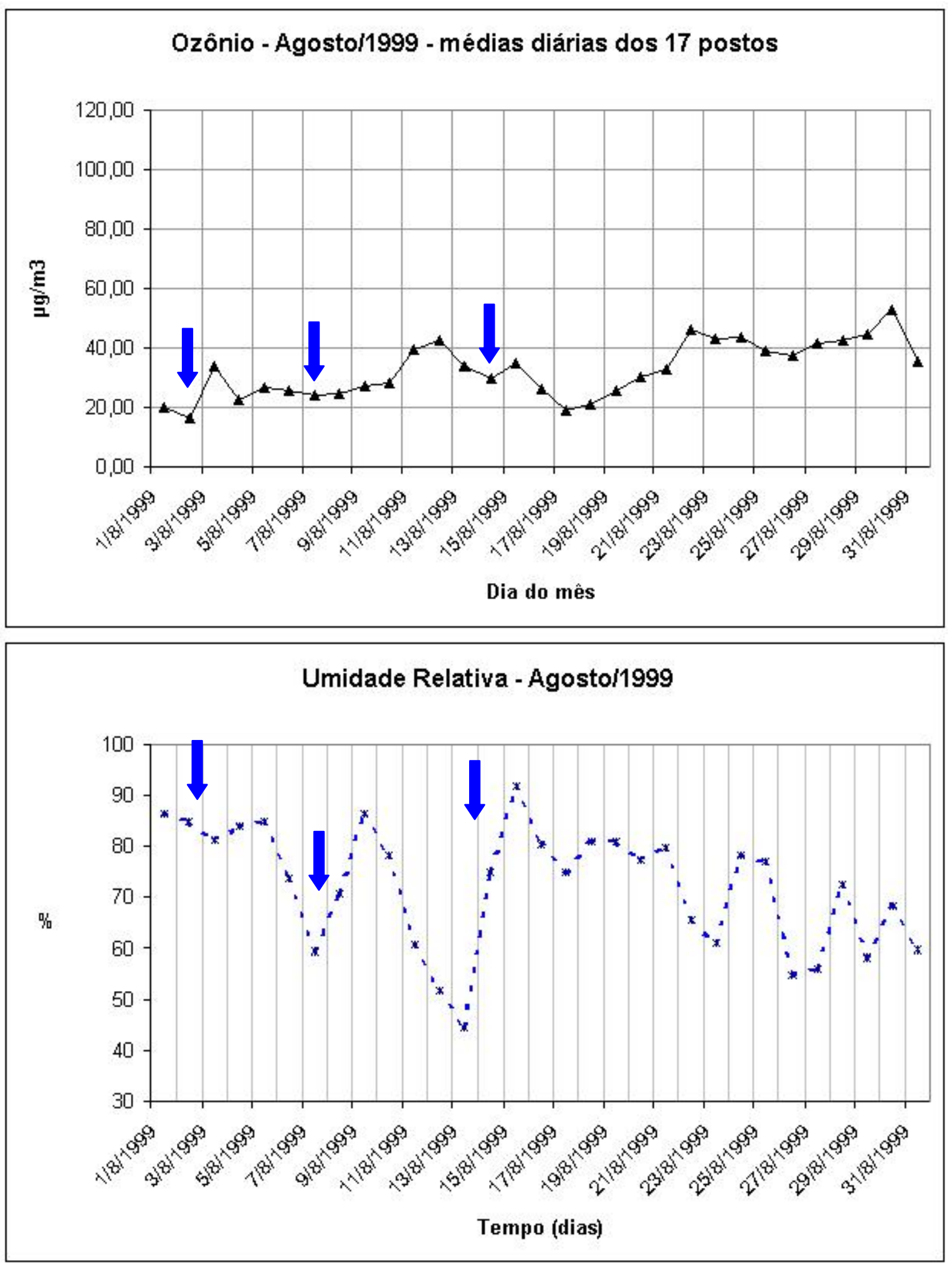

Figura 95a: Médias diárias de ozônio troposférico e umidade relativa em agosto de 1999. Os dias de passagem frontal estão identificados pela seta. 

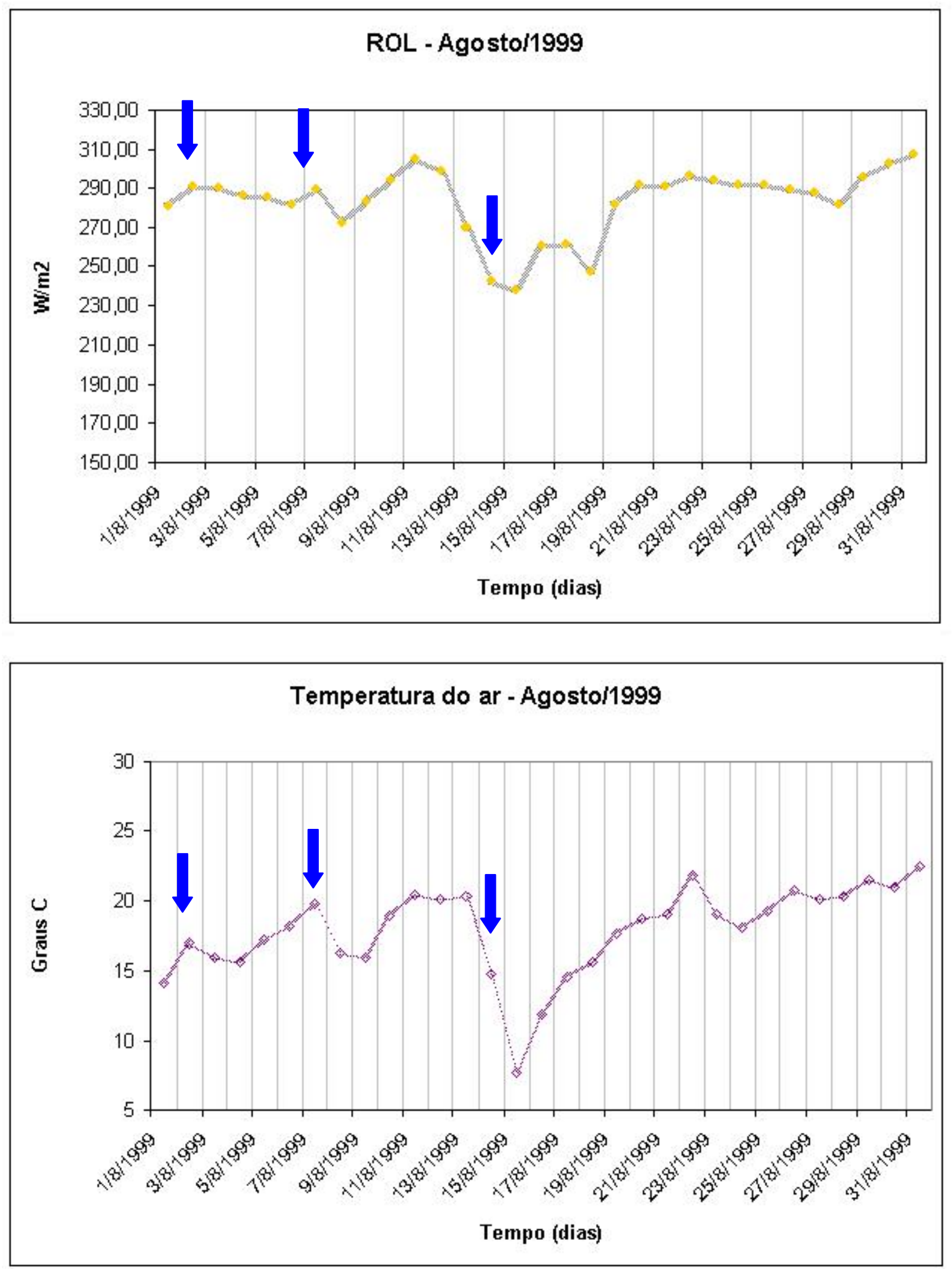

Figura 95b: Médias diárias de ROL e temperatura do ar em agosto de 1999. Os dias de passagem frontal estão identificados pela seta. 

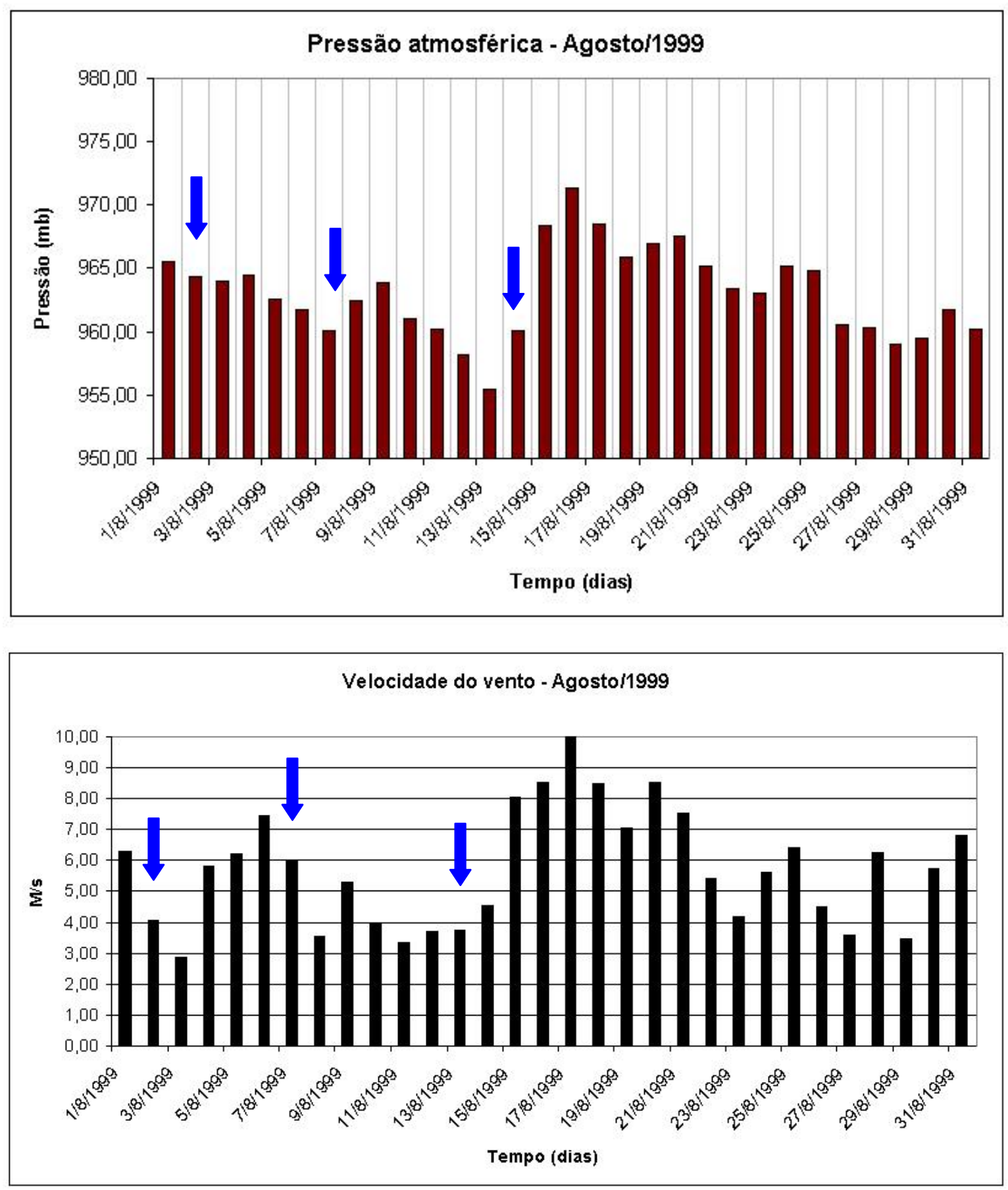

Figura 95c: Médias diárias de pressão atmosférica e velocidade do vento em agosto de 1999. Os dias de passagem frontal estão identificados pela seta. 

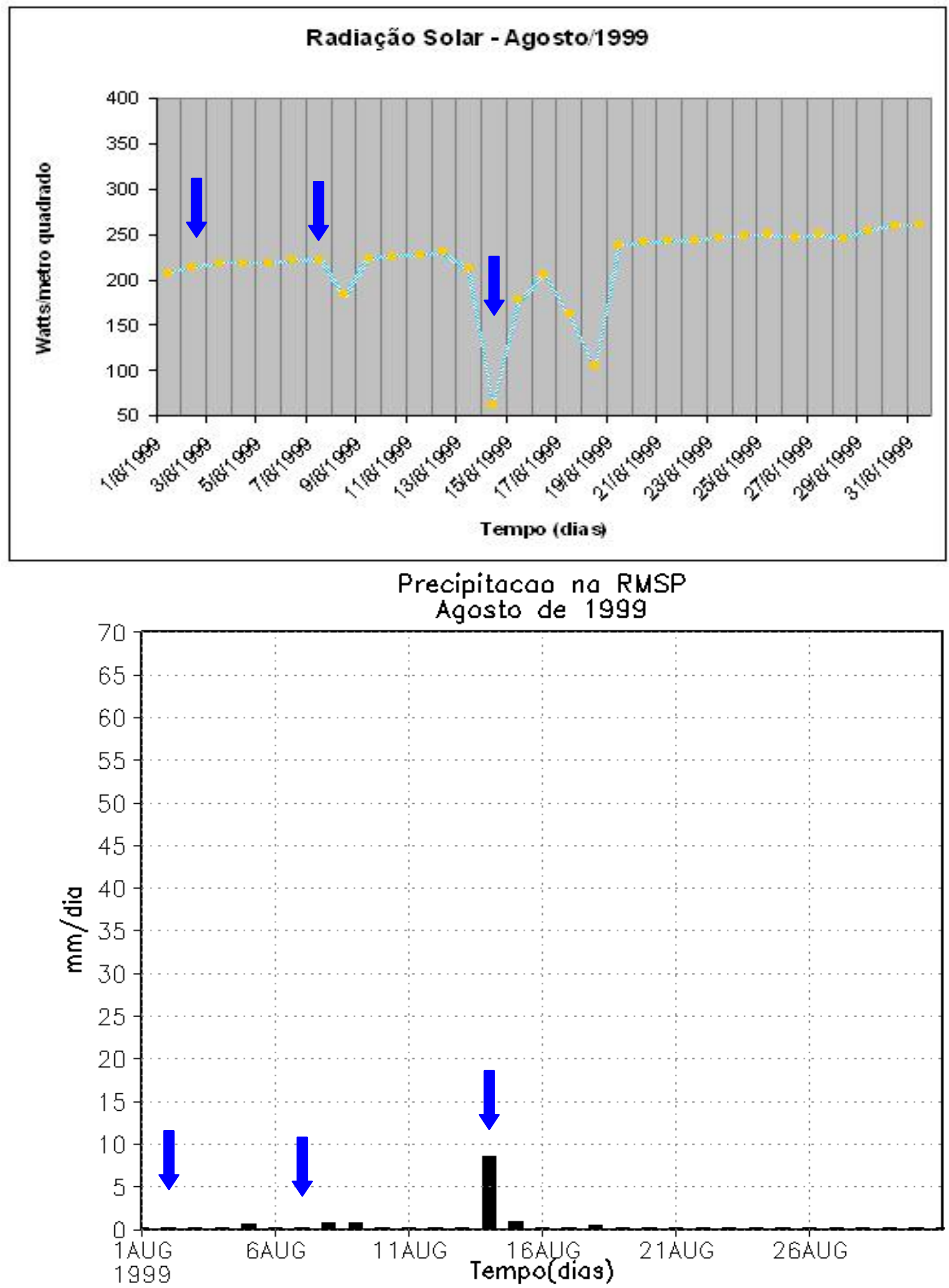

Figura 95d: Médias diárias de radiação solar e precipitação diária em agosto de 1999. Os dias de passagem frontal estão identificados pela seta. 


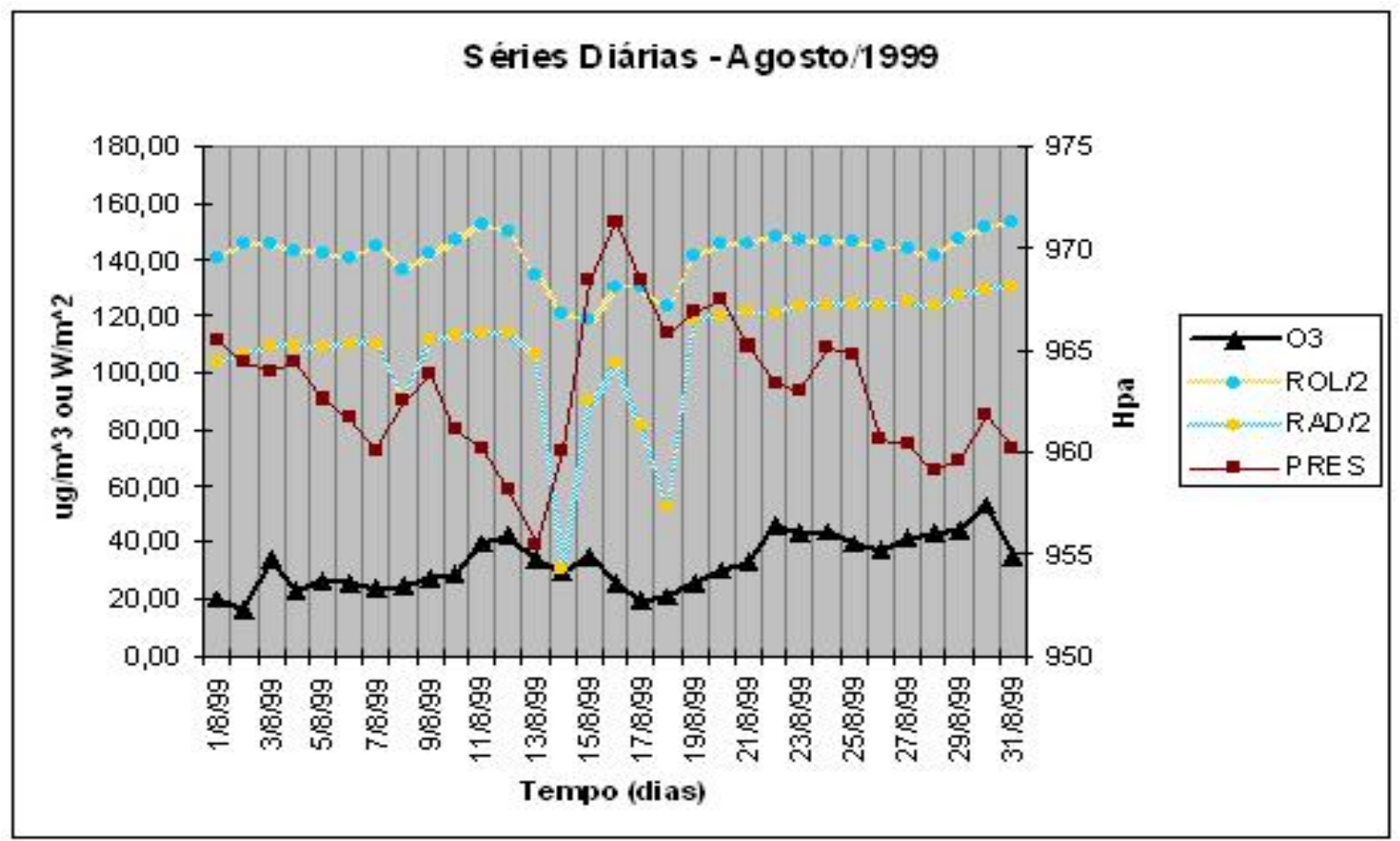

Figura 95e: Médias diárias de ozônio troposférico, radiação solar, ROL e pressão atmosférica em agosto de 1999. 


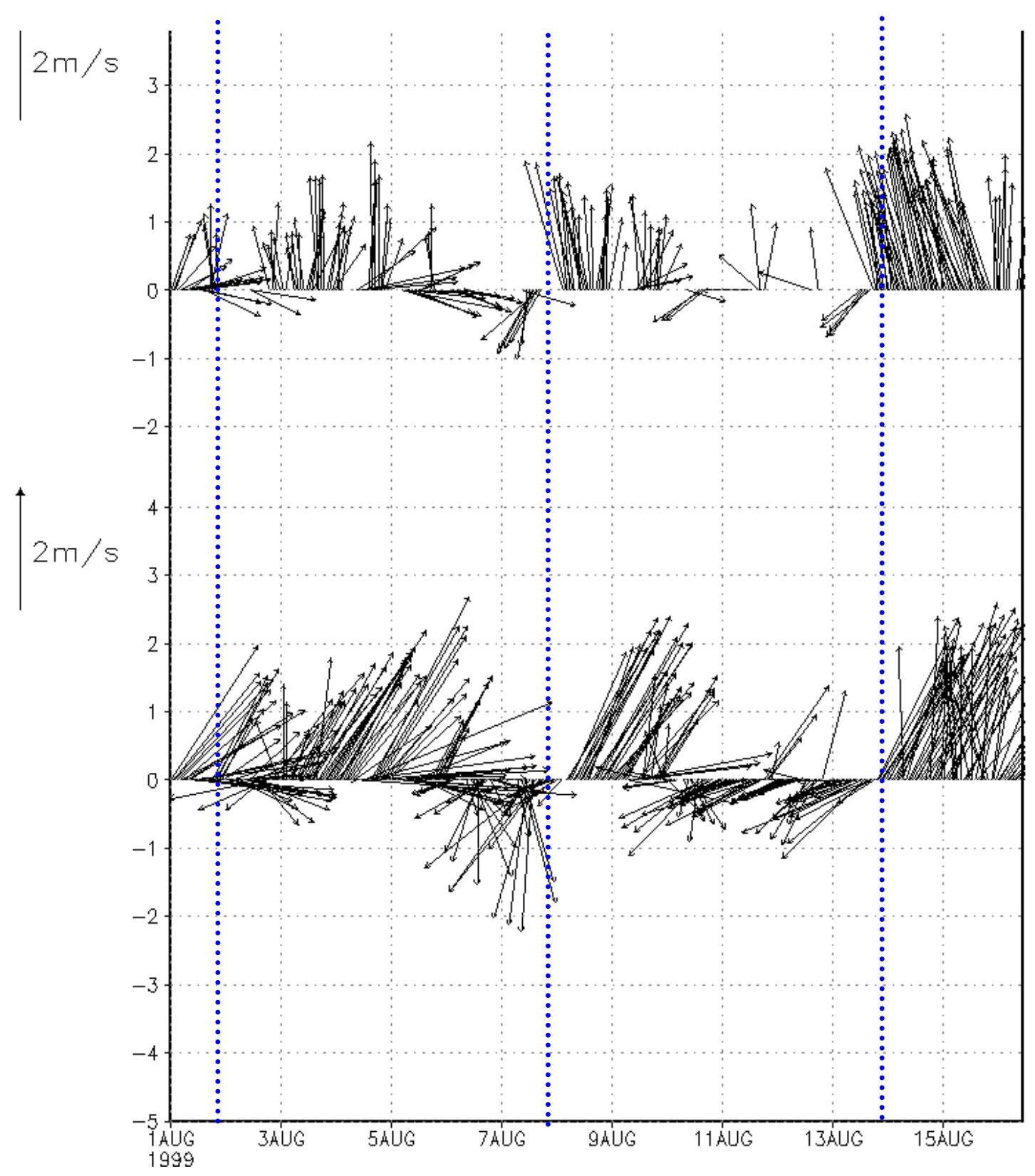

Figura 96a: evolução das sentido e velocidade do vento nas estações lbirapuera e Osasco de 1 a 16 de agosto de 1999. A linha pontilhada marca os dias de passagem de sistema frontal. 


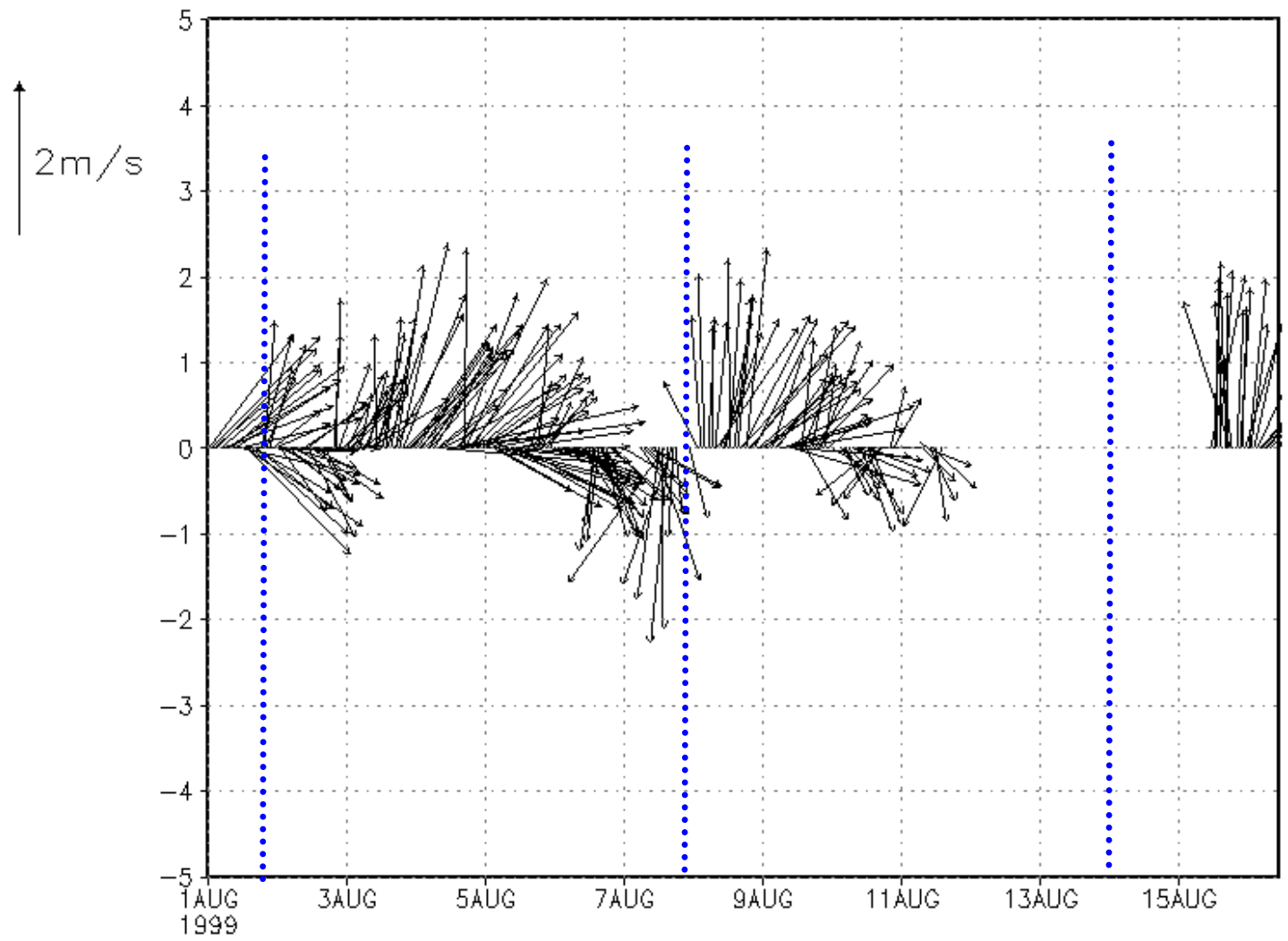

Figura 96b: evolução mensal de sentido e velocidade do vento na estação Parque D. Pedro II, de 1 a 16 de agosto de 1999. A linha pontilhada marca os dias de passagem de sistema frontal. 


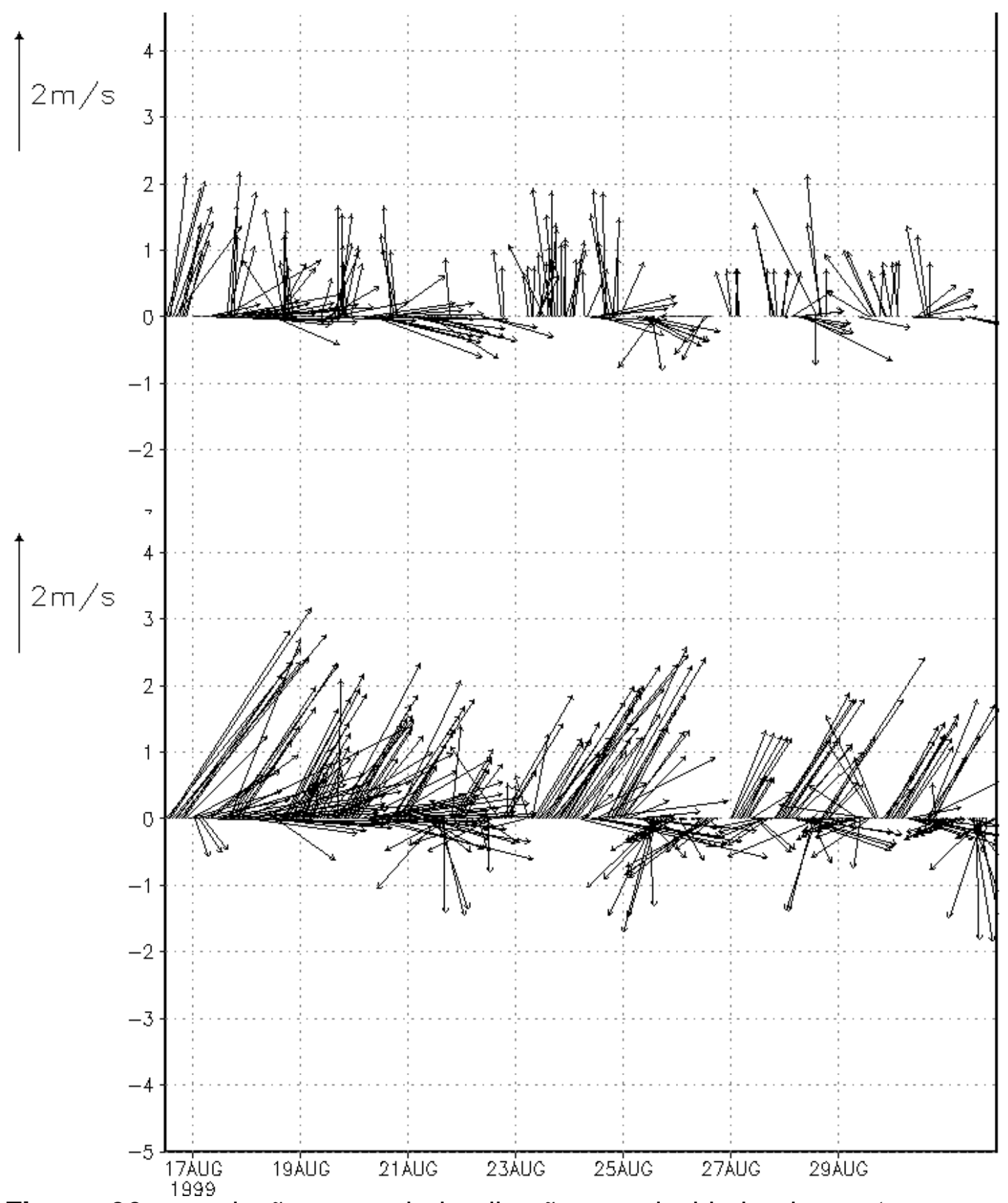

Figura 96c: evolução mensal de direção e velocidade do vento nas estações Ibirapuera e Osasco de 17 a 1 de setembro de 1999. A linha pontilhada marca os dias de passagem de sistema frontal. 


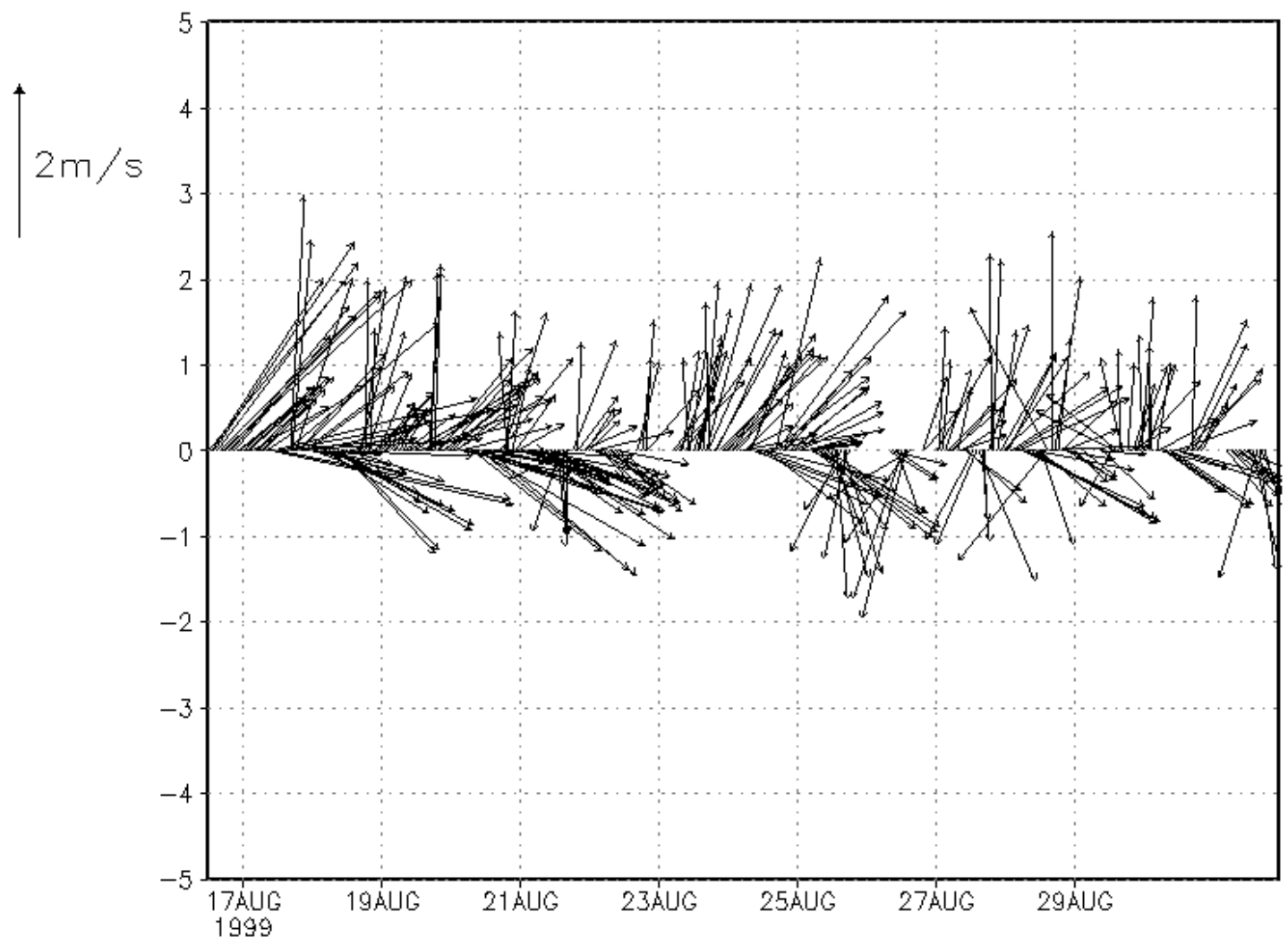

Figura 96d: evolução mensal de direção e velocidade do vento na estação Parque D. Pedro II, de 17 de agosto a 1 de setembro de 1999. A linha pontilhada marca os dias de passagem de sistema frontal. 


\section{Março de 2002}

O mês de março de 2002 foi considerado como pertencente à classe +2 , com anomalias de $+10 \mu \mathrm{g} / \mathrm{m}^{3}$ da concentração de $\mathrm{O}_{3}$. Embora neste mês tenham sido observados sete sistemas frontais atuantes no Sul do país (figura 73), apenas um deles influenciou as condições atmosféricas na RMSP, no dia 20. Ou seja, para a latitude da RMSP, houve grande desvio negativo em relação o número de sistemas frontais atuantes neste mês, pois a média equivale à sete sistemas - justamente o que foi observado na região Sul. Em escala sinótica, a região onde está inserida a RMSP apresentou anomalias positivas de pressão à superfície, de radiação solar, de ROL e de temperatura figuras (74a a 74c). Quanto à circulação, foi observada anomalia convergente em altos níveis e anomalia divergente em baixos níveis sobre a Região Sudeste do Brasil, dificultando a intensificação de sistemas precipitantes (74d e 74e).

Apesar de ter sido notada a atuação de apenas uma frente fria na RMSP no dia 20, durante o início do mês foram observados vários episódios de precipitação (figura 97d) e valores baixos de radiação solar e ROL com mínimos nos dias 8 e 14, indicando instabilidade atmosférica. No dia 24 foi observado o valor mínimo de ROL durante este mês, indicando significativa presença de nebulosidade (97b). Como se trata de período de verão na região, os deslocamentos de massa de ar de latitudes mais altas não provocam grande diminuição na temperatura (fig 97b), apesar de relativo aumento de pressão em superfície nos dias subseqüentes (figura 97c).

Nas figuras 98 a a 98c, pode-se notar uma mudança de ventos de N/NO para S/SO no período da passagem do sistema frontal (dia 20). Do dia 20 ao dia 24 ocorre também redução nos valores de ROL e radiação de onda curta (figura 97b e 97d), que coincidem com uma ligeira redução das concentrações de ozônio, sugerindo mais uma vez a correlação de radiação solar com produção de $\mathrm{O}_{3}$. No dia 24 ocorreu o evento mais intenso de precipitação do mês. No restante do mês não houve a passagem de outros sistemas frontais.

A figura 97d indica que houve contínuos eventos de precipitação no início do mês, nos dias 2,3 e 4, e pode-se notar que os valores de ROL são menores nestes dias do que nos dias subseqüentes, sem chuvas, que apresentam valores de ROL 
mais altos e estáveis. O mesmo ocorre com a temperatura e a umidade relativa do ar. Nos dias 7 e 8 ocorrem novos eventos de precipitação, juntamente com um mínimo de $\mathrm{ROL}$ e radiação de ondas curtas. Os valores de ROL oscilam bastante durante o mês e apresentam um mínimo (em torno de $170 \mathrm{~W} / \mathrm{m}^{2}$ ) no dia 24 , quando houve precipitação persistente durante o dia todo, associada à passagem frontal.

As concentrações de ozônio são altas durante este mês, mas oscilam consideravelmente em comparação com os meses de classe +2. Os valores máximos (59 e $66 \mu \mathrm{g} / \mathrm{m}^{3}$ ) ocorrem nos dias 09 e 10, quando há aumento dos valores de $\mathrm{ROL}$ e radiação solar e não ocorre precipitação. Ao contrário do que verificado em outros meses de classe +2 e -2 , a concentração de $\mathrm{O}_{3}$ não sofre aumento anteriormente à passagem do sistema frontal pela RMSP (dia 20); de fato, sofre redução, acompanhada pela diminuição dos valores de ROL, conforme mencionado acima. As menores concentrações de $\mathrm{O}_{3}$ no mês ocorrem no dia 24 (média diária de $9 \mu \mathrm{g} / \mathrm{m}^{3}$ ), durante um evento de precipitação que esteve associado à persistente nebulosidade; e nos dias 8 e 14, associados à redução dos valores de radiação solar e ROL. O coeficiente de correlação linear entre as concentrações de $\mathrm{O}_{3}$ e ROL neste mês foi 0,45 .

Pode-se notar pelos gráficos de direção e intensidade do vento que há uma predominância de ventos de $\mathrm{N}, \mathrm{O}$ e $\mathrm{NO}$ nas três primeiras semanas do mês, nas estações da CETESB. A estação Parque D. Pedro II apresenta predomínio de ventos de N/NO, enquanto que São Caetano do Sul e Santo André, de NO. A estação Santana apresenta predominância de ventos de O, e São Miguel Paulista, de SO. A estação Mooca oscila entre a predominância de ventos de NO e NE. De qualquer forma, esta configuração sugere que haja divergência atuando sobre a RMSP. Após a passagem do sistema frontal (dia 20), as concentrações de $\mathrm{O}_{3}$ diminuem e os ventos passam a ter uma componente de $S$ mais atuante. $O$ máximo secundário de $\mathrm{O}_{3}$ no final do mês (27/03) é acompanhado novamente por direções do vento que sugerem uma situação de divergência do ar em superfície, de acordo com as estações medidoras da CETESB. Nos últimos dias do mês, quando as concentrações se tornam mais estáveis (a partir do dia 28/03), percebe-se uma nova predominância de ventos de S, SE e SO. 

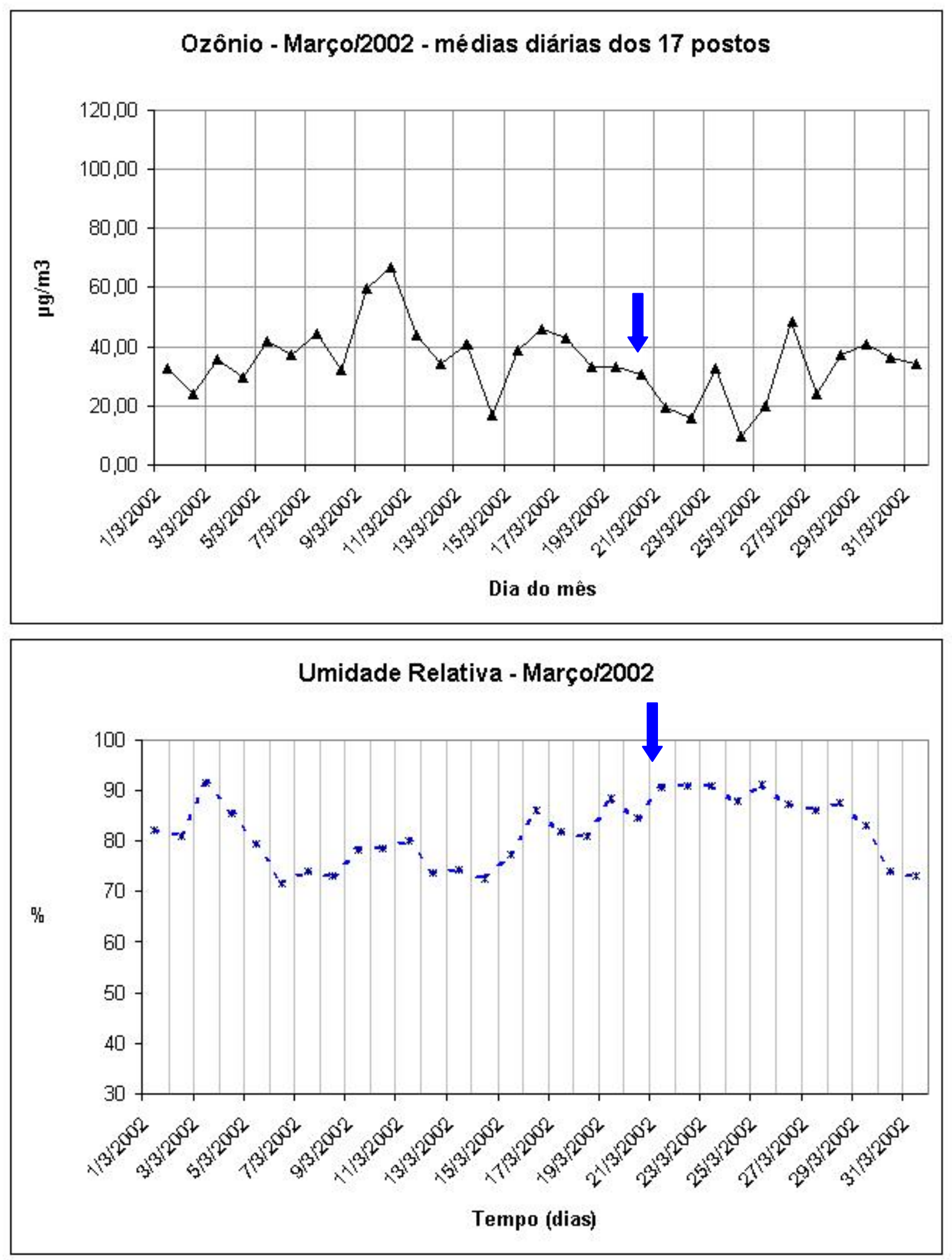

Figura 97a: Médias diárias de ozônio troposférico e umidade relativa em março de 2002. Os dias de passagem frontal estão identificados pela seta. 

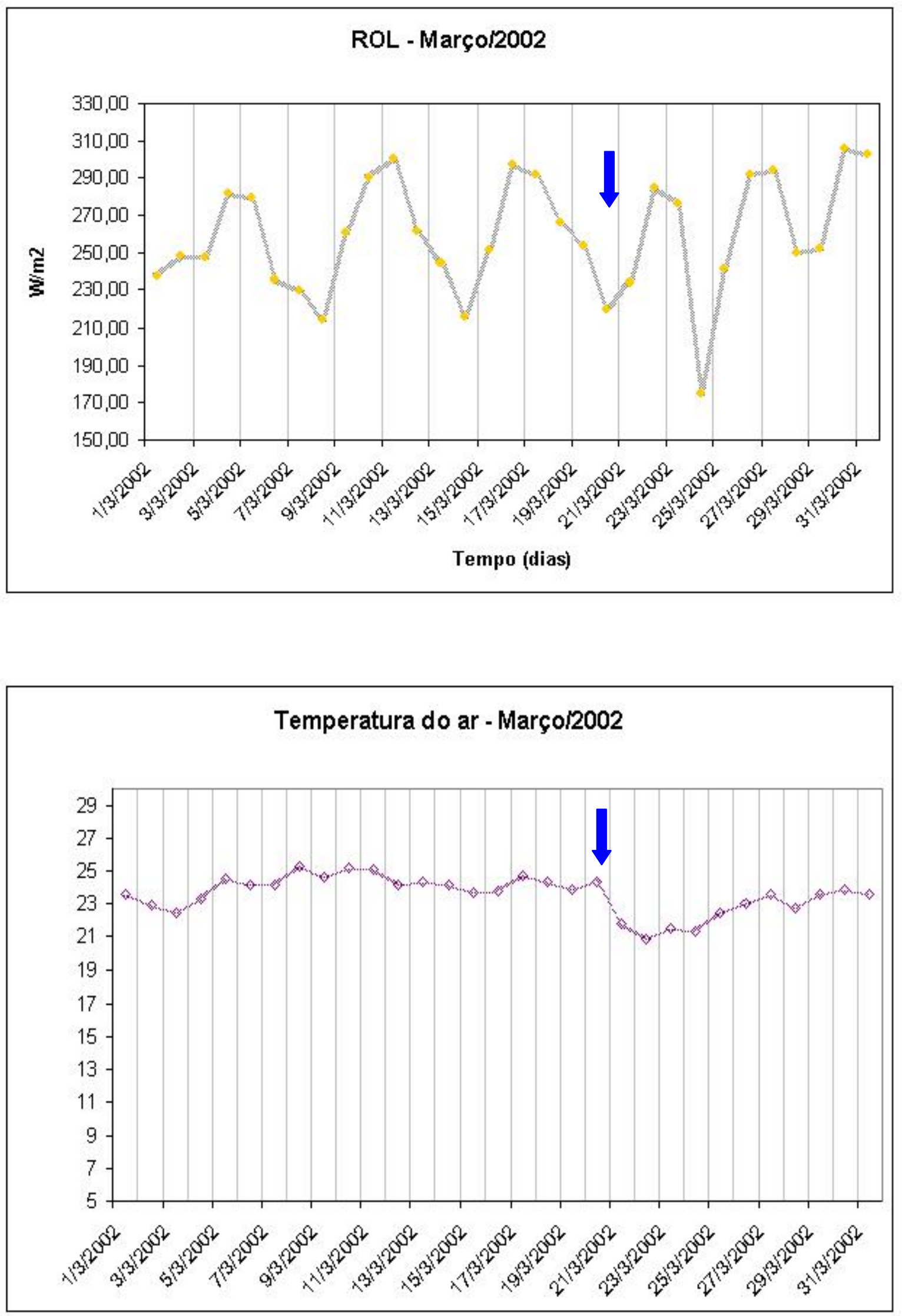

Figura 97b: Médias diárias de ROL e temperatura do ar em março de 2002. Os dias de passagem frontal estão identificados pela seta. 

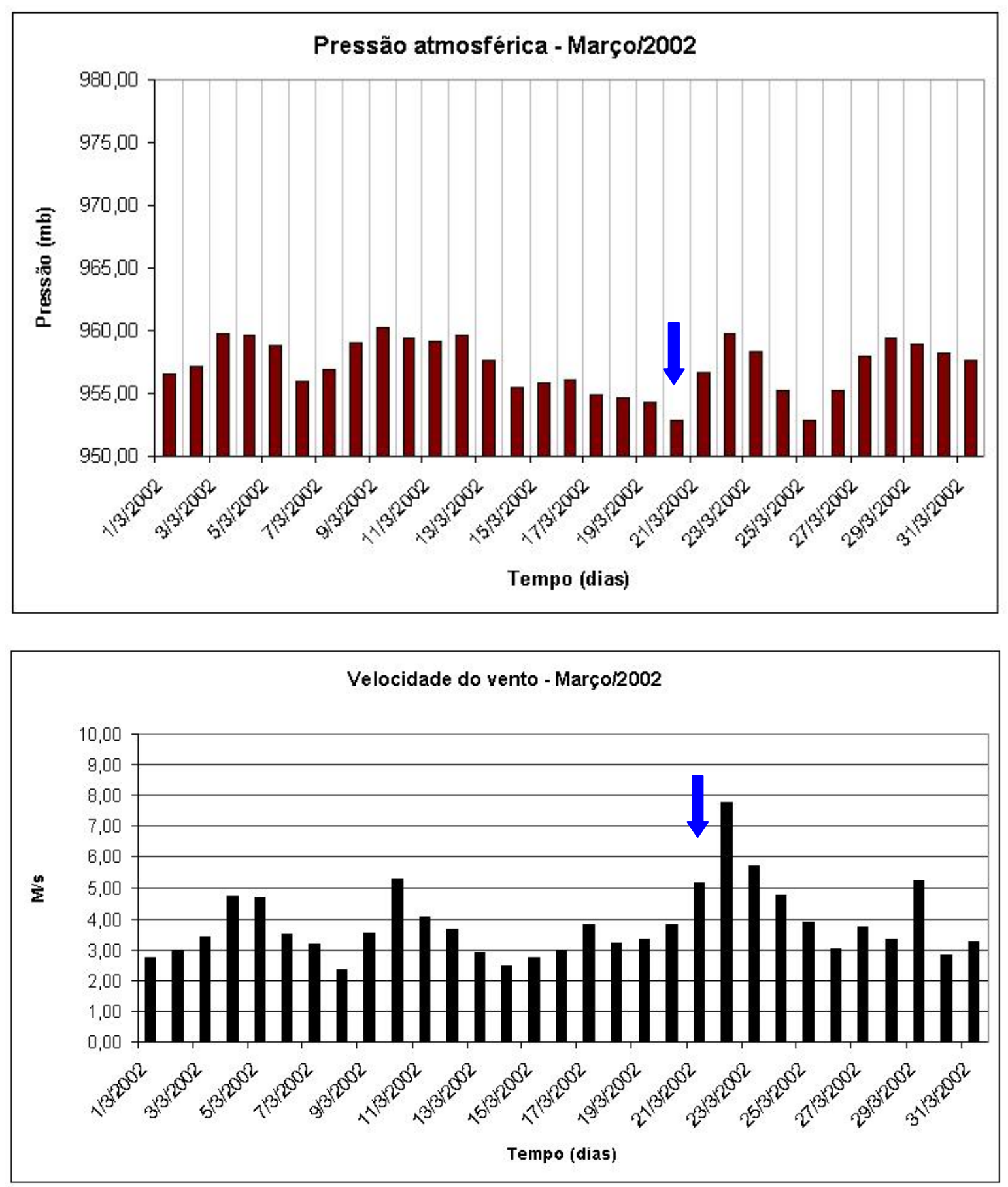

Figura 97c: Médias diárias de pressão atmosférica e velocidade do vento março de 2002. Os dias de passagem frontal estão identificados pela seta. 

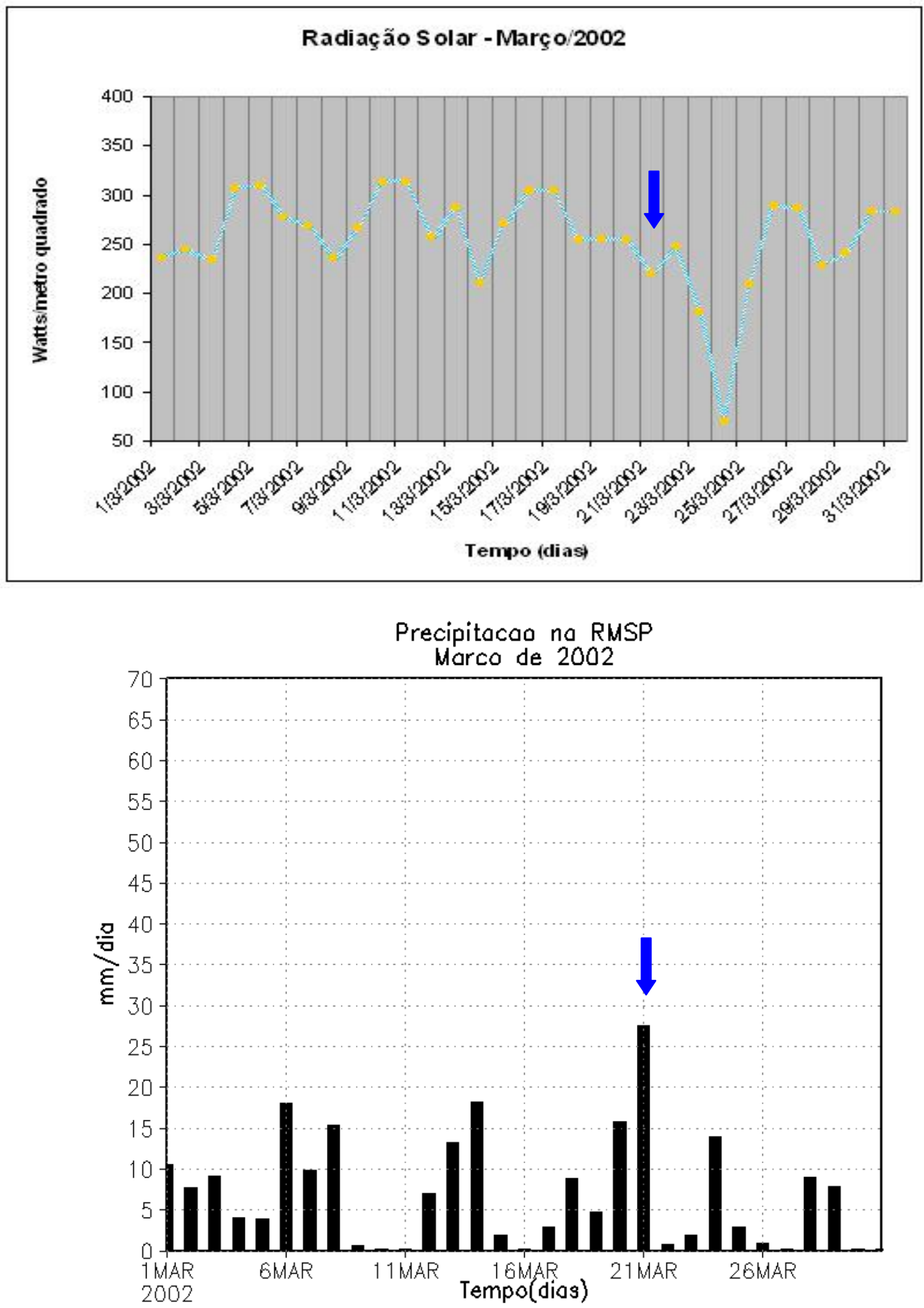

Figura 97d: Médias diárias de radiação solar e precipitação diária em março de 2002. Os dias de passagem frontal estão identificados pela seta. 


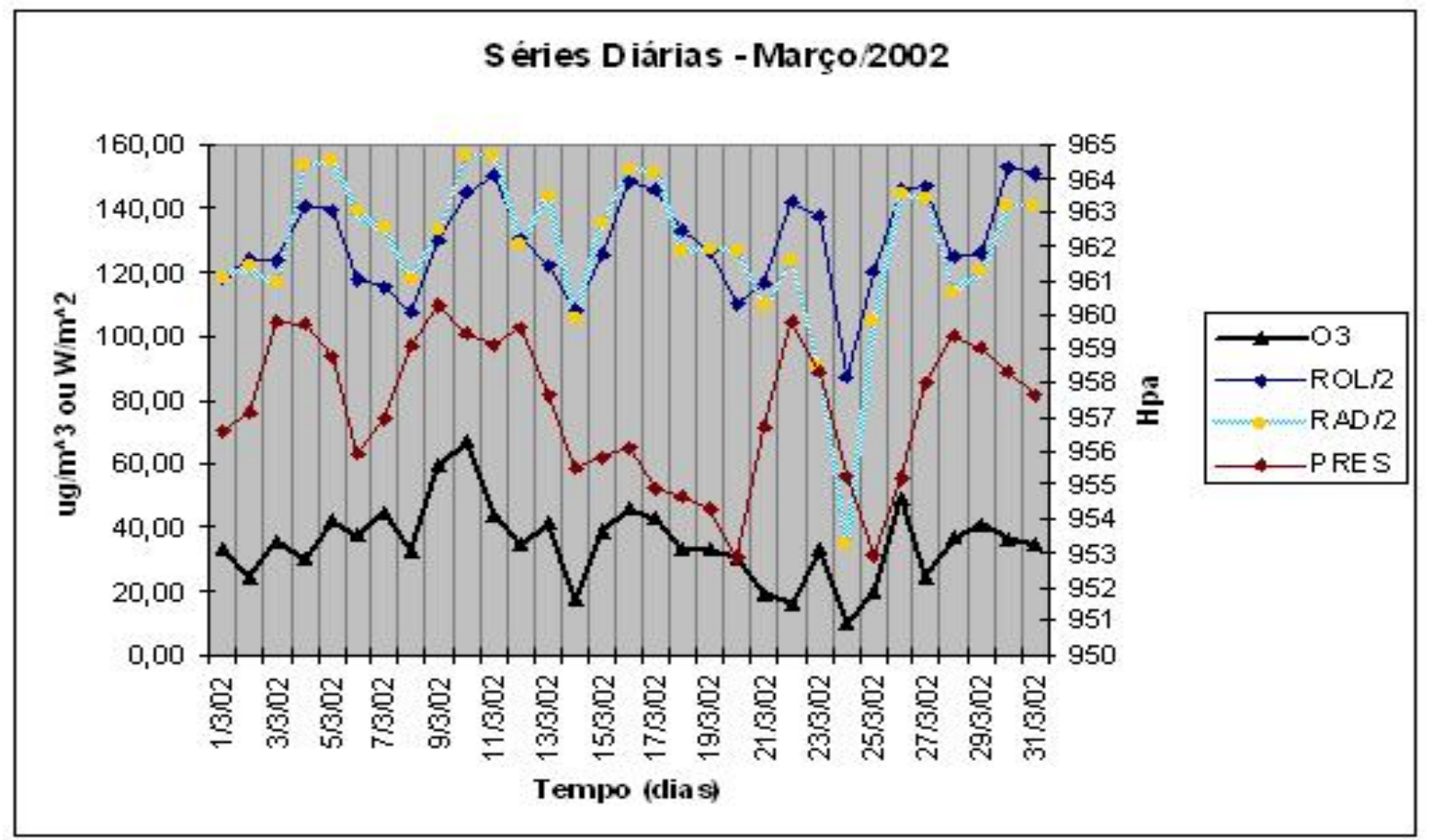

Figura 97e: Médias diárias de ozônio troposférico, radiação solar, ROL e pressão atmosférica em março de 2002. 


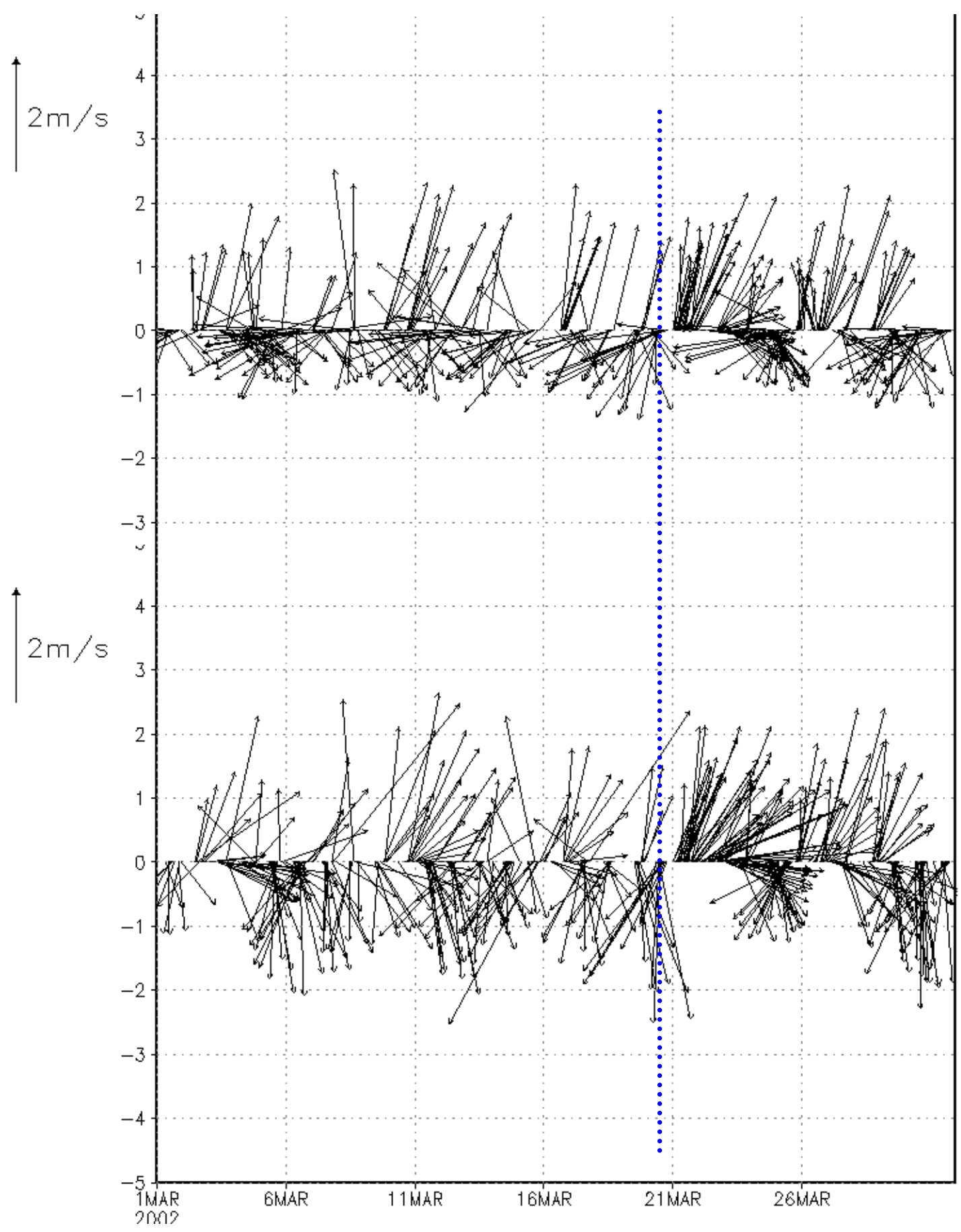

Figura 98a: Evolução temporal de sentido e velocidade do vento nas estações Mooca, Parque D. Pedro II no mês de março de 2002. A linha pontilhada marca os dias de passagem de sistema frontal. 


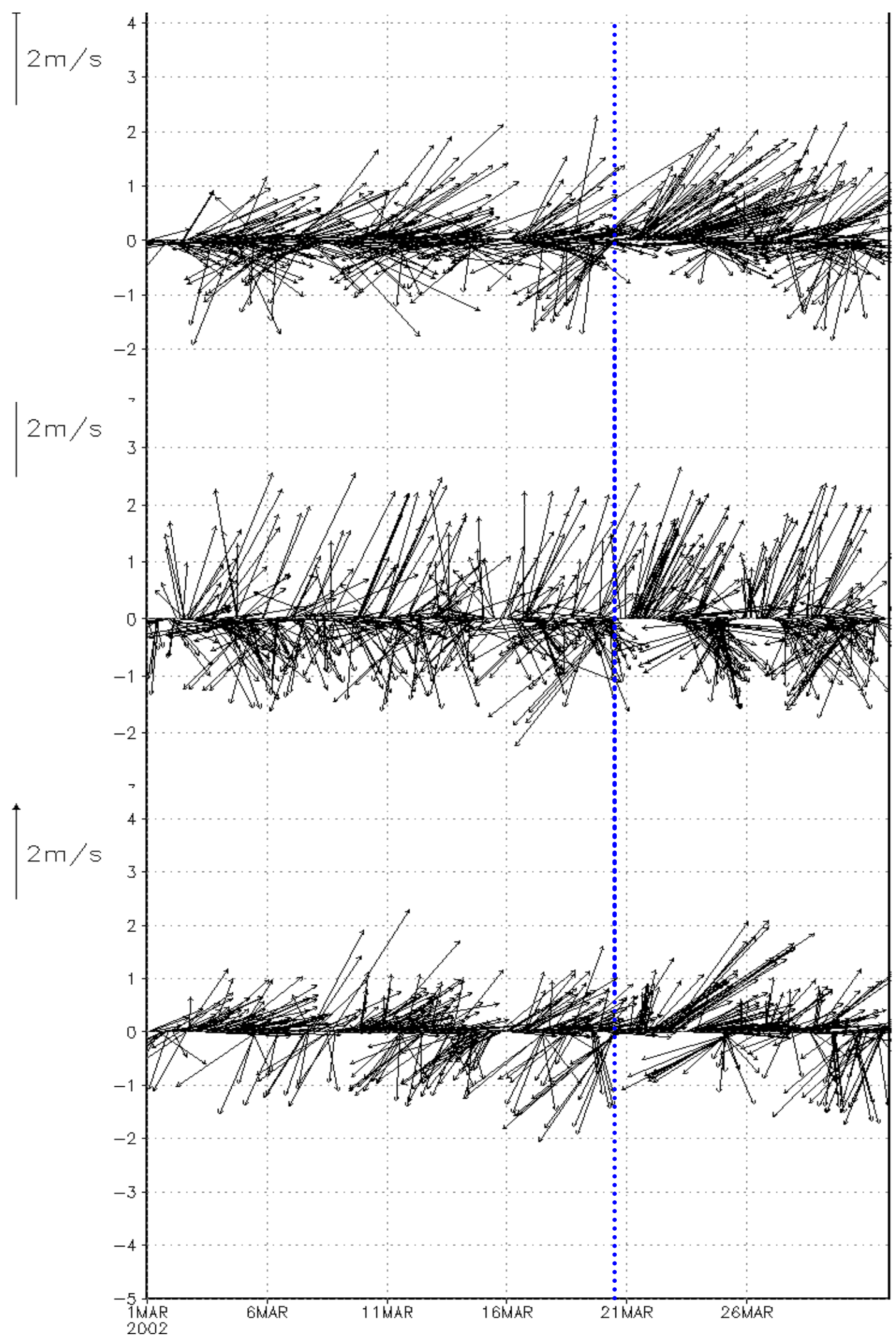

Figura 98b: Evolução temporal de sentido e velocidade do vento nas estações Santana, São Caetano do Sul e São Miguel Paulista no mês de março de 2002. A linha pontilhada marca os dias de passagem de sistema frontal. 


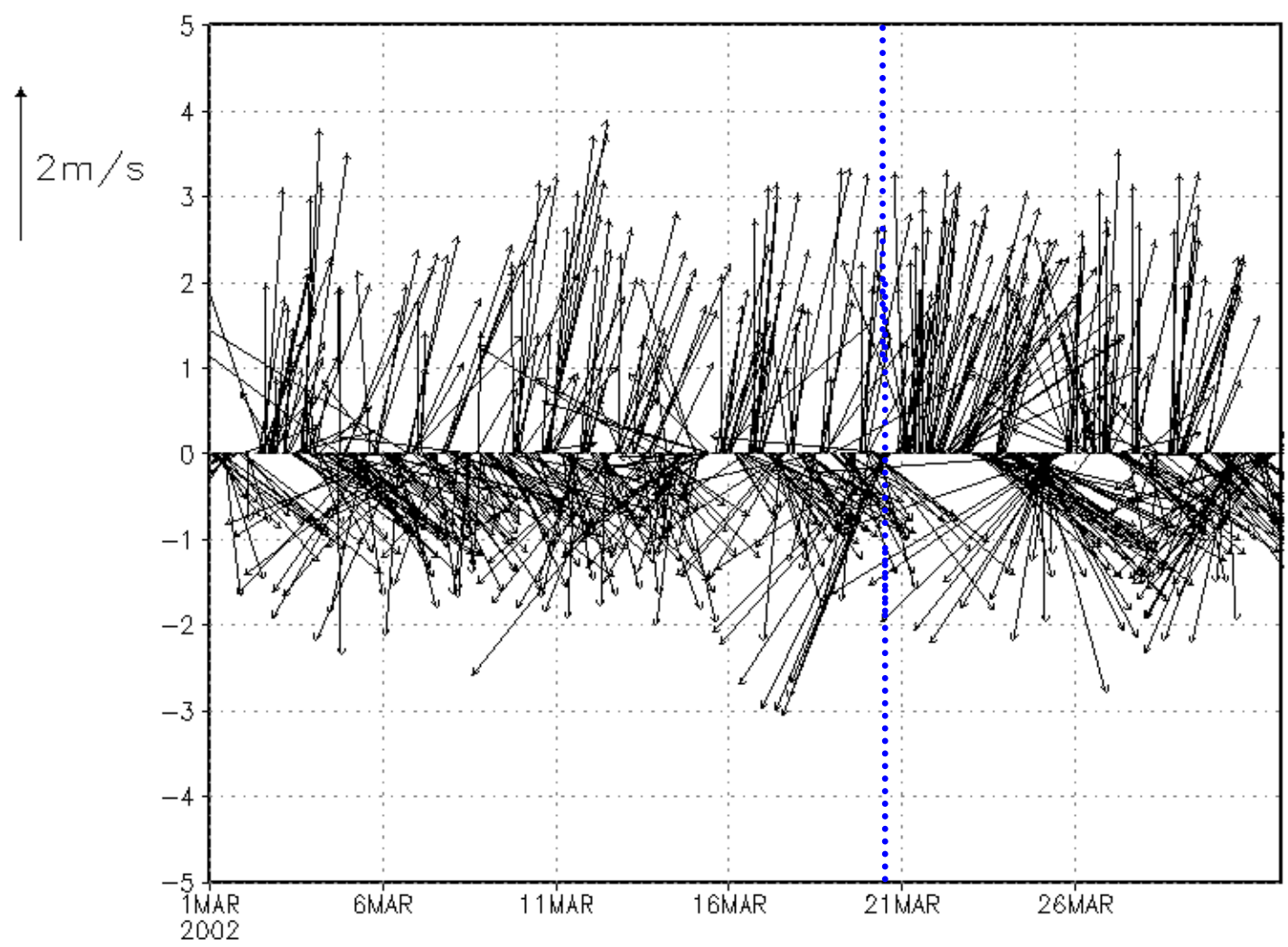

Figura 98c: Evolução temporal de sentido e velocidade do vento na estação Santo André - Capuava no mês de março de 2002. A linha pontilhada marca os dias de passagem de sistema frontal. 


\section{Fevereiro de 2003}

Este mês também foi considerado como pertencente à classe +2 . Houve a atuação de apenas duas frentes frias na região da RMSP, embora entre as latitudes de $35^{\circ} \mathrm{S}$ e $25^{\circ} \mathrm{S}$ tenha havido a passagem de oito frentes, duas além da média climatológica do mês. Foram observadas anomalias semelhantes ao mês de março de 2002 - positivas de temperatura, PNM, radiação solar, ROL e negativas para umidade relativa e específica, com divergência do ar em superfície. Segundo o boletim Climanálise deste mês, a atuação de alguns VCANs sobre diversas áreas do Brasil dificultou a penetração de sistemas frontais sobre a RMSP, e também foram registrados desvios negativos de precipitação.

De acordo com a figura 99a, a concentração de $\mathrm{O}_{3}$ oscilou significativamente durante o mês de fevereiro 2003, em comparação aos de classe -2, e mesmo aos de classe +2 . A concentração de $\mathrm{O}_{3}$ acompanha de certo modo os valores de ROL e radiação solar, coeficiente de correlação de Pearson de 0,44 para ozônio e ROL e 0,58 para radiação de ondas curtas e ozônio. Durante este mês foram registradas pressões baixas à superfície nos dias 6, 11 e 17 (valor mínimo), o que foi acompanhado por valores mínimos de ROL nos dias 6, 12, 14, 17 e 22. Os valores mínimos de $\mathrm{O}_{3}$ foram observados nos dias 7, 14 e 17 (mínimo absoluto do mês, 14 $\mu \mathrm{g} / \mathrm{m}^{3}$ ). Apesar de apenas duas passagens frontais terem sido indicadas pelo boletim Climanálise, situações de pressão baixa em níveis baixos, associadas à turbulência e formação de nebulosidade, foram observadas em alguns períodos do mês (figuras 99b, 99c e 99e). É possível notar pelos valores de pressão à superfície que a ocorrência de um mínimo no dia 17 é acompanhada por valores mínimos de $\mathrm{O}_{3}$, evidenciando a diminuição gradativa de radiação solar ao longo da primeira quinzena do mês. Na segunda semana do mês, no entanto, pode-se perceber com mais clareza a tendência de diminuição da nebulosidade (figura 99b) aumento da radiação de ondas curtas (figura 99e) e da concentração do poluente (figura 99a).

Neste mês, as concentrações de ozônio permaneceram sobremaneira altas e as eventuais reduções observadas foram provavelmente influenciadas pela cobertura de nuvens devido a eventos de precipitação, sem considerar aqui os mecanismos químicos de redução do $\mathrm{O}_{3}$. Destaca-se no início do mês um aumento contínuo na nebulosidade na RMSP, dos dias 3 e 6, associado à ocorrência de um 
VCAN com centro no Estado da Bahia. De acordo com o estudo de Silva (2005), regiões que estejam de 1000 a 2000 km de distância nos setores Nordeste, Leste e Sudeste do centro de um VCAN podem sofrer aumento na freqüência de precipitação, devido à banda de nebulosidade convectiva que se posiciona a oeste do sistema. Assim, esta hipótese pode ser levantada para a RMSP nestes dias, pois neste período, as concentrações de $\mathrm{O}_{3}$ demonstram ligeira tendência de queda e precipitação freqüente (figura 99e).

No entanto, nota-se pela figura 99b uma diminuição de nebulosidade e precipitação a partir do dia 19/02, acompanhadas de elevação nas concentrações de ozônio. Segundo o boletim da Climanálise deste mês, forma-se um VCAN no litoral do Brasil no dia 20, que se desloca pelo interior do continente, chegando ao norte da Argentina no dia 28 (figura 99d - VCANs fevereiro/03), que influenciou negativamente a distribuição de chuvas principalmente em Minas Gerais e São Paulo. Pode-se ver estas diferentes atuações dos VCANs nas figuras 99d e (imagens de satélite fevereiro/03).

Nota-se que não há direção predominante do vento nas duas primeiras semanas do mês e as concentrações de $\mathrm{O}_{3}$ oscilam consideravelmente neste período, em comparação aos outros meses de classe +2 , inclusive atingindo 0 máximo do mês no dia 10/02. No entanto, a partir do dia 14, as concentrações de $\mathrm{O}_{3}$ sofrem queda considerável, coincidindo com uma predominância de ventos de sentido $\mathrm{N}$ em todas as estações medidoras. Este evento de queda de ozônio não ocorreu acompanhado da passagem de um sistema frontal, mas pode ter sido influenciado pela diminuição da pressão a partir do dia 8 (figura 97c) e aumento na umidade do ar a partir do dia 12 (figura 97a), com melhores condições de dispersão de poluentes. Nestes dias, também ocorre aumento de nebulosidade (figura 97b) e episódios de precipitação (figura 97d), podendo estar ligada a uma influência mais remota do sistema frontal, que chegou até Iguape no dia 12. Na semana do dia 14 ao 21, as concentrações de $\mathrm{O}_{3}$ apresentam tendência de queda até o dia da passagem da primeira frente fria do mês no dia 17. A partir deste dia, elas seguem em progressiva elevação até 24/02. Ocorre a passagem de uma frente fria pela RMSP no dia 22/02, ocasionando a mudança no sentido do vento (que passa a ter sentido SO, e SE na estação Santo Amaro) nas estações da CETESB (figura 100a a 
100c), que persiste até o final do mês. Neste período, as concentrações de ozônio não voltam a se elevar, embora permaneçam altas em relação ao período anterior.

Como conclusão para a análise realizada nesta seção, pôde-se perceber com maior detalhe a interferência das variáveis atmosféricas na variabilidade diária do ozônio troposférico. A interferência devido à atuação de sistemas frontais é percebida de diferentes maneiras nas concentrações de ozônio. Quando estes sistemas possuem significativa freqüência e intensidade, como no caso de abril de 1998 e julho de 2005, trazem condições propícias à dispersão do ozônio. Por outro lado, o forte sistema frontal observado no mês de agosto de 1999, responsável pela redução das concentrações do poluente quando ocorreu sua passagem, atuou isoladamente no mês. Assim, sob a influência de um sistema de alta pressão localizado no interior do país, foram observados no restante deste mês níveis mais elevados de concentração em relação ao esperado para o mês de agosto. Já os meses de fevereiro de 2003 e março de 2002 demonstraram poucos sistemas frontais, de fraca intensidade, devido aos padrões atmosféricos observados nos meses de verão e atuação dos VCANs no caso de fevereiro de 2003. Nestes meses, embora tenham sido observados diversos episódios de precipitação, ocorreram anomalias negativas desta variável bem como de nebulosidade, que propiciaram condições de produção e acúmulo de ozônio em superfície, dada a intensidade de radiação solar de ondas curtas observada no verão. 

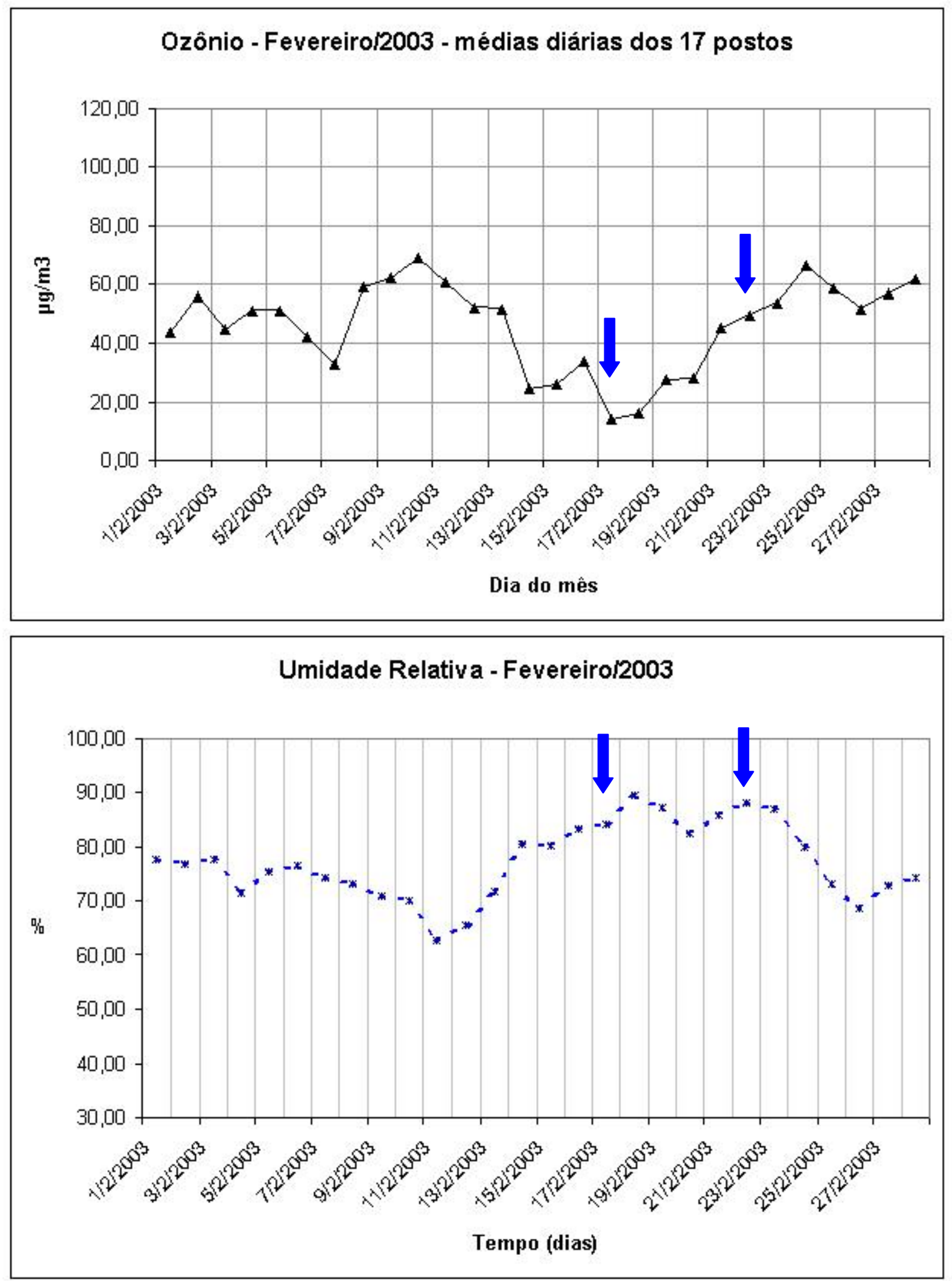

Figura 99a: Médias diárias de ozônio troposférico e umidade relativa em fevereiro de 2003. Os dias de passagem frontal estão identificados pela seta. 

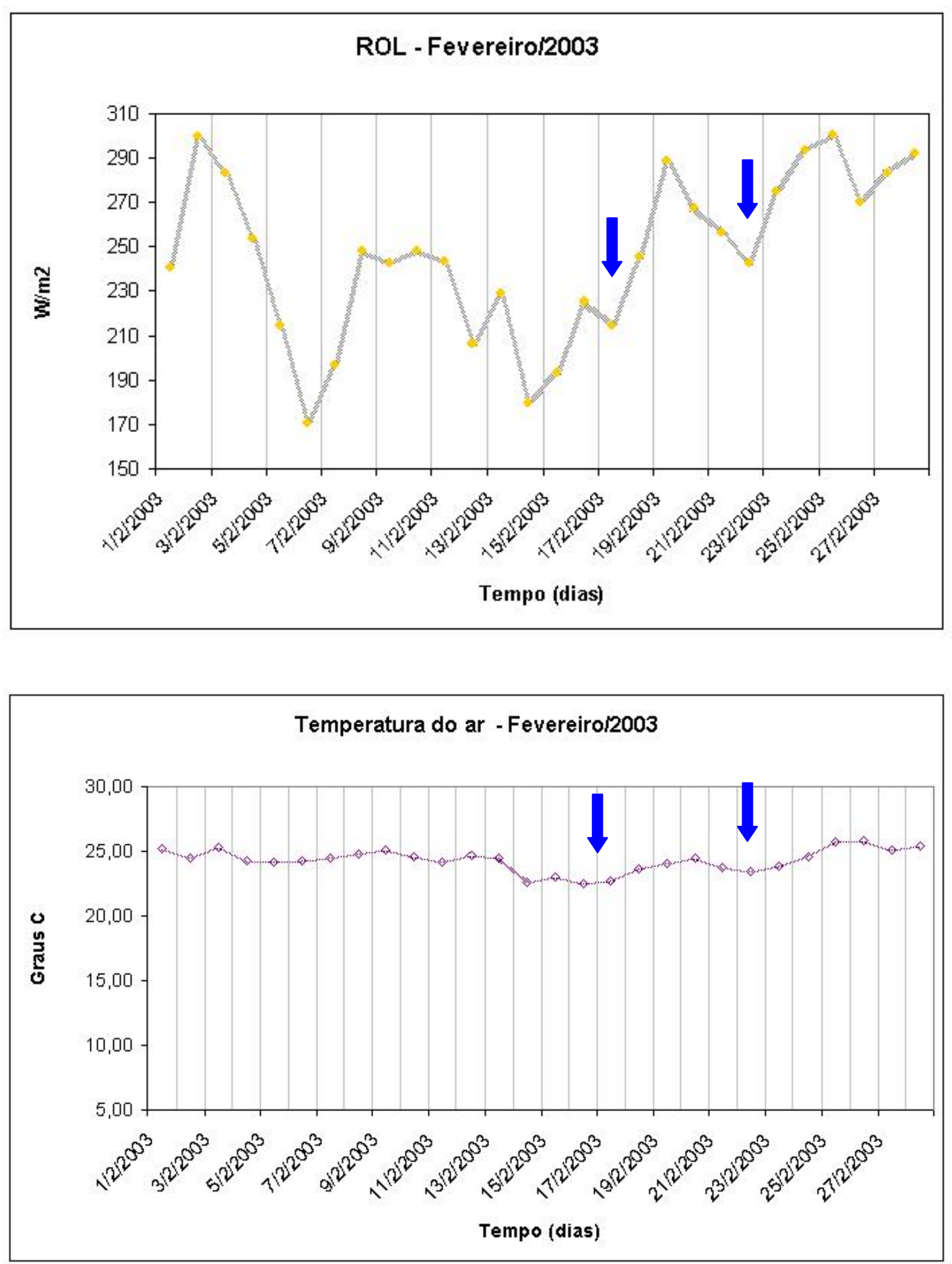

Figura 99b: Médias diárias de ROL e temperatura do ar em fevereiro de 2003. Os dias de passagem frontal estão identificados pela seta. 

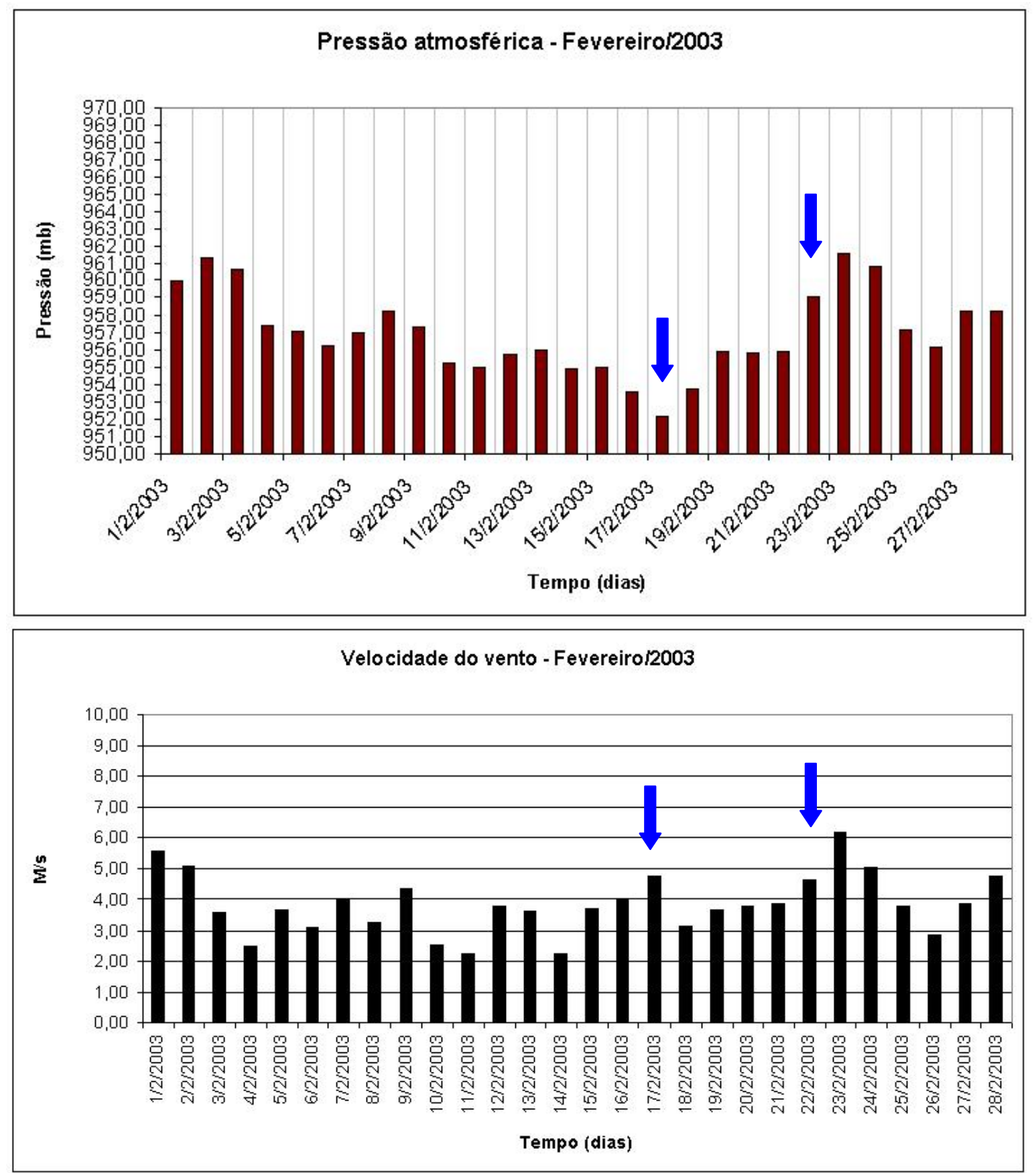

Figura 99c: Médias diárias de pressão atmosférica e velocidade do vento em fevereiro de 2003. Os dias de passagem frontal estão identificados pela seta. 


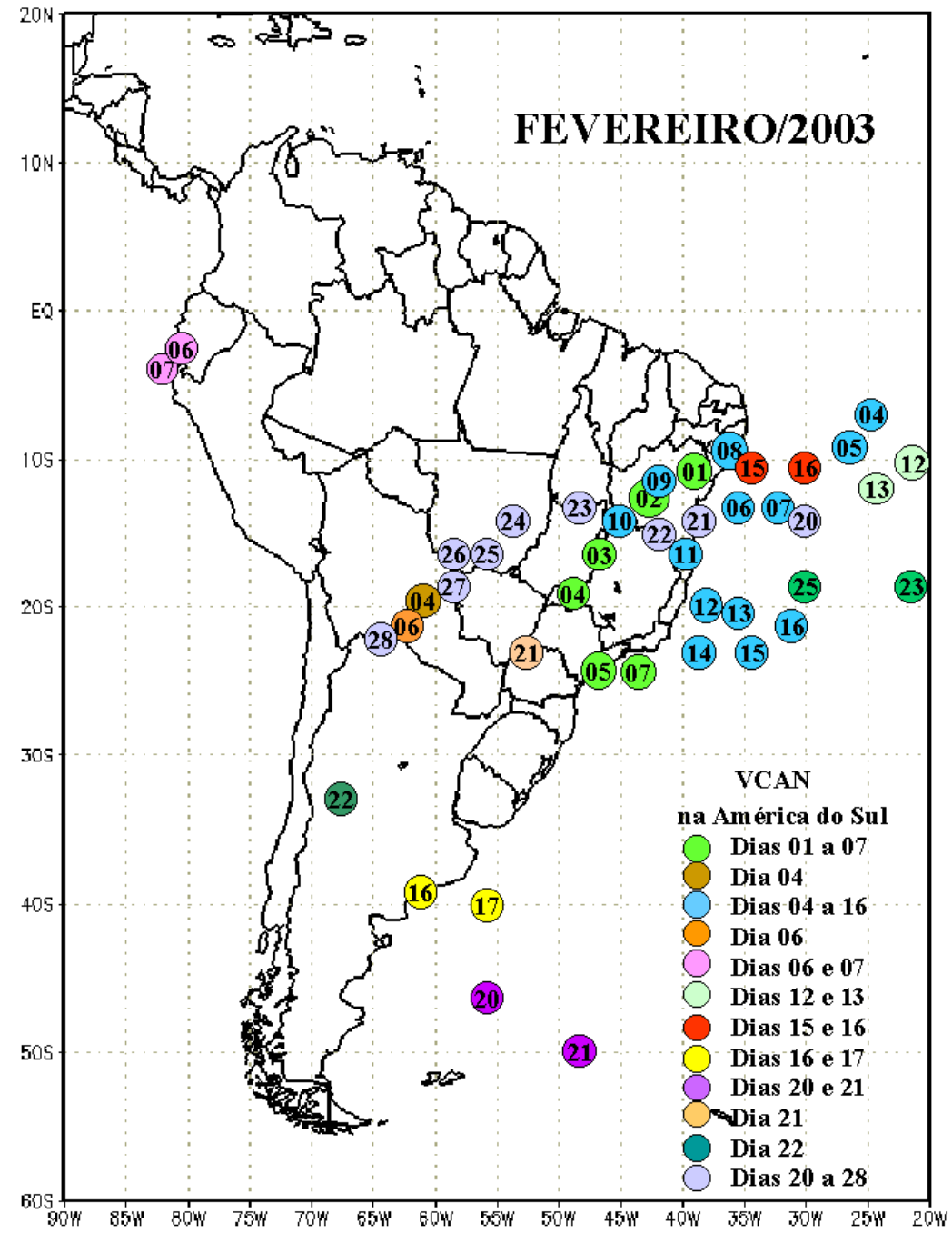

GraDS: COLAR/lGES

Figura 99d: Atuação dos VCANs na América do Sul no mês de fevereiro de 2003. 

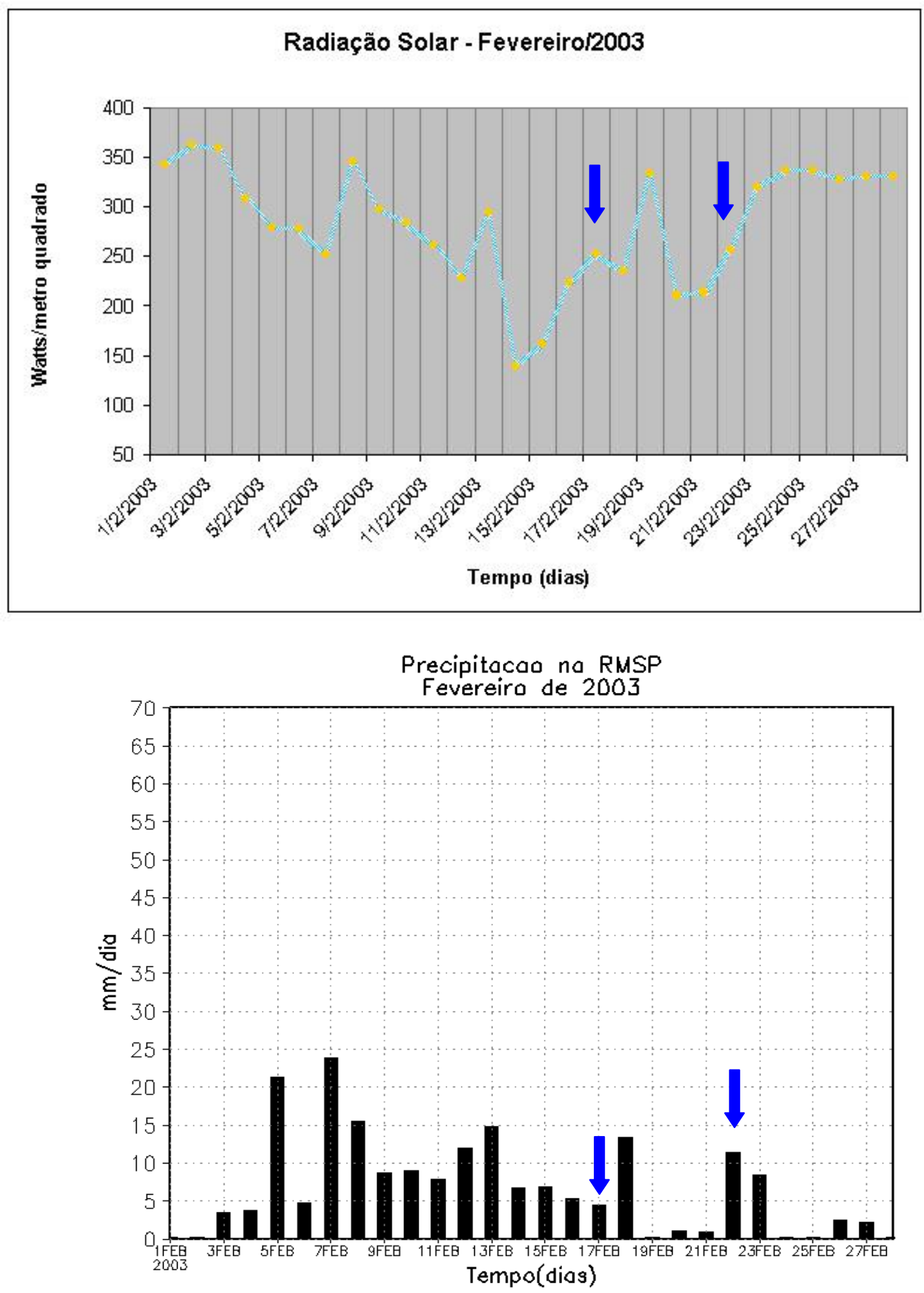

Figura 99e: Médias diárias de radiação solar e precipitação diária em fevereiro de 2003. Os dias de passagem frontal estão identificados pela seta. 


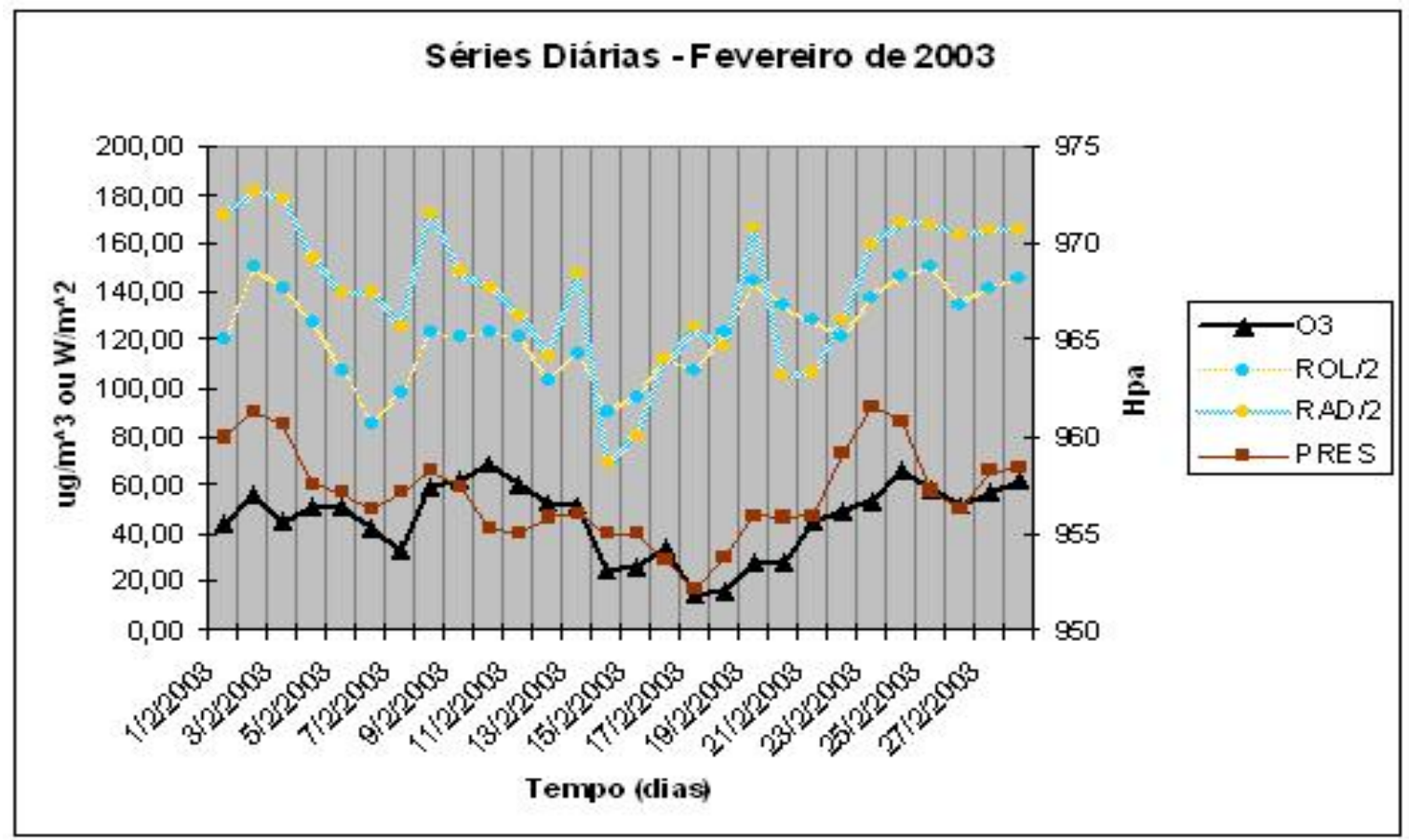

Figura 99f: Médias diárias de ozônio troposférico, radiação solar, ROL e pressão atmosférica em fevereiro de 2003. 


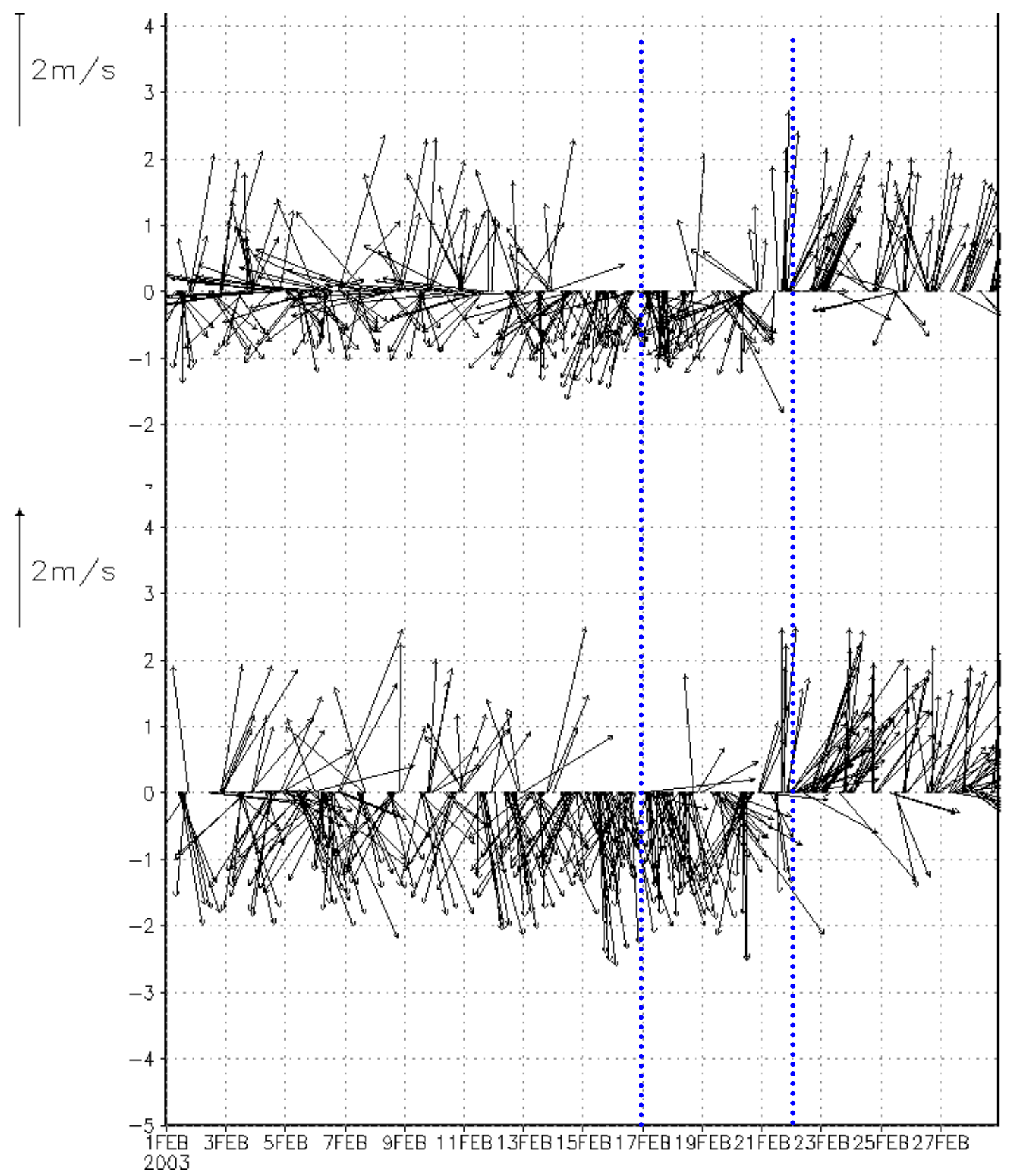

Figura 100a: evolução mensal de sentido e velocidade do vento nas estações Mooca e Parque D. Pedro II no mês de fevereiro de 2003. A linha marca os dias de passagem de sistema frontal. 


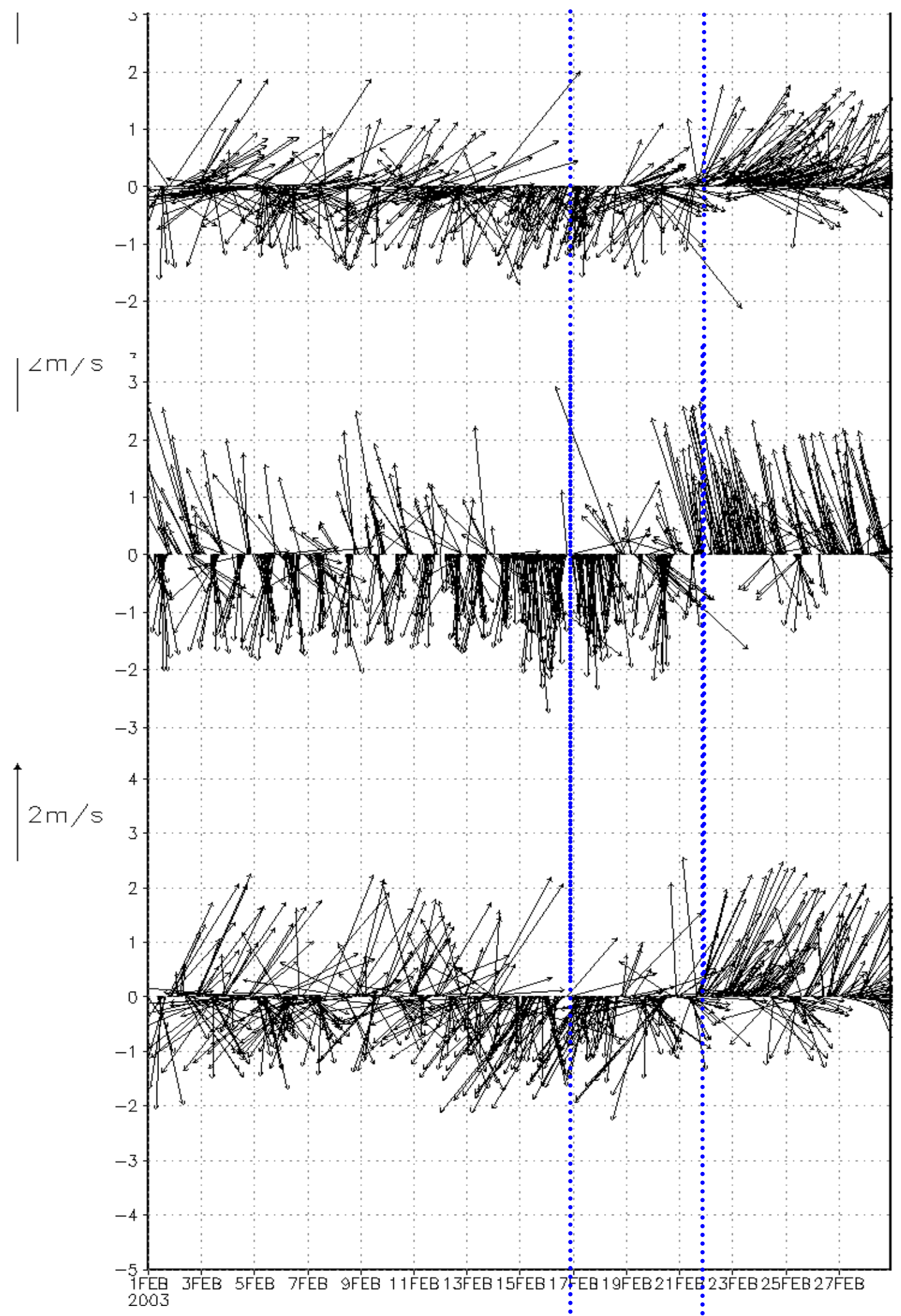

Figura 100b: evolução mensal de sentido e velocidade do vento nas estações Santana, Santo Amaro e São Caetano do Sul no mês de fevereiro de 2003. A linha pontilhada marca os dias de passagem de sistema frontal. 


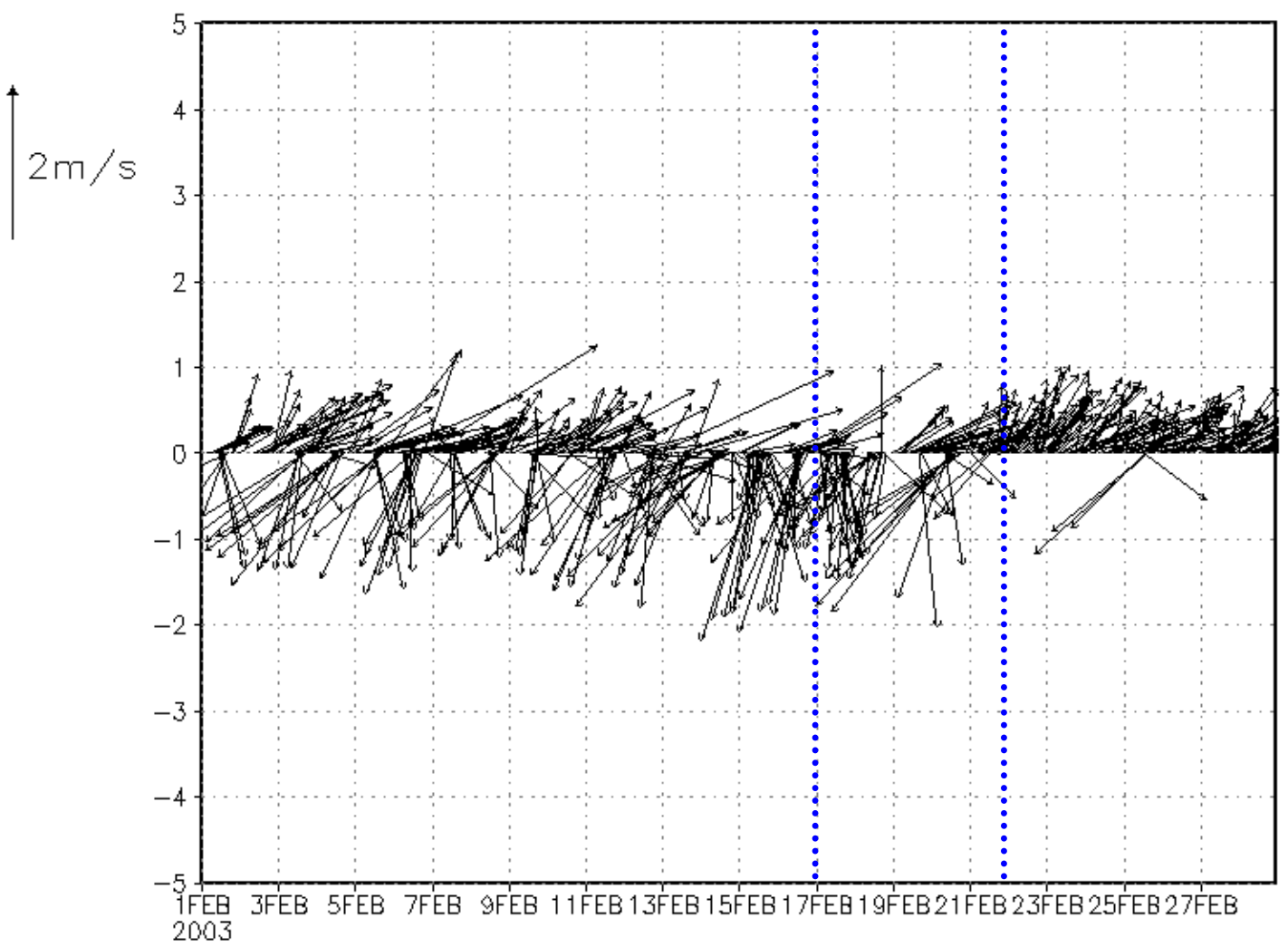

Figura 100c: evolução mensal de sentido e velocidade do vento na estação São Miguel Paulista no mês de fevereiro de 2003. A linha pontilhada marca os dias de passagem de sistema frontal. 


\section{Conclusões e considerações finais}

À medida em que se concebe a poluição atmosférica como originária de diversas atividades inseridas no cotidiano produtivo das grandes cidades, capaz de influenciar negativamente na saúde dos seres humanos, meio ambiente e visibilidade, é vital que se compreenda os modos de controle sobre a concentração dessas substâncias para se minimizar o problema. Assim, a compreensão do controle exercido pela atmosfera sobre a poluição do ar na RMSP possui importância crucial para o cotidiano de cerca 20 milhões de pessoas.

Neste trabalho, primeiramente foi realizado um estudo do comportamento médio do poluente na RMSP, por meio de séries temporais anuais, mensais e diárias do poluente, além de uma breve avaliação de sua distribuição espacial. Em relação às médias de ozônio nestas escalas temporais (a partir de dados horários obtidos da rede de monitoramento da CETESB), pôde-se estabelecer critérios de divisão entre as concentrações das estações analisadas, baseados na diferença entre as concentrações observadas, na tendência da série temporal, definição ou não do ciclo sazonal e variabilidade diária. Os resultados indicaram que as estações localizadas diretamente sob a influência de emissões veiculares em áreas de intensa atividade urbana (ex: Lapa, Congonhas e Osasco) apresentam menor variabilidade (na escala diária), ciclo sazonal menos definido e menor concentração de ozônio em relação à outras localizadas não só em zonas predominantemente residenciais; mas principalmente em relação às situadas em áreas mais afastadas de tais fontes e do centro da mancha urbana, localizadas próximas de áreas verdes, em parques urbanos, escolas e centros esportivos e educacionais (ex: Santana, Santo Amaro e Pico do Jaraguá). Pôde-se então sugerir que a distribuição espacial do poluente na RMSP pode estar associada ao uso do solo em cada localidade, devido ao consumo deste poluente pelos NOx emitidos por veículos, resultados semelhantes os obtidos por NARSTO (2000), Azevedo (2002) e CETESB (2004). Estas estações também apresentaram melhor definição do ciclo sazonal médio, com um máximo em outubro e mínimo em junho, além de um máximo secundário em fevereiro, fortemente associados à disponibilidade da radiação solar e cobertura de nuvens durante o ano, com coeficiente de correlação linear atingindo 0,98 para o ciclo anual médio de ozônio e de radiação solar. 
Confirmou-se que na escala horária ocorre maior concentração do poluente no período do meio da tarde, de acordo com o resultado de outras pesquisas (CETESB,2008; ANDRADE et al, 2004; MARTINS, 2006).

A estação com a maior tendência de elevação foi Pico do Jaraguá (com coeficiente angular de 0,3) e a estação com tendência de redução mais significativa foi Horto Florestal (coeficiente angular de -0,4). Ao se analisar a série temporal média das 17 estações, encontrou-se uma tendência de elevação nela que, contudo, não deve ser tomada como um aumento absoluto da concentração do poluente na RMSP, pois as estações contam com diferentes períodos de funcionamento. O que se pode sugerir a partir destes dados é que a concentração de ozônio na RMSP também era elevada em períodos anteriores a 1996, quando se iniciaram as medições na maioria das estações. A estação com menor desvio nos dados diários foi Congonhas $(\sigma=8,01 \mu \mathrm{g} / \mathrm{m} 3)$ e a maior Santo Amaro $(\sigma=19 \mu \mathrm{g} / \mathrm{m} 3)$. Foi possível verificar que as estações Congonhas e Lapa demonstraram maior porcentagem média de dados inválidos (16,7\% e 10,3\%, respectivamente), enquanto que Santo Amaro, Pico do Jaraguá e Horto Florestal não registraram dados inválidos.

A análise das relações entre o comportamento da atmosfera e a variabilidade das concentrações de ozônio foi feita para os períodos em que se observou anomalias extremas de concentração, retirando-se a influência do ciclo sazonal médio da média das estações. Desta análise conclui-se que os desvios positivos $(>+1 \sigma)$ das concentrações de ozônio ocorrem mais freqüentemente (85\%) em situações de menores nebulosidade e umidade relativa do ar, e, consequentemente, maior incidência de radiação solar e maiores valores de temperatura do ar e pressão atmosférica. Por outro lado, não foi possível estabelecer relações tão fortes entre os desvios das variáveis atmosféricas e a ocorrência de desvios negativos $(<-1 \sigma)$ da concentração de ozônio, pois elas ocorrem em diversas situações, para as quais não foi possível identificar um padrão característico neste conjunto de dados (ver tabelas 18 e 21).

Com base na análise de composições atmosféricas obtidas com dados da reanálise II, para a área definida por $35^{\circ}$ e $10^{\circ} \mathrm{S}$ e $30^{\circ}$ e $60^{\circ} \mathrm{O}$, centrada na RMSP, 
pôde-se verificar que a predominância de alguns padrões atmosféricos, em escala mensal, influenciam a concentração, produção e dispersão do $\mathrm{O}_{3}$ em baixos níveis.

Em relação aos meses com anomalias positivas de ozônio próximas ou superiores a $2 \sigma$, pôde-se enumerar algumas situações atmosféricas típicas que se repetiram em diversos meses analisados, como a intensificação de sistemas que causavam divergência do ar em superfície, tais como o anticiclone do Atlântico Sul e VCANs originários da Região Nordeste (nos meses de verão) ou outras massas de ar de latitudes mais altas que se intensificaram após chegarem ao interior do continente (no inverno ou primavera). Observou-se também o número e a intensidade dos sistemas frontais que alcançavam a latitude da RMSP no mês (pelos boletins Climanálise). Na maioria dos meses com anomalias positivas, não só houve menor passagem de sistemas frontais pela RMSP, mas também menor intensidade. Estes sistemas também causavam desvios negativos de precipitação, que contribuem direta e indiretamente para a redução de ozônio troposférico.

Além disso, verificou-se que na maioria dos meses com anomalias positivas ocorre intensificação da divergência do ar em superfície e sentido do vento predominante de NE, provavelmente associado à intensificação do anticiclone do Atlântico Sul. A análise da velocidade do vento em escala sinótica, no entanto, deve ser realizada com maior cuidado devido à urbanização e ao relevo que interferem significativamente na circulação atmosférica em escala local.

A análise dos meses com anomalias negativas da concentração de $\mathrm{O}_{3}$, da classe -2 e próximos a este limiar também sugere que certos padrões atmosféricos propiciem a dispersão ou dificultem a formação do $\mathrm{O}_{3}$ na troposfera. $A$ atuação mais bem distribuída e frequente de sistemas frontais (novembro/2007), combinada com a maior intensidade dos sistemas (julho/2005), aparentemente contribui para "reciclar" o ar da RMSP e favorecer a dispersão dos poluentes, o que esteve, na maioria das vezes, associado a anomalias positivas de precipitação. Além disso, houve em diversos destes meses anomalias negativas de ROL, e também a ocorrência de dois episódios de ZCAS que provavelmente contribuíram para as anomalias negativas do poluente. O sentido do vento também mostrou padrão característico: ventos de SE e $E$, com anomalias mais frequentes de SE. Isto pode estar ligado à ocorrência da 
ZCAS nos meses de verão acima citados. Diferentemente dos meses da classe +2 , a divergência do ar em superfície não apresentou um comportamento padrão nos meses de classe -2 . Entretanto, verificou-se pela análise da figura $X X$ que estes meses eram sempre precedidos de outros meses com anomalias já negativas, próximas de zero ou com tendência de queda, sugerindo que a continuidade da série temporal das anomalias tem algum peso na determinação de anomalias negativas.

Por meio da análise da evolução diária de ozônio e das variáveis atmosféricas escolhidas nos meses de anomalias intensas do poluente percebeu-se que, para alguns meses, ocorreu redução das concentrações de ozônio nas situações préfrontais (abril/1998), em outros, aumento (fevereiro/2003) ou ambas as situações (julho/2005). Nos meses de classe 2, observou-se condições de alta incidência de radiação solar e baixa umidade do ar em diversos dias seguidos, quando houve elevação contínua das concentrações de ozônio, além de fraca atividade frontal (menor número e/ou intensidade de sistemas frontais) e anomalias negativas de precipitação.

Os meses de abril de 1998 e julho de 2005 apresentaram incursão de sistemas frontais que apresentaram maior intensidade, atuando no sentido de remover o ozônio e seus precursores por meio da freqüente instabilização da atmosfera e episódios de precipitação associada e à maior nebulosidade. Novamente, notou-se a importância da intensidade dos sistemas para redução das concentrações do poluente, pois no mês de outubro de 2002, por exemplo, sete sistemas frontais passaram pela latitude da RMSP; no entanto a maioria destes sistemas era de fraca intensidade e não provocou grandes mudanças na atmosfera da RMSP (boletim Climanálise, figura 80). Já o mês de julho de 2005, por exemplo, sofreu a influência de quatro sistemas relativamente intensos, que causaram modificações significativas na atmosfera da RMSP e, portanto, foram eficientes para redução das concentrações.

$\mathrm{Na}$ escala diária, a umidade relativa do ar continua se comportando de maneira inversamente proporcional ao ozônio, com índices de correlação de Pearson variando entre $-0,3$ (julho de 2005) e $-0,6$ (fevereiro de 2003). A radiação 
solar se correlaciona de maneira extremamente variável com o ozônio troposférico, entre 0,1 (julho de 2005) e 0,6 (fevereiro de 2003). A maior correlação entre as concentrações de ozônio e a pressão atmosférica foi de 0,38 em abril de 1998.

Ao longo do processo de avaliação dos resultados, foi possível perceber que a poluição por ozônio na RMSP ocorre de maneira desigual, tanto temporal quanto espacialmente. Ao se combinar as situações de maior concentração de ozônio na escala espacial e temporal, chega-se à um quadro tão irônico quanto perigoso. A periculosidade da situação começa, claramente, com os níveis de concentração de ozônio, pois quando ultrapassam o PQAr provocam efeitos adversos à saúde como ardor nos olhos, envelhecimento precoce da pele e um comprometimento da integridade do sistema respiratório, principalmente nos grupos mais sensíveis da população (crianças, idosos e pessoas com problemas respiratórios). Esta situação pode ser agravada dependendo do grau de exposição da população a concentrações altas deste poluente - pois ocorre justamente em áreas consideradas de "ar mais puro". Os dias ensolarados, tidos como ideais para passeios e práticas de esporte, em especial no período da tarde, também são os períodos ideais de maior concentração de ozônio. É importante ressaltar dentro deste contexto o "efeito fim de semana": as concentrações deste poluente tendem a ser mais altas nos sábados ou domingos do que nos dias de semana devido à menor atividade urbana em finais de semana, que implica em menores quantidades de NOx e MP, que pode ser importante devido ao efeito de espalhamento da luz solar e de consumo do ozônio pelos NOx (QIN et al, 2004, AZEVEDO, 2002). Considerando todos estes fatores, tem-se que a concentração de ozônio na RMSP serão mais altas justamente aos finais de semana, ensolarados, nos períodos da tarde, em parques ou locais relativamente distantes das grandes avenidas.

Deve-se fazer um esforço no sentido de conscientizar tanto a população quanto as autoridades responsáveis pelo gerenciamento da saúde sobre este quadro complexo e de difícil solução imediata em que a saúde da população e o meio ambiente como um todo estão sujeitos a efeitos nocivos devido às altas concentrações deste poluente, cuja variabilidade em diferentes escalas temporais é influenciada pelo uso do solo e a composição atmosférica dos locais, pelas 
concentrações do poluente observadas em períodos anteriores e as condições atmosféricas predominantes em cada situação.

Estudos futuros poderão contribuir significativamente para a elucidação deste problema por meio da utilização de modelos atmosféricos que incluam variáveis como o relevo da RMSP e a circulação do ar em escala local. Outra questão importante a ser explorada é o comportamento do ozônio troposférico nas diversas situações de mistura vertical e as concentrações de VOC e NOx (ver anexo 4). Estudos que trabalhem apenas com os dados das estações de monitoramento de concentrações mais elevadas e que levem em conta a distribuição espaço-temporal do fluxo de pessoas e automóveis na RMSP podem contribuir para responder questões sobre o grau de exposição da população a este poluente.. 


\section{Referências}

ANDRADE et al, Air quality model simulating photochemical formation of pollutants: the Sao Paulo Metropolitan Area, Brazil, In: J. Environment and Pollution, Vol 22, No 4 p 460-475, 2004.

AMARAL, M. C. Barros do. Tipos de tempo e a poluição atmosférica no $A B C D$ paulista. Relatórios I e II enviados à Fundação de Amparo à Pesquisa do Estado de São Paulo, Laboratório de Climatologia, Instituto de Geografia, São Paulo, original inédito, 1970.

AZEVEDO, O Ritmo da Atividade Humana e a Concentração de Ozônio na Camada de Mistura na Região Metropolitana de São Paulo e Arredores, artigo, X Simpósio de Geografia Física Aplicada, João Pessoa, 2003.

ARTAXO, P. et al. Smoking rain clouds over the Amazon, Artigo da Revista Science, fevereiro de 2004. Estudo financiado pela Fapesp, Instituto do Milênio/MCT (Milênio LBA), e Comunidade Européia.

BOIAN, C., KIRCHHOFF, V. W. J. H., Surface ozone enhancements in the south of Brazil owing to large-scale air mass transport. In: Atmospheric Environment no 39, pp 6140-6146.

BRASSEUR, G. P., ORLANDO, J. J.; TYNDALL, G. S., Atmospheric Chemistry and Global Change, 1999.

CARAMANO, A. A.; ABRAMOVAY, R. Exxodo rural, envelhecimento e masculinização no Brasil: Panorama dos últimos 50 anos. Texto para discussão $\mathrm{n}^{\circ}$ 621, Estudos Econômicos, Departamento de Economia, Faculdade de Economia e Administração, USP, São Paulo, 1999. 
CASARIN, D. P., e V. E. KOUSKY, 1986: Anomalias de precipitação no sul do Brasil e variações da circulação atmosférica. Revista Brasileira de Meteorologia, número 1, 83-90.

CASTANHO, A. D., A Determinação Quantitativa das Fontes do Material Particulado na Atmosfera da Cidade de São Paulo, Dissertação de Mestrado, Instituto de Física, USP, São Paulo, 1999.

CASTRO, Maria Glória da Silva. A Chuva Ácida na Cidade de São Paulo. Dissertação de Mestrado apresentada ao Departamento. de Geografia da FFLCH, USP, São Paulo, 1993.

CHATFIELD, C., 1996: The Analysis on Time Series - An Introduction. Chapman \& Hall, fifth edition, New York.

CERQUEIRA, F. A. Estudo climatológico-dinâmico dos sistemas sinóticos que afetam o sudeste do Brasil, Monografia relativa à disciplina Climatologia Dinâmica, Centro de Previsão de Tempo e Estudos Climáticos, Cachoeira Paulista, 2006.

CHIQUETTO, J. B. A Evolução Histórica da Poluição Atmosférica Medida na Região Metropolitana de São Paulo, de 1973 a 2003, Trabalho de Graduação Individual, Departamento de Geografia, FFLCH, USP, São Paulo, 2005. CHIQUETTO, J. B., SIQUEIRA SILVA, M. E., Variabilidade Temporal e Espacial do Ozônio Troposférico na Região Metropolitana de São Paulo, XV Congresso Brasileiro de Meteorologia, São Paulo, 2007.

COLBECK, L. e MACKENZIE, R. Air Pollution by Photochemical Oxidants, Elsevier, 1994.

CRESSMAN, G. P., An Operational Objective Analysis System, Monthly Weather Review, Volume 87, p 367 - 374, 1959

DANNI-OLIVEIRA, I. M. A cidade de Curitiba e a poluição do ar: Implicações de seus atributos urbanos e geoecológicos na dispersão de poluentes em período de 
inverno. Tese de Doutorado, São Paulo, Departamento de Geografia, FFLCH, USP, 2000, IN: Clima Urbano, São Paulo, editora Contexto, 2003, 192 p.

DETELS, R. et al. "The UCLA Population Studies of Chronic Obstructive Respiratory Disease IV - Respiratory Effect on Long Term Exposure to Photochemical Oxidants, Nitrogen Dioxide and Sulfates on Current and Never Smokers". In American Review of Respiratory Disease, V 123, 1981.

FIGUEIREDO, J.C. e SCOLAR, J.,: Estudo da trajetória dos sistemas convectivos de mesoescala na América do Sul. VII Congresso Argentino de Meteorologia e VII Congresso Latinoamericano e Ibérico de Meteorologia, Buenos Aires, Argentina, Setembro 1996, 165-166.

FREITAS, E. D. Curso Básico de Programação em Linguagem FORTRAN-77. Material didático do Departamento de Ciências Atmosféricas, Instituto Astronômico e Geofísico, USP, São Paulo, 2004; Circulações locais em São Paulo e sua influência sobre a dispersão de poluentes. Tese de doutoramento apresentada ao Departamento de Ciências Atmosféricas do IAG, USP, São Paulo, 2003.

FRUEHAUF, GEORGE L. C. A deterioração da qualidade do ar e do clima na região metropolitana de São Paulo. Tese de doutoramento apresentada ao Departamento de Geografia, FFLCH, USP, São Paulo, 1998

FINLAYSON-PITTS, B. J.; PITTS Jr., J. N.; Chemistry of the Upper and Lower Atmosphere; Academic Press: San Diego (CA), 2000.

GALVANI, E; AZEVEDO, T. R., A Frente Polar Atlântica e as Características de Tempo Associadas: Estudo de Caso, X Simpósio Brasileiro de Geografia Física Aplicada, 11 a 16 de novembro de 2003, Rio de Janeiro.

GONÇALVES, F. L. T., CARVALHO, L. M. V., LATORRE, R.D.O., CONDE, F. C., SALDIVA, P. H. N, BRAGA, A. L. F. The effects of atmospheric pollution and meteorological parameters on respiratory morbidity during the summer in São Paulo city. Env. International,31,343-349, 2005. 
GUTJAHR, M. R., A Poluição do Ar em Paulínia: uma Análise Histórico-Geográfica do Clima, tese de doutoramento pela Universidade de São Paulo, Faculdade de Filosofia, Letras e Ciências Humanas, Departamento de Geografia, São Paulo, 2003 (edição revisada).

JACOB, J. D., An Introduction to Atmospheric Chemistry, Harvard University, Princeton University Press, Princeton, 1999.

HAAGEN-SMIT, A.J., Chemistry and physiology of Los Angeles smog, Industrial and Engineering Chemistry. No 44, pp. 1342-1346, 1952

KALNAY et al.,The NCEP/NCAR 40-year reanalysis project, Bull. Amer. Meteor. Soc., 77, 437-470, 1996

KANAMITSU, M, EBISUZAKI, WOOLLEN, J. YANG, S-K, HNILO, J.J. e POTTTER, G. L, NCEP-DEO AMIP-II Reanalysis (R-2): Bulletim of the Atmos. Met. Soc., p. 1631-1643, Novembro de 2002

KOREN I. et al, Measurement of the Effect of Amazon Smoke on Inhibition of Cloud Formation. Revista Science, Vol 303, No. 5662, páginas 1342-1345, Fevereiro de 2004

LEJENAS, H., OKLAND ,H. Characteristics of Northern Hemisphere blocking as determined from a long time series of observational data. Tellus, 35A: 350-362, 1983.

LIEBMANN, B. C., CARVALHO, L. M. V., JONES, C. Interannual variability of extreme precipitation events in the State of São Paulo, Brazil. J. Climate, 14, 208218.

LIU et al, Ozone production in the rural troposphere and the implications for regional and global ozone distributions, Journal of Geophysical Research-Atmospheres 92 (D4): pg 4191-4207, Abril de 1987.

LOMBARDO, M. A. Ilha de Calor nas Metrópoles - o exemplo de São Paulo. São Paulo, Ed. HUCITEC, 1985. 
MARTINS, L. D., Sensibilidade do Ozônio Troposférico às Emissões Veiculares na Região Metropolitana de São Paulo, tese de doutoramento pela Universidade de São Paulo, Insituto de Astronomia, Geofísica e Ciências Atmosféricas, Departamento de Ciências Atmosféricas, São Paulo, 2006.

MARTINS, M.H.R.B. et al, Evolution of air quality in the São Paulo metropolitan area and its relation with public policies, in J. Environment and Pollution, Vol 22, No 4, p. 430-440, 2004.

MASSAMBANI, O. ANDRADE, F., Seasonal Behavior of Tropospheric Ozone in the Sao Paulo (Brazil) Metropolitan Area, Atmospheric Environment Vol.28, No19, p. $3165-3169,1994$

MATEUS, R. S. A Relação entre o clima e o abastecimento de água na RMSP. Uma proposta de modelagem conceitual da Bacia Hidrográfica da Represa Guarapiranga, Relatório para Exame de Qualificação de Mestrado, Departamento de Geografia, Faculdade de Filosofia, Letras e Ciências Humanas, USP, São Paulo, 2005.

MONTEIRO, C. A. de F. Teoria e Clima Urbano. Tese apresentada ao concurso de Livre-Docência junto ao Departamento de Geografia, FFLCH, Universidade de São Paulo, São Paulo, 1975.

MOSEHOLM L., Taudorf E, Frosig A. Pulmonary function changes in asthmatics associated with low-level SO2 and NO2 air pollution, weather, and medicine intake. Allergy 1993;48:334- 44 .

MOUVIER , G. A poluição atmosférica, Editora Ática, São Paulo, 1997.

MUSA, M., Variabilidade Intrasazonal e Interanual dos Eventos Extremos de Precipitação e Seca no Sul e Sudeste do Brasil durante o Verão Austral. Dissertação de Mestrado apresentada junto ao Departamento de Ciências Atmosféricas, IAG, USP, São Paulo, 2005. 
OLIVEIRA, S.; BRUNI, A.; SAGULA, M.L.A. Análise do fluxo de vento visando o transporte de poluentes na Região da Grande São Paulo. Companhia de Tecnologia e Saneamento Ambiental - CETESB. São Paulo, 1983.

QIN, Y., G.S. TONNESEN, WANG, Z. Weekend/weekday differences of ozone, NOx, VOCs, PM10 and the light scatter during ozone season in southern California, In: Atmospheric Environment no 38, pp 3069-3087, 2004.

PEREIRA, P. A. et al, Alcohol- and Gasohol-Fuels: A Comparative Chamber Study of Photochemical Ozone Formation, Journal of Brazilian Chemical Society, Vol. 15, No. 5, pg 646-651, 2004

RECUERO, F. S., Estudo do Transporte das Partículas de Aerossol de Queimada via Sensoriamento Remoto, Dissertação de mestrado apresentada ao Departametno de Ciências Atmosféricas do Instituto Astronômico e Geofísico, USP, 2003.

ROSENFELD, D. Supression of Rain and Snow by Urban and Industrial Air Pollution, Revista Geophysical Research Letter, 2000

SAMPAIO SILVA, R. Análise crítica da rede de monitoramento da qualidade do ar da CETESB na Grande São Paulo. Trabalho de Graduação Individual realizado no Laboratório de Climatologia do Departamento de Geografia, FFLCH, USP, São Paulo, 2000.

SÁNCHEZ-CCOYLLO, O.R., SILVA DIAS, P. L., ANDRADE, M. F., FREITAS, R. S., Determination of $\mathrm{O}_{3}, \mathrm{CO}$ and PM10 transport in the metropolitan area of Sao Paulo, Brazil, through synoptic-scale analysis of back trajectories, Meteorology and Atmospheric Physics, Vol 92, pg 83-93, 2006; O transporte de poluentes emitidos em cubatão para a RMSP: estudo de caso de agosto de 1999. In: Congresso Brasileiro de Meteorologia, 2000, Rio de Janeiro, 2000. p. 2976-2982.

SÃO PAULO (Estado). Caracterização das Estações da Rede Automática de Monitoramento da Qualidade do Ar na RMSP, estação Congonhas; estação Ibirapuera (2004) ; estação Lapa (2004); estação Mooca(2007); estação 
Osasco(2006); estação Pico do Jaraguá(2007); estação São Caetano do Sul(2003), CETESB - Divisão de Qualidade do Ar, São Paulo, 2003, 2004, 2006, 2007

SÃO PAULO (Estado). Comportamento Sazonal da Poluição do Ar em São Paulo Análise de Quatorze Anos de Dados da RMSP e Cubatão: 1981 a 1994, Companhia de Tecnologia de Saneamento Ambiental (CETESB) - Divisão de Análise de Dados, 1995.

SÃO PAULO (Estado). Estudo Comparativo de Ozônio das estações Ibirapuera e Congonhas, Companhia de Tecnologia de Saneamento Ambiental (CETESB), Divisão de qualidade do ar, Setor de interpretação de dados, Abril de 1997.

SÃO PAULO (Estado). Formação e Ocorrência dos Oxidantes Fotoquímico na Região da Grande São Paulo, Companhia de Tecnologia de Saneamento Ambiental (CETESB) - Diretoria de Tecnologia de Saneamento do Ar e de Controle de Fontes de Poluição, Estudo Especial, São Paulo, 1979.

SÃO PAULO (Estado). Relatório Anual da Qualidade do Ar do Estado de São Paulo, 1990, Companhia de Tecnologia de Saneamento Ambiental (CETESB) - Divisão de Análise de Dados, São Paulo, 1991; Relatório Anual da Qualidade do Ar do Estado de São Paulo, 1995, CETESB - Divisão de Análise de Dados, São Paulo, 1996; Relatório Anual da Qualidade do Ar do Estado de São Paulo, 1998, CETESB Divisão de análise de Dados, São Paulo, 1999; Relatório Anual da Qualidade do Ar do Estado de São Paulo, 2000, CETESB - Divisão de análise de Dados, São Paulo, 2001; Relatório Anual da Qualidade do Ar do Estado de São Paulo, 2003, CETESB Divisão de análise de Dados, São Paulo, 2004.

SÃO PAULO (Estado). Relatório Anual da Qualidade do Ar da Região Metropolitana de São Paulo e do Interior, Companhia de Tecnologia de Saneamento Ambiental (CETESB) - Divisão de Análise de Dados, São Paulo, 1986.

SEINFELD, J. H.; PADIS, S. N, Atmospheric Chemistry and Physics: from air pollution to climate change, John Wiley \& Sons, Nova York, 2006 
SILVA DIAS, M. A. F., 1987: Sistemas de Mesoescala e previsão de tempo a curto prazo. Revista Brasileira de Meteorologia, No 2, pág. 133-150.

SOBRAL, Helena Ribeiro W. Poluição do Ar e Doenças Respiratórias em Crianças da Grande São Paulo: Um Estudo de Geografia Médica. Tese de Doutoramento apresentada ao Depto. de Geografia, FFLCH, USP, São Paulo, 1988.

TARIFA, J. R.; AZEVEDO, T. R (Org). Os Climas na Cidade de São Paulo: teoria e prática. Programa de Pós-graduação em Geografia, Laboratório de Climatologia e Biogeografia, Departamento de Geografia, FFLCH, USP, São Paulo, revista Geousp, coleção novos caminhos, 2001.

VELASCO, I. e FRITSCH, J.M., 1987: Mesoscale convective complexes in the Americas. J. Geophys. Res., 92, D8, 9591-9613.

WISE, E.K., COMRIE, A. C., Meteorologically adjusted urban air quality trends in the Southwestern United States, Department of Geography and Regional Development, University of Arizona, 2005.

WHITE, M.C., ETZEL, R.A., WILCOX, W.D., LLOYD, C. Exacerbation of childhood asthma and ozone pollution in Atlanta. Environmental Research, 1994;65:56- 68.

Material adquirido e aulas dos cursos de: Meteorologia Ambiental (IAG), cursado durante a graduação no primeiro semestre de 2003; Química Atmosférica e Mudanças Climáticas (IQ), cursado durante a pós-graduação no primeiro semestre de 2006;

Documentos online:

CLIMANÁLISE, Boletins mensais do Centro de Previsão de Tempo e Estudos Climáticos do Inpe; edições de janeiro de 1996 a junho de 2006; ROCHA, A. M. G de C., e GANDU, A. W. A Zona de Convergência do Atlântico Sul, Departamento de Ciências Atmosféricas, Instituto Astronômico e Geofísico, Universidade de São Paulo; DIAS, M. A. F. da S., Complexos Convectivos de Mesoescala sobre a Região Sul do Brasil, Departamento de Ciências Atmosféricas, Instituto Astronômico e 
Geofísico, Universidade de São Paulo. MARQUES, R. F. C., e RAO, V. B., Bloqueio Atmosférico no Hemisfério Sul durante o período de 1980 a 1993, Departamento de Ciências Meteorológicas, INPE.

Disponíveis em:

< http://www.cptec.inpe.br/products/climanalise/ >

Acesso em: diversas datas desde 07/2006

DOTY, B; The Grid Analysis and Display System, Edição revisada por Tom Holt da University of East Anglia e Mike Fiorino do Lawrence Livermore National Laboratory, 1995. Disponível em:

$<$ http://www.master.iag.usp.br/ind.php?inic=00\&prod=mapa $>$ Acesso em 11/2006

HERRMANN, V, I., FREITAS, S. R. Um estudo do transporte vertical de CO2 na atmosfera da Bacia Amazônica através dos sistemas convectivos, II Congresso de Estudantes e Bolsistas do Experimento LBA, Manaus, 2005.

Disponível em:

$<$ http://www.lbaconferencia.org/cgi-

bin/manaus conf 2005/stud05 ab search.pl?action=3\&ab id=142 >

Acesso em 01/2007

LANDIM et al., Introdução à confecção de mapas pelo software SURFER,®. Universidade Estadual Paulista - UNESP, Departamento de Geologia Aplicada IGCE, Laboratório de Geomatemática, texto didático 08. Rio Claro, 2002 Disponível em:

< http://omega.rc.unesp.br/mauricio/curso/bibliografia/8/216/Surfer.pdf $>$

RUBIN, M. B., THE HISTORY OF OZONE. THE SCHÖNBEIN PERIOD, 1839-1868, Bulletim of Historical Chemistry, Volume 26, No. 01, pg. 40-56, 2001.

Disponível em:

< http://www.scs.uiuc.edu/ mainzv/HIST/awards/OPA\%20Papers/2001-Rubin.pdf >

Sites consultados: 
Companhia de Tecnologia de Saneamento Ambiental

$<$ www.cetesb.sp.gov.br >

Acesso em: diversas datas em 2006, 2007 e 2008.

Empresa Paulista de Planejamento Metropolitano SA - EMPLASA

< www.emplasa.sp.gov.br >

Acesso em 09/2006

Grupo de Estudos em Multiescalas:

< $\underline{\text { http://www.icess.ucsb.edu/gem/index.htm }}>$

Acesso em: diversas datas em 2006 e 2007

Instituto Brasileiro de Geografia e Estatística:

$<\underline{\text { www.ibge.gov.br/home }}>$

Acesso em 03/2009

Instituto Nacional de Meteorologia

$<\underline{\text { www.inmet.gov.br }}>$

Acesso em 01/2007 e 03/2009

LBA - Large Scale Biosphere-Atmosphere Experiment in Amazonia.

< http://lba.cptec.inpe.br/lba/site/ >

Acesso em: 11/2006

Meteorologia Aplicada a Sistemas de Tempo Regionais

< http://www.master.iag.usp.br >

Acesso em 01/2007

National Oceanic \& Atmospheric Administration

$<$ http://www.cdc.noaa.gov/cgi-bin/db search/SearchMenus.pl >

< http://www.cpc.ncep.noaa.gov/products/wesley/reanalysis2/kana/reanl2-1.htm > Acesso em: diversas datas de 2006 a 2008

ONU, Social Indicators, 2006. Disponível em: 
< http://unstats.un.org/unsd/demographic/products/socind/hum-sets.htm $>$ Acesso em: 10/2006 
ANEXOS 
Anexo 1: Médias mensais para cada estação e tendência linear.

Anexo 2: Padrões atmosféricos observados no mês de setembro de 2004.

Anexo 3: Distribuição espacial média do ozônio troposférico na RMSP (Interpolando em grade 0,02 e 0,03).

Anexo 4: Evolução diária dos limites de produção de ozônio por COV ou NOx, de acordo com o horário do dia e a condição de mistura vertical (to topo - mistura moderada, ao centro - mistura fraca, embaixo - estagnação).

Anexo 5: Climatologia de precipitação, temperatura, umidade relativa e perssão tmosférica da RSMP, e localização das estações da CETESB, hidrografia e relevo na RMSP. 


\section{ANEXO 1}

\section{MÉDIAS MENSAIS PARA CADA ESTAÇÃO E TENDÊNCIA LINEAR}
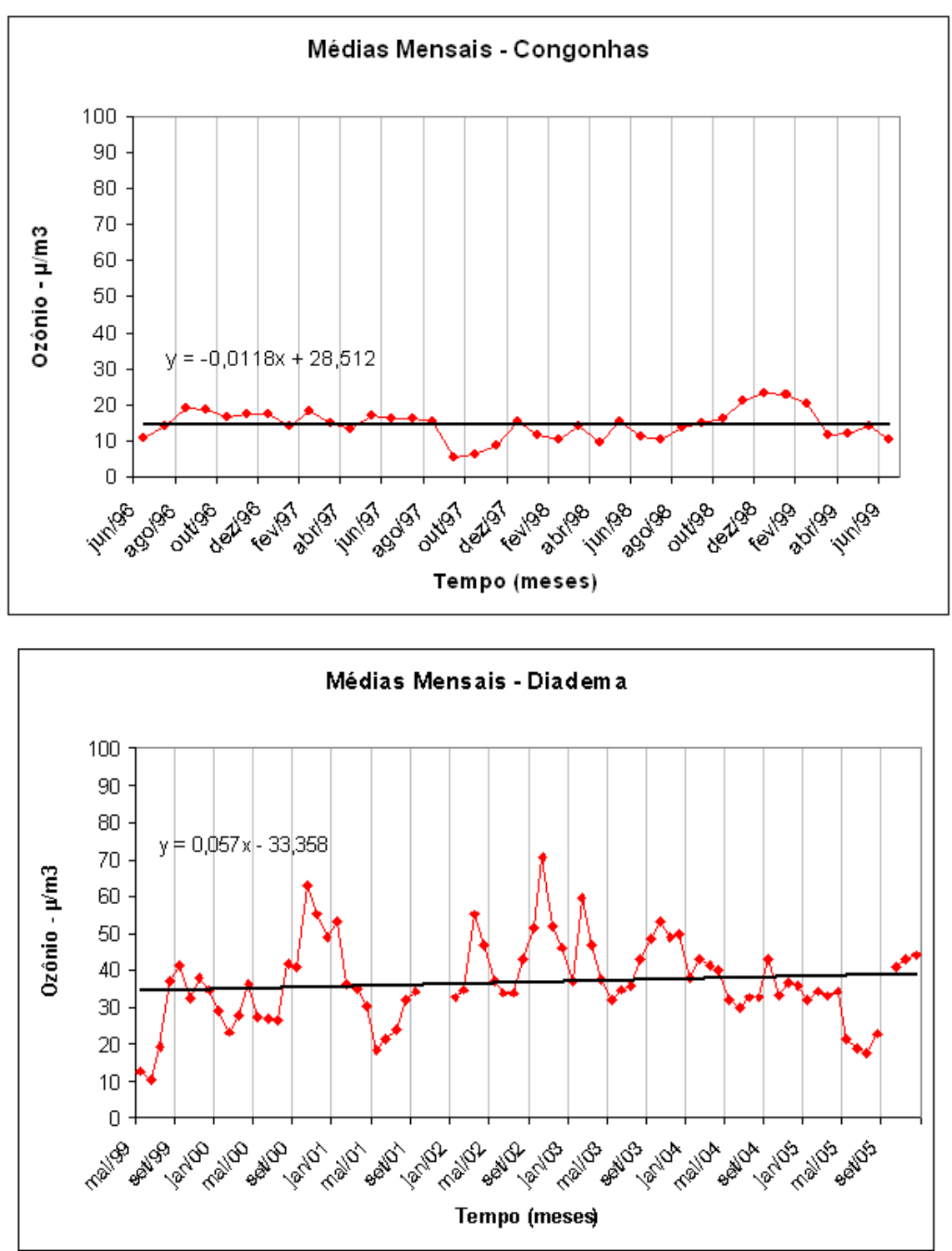

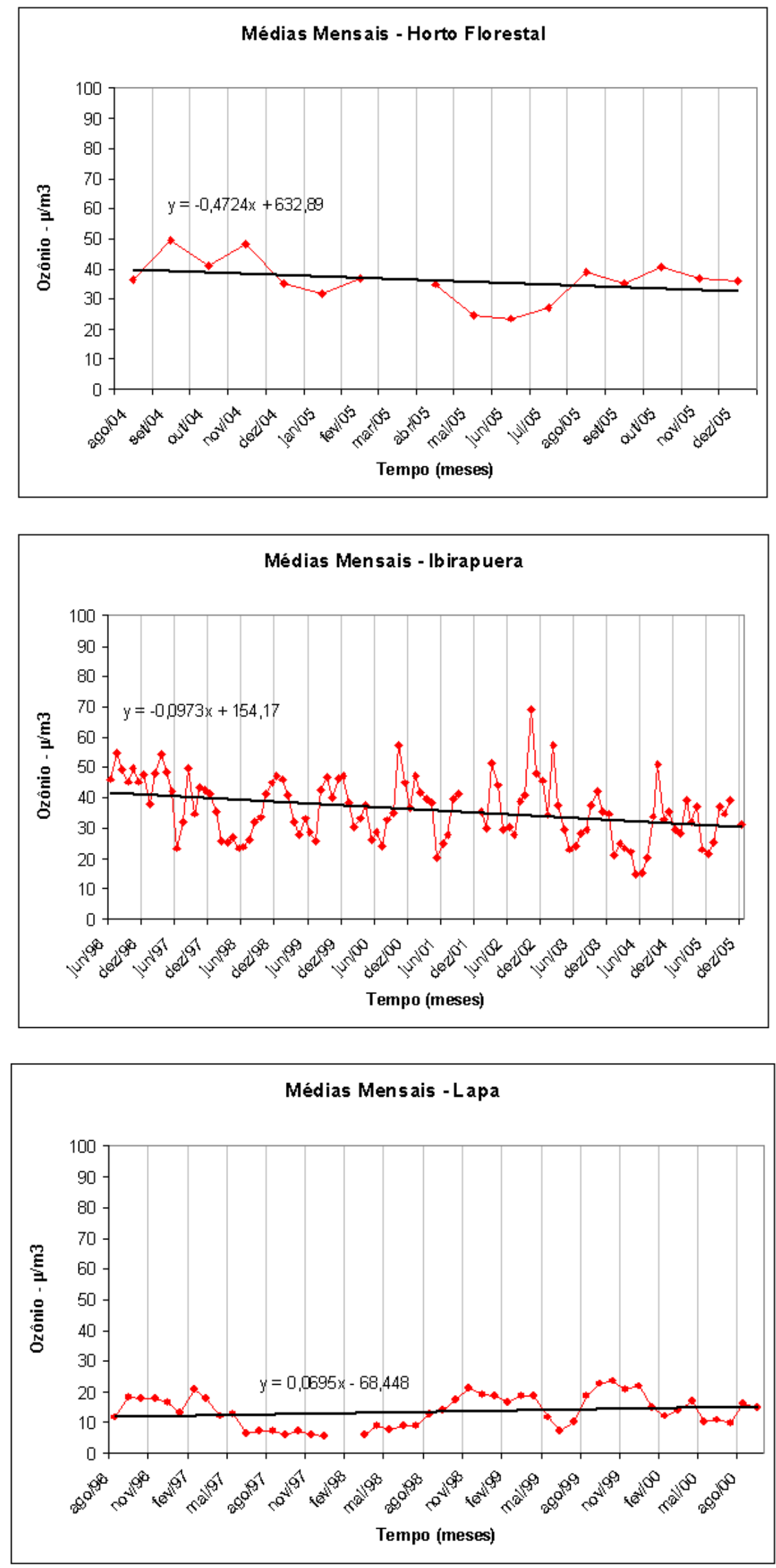

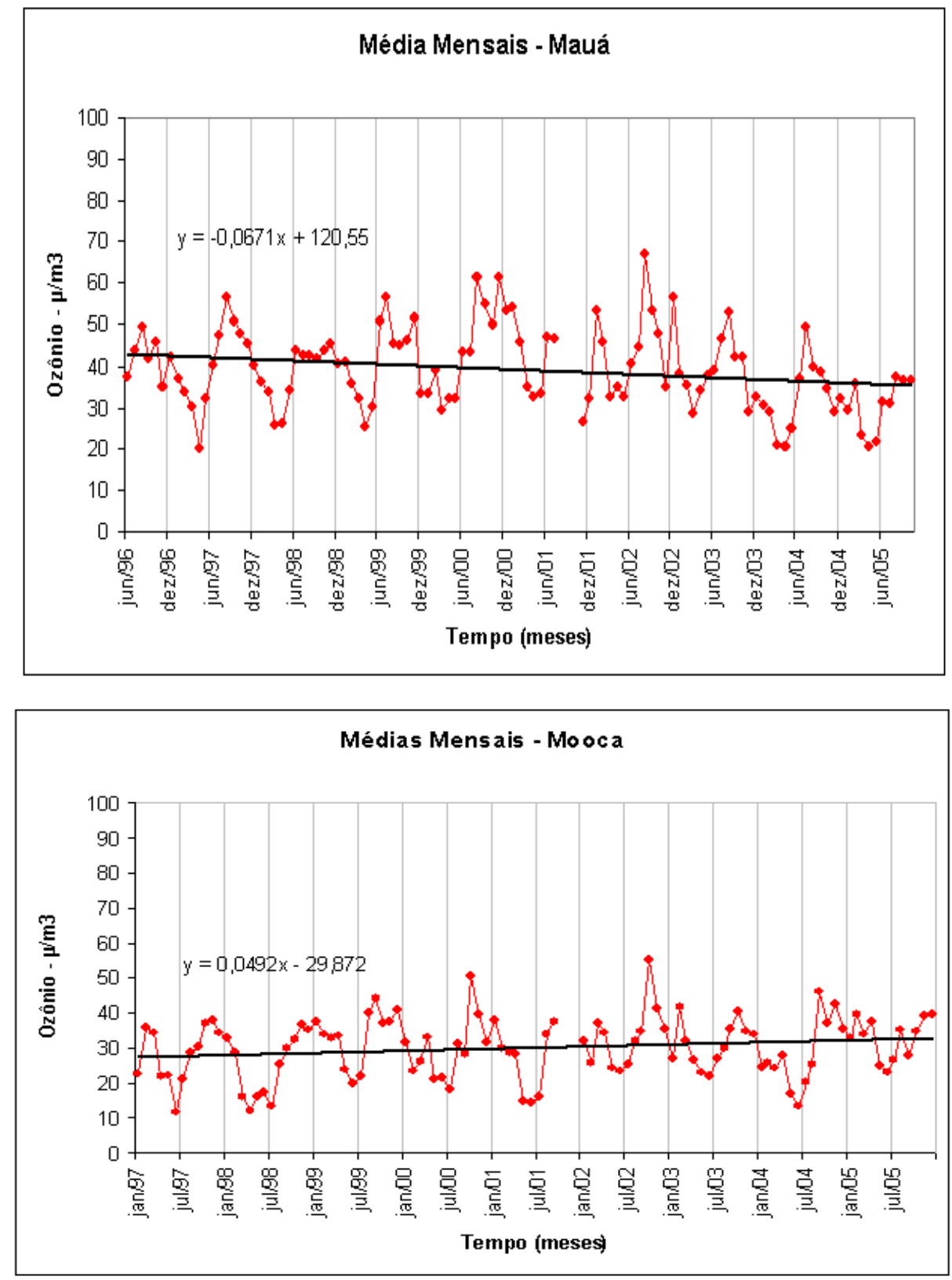

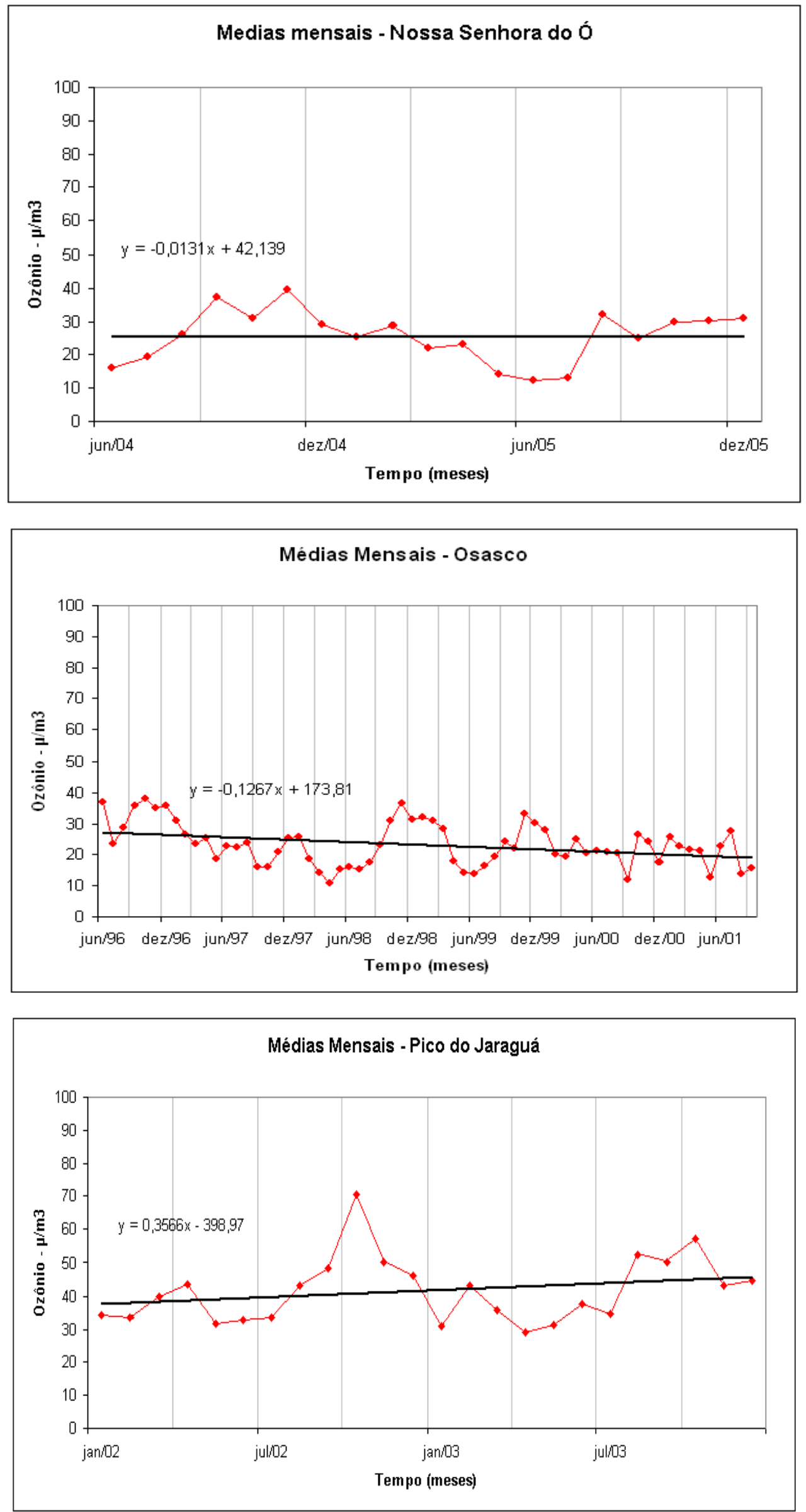

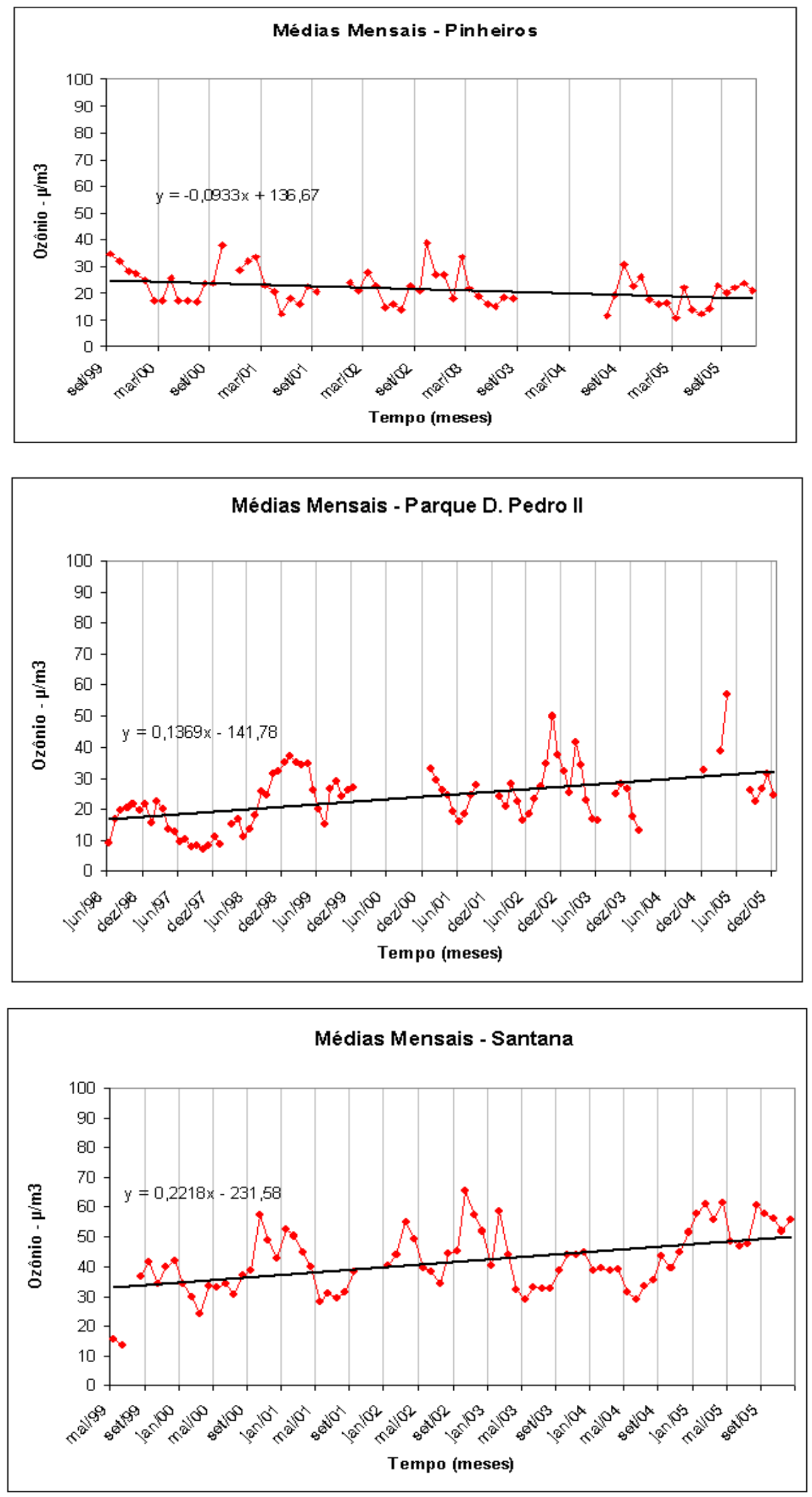

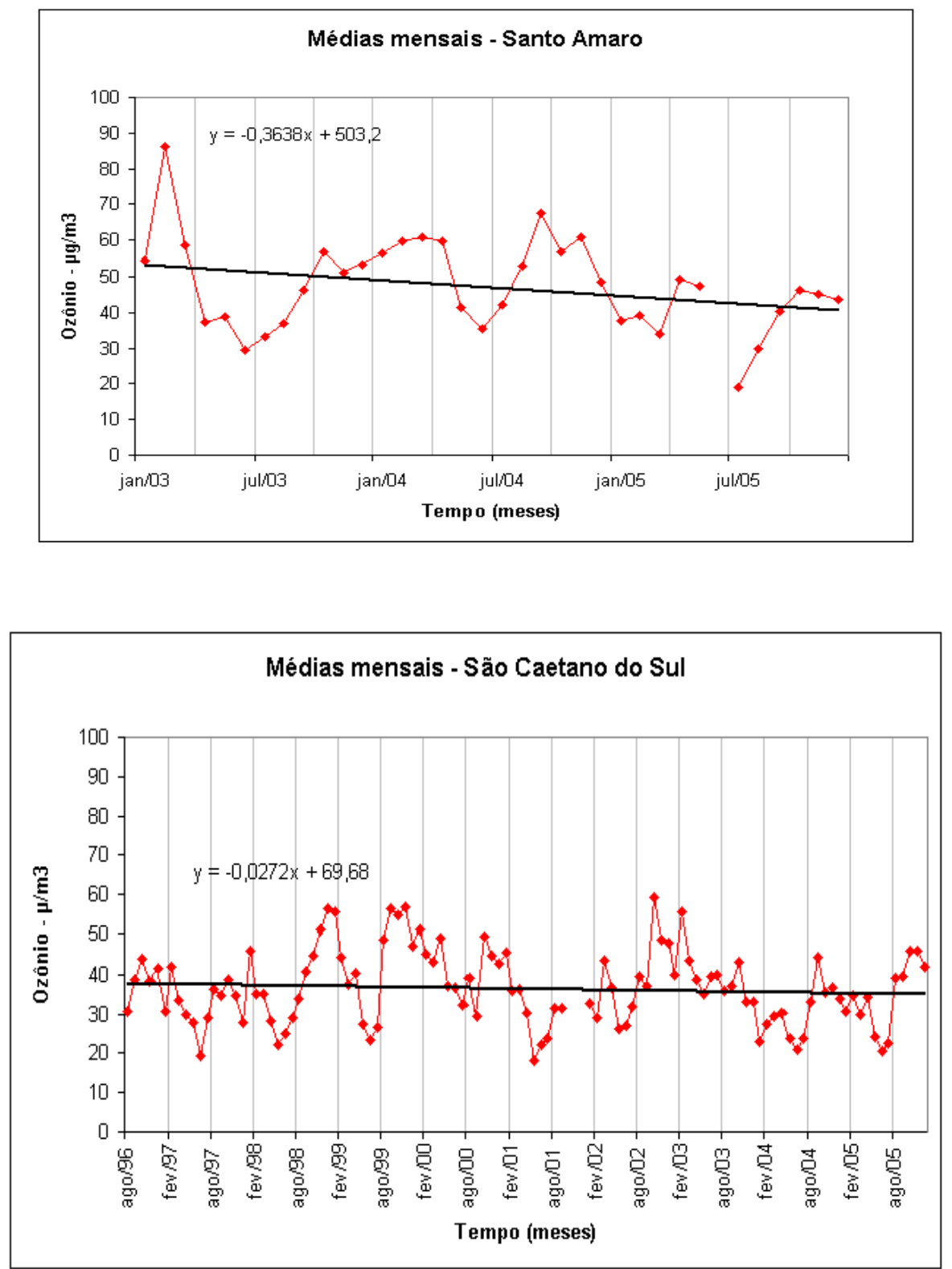

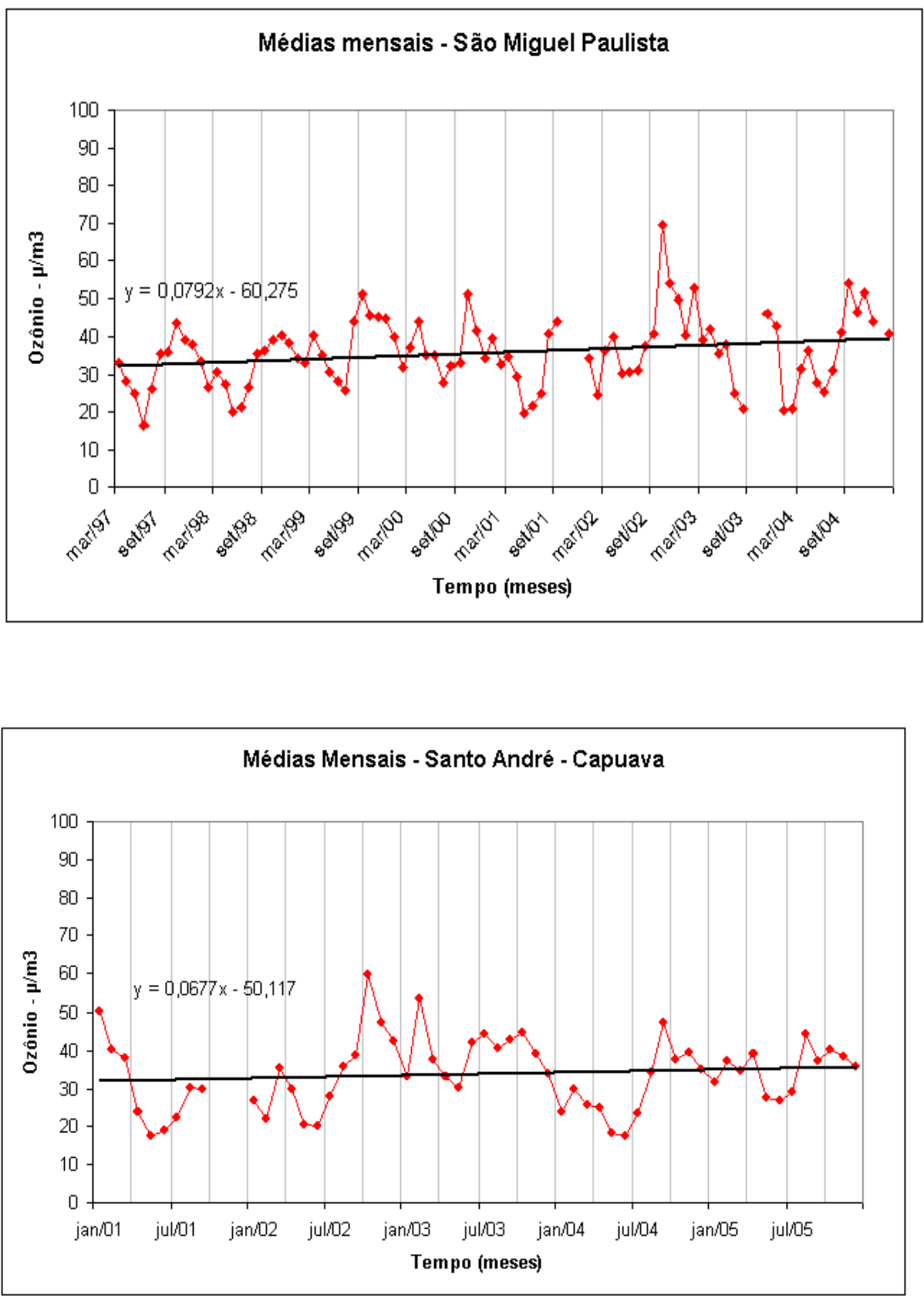


\section{ANEXO 2}

\section{PADRÕES ATMOSFÉRICOS OBSERVADOS NO MÊS DE}

SETEMBRO DE 2004
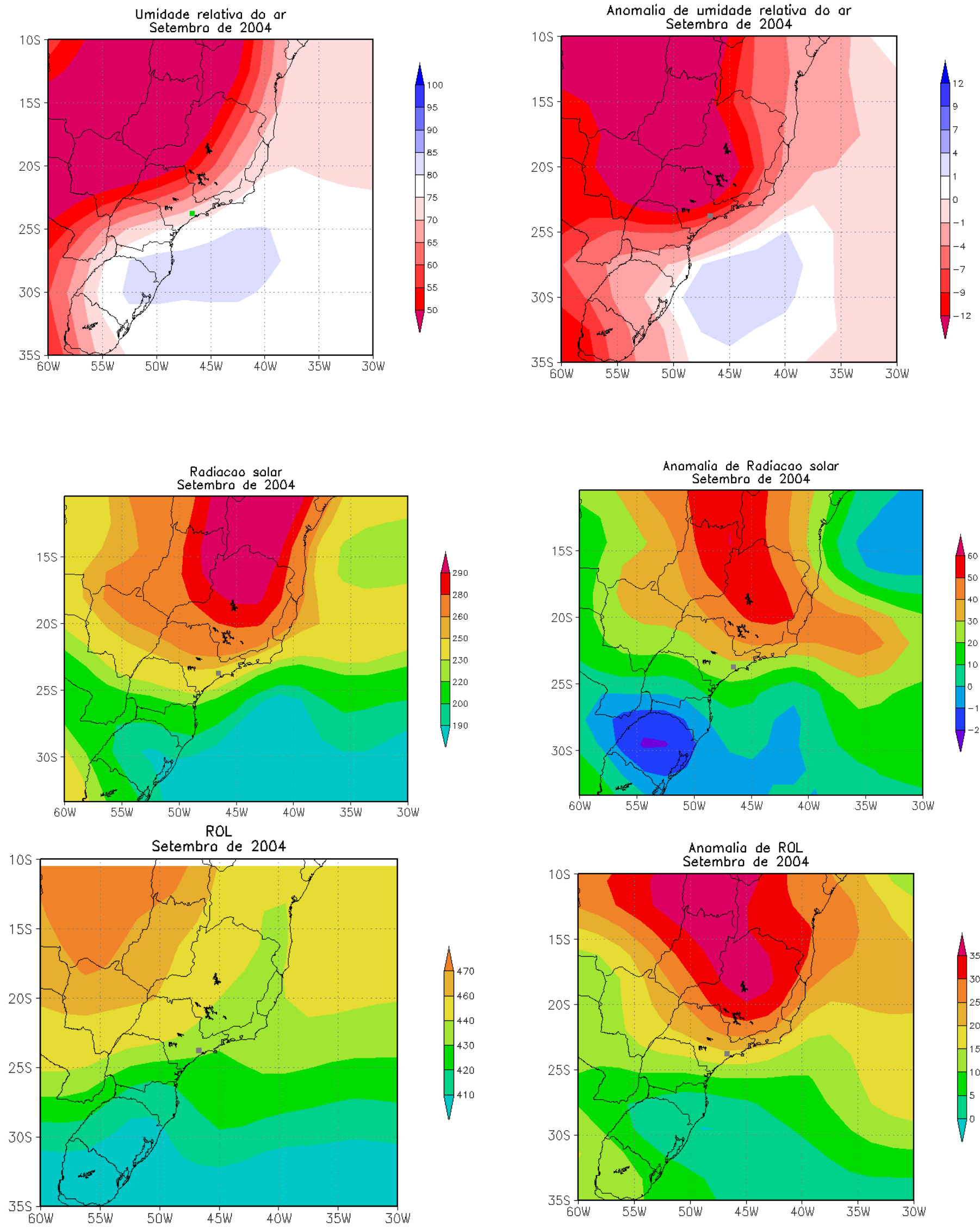

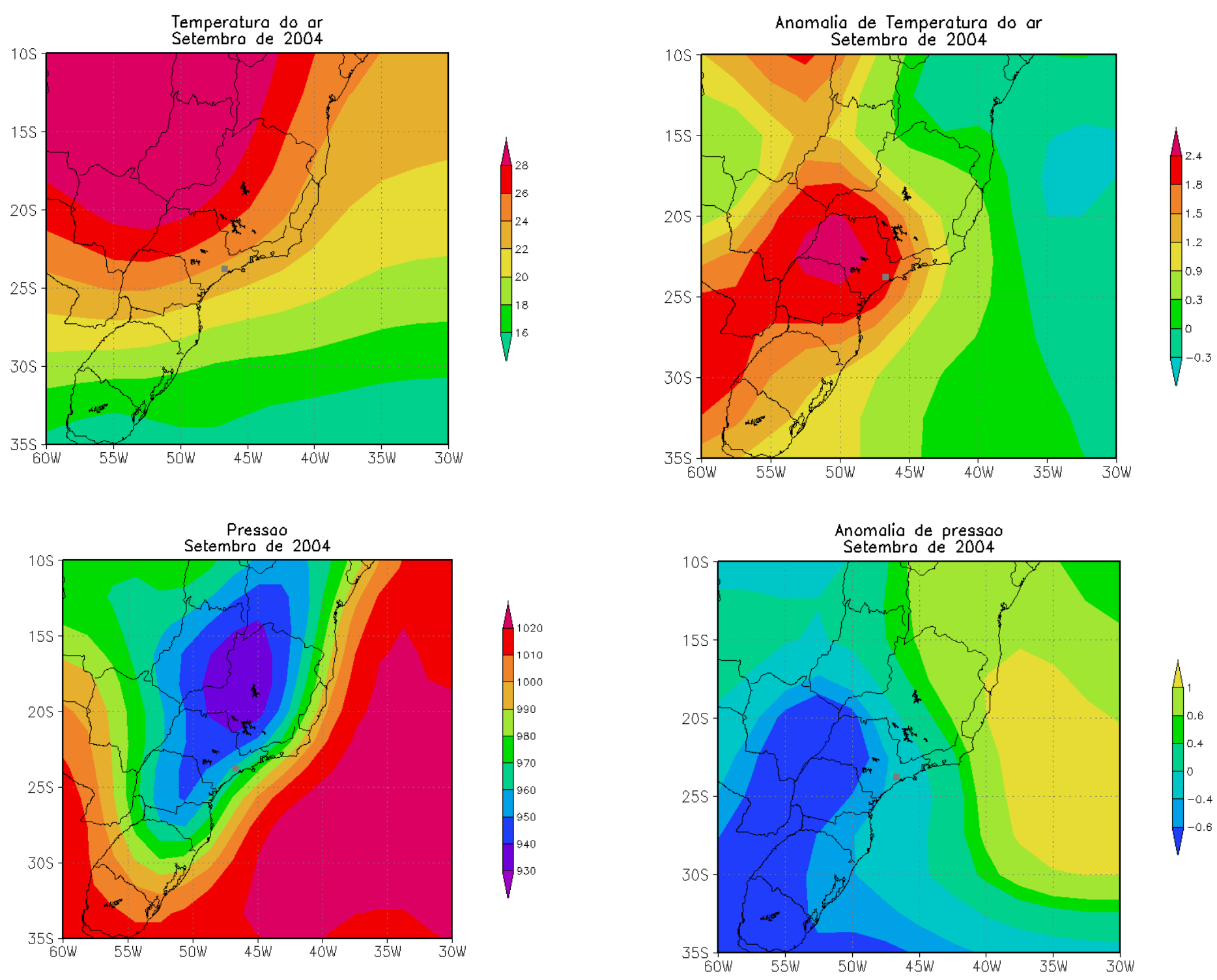

Vento

Setembro de 2004
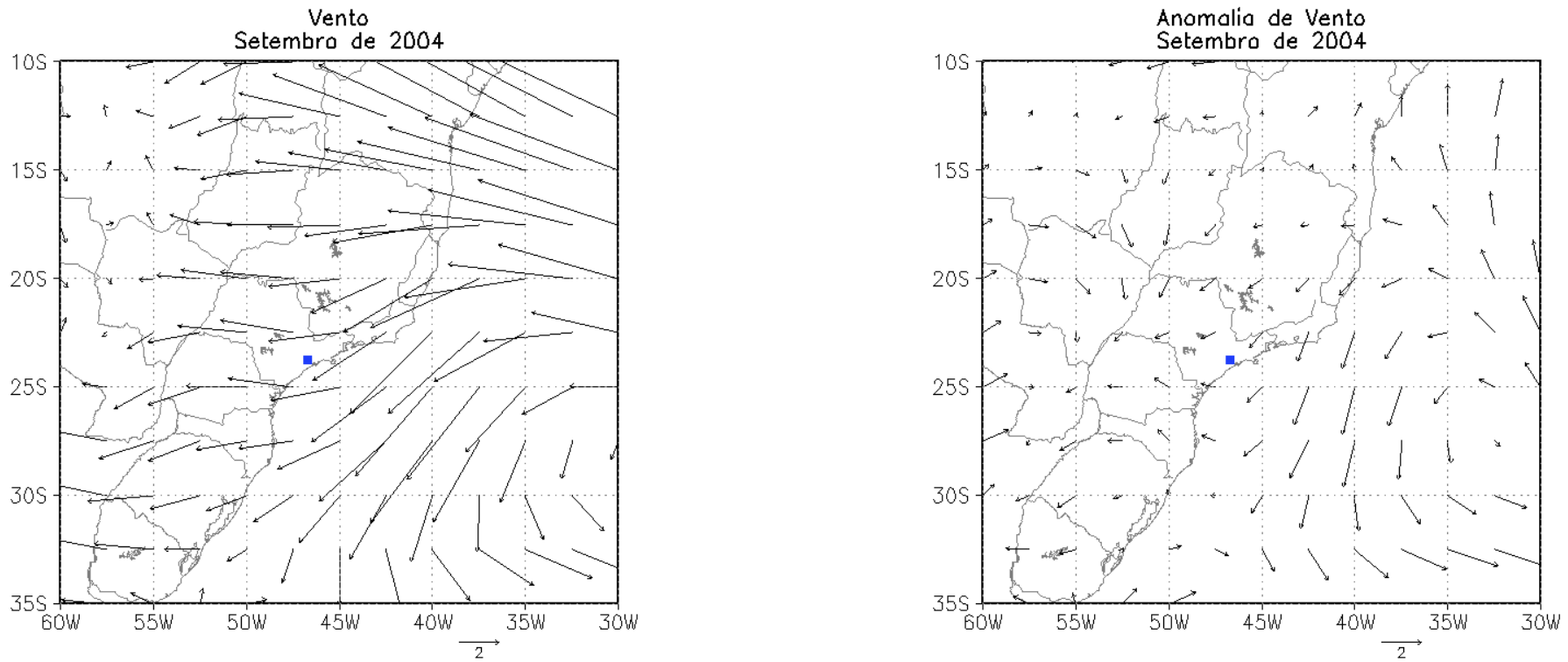

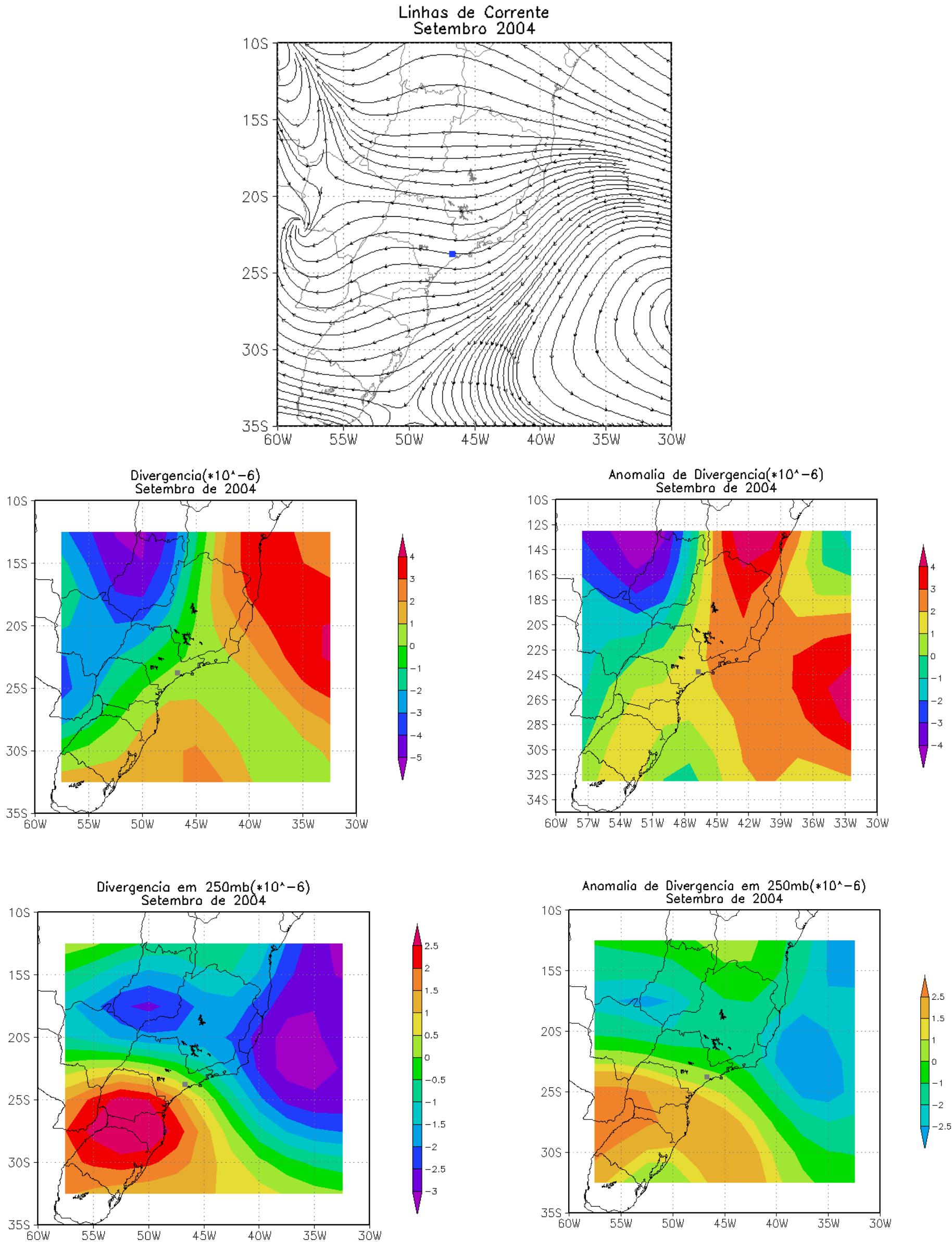


\section{ANEXO 3}

\section{DISTRIBUIÇÃO MÉDIA DO OZÔNIO TROPOSFÉRICO NA RMSP (INTERPOLANDO EM GRADE 0,02 E 0,03)}
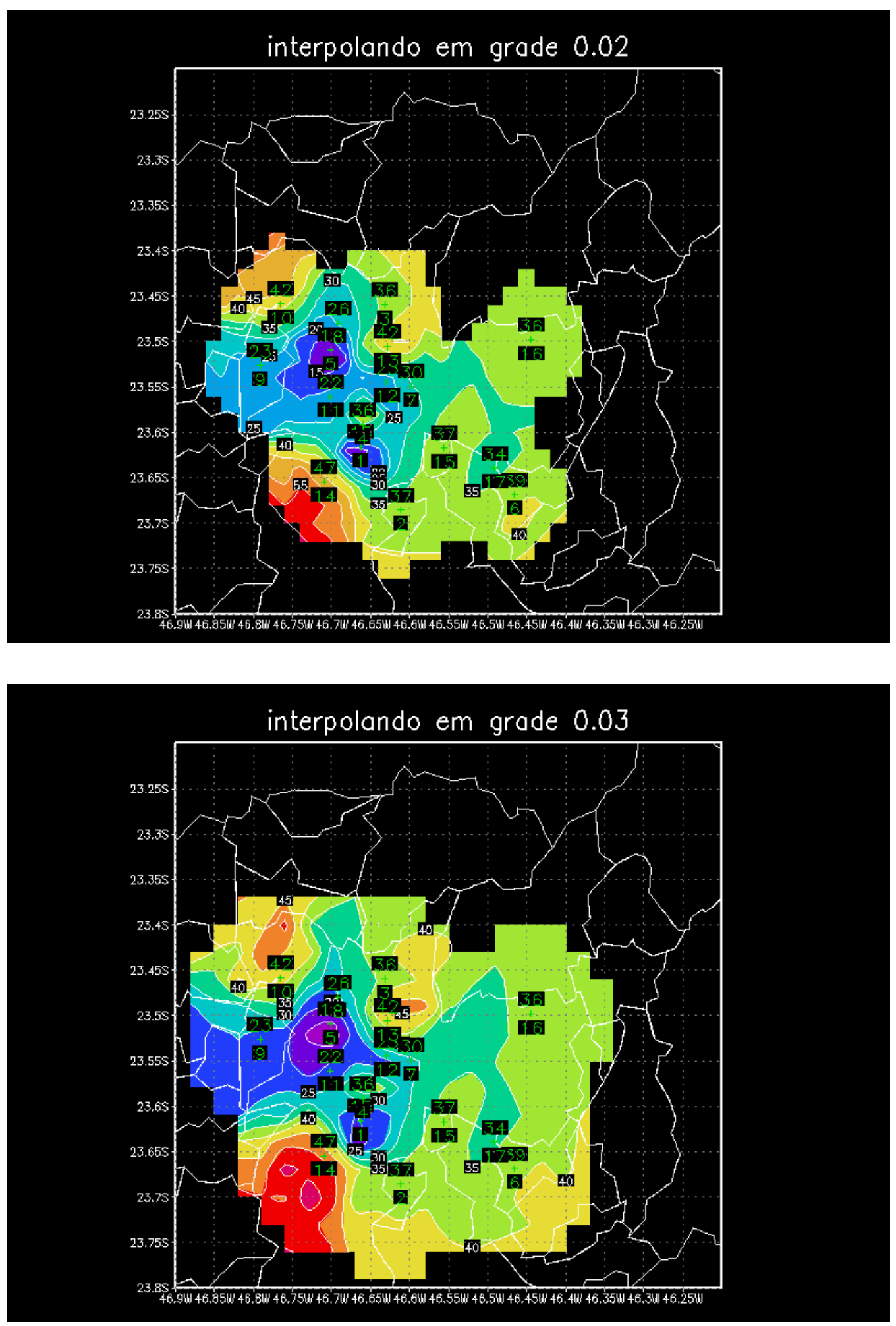
ANEXO 4

NARSTO, 2000
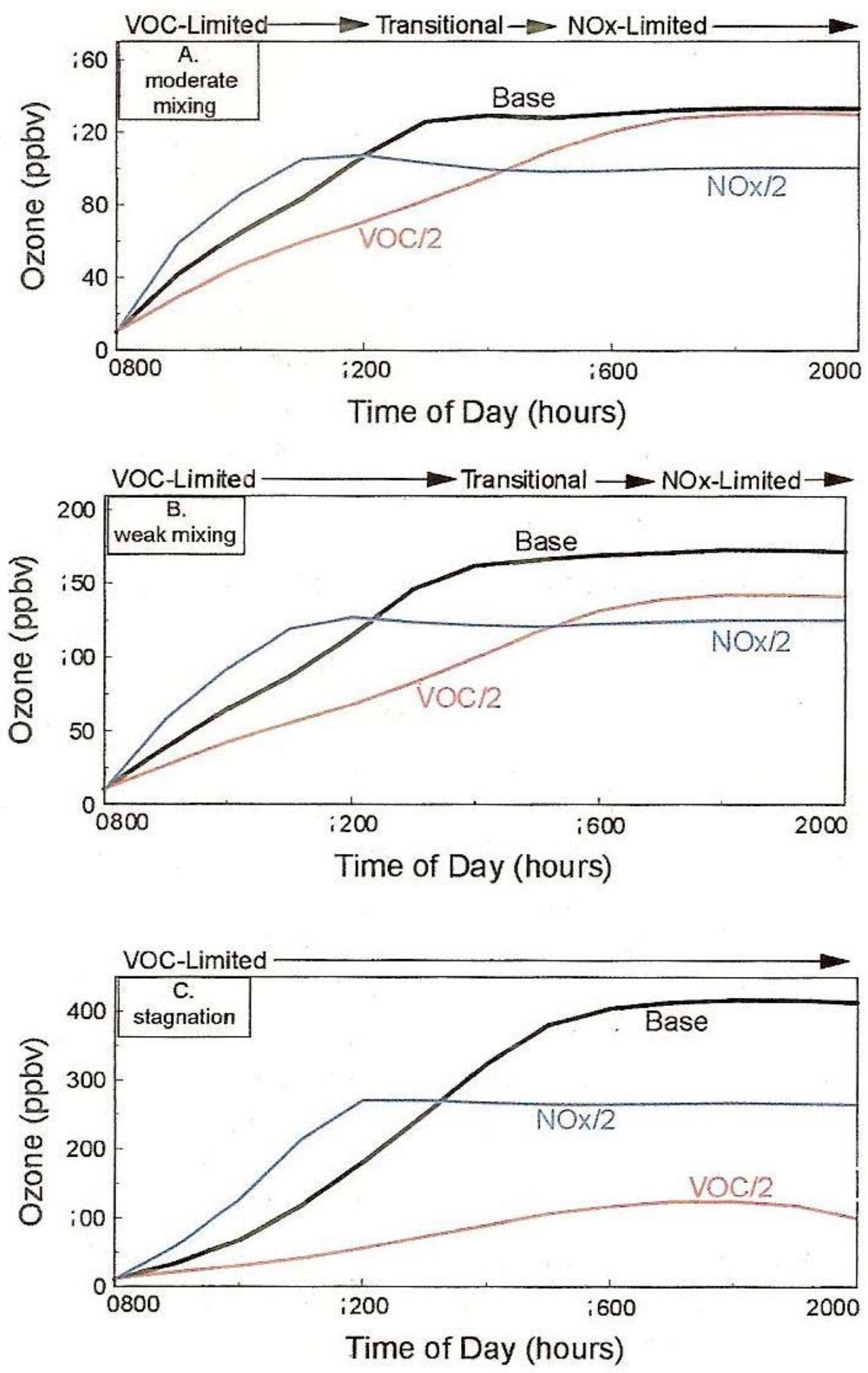


\section{ANEXO 5}

Climatologia da cidade de São Paulo (INMET) e localização das estações da CETESB na RMSP (Elaborado por Machado, 2008).
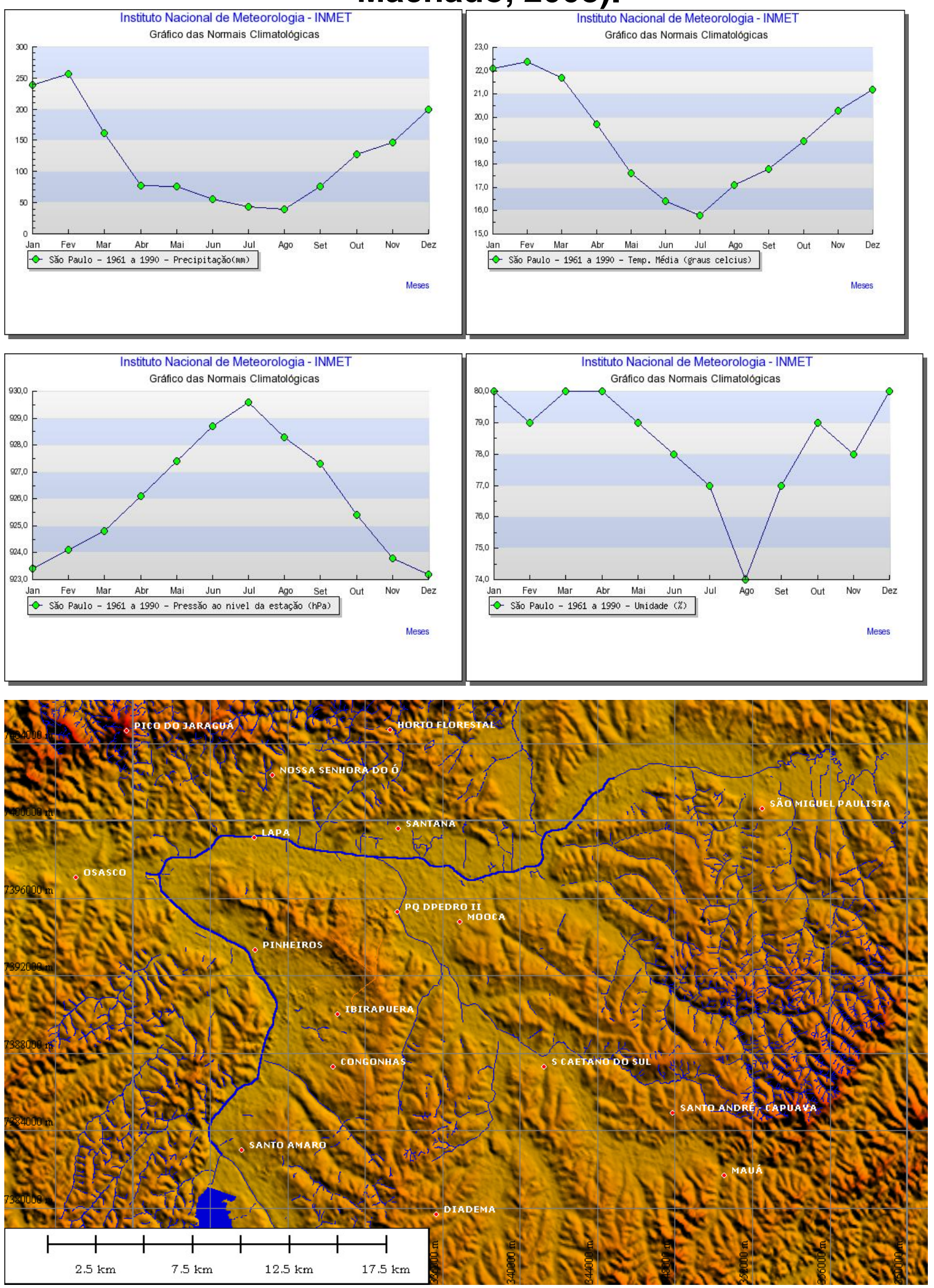